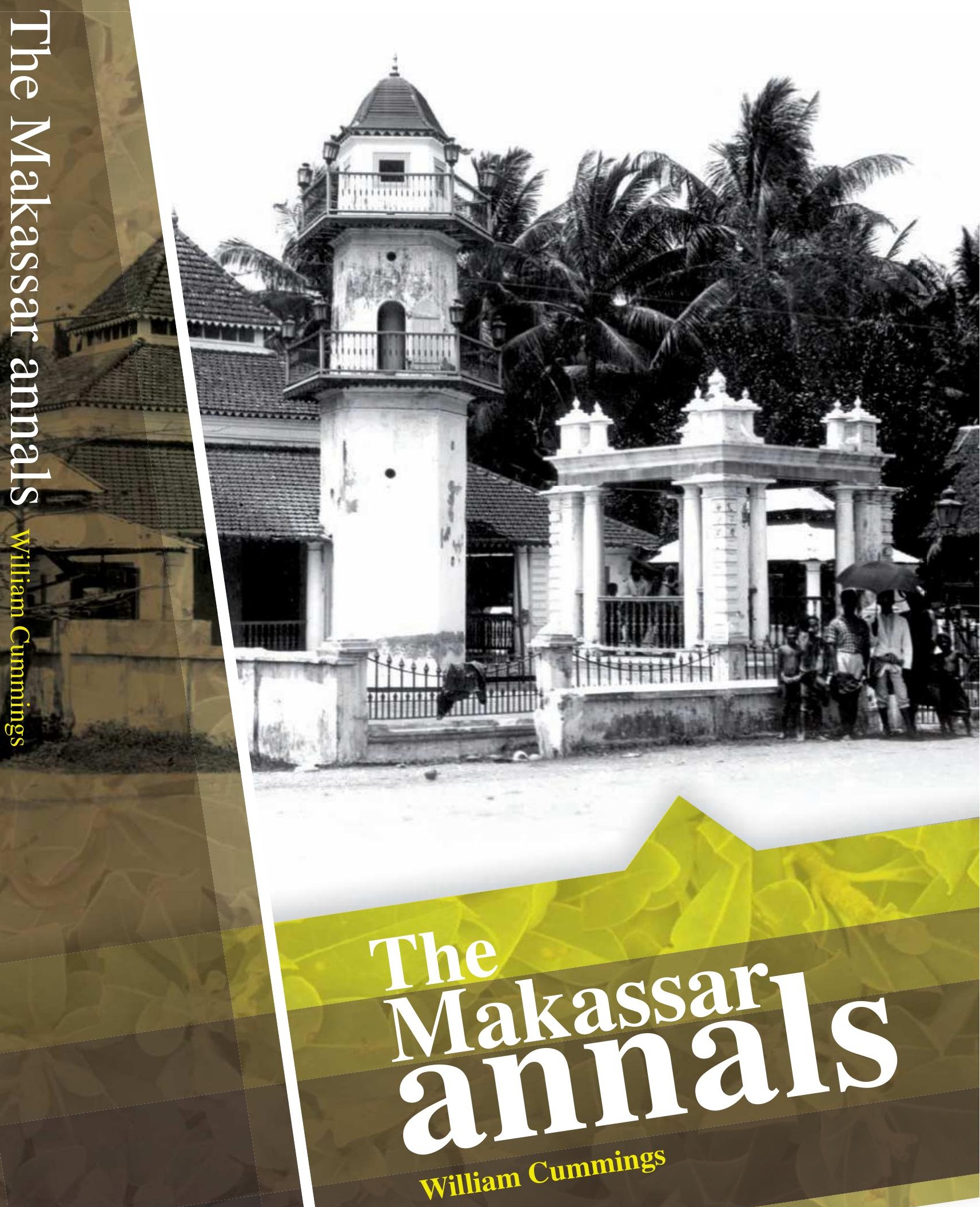

(9) 
THE MAKASSAR ANNALS 
The Bibliotheca Indonesica is a series published by the Koninklijk Instituut voor Taal-, Land- en Volkenkunde (Royal Netherlands Institute of Southeast Asian and Caribbean Studies), Leiden. The series contains critical editions of texts in various Indonesian languages, together with a translation and commentary in English. 


\author{
BIBLIOTHECA INDONESICA \\ published by the \\ KONINKLIJK INSTITUUT \\ VOOR TAAL-, LAND- EN VOLKENKUNDE \\ 35

\section{THE MAKASSAR ANNALS} \\ translated and edited by

\section{WILLIAM CUMMINGS}

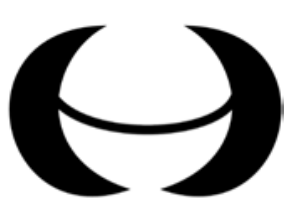

KITLV Press

Leiden

2010 
Published by:

KITLV Press

Koninklijk Instituut voor Taal-, Land- en Volkenkunde

(Royal Netherlands Institute of Southeast Asian and Caribbean Studies)

P.O. Box 9515

2300 RA Leiden

The Netherlands

website: www.kitlv.nl

e-mail: kitlvpress@kitlv.nl

KITLV is an institute of the Royal Netherlands Academy of Arts and Sciences (KNAW)

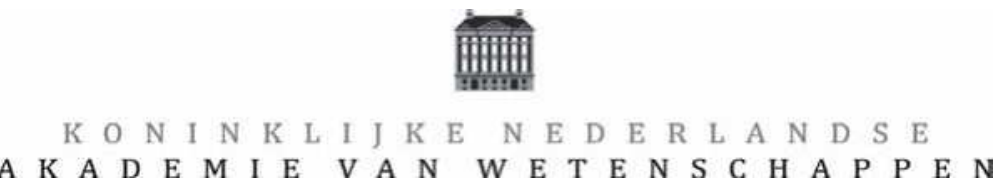

Cover: Creja ontwerpen, Leiderdorp

Cover photo: Gowa's main mosque, c. 1925 (KITLV 34239)

ISBN 9789067183666

KITLV Press applies the Creative Commons Attribution-NonCommercialNoDerivs 3.0 Unported License (http://creativecommons.org/licenses/by-ncnd/3.0/) to selected books, published in or after January 2011.

Authors retain ownership of the copyright, but they permit anyone unrestricted use and distribution within the terms of this license.

Printed editions manufactured in the Netherlands 


\section{Contents}

Preface vi vi v v

Abbreviations $\quad$ viii

I Introduction 1

II The annals; Transliteration, translation, and notes 33

$\begin{array}{ll}\text { III A further annals; ANRI 16/6 } & 307\end{array}$

IV Index of personal names 313

Glossary 349

Reigns lists for the rulers of Gowa and Talloq 351

$\begin{array}{ll}\text { Bibliography } & 355\end{array}$

$\begin{array}{ll}\text { Index } & 357\end{array}$ 



\section{Preface}

Beginning in perhaps the 1630s, a series of annalists at the main courts of Makassar began keeping a novel form of historical record. Lontaraq bilang, or 'counting manuscripts', contained carefully dated and chronologically ordered entries recording significant or surprising events. They were a clear departure in form and function from the genealogically-structured chronicles being composed about the ruling families of Gowa and Talloq in the same era. Most significant, perhaps, whereas Makassarese chroniclers ceased their work with (or at least by the time of) the conquest of Gowa and Talloq by the Dutch East India Company (VOC) and their Bugis allies in the 1660s, the annalists continued to make entries in their manuscripts. The Makassarese annals translated here continue unabated until the close of 1751. Moreover, the genre itself flourished in South Sulawesi and similar annals became a common form of record keeping among Makassarese and Bugis into the twentieth century.

The greatest obstacle to historical investigations into the events and dynamics of premodern Southeast Asia has long been the availability of sources. Manuscripts are too few, and too subject to the vagaries of chance and the depredations of a harsh tropical climate. Often we have little more than the impressionistic or inconsistent observations of European voyagers whose descriptions of Southeast Asian shores yield frustration at unasked questions as often as they do kernels of insight. The Makassar annals are a welcome refuge for historians accustomed to working with fragments like so many scattered tea leaves. Over the course of nearly a century and a half a series of annalists recorded 2360 entries - an average of 19.1 entries per year beginning in 1631. Moreover, these entries are carefully dated and the vast majority appear factually accurate as well as chronologically precise.

A textual lode of 2360 historical entries describing seventeenth and eighteenth-century events is a rare and precious resource for scholars of Southeast Asia. This translation is an invitation to scholars to use this rich resource in as many ways as possible to shed light on a fascinating part of the Indonesian archipelago. There are many possibilities here whether our interest is in biographical accounts of nobles and notables, the scaffolding 
of significant events to write narrative accounts of Makassarese and early colonial history, prosopographical analysis of distinct social groups and their dynamics over time, quantitative studies of entries to answer demographic questions, or any other approach to the multitude of subjects that captured the attention of generations of annalists at the courts of Makassar. We have an opportunity to repay their diligent efforts with our own.

My labors in translating and analyzing the lontaraq bilang have been considerably eased by friends, colleagues, and family. I owe Michael Decker for a thousand espressos, and John Belohlavek for nearly that many glasses of wine. Such friends make the solitary work of pondering and puzzling archaic historical entries bearable. Campbell Macknight and Anthony Jukes offered suggestions on this manuscript at different stages, no doubt too few of which I have followed. I would also like to express my ongoing appreciation to my teachers at the University of Hawai'i: Leonard Andaya, Barbara Watson Andaya, and Robert Van Niel. Portions of the Introduction were previously published in the Journal of Southeast Asian Studies and Bijdragen tot de Taal-, Land-en Volkenkunde. I owe a great debt to my Makassarese tutor, the late Djohan Daeng Salengke. Maile and Sophie were also much in my thoughts as this project came to fruition. My greatest obligation and thanks, however, belong to Sharon. How someone who can make all this seem so irrelevant and yet still encourage me is a wonderful mystery I have yet to fully untangle. 


\title{
Abbreviations
}

\author{
ANRI Arsip Nasional Republik Indonesia \\ NBG Nederlandsch Bijbel Genootschap \\ VOC Vereenigde Oost-Indische Compagnie \\ VT Miscellaneous languages collection [Verschillende Talen], \\ Perpustakaan Nasional Republik Indonesia, Jakarta
}





\section{I \\ Introduction}

The Makassarese genre of historical writing known as lontaraq bilang, or 'counting manuscripts,' contain specific and dated information about a wide variety of topics, including the births and deaths of notable individuals, the actions of rulers, the spread of Islam, trade and diplomacy, the built environment, ritual activity, warfare, internal political struggles, social and kinship relations, eclipses and comets, and more.

These texts are what are commonly called 'annals'. They are records of year-by-year events set down serially. Lontaraq bilang have been useful indeed to historians of South Sulawesi. More than other available writings, they have been seen as supremely factual, reliable, and uncontaminated by mythical or controversial elements. Historians have trusted the facts in these texts as by and large referential and accurate. Cense (1966:418) described lontaraq bilang as 'pre-eminently [sic] characterized by a sober conciseness, and which, as far as I know, is met with in Indonesia only in South Celebes [South Sulawesi] and a few other areas which have undergone influence from the Macassarese and Bugis'. Based on this assessment, Cense and other historians (Noorduyn 1965; Omar 2003; Tol 1993) have considered lontaraq bilang reliable sources of factual historical information. This is how the Makassar annals have typically been used: historians have looked in them for facts about wars, political successions, inaugural events, and so forth, attempted to determine their veracity through comparison with other indigenous sources and Western accounts, and then used these facts as scaffolding on which to build historical narratives. But collectively we have only begun to make use of this rich archive and its possibilities for yielding insight into South Sulawesi's past. In part this is because of how we approach annals.

Historians have commonly seen annals like lontaraq bilang on their own as being incomplete, inferior, or quasi-historical forms of record-keeping because they do not contain the causal chains of reasoning that transforms a collection of facts into a coherent story with a definable plot and outcome. As Hayden White writes of the medieval Annals of Saint Gaul, 
What is lacking in the list of events to give it a similar regularity and fullness is a notion of a social center by which to locate them with respect to one another and to charge them with ethical or moral significance. It is the absence of any consciousness of a social center that prohibits the annalist from ranking the events he treats as elements of a historical field of occurrence. And it is the absence of such a center that precludes or undercuts any impulse he might have had to work up his discourse into the form of a narrative. (White 1987:11.)

However, this may not be accurate in the case of the Makassar annals. The inferred textual position of the rulers of Makassar provides precisely such a social center, making this text rather more complex than White's example.

This social centrality is also conveyed spatially. The lontaraq bilang are written from what is nearly, but not quite, a geographical location: Gowa and Talloq, and the Gowa and Talloq courts in particular. Ships and people are recorded arriving and departing. But in reality this is done because this is where the ruler dwells. He is the true spatial anchor of the text and its entries during any given reign. The effort to record the construction, repair, and fate of the various royal palaces (Tamaqrappo, Tamalate, Macciniqdanggang) of the rulers of Gowa are important not just because they are significant structures, but also because they textually locate the presence of the ruler. The perambulations of rulers are followed closely as they made war, supervised construction or irrigation projects, attended meetings with other rulers, or simply went to live elsewhere while palaces were renovated. In all but a few cases, no other events are recorded in lontaraq bilang before the ruler returns. The exceptions involve notations about the births of high-ranking offspring of Gowa nobles. For the most part, however, activity stops when the ruler is absent. More precisely, history and activity revolves around the ruler, and where he goes they follow. Lontaraq bilang are not apolitical and objective, but have a subject and a politics.

There are other contexts too that have influenced the annalists who wrote these manuscripts and which make them more promising than Hayden White's description indicates. The social context in which rank and statusrivalry motivated behavior and shaped events; the political context in which Gowa's empire first expanded, then collapsed, and finally gave way to renewed struggles for pre-eminence; the religious context as Islam spread and transformed Makassar into a Muslim society tied to the Islamic networks across the archipelago; even the temporal context in which later annalists made determinations about which early entries needed to be copied and preserved and which did not changed dramatically from the seventeenth to the eighteenth century - all of these contexts and more besides make the lontaraq bilang a far more complex historical source than 'annals' have customarily received. This introduction will briefly explore some of these contexts and 
illustrate a few of the many analytical paths that scholars might follow in examining and making use of this unique body of material. We can begin by considering the nature of the genre and how it grew within the historical context of early seventeenth century Makassar.

\section{The lontaraq bilang genre; Origins and development}

In appearance, Roger Tol described this genre as 'more or less similar to a condensed form of the modern executive diary' (Tol 1993:618). The annalist typically wrote the year at the top of each page, placed a vertical column for the names of months and days (both Gregorian and Hijri or Islamic dating) along one side of the page, thus making horizontal spaces for entries. On those days in which events judged significant take place, the annalist notes what occurred. Many, and in some cases most, days are left blank. Early lontaraq bilang had very few entries each year, suggesting that when the genre began this preformatted grid was not yet used. The seventeenth-century Makassarese annal entries tend to be shorter than the equivalent Bugis sureq bilang entries reviewed by Cense (1966), who described them as containing much longer and more detailed descriptions of events.

There are clues to the origins, purpose, initial date, and social context in which the first Makassarese annalist inscribed his text from the initial entries. Six of the first seven entries are marked with the term 'purportedly', kutaeng or bedeng in Makassarese. The first writer put these entries in retrospectively (presumably at the same time) based on personal memory, oral report, or calculated backdating. The death of Tunijalloq is recalled precisely, for it was a decisive moment that did not need to be estimated. The 1602 entry for the Dutch East India Company, or VOC, undoubtedly dates from a later period, and was interpolated into the lontaraq bilang because of its significance to later Makassarese history combined with Makassarese convictions about the significance of origins.

The next entry is the famously erroneous dating for the 22 September 1605 conversion of Karaeng Matoaya of Talloq and Sultan Ala'uddin of Gowa (Noorduyn 1956). It is risky to read too much into what after all could simply be scribal error, but it is nevertheless hard to imagine that the writer would have gotten the date wrong by two years if he was recording contemporaneously. The first fully dated and presumably reliable entry is for the birth of Ala'uddin's son and later successor Malikussaid, on 11 December 1607. The next entry comes from the same year, and apparently took place slightly before Malikussaid's propitious birth. On 9 November 1607 Friday prayers were begun in Talloq and, purportedly, a war was fought in Tamappalo. We also read that the people of Soppéng embraced Islam after their defeat 
in battle, an undated event that probably took place in 1609. The improper chronology and use of kutaeng or bedeng suggest that these events too were recorded by the writer afterwards rather than contemporaneously. It is when Gowa and Talloq forced the people of Wajoq to accept Islam on 10 May 1610 that the lontaraq bilang entries become more chronologically ordered, carefully dated, and freer of the tentativeness of purported events.

The momentousness of this date is worth underscoring, for it is clear that entries related to Islam are a prominent feature of the early lontaraq bilang. This was a landmark event marking a new chapter in the tumultuous rivalry for dominance between Gowa and the major Bugis states of Wajoq, Soppéng, and Boné. From this perspective, the lontaraq bilang were initiated within a specific historical context involving the spread of Islam and the concomitant expansion of Gowa's empire. Indeed, the second contemporary entry on 23 November 1611 records Gowa's defeat of Boné in their war of Islamization (bunduq kasallannganna). Historically, it is quite possible that the 1607 war at Tamappalo also involved the spread of Islam by force of arms. For that matter, historiographically it is conceivable that the entry describing the 1609 defeat of Soppéng and their forced embrace of Islam was recorded in 1610 as well. However, the recordings of these specific events probably pre-date the creation of the lontaraq bilang genre, as becomes clear from other evidence within the text.

Considered together with the entries describing Matoaya and Ala'uddin's initial conversion and the formal marking of the beginning of Friday prayer services in Talloq, it is remarkable how the lontaraq bilang written later focused on marking watershed dates in the history of Islam's spread. This is an essential clue to understanding the genre's origins. The early decades of the seventeenth century were a time when Gowa and Talloq's rulers were active in recreating the social and political landscape around them in the image of an Islamic society. The function of lontaraq bilang became in part to commemorate this transformation and to mark the expansion of Islam.

It is also noteworthy that Makassarese historically wrote using a modified form of Arabic script known as serang when they wished to emphasize or impart an aura of religiosity to a text. Using serang itself connoted that a text is Islamic. From this perspective it should be mentioned that VT 25 - which is the main text used in this translation and edition - is written in the serang script. While this suggests a connection between the genre and Islam, other lontaraq bilang manuscripts were written in the conventional Makassarese script. Unfortunately we do not have access to original seventeenth-century manuscripts which could confirm the suspicion that the first lontaraq bilang texts employed serang and thus in appearance were 'Islamic'.

With this historical context in mind, we can also consider the historiographical dimension of lontaraq bilang's early development. In Makassarese 
eyes all histories, by definition, began with accounts of origins (Bellwood, Fox, and Tryon 1995; Fox and Sather 1996). Thus in addition to focusing on turning points in the spread of Islam in South Sulawesi, the contents of the early entries also deal extensively with the births and deaths of rulers. This genealogical component comes as no surprise given the central importance of rulers in the lives of Makassarese and their pivotal role in historical chronicles. Patturioloang were structured as elaborate genealogies relating the history of Gowa and Talloq's chains of kings. It was the lives of rulers that defined eras and marked the passage of time. This conception of the past dominated Makassar at the beginning of the seventeenth century. The writer of the lontaraq bilang incorporated this reverential, genealogical aspect of Makassarese historical thought by adding the births of seven of the most prominent Makassarese (all but Karaeng ri Barombong were rulers of either Gowa or Talloq) and the death of one.1 While patturioloang and lontaraq bilang have substantial differences in form and purpose, the perception that the lives of rulers are an inescapable structural feature of the past is an important continuity between the two genres. Nor should we forget that conversion to Islam itself was a practice initiated and encouraged by Gowa and Talloq's rulers.

We can gain a sense of the genre's development by examining the entries that over the next two decades recorded significant moments in the history of this Muslim kingdom. As a glance at the entries for the 1610s and 1620s makes evident, adjudicating between the Gregorian and Hijri calendars used by the lontaraq bilang annalist is difficult. It is not possible to conclude that one or the other calendrical system is accurate. On balance the Hijri dates are more reliable. Six entries have no Gregorian date; only two have no Hijri date. In terms of chronology, in numerous cases the Hijri dates seem more dependable because they better match the sequential order of the entries, but again this is not always so. For several entries there is no obvious reason to prefer one date over the other. Overall, however, there seems to be a tendency for the annalist to prefer the Islamic calendar. The more important considerations are what this tendency and the high frequency of contradictory dates tells us about Makassarese society in the early seventeenth century.

To answer these questions, let us assume that we are not dealing with calendrical incompetence on the part of our annalist. A few mistakes are easily understood, but the steadfast inconsistency witnessed here suggests another explanation. I think the annalist did not consider getting the date

1 It is also worth considering whether the inclusion of these moments within what was a text concerned primarily with Islam was in itself a subtle act of incorporation that implicitly and retroactively Islamicized Karaeng Matoaya and Sultan Ala'uddin's predecessors. Such an act would have been in keeping with what we know of Makassarese desires to claim the earliest possible link to Islam. 
precisely correct very important. That is to say, in the early years of this genre what was significant about the events chosen for inclusion in the text was not their precise position along a time line. Chronological accuracy was less valued than we might expect when first viewing these premodern executive diaries. To put this still another way, the column with Gregorian and Hijri dates was not the focus of the text; that honor belonged to the information about people and events. So what was the writer of the lontaraq bilang accomplishing by recording this information and why was he doing it?

I believe what we witness over the early decades of the seventeenth century is a changed perception of dating and time and, in particular, the relationship between Makassarese and universal systems of marking time. We do not need to argue that this is a cognitive change of the sort suggested by Eviator Zerubavel (2003). The perception that concerns me is a social one about how Makassarese converts viewed their connection to the Muslim umma as a whole. Rulers remained the lodestone of their communities, but alongside this heroic conception of history developed a sense that the place of Makassarese Muslims in the umma and in Islamic history needed articulation.2

Muslims and Christians both reckoned time by universal calendars that, theoretically, could locate any and all events along a linear path. The world now possessed a Beginning and an End. The decision of the early lontaraq bilang writers to employ both of these calendrical systems was a deliberate choice that evidences their desire to place events and people in Makassar within a wider context. It was this intent that is striking. This is an example, I think, of how the form of a text can be deceptive to modern eyes. We should not mistake the appearance of accuracy and specificity - columns of dates - for accuracy and specificity. Including an event such as the 28 Zulkaedah 1028 (5 November 1619) feasting at Tamaqrappo or even the explicitly Islamic circumcision of Tumamenang ri Papambatuna that same year within the text was itself a means of locating it within the context of universal, calendrical time. Its precise location was less important than the fact of its inclusion. Precise dates aside, we can even legitimately question the importance of sequential accuracy in the entries as well. After all, patturioloang reign narra-

2 We see this trend in Makassarese chronicles as well. As reign accounts progress in the Gowa and Talloq patturioloang there is increasing concern to provide specific dates. Indeed, there is a dramatic change in the amount of calendrical information over the course of Ala'uddin's reign in particular. While at the beginning we are not told the date of his birth, at the end of the account of his reign we read, 'This karaeng lived to age fifty-three. For forty-six years he ruled then died. Above in Cikkoang, while inside Jongaya, illness came to him on the ninth night of the month of Safar, on the tenth night of June, on Sunday night. Once it was day on Sunday he was brought down to his home. On the twelfth of the [Islamic] month, on the fifteenth night of the Christian month, on Wednesday, at the stroke of one in the night, he died, 1639 of the Christian calendar, 1049 of the Islamic calendar' (Cummings 2007a:45). 
tives do not relate events in chronological order, and this was the dominant historiographical style when the lontaraq bilang were begun.

The genealogical entries of births and deaths help make this point. Being granted a textual place within the lontaraq bilang was recognition that an individual was of high status. It meant they were considered likely to have a decisive influence on the Makassarese around them because of their social position. Inclusion marked status and potential significance. The entries between 1611 and 1630 included many more non-rulers than did the first entries. All were important figures, usually close kin of the rulers of Gowa and Talloq, and their appearance in the lontaraq bilang presents us with a social map of the pre-eminent figures that dominated Makassarese society. The three instances of 'purportedly' that we encounter during these two decades are best interpreted as later additions to the text estimating the birth dates of individuals who had achieved prominence. Shaykh Yusuf, born around 1626, is a perfect example of this, for it was only toward the end of the century that this Sufi master gained fame as an Islamic scholar and enemy of the Dutch throughout the archipelago.

In an analogous fashion what events and which people were inscribed in the lontaraq bilang was a politically aware decision rather than a neutral judgment of historical significance. It was only later that the fit between Gregorian and Hijri dates became closer. The apparent confusion and inconsistency of dates is a clue to how Makassarese adopted textual practices from (most likely) the Portuguese and the Malays and put them to uses which were not entirely novel or removed from the original, but which clearly were adapted to local needs and purposes. Makassarese found use in these imported calendars and systems of temporal reckoning for integrating their society into the global community of believers. They did not import Islamic genres of historical writing from the Middle East wholesale with the possible exception of the Makassarese compilations of guidelines from renowned ancestors known as rapang which resemble Arabic hadith and akhbar (Cummings 2002; Khalidi 1994; Robinson 2003).

In addition to what this examination of dates and calendrical systems reveals, several themes also emerge from a consideration of the contents of these entries that indicates the presence of shaping contexts that charged the entries with special significance. The genealogical expansion of the text to include a somewhat wider array of individuals has already been noted. A second evident theme is overseas conquest. In particular, Makassarese naval expeditions brought the islands of Buton and Sumbawa into the ambit of Gowa's expanding empire. In early 1626 Karaeng Matoaya and Sultan Ala'uddin personally led a voyage eastwards to Buton. Buton was an important source of slaves traded in the archipelago and occupied a strategic position athwart the shipping lanes leading to the spice islands of Maluku. 
Matoaya and Ala'uddin conquered the island and accepted the formal submission of its local rulers. Soon afterward they departed Buton and sailed south and west to the island of Sumbawa. Four main kingdoms on the island- Bima, Dompu, Sumbawa, and Kengkelu [Tambora] - all succumbed quickly to the Makassarese forces. But this was not the first time that Matoaya and Ala'uddin had conquered Bima. Nearly a decade earlier Sumbawa had been the first overseas target of Gowa after its defeat of the Bugis lands of Soppéng, Wajoq, and Boné. In roughly 1618 'I Luqmuq ri Mandalleq went over to Bima and conquered Bima with only nine vessels' and then again in 1619 'Karaeng ri Maroanging went over to Bima and conquered Bima and Sumbawa'. There is uncertainty about the dates, but clearly it took three wars and the personal attention of Matoaya and Ala'uddin before the kingdom of Bima accepted Gowa's overlordship.

Entries describing the defeat of Bima in the lontaraq bilang are particularly important because the explicit purpose of the conquest was to spread Islam. This was the first extension of Gowa and Talloq's wars of Islamization (bunduq kasallannganna) outside of South Sulawesi. We know a considerable amount about this effort from other Makassarese historical texts and European sources that have been analyzed by J. Noorduyn (1987). One such Makassarese text describes how the kingdoms on Sumbawa 'were defeated as infidels, were made to embrace Islam, and were all enslaved by the karaeng except for Sanggar, which the karaeng freed because it had been the first to allow them to land'. It was after the second expedition that Islamic practices began to be enforced. There was significant resistance to the Makassarese proselytizers and internal political divisions between those who accepted the new faith and those who refused. The same Makassarese text describes the tribute obligations of the defeated kingdoms. It also describes how Makassarese established mokkeng, from the Arabic word muqim, meaning 'inhabitant' in Bima. This referred to people the ruler of Gowa appointed to attend the Friday prayer service, ensuring that the minimum number of forty people demanded by Shafi'ite doctrine were present for the service to be valid. The text relates, 'He [Karaeng Matoaya] established the Friday service in those overseas countries. The karaeng hope to gain reward by appointing mokkeng and then setting them free. Just those people called mokkeng were free, and the commoners were slaves.'

Gowa's expanding empire certainly had many motivations, and we would be remiss if we failed to acknowledge the political and economic benefits that accrued to Matoaya and Ala'uddin, but there is no doubt that the extension of Gowa's authority was conceived of as a fundamentally Islamic act of faith. Having joined the umma, Matoaya and Ala'uddin took seriously their religious obligation to extend the community of believers. The author of the Talloq patturioloang praised Matoaya for precisely this, recording that 
'This karaeng Islamicized the people of Makassar until they became Islamic. Except for Luwuq, he Islamicized the Bugis throughout the Bugis lands, except only for the unbelievers [highland groups]' (Cummings 2007a:87-8). Their conquests stemmed from religious certainty. Empire and Islam were two sides of the same coin, and they came together both in the expeditions to Sumbawa and in the entries of the lontaraq bilang recording these expeditions. It is also in this context that it became important to enter into the annals events related to the VOC, Gowa's chief adversary in the eastern archipelago and a representative of Islam's own rival Christianity. It would be fascinating indeed to know when the 2 March 1602 entry about the founding of the VOC was interpolated into the annals.

By 1631 Gowa had become a very different place than it was two decades before when the lontaraq bilang was initiated. In 1610 Sultan Ala'uddin was a seventeen year old young man dependent on his uncle and patron Karaeng Matoaya; in 1631 he was now a mature ruler sure of his grip on power, confident in his abilities, and possessed of a remarkable history of victories in expanding Gowa's authority and influence. Karaeng Matoaya, though still alive, had abdicated Talloq's throne and his position as tumabicarabutta or chief advisor of Gowa in favor of his equally capable son Tumammaliang ri Timoroq. Reading the Talloq Chronicle makes clear the extraordinary changes that took place under Matoaya and Ala'uddin: there is a long list of communities that had been conquered and now acknowledged Gowa and Talloq's supremacy, a long list of military innovations in such areas as building ships and forging firearms, and a long list of advances in areas as diverse as writing and woodcarving. What had begun as a fairly unpromising reign by a young boy following the expulsion of his elder brother and successor Tunipasuluq flourished beyond what anyone could have expected. By 1631 Ala'uddin and Gowa had reached the pinnacle of their influence in eastern Indonesia.

The lontaraq bilang changed by 1631 as well. After averaging 1-2 entries per year for the preceding two decades, beginning in 1631 we see large numbers of entries recorded. There are sixteen entries for 1631 alone. Whether this can be explained by simply positing that a new, more dedicated annalist succeeded one much stingier with his words is difficult to determine. It may be that something changed in Makassarese society that encouraged a more intensive interest in recording significant events. In addition, beginning in late 1629 the annalist's use of Gregorian and Hijri calendars consistently coincides or matches. In no cases do the dates differ by more than a month; most refer to the same day or are but a few days apart. In all likelihood, then, the lontaraq bilang genre as we know it dates to 1631.

One possible theory is that Datoq Hafid, who died on 13 November 1629, was the annalist in charge of the lontaraq bilang and that he was succeeded by a more diligent writer who began, fittingly, by recording his predeces- 
sor's death. Lacking other evidence this can be no more than conjecture. If true it indicates that the lontaraq bilang genre either originated with or at least was influenced by Datoq Hafid's Malay background. There was a thriving Makassarese Malay community in Makassar during Sultan Ala'uddin's reign that had close links to the ruling families of Gowa, Talloq, and other coastal Makassarese communities. The 29 October 1631 conflagration in the Javanese quarter refers to this Malay community, for Makassarese used the term 'Javanese' to refer to all those from the western archipelago, primarily Malays. It would be a diffusionist error, and sloppy scholarship, to simply argue that this genre was imported by Malays to Gowa, however. Neither Makassarese annals nor chronicles resemble Malay historical genres such as hikayat and syair. What is intriguing and suggestive about this theory is that Malays certainly are well known for their role in spreading Islam to Makassar. The presence of a Malay community was impetus for Tunijalloq (r. Gowa 1565 to 1590) to build the first mosque in Mangallekana and encourage Muslims to make the hajj, for example. It was a Mingangkabau Malay named Katte Tungallaq who led Karaeng Matoaya and Sultan Ala'uddin in their profession of faith in 1605. Malays frequently served as religious officials and teachers in seventeenth-century Makassar as well. This would at least provide contextual support for the argument that lontaraq bilang represent an Islamicized genre of Makassarese historical writing. If Datoq Hafid indeed was a lontaraq bilang annalist this is best interpreted as testament to the deep connections between Malays and Makassarese and the two-way process of acculturation taking place during Ala'uddin's reign.

From their beginning lontaraq bilang displayed an interest in marking the births and deaths of powerful nobles because history was conceptualized and society organized genealogically. But births and deaths began to take on an added significance, for they now also marked the boundaries of the growing Muslim community in Makassar. We see an increase in the quantity and quality of genealogical information recorded. Instead of children simply 'appearing' we now get information on genealogical relationships. For example, on 3 June 1631 'a wife of Karaeng ri Popoq gave birth to his oldest son named I Liba who lived just twenty-nine days' and on 25 June 1631 the 'wife of I Daeng Kalula had a daughter named I Taniq'. It is difficult to be certain, but in a society where Islam spread through kinship and patron-client ties, these details about relationships may have gained in importance during the course of Ala'uddin's reign. Important relationships with kingdoms such as Mataram did make their appearance in the annals as Gowa and Talloq forged ties with other Muslim kingdoms. Later entries from Ala'uddin's reign contain a growing number of entries marking these relationships as envoys and messengers from Aceh, Maluku, Banten, and elsewhere arrive and depart Gowa. Annals entries recorded and in so doing affirmed the significance of 
Gowa within the network of Muslim kingdoms spanning the archipelago.

Linked to this concern with the boundaries of the umma was a growing concern with how Makassarese Muslims should behave. We can begin to sense around this time interest in and possibly debate over the role of Islamic practices, requirements, and prohibitions in Makassarese society. Christian Pelras (1994) posited that there were elements of Islamic doctrine that rulers from South Sulawesi judged incompatible with indigenous beliefs, delaying conversion to Islam until the beginning of the seventeenth century. While this is unlikely to explain the timing of Matoaya and Ala'uddin's conversion, he is correct that Makassarese had to find ways to overcome potential conflicts and incorporate Islamic requirements into existing practices. For example, maritime trade played an important role in providing revenue sustaining Gowa's empire. We know this from a variety of sources, including the entries here noting that Ala'uddin had a royal hall constructed near where these transactions took place named 'Watching Trade' or Macciniqdanggang. Yet Islamic law's concern over usury also prompted Ala'uddin and Matoaya to decide that it would be forbidden to pay interest on debts. The inscription of this decision on 24 May 1631 recorded Ala'uddin's desire to further Islamicize Makassar and was an instrumental textual act that itself helped achieve this end.

By 1631 we can consider the lontaraq bilang genre mature. The style of entries and broad range of concerns that annalists would record had become established. There would be no more significant transformations of the genre in either form or content until the tribulations of defeat in the Makassar War in 1669 made themselves felt in these pages. During this 'classical' period in Makassarese historical discourse the textual influence of Gowa as a powerful Islamic empire would remain strong.

For example, there was great concern on the part of the annalist to mark important steps in Gowa and Talloq's Islamization. This particularly involved tracking the adoption of what was considered proper religious practices. Most obviously, it was for this reason that the 1605 conversion of Matoaya and Ala'uddin was included. This was also true for the commencement of Friday prayer services in Talloq in 1607, Tumamenang ri Papambatuna's circumcision in 1619, the use of Islamic wedding rites beginning in 1626, and the forbidding of interest on debts in 1631. All of these are in addition to the multiple entries tracing the advances in the wars of Islamization to spread the faith in and beyond South Sulawesi. This steady progress of Islamization clearly continued during this period. In rapid succession in 1632 there apparently was a public declaration about how tobacco interfered with Islamic teachings about sobriety, the first Makassarese man (that we know of) was encouraged to embark on the pilgrimage to Mekka, and people were pointedly assembled for Friday prayer services. We read the 
first reference to an 'Arabic name' given to a newborn, and indeed Muslim names make ever more frequent appearances. The construction of new mosques, initial Friday prayer services, and the arrival of Islamic shayks from overseas would become standard features of the annals. In short, it was intensely important to the text's annalists to make explicit Gowa's Islamic character and identity. The Makassar annals was not simply a neutral record, but an interested account or argument that through its entries demonstrated commitment to Islam.

So too Makassarese annalists closely tracked events related to Gowa's empire. Uprisings overseas on Bima and efforts to subdue the recalcitrant rebels are noted with regularity. A 1632 revolt against Gowa's rule took place not long after the third Makassarese conquest of Bima recorded earlier in the lontaraq bilang. We know from Dutch harbor records from Batavia that a Makassarese armada of some 400 vessels devastated the kingdom, destroying houses and sending people fleeing into the hills. So thoroughly was the revolt crushed by Karaeng ri Buraqne, and so in awe of Gowa's power was the ruler of Bima, that he forbid the VOC to trade in Bima (Dagh-Register 16311634:174-5). Even the formal act of submission by envoys from Bima on 21 June 1633 did not end the desire of many to escape Gowa's overlordship, for shortly after Ala'uddin's death news arrived of another impending revolt. In subsequent years dozens of entries track the efforts of Sultan Ala'uddin and Tumammaliang ri Timoroq to maintain or extend their authority over South Sulawesi. Armed expeditions to Toraja, Kabaena, and Mandar; envoys from major kingdoms in the archipelago such as Maluku, Mataram, and Aceh; and messengers from the Sula and Banggae islands, Luwu, Mandar, Boné, and Ambon all find their place in the text. In short, Makassarese annalists continued to feel that marking Gowa's empire and the status of its relations with other polities was essential. Just as it was a record as well as a manifestation of Gowa and Talloq's Islamic identity, it was a record and a manifestation of Gowa's imperial ambitions.

To return to Hayden White's bleak assessment of annals, we can in contrast identify in the early lontaraq bilang entries strong unifying social contexts and centers of attention that relate events together and give them at least the sense of a narrative that White found so lacking in the annals of medieval Europe. Analyzing the origins and development of the lontaraq bilang reveals much about when and why they were composed in the early seventeenth century. Through a similar close reading we can also establish where they were kept and by who as the annals evolved over the course of the next century.

Based on internal evidence, it appears that the Gowa court was where the annalists worked, at least until the Makassar War of the 1660s and probably for the remainder of the seventeenth century. The best indication of this is 
the paucity of entries about Talloq's rulers compared to those about Gowa's rulers during this period. Tumammaliang ri Timoroq, who ruled Talloq from 1623 until 1641, and his brother and successor Karaeng Pattingalloang, who ruled until 1654, make relatively few appearances in the lontaraq bilang. The year of Tumammaliang ri Timoroq's purported birth is included, and one marriage in 1637, but the next we hear is that he refused to return to Gowa on 25 December 1640. His voyage and return from Timor the following year, and his subsequent death are recorded, but of his actions as ruler of Talloq nothing is written. Pattingalloang too is only mentioned incidentally before his 15 September 1654 death. Pattingalloang's succession to the throne is not noted, nor is the succession of his nephew Harrunarasyid (which took place in either late 1654 or possibly early 1655). These omissions are striking both because Tumammaliang ri Timoroq and Karaeng Pattingalloang were such important figures and because this scant treatment contrasts strongly with the quantity and quality of entries about Gowa's rulers during this period.

Sultan Ala'uddin, who ruled Gowa from 1593 to 1639, his son and successor Sultan Malikussaid, who ruled until 1653, and in turn his son and successor Sultan Hasanuddin appear frequently in the annals. During the $1630 \mathrm{~s}$ when we hear of Tumammaliang ri Timoroq once we hear of Ala'uddin sixteen times. The same discrepancy exists with Malikussaid. We are told of when he first received his karaeng-title, two of his marriages (along with one reconciliation and a divorce), the ritual establishing him as patimatarang or heir designate, his installation as ruler of Gowa, his precise actions in war (once to the hour), his movement while one royal hall was rebuilt and later his occupation of a new one, how word reached him of events elsewhere, his departures and returns from trips, and his anger at being disobeyed. Hasanuddin is afforded the same careful attention from his birth, circumcision, and teeth filing to his deliberations in war and pronouncements at court before his own death in 1670. In short, the preponderance of internal evidence suggests that the early annalists lived at the Gowa court and were far more concerned about events there than those in nearby Talloq.

If this conclusion is accurate, it means that the lontaraq bilang were being composed at a different court than the Makassarese royal chronicles being written at the same time. The internal evidence, albeit suggestive rather than definitive, for the patturioloang suggests that they were composed at the behest of the rulers of Talloq (Cummings 2007a:22-3). The historiographical differences between the two genres and the surprisingly few instances in which people mentioned in one genre also appear in the other are discussed below. At some point, however, the lontaraq bilang began to be kept at the Talloq court. This probably took place around the turn of the eighteenth century. The overall pattern of entries (see Figure 1) in VT 25 and the existence of several lontaraq bilang manuscripts such as ANRI 16/6 (which ends in 1682) 


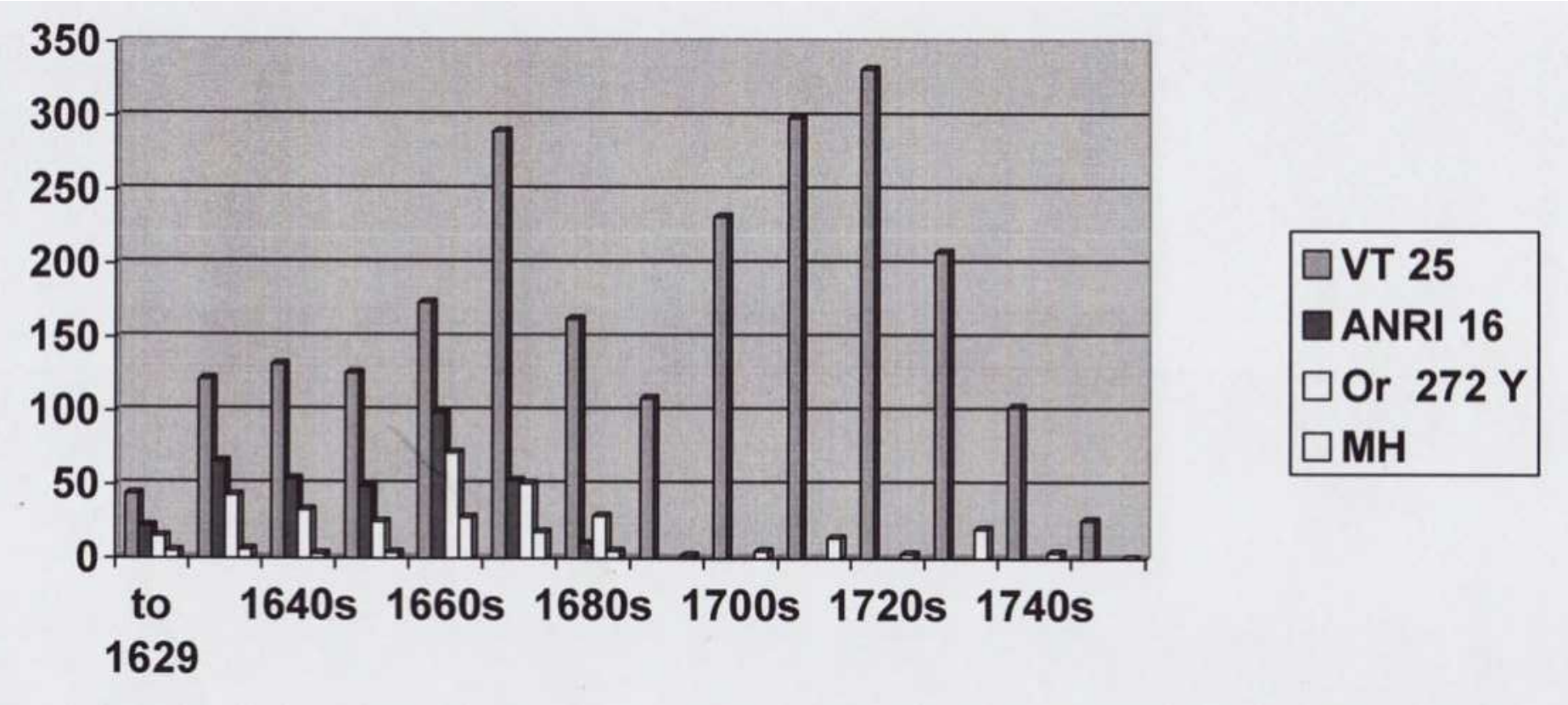

Figure 1. Lontanaraq bilang manusript entries by decade 
and Or. 272Y (which ends in 1689) that only cover the seventeenth century fit this hypothesis. It is during the early eighteenth century that the annals seem to recover from their nadir in the 1690s. Politically, it was also during the early eighteenth century that Talloq's rulers 'captured' the throne of Gowa through marriage, installing a son of Sultan Abdul Kadir of Talloq as Gowa's ruler in 1709. Moreover, it is shortly after this that we get definitive proof that the Makassar annals were now being composed by a Talloq noble.

The one annalist whose identity we know was Karaeng Lempangang, who was born on 7 December 1709. He was a son of the newly-crowned ruler of Talloq Sultan Sirajuddin, and himself succeeded a brother as ruler of Talloq in 1739. When Karaeng Lempangang became an annalist is uncertain, as is exactly how long he performed this duty. It may have only been a few years, but he performed the important work of making a new copy of the annals and in so doing inscribed his identity into the text. He did so by using the first person, identifying other nobles as 'my younger uncle', 'my grandparent', 'my mother', or 'my friend'. His recopied 18 December 1714 entry describing when he gained his karaeng-title reads, 'the people of Lempangang went to myself'. He was not always consistent at this, however, for a 1 December 1722 entry using his personal name reads 'I Mappaingaq Syafiuddin circumcised'. But in numerous entries from 1713 to 1731 Karaeng Lempangang used the first person to describe his kinship relations with those whose actions were recorded in the annals. After this period, however, all later references to Karaeng Lempangang are in the customary third person, beginning 15 June 1733. This indicates that he had passed on the lontaraq bilang duties to another annalist in the early 1730s. In the manuscript that Ligtvoet (1880:3) copied and used, a change in paleography coupled with the entries about Karaeng Lempangang convinced Ligtvoet that after 1731 a new annalist took over. It seems likely that sometime in 1731 Karaeng Lempangang made a complete copy of the lontaraq bilang manuscript that he had inherited and which he bequeathed to a new annalist shortly thereafter. ${ }^{3}$

The kind of editorial changes that Karaeng Lempangang made were not unusual. Numerous writers replaced names or titles of individuals in a given entry with posthumous or other titles that the subject had received later. The proliferation of titles and the inconsistency of annalists sometimes makes it difficult to determine whose actions are being recorded, especially because many karaeng-titles in particular were held by several people over the

3 A second annalist who refers to himself by name is Makkaraeng Zainuddin, who recopied the entry noting his birth on 26 December 1722 using the first person. His 27 January 1748 entry suggests he had taken over the duties of annalist by that point. The only other annalist to use the first person was an unknown successor to Karaeng Lempangang who on 16 June 1751 wrote 'I hear of the death of I Puaq Ninaq across on Sumbawa.' 
course of a century or more. Even more problematic are entries describing people in terms of kinship relations from a much later period. For example, a 1626 entry reads, 'a grandparent of Karaeng ri Bontoa born who was only four months older than the mother of Karaeng ri Balloq'. In some cases we can determine the names of such individuals, and in other cases we cannot. These entries do mark the importance of, in this case, Karaeng ri Bontoa and Karaeng ri Balloq in the eyes of the annalist copying the text, which opens up other analytical possibilities even as it complicates identifying individuals in the text. Annalists also interpolated events they considered of special importance into the manuscript, such as the 2 March 1602 founding of the VOC, Arung Palakka's 25 December 1660 flight from Boné to Buton, and Shaykh Yusuf's death at the Cape of Good Hope on 22 May 1699.

There was clearly no sense among annalists that the text was inviolate and needed to be preserved verbatim. But overall the changes they made were cosmetic, at least when they were making a new copy of the lontaraq bilang to replace an older (and probably decaying) manuscript. But as the section below describing other lontaraq bilang manuscripts indicates, writers were free to create new texts that were extracted from the main court manuscript that VT 25 represents. In these texts, Makassarese could pick and choose the entries for inclusion they considered relevant based on criteria far different from those annalists used many decades earlier.

Whether Karaeng Lempangang and other annalists decided on their own which events were worthy of recording, or whether they entered events into lontaraq bilang at the instruction of the ruler of Gowa (or Talloq) is unknown. Given the political implications of the choices it seems certain that at least some events were entered at the command of the ruler. But other events may have been at the discretion of the annalist.

We also have no way of knowing how Makassarese read, consulted, or used lontaraq bilang during the seventeenth or eighteenth century. We can speculate that Makassarese at the Gowa and Talloq courts may have turned to them for examples of how past rulers confronted different situations, but whether this was with practical, pedagogical, or pleasurable intent is uncertain. It is quite likely that they were important as tangible incarnations of a sacred past, the paper equivalent of the genealogical ties that linked Gowa and Talloq's rulers to an illustrious past. From this perspective, simply having the manuscript may have been more important than actually reading it. It may have been enough to charge a court annalist with the crucial symbolic task of adding new entries to the text, thereby linking the current court and ruler with his chain of predecessors. We simply do not know.

The lontaraq bilang are usefully contrasted with the patturioloang, or royal chronicles, of Gowa and Talloq. From the outset it is clear that these two genres represent quite different historiographical projects. The chronicle 
tradition evolved from oral tales about past rulers and the sacred origins of communities; the annals tradition was borrowed from foreigners, probably Portuguese. Chronicles were genealogically-structured accounts of individual reigns; annals were chronologically-structured accounts of events. Segments of the chronicles were composed at the end of a ruler's life; the annals were progressively composed and events entered as they occurred. It is likely that different individuals were responsible for these two different historiographical genres, for we have no good evidence that lontaraq bilang were a source used by chroniclers, or vice versa. For example, very few individuals named in a given reign of the Gowa or Talloq chronicle are also found in the annals, and the annal entries contain abundant historical information not incorporated into the chronicles. This intriguing fact is further indication of the wide gulf that separates modern historiographical sensibilities from those that influenced the practices of Makassarese historians of the seventeenth century.

\section{Lives, deaths, and other analytical possibilities}

The simplest way that scholars have used the lontaraq bilang is to search among the entries for information about the lives of individuals (especially rulers) or about a particular historical subject such as the establishment of Islamic practices or the construction of fortifications. The sheer quantity of entries also allows us to analyze them in other ways, and this section explores some (but by no means all) of these further analytical possibilities.

As noted previously, we do not know how Makassarese read, consulted, or used lontaraq bilang. But the wealth of genealogical information VT 25 contains allows us to follow the lives of prominent individuals whose birth, experiences, marriages, children, and death were recorded. This biographical perspective on individuals also yields insights into the social dynamics that shaped the lives of the Makassarese nobility. Lontaraq bilang mapped the lives of prominent individuals. Who was deemed worthy of inclusion by the annalists of lontaraq bilang depended on two main factors: rank and political favor. The more closely related an individual was to the ruler at the time that entries were made, the greater the chance that the events of his or her life (and even the fact that he or she existed) would be judged significant. But politics played its inevitable role too.

Not all births, marriages, and deaths were recorded by annalists, even among those closely related to the ruler. The Gowa Chronicle, for example, tells us that $X$ married $X$ times, but only $X$ of his marriages to these wives is commemorated in VT 25. In general, those whose children's births were recorded represent those who were politically in favor at the Gowa court at 
that moment. As court factions contested for influence, gaining or losing the favor of the ruler, the political significance of any one figure would thus wax and wane over time. With the exception of the rulers of Gowa in the seventeenth century, and the rulers of Talloq later, no figure's presence in the lontaraq bilang remained consistent. Reading when a given person appears in the annals, and when they do not, provides insight into the never-ending contests for status and influence that permeated Makassarese political and social life.

An excellent and dramatic example of this is the controversial Makassarese noble Karaeng Karunrung, a central figure at Sultan Hasanuddin's court in the 1650 s and 1660s. Lontaraq bilang entries inform us that Karunrung, a son of the ruler of Talloq Karaeng Pattingalloang, was born on 4 September 1631. In 1654 he became tumabicarabutta or 'speaker of the land', the chief advisor and minister of Sultan Hasanuddin, and in 1660 helped in the fight to put down a major Bugis rebellion. Dutch sources indicate that Karunrung favored war with the VOC and that his advice carried much weight, though it appears that by 1661 he had been replaced as tumabicarabutta by his chief rival, Karaeng Sumannaq (Andaya 1981:60-1). Another political enemy was Sultan Harrunarasyid, the ruler of Talloq who had succeeded Karunrung's father, and the two convinced Sultan Hasanuddin to exile Karunrung in 1664 and then again in 1666. The Makassar annals dutifully record his changing fortunes, including his first exile and loss of possessions on 26 May 1664, his return from banishment on 17 February 1666, his second exile nine months later on 28 November 1666, and his subsequent return to Gowa and to favor on 20 July 1667.

Karaeng Karunrung's turbulent career in Makassarese politics would continue unabated until his death on 27 January 1685. It is particularly noteworthy that while in exile Karaeng Karunrung for all intents and purposes ceased to exist. Dropping off the page and dropping off the face of the earth were much the same thing, it seems. For Karaeng Karunrung, and for other figures in the lontaraq bilang as well, social and textual exile were identical. His presence or absence in the text indicates the changing nature of his relationship to Sultan Hasanuddin, the ruler of Gowa during its most turbulent years. Biographically, then, the Makassar annals can be read as a 'who's who' that assigns significance based on blood rank and political status.

We are not confined to tracking such obvious luminary figures as Karaeng Karunrung, however. Selecting other figures can often shed the most light on Makassarese society and politics. Consider, for example, the role of powerful women in Makassarese politics, something only hinted at in the royal chronicles and the fragmentary Dutch sources of the time. One of the noble women about whom we can learn a substantial amount from her many appearances in the Makassar annals is Karaenta ri Bontojeqneq.

During her lifetime Karaenta ri Bontojeqneq married and divorced four times, twice to rulers of overseas kingdoms within Gowa's political ambit 
(Bima and Sumbawa) and twice to Karaenta ri Jarannika, one of the foremost nobles in Gowa. The motives for these marriages and divorces are not transparent, but their overall effect is clear: they placed Karaenta ri Bontojeqneq along the lines linking future generations with powerful forebears. The rulers of Bima would trace their ascent through her, and had the marriage not failed, the same might have been true of later rulers of Sumbawa and even Gowa through her daughter's marriage to Tuammenang ri Lakiung. Though they produced no children, Karaenta ri Bontojeqneq's two marriages to Karaenta ri Jarannika were strategic and potentially of enormous significance. In fact, Karaenta ri Bontojeqneq was apparently active in court politics, forcing her brother Sultan Hasanuddin to temporarily exile her in 1662. Karaenta ri Bontojeqneq also supervised politically important marriages of her daughters from her first marriage. One married a son of Karaeng Karunrung, the dominant figure at the Gowa court and in Makassarese politics for over two decades. Another daughter was married to a son of Karaenta ri Bontojeqneq's brother Sultan Hasanuddin. Offspring from this marriage of first cousins would have been influential and high-ranking figures at the Gowa court, but the marriage failed shortly before Karaenta ri Bontojeqneq died. Undaunted, her daughter married the ruler of Talloq three months later.

The expansion of a political and social order in which marriage and descent were critical shaped how noble Makassarese women sought influence both in the present and in the future by becoming ancestors linking later generations with influential forebears. Historical records are often made with an eye toward how those in the future will read the past. While this sense of acting for posterity may be increasingly rare in the modern world, it was of the utmost significance in seventeenth-century Makassar. This was a world in which ancestors provided the social rank of their descendants. It was from their blood that one's potential for greatness flowed. Makassarese viewed notable ancestors as the source of their most important values and traditions, and for centuries handed down their words unchanged, seeing them as repositories of ancient, unimpeachable wisdom. The social heights that ancestors occupied was therefore a resource to which later Makassarese were eager to demonstrate connections. Makassarese charted their histories along genealogical lines, passing from one ancestor to the next, tracing their ascent back to the high-ranking and most ancient ancestor possible. It is no surprise that to some day be remembered as an important ancestor was a potent stimulus for Makassarese.

With their ability to marry numerous prominent men, and to bear highranking offspring from more than one noble, Makassarese women such as Karaenta ri Bontojeqneq maximized their chances to become revered ancestors even as they positioned themselves as formidable individuals wielding great influence at court. Karaenta ri Bontojeqneq was not the only 
Makassarese woman to manipulate the politics and possibilities of marriage, offspring, and divorce. Throughout lontaraq bilang manuscripts there are women who astutely maneuver themselves into positions of influence, aligning first with one noble and then another. Examining their lives as recorded in lontaraq bilang brings into sharp focus perspectives on status, success, and political life of high-ranking women in seventeenth-century Makassar.

One final figure whose life and unusual presence within the lontaraq bilang is also worth examining, both for his historical importance and for what he illustrates about the analytical possibilities in these annals. Yusuf was a Makassarese purportedly born, the annals tell us, in 1626 . The fact of his birth was no doubt interpolated into the text at a later date when the significance of his life had become clear. Subsequent entries report with precision that Yusuf requested permission from Gowa's ruler Sultan Malikussaid to go on the haj to Mecca on 22 September 1644 and set sail a month later on October 20th. He likely never returned to Makassar, but occasional entries indicate his importance to annalists. Finally, an entry on 22 May 1699 reports that this was, 'the night of I Tuang Shaykh Yusuf's death overseas at the Cape at the age of 74.' Indeed, it is only then that the curious story of Shaykh Yusuf's posthumous influence over Makassar begins to unfold in earnest.

What followed over the next few years was considerable debate over what to do with Yusuf's corporal remains. We know from other sources that Gowa's ruler Abdul Jalil formally requested that his remains be returned to Makassar, and that this was the subject of much debate among VOC officials. The Makassarese even presented 2000 rijksdaalders on 11 May 1689 to President Hartsink to pay for the expense of returning Shaykh Yusuf (Andaya 1981:276-7). Suspicion over Abdul Jalil's motives and the possible impact of such a repatriation meant that years were to pass before anything happened. Of this diplomatic wrangling the annalists have nothing to say, though it is likely that the 15 June 1699 entry reporting that three moons were seen and the 25 July 1699 entry reporting that two suns were seen were portents connected to Yusuf's death.

Eventually, on 5 April 1705, 'the remains of I Tuang Shaykh Yusuf (may Allah bless him) arrived and was buried in Lakiung the next day.' Burials were elaborate affairs in premodern Makassar (Gervaise 1701:140-7) and locating Yusuf's grave in Lakiung in close proximity to the royal graves of the rulers of Gowa was an indication of his significance in both life and death. It is from this date that the tradition of Shaykh Yusuf's grave as a site of spiritual pilgrimage dates. Subsequent entries confirm Shaykh Yusuf's importance in Makassar. His descendants married into the royal families of South Sulawesi, and an entry from 3 July 1747 specifically describes the completion of a domed structure over his grave. In other words, with the case of Shaykh Yusuf we have a range of textual clues about Makassarese attitudes toward the death of exceptional individuals and the development 
of religious practices within a contested colonial environment.

The lives of individuals like Karaeng Karunrung, Karaeng ri Bontojeqneq, and Shaykh Yusuf are a rich province for historical analysis. As one would expect in a genre centered on royal courts inhabited by an ever-changing cast of nobles and notables concerned with the omnipresent struggles for social status and political influence, the social maps we can sketch are by and large concerned with the pre-eminent figures of their time. Tracking such luminaries as they jockeyed for power, moved in and out of the textual record, or in other ways cast a long shadow over the Makassarese historical landscape is one of the most obvious ways historians can tap these records. But there are other ways to analyze the Makassar annals that move beyond simple biographies or tracking events.

For example, a coherent body of 2360 entries is ripe for demographic and quantitative analysis. One way to begin mining this enormously rich vein of information is by asking which of these diverse topics most consistently captured the attention of annalists. From this perspective, it is clear that the greatest concern of Makassarese annalists was death. For over a century, the deaths of their fellow nobles, close relatives, and even notables far from Makassar were the events annalists were most inclined to preserve. From the first entries in the early seventeenth century until the last entry at the close of 1751, successive annalists recorded 768 deaths in the 2360 dated entries in the text. In other words, a third of all entries dealt with the fact of death. This is over twice the number of entries dealing with the other great social and demographic concerns of premodern Makassar: births are noted in 342 entries $(14 \%)$, marriages of one sort or another in 327 entries $(14 \%)$, and divorces in 155 entries (7\%).

Death forces us to find meaning in tragedy (or triumph) and to order social relationships with those already dead and those still living. For Makassarese, memorializing deaths was a means to grapple with the dominant social and political themes of their era, such as the spread of Sufi Islamic brotherhoods and the existential threat posed by the advent of Dutch colonial rule in the late seventeenth century. It was also a chance for individual annalists to ponder more personal questions about their own identities and systems of belief.

Demographics and the lives of individuals like SY with his life, death, and subsequent career can also be a starting point for other kinds of analysis. We can calculate a wide array of demographic information of which for most of Southeast Asia during this period we have only impressionistic evidence. For example, we can calculate the average age at which such rituals as circumcisions and teeth filings were performed, the age of men and women at their first marriage, the frequency of divorce, lifespan among noble men and women, and so forth. These examples are but the proverbial tip of the iceberg. The richness of these entries to historians is limited only by our imagination in putting them to creative analytical use. 


\section{The lontaraq bilang manuscripts}

There is no canonical lontaraq bilang text. In $1880 \mathrm{~A}$. Ligtvoet published a transcription and Dutch translation of a Makassarese lontaraq bilang manuscript currently catalogued as Or. 236 in KITLV. He made his copy of the manuscript in the mid-nineteenth century, but noted that it was not the only lontaraq bilang manuscript (Ligtvoet 1880:1-2). Or. 236 is nearly identical to and seems to be a copy of VT 25, an Indonesian National Library manuscript dated 1874 that may itself be the manuscript Ligtvoet used or another copy of it. Ligtvoet's 'Transcriptie van het Dagboek der Vorsten van Gowa en Tello' is the standard text that subsequent scholars have consulted, preferring it to an Indonesian translation of the same manuscript published more recently (Kamaruddin et al. 1985-1986). Yet Kamaruddin et al. (1985-1986) contains numerous entries not found in Ligtvoet, who stated clearly that he was only publishing extracts rather than a complete transcription and translation of the manuscript. For example, there are 122 entries in VT 25 for the 1630s, all of which are in Kamaruddin et al. but 27 of which are not found in Ligtvoet. There is also the problem that sometimes the Makassarese text is given but no translation provided in Ligtvoet, which makes this edition problematic for scholars working only with the Dutch translation. Furthermore, some entries contained in VT 25 are found in neither Ligtvoet nor Kamaruddin, with the result that important information has not been available to historians of the period. Indeed, an entire manuscript page of seventeen entries from 1721-1722 is missing in Kamaruddin and reduced to seven entries in Ligtvoet. In total, while VT 25 contains 2360 entries, Kamaruddin's Indonesian translation contains 2320 entries (98\%) and Ligtvoet's Dutch translation only 1241 entries (53\%).

Figure 1 represents the total number of entries per decade in VT 25 and three other lontaraq bilang manuscripts. Two of these additional manuscripts contain only seventeenth-century entries. VT 25 stands out for both its chronological breadth and its quantity of entries. VT 25 has 175 manuscript pages containing 2360 individual entries. There are only 46 entries from 1545 to 1630, and then 2314 entries (an average of 19.1 per year) from 1631 to 1751. Some decades are comparatively rich with entries (the 1720s average 33.2 entries per year) and some are comparatively poor (the 1690s average 10.9 entries per year). The number of entries begins to decline in the early 1740s, though there are 16 entries for the final year of 1751 . The first spikes in entries during the 1670s, followed by a decline in annalist activity before another period of intense recording in the 1710s and 1720s, indicate that this was by no means a static or consistent tradition. The paucity of entries in the last decade of the seventeenth century may well be a reflection of the chaos and despair that gripped Gowa in the wake of the Makassar War (1666-1669). The tradition moved to Talloq's court in the eighteenth century, and the upswing 
in entries beginning in the 1710s no doubt reflects the personal diligence of Karaeng Lempangang.

The following additional manuscripts were consulted in preparing this edition:

1. ANRI 16/6 (a copy is held at the Universiteitsbibliotheek, Universiteit Leiden under catalog number Cod. Or. 14,450 and is described as a manuscript owned by Andi Ijo, former karaeng of Gowa) has a section of lontaraq bilang entries on pages 47-65 that cover years 1605 to 1682. It is written in the lontaraq beru script. The text does not give days of the week for entries, and it omits much of the genealogical information about births, marriages, and deaths found in VT 25. Yet it does contain valuable information not found in VT 25. This includes details within entries and complete entries not found in VT 25. The unique entries in this manuscript are provided in chapter III.

ANRI 16/6 is the most fascinating of the lontaraq bilang texts because of its striking uniqueness.

The variations in phrasing, word choice, and word order within parallel entries are evidence that this text is not a simple copy of VT 25's ancestor. Coupled with the presence of entries either not found or substantially different from those in VT 25 and the differences in dates for the same events (such as the initial conversion to Islam in 1605), it is highly likely that the ancestor of ANRI 16/6 represents a separate lontaraq bilang tradition. It may well have been written contemporaneously with the ancestor of VT 25. A good example of the differences in perspective that suggest this possibility are the entries for 9 December 1632. VT 25 stresses that an envoy from Banten arrived bearing the body of Tumatea ri Banten, while ANRI 16/6 notes that this envoy was from Mataram and brought a text written on slats of bamboo that had been woven together. Despite the discrepancy in understanding about where on Java the envoy arrived from, both may be correct and represent the different perceptions of two annalists about what most important to record (or simply what they individually witnessed) about the envoy's arrival. On other occasions, relatively long entries such as 29 February 1636 have the same wording, which may simply mean that the two annalists listened to the same report about what transpired. A good example of simple differences is the entry for 11 August 1663: VT 25 has 'namaqballaq taua ri Jongaya' (people built houses in Jongaya) and ANRI 16/6 has 'paqballaqballakangi ri Jongaya' (houses were built in Jongaya). Frequently too different titles are used to describe the same person in parallel entries.

One of the most striking differences between VT 25 and ANRI 16/6 is the latter's indifference to the noble births, deaths, marriages, and divorces that attracted the attention of VT 25's annalist. In this ANRI 16/6 resembles Or. 272Y and the c. 1795 translation in 'Makasaarsche Historiën'. Whether ANRI 
16/6 underwent a culling process by which entries deemed no longer significant is not clear.

The same text contains (with no breaks or other visual clues after the last dated entry to mark a transition) a list of the names and ages of 8 of Gowa's and 4 of Talloq's rulers. The list does not contain Tunipasuluq (not surprising given his reputation) or Pattingalloang (which is surprising and may be a simple omission), but it is more noteworthy that the last rulers in mentions both died in 1709: Tumamenang ri Lakiung of Gowa and Tumamenang ri Passiringanna of Talloq. This helps us approximately date the text; either the original or a very early copy was probably written shortly after 1709 .

2. MH - 'Makasaarsche Historiën'. Tijdschrift voor Indische Taal-, Land- en Volkenkunde 4 (1855):111-45. This article consists of an edited Dutch translation of a 1795 historical manuscript owned by an old man named Ince' Timor living in Maros. The Makassarese text is not provided. Ince' Timor was presumably of mixed Malay-Makassarese descent. We do not know if he was from Maros or if the text was authored there. He did have access to the royal court in order to copy extracts of existing Makassarese texts and the education to author new sections. Part of the manuscript is a lontaraq bilang text containing 117 entries, the first dated 1602 and the last 2 April 1747. Virtually all entries from the seventeenth century are found in VT 25, though the number of entries is much smaller. Many of the eighteenth-century entries that also are found in VT 25 are consistently misdated: generally events took place three years earlier than this text states.

3. Or. $272 \mathrm{Y}$ of KITLV contains 16 pages of lontaraq bilang entries covering the years 1600 to 1689. It is written in the lontaraq beru script. It has 253 entries, about $25 \%$ as many as VT 25 during the same years. It has no unique entries and few noteworthy differences in the content of its individual entries. It is, in other words, highly derivative.

Examination of the similarities and differences between these and VT 25 can reveal much about the lontaraq bilang genre and more general changes taking place in South Sulawesi during this period. To begin, it is striking how the annalist-editors of both $\mathrm{MH}$ and Or. 272 judged the significance of the entries in the royal court annals tradition represented by VT 25. Both MH and Or. 272 are the textual results of an annalist with access to an earlier lontaraq bilang text who selected the entries he or she wished to include. The author of Or. 272Y (or subsequent owners of the manuscript) was apparently content simply with preserving his selection of entries from the seventeenth century. The author of $\mathrm{MH}$ (or, again, subsequent holders of the manuscript) went on from that foundation to continue adding entries to the annals. Both the selection of events concerning the seventeenth century and the nature of the new 
entries in $\mathrm{MH}$ from the eighteenth century provide insight into Makassarese perceptions of their past and present.

Broadly speaking, $\mathrm{MH}$ and Or. 272 represent an eighteenth-century perspective on seventeenth-century Makassarese history. A social, political, and historical re-evaluation took place which derived from the central event in seventeenth-century Makassarese history: the Makassar Wars (1666-1669) and the accompanying fall of the rulers of Gowa and rise of Arung Palakka. The implications for eighteenth-century Makassarese is evident in their choices of initial entries.

The first seven entries in VT 25 cover the years 1545 to 1600. They record the birthdates of Tunijalloq (ruled Gowa 1565 to 1590), Karaeng ri Barombong (a prominent Gowa noble, father of Karaeng Sumannaq), Karaeng Matoaya (ruled Talloq 1593-1623), Tuammenang ri Gaukanna (Sultan Ala'uddin, ruled Gowa 1593 to 1639), Tumammaliang ri Timoroq (ruled Talloq 1623 to 1641), and Tuammenang ri Bontobiraeng (Karaeng Pattingalloang, ruled Talloq 1641 to 1654), calculated by backdating from their ages the year they died, and the death of Tunijalloq in 1590. These six births and one death register the lives and significance of some of the most prominent figures in Gowa and Talloq's history. The eighth entry, dated 2 March 1602 though obviously added much later, registers the creation of the VOC. It is telling that of these eight events, only the 2 March 1602 entry about the VOC is found in Or. 272Y and $\mathrm{MH}$. In fact, it is the first entry in both of these texts. None of the births or deaths of six towering figures in Makassarese history were seen as worthy of inclusion. This is remarkable because the inaugural entries in an annals manuscript are paradigmatic signs of the themes and events deemed most historically significant.

VT 25's seventeenth-century entries are fundamentally concerned with the births, deaths, marriages, and divorces of Makassar's nobility, as Figures 2 and 3 indicate. Nearly two-thirds of VT 25's entries address these four kinds of events; they are the sinews of the text. But from the outset this was deliberately and drastically changed by the creators of $\mathrm{MH}$ and Or. 272Y. Indeed, not a single one of the 72 seventeenth-century entries in $\mathrm{MH}$ commemorates a marriage or divorce. Three births are mentioned, but one of these is of a non-Makassarese shaykh (12 March 1680), and the other two may only have been included because they are embedded in entries discussing the spread of Islam (23 November 1611; 19 April 1632). Or. 272Y has 253 seventeenth-century entries, and thus represents a less rigorous culling on the past of its analyst, but here too the same pattern is evident. The births of only seven Makassarese notables are included, along with three of their marriages and two divorces. Deaths are mentioned frequently in both texts largely because they recorded deaths in battles against the Dutch, but deaths of royal children commonly mentioned in VT 25 are omitted in both $\mathrm{MH}$ and Or. 272Y. In other words, Or. 272Y or MH considered genealogical informa- 


\begin{tabular}{|c|c|c|c|c|c|c|c|c|c|c|c|c|c|c|c|}
\hline & to 1629 & $1630 \mathrm{~s}$ & $1640 \mathrm{~s}$ & $1650 \mathrm{~s}$ & $1660 \mathrm{~s}$ & $1670 \mathrm{~s}$ & $1680 \mathrm{~s}$ & $1690 \mathrm{~s}$ & $1700 \mathrm{~s}$ & $1710 \mathrm{~s}$ & $1720 \mathrm{~s}$ & $1730 \mathrm{~s}$ & $1740 \mathrm{~s}$ & $1750 \mathrm{~s}$ & total \\
\hline \# entries & 44 & 122 & 132 & 126 & 174 & 290 & 163 & 109 & 232 & 299 & 332 & 208 & 103 & 26 & 2360 \\
\hline births ${ }^{1}$ & $18(41 \%)$ & $20(16 \%)$ & $26(20 \%)$ & $33(26 \%)$ & $15(9 \%)$ & $42(14 \%)$ & $35(21 \%)$ & $18(17 \%)$ & $24(10 \%)$ & $30(10 \%)$ & $46(14 \%)$ & $10(5 \%)$ & $11(11 \%)$ & $4(15 \%)$ & $342(14 \%)$ \\
\hline deaths ${ }^{2}$ & $6(14 \%)$ & $32(26 \%)$ & $43(33 \%)$ & $27(21 \%)$ & $45(26 \%)$ & $84(29 \%)$ & $39(24 \%)$ & $43(39 \%)$ & $70(30 \%)$ & $92(31 \%)$ & $147(44 \%)$ & 98 (47\%) & $32(31 \%)$ & $10(38 \%)$ & 768 (33\%) \\
\hline marriages $^{3}$ & $2(5 \%)$ & $6(5 \%)$ & $14(11 \%)$ & $20(10 \%)$ & $17(10 \%)$ & $75(26 \%)$ & $37(23 \%)$ & $10(9 \%)$ & $44(19 \%)$ & $39(13 \%)$ & $35(11 \%)$ & $13(13 \%)$ & $13(13 \%)$ & $2(8 \%)$ & $327(14 \%)$ \\
\hline divorces 4 & $1(2 \%)$ & $1(1 \%)$ & $1(1 \%)$ & $12(10 \%)$ & $12(7 \%)$ & $38(13 \%)$ & $21(13 \%)$ & $3(3 \%)$ & $26(11 \%)$ & $19(6 \%)$ & $11(3 \%)$ & $6(1 \%)$ & $1(1 \%)$ & $3(12 \%)$ & 155 (7\%) \\
\hline
\end{tabular}

1 Includes reports of births elsewhere.

2 Includes reports of deaths elsewhere and infants who died soon after birth.

3 'Marriages' refers here to all types of recognized relationships established between men and women, including 'married' (sikalabini, which is by far the most common), 'wed' (bunting), 'wed [in accordance with Islamic custom]' (nikka), 'returned to each other' (sipolei), 'engaged' (parekang), 'proposed to', (nipassuroi), 'eloped' (loriang), 'pledged to each other' (pasibayuang), and 'slept with' (lusereq).

4 'Divorces' likewise refers to several ways of ending relationships, including 'divorced' (sipelaq, by far the most frequent), 'broke off' (tappuki), 'forcibly separated' (sisallaqlaq), and 'severed' (katto).

Figure 2. Number of births, deaths, marriages, and divorces per decade (absolute and as percentage of entries 


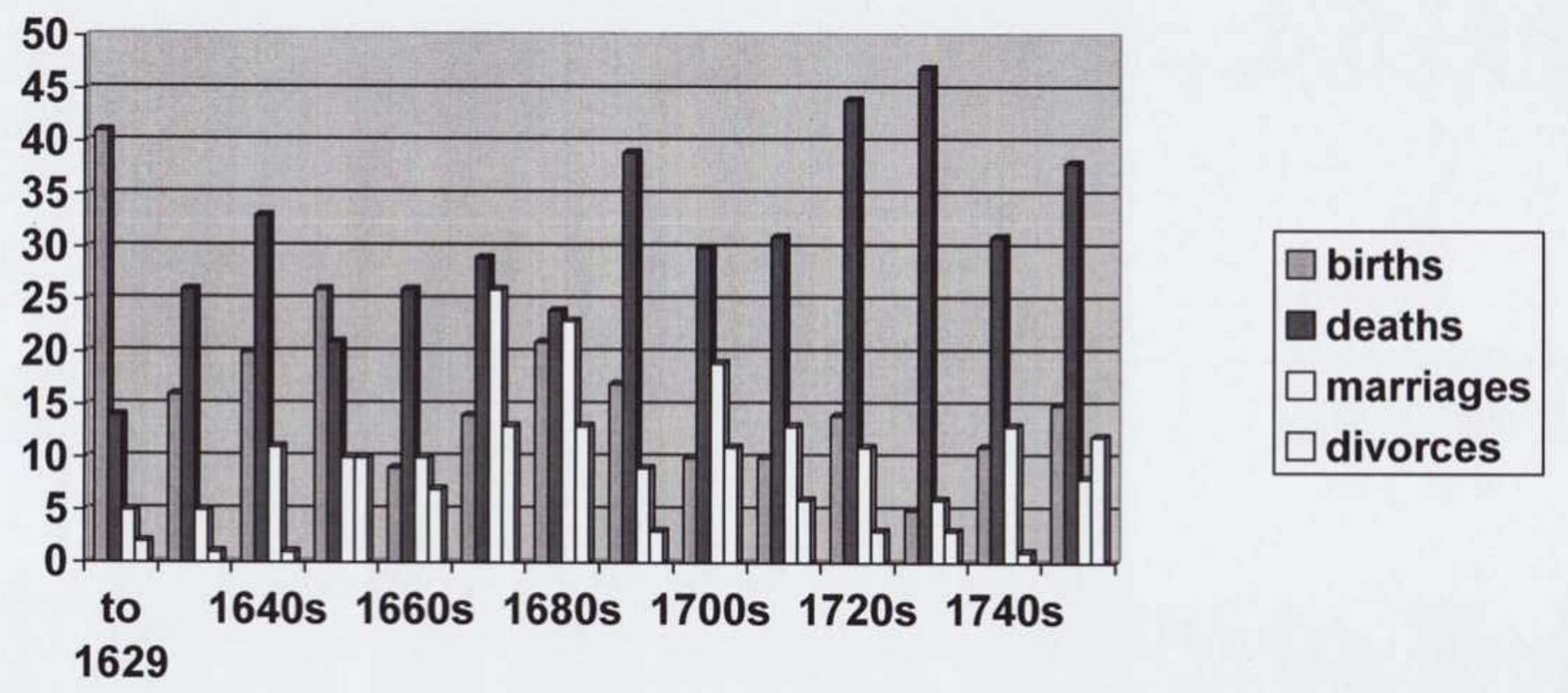

Figure 3. Percentage of entries per decade containing births, deaths, maariages, and divorces 
tion about the rulers of Gowa no longer significant in an eighteenth-century Makassar these rulers no longer controlled.

What did concern the writers of $\mathrm{MH}$ and Or. 272Y was Islamic practices and innovations, the life and deeds of Arung Palakka, natural and supernatural portents, and war with the VOC. Following the first entry noting the establishment of the VOC, the next five entries in Or. 272Y (and the next four entries in $\mathrm{MH}$ ) all concern Islam. Matoaya and Ala'uddin's conversion to Islam, the first Friday prayer service in Talloq (Or. 272Y only), and the wars of Islamization against Soppéng, Wajoq, and Boné are dutifully chronicled. That is to say, these were judged as being of the utmost historical importance. This attention to Islamic practices and foundational events in Islam's spread in South Sulawesi is evidence of the degree to which Makassarese conceptualized themselves as living in a Muslim society whose past needed to recount the story of how that happened. The writers of MH and Or. 272Y in essence Islamicized Makassar's past to a much greater degree than we see in either VT 25 or the royal chronicles of Gowa and Talloq.

$\mathrm{MH}$ and Or. 272Y were also much concerned with Arung Palakka and the war with the VOC that brought Arung Palakka to political power in South Sulawesi. In MH, 16 entries record his movements, actions, wounds, and finally his death on 6 April 1696. So too the turbulent decades of the 1660s (28 entries) and 1670s (18 entries) are well represented in this lontaraq bilang. The annalist of this text judged the events of the Makassar War and the tumultuous upheaval that followed the overthrow of the rulers of Gowa and Talloq by Arung Palakka and the VOC of enduring significance. Undoubtedly this is because these decades marked the fundamental watershed that led to the world that eighteenth-century Makassarese experienced. The tremendous uncertainty that this produced is recorded in another way as well.

Far more frequently than VT 25, MH and Or. 272Y record all manner of wondrous events and supernatural omens, from two suns appearing in the sky to comets eight consecutive nights to dead men coming back to life. In the years before 1667 only three such events are noted (an average of one every 22 years) in $\mathrm{MH}$, while for the years after 1667 nineteen such events are registered (an average of one every four years). Or. 272Y shows the same pattern. These entries record a perception of a world that had changed fundamentally and that was filled with ambiguous happenings. These two annals are an acknowledgment of how much Makassar had been transformed by the events set in motion by the Makassar War. In this new presentation of the past, the lives of Makassarese rulers textually disappeared, while the presence of Arung Palakka, the momentous events he caused, and the uncertain world in which Makassarese now found themselves remained.

What Or. 272Y or MH represent is a shift from an annalist recording what was socially significant at the time to an annalist selecting entries for inclu- 
sion based on what was judged historically significant. This is a considerable change. What separates the two writers is of course time's passing and, perhaps more importantly, colonialism. Once Gowa and Talloq had lost not simply their pre-eminence within South Sulawesi but their independence after the 1669 conquest by the VOC and their Bugis allies the social order built upon dense layers of kinship and status relationships that sustained and defined these two kingdoms crumbled. It no longer made a difference when the nobles of a bygone age had married, had children, and died. That world no longer existed, and its commemoration served no purpose. In contrast, entries related to Islam, conquests, wars with the Dutch, and unusual or supernatural events did still matter. The shift in mentality is revolutionary, and a comparison of annals like $\mathrm{MH}$ and Or. $272 \mathrm{Y}$ with the royal court lontaraq bilang tradition that VT 25 preserved allows us to bring it into sharp and dramatic focus.

We can also gain a useful perspective on this shift in mentality by collating the entries from the five manuscripts that cover the same period of the seventeenth century. In particular, we can better appreciate what might have been the 'core' themes of the annals tradition by examining the common entries found in all five manuscripts. The following are the dates of the entries from the seventeenth century found in VT 25, ANRI 16/6 (up to 1682), Or. 272Y (up to 1689), and 'Makasaarsche Historiën' (to 1700).

\begin{tabular}{|c|c|}
\hline & 22 September 1605 \\
\hline $1600 \mathrm{~s}$ & 1609 \\
\hline \multirow[b]{2}{*}{ 1610s } & 10 May 1610 \\
\hline & 23 November 1611 \\
\hline \multirow[b]{3}{*}{$1640 s$} & 14 January 1641 \\
\hline & 16 May 1642 \\
\hline & 13 January 1649 \\
\hline \multirow{12}{*}{$1650 s$} & 25 November 1651 \\
\hline & 23 October 1655 \\
\hline & 13 December 1656 \\
\hline & 12 June 1660 \\
\hline & 21 September 1660 \\
\hline & 11 October 1660 \\
\hline & 24 November 1660 \\
\hline & 2 December 1660 \\
\hline & 20 August 1663 \\
\hline & 16 August 1666 \\
\hline & 19 December 1666 \\
\hline & 18 December 166 \\
\hline
\end{tabular}


23 December 1666

25 December 1666

13 July 1667

1 August 1667

19 August 1667

4 September 1667

18 November 1667

21 November 1667

29 December 1667

6 March 1668

14 April 1668

8 November 1668

13 November 1668

16 June 1669

24 June 1669

28 July 1669

1660s 28 October 1669

28 March 1670

29 March 1670

28 May 1670

22 April 1674

27 Sep 1675

28 March 1676

3 April 1676

11 April 1676

27 April 1676

13 May 1676

17 April 1677

3 May 1677

23 May 1677

27 July 1677

7 October 1678

1670s 21 October 1679

12 March 1680

15 June 1680

24 July 1683

3 February 1687

1680s 8 February 1689

6 April 1696

15 June 1699

1690s 25 July 1699 
There are 60 common entries through 1700. The early common entries from the 1600s and 1610s are few in number, but all concern the adoption and spread of Islam in Gowa's wars of Islamization. They are thus crucial moments in the history of a Muslim society whose inclusion in all five of the texts is to be expected. The six entries from the 1640s and 1650s all deal with foreigners in one way or another, either as bringers of rare gifts such as an elephant or tiger, or as dangerous foes whose conquests and activities were important to mark.

The vast bulk of the common entries concern the 1660 s and 1670s. It is not surprising that the 26 entries from the 1660s deal almost exclusively with Gowa's wars against the VOC and Arung Palakka. Similarly, the 16 entries from the 1670s deal almost exclusively with the actions of Arung Palakka, who from the perspective of these common entries is clearly the historical protagonist dominating this decade. Of the remaining eight entries, two again concern Arung Palakka, while the other six describe unusual portents from the natural world such as eclipses and sightings of multiple moons and suns.

Like the editorial judgments about past events made by the writers of $\mathrm{MH}$ and Or. 272Y as they selected what to copy, the nature of the common entries are a window onto the mentality of Makassarese living in an era in which old certainties had evaporated. The rulers of Gowa and Talloq before 1669 had anchored Makassarese society. They had provided the social and political center around which others moved in orbit and by which they judged themselves. Neither the Bugis after the death of Arung Palakka or the Dutch in their Makassar factory dominated Makassarese society to any significant degree. But as the events in the annals make clear, neither could the subsequent rulers of Gowa and Talloq recapture or recreate the glory of the past.

Karaeng Bontolangkasaq's rebellion and brief capture of Gowa came close, but his death was in many ways the end of dream that Makassar's golden age could be captured. As one elderly Makassarese warrior reportedly said when he surrendered his sword to the Dutch,

I have seen this city of Gowa in her greatest splendor, when it was master of the whole island of Celebes; also [I saw her] in her first debasement when we were defeated by the Company; however she remained habitable and respected, despite the loss of her greatest splendor; but now she appears brought to ruin. The first time I [surrendered] my dirk at Sombaopu, the second time at Surabaya, and now for the third time I surrender [it] to the victorious weapons of the Company. Nothing remains for me, except to gain forgiveness and to die in peace (Blok 1848:24).

Sporadic rebellions and millenarian movements flared frequently in the second half of the eighteenth century (and beyond), but Makassar was in grievous decline. That the post-conquest era would fixate the people of 
Makassar's attention on portents and omens on the one hand, and on the origins and practices of Islam and on other is ultimately not surprisingly.

In many ways, then, the nearly 2400 entries translated here have much to tell us about Makassarese history. They can be used to learn about specific people and events, broader historical processes and developments, and even provide evidence of more subtle shifts in thinking and culture. Without further ado, let us turn to the annals themselves. 


\section{II \\ The annals \\ Transliteration, translation, and notes}

1545

955 this year Tunijalloq purportedly born; he reached age 45 maka ia anne kutaeng kaanakkanna Tunijalloq 45 umuruqna

1572

982

this year Karaeng ri Barombong ${ }^{1}$ purportedly born; he reached age 70

maka ia anne kutaeng kaanakkanna Karaengta ri

Barombong umuruqna 70

1573

983

this year Karaeng Matoaya purportedly born; he reached age 63

maka ia anne kutaeng kaanakkanna Karaeng Matoaya umuruqna 63

1586

996

this year Karaeng Tumamenang ri Gaukanna [Ala'uddin] purportedly born; he reachedage 53

maka ia anne kutaeng kaanakkanna Karaenga

Tuammenang ri Gaukanna umuruqna 53

1 A son of Tumenanga ri Makkoayang and half-brother of Karaeng Matoaya, he was a figure whose importance is in part concealed by the fact that he never became a ruler and thus does not feature prominently in the chronicles of Gowa and Talloq. 


\section{0}

3 Muh $1002^{2} \quad$ Karaeng Tunijalloq cut down; he reached age 45 nanijalloq Karaenga Tunijalloq umuruqna 45

1593

1008

this year Karaeng Tumammaliang ri Timoroq Mudhaffar purportedly born; he reached age 43

maka ia anne kutaeng kaanakkanna Karaenga Tumammaliang ri Timoroq Mudhaffar umuruqna 43

1600

Aug 1009

this year Tumamenang ri Bontobiraeng [Pattingalloang] purportedly born; he reached age 54

maka anne kutaeng kaanakkanna Tuammenang ri Bontobiraeng umuruqna 54

1602

2 Mar (W) the Dutch company [Verenigde Oostindische Compagnie] established; 73 people amassed 2,640,000 reals ${ }^{3}$ namappareq kompania Balandaya 73 tau namappasseqre realaq 2640000

1605

22 Sep (R eve) the two brother-karaengs [Matoaya and Ala'uddin] embraced Islam

9 Jawl $1015^{4} \quad$ namantama Islam karaeng rua sisariqbattang

1607

11 Dec (T) Karaeng Tumamenang ri Papambatuna Muhammad Said [Malikussaid] born

Raj $1016^{5} \quad$ naanaq Karaenga Tuammenang ri Papangbatuna Muhammad Said

2 The Hijri date converts to 28 Sep 1593. Discrepancies will only be mentioned in the notes if the two dates differ by more than a week. In all other cases readers may assume a close correspondence between the two calendrical systems. If an entry contains only a Hijri date, the equivalent Gregorian date is found in the notes.

3 This entry is certainly a later interpolation into the text. A real was a Spanish silver coin widely used in Asia. Its value tended to vary, but normally was worth about 2,5 Dutch guilders (Andaya 1981:footnote 317).

4 The Hijri date converts to 12 Sep 1606. Though this entry gives a Gregorian date of 22 Sep 1603 , this is incorrect and has been changed to 22 Sep 1605. Noorduyn (1956) concluded that this was the correct date, and in fact is the date given in ANRI 16/6.

5 The Hijri date is approximately one month earlier. ANRI 16/6 places this birth in 1606. 
$9 \operatorname{Nov}(\mathrm{F}) \quad$ Friday public prayers first established in Talloq; we were first Muslim; this year purportedly took place the war at Tamappalo ${ }^{6}$

18 Raj 10177 nauru mammenteng jumaka ri Talloq uru sallanta ia anne bedeng bunduka ri Tamappalo

16098

the people of Soppéng embrace Islam [after] battle at Pakenya namantama Islam tuSoppenga bunduka ri Pakenya

1610

10 May

10 Saf 1019

the people of Wajoq embrace Islam

namantama Islam tuWajoka

1611

$23 \operatorname{Nov}(\mathrm{T}) \quad$ Boné defeated in the war of Islamization; this year I Amboq purportedly born ${ }^{9}$

23 Ram 1020 nabeta Bone ri bunduq kasallanganga ia anne bedeng nakaanakkang I Amboq

1615

28 Apr

sabannaraq Anciq Using taken by the Dutch ${ }^{10}$

28 Rawl 1024 nanialle Anciq Using sabannaraka ri Balandaya

12 Dec (S) Karaeng ri Tangallaq Sitti Maradiah ${ }^{11}$ born

20 Zulk 1024 naanaq Karaengta ri Tangallaq Sitti Maradiah

1616

Nov

Karaeng ri Kassiqjala born

Syaw 1025

naanaq Karaengta ri Kassiqjala

6 Presumably this refers to a major battle in Gowa's first war of Islamization (bunduq kasallannganna) against Boné, Soppéng, and Wajoq.

7 The Hijri date for this momentous event converts to 27 Oct 1608, nearly a year later than the Gregorian date.

8 No date is provided for this entry, but based on Bugis sources Ligtvoet (1880:footnotes 86 and 87) concludes that this must have taken place in 1609. ANRI 16/6, however, records that it was in 1608 .

9 I Amboq's purported birth is almost certainly a later interpolation.

10 The Dutch capture of two Makassarese notables in April 1615 is discussed in IJzerman 1922:344. ANRI 16/6 adds that the name of the second captive was Karaeng ri Kotengang.

11 A daughter of Tumammaliang ri Timoroq. This name is spelled Sitti Maralia in the Talloq Chronicle. 
$\mathrm{Apr}^{12}$

1 Oct $1618(\mathrm{M})$

16 Syaw $1027^{15}$

$30 \operatorname{May}(\mathrm{R})$

2 Zulk $1028^{17}$

June (F)
1618

I Loqmoq ri Mandalleq went over to Bima and conquered Bima with only nine ${ }^{13}$ vessels; this purportedly was the year Karaeng Matea ri Bima born

nantaqle ri Dima I Loqmoq ri Mandalleq nanabeta Dima salapangji batunna maka ia anne kutaeng taunga nakaanakkang Karaengta Matea ri Dima

ritual with the bamboo ${ }^{14}$ held; something was seen resembling a banner

kaparekanga ri pattonga naniaq niciniq kuntu bate

\section{9}

the Dutch first occupied Jakattaraq ${ }^{16}$

nauru naempoi Jakattaraq Balandaya

Tumamenang ri Papambatuna [Malikussaid] circum-
cised $^{18}$; Karaeng ri Maroanging went over to Bima and
conquered Bima and Sumbawa $^{19}$

12 Unusually, no Hijri date is given for this entry. The text does not write the year, which gives the impression that this also took place in 1616, but the graphic arrangement of the text makes it likely that this was a simple omission. While at first glance one would assume the correct year is 1617 - and this is in fact the year given in ANRI 16/6. Based on other sources Noorduyn (1987) concluded that the more likely date is Apr 1618.

13 ANRI 16/6 records that only seven ships were involved.

14 The nature of the ritual described by the phrase 'kaparekang ri pattonga' is unknown.

15 VT 25 has the Hijri year as 1028, but this is likely a copyist error. The same Hijri date for 1027 converts to 5 Oct 1618, which closely matches the Gregorian date and best follows the graphic patterns the writer of the text used to indicate separate years.

16 This is the Makassarese spelling of Jayakerta (Jakarta), which Jan Pieterszoon Coen conquered from the Bantenese and which came to be called Batavia after the VOC trading post there.

17 The writer of the text mistakenly wrote 1618 in place of 1619 for the Gregorian date. The Hijri date converts to 10 Oct 1619. The correct date is 30 May 1619. Makassarese would have learned of this date later and interpolated it into the text, apparently making the simple mistake of writing the wrong year. Less likely, but possibly, the discrepancy can be explained if the annalist learned of it by 10 Oct 1619, which indeed was a Thursday, and the date 2 Zulkaedah 1028 corresponds to its moment of inscription. In this case, the annalist was using the two calendrical systems to record two separate moments: the event itself and the date it was entered into the text.

18 ANRI 16/6 records that he was 'engaged' (nanikaparekanga) rather than circumcised. Given his age (12) this is entirely plausible.

19 ANRI 16/6 adds 'again' (pole), correctly clarifying that this was not the first conquest of Bima and Sumbawa. 
Zulk $1028^{20}$

nanisunnaq Tuammenang ri Papanbatuna namantaqle ri Dima Karaenga ri Maroangin nanabeta Dima Sambawa

26 Zulk 1028 $21 \quad$ Tumamenang ri Bontobiraeng [Pattingalloang] and I

Bissu Caqdi divorced; Karaeng ri Sumannaq ${ }^{22}$ then called her his wife; this the year Tamalate ${ }^{23}$ was built nasipelaq Tuammenang ri Bontobiraeng I Bissu Caqdi Karaengta ri Sumannaq bainea nikana maka ia anne taunga nanibangung Tamalate

28 Zulk $1028^{24}$ there was feasting at Tamaqrappo ${ }^{25}$ napakkaqdokang Tamaqrappo

1620

$1030^{26}$ in the winds there were people who went amuk; this year I Daeng ri Kasammeng purportedly born ${ }^{27}$ panirikang naniaq tumaqjalloq ia anne bedeng kaanakkanna I Daeng ri Kasammeng

20 As in the previous entry, the copyist error of writing 1618 for 1619 has been corrected. The Hijri date converts to Oct 1619. No day was supplied either because the conquest did not take place on a single day or because the annalist's informant did not know the precise date when it was recorded later. This may be a case too where the Hijri date corresponds to the date the annalist recorded the news that arrived from Bima.

21 The Hijri date converts to 3 Nov 1619.

22 A son of Karaeng Barombong and grandson of Tumenanga ri Makkoayang, he later became tumabicarabutta of Gowa.

23 A royal hall of Gowa.

24 The Hijri date converts to 5 Nov 1619.

25 A royal hall of Gowa.

26 The Hijri date converts to late 1620 or 1621 . No more precise date is given, possibly because people went amuk over the extended period of the monsoon season. This entry apparently was written at the end of 1620 and represents the annalist's summation of what took place rather than a contemporary observation.

$27 \quad$ After this entry the copyist mistakenly wrote a portion of the 23 Mar 1623 entry regarding the Portuguese galley. It has been omitted here. 
1622

8 May (S)

16 Jakr $1031^{29}$

earthen works ${ }^{28}$ first established in Borongloe uru panambungianga ri Boronglowe

12 Aug 1622

22 Ram $1031^{30}$

I Daeng ri Takka died

namate I Daeng ri Takka

1623

$23 \operatorname{Mar}(\mathrm{T})$

1 Jawl $1032^{31}$

the Portuguese ship known as a galley raced nanilumba jalleaya biseang Paranggi nikana

1624

17 Mar

14 Jawl $1033^{33}$

Karaeng ri Maroanging 32 died

namate Karaengta ri Maroanging

18 Aug $^{34}$

water first taken from irrigation canals in Pareq nauru nialle jeqneq panaika ri Pareq

28 Ram $1033^{35}$ Samanggi opposed; those living there were unprepared nabali Samanggi naempoi tumaqlaqbe-laqbe

28 The meaning of 'panambungiang' is unclear here. The most likely possibility is that it is a version of 'pattumbungang,' which means a place where something is piled up, typically earth. Borongloe was one of the communities that made up the original core of Gowa's federation. Located along the Jeqneqberang River some $10 \mathrm{~km}$ from the coast, this entry probably refers to building the first levees that made this a rich agricultural area, but also could mean rebuilding the community on higher ground or possibly even constructing earthen fortifications. The surrounding entries provide no contextual indications of its meaning, nor are there clues in the Gowa and Talloq Chronicles to assist interpretation.

29 The Hijri date converts to 27 Apr 1622, a discrepancy of less than two weeks. ANRI 16/6 places this event in 1621.

30 The Hijri date converts to 31 Jul 1622, a discrepancy of less than two weeks.

31 The copyist erroneously wrote 1622 in place of 1623 . The corrected Hijri date converts to 3 Mar 1623. ANRI 16/6 places this event in 1621.

32 A son of Karaeng Patteqne and a tumailalang of Gowa, he had inherited this post from his father, who had been granted it by Tunipasuluq. Karaeng ri Maroanging was succeeded as tumailalang by his nephew Karaeng ri Suli.

33 The copyist erroneously wrote 1623 in place of 1624 . The Hijri date converts to 4 Mar 1624, a discrepancy of approximately two weeks.

34 The copyist erroneously wrote 1623 in place of 1624. ANRI 16/6 places this event in 1623.

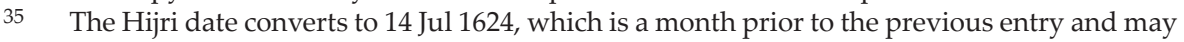
indicate that the news from Samanggi was received later and then added to the text. ANRI 16/6 places this event in 1623. 
1625

12 Apr (F)

22 Jawl $1034^{37}$

there was a council in Malang 36

paqruppa-ruppanga ri Malang

13 Aug

16 Muh $1035^{38}$

Aug

Muh $1035^{39}$

2 Jakr $1035^{40}$

(W eve)

18 Raj $1035^{43}$

3 Jul
Tumamenang ri Papambatuna [Malikussaid] first titled Karaeng ri Lakiung nauru nikana Karae Lakiun Tuammenang ri Papanbatuna

nine ships arrived

nabattu kappalaq salapanga

\section{6}

east to Buton went Karaeng Matoaya with the karaeng [Ala'uddin] for the conquest of Buton; this conquest was the first

namanraiq ri Butun Karaenga Matoaya siagang karaenga lanabetana Butun beta riolona

a grandparent of Karaeng ri Bontoa ${ }^{41}$ born who was only four months older than the mother of Karaeng ri Balloq ${ }^{42}$ naanaq toana Karaengta ri Bontoa patambulanji katoanna ayana Karaengta ri Balloq anne

the karaeng [Ala'uddin] returned from Buton, having stopped in Bima and conquered Bima, Dompu, Sumbawa, and Kengkelu [Tambora]; people wed [in accordance with Islamic custom]; this purportedly the year that Shaykh Yusuf was born

36 This is probably found in Tanete or Agangnionjoq.

37 The copyist erroneously wrote 1624 in place of 1625, though ANRI 16/6 does place this event in 1624. The Hijri date converts to 2 Mar 1625.

38 The copyist erroneously wrote 1624 in place of 1625, though ANRI 16/6 does place this event in 1624. The Hijri year in the text is 1034, but 1035 is presumably correct, for that date converts to 18 Oct 1625 .

39 The copyist erroneously wrote 1624 in place of 1625 . The Hijri date converts to October 1625. ANRI 16/6 places this event in 1626.

$40 \quad$ Ligtvoet (1880:footnote 89) suggested and Noorduyn (1987:327) confirmed that based on other evidence a copyist probably mistakenly wrote 1036 in place of 1035 for this and the next two entries. The corrected Hijri date converts to 1 Mar 1626.

41 Ligtvoet (1880:footnote 89) correctly deduces that this grandparent was Ralle Daeng Paikaq, a daughter of Mallewai Daeng Maqnassa Karaeng Cenrana and full-sister of Karaeng Lengkeseq. 42 This was Daeng Talarra, who gained the title Karaeng Tabaringang after 1636. She had four husbands: Karaeng Kotengang, Karaeng Sanrabone (with whom she had four children), Karaeng Patteqne (with whom she had one child), and Karaeng Katinting, with whom she had Karaeng ri Balloq on 22 Jan 1646.

43 The Hijri date converts to 15 Apr 1626. 
8 Syaw $1035^{44}$ nabattu ri Butun karaenga nasumengka ri Dima nanabeta Dima Dompu Sambawa Kinkelu taua maqnikkah ia anne bedeng taunga nakaanakkang I Tuang Syaikh Yusuf

1627

Oct

1 Syab $1037^{45}$

Karaeng ri Tabaringang died

4 Syaw 103746

namate Karaengta ri Tabaringan

$14 \operatorname{Oct}(\mathrm{N})$

Karaeng ri Ballaq Jawaya died; Karaeng Tamasongoq ${ }^{47}$ born

namate Karaengta ri Ballaq Jawaya naanaq Karae

Tamasongoq

5 Rawl $1037^{49}$

Karaeng ri Lengkeseq ${ }^{48}$ born

naanaq Karaengta ri Lengkeseq

7 Aug (W)

2 Saf 103751

Karaeng ri Katinting 50 born

naanaq Karaengta ri Katinting

1628

7 Aug (M eve)

Karaeng ri Bontojeqneq ${ }^{52}$ born

16 Zulh $1038^{53}$

naanaq Karaengta ri Bontojeqneq

44 The Gregorian date matches Ligtvoet's corrected Hijri date.

45 The Hijri date converts to 6 Apr 1628. Beginning with this entry and continuing through the next six (through the entry marking the introduction of lead coinage) the dates are uncertain. The Gregorian and Hijri dates cannot easily be reconciled, nor does either series proceed chronologically. Scribal errors may be involved, but they are not simple ones that we can deduce and correct. Beginning with the 13 Nov 1629 entry marking the death of Datoq Hafid the two calendrical systems come into close alignment.

46 The Hijri date converts to 7 Jun 1628.

47 I Manguqrangi, a daughter of Karaeng Sumannaq and granddaughter of Karaeng Barombong.

48 Mammaliang Daeng Pole, a son of tumailalang Karaeng Cenrana.

49 The Hijri date converts to 13 Nov 1627.

50 A son of Ala'uddin from a lower-ranking wife and the father of Karaeng Balloq.

51 The Hijri date converts to 12 Oct 1627.

52 I Saniq Daeng Nisakking, a daughter of Malikussaid.

53 The Hijri date converts to 6 Aug 1629. 
1629

4 Jun

6 Syaw 103954

marriage of Karaeng ri Lakiung [Malikussaid]

Feb

6 Jakr 103955

lead coins [introduced]

$13 \operatorname{Nov}(\mathrm{T})$

jugaraq tumberiia

26 Rawl 1039

Datoq Hafid died

namate Datoq Hafid

$13 \operatorname{Aug}(\mathrm{N})$

1630

6 Muh 1040

Matinroa ri Talloq ${ }^{56}$ died

21 Aug (N) Arung Matoa I Toali ${ }^{57}$ expelled [as ruler of Wajoq]; a deci-

namate Matinroa ri Talloq sion was requested regarding their land by the people of Ponreq
15 Muh 1040 nanipasuluq Arung Matoa I Toali nanipalappalaq bicara ri buttana tuPonreka

1631

$12 \operatorname{Jan}(\mathrm{N})$

Karaeng Tumamenang ri Ballaq Pangkana Hasanuddin born

7 Jakr 1040 naanaq Karaenga Tumenanga ri Ballaq Pangkana

Hasanuddin

$15 \operatorname{Jan}(\mathrm{W})$

birth of Karaeng ri Panaikang 58

10 Jakr 1040

nanianakkang Karaengta ri Panaikang

$30 \operatorname{Mar}(\mathrm{N})$

I Daeng Kalling ${ }^{59}$ died below in Segeri; she was known as the mother of Karaeng ri Tangallaq

26 Syab 1040 namate I Daeng Kalling irawa ri Segeri ayana Karaengta ri Tangallaq nikana

54 The Hijri date converts to 19 May 1630.

55 The Hijri date converts to 20 Jan 1630. ANRI 16/6 gives the Gregorian date as 4 Jun 1629.

56 La Tenripale, he ruled Boné from 1608 to 1626.

57 The father-in-law of La Maqdaremmeng, the ruler of Boné who succeeded Matinroa ri Talloq in 1626.

58 Daeng Niaq, a daughter of Tumammaliang ri Timoroq by a slave wife.

59 A daughter of Karaeng Barombong and wife of Tumammaliang ri Timoroq. 
2 May (S)

30 Ram 1040

14 May (R)

12 Syaw 1040

24 May (S)

21 Syaw 1040

3 Jun (T)

2 Zulk 1040

25 Jun (R)

25 Zulk 1040

$22 \operatorname{Aug}(\mathrm{F})$

2 Muh $1041^{63}$

4 Sep (W eve)

6 Saf 1041

$15 \operatorname{Sep}(\mathrm{M})$

17 Saf 1041

28 Oct (T)

2 Rakr 1041 there was rain like thread 60

naniaq bosi kontu banning

birth of I Tamammempo, a child of Tumatea ri Banten ${ }^{61}$ nanianakkang I Tamammempo anaqna Tumatea ri Banten

it was forbidden to pay interest on debts ${ }^{62}$ natanipaqbiannga maqjeqneq inranga

a wife of Karaeng ri Popoq gave birth to his oldest son named I Liba who lived just twenty-nine days namamanaq Karaengta ri Popoq bainea buraqnea nikana I Liba uluana ruampulo banngiji assalapang umuruqna

a wife of I Daeng Kalula had a daughter named I Taniq namamanaq bainenna I Daeng Kalula baine nikana I Taniq

a wife of the ruling karaeng [Ala'uddin] died namate karaenga bainea sombaya

Tumamenang ri Ujung Tana Abdul Hamid ${ }^{64}$ born naanaq Tuammenanga ri Juntana Abdul Hamid

Macciniqdanggang built ${ }^{65}$; sixty-five nights after it was built the karaeng [Ala'uddin] went up into it nanibangun Macciniqdanggang annangpulo banngi allima leqbaqna nibangun nanapanaiki karaenga

word came of the death of Matinroa ri Bantaeng66 nabattu nipabiritta matenna Matinroa ri Bantaeng

60 Or 272Y has that rain fell like stones (batu) not thread (banning).

61 Daeng Mangemba, a son of Karaeng Matoaya.

62 ANRI 16/6 adds 'to charge interest in rice or gold' (ajeqneq aseya bulaenga).

63 The Hijri date converts to 31 Jul 1631.

64 Karaeng Karunrung, a son of Karaeng Pattingalloang who would become tumabicarabutta of Gowa.

65 Macciniqdanggang or 'Watching Trade' was a hall built for the ruler to stay in and reflects royal participation in and oversight of commerce.

66 La Tenrirua, who ruled Boné from 1607 to 1608. 
29 Oct $(W)^{67}$ the 'Javanese' 68 area burned to the ground; 556 houses were consumed

3 Rakr 1041 namaqkanre papparaq Jawaya 556 ballaq nakanre

$13 \operatorname{Nov}(\mathrm{R}) \quad$ Anciq Sumaileq arrived from Mataram bringing I Maisanannga

18 Rakr 1041 nabattu ri Mataran Anciq Sumaileq angerangi I

Maisanannga

17 Nov ( $\mathrm{N}$ eve) the karaeng [Ala'uddin] went up into Macciniqdanggang

22 Rakr 1041 namanaiq karaenga ri Macciniqdanggang

3 Dec $(W) \quad$ Karaeng ri Lakiung [Malikussaid] and Karaeng ri Tangallaq returned to each other [after having divorced]

8 Jawl 1041 nasipolei Karaenga ri Lakiun Karaengta ri Tangallaq

1632

14 Jan (R) I Tamammempo, a child of Tumatea ri Banten, died

20 Jakr 1041 namate I Tamammenpo anaqna Tumatea ri Banten

19 Apr (M) tobacco intoxicating; this the birth year of Daengta Daeng Tuna, a grandparent of the karaeng 69

28 Rum 1041 namammengo tambakau taun kaanakkanna Daengta Daeng Tuna toana karaenga

20 May (R) Tumatea ri Banten went overseas on the haj ${ }^{70}$

29 Syaw 1041 namaqlampa kalauq haqji Tumatea ri Banten

14 Aug (S) the karaeng [Ala'uddin] left after dwelling in

Macciniqdanggang so it could be bricked

67 The annalist incorrectly wrote the 13th, but it is in fact the 29th. This corresponds to the Hijri dating and is also the date given in ANRI 16/6. Splitting the difference, the translated lontaraq bilang text in Makasaarsche historiën (1855:121) gives the date as 23 October.

68 'Javanese' is an umbrella term Makassarese used to refer to peoples from the western archipelago, and usually indicated Malays. This entry testifies to the size of the Malay community in Makassar.

69 It is unclear which ruler of Gowa this refers to, but most likely Abdul Jalil (b. 1652). This entry is an example of how annalists added information to the entries at a later date. They seem to have done so without considering that future generations of readers would not know who was ruling when the entry was made.

70 He died on the trip on 27 Sep 1632 in Banten, from which an envoy returned with his body on 9 Dec 1632. 
namassuluq karaenga maqballaq-ballaq Macciniqdanggang nipandeqdeqang bata

17 Aug (W)

Karaeng ri Lempangang ${ }^{71}$ and Karaeng ri Garassiq ${ }^{72}$ married

1 Saf 1042

nasikalabini Karaengta ri Lempangang Karaengta ri Garassiq

$20 \operatorname{Aug}(\mathrm{F})$

birth of I Pangalaq

3 Saf 1042

nanianakkang I Pangalaq

$24 \operatorname{Aug}(\mathrm{R})$

an envoy from Maluku named Uthman arrived

7 Saf 1042 nabattu surona Malukua nikanaya Uthman

16 Sep (R)

I Lasebauq [a royal banner] ritually blooded ${ }^{73}$; people mustered and called up for Friday public prayers ${ }^{74}$

29 Saf 1042 naniceraq I Lasebauq namarewangan taua nanipatambaq taua maqjumaq

17 Sep $(\mathrm{F})$

people mustered [for Friday public prayers]

1 Rawl 1042

namarewangang taua

18 Sep $(\mathrm{F})$

2 Rawl 1042

the envoy from Maluku departed namaqlampa surona Malukua

27 Sep (M)

Karaeng ri Ujung Tana ${ }^{75}$ died; his subjects numbered 1584 12 Rawl 1042 namate Karaengta ri Juntana bilanna pangatainna 1584

71 A daughter of Ala'uddin, she was also known as I Saqbe and I Daeng Tamaga.

72 A son of Karaeng Buluq Sipong (who was a full brother of Ala'uddin) and grandson of Tunijalloq.

73 As Ligtvoet (1880:92) notes, royal banners were often smeared with blood as part of a ceremony in which Makassarese prepared for war. In this case, it presumably refers to rising tension with the VOC, which sought to blockade Makassar beginning in 1634. There were sporadic outbreaks of violence (and another banner smeared with blood at Ujung Pandang on 15 Nov 1634) followed by periods of inactivity until the conflict ended in 1637. An interesting question arising from this entry is whether this pre-Islamic tradition relying on existing cultural notions about the sacramental potency of blood was incorporated into or linked with the preparations for Islamic Friday public prayer services.

74 This may be a reference to a deliberate effort to assemble the 40 mokkeng needed to make the Friday public prayer service valid according to Shafi'ite doctrine. See Noorduyn 1987:317-8.

75 A son of Tunijalloq. The Gowa Chronicle records that his personal name, may I not be cursed, was I Kelo. His royal name was I Daeng Uraga. His karaeng-title was Karaeng Ujung Tana. He had no children, but Karaeng ri Patukangang was adopted. [I Kelo] died. Tumamenang ri Bontobiraeng received all his possessions except those already given [to his adopted heir].' 
28 Sep (T) those from Ujung Tana went to Tumamenang ri Bontobiraeng [Pattingalloang]

13 Rawl 1042 nanipamange tuJuntanaya ri Tuammenanga ri Bontobiraeng

22 Oct (F) Antoni da Costa died

2 Rakr 1042 namate Antoni di Kosta

27 Sep (M) Tumatea ri Banten died

11 Rawl $1042^{76}$ namate Tumatea ri Banten

22 Oct (F) the karaeng [Ala'uddin] sailed to go into Toraja

20 Rakr $1042^{77}$ namamise karaenga mantama ri Toraja

$13 \operatorname{Nov}(\mathrm{M}) \quad$ the karaeng [Ala'uddin] arrived from Toraja having conquered Bolong; it was reported that the Bimanese revolted

19 Jawl $1042^{78}$ nabattu ri Toraja karaenga anbetai Bolong nanikana marotasaki Dimaya

$25 \operatorname{Nov}(\mathrm{R}) \quad$ Karaeng ri Buraqne sailed over to Bima to put out the revolt ${ }^{79}$

11 Jawl 1042 namamise Karaenga ri Buraqne taqle ri Dima makkaruru

$9 \operatorname{Dec}(\mathrm{R}) \quad$ an envoy from Banten arrived bearing Tumatea ri Banten; 45 nights after his death he was brought back ${ }^{80}$

25 Jawl 1042 nabattu surona Banteng angerangi Tumatea ri Banten 45 bannginna matena nabattu nierang

$24 \operatorname{Dec}(\mathrm{S}) \quad$ people were called up to plant rice in Karebosi

10 Jakr 1042 nanipatambaq taua mannanang ri Karebosi

27 Dec (M) it is said that a dead person came back to life

13 Jakr 1042 nanikana niaq tumate tallasaq pole

76 Presumably this entry is out of chronological order because his death was recorded when word arrived from Banten.

77 The Hijri date converts to 3 Nov 1632.

78 The Hijri date converts to 2 Dec 1632. ANRI 16/6 has the Gregorian date as 22 Nov 1632.

79 ANRI 16/6 adds that Karaeng ri Buraqne went 'with I Kare Laling' (siagang I Kare Laling).

80 His body actually arrived some 73 days after his death. Possibly the annalist meant that his body departed Banten 45 days after his death, indicating that the journey to Gowa took another 28 days. 
1633

27 Jan (M) an envoy from Mataram announced his desire to unite [Mataram and Gowa in an alliance]; Ki Ngabei Saradulla was his name

6 Raj $1042^{81}$ nanakana-kana surona Mataranga eroqna mattauseqre Ki Ngabei Saradula arena

$2 \operatorname{Mar}(\mathrm{W}) \quad$ at the stroke of 8 was the birth of I Maqmiq; her Arabic name was Syafiah; she was called Daengta Daeng Sannging 82

23 Syab 10428 garigantaya nanianakkang I Maqmiq arenga Araqna Shafia Daengta Daenga Sannging nikana

$7 \operatorname{Apr}(\mathrm{R}) \quad$ Karaeng ri Buraqne arrived from Bima 83

28 Rum 1042 nabattu ri Dima Karaenga ri Buraqne

5 Jun $(\mathrm{N}) \quad$ Karaeng Galesong died

27 Zulk 1042 namate Karae Galesong

21 Jun (T) the Bimanese came in person; the karaeng [Ala'uddin] spoke and they agreed

14 Zulh 1042 nabattu kalenna Dimaya makkanami karaenga ammiommi

11 Sep (N) I Daeng Tasannging ${ }^{84}$ and I Daeng Niaq married

2 Rawl 1043 nasikalabini I Daeng Tasannging I Daeng Niaq

16 Sep (F) Karaeng ri Pattunga died; he and I Tamaqlili, from the same family, killed each other ${ }^{85}$

12 Rawl 1043 namate Karaenga ri Pattunga sibunoi sipamanakang I Tamaqlili

81 The Hijri date converts to 17 Jan 1633.

82 A daughter of Karaeng Pattingalloang and wife of Hasanuddin. Maqmiq is short for Maqminasa.

83 ANRI 16/6 again adds that Karaeng ri Buraqne traveled 'with I Kare Laling' (siagang I Kare Laling).

84 A son of Tumammaliang ri Timoroq named I Lita, he was also titled Karaeng Bontosunggu. 85 According to the Gowa Chronicle, Karaeng ri Pattunga married a daughter of Tunijalloq named Karaeng Pacelleq. I Tamaqlili was their third child. 
17 Oct (M) I Daeng Mangamaraq departed and went over to Kabaena to make war along with I Daeng Mangalle

14 Rakr 1043 namaqlampa I Daeng Mangamaraq taqle ri Kabaena maqbunduq siagang I Daeng Mangalle

\section{4}

13 Feb (M) Dutch ships arrived, twelve in number including the small ones ${ }^{86}$

13 Syab 1043 nabattu kappalaqna Balandaya sampulo anrua batunna siagang macaqdia

19 Feb $(\mathrm{N}) \quad$ the [Dutch] ships that neared Paqnakkukang were fired upon

19 Syab 1043 nanibaqdiliq kappalaq mannyeppeka ri Paqnakkukang

$9 \operatorname{Mar}(\mathrm{R}) \quad$ a manuscript arrived from Buton commemorating their oath at Bau-Bau ${ }^{87}$

9 Ram 1043 nabattu lontaraqna Butunga anguqrangi talliqna ri BauBau

4 [Apr] (R) the mother of I Mamangkasi died

5 [Syaw] $1043^{88}$ namate ayana I Mamangkasi

23 [May] (T) Karaeng Matoaya was shaded with the royal umbrella again; people worked on an earthen wall from Ujung Tana to Somba Opu

24 [Zulk] 1043 nanilaqlangi pole Karaenga Matoaya namanjama taua bata butta sanggenna Juttana nasanggenna Somba Opu

28 [May] (N) Lae-Lae destroyed

26 [Zulk] 1043 nanilala Lae-Lae

86 This marks the beginning of the VOC effort to blockade Makassar and thereby deny it access to Maluku and the spice trade which the Dutch were seeking to control (Stapel 1922:2634).

87 This oath probably took place after Matoaya and Ala'uddin's 1626 conquest of Buton.

88 The Gregorian and Hijri months for this and the next four entries are omitted in VT 25. However, the lontaraq bilang text in ANRI 16/6 gives May as the month for the second and third of these entries; assuming the entries are chronologically ordered, the preceding entry can be presumed to have been recorded in April and the subsequent entries in June. The Hijri dates are similarly reconstructed based on sequence and the Gregorian dates. 
22 [Jun] (S eve) an Englishman sailed; he shot someone and was charged 4000 [reals] and a bloodprice

7 [Zulh] $1043^{89}$ nasimonbalaq Anggarrisika namanaba baqdiliqna nanipassala 4000 manyapuqtongi

22 [Jun] (N) sabannaraq I Daeng Pagang died

7 [Zulh] $1043 \quad$ namate I Daeng Pagang sabannaraka

17 Jul (M) the karaeng [Ala'uddin] went up ${ }^{90}$ to Popoq [in Takalar] to take the burned galley

20 Muh 1044 namanaiq ri Popoq karaenga angallei galle nisussuluka

$29 \mathrm{Jul}(\mathrm{S}) \quad$ [Ala'uddin] went over to Paqnakkukang to dwell as its stonework was rebuilt

3 Saf $1044 \quad$ nataqle ri Paqnakkukang maballaq-ballaq nibatana pole

9 Aug $(W) \quad$ Ujung Pandang first fortified with stone

14 Saf 1044 nauru nibata Ujung Pandang

23 Aug (T) Karaeng Balambaru arrived bringing declarations from [the islands of] Sula and Banggae

27 Saf 1044 nabattu Karaeng Balambaru angerangi kananna Sulaya Banggaea

10 Sep (N) Karaeng ri Ballaq Jawaya had a child who was named I Siqra

12 Rawl 1044 naanaq Karaengta ri Ballaq Jawaya iami nikana I Siqra

15 Sep (F) at midday Matinroa ri Bontoalaq Saqaduddin [La

Tentritatta Arung Palakka] born

22 Rawl 1044 tangalloi alloya naanaq Matinroa ri Bontoalaq Saaduddini

10 Nov (F) gunpowder exploded on the bastion ${ }^{91}$

18 Jawl 1044 namakkaqdoq ubaka ri salekoya

89 The reconstructed Hijri date for this and the next entry converts to 3 Jun 1634 .

90 Makassarese adverbs indicating spatial orientation may puzzle readers familiar with the geography of South Sulawesi. In English, 'up' is associated with north and 'down' with south. These are arbitrary conventions. In Gowa, 'up' (naiq) generally corresponds to south and 'down' (naung) to north. Popoq, for example, is south of Gowa. See Liebner 2005 for a detailed discussion of these complex systems of spatial orientation.

91 ANRI 16/6 adds details about casualties from the explosion: 'Karaeng Layu was burned by the powder; eleven anaq karaeng from Turatea were burned by the powder' (nanakaqdo ubaka Karaeng Layu sampulo asseqre anaq karaeng Turate nakaqdo ubaq). 
15 Nov (W) banner ritually blooded at Ujung Pandang

23 Jawl 1044 naniceraq batea ri Ujung Pandang

1635

6 Jan (S) Karaeng ri Suli92 entered Darombo [because] it is said that Luwuq is hostile

6 Raj $1044^{93}$ namantama ri Darombo Karaengta ri Suli nikananna bali Luwuka

$19 \mathrm{Feb}(\mathrm{M}) \quad$ Karaeng ri Buluq Sipong ${ }^{94}$ died

2 Ram $1044 \quad$ namate Karaengta ri Buluq Sipong

$30 \mathrm{Apr}(\mathrm{M}) \quad$ stonework at Barombong strengthened; the number of people [defending] Somba Opu total 855

12 Zulk 1044 nanipakajareq bataya ri Barombong bilana tuSombopuya 855

13 Jun (T eve) the Dutch fired up at Galesong; the karaeng [Ala'uddin] overnighted at Bebaq [north of Galesong]

27 Zulh 1044 namamaqdiliq Balandaya manaiq ri Galesong ri Bebaki karaenga maqbanngi

23 Jun (S) the people at Somba Opu laid stones [in a wall] at the gate

7 Muh 1045 namallonjoq bata tuSombopuya ri timunganga

25 Aug (S) the people of Boné ask permission to strengthen Pallette 11 Rawl 1045 namappalakkana tuBonea ampakajarreki Pallatte

17 Sep (M) the karaeng [Ala'uddin] went down ${ }^{95}$ to fulfill a vow in Laqbakkang

3 Rakr 1045 namanaung karaenga amole tinjaq ri Laqbakkang

$10 \operatorname{Nov}(\mathrm{S}) \quad$ a mosque constructed in Bontoalaq

1 Jawl 1045 nanilonjoq masigika ri Bontoalaq

92 A tumailalang of Gowa from the family of Karaeng Patteqne, who was originally appointed to the post by Tunipasuluq.

93 The Hijri date converts to 27 Dec 1634.

94 A son of Tunijalloq and father of Karaeng ri Garassiq.

95 Makassarese terms of spatial orientation are discussed in the note for entry 17 Jul 1634; Laqbakkang is north of Gowa. 
$24 \operatorname{Nov}(\mathrm{S}) \quad$ Karaeng Matoaya first stricken with illness 15 Jakr 1045 nauru nabattui garring Karaenga Matoaya

$3 \operatorname{Dec}(\mathrm{T}) \quad$ birth of I Mappaseppeq; known as Karaeng Beroanging, he was a child of Karaeng ri Kassiqjala 22 Jakr 1045 nanianakkang I Mappaseppeq Karae Beroanging nikana anaqna Karaengta ri Kassiqjala

\section{6}

$20 \operatorname{Jan}(\mathrm{N})$

13 Syab 1045

Karaeng ri Majannang and Daengta Daeng Marannu married

nasikalabini Karaengta ri Majannang Daengta Daeng Marannu

29 Feb (F)

22 Ram 1045 Balandaya eroq ampapalisiki tuBulo-Buloa namassare

the Dutch hoped to turn the people of Bulo-Bulo [against Gowa] and pledged that in 300 days and nights we would be attacked [by the VOC, but the Dutchmen] were killed by the people of Bulo-Bulo ${ }^{96}$ allo 300 banginna kinabunduq nanibuno ri tuBulo-Buloa

2 May (F) a Mandar envoy arrived reporting that their ruler was beheaded by the people of Sawitto

26 Zulk 1045 nabattu surona Mandaraka angkana-kanai nijalloqna karaenna ri tuSawittoa

1046

this year an epidemic struck many people ${ }^{97}$ anne taunga mapuai taua

96 This is also described in Stapel 1922:30-1.

97 Note that this entry is at the beginning of the year, which by the Gregorian calendar lasted from June 1636 to May 1637. It may have been interpolated here by a later annalist. Makasaarsche historiën (1855:121) has this entry for year 1637. The Dagh-Register (1637:290) mentions a pestilence that left much of the land uninhabited, and Karaeng Matoaya's 2 Jul 1636 pronouncement also indicates the virulence of the epidemic. 
4 Jun (W) the arumpone [La Maqdaremmeng] arrived and spoke with his mother ${ }^{98}$

1 Muh 1046 nabattu arungpone nasiagaang makkana anronna

2 Jul (W) spoke Karaeng Matoaya, 'We must all protect ourselves

29 Muh $1046 \quad$ from raging epidemics and starvation' mapuajaki mapaqrejaki

4 Aug (M) the karaeng [Ala'uddin] went down to dwell at Bontoalaq ${ }^{99}$

3 Rawl 1046 namanaung ri Bontoalaq karaenga maqballaq-ballaq

1 Oct (W) at midday we were left by Karaeng Matoaya at the age of 63

1 Jawl 1046 tangalloi alloa kinapilari Karaenga Matoaya umuruqna 63

29 Oct (W) word came from Karaeng Galesong known as Maruttaki100

29 Jawl 1046 nabattu nipabiritta Karae Galesong nikana maruttaki

19 Nov (W) I Daeng Taduq had a child, a girl named I Roking 20 Jakr 1046 namamanaq I Daeng Taduq baine nikana I Roking

$21 \operatorname{Dec}(\mathrm{N}) \quad$ I Mallelei Jaqfar, known as Karaeng ri Babanga ${ }^{101}$, born

98 La Maqdaremmeng's mother was Datu Pattiro We Tenrisoloreng, a sister of the ruler of Boné Matinroa ri Talloq who died in 1630. This discussion must have been important to merit note in the lontaraq bilang. It is likely that it concerned Islam. As Andaya (1981:39-41) notes, La Maqdaremmeng enforced a stricter version of Islamic practice in Boné after becoming ruler in 1630, but his mother strongly preferred a form of Islam tolerant of pre-Islamic practices and led opposition to her son's actions. Ultimately this conflict would lead to war between Gowa and Boné in 1643, Boné's defeat, and La Maqdaremmeng's expulsion from the kingdom.

99 ANRI 16/6 adds 'reciprocating with Karaeng Matoaya' (maqbalasaqna Karaeng Matoaya).

100 This is the most likely reading, though if Maruttaki is not a name the entry could read 'word came saying that Karaeng Galesong maruttaki'. However, the meaning of 'maruttaki' is uncertain. If it is a variant of ' $r u t u$ ' it may refer to Karaeng Galesong 'exploding' or 'erupting', which would indicate the outbreak of a quarrel or violence, or it could refer to the physical symptoms of disease contracted during this year of epidemics. If it is related to 'rottoq' it may refer to Karaeng Galesong 'bending', perhaps meaning that he broke his word. Local traditions state that the reign of an unnamed ruler of Galesong ended in 1636, which if true would presumably be the result of this incident (Ibrahim et al. 1985:122, 164).

101 A son of Ala'uddin, the Gowa Chronicle records his karaengship of Bawangang (or in some texts Bambangang), not Babanga. This is a question of spelling and transcription rather than a mistake or a reference to different locations. 
2 Raj $1046^{102}$

naanaq I Mallellei Jaqfar Karaengta ri Babanga nikana

$27 \operatorname{Dec}(S)$

25 Raj 1046 the day of the ruler of Aceh named Mahkota Alam's death 103 allo nakamateanga karaenga ri Aceh nikanaya Makutta Alam

$29 \operatorname{Dec}(\mathrm{M})$

Karaeng ri Tabaringang died

1 Syab 1046 namate Karaengta ri Tabaringan

1637

10 Jan $(S)$

I Marajalang 104 arrived from Ambon

18 Syab 1046 nabattu I Marajalaan ri Ambong

13 Feb (F) 17 Ram 1046

the day of I Tuang ri Dima's ${ }^{105}$ birth allo kaanakkanna I Tuan ri Dima

1 Mar (N)

7 Syaw 1046

Karaeng ri Ballaq Jawaya died namate Karaenga ri Ballaq Jawaya

22 Jun (M)

the Dutch anchored at Somba Opu; the Acehnese went to their ships; we raised a white banner; we both met and agreed to the decision of the karaeng [Ala'uddin] that they not place an official [in Makassar] ${ }^{106}$

27 Saf $1047^{107}$ namalabu Balandaya ri Sombopu namange ri biseanna Acea kimappanaiq bate keboq kisitabamo naiomi kananna karaenga tamappaempoa petoroq

5 Jul (S eve)

Karaeng ri Kasuarrang died 11 Saf 1047 namate Karaengta ri Kasuarrang

102 The Hijri date converts to 30 Nov 1636.

103 Mahkota Alam was the name of an Acehnese royal line and Iskandar Muda the name of the ruler who died in 1636.

104 Kamaruddin and Ligtvoet describe I Marajalang as a merchant. ANRI 16/6 states that he was 'known as an anaq karaeng from Ambon' (anaq karaeng ri Ambong nikana).

105 An Arab also known as Shaykh Umar Bamahsuna Rahmahtullah. He first arrived in Makassar on 21 Apr 1684 and was an important religious figure in Gowa until his death on 8 May 1694.

106 The cease fire deliberations are described at length in the contemporaneous Dagh-Register (1937:280-92) and in Stapel (1922:32-4). ANRI 16/6 adds 'that they not place the Dutch official known as Anthonie [in Makassar]' (tamappaempoai petoroq Balandaya nikanaya Ontoni). This refers to Anthonie Caen, a Malay-speaker whom the Council of the Indies wished to place in Makassar. 107 The Hijri date converts to 20 Jul 1637, but this is incorrect. 
$12 \mathrm{Jul}$ (S)

18 Saf 1047

$20 \mathrm{Jul}$ ( $\mathrm{N}$ eve)

26 Saf 1047

22 Aug (S eve)

1 Rakr 1047

13 Sep (T)

17 Rakr 1047

2 Oct (F)

12 Jawl 1047

17 Oct (F eve)

27 Jawl 1047

26 Oct ( $\mathrm{N}$ eve) Karaeng Tumammaliang ri Timoroq slept with Karaeng ri Lempangang; I Daeng Maqbayaraq died [and after his death] I Daeng Lompo became anrongguru of the tumakkajannang; he was succeeded by Daengta Daeng Ago [after 29 Feb 1643] and Daengta Daeng Ago was succeeded by Karaeng ri Popoq ${ }^{110}$ [on 25 May 1663]

6 Jakr 1047

$12 \mathrm{Feb}(\mathrm{F})$

24 Ram 1047

I Loqmoq ${ }^{108}$, the mother of Karaeng ri Bontojeqneq, died namate I Loqmoq anronna Karaengta ri Bontojeqneq

I Kurru Karaeng Mangallekana, known as Zakaria, born naanaq I Kurru Karae Mangallekana nikana Zakaria

Daengta Daeng Taqduq died namate Daengta Daeng Taqduq

Datu ri Luwuq died, cut down by a slave; [he was named] Matinroa ri Somba Opu namate Datua ri Luwuq nijalloki ri atanna Matinroa ri Sombopu

Datu ri Soppéng who was titled Beyoa died namate Datua ri Soppeng nigallaraka Beyoa

Karaeng ri Paqbineang Maemuna ${ }^{109}$ born naanaq Karaengta ri Paqbineang Maemuna namaqlusereq Karaenga Tumammaliang ri Timoroq Karaengta ri Lempangang namate I Daeng Maqbayaraq I Daeng Lompo anronggurunna tumakkajanannganga iaminne nisambeang ri Daengta Daeng Ago naDaengta Daeng Ago nisambeang ri Karaengta ri Popoq

\section{8}

Mandarese give Gorontalo to the karaeng [Ala'uddin] nanapassareang Mandaraka ri karaenga Bolongtaloa

108 A wife of Malikussaid, she was also the mother of Hasanuddin. The title logmoq was commonly held by non-noble wives of rulers.

109 A daughter of Pattingalloang, wife of Hasanuddin, and mother of the future ruler of Gowa Amir Hamzah.

110 A son of Matoaya. 
$25 \operatorname{Apr}(\mathrm{N}) \quad$ Karaeng ri Garassiq went into Luwuq to marry 111

10 Zulh 1047 namantama ri Luwuq Karaengta ri Garassiq maqbaine

30 May $(\mathrm{N}) \quad$ Karaeng ri Paqbineang Maemuna put up in a sling [at about age 7 months]

15 Muh 1048 nanipanaiq ri toeng Karaengta ri Paqbineang

26 Aug (R) a rice barn built in front of Macciniqdanggang

18 Rawl $1048^{112}$ nanibangung ballaq asea ri dallekannaya

Macciniqdanggang

18 Aug (F) the karaeng [Ala'uddin] went up to Turatea, to Naung 2 Rakr 1048 namanaiq ri Turatea karaengta ri Naun

20 Oct $(\mathrm{W}) \quad$ people mustered for the seating of the future Karaeng ri Bontojeqneq

11 Jakr 1048 namarewangang taua lamamempona kaparekanna Karaengta ri Bontojeqneq

22 Oct (R eve) the mother of I Kalula died

13 Jakr 1048 namate ayana I Kalula

23 Oct (S) ears pierced of Karaeng ri Bontojeqneq and Daengta Daeng Naratang; this was the birth of Daengta Daeng, the younger sibling of Aminah

14 Jakr 1048 nanitinting Karaengta ri Bontojeqneq siagaang Daengta Daeng Naratang iaminne kaanakkanna Daengta Daeng anrinna Aminah

4 Nov (R) Daeng I Taniciniq ${ }^{113}$ and Karaeng Bulo-Bulo married 26 Jakr 1048 nasikalabini Daengta I Taniciniq Karaeng Bulo-Bulo

$24 \operatorname{Dec}(\mathrm{F}) \quad$ I Daeng Mau died

17 Syab 1048 namate I Daeng Mau

25 Dec (S) it is said that a boy, I Mattenai Karaeng ri Panjallingang, was born

111 ANRI 16/6 adds '[and] married Opu Peso' (ambaineangi Opu Peso). This detail is also mentioned by Matthes 1883:footnote 54 .

112 The Hijri date converts to $30 \mathrm{Jul} 1638$.

113 A daughter of a ruler of Sanrabone by Karaeng Tabaringang. 
18 Syab 1048

naanaq I Mattenai Karaengta ri Panjallingang buraqnea nikana

\section{9}

17 Feb (R)

12 Syaw 1048

there was word that Karaeng Laqbakkang was besieged by his subjects

$8 \operatorname{Mar}(\mathrm{T})$

2 Zulk 1048 namappalakkana I Topasonriq ampakajarreki Bone naninanipabiritta Karae Laqbakkang niliungang ri atanna

I Topasonriq asked permission to strengthen Boné and it was allowed paqbeang

3 Apr (S eve) I Daeng ri Bulekang went over to Buton

29 Zulk 1048 nantaqle ri Butun I Daeng Bulekang

$28 \operatorname{Apr}(\mathrm{R}) \quad$ I Daeng Massikkiq died

23 Zulh 1048 namate I Daeng Massikkiq

8 Jun (W) I Manguqrangi Sitti Shapora Karaeng ri Panjallingang born, a girl

5 Saf 1049 naanaq I Manguqrangi Sitti Shapora Karaenta ri Panjallingang baine

15 Jun (T eve) at the stroke of one we were left by Karaeng Tumamenang ri Gaukanna Sultan Ala'uddin ${ }^{114}$

12 Saf 1049 tetteq seqrena garigantaya kinapilari Karaenga Tuammenanga ri Gaukanna Sultan Ala'uddin

24 Jun $(\mathrm{F})$

21 Saf 1049

Gallarrang Cambaya died ${ }^{115}$

namate Gallarrang Cambaya

3 Jul (N) the patimatarang [Malikussaid] shaded with the royal umbrella116

1 Rawl 1049 nanilaqlangi patimataranga

114 ANRI 16/6 adds 'he reached age 53' (umuruqna 53).

115 This is a rare entry mentioning a gallarrang, a title borne by local lords ranked below karaeng. It is likely that Gallarrang Cambaya was well known to the annalist.

116 Patimatarang is a title signifying an heir designated as successor to the throne. Interestingly, the term is not found in the Gowa or Talloq Chronicles. This ritual recognition that Malikussaid would indeed succeed Ala'uddin culminated in his formal installation as Gowa's sultan on 19 Dec 1639. 
$26 \mathrm{Jul}(\mathrm{T})$

24 Rawl 1049

agreements were inscribed anew in front of Tamalate ${ }^{117}$ naniukiriq ulukanaya niberuya ri dallekanna Tamalate

12 Aug

11 Rakr 1049

news arrived that the Bimanese intended to fight nabattu kana-kanna Dimaya eroq bali

26 Sep ( $\mathrm{N}$ eve) I Manjagai died

26 Jawl 1049

namate I Manjagai

28 Sep (F)

29 Jawl 1049

Karaeng Bulo-Bulo and Daeng I Taniciniq divorced nasipelaq Karaeng Bulo-Bulo Daengta I Taniciniq

$20 \operatorname{Nov}(\mathrm{N})$ an envoy arrived from Datu [ri Luwuq] announcing that he wanted to be removed [as ruler]

23 Raj 1049 nabattu surona ratua ampabirittai eroqna nipasuluq

19 Dec ( $\mathrm{N}$ eve) the patimatarang [Malikussaid] installed [as ruler of Gowa] 23 Syab 1049 nanilantiq patimataranga

1640

$12 \operatorname{Jan}(\mathrm{R})$

17 Ram 1049 the people namammio Luwuka angkaraengangi ratua

$14 \operatorname{Mar}(\mathrm{W})$

20 Zulk 1049

the karaeng [Malikussaid] issued bila-bila ${ }^{119}$ [summoning vassals for his entourage] for one month hence

$13 \operatorname{Apr}(\mathrm{F})$

20 Zulh 1049 namappalele bila-bila karaenga sibulan

the karaeng [Malikussaid] sailed to go into Luwuq and straight east to Tiworo [islands near Buton] namamise karaenga mantama ri Luwuq natulusuq manraiq ri Tiworo

117 This entry describes the writing down of ritual oaths taken by vassals of Gowa before the royal hall of their new ruler Malikussaid. Like the ritual in which a royal umbrella was raised over his head, this action was another element in the months-long drama that collectively made Malikussaid Gowa's ruler.

118 With this act of recognition an apparent dispute between Sultan Ahmad Nazaruddin Matinroa ri Gowa and his nobles was resolved. He had wanted to step down, but continued to rule Luwuq until 1662.

119 Bila-bila refers to cords made from lontar palm leaves that rulers sent via messengers to their vassals summoning them for war, celebrations, or other formal occasions such as the procession to witness the formal installation of the ruler of Luwuq described here. The number of knots on the cord indicated the number days before those summoned should appear. 
21 May (M)

29 Muh 1050

18 Jun $(\mathrm{T})$

28 Saf

2 Jul (T)

13 Rawl 1050

$13 \mathrm{Jul}(\mathrm{F})$

23 Rawl 1050

$23 \operatorname{Sep}(\mathrm{N})$

6 Jakr 1050

27 Oct (S)

10 Raj 1050

$3 \mathrm{Nov}(\mathrm{S})$

17 Raj 1050

$24 \operatorname{Nov}(S)$

Syab 1050

$15 \operatorname{Dec}(S)$

1 Ram 1050 the karaeng [Malikussaid] arrived from Luwuq nabattu ri Luwuq karaenga

those of Dompu made personal slaves ${ }^{120}$ by Karaeng Tumamenang ri Papambatuna [Malikussaid] nanipareq ata ri kale Dompua ri Karaenga Tuammenanga ri Papanbatuna

teeth filed of Karaeng ri Bontojeqneq

naniariq Karaengta ri Bontojeqneq

the mother ${ }^{121}$ of Karaeng ri Garassiq died

namate ayana Karaengta ri Garassiq

bila-bila issued [summoning vassals for war] for 33 nights hence $^{122}$

nanipalele bila-bilaya 33 bannginna

from Somba Opu the karaeng [Malikussaid] sailed to go into Walinrang [near Toraja] to make war namamise ri Sombopu karaenga mantama ri Walinrang maqbunduq

Tumamenang ri Lampana Harrunarasyid ${ }^{123}$ born naanaq Tuammenang ri Lampana Harunarrasyid

Walinrang conquered

nabeta Walinrang

the karaeng [Malikussaid] arrived from Walinrang and the conquest and mastering of Bolong [in Toraja] nabattu ri Walinrang karaenga nabetana napasombai Bolong

120 The term 'ata ri kale' is translated as 'personal slaves' but does not carry the same connotations of ownership and powerlessness that the English translation may imply. The people of Dompu could not easily escape their bonds of obligation to Tumamenang ri Papambatuna, but they were as much subjects as thralls.

121 I Tadumai, a daughter of Karaeng Barombong who married one of Tunijalloq's sons.

122 ANRI 16/6 adds 'to go into Balera' (mantamaya ri Balera). In this and subsequent entries about the expedition, ANRI 16/6 consistently has 'Balera' for 'Walinrang.'

123 A son of Tumammaliang ri Timoroq, he would succeed as ruler of Talloq after his uncle Pattingalloang's death in 15 Sep 1654. The precise date of his accession to the throne is not recorded in the lontaraq bilang, which is perhaps evidence that the gaining of sovereignty was a process rather than a single moment. 
$22 \operatorname{Dec}(S)$

8 Ram 1050

25 Dec (M eve)

11 Ram 1050
Karaeng ri Bungaya died; the father of I Ambela ${ }^{124}$ died also

namate Karaenga ri Bungaya namate todong aenna I Ambela

the patimatarang [Hasanuddin] went up to Kalakongkong [in Bulukumba] to call back Tumammaliang ri Timoroq, but he refused ${ }^{125}$

namanaiq patimataranga ri Kalakongkong angkalliki Tuamallianga ri Timoroq natea

\section{1}

14 Jan (M)

1 Syaw 1050

Melaka conquered by the Dutch

nanibeta Malaka ri Balandaya

$15 \operatorname{Jan}(\mathrm{T})$

Karaeng ri Talloq [Tumammaliang ri Timoroq] sailed from Kalakongkong east to Timor ${ }^{126}$

2 Syaw 1050 namamise ri Kalakongkong Karaenga ri Talloq manraiq ri Timoroq

$20 \operatorname{Jan}(\mathrm{N})$

Karaeng Cenrana sailed from Somba Opu following Karaeng ri Talloq [Tumammaliang ri Timoroq]

7 Syaw 1050 namamise ri Sombopu Karaenga Cenrana ampinawangi Karaenga ri Talloq

23 Feb ( $\mathrm{N}$ eve) Karaeng ri Karuwisi died

13 Zulk 1050 namate Karaengta ri Kariwisi

124 I Ambela's father was Abdul Kahir, the first sultan of Bima. I Ambela succeeded his father under the title Sultan Abil Khair. Often referred to as Sirajuddin, he ruled from 1640 to 1682 (Noorduyn 1987:323-5).

125 This intriguing incident suggests that Tumammaliang ri Timoroq was acting independently of Sultan Malikussaid, who presumably sent his son and designated successor to summon Tumammaliang ri Timoroq back to Gowa (though in ANRI 16/6 it is Malikussaid himself who pursues Tumammaliang ri Timoroq). Shortly thereafter Tumammaliang ri Timoroq departed for Timor. He was followed by Karaeng Cenrana, a tumailalang of Gowa, again presumably on the command of Malikussaid, but this mission too is a matter of mystery. Karaeng Cenrana could have been sent either to aid or restrain Tumammaliang ri Timoroq. Tumammaliang ri Timoroq's voyage to Timor involved its conquest, for ANRI 16/6 adds in the entry for 15 Jan 1641 that he went to Timor to make war. This accomplishment is also referred to in the Talloq Chronicle. After a short stay on Timor, Tumammaliang ri Timoroq returned and died soon after on 18 May 1641. It is perhaps noteworthy that the writer of the Tallog Chronicle memorializes Tumammaliang ri Timoroq as brave rather than knowledgable.

126 ANRI 16/6 clarifies matters, adding that he went to Timor 'to make war' (maqbunduq). 
28 Mar (R) I Daeng Anne had a son named I Manuruki Muhammad; he was known as the younger brother of Tumamenang ri Ujung Tana [Karunrung]

15 Zulh 1050 namamanaq I Daeng Anne buraqne nikana I Manuruki Muhammad arinna Tuammenang ri Juntana nikana

$21 \operatorname{Apr}(\mathrm{N})$

Karaeng ri Jarannika Abdul Gafar born ${ }^{127}$

9 Muh 1051 naanaq Karaengta ri Jaranika Abdul Gafar

7 May (T)

Karaeng Tumammaliang ri Timoroq arrived from Timor ${ }^{128}$

25 Muh 1051 nabattu ri Timoroq Karaenga Tumammalianga ri Timoroq

18 May (S)

we were left by Karaeng Tumammaliang ri Timoroq

7 Saf 1051 Sultan Mudhaffar; 11 nights after arriving he died kinapilari Karaenga Tumammalianga ri Timoroq Sultan Mudhaffar 11 bannginna battu namate

$19 \operatorname{May}(\mathrm{N})$

I Biba, the mother of I Saqbi, died

8 Saf 1051 namate I Biba anronna I Saqbi

$2 \operatorname{Oct}(\mathrm{W})$

Karaeng ri Lengkeseq and Daengta Daeng Naratang wed [in accordance with Islamic custom]

26 Jakr 1051 nanipaqnikkah Karaengta ri Lengkeseq Daengta Daeng Naratang

30 Oct (W)

I Daeng Sassang died

24 Raj 1051 namate I Daeng Sassang

$11 \operatorname{Nov}(\mathrm{M})$

Tumamenang ri Lampana [Harrunarasyid] first went up to Somba Opu ${ }^{129}$

7 Syab 1051

nauru manaiq ri Sombopu Tuammenang ri Lampana

127 A son of tumailalang Karaeng Cenrana and brother of Karaeng Lengkeseq, he also became a tumailalang and after his death in 1700 was known as Tumatea ri Salaparang.

128 ANRI 16/6 adds 'and the conquest of Timor; eleven nights after arriving he died at age 43' (nanabeta Timoroq sampulo asseqre banngina battu namate umuruqna 43).

129 The significance of this act is uncertain. At the time Harrunarasyid was only a year old, but this may have been a ritual in which as the ruler of Talloq's son he took symbolic possession of this strategic location. ANRI 16/6 is more explicit but perhaps not more enlightening, as it reads 'at his age Tumamenang ri Lampana [Harrunarasyid] was gently brought [?] and laid down at Somba Opu' (naumuruna nunyu [nunnuq?] menangi). 
1642

23 Jan (W) the people mustered who will be going east to Ambon

21 Syaw 1051 namarewangang tulamanraika ri Ambong

3 Feb (M) I Baliung and I Daeng Battu ${ }^{130}$ sailed from Somba Opu east to Ambon

2 Zulk 1051 namamise ri Sombopu I Baliung siagaang I Daeng Battu manraiq ri Ambong

31 Mar ( $\mathrm{N}$ eve) Karaeng ri Sanrabone died

29 Zulh 1051 namate Karaenga ri Sanrabone

28 Apr (M) I Daeng Maingaq died

27 Muh 1052 namate I Daeng Maingaq

16 May (F) I Wiherah came bringing an elephant

15 Saf 1052 naniaq I Wiherah mangerang gaja

16 Jun (M) Tumamenang ri Ballaq Pangkana [Hasanuddin] circumcised

16 Rawl 1052 nanisunnaq Tuammenang ri Ballaq Pangkana

22 Jun (N) Tumamenang ri Ujung Tana [Karunrung] circumcised

22 Rawl 1052 nanisunnaq Tuammenang ri Juntana

13 Jul (S eve) Karaeng ri Sanrabone Malolo ${ }^{131}$ died

15 Rakr 1052 namate Karaenga ri Sanrabone Maloloa

14 Aug (W eve) Karaeng ri Barombong died at the age of 70

16 Jawl 1052 namate Karaengta ri Barombong umuruqna 70

27 Sep (S) the karaeng [Malikussaid] went out to dwell [elsewhere] so damaged wall(s) could be repaired [at his hall]

1 Raj 1052 nassuluq karaenga maqballaq-ballaq lanitampengina bata gesaraka

130 Also known as Karaeng Butta Toa.

131 Known as Karaeng Malolo, according to the Gowa Chronicle he was the son of the ruler of Sanrabone I Pammusurang and Karaeng Tabaringang, a daughter of Tunijalloq. Alternatively, this is simply an awkward way of stating that Karaeng ri Sanrabone was young or new to the position at the time he died (see the similar entry on 3 Aug 1648). The wording led Ligtvoet (1880:footnote 104) to speculate that this may have been a formal position. 
31 Oct (F) Tumamenang ri Papambatuna [Malikussaid] and Karaeng ri Tangallaq divorced ${ }^{132}$

8 Syab 1052 nasipelaq Tuammenang ri Papanbatuna Karaengta ri Lempangang

1643

$24 \operatorname{Jan}(\mathrm{S})$

I Daeng Marannu ${ }^{133}$ married by Tumamenang ri Ballaq Pangkana [Hasanuddin]

3 Zulk 1052 nanibaineang I Daeng Marannu ri Tuammenang ri Ballaq Pangkana

30 Jan $(\mathrm{F})$

I Datoq ri Paqjeqnekang Gafarullah died

9 Zulk 1052

namate I Datoq ri Paqjeqnekang Gafarullah

29 Jan (W eve) Tumamenang ri Papambatuna [Malikussaid] and a grandparent of Karaeng ri Bontoa ${ }^{134}$ married

8 Zulk 1052 nasikalabini Tuammenang ri Papanbatuna toana

Karaengta ri Bontoa

29 Feb (S eve) I Daeng Lompo died

10 Zulh 1052 namate I Daeng Lompo

2 May (S) I Daeng Tuna ${ }^{135}$ had a child

12 Saf 1053 namamanaq I Daeng Tuna

3 May (S eve) I Taniuqrangi had a son named Salahuddin Karaeng ri Bungaya

14 Saf 1053 namamanaq I Taniuqrangi buraqne nikana Shalahuddin Karaengta ri Bungaya

9 May (F eve) sabannaraq I Daeng Maqlaqbaq died

21 Saf 1053 namate sabannaraka I Daeng Maqlaqbaq

132 VT 25 reads that Malikussaid divorced Karaeng ri Lempangang, but this is a scribal error (Karaeng ri Lempangang was a sister of Malikussaid). As Ligtvoet (1880:footnote 104) and Kamaruddin (1985:104) indicate, the woman he divorced must have been Karaeng Tangallaq.

133 This was a common royal name, and we cannot be certain if this woman was the same as the Daeng Marannu who married Karaeng ri Majannang on 20 Jan 1636. No divorce is recorded of this latter couple in the lontaraq bilang, but very few divorces were entered until the 1650s.

134 Also known as Ralle Daeng Paikaq and titled Karaeng Bontoa (see the note for entry 18 Raj 1035 [1626]).

135 Almost certainly not the same person as the Daengta Daeng Tuna born on 19 Apr 1632. 
12 May (T)

24 Saf 1053

$1 \mathrm{Jul}(\mathrm{W})$

15 Rakr 1053
I Daeng Riolo installed as sabannaraq nanitannang sabannaraq I Daeng Riolo

Dutch ships arrive from Ambon and report that they killed the kimalaha ${ }^{136}$ with his siblings and his mother nabattu kappalaqna Balandaya ri Ambong nanakana nabunoi kimalaha sisariqbattang siparanrongang

31 Aug ( $\mathrm{N}$ eve) Karaeng ri Bontomajannang Syaifulmuluq ${ }^{137}$ born 16 Jakr 1053

23 Sep (T eve)

9 Raj 1053

8 Oct $(W)$

23 Raj 1053

$19 \operatorname{Nov}(R)$

6 Ram 1053

$30 \operatorname{Nov}(\mathrm{M})$

17 Ram 1053 naanaq Karaengta ri Bontomajannang Saifulmuluq

\author{
Karaeng ri Bontolangkasaq died \\ namate Karaengta ri Bontolangkasaq
}

the karaeng [Malikussaid] went down to Agangnionjoq [in Tanete] readying [for battle]; he came to Pancana at asar [about $4 \mathrm{PM}$ ]; the ships accompanying him numbered 125

namanaung ri Agangnionjoq karaenga makkaruru asaraki nari Pancana biseanga niaganga pada-pada 125

the karaeng [Malikussaid] arrived after conquering Boné in the Pare-Pare war; I Tobalaq installed as kadi ${ }^{138}$ [of Boné $]^{139}$

nabattu karaenga nabetana Bone ri bunduq Pare-Parea I Tobelaq nitannang kadi

I Daeng ri Pacellekang died; the mother of I

Mallalanngang died namate I Daeng ri Paccellekang namate ayana I Mallalanngang

\footnotetext{
136 This title refers to a community leader in Luhu on Seram in Maluku. On 17 Jun 1643 VOC troops publicly beheaded Kaicili Luhu, his mother, sister, and stepbrother in a display of force intended to intimidate the local population and ensure their loyalty to the VOC's ally Sultan Hamzah of Ternate (Andaya 1993:161).

137 A son of Malikussaid.

138 Kadi (or kali) was the title given to the chief Islamic official and religious advisor to the ruler. This war against La Maqdaremmeng and I Tobalaq's position afterwards are discussed in Andaya (1981:40-3).

139 ANRI 16/6 adds the following: 'the people returning with him were counted: thirty-one thousand, three hundred and sixty men and three hundred and sixteen ships' (pamoterana taua nanibilang taua tallu cokkoang lompoi assicokkoang keke antallu bilanga angannang pulo bilanna biseanga tallu bilangangi assampulo angannang). If this is accurate, why Malikussaid returned with a much larger army than the one he left with is unclear.
} 
24 Dec (R) teeth filed of Tumamenang ri Ballaq Pangkana [Hasaunddin]

12 Syaw 1053 naniariq Tuammenanga ri Ballaq Pangkana

26 Dec (F eve) Karaeng Tumamenang ri Taenga Muhammad Syafie ${ }^{140}$ born

14 Syaw 1053 naanaq Karaengta Tuammenang ri Taenga Muhammad Syafie

1644

$24 \operatorname{Jan}(\mathrm{N})$

13 Zulk 1053

Tumamenang ri Taenga adopted by Karaeng ri Majannang nanialle Tuammenang ri Taenga nikatuo ri Karaengta ri Majannang

28 Jan (R)

a grandparent of I Lumbaq died

16 Zulk 1053

namate toana I Lumbaq

$18 \operatorname{Mar}(\mathrm{F})$

8 Muh 1054

I Daeng Kapetta, a wife of Karaeng ri Katapang, died namate I Daeng Kapetta bainena Karaengta ri Katapang

8 May $(\mathrm{N})$

1 Rawl 1054

I Daeng Buraqne replaced I Daeng Riboko as sabannaraq ${ }^{141}$ naI Daeng Buraqne assambeangi sabannaraka I Daeng Riboko

$23 \mathrm{Jul}(\mathrm{S})$

Matinroa ri Bukaka [La Maqdaremmeng, the defeated ruler of Boné] brought out here to Makassar

18 Jawl 1054 naipantaraqmo mae ri Mangkasaraq Matinroa ri Bukaka

22 Sep (W) I Tuang Shaykh Yusuf asked permission to go overseas on the haj

27 Raj 1054 namappalaq kana I Tuan Syaikhu Yusuf kalauq haqji

3 Oct (M) word reached the karaeng [Malikussaid] of Karaeng Patteqne's departure; I Daeng Mabela replaced him ${ }^{142}$

1 Syab 1054 nanipabiritta ri karaenga paqlampana Karae Patteqne naI Daeng Mabela assambeangi

140 A son of Pattingalloang, he was also known as Karaeng Bontosunggu and Daeng Tasannging, he must not be confused with the much older son of Pattingalloang's brother Tumammaliang ri Timoroq, who was also known as Daeng Tasannging and Karaeng Bontosunggu.

141 There were thus two sabannaraq in Gowa by this time, but whether they had different duties or were responsible for different communities of traders is uncertain.

142 Karaeng Patteqne died later on Buton, and Daeng Mabela replaced him as karaeng of Patteqne and as a tumailalang of Gowa. 
20 Oct (W eve) Karaeng Paranggi set sail from Galesong overseas to Banten carrying I Tuang [Shaykh Yusuf]

18 Syab 1054 namammeloq ri Galesong Karae Paranggi kalauq ri Bantan nadongkokia I Tuan

31 Oct (M eve) I Cabaq died

30 Syab 1054 namate I Cabaq

7 Dec (T eve) I Bayang married by Karaeng ri Popoq

6 Syaw 1054 nanibaineang I Bayang ri Karaengta ri Popoq

$16 \operatorname{Dec}(\mathrm{F}) \quad$ I Nampa died

15 Syaw 1054 namate I Nampa

\section{5}

8 Jan (S eve) I Bissu ${ }^{143}$ had a daughter named Daengta Daeng Naratang ${ }^{144}$ I Sungguminasa Rabiah, called Karaeng ri Sanggiringang

8 Zulk 1054 namamanaq I Bissu baine nikana Daengta Daeng Naratang I Sungguminasa Rabia Karaengta ri Sanggiringan nikana

10 Jan (T) Karaeng ri Bontosunggu [Tumamenang ri Taenga] and Karaeng ri Sanggiringang were engaged to each other

11 Zulk 1054 nanipasiparekanngang Karaengta ri Bontosunggu Karaengta ri Sanggiringan

3 Feb (F)

5 Zulh 1054

I Tija had a daughter named I Nampa Syahribanung namamanaq I Tiji baine nikana I Nampa Syahribanun

12 Feb (N) Tumamenang ri Ballaq Pangkana [Hasanuddin] and Daengta Daeng Sannging married

14 Zulh 1054 nasikalabini Tuammenang ri Ballaq Pangkana Daengta Daeng Sannging

$25 \mathrm{Feb}(\mathrm{S})$

I Daeng Niaq died

27 Zulh 1054 namate I Daeng Niaq

\footnotetext{
143 A wife of Malikussaid.

144 The Gowa Chronicle gives Daeng Nisanga rather than Daeng Naratang as their daughter's royal name.
} 
$16 \operatorname{Mar}(\mathrm{R}) \quad$ Karaeng ri Majannang said ${ }^{145}$, “We send the compassion of the faith to those of Bima and Selayar"146

20 Muh 1055 nanikana Karaengta ri Majannang kisuro kamaseang sadaq ri Dimaya ri Silayaraka

[21] Mar (S) Karaeng ri Bone ${ }^{147}$ died

22 Muh 1055 namate Karaenga ri Bone

17 Mar (F) Karaeng ri Katinting and Karaeng ri Tabaringang 148 married

28 Muh 1055 nasikalabini Karaengta ri Katinting Karaengta ri Tabaringan

20 Jun (M eve) at the stroke of 1 Karaeng ri Naung ${ }^{149}$ died

23 Rakr 1055 tetteq 1 garigantaya namate Karaengta ri Naun

$15 \mathrm{Jul}(\mathrm{S}) \quad$ the father of the kadi I Karaeng150 Tappaq went overseas on the haj

19 Jawl 1055 nakalauq haqji manggena kadia I Karae Tappaq

30 Oct (M) Tumamenang ri Ujung Tana [Karunrung] had a daughter by Tanang named Nurulmahalli

9 Ram 1055 namamanaq Tuammenang ri Juntana baine ri Tanang nikana Nurulmahalli

$10 \operatorname{Dec}(\mathrm{N}) \quad$ the ruler of Agangnionjoq ${ }^{151}$ and I Tumbuq married

20 Syaw 1055 nasikalabini Karae Agangnionjoq I Tumbuq

\section{6}

22 Jan (M) I Daeng Talarra had a son named I Mappatambaq Abdul Gaffur, known as Karaeng ri Ballaq

145 ANRI 16/6 adds that he spoke 'to the karaeng [Malikussaid]' (ri karaenga).

146 This declaration of solidarity refers to the shahadah or Islamic profession of faith ('There is no god but Allah and Muhammad is the messenger of Allah'), but the historical context inspiring this statement is unclear.

147 This refers to the title of a female Makassarese karaeng, not a ruler of the Bugis kingdom of Boné.

148 Daeng Talarra.

149 She was a daughter of Tunijalloq, widow of Karaeng Matoaya, and mother of Tumammaliang ri Timoroq.

150 ANRI 16/6 gives his title as Kare, a lower-ranking title than Karaeng.

151 Ibrahim (or Borahima) Daeng Matiring Matinroe ri Buliana. 
4 Zulh 1055 namamanaq I Daeng Talarra buraqne nikana I Mappatambaq Abdul Gaffur Karaengta ri Ballaq nikana

$26 \mathrm{Feb}(\mathrm{T}) \quad$ a strong earthquake purportedly struck Manila and its many stone buildings

10 Muh 1056 nanataba bedeng ronrong sarro Manila puaraki ballaq batua

18 Apr (W) the karaeng [Malikussaid] sailed to go into Boné for the Passempaka War ${ }^{152}$

1 Rawl 1056 namamise karaenga mantama ri Bone ri Bunduq Passempaka

25 May (F) the karaeng [Malikussaid] arrived from Boné; he conquered Boné

8 Rakr 1056 nabattu ri Bone karaenga ambetai Bone

15 Jun (R) I Tija had a daughter named Ummu Kalsum

7 Jawl 1056 namamanaq I Tija baine nikana Ummu Kalsum

19 Jun $(\mathrm{T})$

Matinroa ri Bukaka [La Maqdaremmeng] went down to live in Siang

4 Jawl 1056 nanipanaung ri Siang mammempo Matinroa ri Bukaka

$10 \operatorname{Aug}(\mathrm{R})$

Daengta Daeng Naratang I Laji ${ }^{153}$ died below in Maranaq 5 Jakr 1056 namate Daengta Daeng Naratang I Laji irawa ri Maranaq

31 Aug (F) Tumamenang ri Ujung Tana [Karunrung] and Karaeng Tamasongoq married

19 Raj 1056 nasikalabini Tuammenang ri Juntana Karae Tamasongoq

3 Sep (M) the ruler of Bima I Ambela [Sirajuddin] and Karaeng ri Bontojeqneq ${ }^{154}$ wed [in accordance with Islamic custom]

22 Raj 1056 namaqnikkah karae Dima I Ambela Karaengta ri Bontojeqneq

152 This was the third battle in a conflict that began in 1643 and ended with this defeat of La Maqdaremmeng's brother La Tenriaji Tosenrima.

153 ANRI 16/6 omits 'Daengta Daeng Naratang', but does add that I Laji's 'posthumous name was Pawelayie ri Maranaq' (areng matena nikana Pawelayie ri Maranaq).

154 A daughter of Malikussaid. 
$30 \operatorname{Sep}(\mathrm{N}) \quad$ I Tumbuq had a child by the ruler of Agangnionjoq, a son named Ibrahim

19 Syab 1056 namamanaq I Tumbuq ri Karae Agangnionjoq buraqne nikana Ibrahimi

2 Nov (F) I Tanriwela died

23 Ram 1056 namate I Tanriwela

$15 \operatorname{Nov}(\mathrm{R}) \quad$ the karaeng [Malikussaid] sunk near Mangindara [in Takalar] while returning from Kalakongkong

6 Syaw 1056 natallang karaenga ri tujunna Mangindara battu ri Kalakongkong

23 Dec (F eve) Karaeng ri Lempangang died

14 Zulk 1056 namate Karaengta ri Lempangang

$27 \operatorname{Dec}(\mathrm{W}) \quad$ I Dodi and I Daeng Malluq married

18 Zulk 1056 nasikalabini I Dodi I Daeng Malluq

1647

25 Jan (R eve) Karaeng ri Jipang died

18 Zulh 1056 namate Karaengta ri Jipang

$28 \mathrm{Feb}(\mathrm{R}) \quad$ Daengta Daeng Masiang born

22 Muh 1057 naanaq Daengta Daeng Masiang

31 Mar (S eve) Karaeng ri Bontomanompoq Mahmud ${ }^{155}$ born

23 Saf 1057 naanaq Karaengta ri Bontomanompo Mahmud

30 Apr (T) I Daeng ri Pannampuq died

23 Rawl 1057 namate I Daeng ri Pannampuq

6 May (M) it is said that a great wind struck Selayar, blowing down houses and trees

5 Rakr 1057 nanikana natabai angin lompo Silayaraq punggangi ballaka kayua

10 May (T eve) Karaeng Masale died

3 Rakr 1057 namate Karae Masale

155 A son of Karaeng Popoq who in 1663 succeeded his father as anrongguru of the tumakkajannang. 
12 May (F) Friday public prayers established this Friday in Garassiq

5 Rakr 1057 namamenteng jumaka ri Garassiq jumaq

11 Jun (T) Haji Neting installed as kadi, assisting Haji Kare $\quad$ H56 Singaraq

7 Jawl 1057 nanitannang kadi Haji Neting aqbali Haji Karae Singaraq

28 Jun (F) Daengta Daeng Naratang ${ }^{157}$ had a son named I Tataraq, known as Karaeng ri Lekoqboqdong who died in Kelo [on Sumbawa]

24 Jawl 1057 namamanaq Daengta Daeng Naratang buraqne nikana I Tataraq Karaengta ri Lekoqboqdong matea ri Kelo nikana

2 Jul (W)

29 Jawl 1057

I Kare Ampaq killed in the stone house in Ujung Pandang nanibuno I Kare Ampaq ri ballaq batua ri Jumpandang

$13 \mathrm{Jul}(\mathrm{S})$

a stone meeting hall built

10 Jakr 1057

nanibangun baruga batua

1 Aug (R)

I Kare Kanjaraq had a son named Ahmad

28 Jakr 1057

namamanaq I Kare Kanjaraq buraqne nikana Ahmad

$12 \operatorname{Aug}(\mathrm{R})$

Untaya died

10 Raj 1057

namate Untaya

$31 \operatorname{Aug}(\mathrm{S})$

Tamalate [a royal hall] torn down

19 Raj $1057^{158}$

nanigesaraq Tamalate

5 Oct (F eve) war leaders sailed over to Sumbawa: [the karaengs of] Layuq [in Binamuq] and Bangkalaq

6 Ram 1057 namamise dulun taqle ri Sambawa Layuq siagang Bangkalaq

$12 \operatorname{Nov}(\mathrm{T})$

ears pierced of Karaeng ri Paqbineang

156 Unlike VT 25, ANRI 16/6 gives his title as Kare, a lower-ranking title than Karaeng. I believe this is the correct reading, as this title appears again in an entry concerning him on 14 Oct 1655 .

157 A wife of Mammaliang Karaeng Lengkeseq. She must not be confused with the daughter of Malikussaid of nearly the same name who was born on 8 Jan 1645, nor with the woman of nearly the same name who died on 10 Aug 1646.

158 The Hijri date converts to 20 Aug 1647. This small difference can easily be explained if a copyist wrote 31 August in place of 21 August. 
14 Syaw 1057 nanitinting Karaengta ri Paqbineang

12 Nov (T eve) Karaeng ri Sanrabone died

14 Syaw 1057 namate Karaenga ri Sanrabone

$12 \operatorname{Dec}(\mathrm{R}) \quad$ [Karaeng] Ballaq Jawaya ${ }^{159}$ and [Karaeng]

Bontomarannu ${ }^{160}$ married

14 Zulk 1057 nasikalabini Ballaq Jawaya Bontomarannu

25 Dec (W) birth of I Daeng Marannu I Pandiq

27 Zulk 1057 nanianakkang I Daeng Marannu I Pandiq

2 Feb (N) Karaeng Paqbundukang died

7 Muh 1058 namate Karae Paqbundukang

20 Mar (T eve) a wife of Karaeng ri Popoq died 161

25 Saf 1058 namate Karaengta ri Popoq bainea

5 Apr (F eve) Karaenta ri Tamasongoq had a son by Tumamenang ri Ujung Tana [Karunrung] named I Manginara Majduddin, known as Daengta Daeng Mattiro

10 Rawl 1058 namamanaq Karaengta ri Tamasongoq ri Tuammenang ri Juntana buraqne nikana I Manginara Majduddin Daengta Daeng Mattiro nikana

12 May ( $\mathrm{N}$ eve) Karaeng ri Bontoa, the mother of the karaeng [Hasanuddin], died

18 Rakr 1058 namate Karaengta ri Bontoa ayana karaenga

14 Jun (F eve) at the stroke of [unknown] Daengta Daeng Naratang had a daughter named Habibah

20 Jawl 1058 tette garigantaya namamanaq Daengta Daeng Naratang baine nikana Habibah

159 Speelman reported that she was a sister of Mammaliang Karaeng Lengkeseq (Ligtvoet 1880:95). The woman bearing this title must not be confused with two previous title-holders who died in 1627 and 1637 respectively.

160 Speelman reported that he was a son of Karaeng Sumannaq (Ligtvoet 1880:108).

161 Presumably but not necessarily the unnamed wife who gave birth to a son on 3 Jun 1631. 
3 Aug ( $\mathrm{N}$ eve) the young Karaeng Jipang ${ }^{162}$ died

13 Raj $1058^{163}$ namate Karae Jipang maloloa

11 Oct (N) I Maqminasa, known as Daengta Daeng Sannging, died

24 Ram $1058^{164}$ namate I Maqminasa Daengta Daeng Sannging nikana

30 Oct (F) Friday public prayers first established this Friday in

Bontoalaq

12 Syaw 1058165 nauru mammenteng jumaka ri Bontoalaq jumaq

30 Nov (M) the child of the ruler of Silaparang [on Lombok] named Ammasa Pamayan became ruler of Sumbawa

14 Zulk 1058 nakaraeng ri Sambawa anaqna Karae Silaparang nikana Ammasa Pamayan

$8 \mathrm{Dec}(\mathrm{W}) \quad$ a building constructed for the great bell [for chiming the hour]

24 Zulk 1058 nanibangun ballaqna gariganta lompoa

$9 \operatorname{Dec}(\mathrm{R}) \quad$ I Assing 166 died

25 Zulk 1058 namate I Assing

1649

$13 \operatorname{Jan}(\mathrm{W})$

29 Zulh 1058

a tiger arrived, brought by an English ship

nabattu macang kappalaq Anggarrisiq mangerang

$21 \mathrm{Feb}(\mathrm{N}) \quad$ I Tumbuq ${ }^{167}$ had a son named Kasim, the ruler of Agangnionjoq, known as Puanna I Tikkaq ${ }^{168}$

162 The other way to interpret this entry is to read Maloloa as Karaeng Jipang's name, which is quite possible. See the similar entry for $13 \mathrm{Jul} 1642$.

163 A copyist incorrectly wrote Ramadan instead of Rajab for the Hijri month.

164 There is considerable confusion in both the Hijri and Gregorian dating for this and the following entry. The most likely corrected sequence is given here, but it is not certain. VT 25 gives the dates as 11 Oct (W) and 12 Ram 1058.

165 Like the previous entry, there is confusion in both the Gregorian and Hijri months here. In the corrected months given here October replaces VT 25's Sepember and Syawwal VT 25's Ramadan. ANRI 16/6 gives the Gregorian date as October 11th, which matches VT 25's Hijri date for the previous entry (and which converts to 29 Sep 1648).

166 A child of Malikussaid.

167 A wife of the ruler of Agangnionjoq Matinroe ri Buliana. According to Dutch sources from 1750, I Tumbuq was a daughter of a ruler of Gowa and karaeng of Panaikang-Ciniq, Laci, Kaci, and Rappociniq (Ligtvoet 1880:109).

168 He was also known as Mappajanji Daeng Mattajang Matinroe ri Sumpampoba. 
8 Saf 1059

namamanaq I Tumbuq buraqne nikana Kasim Karaengta ri Agangnionjoq nikana Puanna I Tikkaq

$25 \mathrm{Feb}(\mathrm{R}) \quad$ I Daeng Pole, known as Karaeng ri Lengkeseq, slept with Karaeng ri Tangalloq

12 Saf 1059 namaqlusereq Karaengta ri Tangallaq I Daeng Pole Karaengta ri Lengkeseq nikana

13 Mar (F eve) Karaeng ri Lakiung Sitti Shafur ${ }^{169}$ born

28 Saf 1059 naanaq Karaengta ri Lakiun Sitti Shafur

17 Mar (T eve) the mother of the ruler of Agangnionjoq died

3 Rawl 1059 namate ayana Karae Agangnionjoq

9 Apr (R eve) a grandparent of I Daeng died

16 Rawl 1059170 namate toana I Daeng

$10 \mathrm{Jul}(\mathrm{S}) \quad$ the child of Karaeng ri Sumannaq named I Mappaonoq Daeng Mammaliang died

29 Jakr 1059 namate anaqna Karaengta ri Sumannaq nikana I Mappaonoq Daeng Mammaliang

10 Sep (R eve) Daengta Daeng Naratang had a son named Ali, known as Karaeng Lambengi

2 Ram 1059 namamanaq Daengta Daeng Naratang buraqne nikana Ali Karae Lambengi nikana

18 Oct (N eve) I Daeng Leqleng died

10 Syaw 1059 namate I Daeng Leqleng

21 Oct $(\mathrm{R}) \quad$ Karaeng ri Tamasongoq had a daughter named Sittu Anisuh

13 Syaw 1059 namamanaq Karaengta ri Tamasongoq baine nikana Sittu Anisuh

19 Nov (T) Karaeng ri Kassiqjala had a daughter named Aisyah, known as Karaeng Mawajang

169 A daughter of Malikussaid and I Ralle Daeng Paikaq, she was also known as I Manneratu and I Daeng Niasseng.

170 The Hijri date converts to 30 Mar 1649. 
24 Zulk 1059171 namamanaq Karaengta ri Kassiqjala baine nikana Aisyah Karae Mawajang nikana

$19 \operatorname{Dec}(\mathrm{N}) \quad$ Karaeng ri Garassiq and I Daeng Singaraq married

14 Zulh 1059 nasikalabini Karaengta ri Garassiq I Daeng Singaraq

1650

6 Jan (R) Tumamenang ri Ujung Tana [Karunrung] and Karaeng ri Tamasongoq divorced

3 Muh 1060 nasipelaq Tuammenang ri Juntana Karaengta ri Tamasongoq

29 Jan (S) Karaeng ri Cenrana and Daeng ri Mangeppeq divorced ${ }^{172}$

26 Muh 1060 nasipelaq Karaengta ri Cenrana Daengta ri Mangeppeq

$3 \mathrm{Feb}$ (W eve) Karaeng ri Katinting died at the age of 23

30 Muh 1060 namate Karaengta ri Katinting umuruqna 23

11 Mar (F) I Bayang had a child by Karaeng ri Popoq, a son named Ibrahim

7 Rawl 1060 namamanaq I Bayang ri Karaengta ri Popoq buraqne nikana Ibrahim

4 Apr (Sun eve) the mother of the karaengs ${ }^{173}$ was married by Karaeng Tumamenang ri Ballaq Pangkana [Hasanuddin]; before becoming ruler he married

2 Rakr 1060 nanibaineang puanna karaenga ri Tuammenang ri Ballaq Pangkana takaraengapi nanibaineang

17 Jun (W eve) the Datu [ri Luwuq] wed [in accordance with Islamic custom] I Manguqrangi Karaeng ri Tamasongoq; Datu ri Luwuq was known as Matinroa ri Gowa

16 Jakr 1060 namaqnikka ratua I Manguqrangi Karaengta ri Tamasongoq nikana Datua ri Luwuq Matinroa ri Gowa

\footnotetext{
171 The Hijri date converts to 29 Nov 1649.

172 Karaeng ri Cenrana, or Mallewai Daeng Maqnassa, was a tumailalang of Gowa, Daeng ri Mangeppeq was a daughter of Karaeng Matoaya and sister of Karaeng ri Popoq.

173 This refers to I Daeng Nisali, who was the mother of two sultans of Gowa, Muhammad Ali (r. 1674 to 1677) and Abdul Jalil (r. 1677 to 1709).
} 
$27 \mathrm{Jul}(\mathrm{T})$

29 Raj 1060

10 Aug (T)

11 Syab 1060

$26 \operatorname{Aug}(\mathrm{R})$

27 Syab 1060

2 Sep (R eve)

4 Ram 1060

27 Sep (T)

30 Ram 1060

2 Nov (M eve) I Sinukuq, the mother of tumailalang Karaeng ri Bontopanno, was wed [in accordance with Islamic custom] by Karaeng ri Popoq

7 Zulk 1060

4 Nov (R eve)

9 Zulk 1060

$13 \operatorname{Nov}(\mathrm{N})$

17 Zulk 1060

gunpowder exploded, killing I Sinse

nanakaqdoq ubaq I Sinse matei

Macciniqdanggang torn down

nanigesaraq Macciniqdanggang

Macciniqsombalaq constructed; by midday it was all erected; 20 bore bosaraq armbands; 181 bore sipappaq armbands ${ }^{174}$; vassals arrived to see it

nanibangun Macciniqsombalaq tangalloi alloa natapenteng ngaseng tumapponto bosaraq 20 tumapponto sipappaq 181 battui palilika macciniq-ciniq

Karaeng ri Majannang died

namate Karaengta ri Majannang

a sister of Karaeng ri Lempangang's mother ${ }^{175}$ died who had married a Mandar man namate sariqbattanna ayana Karaengta ri Lempangan leqbaka maqburaqne Mandaraq

naninikkai ri Karaengta ri Popoq I Sinukuq anronna tumailalang Karaengta ri Bontopanno

the child of Karaeng ri Popoq named Ibrahim died namate anaqna Karaengta ri Popoq nikanaya Ibrahim

the karaeng [Malikussaid] went up into Macciniqsombalaq; eighty-six nights after it was built the karaeng went up into it namanaiqmo karaenga ri Macciniqsombalaq 80 pulo banngi angannang leqbaq nibangung nanapanaiki karaenga

174 Bosaraq armbands were made of several gold rings and sipappaq armbands were single heavy armbands. This entry refers to the processions, feasting, and ritual acts that accompanied the construction of a royal hall for the ruler of Gowa.

175 ANRI 16/6 omits 'mother' (ayana), making it a sister of Karaeng Lempangang who died. 
$28 \operatorname{Nov}(\mathrm{T})$

2 Zulh 1060

$24 \operatorname{Dec}(S)$

29 Zulh 1060

6 Feb (M)

14 Saf 1061

$22 \mathrm{Feb}(\mathrm{W})$

1 Rawl 1061

I Maqdaeng died

namate I Maqdaeng

the wedding of the ruler of Sumbawa [Ammasa

Pamayan] and Karaeng ri Panaikang

nabunting karae Sambawa ri Karaengta ri Panaikang

1651

birth of I Manjawakkang, an older sibling of Karaeng Tumamenang ri Lakiung [Abdul Jalil]; he lived only nine months ${ }^{176}$

nanianakkang I Manjawakkang kakanna Karaenga

Tuammenang ri Lakiun salapang bulanji tallasaqna

the anaq karaeng and the anaq gallarrang went to Karaeng ri Bontomangape ${ }^{177}$

nanipamange ri Karae Bontomangape anaq karaenga siagang anaq gallarranga

$20 \mathrm{Apr}(\mathrm{W} \text { eve })^{178}$ there were earthquakes three times in one night

27 Rakr 1061 naronrong pintallung sipattang

15 May (M)

a judge for the Portuguese established

24 Jawl 1061 nanipatannanngang tumaqbicara Paranggia

22 May (M)

birth of Karaeng ri Tomponga

1 Jakr 1061

nanianakkang Karaengta ri Tomponga

29 Jun $(\mathrm{R})$

Daeng Tasannging, known as Karaeng ri Bontosunggu of Talloq, broke off his relationship with Daengta Daeng Naratang 179

\footnotetext{
176 The Gowa Chronicle reports that this son of Sultan Hasanuddin died at age seven, but given the entry below for 19 Sep 1651 he died after seven months.

177 This indicates that Karaeng Bontomangape (later Sultan Hasanuddin) was given authority over these two groups. Anaq karaeng refers to noble offspring and anaq gallarrang refers to children of local lords. Like the term anaq buraqne, it is not clear the degree to which these represented distinct groups with duties and privileges or was simply a term of reference to social strata.

178 VT 25 and Makasaarsche historiën (1855:121) have 2 Apr for the Gregorian date, but this is incorrect. ANRI 16/6 has the 20th, which is close to the Hijri date (which converts to 18 Apr).

179 This is a challenging entry to interpret because there are two sets of individuals with these names to whom it could refer. Most likely, it describes the end of an engagement between two children: Daengta Daeng Naratang [3] was six years old at the time (b. 8 Jan 1645), and Tumamenang ri Taenga, who was a son of Karaeng Pattingalloang, eight years old (b. 26 Dec
} 
10 Raj 1061 nanitappuki Daengta Daeng Naratang ri Daeng Tasannging Karaengta ri Bontosunggu ri Talloq nikana

18 Aug (F) the karaeng [Malikussaid] was furious at the servants who did not follow him to Agangnionjoq

1 Ram 1061 nanikalarroi ri karaenga bembeng kaqdoqka tamanaunna mamminawang ri Agangnionjoq

19 Sep (T) I Manjawakkang died at the age of 9 months

3 Syaw 1061 namate I Manjawakkang umuruqna 9 bulan

18 Oct (R) I Daeng Tuna and Barombong Karaeng Alluq married

4 Zulk 1061 nasikalabini I Daeng Tuna Barombong Karae Alluq

8 Nov (T) I Daeng Patalo and I Kare Teqne, a child of I Daeng Kalula, married

23 Zulk 1061 nasikalabini I Daeng Patalo I Kare Teqne anaqna I Daeng Kalula

$25 \operatorname{Nov}(\mathrm{S}) \quad$ the Dutch asked for Ambon from the karaeng [Malikussaid]

12 Zulh 1061 nanapalaq Balandaya Ambong ri karaenga

$29 \operatorname{Nov}(\mathrm{N}) \quad$ a child of I Toalaq and the ruler of Binongko [an island southeast of Buton] married

14 Zulh 1061 nasikalabini anaqna I Toalaq karae Binongko

6 Dec (T eve) Karaeng Batupute died

22 Zulh 1061 namate Karae Batupute

$13 \operatorname{Dec}(S) \quad$ the ruler of Bima I Mapparabung Nuruddin born ${ }^{180}$

29 Zulh 1061 naanaq karaenga ri Dima I Mapparabung Nuruddini

1643). They were promised to each other on 10 Jan 1645 . However, it is conceivable that it describes the end of a relationship between an older Karaeng Bontosunggu (also named Daeng Tasannging, a son of Tumammaliang ri Timoroq), and an older Daengta Daeng Naratang [2].

180 Also known as Daeng Matalliq Karaeng Panaragang. He was a son of the ruler of Bima Sultan Abil Khair, also known as I Ambela and Sirajuddin, by Malikussaid's daughter Karaeng Bontojeqneq. 


\section{2}

4 Apr (W eve) Karaeng ri Suli died

23 Rakr 1062 namate Karaenga ri Suli

14 Apr (S eve) tumailalang Karaeng Bontopanno Abdul Gafur ${ }^{181}$ born 4 Jawl 1062 naanaq tumailalang Karae Bontopanno Abdul Gafur

31 May (F) Karaeng ri Bontokamase Abdurrahman born

21 Jakr 1062 naanaq Karaengta ri Bontokamase Abdurrahman

27 Jun $(\mathrm{R})$

19 Raj 1062

a carved house ${ }^{182}$ built in Bontoalaq

$5 \mathrm{Jul}(\mathrm{F})$

24 Raj 1062

nanibangun ballaq niukirika ri Bontoalaq

24 Raj 1062

Karaeng ri Katapang ${ }^{183}$ went down to Mandar to set up fortifications namanaung ri Mandaraq Karaengta ri Katapang mattannang benteng

18 Aug (N) Karaeng Tumamenang ri Lakiung Abdul Jalil184 born

12 Ram 1062 naanaq karaenga Tuammenang ri Lakiun Abdul Jalil

2 Sep (N eve) $\quad \begin{aligned} & \text { Daengta Daeng Onjoq and Daengta Daeng Naratang } 185 \\ & \text { married }\end{aligned}$

27 Ram 1062 nasikalabini Daengta Daeng Onjoq Daengta Daeng

Naratang

181 A son of Karaeng Popoq.

182 Ballaq ukiriq or 'carved house' refers to a building that is ornately decorated, but the purpose or meaning of this structure is uncertain. A 1739 entry in 'Makasaarsche historiën' (1855:130) states that this was the house of the ruler of Boné, but when this became so is unknown. ANRI 16/6 indicates its size, adding that it was built in six sections on pillars (annang paqdaserang) lengthwise.

183 Speelman reported that he was a son of Karaeng ri Dataq, who was a son of Tunibatta (Ligtvoet 1880:111). The Gowa Chronicle too notes that this Karaeng ri Dataq had a son named Karaeng ri Katapang and also records that Karaeng ri Dataq was one who did not flee during Tunipasuluq's disastrous reign in the early 1590s. Karaeng ri Katapang must have been born late in Karaeng ri Dataq's life or have enjoyed exceptional health to lead this expedition 60 years later. 184 A son of Hasanuddin by I Daeng Nisali, his personal name was I Mappadulung, his royal name I Daeng Mattimung, his karaeng-title before he became sultan was Karaeng ri Campagaya, and once the people of Sanrabone expelled their karaeng he became their lord and was thus also known as Karaeng ri Sanrabone.

185 Presumably this refers to the girl of this name whose engagement to was ended on 29 Jun 1651. 
13 Sep (F) I Manna had a girl named Aisyah

9 Syaw 1062 namammanaq I Manna baine nikana Aisyah

21 Nov (R) people mustered around the manuscript from Ternate ${ }^{186}$

19 Zulh 1062 namarewangan taua niuluna lontaraqna Taranate

29 Nov (F) I Daeng ri Bulekang went east to Ambon

27 Zulh 1062 namanraiq ri Ambong I Daeng ri Bulekang

18 Jan (S)

1653

17 Saf 1063

I Bunduq died

namate I Bunduq

$20 \operatorname{Jan}(\mathrm{M})$

I Mappasepeq and the child of Karaeng ri Garassiq named I Sitti married

19 Saf 1063 nasikalabini I Mappasepeq anaqna Karaengta ri Garassiq nikanaya I Sitti

23 Jan (R) Karaeng ri Bontojeqneq ${ }^{187}$ had a daughter named Sitti Aminah

22 Saf 1063 namamanaq Karaengta ri Bontojeqneq baine nikana Sitti Aminah

9 Apr (T eve) Anciq Majjah, anrongguru for Tumamenang ri Papambatuna [Malikussaid], died

10 Jawl 1063 namate Anciq Majjah angronggurunna Tuammenang ri Papangbatuna

$23 \operatorname{Apr}(\mathrm{R})$

24 Jawl 1063

I Kammisiq and I Radin married nasikalabini I Kammisiq I Radin

5 Jun (W eve)

a grandparent of I Tija died

8 Raj 1063

namate toana I Tija

186 This muster was in response to events in Maluku. In 1648 Mandar Syah became sultan of Ternate. He was an unpopular choice, but had the support of the VOC and shared their goal of reducing Makassarese influence in Maluku. On 2 Aug 1650 local Ternate notables revolted against Sultan Mandar, rallying behind his brother Kaicili Manilha. With the aid of a VOC fleet the following year, Mandar was returned to the throne, though resistance continued for several years (Andaya 1993:163-5). The next entry suggests that Malikussaid sent a fleet to Maluku under I Daeng ri Bulekang to aid those opposed to Mandar Syah.

187 The wife of the ruler of Bima I Ambela Sirajuddin. 
12 Jun (R) Karaeng ri Taipaya died

15 Raj 1063 namate Karaenga ri Taipaya

4 Jul (R eve) I Loqmoq Daeng died

9 Syab 1063 namate I Loqmoq Daeng

25 Aug (M) bila-bila issued to go east to Ambon for 71 nights hence

1 Syaw 1063 nanipalele bila-bila manraika ri Ambong 71 bannginna

1 Oct $(\mathrm{W}) \quad$ people mustered at Baroqbosoq; the total number of those who assembled was 9413

9 Zulk 1063 namarewangan taua ri Baroqbosoq bilang pampanna tumarewanganga 9413

8 Oct (W) the ritual was held in Talloq in which the teeth filed of Tumamenang ri Lampana [Harrunarasyid]

16 Zulk 1063 kaparekanga ri Talloq niariqna Tuammenang ri Lampanna

5 Nov (T eve) we were left by Karaeng Tumamenang ri Papambatuna [Malikussaid] ${ }^{188}$

13 Zulh 1063 kinapilari Karaenga Tuammenanga ri Papanbatuna

16 Dec (T) Daengta I Daeng Kalau died

26 Muh 1064 namate Daengta I Daeng Kalau

27 Dec (S) Karaeng ri Mandalleq I Tulolo Tajuddin ${ }^{189}$ born

6 Saf 1064 naanaq Karaengta ri Mandalleq I Tulolo Tajuddini

1654

7 Jan (T eve) Datu [ri Luwuq] and Karaeng ri Tamasongoq divorced 18 Saf 1064 nasipelaq ratua Karaengta ri Tamasongoq

4 Feb (T eve) I Loqmoq, the mother of Karaeng Galesong, married by Tumamenang ri Ballaq Pangkana [Hasanuddin]

15 Rawl 1064 nanibaineang I Loqmoq anronna Karae Galesong ri Tuammenang ri Ballaq Pangkana

\footnotetext{
188 ANRI 16/6 adds '[at the age of] 47' (47).

189 Speelman reported that he was a son of Karaeng Karunrung. His mother was Loqmoq Galorang, a title which indicates non-noble status (Ligtvoet 1880:113).
} 
$16 \mathrm{Feb}(\mathrm{N}) \quad$ I Minaq had a daughter named Maryam

26 Rawl 1064 namamanaq I Minaq baine nikana Maryam

$25 \mathrm{Feb}(\mathrm{W}) \quad$ Karaeng ri Patukangang died

7 Rakr 1064 namate Karaengta ri Patukangan

22 Apr (W) Karaeng ri Bontopaqja Maemuna ${ }^{190}$ born

3 Jakr 1064 naanaq Karaengta ri Bontopaqja Maemuna

27 Apr (M) a wife of the ruler of Agangnionjoq had a son

8 Jakr 1064 namamanaq bainenna karae Agangnionjoq buraqne

21 May (R) Tumamenang ri Ballaq Pangkana [Hasanuddin] and Karaeng ri Paqbineang ${ }^{191}$ married

3 Raj $1064 \quad$ nasikalabini Tuammenang ri Ballaq Pangkana Karaengta ri Paqbineang

2 Jul (R) I Loqmoq Maroangi died

17 Syab 1064 namate I Loqmoq Maroangi

$8 \mathrm{Jul}$ (R eve) the mother of Karaeng ri Mangalliq ${ }^{192}$ divorced by Tumamenang ri Ballaq Pangkana [Hasanuddin]

23 Syab 1064 nanipelaq ri Tuammenang ri Ballaq Pangkana anronna Karaengta ri Mangalliq

15 Sep (R eve) we were left by Karaeng Tumamenang ri Bontobiraeng [Pattingalloang]

6 Zulk 1064 kinapilari Karaengta Tuammenang ri Bontobiraeng

22 Oct (R) it was announced to the vassals that the karaeng [Hasanuddin] would speak for the land 193

10 Zulh 1064 nanikanakanaang palilika karaenga ampakkanangi buttana

190 Ligtvoet (1880:113) noted and Kamaruddin (1985:116) concurred that she was probably a daughter of ruler of Bima I Ambela and Karaeng Bontojeqneq.

191 A daughter of Karaeng Pattingalloang.

192 Karaeng ri Mangalliq was also known as I Manrurungang and I Kare Gappa. His mother's name was I Loqmoq Dayang.

193 In other words, following the death of Karaeng Pattingalloang, the new ruler of Gowa decided that he would not appoint a tumabicarabutta, the chief advisor and minister of Gowa known as 'The Speaker of the Land'. This was a major departure from the practices of his predecessors, who had appointed their counterparts ruling Talloq as tumabicarabutta. 
$12 \operatorname{Nov}(\mathrm{R}) \quad$ Karaeng Tumamenang ri Taenga ${ }^{194}$ circumcised 1 Muh 1065 nanisunnaq Karaengta Tuammenang ri Taenga

$29 \operatorname{Nov}(\mathrm{N}) \quad$ Tumatea ri Jakattaraq Muhammad Ali1 195 born 18 Muh 1065 naanaq Tumatea ri Jakattaraq Muhammad Ali

16 Dec (W) the karaeng [Hasanuddin] declared, 'What do you think, should we go out [to meet them in battle] or should we stay and strengthen [our fortifications]? The Dutch will come up here again.'

7 Saf 1065 nanakana karaenga antekamma keqnang maqlampakiq deq mamattangkiq mappakajarreq namanaiq mae pole Balandaya

\section{5}

13 Jan (F eve) Karaeng ri Mangalliq ${ }^{196}$ born; Daeng Tommaq died 20 Rawl 1065197 naanaq Karaengta ri Mangalliq namate Daeng Tommaq

2 Feb (T) Karaeng ri Tangallaq 198 and Karaeng ri Lengkeseq divorced ${ }^{199}$

26 Rawl 1065 nasipelaq Karaengta ri Tangallaq Karaengta ri Lengkeseq

$15 \mathrm{Feb}$ ( $\mathrm{N}$ eve) I Manuruki, the younger sibling of Tumamenang ri Ujung Tana [Karunrung], died at fifteen years of age

7 Rakr 1065 namate I Manuruki arinna Tuammenang ri Juntana umuruqna sampulo taung allima
$21 \operatorname{Mar}(\mathrm{N})$
Karaeng Tumamenang ri Ballaq Pangkana [Hasanuddin] sailed east to Buton ${ }^{200}$
11 Jawl 1065
namamise Karaenga Tuammenang ri Ballaq Pangkana manraiq ri Butun

\footnotetext{
194 Also known as Karaeng Bontosunggu and Daeng Tasannging, he was a son of Karaeng Pattingalloang.

195 Also known as Karaeng Bisei, he was a son of Hasanuddin and would become sultan of Gowa in 1674.

196 A son of Hasanuddin.

197 The Hijri date converts to 28 Jan 1655.

198 A daughter of Tumammaliang ri Timoroq.

199 Though they apparently reconciled, for they divorced again on 7 Sep 1655, after which he married on 14 Feb 1656.

200 ANRI 16/6 adds 'after eleven nights of travel he conquered Tobea' (nasampulo banngi asseqre lampana nanabeta Tobea).
} 
29 Mar (M) Karaeng Galesong I Maninrori ${ }^{201}$ born

19 Jawl 1065 naanaq Karae Galesong I Maninrori

$18 \operatorname{Apr}(\mathrm{N}) \quad$ Buton fined for their offense 888 kati

12 Jakr 1065 naniloqrosoq salana Butunga 888 katina

14 May (F) the karaeng [Hasanuddin] arrived from Buton and the conquest of Tobea [islands near Buton]; his journey lasted sixty-four nights

7 Raj 1065 nabattu karaenga ri Butun nabetana Tobea 60 banngi angappaq lampana

13 Aug (F) the corpse of I Daeng Battu ${ }^{202}$ was brought back

12 Syaw 1065 nabattu nierang bakkena I Daeng Battu

21 Aug (S) the ruler of Sumbawa [Ammasa Pamayan] and Karaeng ri Panaikang divorced

20 Syaw 1065 nasipelaq karae Sambawa Karaengta ri Panaikang

27 Aug (R eve) a grandparent of I Kacung [I Loqmoq] married by Tumamenang ri Lampana [Harrunarasyid]

24 Syaw 1065 nanibaineang toana I Kacung ri Tuammenang ri Lampanna

7 Sep (M eve) Karaeng ri Lengkeseq and Karaeng ri Tangallaq divorced

7 Zulk 1065 nasipelaq Karaengta ri Lengkeseq Karaengta ri Tanngallaq

14 Oct $(\mathrm{M})^{203}$ Gallarrang Mangasa I Kare Naba died; I Kare Singaraq replaced him [as lord of Mangasa]

13 Zulh 1065 namate Galarrang Mangasa I Kare Naba naI Kare Singaraq assambeangi

23 Oct (S) the Dutch were attacked in Bontocoiq by Karaeng ri Popoq and sunk 204

22 Zulh 1065 nanipirumpaki Balandaya ri Bontocoiq ri Karaengta ri Popoq na tallang

201 A son of Hasanuddin.

202 ANRI 16/6 adds that he was also known as Karaeng Butta Toa.

203 A copyist mistakenly wrote the 4th instead of the 14th for the Gregorian day.

204 ANRI 16/6 adds 'one sloop was overrun' (sibatu soqlloq niluqluka). 
$\begin{array}{ll}8 \text { Dec }(W) & \text { Karaeng ri Bontojeqneq arrived from Bima } \\ 11 \text { Saf } 1066 & \text { nabattu ri Dima Karaengta ri Bontojeqneq }\end{array}$

1656

9 Jan (M eve) I Daeng had a daughter named I Radiah

5 Rawl 1066 namamanaq I Daeng baine nikana I Radiah

14 Feb (N eve) Karaeng ri Lengkeseq and Daengta Daeng Maingaq married

18 Rakr 1066 nasikalabini Karaengta ri Lengkeseq Daengta Daeng Maingaq

24 Feb (M)

ears pierced of Karaeng ri Sanggiringang205

2 Jawl 1066 nanitinting Karaengta ri Sanggiringang

31 Mar (R eve) Tumammaliang ri Alluq Amir Hamzah²06 born 4 Jakr 1066 naanaq Tumammalianga ri Alluq Amir Hamza

29 May (M) Karaeng ri Langeloq Latifah 207 born

4 Syab 1066 naanaq Karaengta ri Langeloq Latifah

6 Aug (N) Tumamenang ri Taenga [Karaeng ri Bontosunggu] and Karaeng ri Sanggiringang married

14 Syaw 1066 nasikalabini Tuammenang ri Taenga Karaengta ri Sanggiringan
8 Aug (T) I Daeng Mattukung, mentor of the envoy Uthman, born $^{208}$
16 Syaw 1066 naanaq I Daeng Mattukung anronggurunna suroa Uthman

\footnotetext{
205 A daughter of Malikussaid.

206 A son of Hasanuddin and Karaeng Paqbineang. His personal name was I Mappasomba and his royal name was I Daeng Uraga, but he had not yet received a karaeng-title when he unexpectedly succeeded his father as ruler of Gowa in 1669

207 A daughter of Hasanuddin. According to the Gowa Chronicle, she was also known as I Sunggu and I Daeng Talebang.

208 This entry is more confounding than it appears. An envoy of the same name arrived from Maluku on 24 Aug 1632 and then departed on 18 Sep 1632. Either there coincidentally were two envoys of the same name, which seems unlikely, or this entry needs to be read in another way. The most likely reading may be 'I Daeng Mattukung was born to the mentor of the envoy Uthman' if we add the preposition ri to the entry.
} 
5 Sep (T) the karaeng [Hasanuddin] was in Kalakongkong when the ruler of Maluku Kaicili Kalamata arrived 209

15 Zulk 1066 ri Kalakongkongi karaenga nabattu karaeng Maluku Kacili Kalimata

29 Sep $(\mathrm{F})$

10 Zulh 1066

I Kare Pate, a wife of Karaeng ri Popoq, had a daughter namamanaq I Kare Pate bainenna Karaengta ri Popoq baine

11 Nov (F eve) Karaeng ri Bontojeqneq had a daughter named I Cinra 23 Muh 1067 namamanaq Karaengta ri Bontojeqneq baine nikana I Cinra

13 Dec (W) Ceylon ${ }^{210}$ conquered by the Dutch; the Bantanese advanced on Jakattaraq

16 Saf $1067^{211}$ nanibeta Selon ri Balandaya nanipanaiki Jakattaraq ri Bantanga

1657

10 Jan $(W)$

Karaeng ri Talloq [Harrunarasyid] arrived from Mandar

23 Rawl 1067 nabattu ri Mandaraq Karaenga ri Talloq

12 Feb (M)

27 Rakr 1067

Karaeng ri Lengkeseq and Karaeng ri Tangallaq returned to each other [after having divorced twice]

$24 \mathrm{Feb}$ (N eve) [future] sabannaraq Daeng Makkulle Abdul Wahid had a child $^{212}$

11 Jawl 1067 naanaq sabannaraka Daeng Makkulle Abdulwahid

$2 \operatorname{Mar}(\mathrm{F}) \quad$ Karaeng ri Lengkeseq and I Daeng Maingaq divorced 15 Jawl 1067 nasipelaq Karaengta ri Lengkeseq I Daeng Maingaq

\footnotetext{
209 Kaicili Kalamata was a brother of the VOC-supported ruler of Ternate, Sultan Mandar Syah, with a reputation as an able ruler knowledgeable about Islam. After first supporting, and then turning against Mandar, Kalamata ultimately was defeated by the Dutch and forced to flee several times before seeking refuge in Gowa (Andaya 1993:164-5). See entries on the events of Nov 1652 for further information. Kalamata would stay and marry Karaeng ri Panaikang.

210 ANRI 16/6 has Sula (islands in Maluku) in place of Ceylon, but this is incorrect. The VOC began its conquest of Portuguese Ceylon in 1656 and completed in by 1658.

211 The Hijri date converts to 3 Dec 1656.

212 The Makassarese appears to read that Daeng Makkulle was born on this date, but that is incorrect. He became sabannaraq on 28 Apr 1661 and died on 7 Sep 1677 at the age of 62.
} 
7 Apr (M) Tumammaliang ri Alluq [Amir Hamzah] put up in a sling [at about age one year]

23 Jakr 1067 nanipanaiq ri toeng Tumammaliang ri Alluq

$19 \operatorname{Apr}(\mathrm{R}) \quad$ Karaeng ri Bontosunggu and Karaeng ri Sanggiringang divorced

5 Raj 1067 nasipelaq Karaengta ri Bontosunggu Karaengta ri Sanggiringan

29 May (T eve) the younger sibling of Tumammaliang ri Alluq [Amir Hamzah] known as Ahmad born

15 Syab 1067 naanaq arinna Tumammaliang ri Alluq nikanaya Ahmad

17 Sep (N eve) I Daeng Mangemba I Kasim, a child of Karaeng ri Lengkeseq, born

8 Zulh 1067 naanaq I Daeng Mangemba I Kasim anaqna Karaengta ri Lengkeseq

19 Oct (F) the karaeng [Hasanuddin] went down to Maros to dig irrigation works in Dulang

11 Muh 1068 namanaung ri Marusuq karaenga makkekeseq jeqneq panaiq ri Dulan

8 Nov (R) Karaeng ri Sanggiringang and Karaeng ri Bungaya married

2 Saf 1068 nasikalabini Karaengta ri Sanggiringan Karaengta ri Bungaya

\section{8}

5 Feb $(\mathrm{T})$

Tumamenang ri Ujung Tana [Karunrung] faced someone running amuk

1 Jawl 1068 namamuntuli tumaqjalloq Tuammenang ri Juntana

27 Mar (W) Karaeng ri Bontojeqneq and the ruler of Bima [Sirajuddin] divorced

22 Jakr 1068 nasipelaq Karaengta ri Bontojeqneq karaenga ri Dima

5 May $(\mathrm{N}) \quad$ birth of the younger sibling of Karaeng ri Langeloq named Ismail

1 Syab 1068 nanianakkang arinna Karaengta ri Langeoq nikanaya Ismail 
20 Jun (W eve) Karaeng ri Jarannika and Karaeng ri Bontojeqneq married

2 Ram $1068^{213}$ nasikalabini Karaengta ri Jarannika Karaengta ri Bontojeqneq

5 Aug (M) Daengta Daeng Mangaungi Hasan born

5 Zulk 1068 naanaq Daengta Daeng Mangaungi Hasan

12 Aug (N eve) Daengta Daeng Mangalle Abdul Hamid born

12 Zulk 1068 naanaq Daengta Daeng Mangalle Abdul Hamid

30 Aug (R eve) a grandparent of Karaeng ri Bontoa ${ }^{214}$ and the ruler of Bima married

30 Zulk 1068 nasikalabini toana Karaengta ri Bontoa karaenga ri Dima

21 Sep (S) the day of Shaykh Nuruddin's death in Aceh

22 Zulh 1068 allo nakamateanga Syekhu Nuruddini ri Aceh

18 Oct (R eve) I Kammisiq had a daughter named Halimah

21 Muh 1069 namamanaq I Kammisiq baine nikana Halimah

$19 \operatorname{Nov}(\mathrm{T}) \quad$ the elephant died ${ }^{215}$

22 Saf 1069 namate gajaya

23 Nov (S) the ruler of Sanrabone ${ }^{216}$ went down to Talloq as he was going to be expelled [as ruler]

26 Saf 1069 namanaung ri Talloq karaenga ri Sanrabone lanipasuluqna

$28 \operatorname{Nov}(\mathrm{W}) \quad$ the ruler of Sanrabone was bound ${ }^{217}$

213 The Hijri date converts to 4 Jun 1658; this discrepancy is most likely the result of a copyist error.

214 Not to be confused with the Karaeng ri Bontoa who died a decade earlier on 12 May 1648.

215 It was brought to Gowa on 16 May 1642.

216 ANRI 16/6 also gives his name, Puanna I Jenalaq. A chronicle from Sanrabone has this to say about him: 'This ruler was deposed. He went over to Bali. Over there he died a death from disease. His personal name was I Kase. His royal name was I Daeng Talebang' (Cummings 2002:138). Speelman reported that he was named Abdul (Ligtvoet 1880:116).

217 This gives the impression that he was deposed by being bound with ropes, but given the fact that he had already fled to Talloq the wording in ANRI 16/6 makes more sense. It adds the word 'kalena' to indicate that 'the ruler of Sanrabone bound himself.' Exactly what this means is not clear, but it does make more contextual sense as an action he undertook to remove himself from power. 
2 Rawl 1069 nanisikkoq karaenga ri Sanrabone

4 Dec (W) Karaeng ri Mandalleq I Daeng Sisila Ibrahim ${ }^{218}$ born

9 Rawl 1069 naanaq Karaengta ri Mandalleq I Daeng Sisila Ibrahim

\section{9}

10 Jan $(\mathrm{F}) \quad$ I Cacong divorced by Karaeng Tumamenang ri Ballaq Pangkana [Hasanuddin]

15 Rakr 1069 nanipelaq I Cacong ri Karaenga Tuammenang ri Ballaq Pangkana

26 Feb (W) Karaeng Bintang, a child of Karaeng ri Garassiq, died 3 Jakr $1069^{219}$ namate Karae Bintang anaqna Karaengta ri Garassiq

21 Apr (M) the karaeng [Hasanuddin] sailed from Somba Opu down to Mandar; his ships numbered 1183

27 Raj 1069 namamise ri Sombopu karaenga manaung ri Mandaraq bilanna biseanga 1183

29 May (R) the karaeng [Hasanuddin] arrived from Mandar; this the year of Daengta Daeng Majannang's birth220

7 Ram 1069 nabattu ri Mandaraq karaenga iaminne taunga kaanakkanna Daengta Daeng Majannang

14 Jun (F eve) Karaeng ri Pattunga died

23 Ram 1069 namate Karaengta ri Pattunga

25 Aug (M) Karaeng ri Lembaya ${ }^{221}$ died

6 Zulh 1069 namate Karaengta ri Lembaya

1 Sep (N eve) Karaeng Balambaru died below in Majeqneq

15 Zulh 1069 namate Karaeng Balambaru irawa ri Majeqneq

218 Dutch sources from 1681 and 1712 report that, like I Tulolo Tajuddin, who was also titled Karaeng Mandalleq and born 27 Dec 1653, he was a son of Karunrung (Ligtvoet 1880:117).

219 A copyist mistakenly wrote Jumadilawal for Jumadilakhir, which converts correctly to the Gregorian date.

220 The lack of precision indicates that this birth was interpolated into the text at a later date. She only became important enough to mention in the annals after her marriage to Amir Hamzah on $13 \mathrm{Jul} 1671$. This conclusion is supported by the fact that Or 272Y contains only the first half of this entry.

221 A son of Matoaya, he was also known as I Manibang (or Mannimang) and I Daeng Matutu. 
10 Sep (W) Daengta Daeng Takontu Fatimah 222 born

22 Zulh 1069 naanaq Daengta Daeng Takontu Fatimah

29 Sep (N eve) ${ }^{223}$ Karaeng ri Agangjeqneq ${ }^{224}$ born

11 Muh 1070 naanaq Karaengta ri Agangjeqneq

20 Dec (F eve) Karaeng Bulo-Bulo and Karaeng ri Tamasongoq married 6 Rakr 1070 nasikalabini Karaeng Bulo-Bulo Karaengta ri Tamasongoq

3 Jan (F eve) Karaeng ri Jarannika and Karaeng ri Bontojeqneq divorced

21 Rakr 1070 nasipelaq Karaengta ri Jarannika Karaengta ri Bontojeqneq

15 Jan (R) Karaeng ri Bontomajannang and I Daeng Marannu I Pandiq married

3 Jawl 1070 nasikalabini Karaengta ri Bontomajannang I Daeng Marannu I Pandiq

26 Jan (M) I Loqmoq ri Mangeppeq died

14 Jawl $1070 \quad$ namate I Loqmoq ri Mangeppeq

$4 \mathrm{Feb}(\mathrm{W}) \quad$ the mother of I Mininrori had a daughter named Shafiatuddin, known as I Daeng Rikong 225

21 Jawl 1070 namamanaq anronna I Mininrori baine nikana Shafiatuddini I Daeng Rikong nikana

17 Feb (T) I Datoq, kadi Abdul Maula, died

5 Jakr 1070 namate I Datoq kadi Abdulmaula

10 Mar (T eve) Karaeng ri Bontomarannu and Karaeng ri Ballaq Jawaya divorced

28 Jakr 1070 nasipelaq Karaengta ri Bontomarannu Karaengta ri Ballaq Jawaya

222 A daughter of Hasanuddin also known as Karaeng Campagaya.

223 This entry and the next are placed in correct chronological order here, but in VT 25 are reversed. Presumably a copyist accidentally skipped an entry while copying a source text and then corrected his error.

224 A son of Hasanuddin, also known as I Makkarurung and I Daeng Mattulu.

225 A daughter of Hasanuddin, in the Gowa Chronicle her personal name is rendered as I Sapia. A 9 Mar 1673 entry gives her personal name as simply Shafiah. 
18 Mar (W eve) the interpreter I Dododi died 5 Raj $1070 \quad$ namate I Dododi jurubasa

1 Apr (W eve) the people of Sanrabone were brought back down to Talloq226

19 Raj $1070 \quad$ nanibaliangang tuSanrabonea manaung ri Talloq

5 Apr (M) Karaeng ri Pasiq 227 born

24 Raj $1070 \quad$ naanaq Karaengta ri Pasiq

12 Jun (S) Paqnakkukang advanced on by the Dutch; the karaengs of Batu-Batu, Tompoqbalang, and Bontomanompoq killed 2 Syaw 1070 nanipanaiki Paqnakkukang ri Balandaya naniposo karae Batu-Batu Tompoqbalang Bontomanompoq

20 Jun $(\mathrm{N})$

teeth filed of Karaeng ri Lakiung

10 Syaw 1070

naniariq Karaengta ri Lakiun

5 Jul (M) Karaeng ri Popoq sailed overseas to Jakattaraq to ransom Paqnakkukang

26 Syaw 1070 namamise Karaengta ri Popoq kalauq ri Jakattaraq amballi Paqnakkukang

7 Aug (F eve) I Tobalaq fled 228

30 Zulk 1070 namalari I Tobalaq

10 Aug (T) Karaeng ri Talloq [Harrunarasyid], Karaeng ri Sumannaq, Karaeng ri Cenrana, and Karaeng ri Karunrung went to go into Boné to put out the revolt of I Tobalaq; 37 servants traveled [with them]

3 Zulh 1070 namaqlampa Karaenga ri Talloq Karaengta ri Sumannaq Karaengta ri Cenrana Karaengta ri Karunrung mantama ri Bone makkaruru balina I Tobalaq 37 bembeng kaqdoq maqlampa

226 This is presumably in connection with the abdication of their ruler eighteen months before.

227 A daughter of Harrunarasyid (Ligtvoet 1880:117).

228 I Tobalaq was the Gowa-appointed leader of Boné and was responsible for ensuring that thousands of Bugis would dig a canal separating Dutch-held Paqnakkukang from the mainland. This onerous task was greatly resented by the Bugis, and Tobalaq and Arung Palakka revolted and fled. This event and the subsequent defeat of Boné is discussed in Andaya (1981:51-6). 
7 Sep (T)

1 Muh 1071

2 Oct (S)

26 Muh 1071

$21 \operatorname{Sep}(\mathrm{T})$

15 Muh $1071^{230}$

11 Oct (M)

5 Saf 1071

18 Oct (M)

12 Saf 1071

$24 \mathrm{Nov}(\mathrm{W})$

20 Rawl $1071^{231}$

$11 \operatorname{Nov}(R)$

7 Rawl 1071

2 Dec (R) 28 Rawl 1071
I Tuang Anciq Jenalaq, the kadi of Somba Opu, died namate I Tuan Anciq Jenalaq kadi ri Sombopu

installed as the kadi of Somba Opu was pakki229 Dambo Abdurrahim, replacing I Tuang Anciq Jenalaq nanitannang kadi ri Sombopu pakkih Dambo Abdurrahim I Tuan Anciq Jenalaq nasambeang

Boné conquered; Karaeng ri Sumannaq was commander; the number of people from Boné beheaded was 269; this was called the Defeat of Tobalaq

nabeta Bone Karaengta ri Sumannaq punggawa bilanna tuBone nibattaya 269 iaminne nikana beta Tobalaq

the day of I Tobalaq's beheading allo nibattangai I Tobalaq

Karaeng ri Sumannaq arrived from conquering Boné nabattu Karaengta ri Sumannaq ambetai Bone

Karaeng ri Popoq arrived from Jakattaraq nabattu ri Jakattaraq Karaengta ri Popoq

spoke the 'Javanese', '[We] were given what is known as the treasury by Karaeng Tumamenang ri Gaukanna'232 nanakana Jawaya nisareangkang ri Karaenga Tuammenang ri Gaukanna nikanaya baitaalmal

we went to speak with the Dutch and together we agreed nakiagaang makkana Balandaya kisitabamo

\footnotetext{
229 From the Arabic fakih, this term refers to someone knowledgable about Islamic canon law.

230 Either this entry was accidentally put after the preceding entry by a copyist, or it was recorded later because word did not arrive of the conquest of Boné until between the 2nd and the 11 th of October.

231 Other than a copyist error, there is no clear reason why this and the following entry are not in chronological order.

232 This entry serves as a reminder that the Malay community since it first settled in Gowa during the reign of Tunipalangga had carefully spelled out rights and obligations vis-à-vis their Makassarese hosts and that the Malay commercial expertise essential to the rulers of Gowa and Talloq extended to fiscal affairs. Possibly the arrangement made with Tumamenang ri Gaukanna was being affirmed at this time because of financial pressures associated with the war against the VOC.
} 
11 Dec (S) Karaeng Tumamenang ri Ballaq Pangkana [Hasanuddin] sailed down to Malang to put out the revolt of Tunisombaya [Arung Palakka] in Lisu [Tanete]

8 Rakr 1071 namamise Karaenga Tuammenang ri Ballaq Pangkana manaung ri Malan makkaruru balina Tunisombaya ri Lisu

25 Dec $(S) \quad$ the day of Tunisombaya's [Arung Palakka's] journey from Campalagi [in Boné] east to Buton²33

22 Rakr $1071 \quad$ allo napaqlampaga Tunisombaya ri Campalagi manraiq ri Butun

\section{1}

8 Jan (F eve) now Karaeng ri Bontosunggu arrived from Jakattaraq and his overseas trip with Karaeng ri Popoq

7 Jawl 1071 nanampa battu ri Jakattaraq Karaengta ri Bontosunggu kalauqna siagaang Karaengta ri Popoq

11 Jan (T)

9 Jawl 1071

the karaeng [Hasanuddin] arrived from conquering Boné and his trip down to Malang nabattu karaenga ambetai Bone manaunna ri Malan

18 Jan (M eve) now Karaeng ri Jarannika arrived also from Jakattaraq 17 Jawl 1071 nanampa todong battu ri Jakattaraq Karaengta ri Jarannika

29 Jan (S)

27 Jawl 1071

teeth filed of Padukka Dompu 234

naniariq Padukka Dompu

18 Apr (M)

18 Syab 1071

an earthen wall built high up [around] Paqnakkukang 235 nanibata butta ri manaianna Paqnakkukang

19 Apr (T)

Karaeng ri Bontojeqneq and Karaeng ri Jarannika divorced

19 Syab 1071 nasipelaq Karaengta ri Bontojeqneq Karaengta ri Jarannika

\footnotetext{
233 Like several later entries about Arung Palakka, this entry must have been interpolated into the annals after he had conquered Makassar with the VOC in 1669 and subsequently become the pre-eminent figure in South Sulawesi for the remainder of the century.

234 A daughter of the ruler of Bima I Ambela and Karaeng ri Bontojeqneq.

235 This key fort had fallen to the Dutch and only recently been regained by Gowa, so this must have been an effort to improve its defenses against future Dutch attacks.
} 
$28 \operatorname{Apr}(\mathrm{R})$

28 Syab 1071

28 May (S)

28 Ram 1071

2 Jun (R)

4 Syaw 1071

25 Jun (S)

27 Syaw 1071

6 Aug (S)

10 Zulh 1071

17 Aug (W)

21 Zulh 1071

19 Sep (M)

25 Muh 1072

1 Oct (F eve)

7 Saf 1072

9 Oct (S eve)

I Daeng Makkulle installed as sabannaraq nanitannang sabannaraq I Daeng Makkulle

Karaeng ri Tangallaq died at the age of 47 namate Karaengta ri Tangallaq umuruqna 47

Karaeng ri Cenrana was ordered to live down in Mariso [north of Somba Opu] with his subjects ${ }^{236}$ nanisuro manaung ri Mariso mamempo Karaengta ri Cenrana siagaang loliqna

a wife of Karaeng ri Bontomajannang had a daughter namamanaq bainenna Karaengta ri Bontomajannang baine

I Daeng Riboko installed as sabannaraq [alongside I Daeng Makkulle] ${ }^{237}$

nanitannang sabannaraq I Daeng Riboko

Karaeng ri Beroanging Muhiddin 238 born naanaq Karaengta ri Beroanging Muhiddini

mincara $^{239}$ I Kare Kanjaraq died namate Mincaraya I Kare Kanjaraq

Daengta Daeng Jipaliq Halimah born, the great grandparent of I Nibbang naanaq Daengta Daeng Jipaliq Halimah boena I Nibbang

a wife ${ }^{240}$ of Karaeng ri Sumannaq died

236 The nature of his task is unclear from this entry, but as a tumailalang of Gowa it must have been of considerable importance. It may have had to do with organizing defenses in the region against expected Dutch attacks. Another possibility is that it involved religious matters, for six months later on 30 Dec we are told that Karaeng ri Cenrana established Friday public prayer services in nearby Baroqbosoq.

237 This was the second time he served as sabannaraq; he had been removed from this position on 8 May 1644.

238 Dutch sources from 1679 and 1681 report that he was a son of Karaeng ri Sanggiringang and Karaeng ri Bungaya (Ligtvoet 1880:120). But this appears to be incorrect. The annals note that his mother died on 23 Aug 1673 but do not give her name or title, while Karaeng Sanggiringang died on 17 Mar 1765.

239 A title used in Luwuq.

240 I Bissu Caqdi, who Karaeng ri Sumannaq married in 1619. 
15 Saf 1072 namate Karaengta ri Sumannaq bainea

23 Nov (W) Daengta Daeng Masiang married by the karaeng [Hasanuddin]

2 Rakr 1072 nanibaineang ri karaenga Daengta Daeng Masiang

$30 \operatorname{Dec}(\mathrm{F}) \quad$ Friday public prayers established by Karaeng ri Cenrana this Friday in Baroqbosoq

7 Jawl 1072 namappapenteng jumaq Karaengta ri Cenrana ri Baroqbosoq jumaq

1662

5 Apr (T eve) Karaeng ri Balloq ${ }^{241}$ and Karaeng ri Lakiung married; she was 13 when she took a husband

15 Syab 1072 nasikalabini Karaengta ri Balloq Karaengta ri Lakiun umuruqna namaqburaqne 13

18 Apr (T)

30 Syab 1072

the day of Karaeng ri Mamampang Bahauddin's ${ }^{242}$ birth allo kaanakkanna Karaengta ri Mamampang Bahauddini

6 May (S) Karaeng ri Panjallingang swore an oath that he did not desire the wife of Karaeng ri Bontomajannang 243

17 Ram 1072 namassapatta Karaengta ri Panjallingang angkaeroki bainena Karaengta ri Bontomajannang

$4 \operatorname{Jun}(\mathrm{N})$

17 Syaw 1072

Karaeng ri Bontojeqneq banished down to the kerasaq house $^{244}$

nanicinde Karaengta ri Bontojeqneq manaung ri ballaq kerasaq

$15 \mathrm{Jul}(\mathrm{S})$

28 Zulk 1072

the people went out to dwell in Tamaqlekko to fire bricks namassuluq taua maqballaq-ballaq ri Tamaqlekko mandeqdeq bata

241 A son of Karaeng Katinting and Karaeng Tabaringang. He was 18 years old at the time.

242 According to Ligtvoet 1880:169, he was a son of the former Karaeng Garassiq.

243 This wife was probably I Daeng Marannu, whom Karaeng ri Bontomajannang divorced on 8 Mar 1663.

244 The meaning of ballaq kerasaq is not certain, but the name implies that Karaeng ri Bontojeqneq was detained there because of an unmet or unpaid demand. Equally possible is the spelling in ANRI 16/6 - ballaq kirasaq - which is simply a house made from the wood of the kirasaq tree (garcinia celebica) found in eastern Indonesia. The significance of using this wood is unknown. 
$9 \operatorname{Aug}(\mathrm{W}) \quad$ Datu ri Luwuq Matinroa ri Gowa died

23 Zulh 1072 namate Datua ri Luwuq Matinroa ri Gowa

15 Aug (W) the people of Barombong first laid stones [in a defensive wall]

1 Muh 1073 nauru mallonjoq bata tuBarombonga

7 Sep (R) Karaeng ri Katapang had a son by a 'sunting'245

23 Muh 1073 namamanaq Karaengta ri Katapang ri sunting buraqne

18 Sep (M) the ruler of Sumbawa [Ammasa Pamayan] and Karaeng ri Bontojeqneq married

6 Saf 1073 nasikalabini karae Sambawa Karaengta ri Bontojeqneq

1 Nov (W) the people returned from dwelling in Tamaqlekko

19 Rawl 1073 namamonoq taua maqballaq-ballaq ri Tamalakko

29 Dec (F) Karaenga Tumamenang ri Ballaq Pangkana [Hasanuddin] went down to Maros for a conference; the number of ships that could be counted was 239

17 Jawl 1073 namanaung Karaenga Tuammenang ri Ballaq Pangkana ri Marusuq maqruppa-ruppa bilanna biseang nigappaya nibilang 239

1663

$3 \mathrm{Feb}(\mathrm{S}) \quad$ the ruler of Sumbawa [Ammasa Pamayan] and Karaeng ri Bontojeqneq divorced

26 Jakr 1073 nasipelaq karae Sambawa Karaengta ri Bontojeqneq

$10 \mathrm{Feb}(\mathrm{S}) \quad$ Daengta Daeng Mattiro ${ }^{246}$ wed Padukka Dompu; at age 13 this was her first husband

1 Raj 1073 nabunting Daengta Daeng Mattiro ri Padukka Dompu uru buraqnenna umuruqna 13

$8 \operatorname{Mar}(\mathrm{R}) \quad$ Karaeng ri Bontomajannang and I Daeng Marannu I Pandiq divorced

29 Raj 1073 nasipelaq Karaengta ri Bontomajannang I Daeng Marannu I Pandiq 
21 Mar (T eve) Karaeng ri Bontomajannang and I Cauccung married 10 Syab 1073 nasikalabini Karaengta ri Bontomajannang I Cauccung

13 Apr (R eve) sabannaraq Karaeng Baroqbosoq died

4 Ram 1073 namate Karae Baroqbosoq sabannaraka

2 May (T eve) Karaeng Patteqne I Daeng Mabela died

25 Ram 1073 namate Karae Patteqne I Daeng Mabela

25 May (R eve) Daengta Daeng Ago died; Karaeng ri Popoq replaced him [as anrongguru of the tumakkajannang]

17 Syaw 1073 namate Daengta Daeng Ago naKaraengta ri Popoq assambeangi

26 Jun (T) Karaeng ri Lakiung had a daughter named Sitti Hadijah; after forty-nine nights she died

19 Zulk 1073 namamanaq Karaengta ri Lakiun baine nikana Sitti Hadijah patampulo banngi assalapang namate

$1 \mathrm{Jul}(\mathrm{S}$ eve) the mother of I Maninrori [Karaeng Galesong] had a son named Suleman

24 Zulk 1073 namamanaq anronna I Maninrori buraqne nikana Sulemana

23 Jul (T) Karaeng ri Balloq went into Bulo-Bulo to install I Daeng Tatea $^{247}$ as Karaeng ri Bulo-Bulo

17 Zulh 1073 namantama ri Bulo-Bulo Karaengta ri Balloq antannangi Karaeng ri Bulo-Bulo I Daeng Tatea

11 Aug (S) people built houses in Jongaya

7 Muh 1074 namaqballaq taua ri Jongaya

20 Aug (M) Tunisombaya [Arung Palakka] went overseas to Jakattaraq; from Buton in the east he went overseas

16 Muh 1074 nakalauq ri Jakattaraq Tunisombaya irayai ri Butun kalauq

7 Sep (F) the back swelled of Karaeng Tumamenang ri Ballaq Pangkana [Hasanuddin]; the palm wine maker died 
4 Saf 1074 namakkambang bokona Karaenga Tuammenang ri Ballaq Pangkana namate pangantin balloq

6 Dec (R) Karaeng ri Lekoqboqdong and Padukka Dompu married $^{248}$

6 Jawl 1074 nasikalabini Karaengta ri Lekoqboqdong Padukka Dompu

\section{4}

16 Jan (W) Karaeng ri Cenrana died and [his son] Karaeng ri Lengkeseq replaced him [as tumailalang]

17 Jakr 1074 namate Karaengta ri Cenrana naKaraengta ri Lengkeseq assambeangi

27 Jan $(\mathrm{N}) \quad$ the karaeng [Hasanuddin] came down to the ground with his swelling healed

27 Jakr 1074 namanaungmo ri butta karaenga mapiana kambangna

6 Feb (W) Tumamenang ri Lakiung [Abdul Jalil] and Datu ri Luwuq quarreled and were found guilty; no fine was taken by the karaeng [Karunrung]; this year Gallarrang Mangasa I Kare Mangalle purportedly born

8 Raj 1074 namaqbesereq Tuammenang ri Lakiun Datua ri Luwuq nanipassala nataniallea salana ri karaengta iaminne bedeng taunga nakaanakkang Gallarrang Mangasa I Kare Mangalle

5 Mar (T eve) Karaeng ri Patteqne, who [later] died on Buton ${ }^{249}$, arrived from his journey

7 Syab 1074 nabattu ri lampanna Karaengta ri Patteqne matea ri Butun

17 Apr (R) Tumamenang ri Lakiung [Abdul Jalil] circumcised

20 Ram 1074 nanisunnaq Tuammenang ri Lakiun

26 May (M) Tumamenang ri Juntana [Karunrung] banished and his belongings seized; he went overseas to Banten; this was his early banishment

29 Syaw 1074 nanicinde nanirappung Tuammenang ri Juntana nakalauq ri Bantang nicinde rioloanna

248 Her divorce from Daengta Daeng Mattiro was not recorded in the lontaraq bilang.

249 ANRI 16/6 has that he 'died in battle' instead of 'died on Buton' (matea ri bunduqna). Either reading may be correct. 
5 Jun (R)

10 Zulk 1074

teeth filed of Karaeng ri Bontomateqne ${ }^{250}$ naniariq Karaengta ri Bontomateqne

9 Jun (N eve) Kaicili Kalamata and Karaeng ri Panaikang divorced 14 Zulk 1074 nasipelaq Kacili Kalimata Karaengta ri Panaikang

25 Aug (M) seventy warriors went to Karaeng ri Talloq [Harrunarasyid]

2 Saf 1075 nanipamange ri Karaenga ri Talloq joaq tujupuloa

$13 \mathrm{Sep}^{251}$ (N eve) a great grandparent of Tumamenang ri Lakiung died 22 Saf 1075 namate boena Tuammenang ri Lakiun

8 Nov (S) Karaeng Tumamenang ri Ballaq Pangkana [Hasanuddin] sailed down to Lanrisang [in Sawitto] for a conference

19 Rakr 1075 namamise Karaenga Tuammenang ri Ballaq Pangkana manaung ri Lanrisang maqruppa-ruppa

$16 \operatorname{Nov}(\mathrm{N}$ eve) unusual stars seen by Karaeng ri Popoq; the comets lasted 2 months and 8 nights then were no longer seen

27 Rakr 1075 namacciniq bintoeng maraqmaraeng-maraeng Karaengta ri Popoq bintoeng makkidong 2 bulangi 8 banngi nanampa tena niciniq

24 Nov ( $\mathrm{N}$ eve) birth of I Daeng Mamangkasi I Mamminawang, a child of Karaeng ri Bontomajannang by Cauccung

5 Jawl 1075 nanianakkang I Daeng Mamangkasi I Mamminawang anaqna Karaengta ri Bontomajannang ri Cauccung

$25 \operatorname{Nov}(\mathrm{T}) \quad$ Tumamenang ri Lakiung [Abdul Jalil] and Karaeng ri Bontomateqne married

6 Jawl 1075 nasikalabini Tuammenang ri Lakiun Karaengta ri Bontomateqne

$30 \operatorname{Nov}(\mathrm{N}) \quad$ Tumatea ri Jakattaraq [Muhammad Ali] and Karaeng ri Mandalleq ${ }^{252}$ circumcised

250 A daughter of the ruler of Bima Sirajuddin and Karaeng Bontojeqneq.

251 A copyist mistakenly wrote August for Sepember.

252 Presumably Tulolo Tajuddin, the older of the two sons of Karaeng Karunrung who had this title and was born on 27 Dec 1653. He also had his teeth filed on the same day as Tumatea ri Jakattaraq on 24 Sep 1665. Such shared rituals were intended to forge a lifelong bond. 
11 Jawl 1075 nanisunnaq Tumatea ri Jakattaraq siagaang Karaengta ri Mandalleq

2 Dec (M eve) the ruler of Dompu [on Sumbawa] and Karaeng ri Lekoqboqdong divorced

28 Jawl 1075²53 nasipelaq karaengta ri Dompu Karaengta ri Lekoqboqdong

\section{5}

15 Jan (R) I Dewa sold to Siamese 254 for three kati [of gold] ${ }^{255}$; this year we were struck by an epidemic

28 Jakr 1075 nanibalukang I Dewa ri Sianga tallu kati niballiangi iaminne taunga kinataba pua

30 Jan (R eve) Karaeng ri Jarannika and Karaeng ri Bontojeqneq divorced

13 Raj 1075 nasipelaq Karaengta ri Jarannika Karaengta ri Bontojeqneq

2 Apr (W eve) people again saw a comet 15 Ram 1075 namacciniq pole taua bintoeng makkidong

4 Apr (F eve) Karaeng ri Bontoa Sitti Muthiatullah ${ }^{256}$ born 17 Ram 1075 naanaq Karaengta ri Bontoa Sitti Muthiatullah

7 Apr (T) Karaeng ri Ujung Pandang died

20 Ram 1075 namate Karae Jumpandang

$26 \operatorname{Apr}(\mathrm{N}) \quad$ the ruler of Majeqneq [in Mandar] was besieged and Karaeng ri Bungaya [thus] avenged

10 Syaw 1075 naniliungang Karae Majeqneq nanipuiang Karae Bungaya

$3 \mathrm{Jul}(\mathrm{F}) \quad$ bila-bila issued to go east to Sula [islands in Maluku]

10 Zulh $1075^{257}$ nanipalele bila-bila manraika ri Suli

253 The Hijri date converts to 16 Dec 1664.

254 Kamaruddin et al. (1985-86:129) believe this refers to Siang (north of Makassar) and not Siamese.

255 The Dutch translation of the lontaraq bilang in Makasaarsche historien (1855:122-3) states that the ruler of Gowa sold his lucky horse to Siamese for 3,000,000 [reals?]. ANRI 16/6 gives no price for the transaction.

256 A daughter of Karaeng ri Balloq and Karaeng ri Lakiung.

257 The Hijri date converts to 24 Jun 1665. 
18 Jul (F eve) Padukka Dompu had a son by Karaeng ri Lekoqboqdong named I Mappaqngara I Daeng Mallulungang

4 Muh 1076 namamanaq Padukka Dompu ri Karaengta ri Lekoqboqdong buraqne nikana I Mappaqngara I Daeng Mallulungang

30 Jul (W eve) Karaeng ri Bontomarannu slaughtered by his wife 17 Muh 1076 nanisamballe ri bainenna Karaengta ri Bontomarannu

$13 \operatorname{Aug}(\mathrm{R}) \quad$ an earthen wall was built by the people beneath [i.e. to the north of] Ujung Pandang

1 Saf 1076 namaqbata butta bilang taua irawanganna Jumpandang

24 Sep (R) teeth filed of Tumatea ri Jakattaraq [Muhammad Ali] and Karaeng ri Mandalleq

14 Rawl 1076 naniariq Tumatea ri Jakattaraq siagaang Karaengta ri Mandalleq

30 Sep (T eve) sabannaraq Karaeng Bantaeng died

20 Rawl 1076 namate Karaeng Bantaeng sabannaraq

7 Oct (W) people mustered [for the attack on Sula]; the total number of those who assembled was 10662; this was called the Muster at Gowa

27 Rawl 1076 namarewangan taua bilang pampanna tumarewanganga 10662 iaminne nikana parewanganngang ri Gowa

12 Oct (M) the war leaders sailed east to Sula

2 Rakr 1076 namamise dulun manraika ri Suli

$26 \operatorname{Nov}(\mathrm{R}) \quad$ Karaeng ri Balloq and I Amuq married

18 Jawl 1076 nasikalabini Karaengta ri Balloq I Amuq

$25 \operatorname{Dec}(\mathrm{F}) \quad$ Friday public prayers established again this Friday in Garassiq

17 Jakr 1076 namamenteng pole jumaka ri Garassiq jumaq 
1666

7 Jan (W eve) Tumamenang ri Passiringanna Abdul Kadir ${ }^{258}$ born

1 Raj 1076 naanaq Tuammenang ri Passiringanna Abdulqadir

17 Feb (W) Karaeng Tumamenang ri Taenga and Karaeng ri Sanggiringang divorced; Tumamenang ri Ujung Tana [Karunrung] arrived from his banishment

12 Syab 1076 nasipelaq Karaengta Tuammenang ri Taenga Karaengta ri Sanggiringan nabattu Tuammenang ri Juntana nicindena

17 Mar (W) the war leaders arrived from going east to Sula and their conquest of Sula

10 Ram 1076 nabattu dulun manraika ri Sula nabetana Sula

24 May (M) Karaeng ri Bontomajannang went into Soppéng to marry a daughter of Datu ri Soppéng named Macallaka Kanukunna ${ }^{259}$

19 Zulk 1076 namantama ri Soppeng Karaengta ri Bontomajannang ambaineangi anaqna Datua ri Soppeng nikanaya Macallaka Kanukunna

29 Jun (T) Karaeng ri Ballaq Jawaya and Tumamenang ri Ujung Tana [Karunrung] divorced

26 Zulh 1076 nasipelaq Karaengta ri Ballaq Jawaya Tuammenang ri Juntana

$4 \mathrm{Jul}(\mathrm{N}) \quad$ bila-bila issued to go east to Ambon in Maluku

1 Muh 1077 nanipalele bila-bila manraika ri Ambong ri Maluku

16 Aug (M) the day of Tunisombaya's [Arung Palakka's] overseas trip to Pariaman [Sumatra]

15 Saf 1077 allo nanakalaukanga ri Pariaman Tunisombaya

258 A son of Sultan Harrunarasyid, he would succeed his father at a young age as Talloq's ruler in 1673. A Dutch source from 1709 reports that his personal name was Mappajanji (Ligtvoet 1880:124).

259 Her name refers to her painted fingernails. Speelman reported that she was named Dassou and had first married Karaeng ri Bontomarannu, but they divorced when her father (La Tenribali Matinroa ri Datunna) was defeated and exiled after allying himself with I Tobalaq against Gowa (Ligtvoet 1880:footnote 124-5). See also Andaya 1981:58-9. 
23 Sep (W eve) the male ${ }^{260}$ Karaeng ri Sumannaq died; Daeng I Taniciniq died

23 Rawl 1077 namate Karaengta ri Sumannaq buraqnea namate Daengta I Taniciniq

23 Oct (S) the war leaders sailed east to Buton; Karaeng ri Bontomarannu was commander

24 Rakr 1077 namamise dulun manraika ri Butun Karaengta ri Bontomarannu punggawa

5 Nov (R eve) I Daeng Maingaq died

8 Jawl 1077 namate I Daeng Maingaq

23 Nov (N eve) Karaeng ri Buluq-Buluq Fatimah born

15 Jawl 1077261 naanaq Karaengta ri Buluq-Buluq Patimah

28 Nov (N) Karaeng Tumamenang ri Ujung Tana [Karunrung] banished again and went over to Saburo; this was his later banishment

1 Jakr 1077 nanicinde pole Karaengta Tuammenang ri Juntana namantaqle ri Saburo nicinde ribokona

13 Dec (M) the mother of I Tuang Shaykh Yusuf died

17 Jakr 1077 namate anronna I Tuan Syeku Yusupu

$19 \operatorname{Dec}(\mathrm{N}) \quad$ Dutch ships were sighted, 21 in number

23 Jakr 1077 nakacinikang kappalaqna Balandaya 21 batunna

18 Dec (S) Tunisombaya [Arung Palakka] captured the Bajo in Tanakeke

22 Jakr $1077^{262}$ namanjakkalaq Bayo Tunisombaya ri Tanakeke

$23 \operatorname{Dec}(\mathrm{F}) \quad$ Tunisombaya [Arung Palakka] set fire to Kalumpangkeke

27 Jakr 1077 nanisussuluq Kalumpang-keke Tunisombaya

260 An annalist apparently was distinguishing him from a later, female holder of this title (for example, the woman mentioned in the 2 Aug 1731 entry).

261 The Hijri date converts to 12 Nov 1666.

262 Presumably word of this reached Gowa after December 19th, which explains why this entry is not in chronological order. Or 272Y and Makasaarsche historiën (1855:123) do not have this as a separate entry, instead incorporating this information into the previous entry. 
25 Dec (S) Tunisombaya [Arung Palakka] set fire to Bantaeng and wounded by a spear

29 Jakr 1077 nanasussuluq Bantaeng Tunisombaya namalokoq poke

3 Jan (M) the war leaders 263 taken on Buton

8 Raj 1077 nanialle dulunga ri Butun

$25 \mathrm{Jan}(\mathrm{T}) \quad$ I Amaq, the younger sibling of Tumammaliang ri Alluq [Amir Hamzah], died

25 Raj 1077 namate I Amaq arinna Tumammaliang ri Alluq

7 Feb (M) Karaeng ri Lengkeseq went into Boné bringing Matinroa ri Bukaka [La Maqdaremmeng] to install as the ruler of Boné ${ }^{264}$

12 Syab 1077 namantama ri Bone Karaengta ri Lengkeseq angerangi

Matinroa ri Bukaka antannangi karaeng ri Bone

12 Mar (S) Aeng [north of Galesong] and Mandalleq given to Karaeng ri Mandalleq

15 Ram 1077 nanisareang Karaengta ri Mandaleq Aeng siagaang Mandaleq

$13 \operatorname{Mar}(\mathrm{N}) \quad$ the treaty went to Tumatea ri Jakattaraq [Muhammad Ali] ${ }^{265}$; the people of Tino [Binamuq] went to Tumamenang ri Lakiung [Abdul Jalil]

16 Ram 1077 nanipamange cappaya ri Tumatea ri Jakattaraq tuTinoa nipamange ri Tuammenang ri Lakiun

$22 \operatorname{Mar}(\mathrm{M}) \quad$ the people of Alluq were given to Tumamenang ri Lakiung [Abdul Jalil]

25 Ram 1077 nanisareang tuAlluq Tuammenang ri Lakiun

$23 \operatorname{Mar}(\mathrm{W}) \quad$ Tumatea ri Jakattaraq [Muhammad Ali] and Daengta

263 Karaeng Bontomarannu led the expedition and he, the ruler of Bima, and the ruler of Luwuq all surrendered to Admiral Speelman.

264 La Maqdaremmeng had ruled Boné previously, but was defeated by Gowa in 1643 and removed from power and taken to Makassar the following year. As Andaya (1981:80) notes, this was a failed effort to neutralize Boné in the war against the Dutch.

265 This is a common indication in the lontaraq bilang that someone formally was recognized as tumabicarabutta of Gowa. It suggests that the keeping and maintenance of relationships between Gowa, Talloq, and other polities was a task performed by the tumabicarabutta. 
26 Ram 1077 nanipaqnikkah Tumatea ri Jakattaraq Daengta Daeng Talarra I Makku

17 Apr (N) Karaeng ri Bontomajannag went up to guard Bantaeng 23 Syaw 1077 namanaiq Karaengta ri Bontomajannang angkammiki Bantaeng

30 May (M) Tumamenang ri Lampana [Harrunarasyid] and Karaeng ri Lengkeseq went into Boné to quash Matinroa ri Bukaka [La Maqdaremmeng]

6 Zulh 1077 namantama ri Bone Tuammenang ri Lampanna Karaengta ri Lengkeseq angkarurui Matinroa ri Bukaka

6 Jun (N eve) Daengta I Kare Maqnassa died

13 Zulh 1077 namate Daengta I Kare Maqnassa

$6 \mathrm{Jul}(\mathrm{W}) \quad$ all of the anaq karaeng of the people of Sanrabone and the gallarrang arrived before Tumamenang ri Lakiung [Abdul Jalil] bringing all the gaukang of Sanrabone ${ }^{266}$

13 Muh 1078 nabattu ngaseng anaq karaeng tuSanrabonea siagaang gallaranna ri Tuammenang ri Lakiun angerangangi lollong gaukanga ri Sanrabone

$8 \mathrm{Jul}(\mathrm{F})$

15 Muh 1078 nabattu surona Karaengta ri Bontomajannang angkana nipanaiki ri Balandaya nanibeta ri Bantaeng

$13 \mathrm{Jul}(\mathrm{W}) \quad$ the Dutch dropped anchor: 17 ships in number, 20 prauws in number, 10 sloops in number, and 41 small ships

20 Muh 1078 namaqlabu kappalaqna Balandaya 17 batunna juangan 20 batunna soqlloq 10 batunna biseang caqdi 41

20 Jul (W) Tumamenang ri Ujung Tana [Karunrung] arrived from his later banishment

266 Gaukang usually refers to sacred stones that mark the heart of a community, but it is used here to describe the prized regalia of a community, typically called kalompoang (Cummings 2002:55-6). This ceremonial act meant that the people of Sanrabone recognized Abdul Jalil as their ruler. 
29 Muh 1078 nabattumo Tuammenang ri Juntana nicinde ribokona

1 Aug (M) the Dutch went up to Manalo and in the fighting 34 Dutchmen were beheaded

12 Saf 1078 namanaiq ri Manalo Balandaya namaqbunduqmo taua 34 Balanda nibatta

19 Aug (F) Galesong conquered by the Dutch

28 Saf 1078 nanibeta Galesong ri Balandaya

$4 \operatorname{Sep}(\mathrm{N}) \quad$ the Dutch went up to Batu-Batu and built fortifications in Aeng

14 Rawl 1078 namanaiq ri Batu-Batu Balandaya namaqbenteng ri Aeng

$18 \mathrm{Nov}(\mathrm{F}) \quad$ together we agreed at Bungaya ${ }^{267}$

3 Jakr 1078 kisitabamo ri Bungaya

21 Nov (M) Ujung Pandang occupied by the Dutch

6 Jakr 1078 nanaempoi Jumpandang Balandaya

29 Dec (R) Karaeng ri Lengkeseq went over to the Dutch 268

14 Raj 1078 namantaqle ri Balandaya Karaengta ri Lengkeseq

1668

12 Jan $(\mathrm{R}) \quad$ teeth filed and ears pierced of Karaeng ri Langeloq

26 Raj 1078 naniariq nanitinting Karaengta ri Lengeloq

17 Feb (F) Matinroa ri Bontoalaq [Arung Palakka] went to Karaeng Tumamenang ri Ballaq Pangkana [Hasanuddin] to grasp hands

3 Ram 1078 namae ri Karaenga Tuammenang ri Ballaq Pangkana Matinroa ri Bontoalaq maqjabat tangan

$29 \mathrm{Feb}$ (T eve) Haji Bulo-Bulo died and was buried in Bayaoa

15 Ram 1078 namate Haji Bulo-Bulo niawang ri Bayaoa

267 ANRI 16/6 incorporates the subsequent entry here, stating 'three nights after people met, the Dutch occupied Ujung Pandang' (natallu banngi lebaq sitaba tauwa nanaempoi Jungpandang Balandaya).

268 Speelman reported that in response to this betrayal Hasanuddin seized his lands of Cenrana and Siwa and Larompong on the Bay of Boné (Ligtvoet 1880:128). It is not surprising that the Sj'air Perang Mengkasar describes Karaeng ri Lengkeseq as 'a harsh karaeng, whose conduct was wicked and unbecoming a Muslim' (Skinner 1963:190). 
$6 \operatorname{Mar}(\mathrm{T}) \quad$ something white was seen toward the sea standing stiffly; on three occasions it was seen

21 Ram 1078 naniaq anu makeboq niciniq ilauq tappenteng kontu bata tallung sawe niaki niciniq

13 Mar (M eve) all the anaq karaeng and tumakkajannang swore oaths to the karaeng [Hasanuddin]

27 Ram 1078 nanitalliq ngaseng ri karaenga anaq karaenga siagaang tumakkajannannganga

16 Mar (R eve) Tunisombaya [Arung Palakka] and Karaeng ri Ballaq Jawaya married

3 Syaw 1078 nasikalabini Tunisombaya Karaengta ri Ballaq Jawaya

28 Mar (W) Tumamenang ri Lakiung [Abdul Jalil] installed as Karaeng ri Sanrabone

15 Syaw 1078 nanitannang Karaeng ri Sanrabone Tuammenang ri Lakiun

14 Apr (F eve) the Dutch fired as a result of a quarrel

2 Zulk 1078 namammaqdiliq Balandaya sisala ribokota

21 May (M) Tumamenang ri Lakiung [Abdul Jalil] was brought east to Gowa and a sunshade raised over his head, an embossed sunshade 269

9 Zulh 1078 nanierang manraiq ri Gowa nipirangkaki laqlang Tuammenang ri Lakiun laqlang nicaka

9 Jun (S) Karaeng ri Garassiq died 28 Zulh 1078 namate Karaengta ri Garassiq

20 Jun (T eve) Karaeng ri Tamalaqba died

9 Muh 1079 namate Karaengta ri Tamalaqba

$23 \mathrm{Jul}(\mathrm{M}) \quad$ Daeng ri Sampulungan died

13 Saf 1079 namate Daengta ri Sampulungan

$31 \mathrm{Jul}$ (M eve) Karaeng ri Katapang died 21 Saf 1079 namate Karaengta ri Katapang 
13 Aug (M) Karaeng ri Panjallingang beheaded below in Maros ${ }^{270}$ at the age of 31

5 Rawl 1079 nanibatta Karaengta ri Panjallingang irawa ri Marusuq umuruqna 31

27 Aug (M) Karaeng ri Bontomajannang struck

19 Rawl 1079 nanitaba Karaengta ri Bontomajannang

10 Sep (M) Karaeng ri Bontomajannang died at the age of 26

3 Rakr 1079 namate Karaengta ri Bontomajannang umuruqna 26

27 Sep (R) Daengta I Karaeng Sallang died

20 Rakr 1079 namate Daengta I Karae Sallang

12 Oct $(\mathrm{F})^{271} \quad$ I Tosaqdang killed ${ }^{272}$

6 Jawl 1079 naniposo I Tosaqdang

14 Oct $(\mathrm{N}) \quad$ Karaeng ri Tomponga beheaded

8 Jawl 1079 nanibatta Karaengta ri Tomponga

27 Oct (S) Paccocconga killed

19 Jawl 1079 naniposo Paccocconga

$8 \mathrm{Nov}(\mathrm{R}) \quad$ there was fierce rain

3 Jakr 1079 naniaq bosi maqdonteng

13 Nov (T) there was wood felled that raised itself again toward the uplands in Lataq ${ }^{273}$

8 Jakr 1079 naniaq kayu nitaqbang mambangunna pole iraya ri Lataq

$14 \operatorname{Nov}(\mathrm{W}) \quad$ pakki Dambo Abdurrahim died

9 Rakr 1079 namate paqqih Dambo Abdurrahim

270 According to ANRI 16/6 he was killed in Barasaq, not Maros.

271 This and the following entry appear in reverse order in VT 25.

272 Arung Belo, a son of the ruler of Soppéng La Tenribali Matinroa ri Datunna. ANRI 16/6 adds 'spaced two nights apart Karaeng ri Panjallingang was beheaded at the age of 18' (ruwa banngi allaqna nanibatta Karaengta ri Panjallingang umuruqna 18), but this in fact refers to Karaeng ri Tomponga.

273 Coupled with the mysterious white object that appeared toward the sea earlier in the year, this was certainly interpreted as heralding great change by Makassarese and is evidence of the uncertainty and trepidation that marked the war years. 
1669

21 Jan $(\mathrm{M})$

18 Syab 1079

Tumammaliang ri Alluq [Amir Hamzah] circumcised

4 Feb (M) Tumamenang ri Lakiung [Abdul Jalil] and Karaeng ri nanisunnaq Tumammaliang ri Alluq Bontomateqne divorced, then Tumamenang ri Lampana [Harrunarasyid] divorced I Loqmoq, a grandparent of I Kacung

2 Ram 1079 nasipelaq Tuammenang ri Lakiun Karaengta ri Bontomateqne nanipelaq I Loqmoq toana I Kacung ri Tuammenang ri Lampanna

$8 \mathrm{Feb}(\mathrm{F}) \quad$ Karaeng ri Bontojeqneq died at the age of 41

6 Ram 1079 namate Karaengta ri Bontojeqneq umuruqna 41

1 Mar (R eve) Karaeng ri Kaballokang274 and Karaeng ri Langeloq married; I Loqmoq, the mother of Karaeng ri Patukangang, proposed to by Tumamenang ri Lakiung [Abdul Jalil]

26 Ram 1079 nasikalabini Karaengta ri Kaballokang Karaengta ri Langeloq nanipassuroi I Loqmoq anronna Karaengta ri Patukangang ri Tuammenang ri Lakiun

10 May (R eve) Tumamenang ri Lampana [Harrunarasyid] Karaeng ri Bontomateqne wed [in accordance with Islamic custom] and left immediately 275

10 Zulh 1079 namaqnikkah Tuammenang ri Lampanna Karaengta ri Bontomateqne mange memang tommi

1 Jun $(S)$

2 Muh 1080

Karaeng ri Lakiung died; she reached age 21

namate Karaengta ri Lakiun umuruqna 21

3 Jun (N eve) Karaeng ri Tabaringang died

4 Muh $1080 \quad$ namate Karaengta ri Tabaringan

274 He was a son of Karunrung also known as Mamminawang Daeng Mangalliki (Ligtvoet 1880:130). He must not be confused with either I Daeng Mamangkasi I Mamminawang, a child of Karaeng ri Bontomajannang by Cauccung born on 24 Nov 1664, or Karaeng ri Mangalliq I Manrurungang I Kare Gappa, a son of Hasanuddin born on 13 Jan 1655.

275 They went to Bima. Karaeng ri Bontomateqne died there on 13 Mar 1671, and a few months later on 5 Aug 1671 Karaeng Galesong arrived there to invite Harrunarasyid to return to Makassar. 
16 Jun (S eve) the bastion of Somba Opu breached ${ }^{276}$

17 Muh 1080 nanibangka salekoa ri Sombopu

24 Jun (M) Somba Opu conquered

25 Muh 1080 nabeta Sombopu

29 Jun (S) Tumammaliang ri Alluq [Amir Hamzah] had a sunshade raised over his head ${ }^{277}$

30 Muh 1080 nanipirangkaki laqlang Tumammaliang ri Alluq

7 Jul (S eve) Daengta Daeng Naratang died

8 Saf 1080 namate Daengta Daeng Naratang

$28 \mathrm{Jul}(\mathrm{N}) \quad$ people agreed by the new $\operatorname{river}^{278}$

29 Saf 1080 nasitaba taua ri binanga berua

16 Sep (M) Karaeng ri Paqbineang and Addatuang Sidénréng279 married

21 Rakr 1080 nasikalabini Karaengta ri Paqbineang Aqdatuanga

28 Oct (M) Tumamenang ri Lampana [Harrunarasyid], [the karaengs of] Bisei, Mandalleq, Balloq, Palemba ${ }^{280}$, [and the gallarrang of] Mangasa and Tomboloq went overseas to Jakattaraq

4 Jakr 1080 nakalauq ri Jakattaraq Tuammenang ri Lampanna Bisei Mandalleq Balloq Palemba Mangasa Tomboloq

23 Nov (F eve) Karaeng ri Pattunga died

23 Jakr 1080 namate Karaengta ri Pattunga

276 ANRI 16/6 adds more information, explaining how 'a hole was dug and as night fell the gunpowder was then lit' (nikekkeseki nibanggiangi ubaq nanisussuluq). Andaya (1981:130-1) describes in detail this explosive-filled tunnel and its crucial role in the fall of Somba Opu.

277 With this act, Hasanuddin stepped down and his son became Sultan Amir Hamzah, ruler of Gowa. ANRI 16/6 notes that his father Hasanuddin raised the sunshade over him.

278 Thus the Makassar War came to an end beside the canal that Bugis workers dug in 1660 to separate Paqnakkukang from the mainland.

279 Arung Ujumpuluq, known as La Tenritippaq ToWalenae, who later became ruler of Sidénréng.

280 In Dutch archival sources he is known as Karaeng Mamu or Mamut (Ligtvoet 1880:131). 
26 Nov (M eve) Tumamenang ri Lakiung [Abdul Jalil] and Daengta Daeng Talarra ${ }^{281}$ married

1 Raj 1080 nasikalabini Tuammenang ri Lakiun Daengta Daeng Talarra

\section{0}

$10 \mathrm{Jan}$ (R eve) the ruler of Akkotengang died

17 Syab 1080 namate karaenga ri Akkotengang

27 Feb (W eve) I Daeng Manyikkoq I Shadiq, a child of Karaeng ri Palemba, born

6 Syaw 1080 naanaq I Daeng Manyikkoq I Shadiq anaqna Karaengta ri Palemba

10 Mar (M) Karaeng ri Pangkajeqneq Abdul Muqmin ${ }^{282}$ born 18 Syaw 1080 naanaq Karaengta ri Pangkajeqneq Abdulmuqmin

28 Mar (R eve) Tumamenang ri Lampana [Harrunarasyid] arrived from Jakattaraq

3 Zulk 1080 nabattu ri Jakattaraq Tuammenang ri Lampanna

$29 \operatorname{Mar}(\mathrm{S}) \quad$ Tunisombaya [Arung Palakka] arrived from Jakattaraq bringing his wife [Daeng Talele]

8 Zulk 1080 nabattu ri Jakattaraq Tunisombaya angerangi bainenna

$13 \operatorname{Apr}(\mathrm{N}) \quad$ Karaeng ri Mandalleq and I Daeng Maingaq, [later known as] Karaeng Balua ${ }^{283}$, married

21 Zulk 1080 nasikalabini Karaengta ri Mandalleq I Daeng Maingaq Karaengta Balua

16 Apr (W) Tumamenang ri Lakiung [Abdul Jalil] and Daengta Daeng Talarra divorced 25 Zulk 1080 nasipelaq Tuammenang ri Lakiun Daengta Daeng Talarra

21 May (T eve) the younger sibling of I Kaiq died

281 She had married Abdul Jalil's older brother Muhammad Ali on 23 Mar 1667, but their divorce is not recorded in the annals. This marriage lasted less than four months, after which she would marry Sultan Harrunarasyid of Talloq on 3 Jul 1670.

282 Dutch sources from 1709 reported that he was a son of Abdul Jalil's sister, thus probably a son of Karaeng Langeloq from her marriage to Karaeng Kaballokang (Ligtvoet 1880:132).

283 This karaeng-title does not reflect a toponym, but indicates that she was a widow $(\mathrm{balu})$ of the ruler. 
1 Muh $1081 \quad$ namate arinna I Kaiq

28 May (M) something was seen resembling a rainbow that spanned the earth

6 Muh 1081 naniaq niciniq kuntu tarahuwe taqbannyang ri buttaya

2 Jun (M) the walls of Talloq torn down

13 Muh 1081 nanigesaraq bataya ri Talloq

3 Jun (T) the walls of Gowa torn down

14 Muh 1081 nanigesaraq bataya ri Gowa

12 Jun (R) we were left by Karaeng Tumamenang ri Ballaq

Pangkana [Hasanuddin] at the age of 41

23 Muh 1081 kinapilari Karaenga Tuammenang ri Ballaq Pangkana umuruqna 41

3 Jul (R eve) Tumamenang ri Lampana [Harrunarasyid] and Daengta Daeng Talarra married

7 Rawl 1081284 nasikalabini Tuammenang ri Lampanna Daengta Daeng Talarra

1 Aug (R eve) Tumamenang ri Ujung Tana [Karunrung] and I Taniq married

14 Rawl 1081 nasikalabini Tuammenang ri Juntana I Taniq

7 Aug (R) Tunisombaya [Arung Palakka] went into Wajoq to make war $^{285}$

20 Rawl 1081 namantama ri Wajoq Tunisombaya maqbunduq

28 Aug (T eve) birth of Daengta Daeng Mami Ruqiah ${ }^{286}$

11 Rakr 1081 nanianakkang Daengta Daeng Mami Ruqiah

29 Aug (R eve) I Sunggu, a child of Karaeng ri Panjallingang, died, killed from a blow by a wife of the ruler of Talloq

22 Rakr $1081^{287}$ namate I Sunggu anaqna Karaengta ri Panjallingang nibuno pattunrung ri karaenga bainea ri Talloq

284 The Hijri date converts to 24 Jul 1670.

285 The ruler of Wajoq's refusal to submit to Arung Palakka and his war against it and the similarly recalcitrant Lamuru is discussed in Andaya (1981:138-40).

286 A daughter of Hasanuddin by I Loqmoq Toboq.

287 The Hijri date converts to 7 Sep 1670. 
12 Sep (R eve) Tumatea ri Jakattaraq [Muhammad Ali] and I Sitti Karaeng ri Kampong Beru ${ }^{288}$ married; Karaeng ri Mangalliq and I Tumbuq ${ }^{289}$ married

27 Rakr 1081 nasikalabini Tumatea ri Jakattaraq I Sitti Karaenga ri Kampongberu Karaengta ri Mangalliq sikalabini I Tumbuq

30 Oct (W eve) Karaeng Tumamenang ri Lampana [Harrunarasyid] went over to Bima

15 Jakr 1081 namaqlampa Karaenga Tuammenang ri Lampanna taqle ri Dima

$19 \operatorname{Dec}(\mathrm{F})$

9 Syab 1081

Tunisombaya [Arung Palakka] arrived from Wajoq and the conquest of Tosora nabattu ri Wajoq Tunisombaya nabetana Tosora

1671

10 Jan (S)

there were those who saw two suns

27 Syab $1081^{290}$ naniaq anciniki rua matanna alloa

$26 \operatorname{Jan}(\mathrm{R})$

Karaeng ri Ballaq Jawaya divorced by Tunisombaya [Arung Palakka]

17 Syaw $1081^{291}$ nasipelaq Karaengta ri Ballaq Jawaya ri Tunisombaya

9 Mar (N eve) I Daeng Maingaq ${ }^{292}$ died

26 Syaw 1081 namate I Daeng Maingaq

$13 \operatorname{Mar}(\mathrm{F}) \quad$ the day of Karaeng ri Bontomateqne's death across in Bima at the age of 18

1 Zulk 1081 allo nakamateanga Karaengta ri Bontomateqne ibaqle ri Dima umuruqna 18

288 Also known as Daeng Talele, but she must not be confused with the Daeng Talele who was Arung Palakka's wife.

289 Presumably not the same I Tumbuq who married the ruler of Agangnionjoq on 10 Dec 1645.

290 These dates do not match as the result of a copyist error. It is most probable that a copyist mistakenly wrote Ramadan instead of Syaban for the Hijri month, and this correction is made here, but also possible that the Gregorian month should be February rather than January.

291 These dates also do not match as the result of a copyist error. It is most probable that a copyist mistakenly wrote Syawwal instead of Ramadan for the Hijri month, and this correction is made here, but also possible that the Gregorian month should be February rather than January. 292 Clearly this does not refer to Karaeng Balua, Karaeng ri Mandalleq's wife of the same name. 
$14 \operatorname{Mar}(\mathrm{S})$

2 Zulk 1081

$19 \operatorname{Mar}(\mathrm{R})$

6 Zulk 1081

17 Apr (R eve) Karaeng ri Jarannika and the mother of Karaeng ri Pasiq married

7 Zulh 1081

20 May (W)

11 Muh 1082

14 Jun (M)

7 Saf 1082

21 Jun $(\mathrm{N})$

14 Saf 1082

23 Jun (M eve)

16 Saf 1082

$13 \mathrm{Jul}(\mathrm{M})$

6 Rawl 1082

I Shafiah and Karaeng Tumaqdanggang married nasikalabini I Shafiah Karae Tumaqdanggang

the day of I Daeng Onjoq's death across in Bima allo kamateanga I Daeng Onjoq ibaqle ri Dima

nasikalabini Karaengta ri Jarannika puanna Karaengta ri Pasiq

the father of Matinroa ri Nagaulang [La Patauq] and his mother married 293

nasikalabini aenna Matinroa ri Nagaulang ayana

Karaeng ri Agangjeqneq circumcised

nanisunnaq Karaengta ri Agangjeqneq

Karaeng ri Jarannika and the mother of Karaeng ri Pasiq divorced

nasipelaq Karaengta ri Jarannika puanna Karaengta ri Pasiq

Daengta Daeng Jipaling had a son

namamanaq Daengta Daeng Jipaling buraqne

Tumammaliang ri Alluq [Amir Hamzah] and Daengta Daeng Majannang married; Karaeng ri Bontomanompoq and Daengta Daeng Masiang married nasikalabini Tumammaliang ri Alluq Daengta Daeng Majannang nasikalabini Karaengta ri Bontomanompoq Daengta Daeng Masiang

5 Aug (T eve) Karaeng Galesong 294 went over to Bima to request [the return of] Tumamenang ri Lampana [Harrunarasyid]

29 Rawl 1082 namantaqle ri Dima Karaeng Galesong ambuntuli Tumammenang ri Lampanna

293 La Patau's father was Pakkokoe Arung Timurung Matinroe ri Timurung (a son of the ruler of Boné La Maqdaremmeng) and his mother was We Mappolobombang Da Upi (a full sister of Arung Palakka). La Patauq would succeed his uncle Arung Palakka. The political context of this marriage is discussed in Andaya (1981:243-5).

294 A son of Hasanuddin also known as I Maninrori and I Kare Tojeng. 
9 Aug (N) Karaeng Bontokappong 295 died

4 Rakr 1082 namate Karae Bontokappong

10 Aug (M) Tumammaliang ri Alluq [Amir Hamzah] and Daengta Daeng Majannang divorced; they were married 27 nights

5 Rakr 1082 nasipelaq Daengta Daeng Majannang Tumammaliang ri Alluq 27 bannginna sikalabini

11 Aug (T) I Daeng Nisimba Rabiah born

6 Rakr 1082 naanaq I Daeng Nisimba Rabiah

13 Aug (W eve) I Daeng Talarra married by Tumammaliang ri Alluq [Amir Hamzah]

7 Rakr 1082 nanibaineang I Daeng Talarra ri Tumammaliang ri Alluq

20 Aug (R) Karaeng Balua [Daeng Maingaq] had a son by Karaeng ri Mandalleq: Muhammad Said

14 Rakr 1082 namamanaq Karaengta Balua ri Karaengta ri Mandalleq buraqne Muhammad Said

21 Sep (M) Karaeng ri Bontosunggu had a son by Karaeng ri Sanggiringang named I Manggaukang

16 Jawl 1082 namamanaq Karaengta ri Bontosunggu ri Karaengta ri Sanggiringang buraqne nikana I Manggaukang

21 Sep (F) Karaeng Bangkalaq died

21 Jawl 1082 namate Karae Bangkalaq

6 Oct (T) Tunisombaya [Arung Palakka] went down to Mandar

1 Jakr 1082 namanaung ri Mandaraq Tunisombaya siagaang Karaengta ri Bontosunggu

19 Oct (M) Karaeng Tumaqdanggang and I Shafiah divorced

15 Jakr 1082 nasipelaq Karae Tumaqdanggang I Shafiah

21 Oct (T eve) Karaeng ri Langeloq had twins, two girls; the one born later died 2 [nights] after; the one born earlier died 3 nights after 
17 Jakr 1082

namamanaq Karaengta ri Langeloq kambaraq baine rua ribokoanga lassuq 2 namate rioloanga lassuq 3 banngi namate

13 Nov (F) Tumamenang ri Ujung Tana [Karunrung] changed the ruling in which fathers have no share of their children ${ }^{296}$

10 Raj 1082 nanilesang ri Tuammenang ri Juntana bicara ilalangta tamanabai anaq manggea

$15 \operatorname{Nov}(\mathrm{N}) \quad$ Tunisombaya [Arung Palakka] arrived from Mandar

12 Raj 1082 nabattu ri Mandaraq Tunisombaya

18 Nov (T eve) Karaeng ri Parang-Parang Khadijah ${ }^{297}$ born

15 Raj 1082 naanaq Karaengta ri Parang-Parang Khadijah

$7 \operatorname{Dec}(\mathrm{M})$

the people of Cenrana swore oaths to Tunisombaya [Arung Palakka]

5 Syab 1082 nanitalliq tuCenranaya ri Tunisombaya

1672

5 Jan (M eve) Haji I Daeng Tappaq and Karaeng Tamasongoq married

4 Ram 1082 nasikalabini Haqjia I Daeng Tappaq Karae Tamasongoq

20 Jan (W) Daengta Daeng Tamemang298 born in the same house with Karaeng Panaikang Khadijah

19 Ram 1082 naanaq Daengta Daeng Tamemang siballaqna Karae Panaikang Khadijah

28 Jan (W eve) Karaeng ri Pangkajeqneq set foot on the ground 299

296 This decision is likely the origin of several rapang (guidelines from renowned ancestors) that describe the rights of fathers and mothers to children. See Cummings 2002:176-7.

297 A daughter of Tumatea ri Jakattaraq (Muhammad Ali) and Karaeng ri Kampong Beru (Daeng Talele). See Ligtvoet (1880:footnote 135) for a discussion of this identification.

298 Dutch sources from 1684 report that she was a sister of Karaeng Lengkeseq (Ligtvoet 1880:154).

299 This ritual act was performed for children at a young age, before which they were carried for their protection. Gervaise (1701:134) referred to this practice in the context of an Islamic ceremony for boys in which their feet were placed on a scimitar to ensure their bravery as warriors and they received an Islamic name. He noted that Makassarese parents, 'would think themselves guilty of a very great crime, should they be so indulgent as to let him set his feet upon the ground, before they had been sanctify'd by touch of the saber'. Born 10 Mar 1670, at this time Karaeng ri Pangkajeqneq was less than two years old, and Gervaise is no doubt exaggerating or was misinformed when he goes on to say that, 'The same scruple of conscience also will not 
27 Ram 1082 nanipaonjoq ri butta Karaengta ri Pangkajeqneq

19 Feb (R eve) I Kare Tulolo and I Punngaq Karaeng Tamalingu divorced

19 Syaw 1082 nasipelaq I Kare Tulolo I Punngaq Karae Tamalingu

1 Mar (M eve) a child of Karaeng Mandalleq died at the stroke of 3

30 Syaw 1082 namate anaqna Karaeng Mandalleq 3 garigantaya

23 Mar (W) Karaeng ri Mangalliq and I Taniq, a child of the tumailalang ${ }^{300}$ who died on Salaparang, married

22 Zulk 1082 nasikalabini Karaengta ri Mangalliq I Taniq anaqna tumailalang matea ri Salaparang

12 Apr (M eve) I Daeng Makaqbang, the father of I Daeng Manyampaq Balambaru, died

13 Zulh 1082 namate I Daeng Makaqbang manggena I Daeng Manyamppaq Balambaru

18 Apr (M) Tumammaliang ri Alluq [Amir Hamzah] first performed a Maluku war dance; after sunset it ended and people went out

19 Zulh 1082 nauru makkanjaraq Maluku Tumammaliang ri Alluq saqrappi alloa nalaqbusuq taua massuluq

1 May (S eve) a child of Karaeng Mandalleq died at the stroke of 7 2 Muh 1083 namate anaqna Karae Mandalleq 7 garigantaya

30 Jun (W eve) at the stroke of 1 I Uru had a son named Muhammad Shaleh

4 Rawl 10831 garigantaya namamanaq I Uru buraqne nikana Muhammad Shaleh

$22 \mathrm{Jul}(\mathrm{F}) \quad$ Sitti Aminah born

26 Rawl 1083 naanaq Sitti Aminah

25 Jul (M) I Daeng Maqgeaq died

29 Rawl 1083 namate I Daeng Maqgeaq

suffer them to let children of quality go, before they are eight or nine years of age; and therefore their nurses or their governors always carry them in their arms, or at their backs.'

300 This tumailalang was Karaeng Jarannika, who died on 14 May 1700. 
14 Aug (S eve) I Asseng married by the ruler of Maluku [Ternate] 30 Rakr $1083^{301}$ nanibaineang I Asseng ri Karae Maluku

5 Sep (M) a wife of Karaeng ri Bontomanompoq had a son purportedly named I Daeng Mamangung I Karisaq ${ }^{302}$

12 Jawl 1083 namamanaq bainenna Karaengta ri Bontomanompoq buraqne I Daeng Mamangun I Karisaq kutaeng

12 Sep (N eve) I Timoroq and I Sitti married

19 Jawl 1083 nasikalabini I Timoroq I Sitti

16 Sep $(S)^{303} \quad$ I Taniq divorced by Tumamenang ri Ujung Tana [Karunrung]

24 Jawl 1083 nanipelaq I Taniq ri Tuammenang ri Juntana

21 Sep (W eve) Daengta Daeng Majannang and Karaeng ri Mandalleq married; the very same day I Sitti ${ }^{304}$ divorced by Aqduluq

28 Jawl 1083 nasikalabini Daengta Daeng Majannang Karaengta ri Mandalleq julu alloji nipelaqna I Sitti ri Aqduluq

21 Oct (R eve) Sitti Lambengi married by Tumatea ri Jakattaraq [Muhammad Ali]

29 Jakr 1083 nanibaineang Sitti Lambengi ri Tumatea ri Jakattaraq

22 Oct (S) I Daeng Nisimba married by Tumammaliang ri Alluq [Amir Hamzah]

30 Jakr 1083 nanibaineang I Daeng Nisimba ri Tumammaliang ri Alluq

28 Oct (R eve) I Daeng Maingaq Karaeng Balua and Tumammaliang ri Alluq [Amir Hamzah] married

6 Raj 1083 nasikalabini I Daeng Maingaq Karaengta Balua Tumammaliang ri Alluq

301 The Hijri date converts to 24 Aug 1672.

302 Whether the annalist was uncertain of both of his names or just whether his personal name was I Karisaq is not clear.

303 A copyist wrote 12 Sep for the Gregorian date (probably looking at the previous entry as he began this one), but the correct date is 16 Sep.

304 Sitti is a common name, and given the pattern of brief marriages in the annals it is by no means certain that this is the same Sitti who married only nine days beforehand; if so Aqduluq and Timoroq are the same person. 
$3 \operatorname{Nov}(\mathrm{F})^{305} \quad$ Matinroa ri Nagaulang Idris [La Patauq] born

12 Raj 1083 naanaq Matinroa ri Nagaulang Idris

17 Nov (W eve) Karaeng ri Langeloq had a son named Abdul Rasyid 26 Raj 1083 namamanaq Karaengta ri Langeloq buraqne nikana Abdulrrasyid

$8 \mathrm{Dec}(\mathrm{R}) \quad$ I Sitti, a wife of I Japaraq, had a son

17 Syab 1083 namamanaq I Sitti bainenna I Japaraq buraqne

11 Dec (N) I Daeng Nisimba divorced by Tumammaliang ri Alluq [Amir Hamzah]; they were married only 54 nights

20 Syab 1083 nanipelaq I Daeng Nisimba ri Tumammaliang ri Alluq 50 banngiji angappaq sikalabini

13 Dec (T) I Sitti Lambengi divorced by Tumatea ri Jakattaraq [Muhammad Ali]; they were married 54 nights

22 Syab 1083 nanipelaq I Siti Lambengi ri Tumatea ri Jakattaraq 50 angappaq sikalabini

$17 \operatorname{Dec}(\mathrm{S}) \quad$ Daengta Daeng Nisali Sitti Sarah, the widow of Karaeng ri Mandalleq ${ }^{306}$, born

26 Syab 1083 naanaq Daengta Daeng Nisali Sitti Sarah balunna Karaengta ri Mandalleq

$26 \operatorname{Dec}(\mathrm{M}) \quad$ I Daeng Manangaraq, a child of Karaeng Ujung Pandang, died

6 Ram 1083 namate I Daeng Manangaraq anaqna Karae Jumpandang

1673

2 Jan (N eve) I Daeng Manangaraq Assang died

3 Ram $1083^{307}$ namate I Daeng Manangaraq Assang

7 Jan (F eve) the child of Karaeng ri Langeloq named Abdul Rasyid died

18 Ram 1083 namate anaqna Karaengta ri Langeloq nikanaya

Abdulrrasyid

305 ANRI 16/6 has this date as 3 Jan 1672, but this does not match the Hijri date, which is likely correct.

306 Which Karaeng Mandalleq this refers to is uncertain.

307 The Hijri date converts to 23 Dec 1672. 
17 Jan (M eve) Karaeng ri Mangalliq and I Mamo divorced

28 Ram 1083 nasipelaq Karaengta ri Mangalliq I Mamo

21 Jan (F eve) the mother of the karaeng named Talebang died

2 Syaw 1083 namate anronna karaenga nikanaya Talebang

$9 \operatorname{Mar}(\mathrm{R}) \quad$ I Daeng Mangemba, the ruler of Siang 308 , and I Daeng Rikong I Shafiah ${ }^{309}$, the older sibling of Daengta Daeng Mami, married

16 Zulk 1083 nasikalabini I Daeng Mangemba Karae Siang I Daeng Rikong I Shafiah kakanna Daengta Daeng Mami

31 Mar (F) a child of Karaeng ri Palemba died

11 Zulh 1083 namate anaqna Karaengta ri Palemba

6 Apr (R) Karaeng ri Mandalleq I Daeng Sisila and Daengta Daeng Takontu married; Karaeng ri Kaballokang and Karaeng ri Langeloq divorced

17 Zulh 1083 nasikalabini Karaengta ri Mandalleq I Daeng Sisila Daengta Daeng Takontu nasipelaq Karaengta ri Kaballokang Karaengta ri Langeloq

21 Apr (F) Karaeng ri Tana-Tana Fatimah ${ }^{310}$ born

3 Muh 1084 naanaq Karaengta ri Tana-Tana Fatimah

27 Apr (R) Tunisombaya [Arung Palakka] went down to Massepe to make war 311

9 Muh 1084 namanaung ri Massepe Tunisombaya maqbunduq

9 May (T) Sitti Lambengi married by Karaeng ri Kaballokang

21 Muh 1084 nanibaineang Siti Lambengi ri Karaengta ri Kaballokang

13 May (S) birth of I Daeng Tapallaq I Piqdaq

26 Muh 1084 nanianakkang I Daeng Tapallaq I Piqdaq

308 Dutch sources report that Daeng Mangemba was also named Pakampi and was a son of the Boné leader Arung Tanette Matowa. Speelman called Daeng Mangemba Gallarang Tosawa (Ligtvoet 1880:159).

309 A daughter of Hasanuddin. In the Gowa Chronicle her personal name is rendered as I Sapia.

310 A daughter of Karaeng Bisei Tumatea ri Jakattaraq and Daeng Talele Karaeng Kampongberu.

This identification is discussed in Ligtvoet (1880:footnote 136).

311 This war concluded Arung Palakka's efforts to establish himself as overlord of South Sulawesi in the wake of the 1669 conquest of Gowa and is discussed in Andaya (1981:148-51). 
25 May (R eve) Karaeng ri Mangalliq and [I Taniq,] a child of Tumatea ri Salaparang [Karaeng Jarannika] divorced

8 Saf 1084 nasipelaq Karaengta ri Mangalliq anaqna Tumatea ri Salaparang

8 Jun (R) the head of Karaeng Massepe brought back

21 Saf 1084 nabattu nierang ulunna Karae Massepe

13 Jun (M eve) Tunisombaya [Arung Palakka] arrived and with him brought I Sarampa

28 Saf 1084 nabattumo Tunisombaya niaqmi I Sarampa naerang

16 Jun ( $\mathrm{R}$ eve) we were left by Karaeng Tumamenang ri Lampana [Harrunarasyid] across on Sumbawa at the age of 34

29 Saf 1084 kinapilari Karaenga Tuammenang ri Lampanna ibaqle ri Sambawa umuruqna 34

19 Jun (M) Karaeng ri Lekoqboqdong and I Daeng Memang I Munaq divorced

3 Rawl 1084 nasipelaq Karaengta ri Lekoqboqdong I Daeng Memang I Munaq

20 Jun (M eve) Karaeng ri Mangalliq and I Sitti married

4 Rawl 1084 nasikalabini Karaengta ri Mangalliq I Sitti

2 Jul (S eve) Karaeng ri Lekoqboqdong and Karaeng ri Langeloq married

6 Rawl $1084^{312}$ nasikalabini Karaengta ri Lekoqboqdong Karaengta ri Langeloq

$20 \mathrm{Jul}(\mathrm{R}) \quad$ Tunisombaya [Arung Palakka] went into marry Datu ri Watu 313

5 Rakr 1084 namantama Tunisombaya ambaineangi Datua ri Watu

$20 \mathrm{Jul}(\mathrm{R}) \quad$ I Kare Loqmoq, I Sarampa, and I Minaq divorced by Tunisombaya [Arung Palakka]

312 The Hijri date converts to 21 Jun 1673.

313 We Adda Matinroe ri Madello, a daughter of Datu Soppéng La Tenribali. ANRI 16/6 adds 'in Soppéng' (ri Soppeng). 
5 Rakr 1084

17 Aug (R)

4 Jawl 1084

23 Aug (T eve)

10 Jawl 1084

4 Sep (N eve)

22 Jawl 1084

4 Sep $(M)^{314}$

22 Jawl 1084

13 Sep (W)

1 Jakr 1084

23 Sep (F eve)

11 Jakr 1084

30 Sep (F eve)

18 Jakr 1084

20 Oct (F)

8 Raj 1084

$22 \operatorname{Oct}(\mathrm{N})$

10 Raj 1084

30 Oct (M) nanipelaq I Kare Loqmoq I Sarampa I Minaq ri Tunisombaya

a child of the ruler of Laikang and a child of I Daeng Niaq married

nasikalabini anaqna Karae Laikang anaqna I Daeng Niaq

the mother of Karaeng Beroanging died

namate ayana Karae Beroangin

Karaeng ri Kaballokang and Karaeng Mateqne married nasikalabini Karaengta ri Kaballokang Karae Mateqne

after the clock struck Sitti Fatimah had a daughter named Zalikha

leqbaki tetteq garigantaya namamanaq Sitti Fatimah baine nikana Zalikha

I Malung, a wife of Karaeng ri Balloq, had a son named I Mangellai

namamanaq I Malung bainenna Karaengta ri Balloq buraqne nikana I Mangellai

I Daeng Manyampaq Alluq and I Kare Alle married nasikalabini I Daeng Manyampaq Alluq I Kare Alle

a child of Daengta Daeng Majannang died namate anaqna Daengta Daeng Majannang

ears pierced of Karaeng ri Bontorambaq ${ }^{315}$ nanitinting Karaengta ri Bontorambaq

Karaeng Tamaqdanggang and I Daeng Talarra I Mene, a child of Karaeng Laikang, married nasikalabini Karae Tamaqdanggang I Daeng Talarra I Mene anaqna Karae Laikang

I Daeng Singaraq, a child of the ruler of Sula, died

314 The discrepancy is not large, but the Gregorian date for this and the previous entry has been corrected; a copyist mistakenly wrote the 9 th.

315 A daughter of Karunrung and Karaeng Ballaq Jawaya (Ligtvoet 1880:142). 
18 Raj 1084

31 Oct $(\mathrm{T})$

19 Raj 1084

$29 \operatorname{Nov}(\mathrm{W})$

19 Syab 1084

$4 \operatorname{Dec}(\mathrm{M})$

24 Syab 1084

30 Dec (F eve)

21 Ram 1084

3 Jan $(W)$

25 Ram 1084

31 Jan (T eve)

23 Ram 1084

4 Feb (N) namate I Daeng Singaraq anaqna Karaengta ri Sula

Tunisombaya [Arung Palakka] sailed down to Mandar to make war ${ }^{316}$; Karaeng Tompoqbalang accompanied him namammise Tunisombaya manaung ri Mandaraq maqbunduq Karae Tompoqbalang naaganga

Karaeng Tumammaliang ri Alluq [Amir Hamzah] ended performing of the Maluku war dance kaleqbakkang makkanjaraq Malukuna Karaenga Tumammaliang ri Alluq

Karaeng ri Beroanging circumcised along with I Makkaraeng nanisunnaq Karaengta ri Beroangin siagaang I Makkaraeng

Sitti Maradiah had a son at the stroke of 3 namamanaq Sitti Maradiah buraqne 3 garigantaya

1674

Daengta Daeng Rikong I Shafiah, the older sibling of Daengta Mami, died giving birth namate Daengta Daeng Rikong I Shafiah kakanna Daengta Mami mate mamanaki

Karaeng ri Lekoqboqdong and Karaeng ri Langeloq divorced

nasipelaq Karaengta ri Lekoqboqdong Karaengta ri Langeloq

I Jaga advanced on by the karaeng [Amir Hamzah] and the people of Boné317; this was called the Tinangga Uproar $^{318}$

316 On this expedition see Andaya 1981:152-3.

317 In place of 'the people of Boné' (rituBonea) ANRI 16/6 has 'Tunisombaya' (Arung Palakka), which makes rather more sense.

318 In the wake of Arung Palakka's victory over Gowa, several Makassarese noblemen insulated and shamed Arung Palakka by kidnapping, molesting, or having illicit sexual relations with his wives and concubines. This was a particularly damaging insult because Arung Palakka was childless. Kare Jaga was one such offender. He kidnapped one of Arung Palakka's women and refused to surrender her. Under pressure to resolve the situation, Amir Hamzah was unable to 
27 Syaw 1084 nanipanraiki I Jaga ri karaenga siagaang rituBonea iaminne nikana gegereq Tinanggaya

9 Feb (F) Karaeng ri Patukangang Maryam ${ }^{319}$ born

1 Zulk 1084 naanaq Karaengta ri Patukangan Maryam

13 Feb (T) Tumammaliang ri Alluq [Amir Hamzah] arrived from [his attack] on Jaga ${ }^{320}$

6 Zulk $1084 \quad$ nabattu ri Jaga Tumammaliang ri Alluq

15 Feb (W eve) I Tinangga killed

8 Zulk 1084 nanibuno I Tinangga

21 Feb (W eve) I Daeng Talebang and Karaeng ri Kaballokang married 15 Zulk 1084 nasikalabini I Daeng Talebang Karaengta ri Kaballokang

27 Feb (T) I Daeng Manyallang died

20 Zulk 1084 namate I Daeng Manyallang

1 Mar (R) Karaeng ri Agangjeqneq and I Daeng Taloqmoq married

22 Zulk 1084 nasikalabini Karaengta ri Agangjeqneq I Daeng Taloqmoq

24 Mar (S) Karaeng ri Patukangang put up in a sling [at about age 6 weeks]

15 Zulh 1084 nanipanaiki ri toeng Karaengta ri Patukangan

$25 \operatorname{Mar}(\mathrm{N}) \quad$ tumailalang Karaeng Lekoqboqdong 321 born

16 Zulh 1084 naanaq tumailalang Karae Lekoqboqdong

$29 \operatorname{Mar}(\mathrm{R}) \quad$ Karaeng ri Mandalleq and I Daeng Nisayu I Dara married

20 Zulh 1084 nasikalabini Karaengta ri Mandalleq I Daeng Nisayu I

Dara

capture I Jaga, though he was able to capture and kill Tinangga, who may have been the woman stolen, on Feb 15th. The personal animosities during this tense period led to a brief war in 1677 between Arung Palakka and Gowa, Gowa's defeat, and the abdication of Muhammad Ali in favor of Abdul Jalil as Gowa's sultan (Andaya 1981:168-76, 180-6). See the note accompanying the entry for 28 Mar 1676.

319 A daughter of Abdul Jalil.

320 ANRI 16/6 incorporates the subsequent entry, adding, 'two nights [after Amir Hamzah] returned I Tinangga was killed' (rua banngi battu nanibuno I Tinangga).

321 Though he is consistently referred to as tumailalang in subsequent entries as well, he did not become tumailalang until 24 Jun 1717 at the age of 41. 
4 Apr (T eve) Karaeng ri Lekoqboqdong and I Daeng Singaraq, the older sibling of Karaeng ri Bontokamase, married

26 Zulh 1084 nasikalabini Karaengta ri Lekoqboqdong I Daeng Singaraq kakanna Karaengta ri Bontokamase

$22 \operatorname{Apr}(\mathrm{N}) \quad$ the Dutch cloth warehouse consumed [by fire]

15 Muh 1085 namakkaqdoq gaqdong topena Balandaya

7 May ( $\mathrm{N}$ eve) at the stroke of 1 we were left by Karaeng Tumammaliang ri Alluq [Amir Hamzah] at the age of 19

30 Muh 1085 tetteq 1 garigantaya kinapilari Karaenga Tumammaliang ri Alluq umuruqna 19

14 May (N eve) I Daeng Maqruppa and I Daeng Nisayu ${ }^{322}$, the mother of tumailalang [Karaeng] Lekoqboqdong, divorced

7 Saf 1085 nasipelaq I Daeng Maqruppa I Daeng Nisayu ayana tumailalang Lekoqboqdong

21 May ( $\mathrm{N}$ eve) Karaeng Jipammana ${ }^{323}$ and I Daeng Manyiwi married 14 Saf 1085 nasikalabini Karae Jipammana I Daeng Manyiwi

24 Jun (S eve) Daengta Daeng Talebang and Karaeng ri Palemba divorced

19 Rawl 1085 nasipelaq Daengta Daeng Talebang Karaengta ri Palemba

17 Jul (T) Karaeng Lambengi and Sitti Fatimah divorced

12 Rakr 1085 nasipelaq Karae Lambengi Sitti Fatimah

$29 \mathrm{Jul}(\mathrm{N}) \quad$ I Daeng Niasseng had a daughter named Habibah

24 Rakr 1085 nammanaq I Daeng Niasseng baine nikana Habibah

3 Aug (R eve) I Cocuq and sabannaraq Daeng Makkulle married 29 Rakr 1085 nasikalabini I Cocuq sabannaraka Daeng Makkulle

4 Aug (F eve) Karaeng Lambengi and Daengta Daeng Takontu married 1 Jawl 1085 nasikalabini Karae Lambengi Daengta Daeng Takontu 1880:139). She is not the I Dara who married on 29 Mar 1674.

323 He was the ruler or Datu of Pammana, south of Wajoq (Ligtvoet 1880:139). 
28 Aug (M eve) I Taniq and Karaeng Bangkalaq married 25 Jawl 1085 nasikalabini I Taniq Karae Bangkalaq

5 Sep (T eve) the mother of Karaeng Lekoqboqdong [Daeng Nisayu] and the ruler of Agangnionjoq ${ }^{324}$ married

4 Jakr 1085 nasikalabini ayana Karae Lekoqboqdong Karae Agangnionjoq

11 Sep (T) Tunisombaya [Arung Palakka] went down to Mandar with the karaengs of Palemba, Manjalling, and Bontopaqdinging

10 Jakr 1085 namanaung ri Mandaraq Tunisombaya siagaang Karae Palemba Manjalling Bontopaqdinging

12 Sep $(W) \quad$ ears pierced of Sitti Sarah

11 Jakr 1085 nanitinting Sitti Sarah

3 Oct (W) Tumatea ri Jakattaraq [Muhammad Ali] had a sunshade raised over his head, a golden sunshade ${ }^{325}$; Tunisombaya [Arung Palakka] arrived from Mandar

2 Raj 1085 nanipirangkaki laqlang Tumatea ri Jakattaraq laqlang bulaeng nabattu ri Mandaraq Tunisombaya

9 Oct (F eve) Daengta Takontu and Karaeng Lambengi divorced; [they were married] only 2 months and sixteen nights then divorced ${ }^{326}$; after twenty nights returned to each other

19 Raj 1085 nasipelaq Daengta Takontu Karae Lambengi 2 bulanji assampulo banngi angannang nasipelaq naruampulo banngi nasipolei

30 Oct (T) I Daeng Tapallaq, the mother of I Jaga Azizah, born ${ }^{327}$

24 Raj 1085 naanaq I Daeng Tapallaq anronna I Jaga Azizah

$13 \operatorname{Nov}(\mathrm{T}) \quad$ I Sitti and Karaeng ri Mangalliq divorced

324 Mappatuntu Daeng Mattulung Matinroe ri Segeri, a son and successor of Ibrahim Daeng Matiring Matinroe ri Buliana.

325 Thus replacing his brother Amir Hamzah as ruler of Gowa.

326 This entry is interesting because it suggests that the Hijri calendar was the preferred one used by annalists.

327 Not to be confused with the I Daeng Tapallaq I Piqdaq born on 13 May 1673. Kamaruddin et al. (1985:149) reads this entry as intending 'I Daeng Tapallaq born whose mother was I Jaga Azizah.' This is also possible, though I think it less likely. 
14 Syab 1085 nasipelaq I Sitti Karaengta ri Mangalliq

3 Nov (F eve) I Opu and I Saidah married

4 Syab 1085 nasikalabini I Opu I Saidah

15 Nov (W eve) Daengta Daeng Talebang had a son named Abdul Karim 16 Syab 1085 namamanaq Daengta Daeng Talebang buraqne nikana Abdulkarim

22 Nov (W eve) Karaeng Baroqbosoq and I Daeng Tuna married 23 Syab 1085 nasikalabini Karae Baroqbosoq I Daeng Tuna

23 Nov (R eve) I Kare Loqmoq married by Karaeng ri Palemba 24 Syab 1085 nanibaineang I Kare Loqmoq ri Karaengta ri Palemba

26 Nov $(\mathrm{M}) \quad$ Karaeng ri Beroanging and I Daeng Tamemang I Maqminasa married

27 Syab 1085 nasikalabini Karaengta ri Beroangin I Daeng Tamemang I Maqminasa

27 Nov (T) Karaeng ri Mangalliq and I Taniq returned to each other 28 Syab 1085 nasipolei Karaengta ri Mangalliq I Taniq

10 Dec (M) Haji I Kare Takko died

12 Ram 1085 namate Haqji I Kare Takko

18 Dec (M eve) the child of Karaeng ri Balloq known as I Mangellai died 20 Ram 1085 namate anaqna Karaengta ri Balloq nikanaya I Mangellai

21 Dec (R eve) I Daeng Maqruppa and I Daeng Talele, a child of I Daeng ri Jonggoa, married

23 Ram 1085 nasikalabini I Daeng Maqruppa I Daeng Talele anaqna I Daeng ri Jonggoa

22 Dec ( $\mathrm{F}$ eve) Karaeng ri Tana-Tana set foot on the ground ${ }^{328}$

24 Ram 1085 nanipaonjoq ri butta Karaengta ri Tana-Tana

26 Dec (T eve) I Daeng Majannang died 28 Ram 1085 namate I Daeng Majannang

328 See the explanatory note for 28 Jan 1672. 


\section{5}

15 Jan (T) Karaeng ri Kaballokang and I Daeng Talebang divorced

18 Syaw 1085 nasipelaq Karaengta ri Kaballokang I Daeng Talebang

16 Jan (W) I Tahiriq and I Daeng Talele divorced

19 Syaw 1085 nasipelaq I Tahiriq I Daeng Talele

17 Jan (R) I Daeng Maqruppa and I Daeng Talele divorced

20 Syaw 1085 nasipelaq I Daeng Maqruppa I Daeng Talele

21 Jan (M) Karaeng Baroqbosoq and I Mamo divorced

24 Syaw 1085 nasipelaq Karae Baroqbosoq I Mamo

13 Feb (T eve) Tumamenang ri Lakiung [Abdul Jalil] and Karaeng Balua [Daeng Maingaq] married 282 nights after she widowed

17 Zulk 1085 nasikalabini Tuammenang ri Lakiun Karaengta Balua 282 bannginna leqbaq balu

$3 \operatorname{Mar}(\mathrm{N}) \quad$ Karaeng ri Kaballokang and Karaeng Suriwaq married

5 Zulh 1085 nasikalabini Karaengta ri Kaballokang Karae Suriwaq

17 Mar (S eve) Karaeng ri Sanggiringang died at the age of 30

19 Zulh 1085 namate Karaengta ri Sanggiringan umuruqna 30

23 Mar (F eve) the mother of I Daeng Tuna died

25 Zulh 1085 namate anronna I Daeng Tuna

26 Apr (F eve) Karaeng Barrung and Daengta Daeng Takontu wed [in accordance with Islamic custom]

29 Muh 1086 nanikka Karae Barrung Daengta Daeng Takontu

1 May (W) Karaeng Barrung and Daengta Daeng Takontu married ${ }^{329}$

5 Saf 1086 nasikalabini Karae Barrung Daengta Daeng Takontu

3 May (F) Haji Kare Gappa died

7 Saf 1086 namate Haqji Kare Gappa

7 May (M eve) I Manngallei died

329 This pair of entries makes it clear that Makassarese distinguished between what we might term customary and Islamic weddings. This is the only case in which two individuals are recorded as participating in both types of ceremonies. 
11 Saf 1086 namate I Manngallei

11 May (S) I Loqmoq, the mother of Karaeng ri Patukangang, had a son named Jaqfar Shadiq 330

15 Saf 1086 namamanaq I Loqmoq anronna Karaengta ri Patukangang buraqne nikana Jaqfar Shadiq

15 May (W) I Daeng Mamaro and I Sarah divorced

19 Saf 1086 nasipelaq I Daeng Mamaro I Sarah

27 Jun (R) Arung Teko $\quad$ A31 and Karaeng ri Langeloq married

5 Rakr 1086 nasikalabini Aruq Teko Karaengta ri Langeloq

14 Jul (S eve) I Cocuq had a child by sabannaraq Daeng Makkulle

20 Rakr 1086 namamanaq I Cocuq ri Daeng Makkulle sabannaraka

25 Jul (W eve) I Minnah married by Karaeng Pamolikang; the brideprice was 40 [reals]

1 Jawl 1086 nanibaineang I Minnah ri Karae Pamolikang 40 sunranna

8 Aug (M eve) I Tuang Anciq Baru died

13 Jawl 1086 namate I Tuan Anciq Baru

18 Aug (S eve) the female Karaeng Lekoq Alaq died

25 Jawl 1086 namate Karae Lekoq Alaq bainea

22 Aug (W eve) Sitti Fatimah had a son

29 Jawl 1086 namamanaq Sitti Fatimah buraqne

4 Sep (W) Karaeng Tumatea ri Jakattaraq [Muhammad Ali] went into Boné, to Wawodataq to enclose a deer-hunting preserve

13 Jakr 1086 namantama ri Bone Karaenga Tumatea ri Jakattaraq nari Wawodataq maqbara jonga

12 Sep (W eve) Sitti Hajar, a child of Toadaeng, died

21 Jakr 1086 namate Sitti Hajar anaqna Toadaeng

20 Sep (R eve) I Salamah married by Karaeng Bontotannga

330 His father was Abdul Jalil.

331 A Boné noble and one of Arung Palakka's lieutenants. 
29 Jakr 1086

25 Sep (W)

5 Raj 1086

27 Sep (R eve)

7 Raj 1086

1 Oct (T)

11 Raj 1086

11 Oct (F)

21 Raj 1086

21 Oct ( $\mathrm{N}$ eve)

1 Syab 1086

$8 \operatorname{Nov}(F)$

19 Syab 1086

$25 \mathrm{Nov}(\mathrm{N}$ eve)

7 Ram 1086

2 Dec ( $\mathrm{N}$ eve)

14 Ram 1086

6 Dec (R eve)

18 Ram 1086

9 Dec ( $\mathrm{N}$ eve)

21 Ram 1086

12 Dec (R)

24 Ram 1086 nanibaineang I Salamah ri Karae Bontotannga

ears pierced of I Daeng Tonji I Saenaq, a child of Arung Kaju

nanitinting I Daeng Tonji I Saenaq anaqna Aruq Kayu

something shining was seen in the sky

naniaq niciniq maqrinra ri langika

a child of Karaeng Lambengi that had been adopted by Karaeng Buqdia died

namate anaqna Karae Lambengi nikatuoa ri Karae Buqdia

the karaeng [Muhammad Ali] arrived from Boné

nabattu ri Bone karaenga

Daengta Daeng Massuro and Daeng Jipaling married nasikalabini Daengta Daeng Massuro Daeng Jipaling

I Mappakana, a child of the ruler of Agangnionjoq, circumcised

nanisunnaq I Mappakana anaqna Karae Agangnionjoq

I Daeng Ngaseng I Bataq and Karaeng ri Patukangang were engaged to each other [by their parents] nanipasiparekanngang I Daeng Ngaseng I Bataq Karaengta ri Patukangang

a wife of Karaeng ri Balloq had a son

namamanaq bainenna Karaengta ri Balloq buraqne

I Sarampa married by Tumamenang ri Ujung Tana [Karunrung]; I Daeng Anrenne and Karaeng ri Agangjeqneq married nanibaineang I Sarampa ri Tuammenang ri Juntana nasikalabini I Daeng Anrenne Karaengta ri Agangjeqneq

I Bayang married by Karaeng Bontotannga nanibaineang I Bayang ri Karae Bontotannga

Karaeng Tammattuq died namate Karaeng Tammattuq 
16 Dec (N eve) Karaeng ri Patukangang set foot on the ground ${ }^{332}$ 27 Ram 1086 nanipaonjoq ri butta Karaengta ri Patukangang

1676

3 Jan (F) a grandparent of Karaeng Tumamenang ri Passiringanna [Abdul Kadir] died

16 Syaw 1086 namate toana Karaenga Tuammenang ri Passiringanna

16 Jan (R) Tumamenang ri Passiringanna [Abdul Kadir] circumcised 30 Syaw 1086 nanisunnaq Tuammenang ri Passiringanna

20 Jan (N eve) Karaeng Pamolikang and I Munaq, a child of Karaeng Batu-Batu, married

4 Zulk 1086 nasikalabini Karae Pamolikang I Munaq anaqna Karae Batu-Batu

$1 \mathrm{Feb}(\mathrm{S}) \quad$ Karaeng ri Jarannika and I Daeng Jinne, an older sibling of the widow [Daeng Maingaq], married

16 Zulk 1086 nasikalabini Karaengta ri Jarannika I Daeng Jinne kakanna balua

23 Feb $(\mathrm{N}) \quad$ Kaicili Kalamata died

9 Zulh 1086 namate Kacili Kalimata

$24 \mathrm{Feb}(\mathrm{N}$ eve) a child of Tumamenang ri Lakiung [Abdul Jalil] named Jaqfar Shadiq died

10 Zulh 1086 namate anaqna Tuammenang ri Lakiun nikanaya Jaqfar Shadiq

12 Mar (R) Karaeng Bontokeke ${ }^{333}$ and I Daeng Singaraq ${ }^{334}$ divorced

27 Zulh 1086 nasipelaq Karae Bontokeke I Daeng Singaraq

27 Mar (R eve) Daeng ri Mangeppeq died

12 Muh 1087 namate Daengta ri Mangeppeq

332 See the note for the 28 Jan 1672 entry.

333 A son of Karaeng Jarannika.

334 Presumably the same I Daeng Singaraq who had married Karaeng ri Lekoqboqdong on 4 Apr 1674. 
$28 \operatorname{Mar}(\mathrm{S}) \quad$ we were opposed by Tunisombaya [Arung Palakka] after the first quarrel in Gowa 335

13 Muh 1087 kinasongkaang ri Tunisombaya sisala rioloanta ri Gowa

$3 \operatorname{Apr}(\mathrm{F})$

19 Muh 1087

people battled and Daengta Daeng Mamo was killed ${ }^{336}$

$11 \operatorname{Apr}(S)$ namaqbunduqmo taua naniposo Daengta Daeng Mamaro

27 Muh 1087

Tumamenang ri Lakiung [Abdul Jalil] went from Gowa and over to Tunisombaya [Arung Palakka]

27 Muh 1087 namaqlampa ri Gowa Tuammenang ri Lakiun taqle ri Tunisombaya

27 Apr (M)

13 Saf 1087

Tunisombaya [Arung Palakka] wounded in his left thigh namalokoq Tunisombaya bongga kairinna

30 Apr (R)

Karaeng Pamolikang and I Munaq divorced

26 Saf 1087337 nasipelaq Karae Pamolikang I Munaq

13 May (W) the karaeng [Muhammad Ali] and Tunisombaya [Arung Palakka] were brought to an agreement by the Dutch; 40 [nights] after quarreling they agreed and Karaeng Lambengi was brought seawards to Ujung Pandang

29 Saf 1087 nanipasitaba ri Balandaya karaenga Tunisombaya 40 sisala nanipasitaba nanierang kalauq ri Jumpandang Karae Lambengi

29 May (R eve) the child of Karaeng ri Popoq that had been adopted by Karaeng Mandalleq died

15 Rawl 1087 namate anaqna Karaengta ri Popoq nikatuoa ri Karae Mandalleq

9 Jun (T)

the child of Karaeng ri Palemba that had been adopted by a wife of Karaeng Mandalleq died

335 This quarrel and the subsequent conflict stemmed from the illicit sexual relations that three Makassarese nobles (Karaeng Lambengi, Daeng Mamara, and Sultan Muhammad Ali) had with Arung Palakka's women during Muhammad Ali's trip to Boné to enclose a deer-hunting preserve the previous year. See the note to the 4 Feb 1674 entry and Andaya 1981:168-76.

336 The lontaraq bilang entry in Makasaarsche historien 91855:125) states that this battle was between Arung Palakka and Gowa.

337 The Hijri date converts to 9 May 1676. 
26 Rawl $1087^{338}$ namate anaqna Karaengta ri Palemba nakatuoa bainenna Karae Mandalleq

16 Jun (T) Karaeng Tumamenang ri Ujung Tana [Karunrung] went from Gowa down to Talloq

3 Rakr 1087 namaqlampa ri Gowa Karaengta Tuammenang ri Juntana manaung ri Talloq

17 Jun (W) teeth filed of Tumamenang ri Passiringanna [Abdul Kadir] 5 Rakr 1087 naniariq Tuammenang ri Passiringanna

19 Aug (T eve) Datu ri Soppéng 339 died

9 Jakr $1087 \quad$ namate Datua ri Soppeng

20 Aug (W eve) Karaeng ri Bontosunggu and the mother of the karaengs ${ }^{340}$ married

10 Jakr 1087 nasikalabini Karaengta ri Bontosunggu puanna Karaenga

27 Aug (R) word arrived that Haji I Kare Lumu died across on Sumbawa

17 Jakr 1087 nabattu erang kananna Haqjia I Kare Lumu matei baqle ri Sambawa

2 Sep (W) Tunisombaya [Arung Palakka] sailed to go into Luwuq to make war ${ }^{341}$

23 Jakr 1087 namammise Tunisombaya mantama ri Luwuq maqbunduq

5 Sep (S) t theeth filed of Karaeng ri Bontorambaq

26 Jakr 1087 naniariq Karaengta ri Bontorambaq

19 Sep (F eve) I Makkaraeng and I Kare Sallang, the mother of I Saqbaraq, married

10 Raj $1087^{342}$ nasikalabini I Makkaraeng I Kare Sallang anronna I Saqbaraq

338 A copyist mistakenly wrote Rabi'ul-akhir for the Hijri month.

339 La Tenribali Matinroe ri Datunna.

340 'Puanna' can be a challenging term to interpret. It means royal mother or father (or an aunt or uncle of the same generation), as in this case, but was sometimes part of a name as well, as in Puanna I Mattaq (La Padangsajati).

341 This expedition is discussed in Andaya 1981:177-9.

342 A copyist mistakenly wrote Jumadilakhir for the Hijri month. 
27 Sep $(\mathrm{N}) \quad$ the mother of Karaeng Tamalingu died

18 Raj 1087 namate anronna Karae Tamalingu

29 Sep (M eve) I Kare Tonji I Maqmiq born

20 Raj 1087 naanaq I Kare Tonji I Maqmiq

3 Oct (S) Karaeng Bontolangkasaq, who died in Salaparang [Lomboq], born 343

24 Raj 1087 naanaq Karae Bontolangkasaq matea ri Salaparang

13 Nov (R eve) I Daeng Rikong, a grandparent of I Mene, died 6 Ram 1087 namate I Daeng Rikong toana I Mene

16 Dec (R eve) Tunisombaya [Arung Palakka] arrived from Luwuq 11 Syaw 1087 nabattu ri Luwuq Tunisombaya

$27 \operatorname{Dec}(\mathrm{N}) \quad$ Daengta Daeng Jipaling and Daengta Daeng Massuro divorced

20 Syaw 1087 nasipelaq Daengta Daeng Jipaling Daengta Daeng Massuro

\section{7}

27 Jan (T eve) I Sitti, a wife of I Daeng Maqruppa, died

22 Zulk 1087 namate I Sitti bainenna I Daeng Maqruppa

13 Feb (F eve) Haji Bantaeng died

10 Zulh 1087 namate Haqji Bantaeng

11 Mar (R) Tumamenang ri Passiringanna [Abdul Kadir] and Karaeng ri Bontorambaq married

6 Muh 1088 nasikalabini Tuammenang ri Passiringanna Karaengta ri Bontorambaq

31 Mar (T eve) I Shaleh, a child of Karaeng Lambengi, died 26 Muh 1088 namate I Shaleh anaqna Karae Lambengi

3 Apr (S) Tuammenang ri Lakiung [Abdul Jalil] went down to live in Talloq

343 Dutch sources from 1698 reported that he was a son of a sister of the sultans of Gowa Muhammad Ali and Abdul Jalil (Ligtvoet 1880:143). 
29 Muh 1088 namanaung ri Talloq mammempo Tuammenang ri Lakiun

8 Apr (R)

5 Saf 1088

15 Apr (R)

11 Saf 1088

$17 \operatorname{Apr}(\mathrm{S})$

14 Saf 1088

3 May ( $\mathrm{N}$ eve)

30 Saf 1088

$22 \operatorname{May}(S)$

19 Rawl 1088

23 May $(\mathrm{N})$

20 Rawl 1088

2 Jun $(\mathrm{W})^{345}$

1 Rakr 1088

12 Jun (F eve)

11 Rakr 1088

$25 \mathrm{Jul}(\mathrm{N})$

24 Jawl 1088

$27 \mathrm{Jul}(\mathrm{T})$
Karaeng ri Palemba killed in Bontoalaq 344 nanibuno Karaengta ri Palemba ri Bontoalaq

the people of Cenrana were made vassals by the karaeng [Muhammad Ali] nanipalilikang tuCenranaya ri karaenga

Gowa was attacked by Tunisombaya [Arung Palakka] as a result of the quarrel

nanaosongi Gowa Tunisombaya sisala ribokota

Tunisombaya [Arung Palakka] wounded by a spear in the flesh of his buttock

namalokoq poke Tunisombaya rappo pajama

a child of Tumamenang ri Lakiung [Abdul Jalil] named Sitti Aminah died at 5 years of age namate anaqna Tuammenang ri Lakiun nikanaya Sitti Aminah umuruqna 5 taung

Bisei overrun and Karaeng ri Agangjeqneq killed nanibangka Bisei naniposo Karaengta ri Agangjeqneq

I Daeng Maqruppa died namate I Daeng Maqruppa

Karaeng Suriwaq died below in Agangnionjoq namate Karae Suriwaq irawa ri Agangnionjoq

I Makkaraeng was struck and died after nightfall nanitaba I Makkaraeng nabanngipa namate

Gowa conquered; Tumatea ri Jakattaraq [Muhammad

\footnotetext{
344 Also known as Karaeng Mamu, he was killed by Bugis. This was another episode in the growing conflict between Makassarese nobles and Arung Palakka in the wake of the interference with Arung Palakka's wives and concubines. See Andaya 1981:182-3.

345 A copyist mistakenly wrote Friday eve from the following entry in place of Wednesday, the correct day.
} 
Ali] expelled by the Dutch and Tumamenang ri Lakiung [Abdul Jalil] put in as Karaeng ri Gowa ${ }^{346}$

26 Jawl 1088 nabeta Gowa nanipasuluq Tumatea ri Jakattaraq ri Balandaya naTuammenang ri Lakiun nipantama Karaeng ri Gowa

7 Aug (F eve) Karaeng Lambengi brought overseas to Jakattaraq with I Daeng Mattuju and his sibling ${ }^{347}$

7 Jakr 1088 nanierang kalauq ri Jakattaraq Karae Lambengi siagaang I Daeng Mattuju sisaqribattang

11 Aug (W) Arung Maroangi and I Daeng Nisayu, mother of tumailalang Karaeng Lekoqboqdong, married

11 Jakr 1088 nasikalabini Aruq Maroangi I Daeng Nisayu ayana tumailalang Karae Lekoqboqdong

16 Aug (M) I Daeng Mamo I Nampa, a younger sibling of Karaeng ri Balloq, died

16 Jakr 1088 namate I Daeng Mamo I Nampa arinna Karaengta ri Balloq

23 Aug (N eve) I Kare Ago I Timoroq and I Daeng Nisayu Andoqpoaq married

23 Jakr 1088 nasikalabini I Kare Ago I Timoroq I Daeng Nisayu Andoqpoaq

7 Sep (M eve) sabannaraq I Daeng Makkulle died at the age of 62

9 Raj $1088 \quad$ namate sabannaraka I Daeng Makkulle umuruqna 62

22 Sep (T eve) I Ali died

23 Raj $1088 \quad$ namate I Ali

24 Sep (R eve) I Sitti, a child of Faqqia, died

25 Raj $1088 \quad$ namate I Sitti anaqna Faqqia

346 Thus a brief war ended with Abdul Jalil installed as sultan in place of his brother, with whom he had quarreled. Abdul Jalil had gone over to the side of Tunisombaya on 11 Apr 1676. The war is discussed in Andaya 1981:184-7.

347 Karaeng Lambengi was exiled for his role in the affair with Arung Palakka's women. Daeng Mattuju was the deposed ruler of Luwuq defeated by Arung Palakka the previous year and held prisoner in Fort Rotterdam by the Dutch. The sibling and fellow prisoner who accompanied Daeng Mattuju was Daeng Mattola. 
25 Oct $(\mathrm{M})$ 27 Syab 1088

$31 \operatorname{Oct}(\mathrm{N})$

4 Ram 1088

$2 \operatorname{Nov}(\mathrm{T})$

6 Ram 1088

$16 \operatorname{Nov}(\mathrm{M}$ eve $)$

20 Ram 1088

$19 \operatorname{Nov}(\mathrm{R}$ eve)

24 Ram 1088

$26 \operatorname{Nov}(F)$

1 Syaw 1088

$4 \operatorname{Dec}(S)$

9 Syaw 1088

$22 \operatorname{Dec}(\mathrm{W})$

28 Syaw 1088
Rabiah, a child of Karaeng ri Mangalliq, died namate Rabiah anaqna Karaengta ri Mangalliq

Daengta Daeng Nisayu, a grandparent of Karaeng Tanasanga, and Arung Teko married nasikalabini Daengta Daeng Nisayu toana Karae Tanasanga Aruq Teko

a child of Karaeng Junggo died

namate anaqna Karaeng Junggo

Karaeng Baroqbosoq died

namate Karae Baroqbosoq

Karaeng Tamaqdanggang and I Sitti Lambengi married nasikalabini Karae Tamaqdanggang I Siti Lambengi

the name of Tunisombaya [Arung Palakka] was praised in the sermon and he was named Saqaduddin 348 naarenna Tunisombaya nipuji ri khutbaya nikana Saaduddini

I Daeng Situju and Karaeng ri Lekoqboqdong divorced nasipelaq I Daeng Situju Karaengta ri Lekoqboqdong

I Manggaukang, a child of Tumamenang ri Taenga, died at the age of 6 years, 5 months, and 8 nights $^{349}$ namate I Manggaukang anaqna Tuammenang ri Taenga umuruqna 6 taung 5 bulan 8 banngi

1678

7 Jan $(\mathrm{F})$ 14 Zulk 1088

I Raba, a child of Karaeng Bidara, died namate I Raba anaqna Karaeng Bidara

2 Feb (W)

9 Zulh 1088
I Daeng Talebang and I Daeng Manjarreki married nasikalabini I Daeng Talebang I Daeng Manjarreki

348 Thus Arung Palakka began to be honored instead of the ruler of Gowa, who traditionally had been praised in the Friday sermon.

349 This careful reckoning from I Manggaukang's birth on 21 Sep 1671 indicates that the annalist primarily used the Hijri calendar, for 28 Syaw 1088 is 6 years, 5 months, and 8 days from 21 Jawl 1082. 
$5 \mathrm{Feb}(\mathrm{S})$

12 Zulh 1088

6 Feb (S eve)

13 Zulh 1088

8 Feb (T)

15 Zulh 1088

10 Feb (R)

17 Zulh 1088

$20 \mathrm{Feb}(\mathrm{N})$

27 Zulh 1088

$2 \operatorname{Mar}(\mathrm{W})$

7 Muh 1089

$20 \operatorname{Mar}(\mathrm{N})$

25 Muh 1089

$25 \operatorname{Mar}(\mathrm{F})$

1 Saf 1089

4 Apr (M)

11 Saf 1089

$4 \operatorname{Apr}(\mathrm{M})$

11 Saf 1089

8 Apr (R eve)

15 Saf 1089

$18 \operatorname{Apr}(\mathrm{M})$

25 Saf 1089 a child of Karaeng ri Mandalleq I Daeng Sisila died namate anaqna Karaengta ri Mandalleq I Daeng Sisila

a child of Arung Teko named I Tanisunggu died namate anaqna Aruq Teko nikanaya I Tanisunggu

Arung Teko and Karaeng ri Langeloq returned to each other and [Arung Teko] divorced Daengta Daeng Nisayu nasipolei Aruq Teko Karaengta ri Langeloq nanapelaq Daengta Daeng Nisayu

I Makkaruru, a child of Arung Teko, died namate I Makkaruru anaqna Aruq Teko

I Manappakki, a child of Karaeng Banyuanyaraq, died namate I Manappakki anaqna Karae Banyuanyaraq

I Tuang Rappang arrived; Abdul Bashir [as he was also known] first arrived from Banten

nabattu I Tuan Rappan uru battuna ri Bantan Abdulbashir

Arung Teko and Karaeng ri Langeloq divorced

nasipelaq Aruq Teko Karaengta ri Langeloq

I Toaq Daeng died

namate I Toaq Daeng

Gallarrang Mangasa I Kare Ruppa died

namate Gallarrang Mangasa I Kare Ruppa

I Daeng Maingaq, a grandparent of I Sarah, died in Agangnionjoq

namate I Daeng Maingaq toana I Sarah ri Agangnionjoq

I Sitti, a wife of I Daeng Manyampaq Sengoroq, died namate I Sitti bainenna I Daeng Manyampaq Sengoroq

the mother of tumailalang [Karaeng] Lekoqboqdong had a son by Arung Maroangi; Arung Teko and I Daeng Nisayu returned to each other namamanaq ayana tumailalang Lekoqboqdong ri Arung Maroangi buraqne nasipolei Aruq Teko I Daeng Nisayu 
22 Apr (R eve) Daengta Daeng Takontu had a daughter by Karaeng Barrung named Hadijah

29 Saf 1089 namamanaq Daengta Daeng Takontu ri Karae Barrung baine nikana Hadijah

$26 \operatorname{Apr}(\mathrm{N}) \quad$ I Mamminawang circumcised by his grandparent

2 Rawl 1089 nanisunnaq I Mamminawang ri toana

6 May (F) the mother of tumailalang Karaeng Lekoqboqdong died; she was buried in Talloq; 18 nights after giving birth she died

13 Rawl 1089 namate ayana tumailalang Karae Lekoqboqdong ri Talloki niawang 18 bannginna leqbaq mamanaq namate

17 May (N eve) I Callaq, a child of Arung Maroangi, died and was buried in Talloq

24 Rawl 1089 namate I Callaq anaqna Aruq Maroangi ri Talloki niawang

5 Aug ( $\mathrm{R}$ eve) it is said that Matinroa ri Bukaka [La Maqdaremmeng] died

16 Jakr 1089 nanikana matei Matinroa ri Bukaka

9 Aug (M eve) I Loqmoq, the mother of Karaeng ri Patukangang, and Tumamenang ri Lakiung [Abdul Jalil], divorced

29 Jakr 1089350 nasipelaq I Loqmoq anronna Karaengta ri Patukangan Tuammenang ri Lakiun

19 Aug (F) a child of Karaeng Pamolikang died

30 Jakr 1089 namate anaqna Karae Pamolikang

8 Sep (R) Daengta Daeng Massuro and I Daeng Maingaq married 20 Raj 1089 nasikalabini Daengta Daeng Massuro I Daeng Maingaq

16 Sep (F) Tumatea ri Jakattaraq [Muhammad Ali] was brought overseas to Jakattaraq; 411 Makassarese traveled with him

28 Raj 1089 nanierang kalauq ri Jakattaraq Tumatea ri Jakattaraq Mankasaraq naagaang sidongkokang 411 
7 Oct (R eve) Tunisombaya [Arung Palakka] sailed overseas to Jakattaraq

20 Syab 1089 nasimombalaq Tunisombaya kalauq ri Jakattaraq

28 Oct (F) the people of Kampong Beru went up to Sanrabone requesting Sudanga from Tumamenang ri Lakiung [Abdul Jalil] 351

12 Ram 1089 namanaiq ri Sanrabone tuKampong Berua ampalaki Sudanga ri Tuammenang ri Lakiun

$7 \mathrm{Nov}(\mathrm{T})$

22 Ram 1089

the ship carrying Karaeng ri Popoq sailed over to Bima nasimombalaq kappalaq nadongkokia Karaengta ri Popoq taqle ri Dima

24 Dec (F eve) I Daeng Masseqre I Jaga and I Daeng Tuna I Salamah married

10 Zulk 1089 nasikalabini I Daeng Masseqre I Jaga I Daeng Tuna I Salamah

29 Jan (S eve) I Daeng Mamuntuli Arung Kaju Ahmad born 352

16 Zulh 1089 naanaq I Daeng Mammuntuli Aruq Kayu Ahmad

7 Feb (M eve) I Daeng Sisala, a child of Karaeng ri Mandalleq, died in Malakaya ${ }^{353}$

25 Zulh 1089 namate anaqna Karaengta ri Mandalleq I Daeng Sisala ri Malakaya

$12 \mathrm{Feb}(\mathrm{N}) \quad$ Karaeng ri Beroanging and I Daeng Tamemang I

Maqminasa divorced

351 One of Gowa's most sacred kalompoang (regalia) was a sword named Sudanga. According to the Gowa Chronicle it was brought to Gowa by Lakipadada, brother of Karaeng Bayo who married the tumanurung ('the person who descended', this was a heavenly ancestor of pure white blood). Their offspring established the ruling line of Gowa, and Sudanga was kept in trust by Gowa's karaeng. During this period Abdul Jalil had little support among Makassarese because of his alliance with Arung Palakka; many remained loyal to Abdul Jalil's deposed brother Muhammad Ali. The 'people of Kampong Beru' refers to Muhammad Ali and his allies living in exile in this new community next to Fort Rotterdam. They sent a letter to Abdul Jalil offering to let him live in peace if he would surrender Sudanga to them. This would have amounted to abdicating as ruler in the eyes of Makassarese. ANRI 16/6 notes Abdul Jalil's refusal, adding that 'it was not given by the karaeng [Abdul Jalil]' (natanisareanga ri karaenga). See Andaya 1981:198-201.

352 A son of Arung Teko and I Daeng Tonji I Saenaq, a daughter of Arung Kaju (Ligtvoet 1880:146).

353 Presumably this is a community in Makassar, but could conceivably refer to Malaka. 
30 Zulh 1089 nasipelaq Karaengta ri Beroangi I Daeng Tamemang I Maqminasa

19 Feb (S eve) Daengta Daeng Mangemba and I Daeng Anrenne, a grandparent of Karaeng Bontolangkasaq, married

7 Muh 1090 nasikalabini Daengta Daeng Mangemba I Daeng Anrenne toana Kara Bontolangkasaq

18 May (R) Karaeng ri Bontomanompoq and Daengta Daeng Masiang divorced

7 Rakr $1090 \quad$ nasipelaq Karaengta ri Bontomanompoq Daengta Daeng Masiang

24 May (S eve) a wife of Karaeng ri Balloq had a son [named] I Daeng Mabela I Mangassengi

17 Rakr 1090 namamanaq bainenna Karaengta ri Balloq buraqne I Daeng Mabela I Mangasengi

4 Jun (S eve) I Matti and I Daeng Maliq divorced

24 Rakr 1090 nasipelaq I Matti I Daeng Maliq

$15 \mathrm{Jul}$ (F eve) I Maqminasa died giving birth ${ }^{354}$

6 Jakr $1090 \quad$ namate mamanaq I Maqminasa

16 Jul (N) Daengta Daeng Singaraq, an older sibling of Karaeng ri Bontokamase, had a child, a son

7 Jakr 1090 namamanaq Daengta Daeng Singaraq kakanna Karaengta ri Bontokamase buraqne anaqna

2 Aug (W) the day of Karaeng ri Ujung's death above in Kalakongkong

24 Jakr $1090 \quad$ allo nakamateanga Karaengta ri Ujung irate ri Kalakongkong

26 Aug (F eve) I Daeng Tummamo Abdul Jalil born 18 Raj 1090 naanaq I Daeng Tummamo Abdul Jalili

5 Sep (M eve) Daengta Daeng Massuro had a daughter by Daeng Maingaq named Latifah 
28 Raj 1090 namamanaq Daengta Daeng Massuro ri Daeng Maingaq baine nikana Latifah

$26 \operatorname{Sep}(\mathrm{T})$

20 Syab 1090

15 Oct (S eve) I Daeng Mabela I Gacung born; born overseas in Keper [East Java]

9 Ram 1090

21 Oct (S)

15 Ram 1090

$14 \operatorname{Nov}(\mathrm{T})$

10 Syaw 1090

22 Nov (T eve)

18 Syaw 1090

26 Nov (S eve) 22 Syaw 1090

24 Dec (S eve)

20 Zulk 1090

$18 \mathrm{Feb}(\mathrm{N})$

a grandparent of I Sallang named Pirannuang died namate toana I Sallang Pirannuang nikana

naanaq I Daeng Mabela I Gacung ilauka ri Kapparaq anaq

Keper conquered by Tunisombaya [Arung Palakka] ${ }^{355}$ nanibeta Kapparaq ri Tunisombaya

Daengta Daeng Singaraq and Karaeng Bontokeke married $^{356}$

nasikalabini Daengta Daeng Singaraq Karae Bontokeke

Karaeng Galesong died overseas in Banten

namate Karae Galesong ilauq ri Bantan

Karaeng ri Mandalleq 357 and Daengta I Kare Pate married nasikalabini Karaengta ri Mandalleq Daengta I Kare Pate

I Daeng Iji I Siqra and sabannaraq I Daeng Makkulle 358 married

nasikalabini I Daeng Iji I Siqra I Daeng Makkulle sabannaraka

1680

a wife of Daengta Daeng Manina died

355 Keper was the site of a Makassarese stronghold in eastern Java and an important battleground in the VOC-Amangkurat II alliance against Trunajaya. Makassarese who fled Sulawesi after the Makassar War were an important part of Trunajaya's army. With the assistance of Arung Palakka the Makassarese were defeated at Keper. See Andaya (1981:213-23) and Ricklefs (2001:95-9) for discussions of this conflict. ANRI 16/6 adds 'opposing [them] all the way to Maros' (mabali anggena ri Marusuq), but this is most likely a mistake and probably refers to Madura rather than Maros, for Arung Palakka did continue to pursue the Makassarese and their Madurese allies after the fall of Keper.

356 They had married previously and then divorced on 12 Mar 1676.

357 We cannot be certain which Karaeng Mandalleq this refers to, most likely it is Tulolo Tajuddin.

358 Presumably the son and successor to the sabannaraq I Daeng Makkulle who died on 7 Sep 1677. 
17 Muh 1091 namate bainenna Daengta Daeng Manina

27 Feb (M eve) a child of Karaeng ri Bontomanompoq named I Okong died

26 Muh 1091 namate anaqna Karaengta ri Bontomanompoq nikanaya I Okong

4 Mar $(\mathrm{N}) \quad$ I Mamo ${ }^{359}$ divorced by Karaeng ri Jarannika

2 Saf 1091 nanipelaq I Mamo ri Karaengta ri Jarannika

7 Mar (W eve) the night of Karaeng ri Popoq's death across in Bima at the age of 67360

5 Saf 1091 banngi nakamateanga Karaengta ri Popoq ibaqle ri Dima umuruqna 67

12 Mar (T) Tunisombaya [Arung Palakka] arrived from Keper and its conquest; this the day of I Shaykh's birth; 13 nights after [the conquest] he arrived

10 Saf 1091 nabattu ri Kapparaq Tunisombaya nabetana iaminne kaanakkanna I Syeh 13 bannginna battu

18 Mar (N eve) Karaeng ri Balloq died in Kampong Beru but was buried in Gowa at the age of 36

16 Saf 1091 namate Karaengta ri Balloq ri Kampong Beru ri Gowaji niawang umuruqna 36

23 Apr (M eve) Daengta Daeng Sangging I Sarah, a child of Tumamenang ri Taenga, died

23 Rawl 1091 namate Daengta Daeng Sangging I Sarah anaqna Tuammenang ri Taenga

23 May (W eve) a wife of Karaeng ri Rappociniq had a son who was taken and adopted by Tumamenang ri Lakiung [Abdul Jalil]

24 Rakr 1091 namamanaq bainenna Karaengta ri Rappociniq buraqne nanialle nikatuo ri Tuammenang ri Lakiun

15 Jun (F eve) three were seen shining

359 Presumably the same woman who had previously divorced from both Karaeng ri Mangalliq (17 Jan 1673) and Karaeng Boroqbosoq (21 Jan 1675).

360 Ligtvoet (1880:148) surmised that is probably he who Makassarese called Karaeng Matea ri Bima. 
18 Jawl $1091^{361}$ naniciniq tallu baribaria

27 Jun (W eve) Karaeng ri Panaikangciniq ${ }^{362}$ died across in Bima 30 Jawl 1091 namate Karaengta ri Panaikangciniq ibaqle ri Dima

13 Jul $(\mathrm{W})^{363}$ in Ujung Tana a house was built for the karaeng [Abdul Jalil] which he then occupied

16 Jakr 1091 nanibangun ri Ujungtana ballaqna karaenga lanaempoinna

23 Jul (M eve) Karaeng Bungaya I Daeng Mattalliq Jusuf born 26 Jakr 1091 naanaq Karae Bungaya I Daeng Mattalliq Jusupu

$6 \operatorname{Aug}(\mathrm{T})$

10 Raj 1091

$8 \operatorname{Aug}(\mathrm{R})$

12 Raj 1091

$13 \operatorname{Aug}(\mathrm{T})$

17 Raj 1091

$15 \operatorname{Aug}(\mathrm{R})$
Sitti Maryam had a daughter

namamanaq Sitti Maryam baine

I Kare Pate I Sarampa ${ }^{364}$ married by Karaeng ri

Rappociniq 365

nanibaineang I Kare Pate I Sarampa ri Karaengta ri Rappociniq

Tumamenang ri Passiringanna [Abdul Kadir] and

Karaeng ri Bontorambaq divorced

nasipelaq Tuammenang ri Passiringanna Karaengta ri

Bontorambaq

Karaeng ri Langeloq and the ruler of Agangnionjoq ${ }^{366}$ married

361 Bariq-bariq refers to something stripped, spotted, or flaming. Kamaruddin et al. (1985:162) interpreted this as referring to objects twinkling in the sky, particularly Venus. More explicitly, the entry in Makasaarsche historiën (1855:126) describes how three morningstars were seen instead of the usual one (Venus).

362 Speelman reported that she was a sister of the mother of the ruler of Bima I Ambela Sirajuddin and a great aunt of Hasanuddin (Ligtvoet 1880:footnote 148). She first married a noble from Luwuq, and then the ruler of Bulo-Bulo. Her daughter had a son named Ibrahim.

363 A copyist mistakenly wrote the $3 \mathrm{rd}$ instead of the 13 th.

364 One of Arung Palakka's former wives.

365 Dutch sources report that he accompanied Karaeng Galesong to Java and fought with Trunajaya against Mataram and the VOC. But according to Speelman he was actually a Boné noble named Mappa Arung Tonra loyal to Gowa (Ligtvoet 1880:148-9).

366 Mappajanji Daeng Mattajang Matinroe ri Sumpampoba. He was also known as Kasim and Puanna I Tikkaq. Dutch sources report that he replaced his half-brother as regent of Segeri on the recommendation of Arung Palakka. He had previously been married to a sister of Arung Palakka, with whom he had a child named Arung Patiro before they divorced (Ligtvoet 1880:149, 210). 
19 Raj 1091 nasikalabini Karaengta ri Langeloq Karae Agangnionjoq

26 Aug (T) Daengta Daeng Massuro and I Daeng Maingaq divorced 1 Syab 1091 nasipelaq Daengta Daeng Massuro I Daeng Maingaq

6 Sep (R eve) the child of Karaeng ri Rappociniq who was adopted by Tumamenang ri Lakiung [Abdul Jalil] died

12 Syab 1091 namate anaqna Karaengta ri Rappociniq nakatuoa Tuammenang ri Lakiun

19 Oct (F eve) I Daeng Buraqne I Siang 367 died

25 Ram 1091 namate I Daeng Buraqne I Siang

29 Oct (F eve) I Daeng ri Samata died

3 Syaw 1091 namate I Daeng ri Samata

31 Oct $(\mathrm{W}) \quad$ Arung Teko and Daengta Daeng Nisayu divorced

7 Syaw 1091 nasipelaq Aruq Teko Daengta Daeng Nisayu

4 Nov (M) Tunisombaya [Arung Palakka] went down to Maros to dig irrigation works

12 Syaw 1091 namanaung ri Marusuq Tunisombaya makkekkeseq jeqneq panaiq

3 Dec (T) Karaeng Bidara died and was buried in Talloq

11 Zulk 1091 namate Karaeng Bidara ri Talloki niawang

29 Dec (S eve) Karaeng ri Bontomanompoq and I Daeng Marannu, a child of I Pakkemba, divorced

8 Zulh 1091 nasipelaq Karaengta ri Bontomanompoq I Daeng Marannu anaqna I Pakkemba

1681

1 Jan (W) Daengta Daeng Singaraq and Karaeng Bontokeke divorced, but returned to each other later

11 Zulh 1091 nasipelaq Daengta Daeng Singaraq Karae Bontokeke sipoleiji salla 
$9 \operatorname{Jan}(R)^{368}$

19 Zulh 1091

12 Jan (S eve)

22 Zulh 1091

14 Jan (T)

24 Zulh 1091

10 Feb ( $\mathrm{N}$ eve)

21 Muh 1092

11 Feb (T)

22 Muh 1092

13 Feb (W eve)

24 Muh 1092

9 Mar (S eve)

18 Saf 1092

$11 \operatorname{Mar}(\mathrm{T})$

25 Saf 1092

Tunisombaya [Arung Palakka] sailed down to Galinggang [Sawitto] ${ }^{369}$

$$
\text { namammise Tunisombaya manaung ri Galinggang }
$$

a comet was seen

naniaq niciniq bintoeng makkidong

Galinggang overrun

nanibangkamo Galinggang

Arung Tanete Malolo and I Daeng Memang married nasikalabini Aruq Tanete Malolo I Daeng Memang

the day Addatuang Matinroe ri Salemo ${ }^{370}$ was killed allo nibunona Aqdatuan Matinroa ri Salemo

Arung Teko and Karaeng ri Pasiq married nasikalabini Aruq Teko Karaengta ri Pasiq

I Isa had a son at the stroke of 1 namamanaq I Isa buraqne 1 garigantaya

I Daeng Singaraq had a son named I Baraq Karaeng Bontopattongkoq ${ }^{371}$

namamanaq I Daeng Singaraq buraqne nikana I Baraq Karae Bontopattongko

15 Mar (F eve) the night of Tumatea ri Jakattaraq's [Muhammad Ali's] death $^{372}$

29 Saf 1092

banngi nakamateanga Tumatea ri Jakattaraq

$24 \operatorname{Mar}(\mathrm{M})$

I Boe died and was buried in Karuwisi

3 Rawl 1092 namate I Boe ri Karuwisi niawang

\footnotetext{
368 A copyist mistakenly wrote the 19th instead of the 9th, though ANRI 16/6 gives the 7th.

369 This expedition was launched against Arung Bakke, a former close companion and ally of Arung Palakka who had now become a rival. Arung Bakke dominated the lands around Ajattappareng, but quickly was defeated and after a short flight to Mandar killed on February 11th and his head presented to Arung Palakka. This affair is discussed in Andaya 1981:228-42.

370 Arung Bakke. He was killed on Salemo, an island across from Segeri.

371 His father was Karaeng Bontokeke.

372 ANRI 16/6 adds 'at the age of $28^{\prime}$ (umuruqna 28). Or 272 Y first calls him by the title 'Tumamenanga ri Carabo.'
} 
26 Mar (W) I Kare Pate I Sarampa had a daughter by Karaeng ri Rappociniq named Hadijah

5 Rawl 1092 namamanaq I Kare Pate I Sarampa ri Karaengta ri Rappociniq baine nikana Hadijah

13 Apr $(\mathrm{N})$

23 Rawl 1092

I Kare Pate I Sarampa divorced by Karaeng ri Rappociniq nanipelaq I Kare Pate I Sarampa ri Karaengta ri Rappociniq

27 Jun (R eve) Karaeng ri Bontokamase and Daengta Daeng Jipaling married

10 Jakr 1092 nasikalabini Karaengta ri Bontokamase Daengta Daeng Jipaling

$11 \mathrm{Jul}(\mathrm{R}$ eve) Tanipaccoq died

24 Jakr 1092 namate Tanipaccoq

13 Jul (S eve) Karaeng Tamalingu died and was buried in Talloq

26 Jakr 1092 namate Karaeng Tamalingu ri Talloki niawang

$8 \operatorname{Aug}(\mathrm{F})$

23 Raj 1092

Karaeng ri Mandalleq ${ }^{373}$ departed from Makassar; no one knew of his journey

namaqlampa ri Mankasaraq Karaengta ri Mandalleq taniassengai lampana

22 Oct (M) I Guru Kare Panaiq died

20 Syaw $1092^{374}$ namate I Guru Kare Panaiq

23 Nov (N) Karaeng ri Pangkajeqneq circumcised

12 Zulk 1092 nanisunnaq Karaengta ri Pangkajeqneq

28 Nov (R eve) ${ }^{375}$ Karaeng Bontotannga and I Daeng Rikong divorced 17 Zulk 1092 nasipelaq Karae Bontotannga I Daeng Rikong

5 Dec (R eve) Karaeng Lauq ${ }^{376}$ and Daengta Daeng Takontu married 24 Zulk 1092 nasikalabini Karae Lauq Daengta Daeng Takontu

\footnotetext{
373 Again, presumably this refers to Tulolo Tajuddin, and not his younger brother Daeng Sisila Ibrahim who later bore the same title.

374 The Hijri date converts to 1 Nov 1681.

375 A copyist mistakenly wrote December for November.

376 This was the title of an important Sanrabone noble (Ligtvoet 1880:151).
} 
26 Dec (F) Karaeng Bontokeke and Daengta Daeng Singaraq divorced, but returned to each other later [for the second time]

15 Zulh 1092 nasipelaq Karae Bontokeke I Daeng Singaraq sipoleiji salla

$27 \mathrm{Dec}\left(\mathrm{F}\right.$ eve) the interpreter I Jan Jappon died ${ }^{377}$

16 Zulh 1092 namate jurubasaya I Yanjappong

\section{2}

7 Jan $(\mathrm{W})$

Karaeng ri Pasiq had a daughter by Arung Teko named Aminah

27 Zulh 1092 namamanaq Karaengta ri Pasiq ri Aruq Teko baine nikana Aminah

9 Jan $(\mathrm{F})$

I Daeng Maingaq and I Mappabangka divorced

29 Zulh 1092 nasipelaq I Daeng Maingaq I Mappabangka

2 Feb (N eve) Daengta Daeng Singaraq and Karaeng Bontokeke returned to each other

23 Muh 1093 nasipolei Daengta Daeng Singaraq Karae Bontokeke

3 Feb (T) I Mappabangka and I Sitti divorced

24 Muh 1093 nasipelaq I Mappabangka I Sitti

19 Feb (W eve) I Daeng Manyampakki I Mamminawang I Pakki born 10 Saf 1093 naanaq I Daeng Manyampakki I Mamminawang I Pakki

$21 \mathrm{Feb}$ (F eve) Karaeng ri Langeloq and the ruler of Agangnionjoq divorced

12 Saf 1093 nasipelaq Karaengta ri Langeloq Karae Agangnionjoq

$13 \operatorname{Mar}(\mathrm{F}) \quad$ I Daeng Iji I Siqra, a wife of sabannaraq Daeng Makkulle, had a child; Daengta [?] proposed to by Daeng Mangitung 3 Rawl 1093 namamanaq I Daeng Iji I Siqra bainenna Daeng Makkulle sabannaraka nanipassuroi Daengta ri Daeng Mangitung

$19 \operatorname{Mar}(\mathrm{R}) \quad$ ears pierced of Daengta Daeng Mami

9 Rawl 1093 nanitinting Daengta Daeng Mami

377 He was an interpreter for the VOC. Speelman refers to him as Jan Jappan and notes that he spoke good Malay and the language of Ternate well, but not a word of the local languages of South Sulawesi. 
20 Mar (R eve) Karaeng ri Mangalliq and Daengta Daeng Majannang married

10 Rawl 1093 nasikalabini Karaengta ri Mangalliq Daengta Daeng Majannang

24 Mar (M eve) Daengta Daeng Singaraq had a daughter named I Takkikkiq

14 Rawl 1093 namamanaq Daengta Daeng Singaraq baine nikana I Takkikkiq

$29 \operatorname{Mar}(\mathrm{N}) \quad$ the coffin of Tumatea ri Jakattaraq was brought back 19 Rawl 1093 nabattu nierang allunna Tumatea ri Jakattaraq

11 May (M) I Daeng Maliq and I Sitti divorced 3 Jawl 1093 nasipelaq I Daeng Maliq I Sitti

27 May (W) Karaeng ri Bontorambaq and Karaeng Barrung married 19 Jawl 1093 nasikalabini Karaengta ri Bontorambaq Karae Barrung

$22 \mathrm{Jul}(\mathrm{W}) \quad$ the day of the elder ruler of Bima's death ${ }^{378}$

17 Raj 1093 allo nakamateanga karaenga ri Dima matoaya

27 Jul (N eve) Daengta Daeng Jipaling had a daughter named Shafiah

22 Raj 1093 namamanaq Daengta Daeng Jipaling baine nikana Shafiah

6 Aug (R) the people going into Lettaq to make war departed; after 36 nights journey they arrived 379

2 Syab 1093 namaqlampa tumantamaya ri Littaq maqbunduq 30 banngi angannang lampana nabattu

28 Sep (N eve) I Ali and I Sitti married

25 Ram 1093 nasikalabini I Ali I Sitti

$13 \operatorname{Dec}(\mathrm{R}) \quad$ a child of the younger Arung Tanete and a niece [or nephew] of the elder Arung Tanete married

1 Muh $1094^{380}$ nasikalabini anaqna Aruq Tanete malolo kamanakanna

378 Sultan Abil Khair, also known as I Ambela and Sirajuddin.

379 This refers to an expedition sent to punish the ruler of Lettaq, who eighteen months beforehand aided Arung Bakke in his flight from Arung Palakka's men.

380 The Hijri date converts to 30 Dec 1682. 
Aruq Tanete matoa

1683

6 Jan (W) Daengta Daeng Takontu had a daughter by Karaeng Lauq named Aisyah

7 Muh 1094 namamanaq Daengta Daeng Takontu ri Karae Lauq baine nikana Aisyah

10 Jan (N) I Daeng Manaqgalaq died

11 Muh 1094 namate I Daeng Manaqgalaq

11 Feb (R) Sayyid ${ }^{381}$ Biringkassiq and Sayyid Husain arrive

14 Saf 1094 nabattu Sayyid Biringkassiq Sayyid Husain

$14 \operatorname{Mar}(\mathrm{N}) \quad$ teeth filed of Karaeng ri Parang-Parang; Karaeng ri Bontorambaq had a son named I Mattuppuang Abdul Wahab

15 Rawl 1094 naniariq Karaengta ri Parang-Parang namamanaq Karaengta ri Bontorambaq buraqne nikana I Mattuppuang Abdul Wahhab

20 Mar $(S)^{382} \quad$ Karaeng [Bontokeke and Daengta] Daeng Singaraq had a son named Abdul Karim Karaeng Batupute

21 Rawl 1094 namamanaq Karaengta Daeng Singaraq buraqne nikana Abdul Karim Karae Batuputeh

31 Apr (T eve) Daengta Daeng Massuro and I Mami divorced

1 Rakr $1094^{383}$ nasipelaq Daengta Daeng Massuro I Mami

5 May (N eve) I Mamminawang and I Paleng married

7 Jawl $1094 \quad$ nasikalabini I Mamminawang I Paleng

7 May (R eve) Anciq Ajang and Daengta Daeng Massuro married

9 Jawl $1094 \quad$ nasikalabini Anciq Ajang Daengta Daeng Massuro

27 May (R) Karaeng ri Langeloq and Addatuang ri Sawitto Arung Kaballangang ${ }^{384}$ married

381 Sayyid is an honorific borne by male descendants the Prophet Muhammad.

382 A copyist mistakenly wrote the 2 nd instead of the 20th.

383 The Hijri date converts to 30 Mar 1683.

384 Ligtvoet (1880:153) believed this was the man referred to in Dutch sources from the period as Totanre. 
30 Jawl 1094

nasikalabini Karaengta ri Langeloq Aqdatuanga ri Sawitto Aruq Kaballangang

13 Jun (F eve) I Loqmoq, the mother of Karaeng Panaikang, died ${ }^{385}$

22 Jakr 1094 namate I Loqmoq anronna Karae Panaikang

$27 \operatorname{Jun}(\mathrm{N})$

Arung Balusu and I Mami married

2 Raj 1094 nasikalabini Aruq Bilusu I Mami

16 Jul (R eve) Karaeng ri Lekoqboqdong and I Mutti married

21 Raj 1094 nasikalabini Karaengta ri Lekoqboqdong I Mutti

$24 \mathrm{Jul}(\mathrm{S})$

29 Raj 1094

darkness fell at the stroke of $8^{386}$

napattang mattunruq ri 8 garigantaya

12 Aug (T eve) I Daeng Manaqgalaq I Jamali and I Daeng Maeja married 18 Syab 1094 nasikalabini I Daeng Manaqgalaq I Jamali I Daeng Maeja

21 Aug (R eve) Daengta Daeng Mami and Karaeng Bontomanaiq ${ }^{387}$ married

26 Syab 1094 nasikalabini Daengta Daeng Mami Karae Bontomanaiq

28 Aug (S eve) Arung Teko and Karaeng ri Pasiq divorced

28 Syab 1094 nasipelaq Aruq Teko Karaengta ri Pasiq

4 Sep (S) the karaeng [Abdul Jalil] went to go into Sangallaq [in Toraja] to make war; after 40 nights journey he arrived ${ }^{388}$

12 Ram 1094 namaqlampa karaenga mantama ri Sangallaq maqbunduq 40 banngi lampana nabattu

18 Nov (W eve) Daengta I Kare Pate had a daughter by sabannaraq Daeng Makkulle

28 Zulk 1094 namamanaq Daengta I Kare Pate ri Daeng Makkulle sabannaraka baine

385 I Loqmoq was also known as Daeng Niaq. Karaeng Panaikang's father was Tumammaliang ri Talloq. Speelman reported that she also married Arung Atakka La Tomparima, also known as Arung Pattojo (Ligtvoet 1880:153).

386 An eclipse.

387 Dutch sources report that he was a son of Karunrung (Ligtvoet 1880:153).

388 This refers to an expedition by Arung Palakka to extend his mastery over the only part of South Sulawesi that lay outside his influence. The ruler of Gowa and other nobles accompanied him on this campaign. See Andaya 1981:257-62. 
26 Dec (S eve) Daengta Daeng Takontu had a child named I Makkaraeng Karaeng Manjalling

7 Muh 1095 namamanaq Daengta Daeng Takontu nikana I Makkaraeng Karae Manjalling

\section{4}

11 Jan (M eve) General Speelman who conquered Somba Opu died 23 Muh 1095 namate Jinrala Ispilman ambetayai Sombopu

21 Jan (R eve) Karaeng Jonggoa died

3 Saf 1095 namate Karae Jonggoa

5 Feb (F eve) I Syoga had a son

18 Saf 1095 namamanaq I Syoga buraqne

9 Mar (R) I Mappajanji, a child of Karaeng Mawajang, circumcised 22 Rawl 1095 nanisunnaq I Mappajanji anaqna Karae Mawajang

15 Mar (W) I Daeng Mamangung I Karisaq circumcised

28 Rawl 1095 nanisunnaq I Daeng Mamangun I Karisaq

22 Mar (W) a ship arrived bringing a companion of I Tuang [Shaykh Yusuf] overseas from Cirebon ${ }^{389}$

5 Rakr 1095 nabattu kappalaq angerangi aganna I Tuang ilauq ri Carabong

5 Apr (W) I Sitti, a wife of I Mangambari, had a daughter

19 Rakr 1095 namamanaq I Siti bainenna I Mangambari baine

10 Apr (N eve) Daengta Daeng Mami and Karaeng Bontomanaiq divorced first and then Karaeng ri Langeloq and Addatuanga ri Sawitto [Arung Kaballangang] divorced

24 Rakr 1095 nasipelaq Daengta Daeng Mami Karae Bontomanaiq rioloa nasipelaq Karaengta ri Langeloq Aqdatuanga ri Sawitto

21 Apr (F) I Tuang ri Dima Shaykh Umar Bamahsuna Rahmatullah first set foot in Makassar

6 Jawl 1095 nauru naonjoq Mankasaraq I Tuan ri Dima Syeku Umar Bamahsuna Rahmatullah 
1 May (T) Karaeng Tumamenang ri Lakiung [Abdul Jalil] and Karaeng Tumamenang ri Ujung Tana [Karunrung] quarreled

16 Jawl 1095 nasisala-sala Karaenga Tuammenang ri Lakiun Karaengta Tuammenang ri Juntana

7 May (N) Daengta Daeng Tamemang and the ruler of Bima I Alasaq [Karaeng] Panaragang 390 married

22 Jawl 1095 nasikalabini Daengta Daeng Tamemang karaenga ri Dima I Alasaq Panaragang

23 May (T) Tumamenang ri Passiringanna [Abdul Kadir] and Karaeng ri Buluq-Buluq married

8 Jawl 1095 nasikalabini Tuammenang ri Passiringanna Karaengta ri Bulu-Bulu

22 Jun (R)

I Daeng ri Karuwisi died

9 Raj 1095 namate I Daeng ri Kariwisi

29 Jun (R) Karaeng ri Tanisanga ${ }^{391}$ and the ruler of Sumbawa Datu Lokaq ${ }^{392}$ married

16 Raj 1095 nasikalabini Karaengta ri Tanisanga karae Sambawa Datu Lokaq

15 Jul (F eve) Daengta Daeng Mami and Karaeng Bontomanaiq divorced

2 Syab $1095^{393}$ nasipelaq Daengta Daeng Mami Karae Bontomanaiq

$10 \mathrm{Jul}(\mathrm{M}) \quad$ Heer Kopas took his post

27 Raj 1095 namammempo jagana Her Kopas

9 Aug (T eve) I Mangalle, a child of Karaeng ri Rappociniq by Kare Sali, born

27 Syab 1095 naanaq I Mangalle anaqna Karaengta ri Rappociniq ri Kare Sali

\footnotetext{
390 He was also known as Mapparabung Nuruddin Abu Bakar Ali Syah Daeng Mattalliq.

391 Dutch sources report that she was a daughter of Harrunarasyid by Karaeng Bontomateqne, a daughter of the ruler of Bima I Ambela, and was also known as Halimah (Ligtvoet 1880:154-5). 392 Also known as Mas Banten, he ruled Sumbawa from 1676 to 1701.

393 This and the following entry are in reverse chronological order, presumably because of a copyist error.
} 
9 Aug (T eve) Karaeng Balaqsari Zainab ${ }^{394}$ born

27 Syab 1095 naanaq Karae Balaqsari Zainab

7 Sep (F) Karaeng Mateqne died

27 Ram 1095 namate Karae Mateqne

14 Sep (W eve) I Daeng Marannu395, a child of I Pakkemba, married by Tunisombaya [Arung Palakka]

4 Syaw 1095 nanibaineang I Daeng Marannu anaqna I Pakkemba ri Tunisombaya

27 Sep (W) a house for Karaeng Tumamenang ri Lakiung [Abdul Jalil] was built in Mangallekana and then occupied by him $^{396}$

17 Syaw 1095 nanibangun ballaqna Karaenga Tuammenang ri Lakiun ri Mangallekana lanaempoinna

21 Oct (F eve) Arung Belo ${ }^{397}$ and Daengta Daeng Mami married 16 Zulk 1095 nasikalabini Aruq Belo Daengta Daeng Mami

17 Nov (F) Friday public prayers first established in Mangallekana as it is first occupied [by Abdul Jalil]

9 Zulh 1095 nauru mammenteng jumaka ri Mangallekana uru niempoinna

18 Nov (S) Karaeng ri Buluq-Buluq and Karaeng Tumamenang ri Passiringanna [Abdul Kadir] divorced; [they were married] only 7 months then divorced

10 Zulh 1095 nasipelaq Karaengta ri Buluq-Buluq Karaenga

Tuammenang ri Passiringanna 7 bulanji nasipelaq

394 A daughter of Arung Teko by Daeng Nisayu, sister of Arung Kaju, and future wife of Sirajuddin.

395 Dutch sources report that by 1692 she had become ruler of Laikang (Ligtvoet 1880:155).

396 Mangallekana is located south of Fort Rotterdam. Dutch sources report that he desired this new residence because too many Bugis were living close to Fort Rotterdam and Abdul Jalil's residence, with the result that there were too many fires in this densely populated area as well as too many quarrels between Bugis and Makassarese (Ligtvoet 1880:155). A mosque was built in Mangallekana in 1691.

397 Arung Belo, also known as Towappaq, was a son of the former ruler of Soppéng La Tenribali by a lesser wife. A brother of the ruler of Soppéng Toesang Matinroe ri Salassana (Ligtvoet 1880:156). 
27 Nov (M eve) Karaeng ri Parang-Parang proposed to by Tumamenang ri Passiringanna [Abdul Kadir]; the brideprice was 88 [reals]

21 Zulh 1095 nanipassuroi Karaengta ri Parang-Parang ri Tuammenang ri Passiringanna sunranna 88

1685

7 Jan (M) I Daeng Rapanna I Manuruki, a child of Karaeng ri Mangalliq by Daengta Daeng Majannang, born

1 Saf 1096 naanaq I Daeng Rapanna I Manuruki anaqna Karaengta ri Mangalliq ri Daengta Daeng Majannang

27 Jan (S) $\quad$ we were left by Karaeng Tumamenang ri Ujung Tana [Karunrung] at the age of 55

21 Saf 1096 kinapilari Karaengta Tuammenang ri Juntana umuruqna 55

22 Jun (F) a ship arrived bringing I Daeng Buraqne

19 Raj 1096 nabattu kappalaq angerangi I Daeng Buraqne

13 Aug (M) the ruler of Terasaq ${ }^{398}$ killed by one of his slaves

12 Ram 1096 nanibuno karaeng Terasaq ri atanna

3 Sep (W eve) President Willem Hartsink took his post [in Fort Rotterdam]

6 Syaw 1096 namammempo jagaya ri Parsidenti Welom Harsin

1686

13 Jan $(\mathrm{N}) \quad$ the people going into Baroko [in Toraja] to make war departed

17 Saf 1097 namaqlampa tumantamaya ri Baroko maqbunduq

18 Mar (N eve) Karaeng ri Panaikang died at the age of $105^{399}$

22 Rakr 1097 namate Karaengta ri Panaikang umuruqna 105

$19 \operatorname{Mar}(\mathrm{T}) \quad$ Karaeng ri Rappociniq ${ }^{400}$ died

\footnotetext{
398 Terasaq is located in Boné.

399 This refers to Daeng Niaq, the widow of Kaicili Kalamata, but her age is incorrect. She was born 15 Jan 1631 and thus had reached the age of 55 (or 57 according to the Hijri calendar), not 105.

400 Possibly a Bugis named Mappa Arung Tonra. See the note for the 8 Aug 1680 entry.
} 
23 Rakr 1097 namate Karaengta ri Rappociniq

$25 \mathrm{Apr}$ (W eve) Tumamenang ri Lakiung [Abdul Jalil] arrived from Cenrana [in Boné] and went straight down to Luwuq

1 Jakr 1097 nabattu ri Cenrana Tuammenang ri Lakiun natulusuki manaung ri Luwuq

11 May (F eve) I Daeng Talarra and a child of the ruler of Dompu married

17 Jakr 1097 nasikalabini I Daeng Talarra anaqna karae Dompu

23 May (R) Karaeng ri Jipang died

30 Jakr 1097 namate Karaengta ri Jipang

18 Jul (R) Tumamenang ri Passiringanna [Abdul Kadir] and Karaeng ri Parang-Parang married

26 Syab 1097 nasikalabini Tuammenang ri Passiringanna Karaengta ri Parang-Parang

7 Aug (R) ${ }^{401} \quad$ a younger aunt of Tunisombaya [Arung Palakka] died and was buried in Talloq

17 Ram 1097 namate ayana Tunisombaya ri Talloki niawang

26 Nov (T) Daengta I Daeng Massuro beheaded to the east in Borongloe

10 Muh 1098 nanijalloq Daengta I Daeng Massuro iraya ri Bontoloe

17 Dec (T) Haji Barania died

2 Saf 1098 namate Haqji Barania

1687

26 Jan $(\mathrm{N}) \quad$ Haji Abdullah Zamzami died

11 Rawl 1098 namate Haqji Abdullah Zamzami

$3 \mathrm{Feb}(\mathrm{M}) \quad$ two suns were seen by Karaeng ri Bontosunggu

19 Rawl 1098 naniciniq rua matanna alloa ri Karaengta ri Bontosunggu

7 Mar (F) I Daeng Majannang had a son

8 Rakr $1098^{402}$ namamanaq I Daeng Majannang buraqne

402 The Hijri date converts to $21 \mathrm{Feb} 1687$. 
$16 \operatorname{Mar}(\mathrm{N}) \quad$ I Daeng Mallulungang installed as sabannaraq 24 Rakr 1098 nanitannang sabannaraq I Daeng Mallulungang

4 Apr (F) Matinroa ri Nagaulang [La Patauq] and Karaeng ri Patukangang wed

20 Jawl 1098 nabunting Matinroa ri Nagaulang ri Karaengta ri Patukangan

17 Jun (T) it is said that the people of Duri embraced Islam ${ }^{403}$ 2 Syab 1098 nanikana mantamami Islam tuDuria

$3 \mathrm{Jul}(\mathrm{R})$ 22 Syab 1098

Arung Teko and I Daeng Nisayu divorced 404 nasipelaq Aruq Teko I Daeng Nisayu

$23 \mathrm{Jul}$ (T eve) the ruler of Bima Karaeng Panaragang died 13 Ram 1098 namate karaenga ri Dima Karae Panaragang

$25 \mathrm{Jul}(\mathrm{F})$ 14 Ram 1098

Daengta I Kare Pate had a son by Karaeng ri Mandalleq namamanaq Daengta I Kare Pate ri Karaengta ri Mandalleq buraqne

17 Sep (W) I Daeng Manangaraq Ahmad, a younger sibling of Karaeng Garassiq, born

9 Zulk $1098^{405}$ naanaq I Daeng Manangaraq Ahmad arinna Karae Garassiq

10 Sep (W)

Karaeng ri Bontorambaq had a daughter ${ }^{406}$

2 Zulk 1098 namamanaq Karaengta ri Bontorambaq baine

20 Oct $(\mathrm{M})$ Karaeng ri Langeloq and Datu ri Soppéng ${ }^{407}$ married 13 Zulh 1098 nasikalabini Karaengta ri Langeloq Datua ri Soppeng

24 Oct (R eve) Karaeng ri Ballaq Kiria and Tumamenang ri Taenga married

403 Duri was a Torajan group whose conversion to Islam followed their submission to an army sent by Arung Palakka (Andaya 1981:262).

404 For the second time; they divorced on 31 Oct 1680 as well. The date of their second marriage is not listed.

405 This and the following entry are in reverse chronological order, presumably because of a copyist error.

406 Almost certainly Karaeng Agangjeqneq. See the note to the entry for 29 Nov 1702.

407 Towesa Matinroe ri Salassana. 

Taenga

11 Nov ( $\mathrm{N}$ eve) Karaeng ri Bontoa 408 and Karaeng ri Mandalleq married 5 Muh 1099 nasikalabini Karaengta ri Bontoa Karaengta ri Mandalleq

17 Nov (N eve) birth of the ruler Sultan Sirajuddin 409

11 Muh 1099 nanianakkang karaenga Sultan Sirajuddin

$7 \operatorname{Dec}(N)^{410}$

2 Saf 1099

it is said that the young ruler of Banten ${ }^{411}$ died nanikana matei karaenga ri Bantan maloloa

\section{8}

7 Jan (T eve)

Arung Maroangi died

3 Rawl 1099 namate Arung Maroangi

$20 \operatorname{Mar}(\mathrm{S})$

17 Jawl 1099

the ruler of Sumbawa I Ammasaq ${ }^{412}$ born naanaq karae Sambawa I Ammasaq

$2 \operatorname{Apr}(\mathrm{F})$

1 Jakr 1099

Friday public prayers first established in Bantaeng; I Tuang ri Dima initiated them nauru mammenteng jumaka ri Bantaeng I Tuan ri Dima ampapentengi

409 A son of Abdul Kadir and Karaeng Parang-Parang, he was also known as Mappauqrangi, Tumamenang ri Pasiq, Karaeng Kanjilo, and Tumammaliang ri Talloq. He became ruler of both Gowa and Talloq in 1712 but had a turbulent career as sultan before his death in 1739 .

410 A copyist mistakenly wrote November instead of December.

411 This refers to Sultan Haji, who the VOC called the 'young sultan' when he was crown prince of Banten. He wielded considerable power during the reign of his father, Sultan Ageng, and the Bantenese court split into two factions. Sultan Haji turned to the VOC for support against his father, who was supported by more strident Muslims. Sultan Ageng initially had the support of many Makassarese who had fled South Sulawesi after 1669, but disagreements over women and their unruly behavior led them to flee. Sultan Ageng did have the vocal support of Shaykh Yusuf, however. Yusuf was a famed Makassarese teacher who settled in Banten in 1672 and became an active leader in fighting against the VOC. Sultan Haji deposed his father in 1680, but having alienated so many Bantenese nobles depended on the support of the VOC until his 1687 death (Ricklefs 2001:102-4).

412 Mas Madina, a son of the ruler of Sumbawa Mas Banten and Karaeng Tanisanga.

413 The Hijri date converts to 21 Apr 1688. A copyist may simply have transposed two numbers in the Gregorian date. 
17 May (M) Karaeng Campagaya Sitti Hibatullah ${ }^{414}$ born

16 Raj 1099 naanaq Karae Campagaya Sitti Hibatullah

6 Jun (N) tumailalang Karaeng Jarannika went to go into Toraja to make war

7 Syab 1099 namaqlampa tumailalang Karae Jarannika mantama ri Toraja maqbunduq

4 Jul (S eve) Tumamenang ri Passiringanna [Abdul Kadir] and Karaeng ri Parang-Parang divorced

5 Ram $1099 \quad$ nasipelaq Tuammenang ri Passiringanna Karaengta ri Parang-Parang

5 Aug (R)

the ruler of Bima ${ }^{415}$ and Karaeng ri Tana-Tana wed

8 Syaw 1099 nabunting karaenga ri Dima Karaengta ri Tana-Tana

$6 \operatorname{Aug}(\mathrm{F})$

I Daeng Manggappa I Mommiq born

9 Syaw 1099

naanaq I Daeng Manggappa I Mommiq

$16 \operatorname{Sep}(\mathrm{R})$

Tumamenang ri Passiringanna [Abdul Kadir] and

20 Zulk 1099 Daengta Daeng Tamemang married nasikalabini Tuammenang ri Passiringanna Daengta Daeng Tamemang

19 Sep $(\mathrm{N}) \quad$ Karaeng Bontorambaq and I Daeng Mangemba married 23 Zulk 1099 nasikalabini Karae Bontorambaq I Daeng Mangemba

8 Oct (R eve) I Daeng Mamangkasi Mamminawang, a child of Karaeng ri Bontomajannang, stabbed; Daeng Mamangkasi molested $^{416}$ a child of Karaeng ri Balloq

12 Zulh 1099 nanitoboq I Daeng Mamangkasi Mamminawang anaqna Karaengta ri Bontomajannang Daeng Mamangkasi nonoq anaqna Karaengta ri Balloq

\section{9}

$2 \operatorname{Jan}(\mathrm{N})$

Karaeng Paqbineang Sitti Rahimah ${ }^{417}$ born

9 Rawl 1100

naanaq Karae Paqbineang Sitti Rahimah

\footnotetext{
414 A daughter of La Patauq and Karaeng Patukangang.

415 Jamaluddin, son and successor to Mapparabung Karaeng Panaragang.

416 Nonoq means 'to shake', but here it refers to masturbating or otherwise sexually molesting one of Karaeng ri Balloq's young sons.

417 A daughter of Abdul Kadir and Karaeng Parang-Parang.
} 
1 Feb (M eve) birth of I Daeng Mangago Karaeng Paranggi

10 Rakr 1100 nanianakkang I Daeng Mangago Karae Paranggi

8 Feb (M eve) a strong earthquake rocked houses

17 Rakr $1100^{418}$ naronrong sarro taqlewaki ballaka

5 Jun (N) Daengta I Kare Pate had a daughter by sabannaraq [Daeng Makkulle]

17 Syab 1100 namamanaq Daengta I Kare Pate ri sabannaraka baine

9 Jun (W eve) Karaeng ri Bontopanno sailed overseas to Jakattaraq to request I Tuang Shaykh Yusuf [be returned to Makassar]

21 Syab 1100 nasimombalaq Karaengta ri Bontopanno kalauq ri Jakattaraq ampalaq-palaki I Tuan Syekhu Yusupu

13 Jun (M) Karaeng ri Parang-Parang died at the age of 18

25 Syab 1100 namate Karaengta ri Parang-Parang umuruqna 18

14 Jun (T) I Daeng Majannang had a son who after just 7 nights died 26 Syab 1100 namamanaq I Daeng Majannang buraqne 7 banngiji namate

9 Jul (S eve) a wife of the Karaeng ri Talloq [Abdul Kadir] had a son who after just 5 nights died

22 Ram 1100 namamanaq bainenna Karaenga ri Talloq buraqne 5 banngiji namate

7 Sep (T eve) the ruler of Bima I Mappatalliq Syaad Syah ${ }^{419}$ born 22 Zulk 1100 naanaq karaenga ri Dima I Mappatalliq Syaad Syah

21 Sep (W) Karaeng ri Mangalliq went to go into Toraja to make war 6 Zulh 1100 namaqlampa Karaengta ri Mangalliq mantama ri Toraja maqbunduq

15 Oct (S) Tunisombaya [Arung Palakka] went east to Pariq [location unknown] with Karaeng Tumamenang ri Lakiung [Abdul Jalil]

418 A copyist mistakenly wrote Rabi'ul-awal instead of Rabi'ul-akhir. The text in Makasaarsche historiën (1855:126) gives the date for this as 1 Dec 1690.

419 A son of the ruler of Bima Jamaluddin and Karaeng Tana-Tana, he was later known as Hasanuddin Muhammad Syah. 
1 Muh 1101 namanraiq ri Pariq Tunisombaya siagaang Karaenga Tuammenang ri Lakiun

1690

18 Jan (W) Karaeng Anaq Moncong Ismail ${ }^{420}$ born; just after he arrived it was announced

5 Rakr 1101 naanaq Karae Anaq Moncong Ismail battunaji nipabiritta

8 Mar (W) I Daeng Rikasammeng arrived

27 Jawl 1101 nabattu I Daeng Rikasammeng

9 Apr $(\mathrm{N}) \quad$ Karaeng ri Mandalleq died at the age of 37

29 Jakr 1101 namate Karaengta ri Mandalleq umuruqna 37

4 Oct (W) angrily going [to help], Tunisombaya [Arung Palakka] went down to Lamboko [in Soppéng] bearing arms ${ }^{421}$

30 Zulh 1101 naturung rakka-rakka Tunisombaya manaung ri Lamboko angerangi ewanganna

$17 \operatorname{Nov}(\mathrm{F})$

birth of I Daeng Tapallaq I Diqdaq

15 Muh $1102^{422}$ nanianakkang I Daeng Tapallaq I Diqdaq

1691

6 Jan (S)

6 Rakr 1102

Daengta I Kare Pate had a son

namamanaq Daengta I Kare Pate buraqne

$23 \mathrm{Feb}$ (R eve) Karaeng ri Lekoq Alaq died

24 Jawl 1102 namate Karaengta ri Lekoq Alaq

$15 \operatorname{Mar}(\mathrm{R})$ an Arab from Madina named Shaykh Abdullah Qussyasyi arrived

15 Jakr 1102 nabattu Arab tuMadinaya nikanaya Syekhu Abdullah Qussyasyi

420 A son of La Patauq and Karaeng Patukangang and also named Tosappewali, he would later be known as Matinroe ri Somba Opu or Tumamenang ri Somba Opu. He ruled Gowa after his grandfather Abdul Jalil died in 1709, but was deposed in 1712. He then ruled in both Boné and Soppéng.

421 This refers to an incident in which an irate Arung Palakka felt that his authority was being challenged by Arung Lampoko ('Lamboko' to Makassarese). In response to this defiance Arung Palakka had 'Arung Lampoko's lips sliced off for having uttered offensive words against Arung Palakka and then had him chased into the forest like a wild animal' (Andaya 1981:272).

422 The Hijri date converts to 18 Oct 1690. 
19 Jun (M eve) Karaeng ri Bontokeke and Karaeng ri Bontoa wed [in accordance with Islamic custom]

21 Ram 1102 nanipaqnikkah Karaengta ri Bontokeke Karaengta ri Bontoa

6 Jul (F) Karaeng ri Pangkajeqneq and I Daeng Singaraq divorced 9 Syaw 1102 nasipelaq Karaengta ri Pangkajeqneq I Daeng Singaraq

$29 \mathrm{Jul}(\mathrm{N}) \quad$ I Loqmoq, the mother of I Sandiq, died 423

3 Zulk 1102 namate I Loqmoq anronna I Sandiq

3 Sep ( $\mathrm{N}$ eve $)^{424}$ the people of Garassiq went to Daeng Manarai, known as Karaeng Mamampang

9 Zulh 1102 nanipamange tuGarassika ri Daeng Manarai nikana Karae Mamampang

23 Sep (N) Puanna I Mattaq Suleman [La Padangsajati] ${ }^{425}$ born

29 Zulh 1102 naanaq Puanna I Mattaq Sulemana

15 Oct ( $\mathrm{N}$ eve) a celebration took place for Karaeng Balua [Daeng Maingaq] $]^{426}$ in Paggentungang

22 Muh 1103 namammempo jagana Karaengta Balua ri Paggentungan

31 Oct (W) a mosque built in Mangallekana

9 Saf 1103 nanibangun masigika ri Mangallekana

1692

15 Feb (F) I Daeng Mangemba ${ }^{427}$, the ruler of Siang, died overseas in Jakattaraq

27 Jawl 1103 namate I Daeng Mangemba Karae Siang ilauq ri

Jakattaraq

423 Given that Loqmoq was such a common title, it is impossible to know if this refers to a woman already mentioned in the annals or if she is only mentioned this one time.

424 A copyist mistakenly wrote November instead of Sepember.

425 A son of La Patauq and Karaeng Patukangang, he was also known as La Padangsajati and bore the titles Arung Palakka and Karaeng Katangka. He ruled Boné from 1715 to 1720 .

426 A wife of Abdul Jalil, 'Karaeng Balua' refers to her status as a widow of Amir Hamzah. The nature of this celebration is unknown.

427 This name is probably either incorrect or refers to a different Daeng Mangemba than the one also known as Arung Tanete who married Karaeng Bontorambaq. The latter pair had a daughter named Zainab on 2 Aug 1693, but obviously the Daeng Mangemba mentioned here could not be her father. 
12 Mar (M eve) the mother of Matinroa ri Nagaulang [La Patauq] died 23 Jakr 1103 namate ayana Matinroa ri Nagaulang

16 May (R eve) Karaeng Panaikang I Mappasaqbi Muhammad Said born 29 Syab 1103 naanaq Karae Panaikang I Mappasaqbi Muhammad Said

8 Jun (S eve) Karaeng Mamampang I Daeng Manarai died and was buried in Somba Opu

22 Ram 1103 namate Karae Mamampang I Daeng Manarai ri Sombopui niawang

$11 \mathrm{Jul}\left(\mathrm{R}\right.$ eve) a grandparent of Karaeng ri Bontoa ${ }^{428}$ died and was buried in Somba Opu at the age of 67

25 Syaw 1103 namate toana Karaengta ri Bontoa ri Sombopui niawang umurukna 67

22 Aug (R eve) after living together Karaeng Alluq and Karaeng ri Pangkajeqneq married

9 Zulh 1103 nanibaineang siballaqna Karae Alluq ri Karaengta ri Pangkajeqneq

28 Aug (F) the elder Karaeng Bontolangkasaq and the mother of Karaeng Bontolangkasaq I Mappaseppeq married ${ }^{429}$

16 Zulh 1103 nasikalabini Karae Bontolangkasaq matoaya anronna Karae Bontolangkasaq I Mappaseppeq

29 Sep (W eve) birth of I Daeng Mangalliq I Dondiq 7 Muh $1104^{430}$ nanianakkang I Daeng Mangalliq I Dondiq

23 Sep (M) it is said that the elder ruler of Banten ${ }^{431}$ died 11 Muh 1104 nanikana matei Karae Bantan matoaya

21 Oct (T) Tunisombaya [Arung Palakka] went down to Mandar with Tumamenang ri Lakiung [Abdul Jalil] to celebrate

\footnotetext{
428 Ralle Daeng Paikaq.

429 I Mappaseppeq's unnamed mother was a daughter of Daeng Anrenne and either Karaeng ri Agangjeqneq or Daeng Mangemba. Dutch sources report that the elder Karaeng Bontolangkasaq, who was killed on Lombok in 1700, was a nephew of Abdul Jalil, though Ligtvoet notes that because of conflicting sources it is difficult to determine the precise genealogical connection between them (Ligtvoet 1880:162).

430 The Hijri date converts to 18 Sep 1692. A copyist probably wrote the 29 th instead of the 19th for the Gregorian date.

431 Sultan Ageng. See the note accompanying the entry for 7 Dec 1687.
} 
10 Saf 1104

namanaung ri Mandaraq Tunisombaya siagaang Tuammenang ri Lakiun maqjaga

1693

5 Jan (N eve) Tunisombaya [Arung Palakka] had very strong stomach pains

27 Rakr 1104 nanabattui paqrisiq battang sarro dudu Tunisombaya

14 Mar (S) I Daeng Manaqgalaq and I Daeng Maingaq married

6 Raj 1104 nasikalabini I Daeng Manaqgalaq I Daeng Maingaq

25 Apr (S) I I Papoq I Daeng Mamaro died

18 Syab 1104 namate I Papoq I Daeng Mamaro

29 Apr (T eve) Padukka Dompu died at the age of $62^{432}$

22 Syab $1104^{433}$ namate Padukka Dompu umuruqna 62

5 May (M eve) canning killed by Datu ri Luwuq434

28 Syab 1104 nanibuno canninga ri Datua ri Luwuq

22 May (R eve) Gallarrang I Kare Tulusuq died

15 Ram 1104 namate Gallarrang I Kare Tulusuq

5 Jul (N) I Daeng Nisimba and Daengta I Daeng Mallulungang divorced

2 Zulk $1104 \quad$ nasipelaq I Daeng Nisimba Daengta I Daeng Mallulungang

14 Jul (M eve) Karaeng Taliwang435 cut down by Raden Sanggalea, who escaped

11 Zulk 1104 nanijalloq Karae Taliwan ri Raden Sanggalea lappasaki

432 She was killed at Kambu on the north coast of Dompu. While the rulers of Bima and Dompu each claimed the other was responsible, the nobles of South Sulawesi felt that the ruler of Bima was to blame (Ligtvoet 1880:162-3).

433 The Hijri day is missing but must be the 22nd.

434 Cenning (the Bugis spelling) was a title born by the crown prince of Luwuq. In this case it refers to Umar Tomallinrunge, a son of the exiled ruler of Luwuq Daeng Mattuju and nephew of his successor Daeng Massuro, also known as Sultan Muhammad Muhidin and Matinroe ri Tompotikkaq. According to Ligtvoet (1880:163), Dutch sources report that Umar Tomallinrunge also married a daughter of Daeng Massuro, but was killed by his uncle for having sexual relations with one of Arung Palakka's concubines (who was also killed for this offence).

435 He was a brother of the ruler of Sumbawa Mas Banten and killed with the assistance of an unnamed Sumbawa noble (Ligtvoet 1880:163). 
$21 \mathrm{Jul}(\mathrm{T}) \quad$ Karaeng ri Tanasanga Halimah died

18 Zulk 1104 namate Karaengta ri Tanasanga Halimah

22 Jul (W) Karaeng Bisei Abdullah Manshur ${ }^{436}$ born; Raden

Sanggalea arrived to surrender himself

19 Zulk 1104 naanaq Karae Bisei Abdullah Manshur nabattu Raden Sanggalea angerang kalenna

$23 \mathrm{Jul}(\mathrm{R})$

Karaeng Alluq Shalahuddin born

20 Zulk 1104

naanaq Karae Alluq Shalahuddin

$24 \mathrm{Jul}(\mathrm{F})$

21 Zulk 1104 namatetommo Raden Sanggalea nisuro jarroki ri Karae

Raden Sanggalea died now; the ruler of Sumbawa [Datu Lokaq] ordered him strangled Sambawa

26 Jul (S eve) Karaeng ri Patukangang died at the age of $21^{437}$

23 Zulk 1104 namate Karaengta ri Patukangan umuruqna 21

2 Aug (N) I Sammaraq died; Puanna I Mattaq's [La Padangsajati] wife Zainab born ${ }^{438}$

29 Zulk 1104 namate I Sammaraq naanaq Puanna I Mattaq bainea Zainab

21 Aug (W) the ruler of Bima [Karaeng Panaragang] was sentenced by the Dutch, who said he killed Padukka Dompu ${ }^{439}$

17 Zulh 1104 nanabicara Karaenga ri Dima ri Balandaya nikana ia anbunoi Padukka Dompu

23 Aug (S eve) Gallarrang Mangasa I Kare Mangalle installed as speaker [of the land, or tumabicarabutta]; I Kare Tulusuq was replaced

21 Zulh 1104 nanitannang maqbicara Gallarrang Mangasa I Kare Mangalle I Kare Tulusuq nasambeang

\footnotetext{
436 A son of La Patauq and Karaeng Patukangang, he was also known as Arung Mampu and La Panaungi Topawawoi.

437 In fact, she was 19 years old at the time of her death.

438 She was a daughter of Daeng Mangemba and Karaeng Bontorambaq and later married La Padangsajati (Puanna I Mattaq).

439 This episode involving Padukka Dompu's murder and the subsequent investigation is discussed in Andaya (1981:281-9).
} 
27 Aug $(\mathrm{R})^{440} \quad$ the ruler of Bima taken into the fort

25 Zulh 1104 nanipantamamo ri kotaya Karaenga ri Dima

27 Sep (N) Puanna I Mattaq [La Padangsajati] first set foot in

Mangallekana [at about age 2]

26 Muh 1105 nauru naonjoq Mangallekana Puanna I Mattaq

25 Sep (R eve) Tunisombaya [Arung Palakka] went into Soppéng to celebrate

24 Muh $1105^{441}$ namantama Tunisombaya ri Soppeng jaga

10 Oct (S) Abdul Mukmin, pakki442 of Bontoalaq, died

10 Saf 1105 namate paqqia ri Bontoalaq Abdul Mukmin

16 Nov (M) war leaders I Daeng Buraqne and I Kare Bangung sailed east to Sandao

17 Rawl 1105 namammise dulun manraika ri Sandawo I Daeng Buraqne siagaang I Kare Bangun

19 Dec (F eve) a wife of Tumamenang ri Passiringanna [Abdul Kadir] had a daughter named Sitti Aisyah Karaeng Pasiq

21 Rakr 1105 namamanaq bainenna Tuammenang ri Passiringanna baine nikana Sitti Aisyah Karae Pasiq

$25 \operatorname{Dec}(\mathrm{F}) \quad$ I Boe Jawa died

27 Jakr 1105 namate I Boe Jawa

1694

7 Jan (W eve) a grandparent of I Jabbing died

10 Jawl 1105 namate toana I Jabbing

17 Jan (S eve) I Kare Leoq died

20 Jawl 1105 namate I Kare Leoq

$24 \mathrm{Feb}(\mathrm{W}) \quad$ Karaeng Bontotannga died at the age of 63

29 Jakr 1105 namate Karae Bontotannga umuruqna 63

440 The Gregorian day is missing but must be the 27 th.

441 This entry presumably was recorded after the previous entry because it took time for word of Arung Palakka's movements to reach Makassar.

442 A position occupied by one knowledgeable about Islamic canon law. 
5 Mar (W eve) Karaeng Binamuq died

7 Raj $1105 \quad$ namate Karae Binamuq

5 Mar (R eve) President Prins ${ }^{443}$ died

8 Raj 1105 namate Parsidinta Parinsi laqnatullah

10 Mar (M eve) I Sutting wed [in accordance with Islamic custom] by Karaeng ri Jarannika; the brideprice was 80 [reals]

12 Raj 1105 naninikkahi I Sutting ri Karaengta ri Jarannika sunranna 80

14 Mar (S) Karaeng Bontolangkasaq I Mappaseppeq444 born

16 Raj 1105 naanaq Karae Bontolangkasaq I Mappaseppeq

8 May (S) I Tuang ri Dima Shaykh Umar died at the age of 60

12 Ram 1105 namate I Tuan ri Dima Syekhu Umara umuruqna 60

14 May (F) it is said that [I] Loqmoq divorced by [Karaeng] Jarannika 18 Ram 1105 nanikana nipelaqmi Loqmoq Jarannika

1 Jun (T) I Daeng Buraqne banished east to Parigi; I Kare Bangung expelled from his position ${ }^{445}$

6 Syaw 1105 nanicinde I Daeng Buraqne manraiq ri Parigi I Kare Bangun nipasuluki ri empona

$25 \mathrm{Aug}(\mathrm{W}) \quad$ Karaeng ri Kassiqjala died at the age of 81

3 Muh 1106 namate Karaengta ri Kassiqjala umuruqna 81

7 Sep (M eve) Shaykh Yusuf Ipandi ${ }^{446}$ went to Karaeng Tumamenang ri Lakiung [Abdul Jalil] upon his first arrival

16 Muh 1106 namae ri Karaenga Tuammenang ri Lakiun Syekhu Yusup Ipandi uru battuna

2 Nov (T) Tumamenang ri Lakiung [Abdul Jalil] went east to Gowa to mark out the space for a house that he could then occupy in Gowa

\footnotetext{
443 A former chief merchant of the VOC, François Prins had succeeded Willem Hartsink as President in Makassar.

444 Daeng Mamaro, son of the Karaeng Bontolangkasaq killed on Lombok in 1700.

445 As the war leaders assigned to the expedition against Sandao the previous year, this must have been punishment for their failure there.

446 This is not Muhammad Yusuf al-Maqassari, known as Tuanta ri Salamaka, who was exiled by the VOC and arrived in the Cape of Good Hope on 2 Apr 1694.
} 
14 Rawl 1106 namanraiq mae ri Gowa Tuammenang ri Lakiun mamate passiringanna lanaempoinna Gowa

17 Dec ( $R$ eve) the karaeng [Abdul Jalil] went east to Gowa to live; 10 years, six months, and seven nights he had lived in Mangallekana

29 Rakr 1106 namanraiq mae ri Gowa karaenga mammempo 10 taungi angannang bulan antuju banngi niempoi Mangallekana

$19 \operatorname{Dec}(\mathrm{N})$

house(s) built in Dataq

2 Jawl 1106

nanibangun ballaka ri Dataq

22 Dec (T eve) it is said that I Tuang [Shaykh Yusuf] was banished overseas to the Cape ${ }^{447}$

5 Jawl 1106

nanikana nipelaki I Tuan kalauq ri Kaq

$24 \operatorname{Dec}(\mathrm{F})$

Friday public prayers established in Gowa were first attended

7 Jawl 1106

namammenteng jumaka ri Gowa uru niempoinna

1695

$12 \operatorname{Mar}(\mathrm{S})$

Karaeng ri Beroanging died at the age of 35

26 Raj 1106

namate Karaengta ri Beroangi umuruqna 35

10 Apr (N eve) Karaeng ri Lengkeseq died and was buried in Talloq at the age of 69

25 Syab 1106 namate Karaengta ri Lengkeseq ri Talloki niawang umuruqna 69

13 May (R eve) I Raluq born

27 Ram 1106 naanaq I Raluq

16 Jun (T) thin coins replaced by stamped coins ${ }^{448}$

3 Zulk 1106 nanisambei pitisiq bayanga pitisiq nipanralaq

447 It must be on this date that news of Shaykh Yusuf's arrival in the Cape of Good Hope reached Makassar.

448 Until the VOC conquest of Gowa Makassar's rulers minted lead coins. Speelman described that after the conquest the VOC issued similar coins, 80 of which had the value of a double stuiver, while a Makassarese kupang was valued at three double stuivers. The VOC coins became thinner and by 1692 a single double stuiver was worth 300 or 400 of these coins that now lacked a stamped face. The new coins referred to in this entry were stamped with the VOC's mark and were valued at 48 to a double stuiver (Ligtvoet 1880:footnote 165-6). 
27 Aug (S)

a great meeting hall built in Gowa

16 Muh 1107 nanibangun baruga loea ri Gowa

30 Aug $(\mathrm{T}) \quad$ the ship bearing the ruler of Bima sailed overseas to Jakattaraq

19 Muh 1107 nasimombalaq kappalaq angerangi Karaengta ri Dima kalauq ri Jakattaraq

17 Sep (S) war leaders sailed over to Kengkelu [Tambora]: Arung Tosiada, the commander [of Boné's troops] I Tojumaat, and [Karaeng] Jarannika ${ }^{49}$

8 Saf 1107 namamise dulun taqlea ri Kinkelu Aruq Tassiada punggawa I Tojumaq Jarannika

26 Oct (W)

a mosque built in Gowa ${ }^{450}$

17 Rawl 1107

nanibangun masigika ri Gowa

$15 \operatorname{Dec}(\mathrm{R})$

Karaeng Bontopattongkoq and I Daeng Nisakking Shafiah married

8 Jawl 1107

nasikalabini Karae Bontopattongkoq I Daeng Nisakking Shafiah

20 Dec (M eve) Karaeng Patteqne Fathuddin born

13 Jawl 1107 naanaq Karae Patteqne Fathuddini

\section{6}

21 Jan $(\mathrm{F})$

16 Jakr 1107

it is said that Shaykh Abd al-Ra'uf died in Aceh ${ }^{451}$ nanikana matei Syekhu Abdurrauf ri Aceh

$22 \operatorname{Mar}(R)$

word arrived that Karaeng ri Lekoqboqdong died across on Bima ${ }^{452}$ at 50 years of age

17 Syab 1107 nabattu erang kanana Karaengta ri Lekoqboqdong mate ibaqle ri Dima umuruqna 50 taun

449 Arung Palakka sent this expedition to assist the Dutch in its conflict with the ruler of Kengkelu (Tambora) on Sumbawa, who was trying to master the whole island and in the process both wreaked havoc in Bima, Dompu, and Pekat and attacked the Dutch fort in Bima (Andaya 1981:289-91).

450 The building of this mosque and the great meeting hall two months before followed in the wake of Abdul Jalil's move from Mangallekana back to Gowa the previous year.

451 The exact date of his death is unknown, but the last evidence that he was alive dates from 1693. See Riddell 2001:125-8.

452 According to the entry for 28 Jun 1647, he died in Kelo on Sumbawa. 
6 Apr (F)

3 Ram 1107

$13 \operatorname{Apr}(\mathrm{F})$

10 Ram 1107

$29 \operatorname{Apr}(\mathrm{N})$

26 Ram 1107

6 Jul (R eve)

5 Zulh 1107

27 Aug ( $\mathrm{N}$ eve) Karaeng ri Bontomanompoq and a great grandparent of I Makkaraeng married

28 Muh 1108

28 Aug (T)

29 Muh 1108

15 Oct $(\mathrm{M})$

18 Rawl 1108

$19 \operatorname{Mar}(\mathrm{T})$

29 Syab 1108

Tunisombaya [Arung Palakka] died at the age of 73 namate Tunisombaya umuruqna 73

the name of the karaeng of Gowa [Abdul Jalil] praised in the sermon 453

naarennamo karaenga ri Gowa nipuji ri kuqbaya

Arung Tosiada and I Tojumaat arrived from Kengkelu without gaining [victory over Tambora]

nabattumo Aruq Tassiada siagaang I Tojumaq ri Kinkelu tanakullei

the ruler of Bima I Alasaq died overseas in Jakattaraq at the age of 23

namate karaenga ri Dima I Alasaq ilauk ri Jakattaraq umuruqna 23 nasikalabini Karaengta ri Bontomanompoq boena I Makkaraeng

people built houses in Tete in order to dredge a river there namaqballaq-ballaq taua ri Tete lanikekkeseqna binangaya

Soppéng attacked by Matinroa ri Nagaulang [La Patauq] ${ }^{454}$

nanibunduq Soppeng ri Matinroa ri Nagaulan

1697

Arung Timurung, the father of Matinroa ri Nagaulang [La Patauq], died

namate Aruq Timurung aenna Matinroa ri Nagaulan

453 Beginning 26 Nov 1677 Arung Palakka's name had been ritually praised in the Friday sermon, but with his death that honor returned to the ruler of Gowa.

454 This war was to uphold Arung Palakka's policies regarding Soppéng, a Bugis kingdom with which Arung Palakka had numerous difficulties. He had made his former wife and sister of Datu ri Soppéng, We Adda Datu ri Watu, the effective ruler of Soppéng (Andaya 1981: 272, 278). But following Arung Palakka's death the people of Soppéng installed We Adda's brother Toesang as their ruler, so La Patauq launched a war to restore We Adda - and his own authority - over Soppéng (Ligtvoet 1880:167). 
26 Oct (S)

10 Rakr 1109

teeth filed of Karaeng Bontomateqne

naniariq Karae Bontomateqne

13 Dec ( $R$ eve) Karaeng ri Paqbineang died inside Massepe at the age of 36455

29 Jawl 1109 namate Karaengta ri Paqbineang ilalang ri Massepe umuruqna 36

\section{8}

6 Feb (R)

Arung Pattiro 456 and Datu ri Luwuq Matinroa ri Langkanana ${ }^{457}$ married

24 Raj 1109 nasikalabini Aruq Pattiro Datua ri Luwuq Matinroa ri Langkanana

$\begin{array}{ll}11 \text { Mar (T) } & \text { I Rakhiah born } \\ 28 \text { Syab 1109 } & \text { naanaq I Rakhiah }\end{array}$

30 Apr (T eve) I Paciq born

18 Syaw 1109 naanaq I Paciq

21 May ( $\mathrm{T}$ ) Karaeng Bontotannga I Bebuq born

29 Syaw $1109^{458}$ naanaq Karae Bontotannga I Bebuq

16 Aug (F eve) Taqbiq Jawa died

9 Saf $1110 \quad$ namate Taqbiq Jawa

20 Oct (M) teeth filed of Karaeng Campagaya

15 Rakr 1110 naniariq Karae Campagaya

$3 \operatorname{Nov}(\mathrm{N}) \quad$ I Kare Passeqre I Jaga advanced on in Bantaeng by the people of Boné 459

455 This was the widow of Hasanuddin and Arung Ujumpuluq, a ruler of Sidénréng. But she died at age 62 according to the Hijri calendar, having been born on 27 Jawl 1047 (or 17 Oct 1637). 456 Also named Patekkaqtana, she was a daughter of the ruler of Tanete Mappajanci Daeng Matajang Matinroe ri Sumpangpoba and We Tenrilekke Da Emba, a sister of Arung Palakka (Ligtvoet 1880:168).

457 A son of Daeng Massuro Matinroe ri Tompotikkaq, he was also named Topalaguna and succeeded his father as Sultan Muhammad.

458 The Hijri date converts to 10 May 1698.

459 Dutch sources report that this killing followed several years of poor relations between the rulers of Gowa and Boné. The VOC had given authority over Bantaeng to Arung Palakka's widow Daeng Talele, but I Kare Passeqre I Jaga and Daeng Mangalliki (brother of the regent of Bantaeng) took control of Bantaeng with the tacit approval of Abdul Jalil. Learning of this, 
29 Rakr 1110 nanipanaiki I Kare Passeqre I Jaga ri Bantaeng ri tuBonea

$29 \operatorname{Nov}(\mathrm{S}) \quad$ we erupted at the killing of Sanro Paqlangisang; we faced

25 Jawl 1110 kigegereq nibunona Sanro Paqlangisan sidallekangjaki tasibuangiaki ewangan

$4 \operatorname{Dec}(\mathrm{R}) \quad$ Karaeng Boqdia circumcised

1 Jakr 1110 nanisunnaq Karae Boqdia

$13 \operatorname{Dec}(S) \quad$ it is said that Daengta Daeng Mangalle died

10 Jakr 1110 nanikana matei Daengta Daeng Mangalle

1699

5 Jan ( $\mathrm{N}$ eve) a strong earthquake purportedly struck Jakattaraq; many stone buildings fell; many people died; a great flood [tidalwave] struck also

3 Raj $1110 \quad$ nanataba bedeng ronrong sarro Jakattaraq majai ballaq batu runtung majai tau mate nataba tongi aqba lompo

18 Apr (F eve) I Daeng Mabela I Gacung died at the age of 20

17 Syaw 1110 namate I Daeng Mabela I Kacung umuruqna 20

1 May (F) a wife of Karaeng ri Bontomanompoq had a daughter

1 Zulk 1110 namamanaq bainenna Karaengta ri Bontomanompoq baine

11 May (M) Karaeng ri Bontomanompoq sailed over to Sandao to make war

11 Zulk 1110 namamise Karaengta ri Bontomanompoq taqle ri Sandao maqbunduq

22 May (R eve) the night of I Tuang Shaykh Yusuf's death overseas at the Cape at the age of 74

the VOC Governor in consultation with the ruler of Boné sent a military expedition to drive the Makassarese usurpers from Bantaeng. Before they arrived, however, Bugis under Arung Cello attacked I Kare Passeqre I Jaga, and it is this event to which this entry refers (Ligtvoet 1880:168-9). 460 Sanro Paqlangisang was killed in Mangallekana by Boné Bugis in retaliation for Makassarese raids against them. More violence between the two sides was avoided when the Governor ordered the Bugis to retreat (Ligtvoet 1880:169). 
22 Zulk 1110 banngi nakamateanga I Tuan Syekhu Yusup ilauq ri Kaq umuruqna 74

28 May (W eve $)^{461}$ Karaeng ri Bontolangkasaq fled ${ }^{462}$

28 Zulk 1110 namalari Karaengta ri Bontolangkasaq

15 Jun ( $\mathrm{N}$ eve) three moons were seen by Daengta Daeng Tauq

17 Zulh 1110 naniciniq tallu matanna bulanga ri Daengta Daeng Tauq

22 Jun (T eve) ${ }^{463}$ I Raluq died at the age of 5

24 Zulh 1110 namate I Raluq umuruqna 5

$25 \mathrm{Jul}(\mathrm{S}) \quad$ two suns were seen

27 Muh 1111 naniciniq rua matanna alloa

28 Jul (M eve) Pangerang Aria ${ }^{464}$ and I Daeng Nisayu ${ }^{465}$, a child of Karaeng ri Mandalleq, married

1 Saf 1111 nasikalabini Pangeran Aria I Daeng Nisayu anaqna Karaengta ri Mandalleq

12 Aug $(\mathrm{N})^{466} \quad$ Karaeng ri Manyioi died in Talloq at the age of 56 16 Saf 1111 namate Karaengta ri Manyioi ri Talloq umuruqna 56

28 Aug (R eve) Karaeng ri Tana-Tana and Karaeng ri Mamampang married

2 Rawl 1111 nasikalabini Karaengta ri Tana-Tana Karaengta ri Mamampang

13 Sep (S eve) Karaeng Campagaya died at the age of 12

18 Rawl 1111 namate Karae Campagaya umuruqna 12

30 Sep (W) I Cacoq Paqrappoang went amuk inside the fort ${ }^{467}$

\footnotetext{
461 A copyist omitted the day of the week, but given that it was an evening it must be Wednesday.

462 He went to Sumbawa where he joined Karaeng Pamolikang who 'plundered friend and foe' (Ligtvoet 1880:169).

463 A copyist mistakenly wrote July instead of June.

464 The ruler of Pamukang on the eastcoast of Borneo.

465 This seems to be a different Daeng Nisayu from those already mentioned in the annals.

466 A copyist mistakenly wrote the 2 nd instead of the 12 th.

467 Dutch sources report that at Gowa's instigation Daeng Tulolo, a former ruler of the Mandar community of Paqrappoang (Pamboang), found the opportunity to make himself ruler
} 
6 Rakr 1111 namaqjalloq I Cacoq Paqrappoang ilalang ri kotaya

$\begin{array}{ll}2 \text { Oct }(\mathrm{F}) & \text { I Bewi died } \\ 8 \text { Rakr } 1111 & \text { namate I Bewi }\end{array}$

29 Oct (R) Karaeng ri Bontomanompoq arrived from Sandao

5 Jawl 1111 nabattu Karaengta ri Bontomanompoq ri Sandao

31 Oct (S) I Baku Sitti Abidah born

7 Jawl 1111 naanaq I Baku Sitti Abidah

1700

18 Mar (R eve) Karaeng Bontotannga and Karaeng ri Buluq-Buluq married

27 Ram 1111 nasikalabini Karae Bontotannga Karaengta ri Buluq-Buluq

30 Apr (F eve) Sayyid Zain wed [in accordance with Islamic custom] I

Daeng Tapallaq

11 Zulk 1111 naninikkah Sayyid Zainu I Daeng Tapallaq

1 May (N) Arung Balusu ${ }^{468}$ ordered killed by Arung Teko

12 Zulk 1111 nanisurobuno Aruq Balusu ri Aruq Teko

7 May (F eve) I Kare Passeqre I Jaga arrived to surrender himself to the arumpone [La Patauq]

18 Zulk 1111 nabattu angerangi kalenna I Kare Passeqre I Jaga ri arungpone

14 May (S) the day of Karaeng ri Jarannika's killing by 'Javanese'469 from Bali along with his relative [his son, Karaeng

of Balanipa when its lawful ruler Daeng Buraqne was visiting the ruler of Boné in Bontoalaq. In response, after the expedition against I Kare Passeqre I Jaga was complete in Bantaeng, another expedition of Bugis troops led by Daeng Situju and Arung Mampu went to restore Daeng Buraqne to his throne. Daeng Tulolo fled into the mountains, but his son I Cacoq remained to defend Paqrappoang and was captured. Taken to Makassar, on 30 Sep 1699 he was sentenced to be exiled to the Cape. But as he was about to be put in chains he went amuk and killed a Dutch corporal. For this he was sentenced to have his right hand cut off, after which he would be bound to a pole and krissed, a verdict carried out on 10 Oct 1699 (Ligtvoet 1880:170).

468 Though the spelling of his name is inconsistent in Ligtvoet, this was apparently Toesang, also known as Daeng Mambani, and a half brother of the ruler of Soppéng We Adda Datu ri Watu, Matinroe ri Madello. See the note accompanying the entry for 15 Oct 1696.

469 This term does not refer to Javanese but to inhabitants of the archipelago to the west of Makassar. The annalist explains here that he specifically means Balinese. 
25 Zulk 1111 allo nibunoangai ri Jawa Balia Karaengta ri Jarannika sipamanakang siagaang Karae Bontolangkasaq ibaqle ri Salaparang

25 May (W) Karaeng Mangallekana died at the age of 65

7 Zulh 1111 namate Karae Mangallekana umuruqna 65

2 Jun (R) Karaeng Bontopattongkoq I Baraq installed at tumailalang, replacing his grandparent ${ }^{471}$

15 Zulh 1111 nanitannang tumailalang Karae Bontopattongkoq I Baraq toana nasambeang

18 Jun (S) I Jaga killed by the Dutch; he was hung

2 Muh 1112 nanibunomo I Jaga ri Balandaya nigentungi

18 Aug (R) Karaeng Anaq Moncong circumcised

4 Rawl 1112 nanisunnaq Karae Anaq Moncong

$3 \operatorname{Nov}(\mathrm{R}) \quad$ the karaeng Sultan Sirajuddin circumcised

22 Jawl 1112 nanisunnaq karaenga Sultan Sirajuddin

$15 \operatorname{Dec}(\mathrm{R}) \quad$ I Daeng Mallimpo and I Daeng Nisannging472 I Shafiah married

5 Raj 1112 nasikalabini I Daeng Mallimpo I Daeng Nisannging I Shafiah

\section{1}

21 Jan (S) Karaeng Lambengi and I Daeng Marannu I Biba married 12 Syab 1112 nisikalabini Karae Lambengi I Daeng Marannu I Beba

6 Feb (N eve) Daengta Daeng Manena died in Tallog at the age of 87 27 Syab 1112 namate Daengta Daeng Manena ri Talloq umuruqna 87

22 May (N eve) I Daeng Manyampakki and I Daeng Tasami I Takkiq married

470 The 3 Mar 1707 entry suggests that after this expedition Karaeng Jarannika intended to continue on the haj to Mekka.

471 The grandparent he replaced as tumailalang was Karaeng Jarannika, who was killed on Lombok a few weeks before along with Karaeng Bontopattongkoq's father Karaeng Bontokeke.

472 Presumably this is the same woman referred to as Daeng Nisakking on 15 Dec 1695. 
14 Zulh 1112 nasikalabini I Daeng Manyampaki I Daeng Tasami I Takkiq

7 Jul (F)

2 Saf 1113

$13 \mathrm{Jul}(\mathrm{R})$

8 Saf 1113

$28 \operatorname{Sep}(\mathrm{R})$

26 Saf $1113^{473}$

14 Oct (S)

13 Jawl 1113

18 Dec (M)

19 Raj 1113

21 Dec (R)

22 Raj 1113

18 Jan (W eve)

20 Syab 1113

$21 \operatorname{Jan}(\mathrm{N})$

23 Syab 1113

12 Feb (N eve)

15 Ram 1113
I Baronang born

naanaq I Baronang

Tumamenang ri Lakiung [Abdul Jalil] and Matinroa ri Nagaulang [La Patauq] were brought to see each other by the Dutch inside the fort nanipasiciniqmo ri Balandaya Karaenga Tuammenang ri Lakiun Matinroa ri Nagaulan ilalang ri kotaya

we first went down from all over Gowa to visit [the grave of] Datoq ri Bandang kiuru manaung siGowa anggunjungi ri Datoq ri Bandan

Arung Teko went into the fort

namantamamo ri kotaya Aruq Teko

Karaeng Panaikang circumcised

nanisunnaq Karae Panaikang

I Daeng Tulolo I Mangiq born naanaq I Daeng Tulolo I Mangiq

1702

Datu ri Mari-Mari ${ }^{474}$ died

namate Datua ri Mari-Mari

Karaeng Bontomateqne and the karaeng [Sirajuddin] married

nasikalabini Karae Bontomateqne karaeng

Ballaq Kiria built 475

nanibangun Ballaq Kiria

\footnotetext{
473 The Hijri date converts to 1 Aug 1701.

474 Dutch sources report that she was a sister of Arung Palakka (Ligtvoet 1880:172).

475 'Ballaq Kiria' literally means 'left house' and was a royal hall used by the karaeng of Gowa. 'Kiri' is a Malay and not a Makassarese term meaning 'left'. This is a good example of the increasing use of Malay words in the lontaraq bilang, and the scope and nature of this linguistic evolution merit further analysis.
} 
6 Apr (F) Daengta Daeng Mayiro died

9 Zulk 1113 namate Daengta Daeng Mayiro

7 Apr (F eve) Tumamenang ri Passiringanna [Abdul Kadir] and Daengta Daeng Tamemang divorced

10 Zulk 1113 nasipelaq Tuammenang ri Passiringanna Daengta Daeng Tamemang

8 Apr (S eve) Karaeng ri Mamampang and Karaeng ri Tana-Tana divorced for the second time

11 Zulk 1113 nasipelaq Karaengta ri Mamampang Karaengta ri TanaTana makapinruanna

16 May (T eve) Karaeng Anaq Moncong and Karaeng Paqbineang wed 19 Zulh 1113 nabunting Karae Anaq Moncong Karae Paqbineang

4 Jun $(\mathrm{N}) \quad$ Karaeng Boqdia and Karaeng Buluq-Buluq I Rusiah married

9 Muh 1114 nasikalabini Karae Boqdia Karae Buluq-Buluq I Rusiah

4 Jul (W) $\quad$ Arung Teko brought overseas to Jakattaraq

9 Saf 1114 nanierangmo kalauq ri Jakattaraq Aruq Teko

$12 \mathrm{Jul}$ (W eve) Karaeng Boqdia and Karaeng Buluq-Buluq divorced 17 Saf 1114 nasipelaq Kare Boqdia Karaeng Buluq-Buluq

9 Aug (R) I Daeng Manaqgalaq was cut down by Kare Manjakkalaq I Uqdung but did not die

19 Rawl 1114 nanijalloq I Daeng Manaqggalaq ri Kare Manjakkalaq I Uqdung tamate

10 Sep (M) orang kaya ${ }^{476}$ Kare Gappa died

8 Rakr 1114 namate orangkaya Kare Gappa

19 Sep (W) I Daeng ri Bulekang died

27 Rakr 1114 namate I Daeng ri Bulekang

1 Oct ( $\mathrm{N}$ eve) I Daeng Massese and Daengta Daeng Tamemang married

\footnotetext{
476 Orang kaya is a Malay term that literally means 'rich person' but generally refers to nobles who achieved their wealth through trade.

477 The Hijri date converts to 1 Sep 1702.
} 
10 Jawl 1114 nasikalabini I Daeng Massese Daengta Daeng Tamemang

6 Oct (S) those who were ordered to accompany Matinroa ri Nagaulang [La Patauq] into Makele to make war sailed: [Karaeng] Pangkajeqneq, [Karaeng] Lekoqboqdong; [Karaeng] Bidara

15 Jawl 1114 namammise tunisuroa ampinawangi Matinroa ri Nagaulan mantama ri Makale maqbunduq Pangkajeqneq Lekoqboqdong Bidaraiya

10 Oct (W) Daengta Daeng Tumammo died

19 Jawl 1114 namate Daengta Daeng Tumammo

1 Nov (R) walls torn down that were constructed during our struggle $^{478}$

12 Jakr 1114 nanigesaraq bata nilonjoka ri gegereqta

$29 \operatorname{Nov}(\mathrm{R}) \quad$ the ruler of Sumbawa [Ammasaq] ${ }^{479}$ and Karaeng Agangjeqneq ${ }^{480}$ married

10 Raj 1114 nasikalabini Karae Sambawa Karae Agangjeqneq

3 Dec (M) those who went into Toraja arrived; 173 people from Toraja was the portion of the karaeng [Abdul Jalil] 14 Raj 1114 nabattumo tumantamaya ri Toraja 173 tau Toraja tawana karaenga

5 Dec (W) nayaka $\quad$ n I Punbinduq died and I Loqmoq Rannu replaced him

16 Raj 1114 namate nayakayya I Punbinduq naILoqmoq Rannu assambeangi

\footnotetext{
478 This refers to walls that were constructed in violation of the terms of the Bungaya Treaty.

479 Mas Madina, who succeeded his father Mas Banten after the latter's abdication in 1701.

480 Dutch sources report that she was a daughter of Karaeng Bontorambaq and Karaeng Barrong (Ligtvoet 1880:173). It is probably Karaeng Agangjeqneq's birth that is referred to in the entry for 10 Sep 1687.

481 Nayaka was the title of the head of the bissu, the transvestite ritual specialists who officiated at a number of royal ceremonies even after conversion to Islam. To this point in the lontaraq bilang there has been no mention of bissu, possibly because of the Islamic context in which the genre developed (Cummings 2007b).
} 
19 Dec (T eve) Datu ri Citta ${ }^{482}$ died

1 Syab $1114 \quad$ namate Datua ri Citta

1703

20 Feb (T eve) I Bauwaq born

5 Syaw 1114 naanaq I Bauwaq

12 Mar (M eve) papuq ${ }^{483}$ Daeng Numalo died

25 Syaw 1114 namate I Papuq Daeng Numalo

$19 \operatorname{Mar}(\mathrm{T}) \quad$ it is said that Arung Kaju ${ }^{484}$ died

2 Zulk 1114 nanikana matei Aruq Kaju

3 Apr (W) Karaeng Garassiq and I Daeng Rikong I Jaga married

16 Zulk 1114 nasikalabini Karae Garassiq I Daeng Rikong I Jaga

12 Apr (R eve) I I Daeng Maqleoq I Sumang and I Daeng Takenna I Jaing married

26 Zulk 1114 nasikalabini I Daeng Maqleoq I Suman I Daeng Takenna I Jaing

$16 \operatorname{Apr}(\mathrm{T}) \quad$ I Mangeranngi I Daeng Mattalliq [Karaeng Bungaya] born

1 Zulh 1114 naanq I Mangeranngi I Daeng Mattalliq

24 May (F) Sayyid Muhammad came east here to Gowa to live

9 Muh 1115 namanraiq mae ri Gowa mammempo Sayyid Muhammad

15 Jun (S) Karaeng Barong Patola Mutipah born

1 Saf 1115 naanaq Karae Barong Patola Mutipatullah

17 Jun (M) I Daeng Makkulle Ahmad installed as papuq by his family 3 Saf 1115 nanitannang Papuq ri pamanakanna I Daeng Makkulle Ahmad

482 Dutch sources report that she was a sister of Arung Palakka and widow of the ruler of Sidénréng Matinroe ri Salemo (Ligtvoet 1880:173).

483 Papuq was a title of the head of the Bajo community that traditionally had been loyal to the rulers of Gowa.

484 An important Bugis noble who was one of Arung Palakka's lieutenants during and after the Makassar War. 
$25 \mathrm{Jul}(\mathrm{R}) \quad$ I Loqmoq Saja died

11 Rawl 1115 namate I Loqmoq Saja

21 Aug (T eve) Karaeng Bontopattongkoq expelled as tumailalang

9 Rakr 1115 nanipasuluq tumailalang Karaeng Bontopattongkoq

2 Sep (M) Karaeng Garassiq and I Daeng Rikong divorced

21 Rakr 1115 nasipelaq Karae Garassiq I Daeng Rikong

8 Sep (S eve) I Daeng Massese and Daengta Daeng Tamemang divorced

27 Rakr 1115 nasipelaq I Daeng Massese Daengta Daeng Tamemang

8 Sep $(\mathrm{N}) \quad$ it is said that Arung Meru ${ }^{485}$ died

27 Rakr 1115 nanikana matei Arung Meru

3 Oct (R) Karaeng Bontopattongkoq and Karaeng Manjalling were reconciled

22 Jawl 1115 nanipaqbajikang Karae Bontopattongkoq Karae Manjalling

4 Oct (F) Karaeng Anaq Moncong went into Cenrana [in Boné] with his wife [Karaeng Paqbineang]

23 Jawl 1115 mantama Karae Anaq Moncong ri Cenrana sikalabini

7 Oct (M) house(s) built in Sero

26 Jawl 1115 nanibangun ballaka ri Seroq

24 Oct (R) Karaeng ri Bontoa and Karaeng ri Mamampang married

14 Jakr 1115 nasikalabini Karaengta ri Bontoa Karaengta ri Mamampang

3 Nov (S eve) Daengta I Puwaq's belongings seized [by] Karaeng Tumamenang ri Passiringanna [Abdul Kadir]; it is said he was shamed

24 Jakr 1115 nanirappung Daengta I Puwaq Karaenga Tuammenang ri Passiringanna nikana nabiqnnyaraq

$10 \operatorname{Nov}(\mathrm{N}) \quad$ Karaeng Tumamenang ri Lakiung [Abdul Jalil] sailed to go into Cenrana for the circumcision of Karaeng Bisei 
1 Raj 1115

namamise Karaeng Tuammenang ri Lakiun mantama ri Cenrana lanisunnaqna Karae Bisei

$14 \operatorname{Dec}(S)$

Sudanga and Latea ri Duni ${ }^{486}$ placed side by side in Latimojong [a royal hall]; many people swore oaths to each other; for the first time they were placed side by side $^{487}$

2 Syab 1115 nanipasiempoang Sudanga Latea ri Duni ri Latimojong nasitalliq lompo taua uru nipasiempoanna

$20 \operatorname{Dec}(\mathrm{F})$

Karaeng Bisei circumcised; many people were at the ritual

nanisunnaq Karaeng Bisei kaparekang lompoi taua

1704

8 Jan (W)

1 Ram 1115

the karaeng [Abdul Jalil] arrived from Cenrana nabattumo ri Cenrana karaenga

10 Feb (N eve) Gallarrang I Kare Mangalliq died

5 Syaw 1115 namate Gallarang I Kare Mangalliq

10 Feb (M) I Daeng Takenna died giving birth

5 Syaw 1115 namate mammanaq I Daeng Takenna

8 Mar (S eve) Daengta Daeng Tuna, a grandparent of the karaeng [Abdul Jalil], died at the age of 74

2 Zulk 1115 namate Daengta Daeng Tuna toana karaenga umuruqna 74

$18 \operatorname{Mar}(\mathrm{W})$

Daengta I Kare Pate died at the age of 41

12 Zulk 1115 namate Daengta I Kare Pate umuruqna 41

486 Sudanga, a sword, was a kalompoang or piece of sacred regalia from Gowa and Latea ri Duni was a sword from the regalia of Boné. More than simple accoutrements or objects, these swords were believed to embody the sovereignty of their respective communities and provided tangible links to the tumanurung who founded Gowa and Boné. This ritual was a potent demonstration of the equal importance of the two kingdoms and an effort to assert that they were now closely bound together as allies. The oaths that the nobles of Gowa and Boné swore were witness to this potent piece of political dramaturgy.

487 Ligtvoet (1880:174) notes that the swords actually first were placed side by side during the reign of Tumpaqrisiq Kallonna when he made a treaty with the ruler of Boné. This ritual is not mentioned in the Gowa Chronicle. 
16 Apr (R) Karaeng ri Bontomanompoq sailed east with the people of Boné to Sandao to make war

12 Zulh 1115 namamise Karaengta ri Bontomanompoq manraiq ri Sandawo maqbunduq siagang tuBonea

11 May (M) it is said that Datu ri Luwuq Matinroa ri Tompotikkaq died

8 Muh 1116 nanikana matei Ratua ri Luwuq Matinroa ri Tompotikkaq

3 Jun (W) it is said that Arung Amali488 died 13 nights [ago]

1 Saf 1116 nanikana matei Arung Amali 10 banngimi antallu

17 Jun (W) the shipment to the karaeng [Abdul Jalil] from the ruler of [the islands of] Sulu ${ }^{489}$ arrived: a clock

13 Saf 1116 nabattu pikatunna karaenga ri karaenga ri Suluq goyang sibatu

25 Jun (R) Karaeng Taruq, a child of Karaeng ri Pasiq, died

23 Saf 1116 namate Karae Taruq anaqna Karaengta ri Pasiq

29 Jun (N eve) Karaeng Agangjeqneq and the ruler of Sumbawa

[Ammasaq] divorced

27 Saf 1116 nasipelaq Karae Agangjeqneq karae Sambawa

14 Jul (T) Karaeng ri Bontomanompoq arrived from Sandao

12 Rawl 1116 nabattumo ri Sandawo Karaengta ri Bontomanompoq

19 Jul (N) Karaeng Agangjeqneq had a child I Sugi ${ }^{490}$ by the ruler of Sumbawa [Ammasaq]

17 Rawl 1116 namammanaq Karae Agangjeqneq ri karae Sumbawa I Sugi

29 Jul (W) I Dasunting, a wife of I Tuang [Rappang], died giving birth

27 Rawl 1116 namate mammanaq I Dasunting bainenna I Tuan

488 As (Ligtvoet 1880:175) notes, this Arung Amali must not be confused with the confidant of Arung Palakka by the same name, for he became known as 'the elder Arung Tanete' (Arung Tanete Matoa) and died in 1707.

489 The Sulu islands link Borneo and Mindanao. The annalist may have meant the Sula islands in Maluku, an area that long had connections to Makassar.

490 Probably Karaeng Bontoa (Ligtvoet 1880:203). 
$\begin{array}{ll}6 \text { Aug }(\mathrm{R}) & \text { I Markus died; he was hung } \\ \text { 12 Rakr 1116 } & \text { nanibuno I Markus nigentungi }\end{array}$

31 Aug (M) Karaeng Garassiq and I Limaraq married

1 Jawl 1116 nasikalabini Karae Garassiq I Limaraq

10 Sep (R) people begin to clear the land in Buluq-Buluq

11 Jawl 1116 namappakaramula tauaya maqbelaq ri Buluqburuq

23 Sep $(W) \quad$ Daenga Daeng Niaq died in Sanrabone

24 Jawl 1116 namate Daenga Daeng Niaq ri Sanrabone

10 Oct $(S) \quad$ people withdraw from clearing land [in Buluq-Buluq]

12 Jakr 1116 namammonoqmo tauaya ri belaka

1 Nov (S eve) Arung Belo and Daengta Daeng Mami returned to each other

4 Raj 1116 nasipolei Aruq Belo Daengta Daeng Mami

9 Nov (N eve) I Tuang [Rappang] and I Daeng Nisayu ${ }^{493}$ married

12 Raj 1116 nasikalabini I Tuan I Daeng Nisayu

10 Nov (T) Daeng Mamuntuli and his wife ${ }^{494}$ arrived

13 Raj 1116 nabattu Daeng Mammuntuli sikalabini

$16 \operatorname{Nov}(\mathrm{M}) \quad$ Tumamenang ri Lakiung [Abdul Jalil] sailed to go into Centana for the wedding of the ruler of Sumbawa [Ammasaq]

19 Raj 1116 namamise Tuammenang ri Lakiun mantama ri Cenrana ri paqbuntinganna karae Sambawa

21 Nov (S) it is said that Karaeng Pamolikang died, killed by the Kengkelu [Tambora on Sumbawa]

24 Raj 1116 nanikana matei Karae Pammolikang nibunoi ri Kenkelua

491 A former VOC council secretary in Makassar, Markus Santbeek was accused of a variety of illegal practices by local nobles (Ligtvoet 1880:175).

492 The Hijri date converts to 13 Aug 1704.

493 This is not the same I Daeng Nisayu as the wife of Pangerang Aria, who left for Borneo with him on 17 Jul 1707.

494 Karaeng Barong Patola, a daughter of the former ruler of Sumbawa Mas Banten. 
5 Dec (F eve) Karaeng Bontomateqne had a daughter

8 Syab 1116 namammanaq Karae Bontomateqne baine

11 Dec (R eve) I Jamuq died

14 Syab 1116 namate I Jamuq

16 Dec (W) wedding of the ruler of Sumbawa [Ammasaq] to Arung Timurung [Datu ri Citta] ${ }^{495}$

19 Syab 1116 nabunting karae Sambawa ri Aruq Timurun

1705

1 Jan (F) Karaeng Tumamenang ri Lakiung [Abdul Jalil] arrived from Cenrana

5 Ram 1116 nabattu ri Cenrana Karaeng Tuammenang ri Lakiun

13 Jan (W) Sayyid Zain and I Daeng Tapallaq divorced

17 Ram 1116 nasipelaq Sayyid Zainu I Daeng Tapallaq

$24 \operatorname{Jan}(\mathrm{N}) \quad$ it is said that I Daeng Mamuntuli and Karaeng Barong Patola divorced

28 Ram 1116 nanikana sipelaki I Daeng Mamuntuli Karae Borong Patola

$24 \mathrm{Feb}(\mathrm{W}) \quad$ Taqbi Sattu died

1 Zulk 1116 namate Taqbi Sattu

31 Mar (W) Karaeng ri Taruq's arrival from Jakattaraq took place

2 Zulh 1116 naniaqmo Karaengta ri Taruq battu ri Jakattaraq

1 Apr (R) I Daeng Manyampakki and I Daeng Tasami divorced

7 Zulh 1116 nasipelaq I Daeng Manyampaki I Daeng Tasami

5 Apr ( $\mathrm{N}$ eve) the remains of I Tuang Shaykh Yusuf (may Allah bless him) arrived and was buried in Lakiung the next day

11 Zulh 1116 nabattu mayaqna I Tuan Syekhu Yusupu Radiallahuanhu naniawang ri Lakiun ammuko

$15 \operatorname{Apr}(\mathrm{R}) \quad$ Karaeng Bontopattongkoq I Baraq died

21 Zulh 1116 namate Karae Bontopattongkoq I Baraq

495 Also known as Bataritoja, she was a daughter of La Patauq and Opu Larompong, a sister of Matinroe ri Langkanana (Ligtvoet 1880:176, 196). 
22 Apr (W eve) I Daeng Manyampakki and I Daeng Tasami returned to each other

22 Zulh $1116^{496}$ nasipolei I Daeng Manyampaki I Daeng Tasami

1 May (S) Karaeng Kanjilo's belongings seized by Tumamenang ri Lakiung [Abdul Jalil]

8 Muh 1117 nanirappung Karae Kanjilo ri Tuammenang ri Lakiun

5 May (S) Sayyid Zain and I Daeng Tapallaq returned to each other 15 Muh 1117 nasipolei Sayyid Zain I Daeng Tapallaq

17 May (M) the female ruler Datu ri Soppéng ${ }^{497}$ died

24 Muh 1117 namate Datua ri Soppeng datu bainea

4 Jun (F) Karaeng ri Buluq-Buluq died at 40 years of age

13 Saf 1117 namate Karaengta ri Buluq-Buluq umuruqna 40 taun

12 Jun (S) I Daeng ri Kasammeng died at the age of 87 on just the same day as the birth of Muhammad Ali

21 Saf 1117 namate I Daeng ri Kasammeng umuruqna 87 julu alloji kaanakkanna Muhammad Ali

18 Jun (S) Karaeng Boqdia and I Daeng Tongi Sapiah divorced

28 Saf 1117 nasipelaq Karae Boddia I Daeng Tongi Sapiah

21 Jun (N eve) Ratu Agung died

30 Saf $1117 \quad$ namate Ratu Agung

2 Jul (R eve) Anciq Daeng and I Jamilah married

11 Rawl 1117 nasikalabini Anciq Daeng I Jamilah

22 Aug (N) Karaeng Lambengi and I Daeng Marannu I Biba divorced 3 Jawl 1117 nasipelaq Karae Lambengi I Daeng Marannu I Biba

1 Sep (W) Matinroa ri Nagaulang [La Patauq] came east to Tumamenang ri Lakiung [Abdul Jalil] bringing Karaeng Kanjilo to ask forgiveness

13 Jawl 1117 namanraiq mae Matinroa ri Nagaulan ri Tuammenang ri Lakiun angerangi Karae Kanjilo ampappalaq popporangi

496 The Hijri date converts to 16 Apr 1705.

497 We Adda Datu ri Watu, Matinroe ri Madello. 
5 Sep (S eve) I Daeng Tasami had a daughter

17 Jawl 1117 namammanaq I Daeng Tasami baine

23 Sep (R) Daengta I Puaq died

5 Jakr 1117 namate Daengta I Puaq

25 Sep (S) I Daeng Mamuntuli eloped with Karaeng Barong Patola from the house of [her father] Datu Lokaq [Mas Banten] and was fined 888 reals and her brideprice of 88 [reals]

7 Jakr 1117 nanilariang ri Daeng Mamuntuli Karae Barong Patola ri ballaqna Datu Lokaq nanipassala 880 realaq passunranna 88

$30 \mathrm{Sep}(\mathrm{R}) \quad$ people mustered for the installation of [VOC governor] Erbervelt

12 Jakr 1117 namarewangan taua nilantiqna Erbelpel

2 Oct (F eve) the [body of the] wife of [I Tuang Shaykh Yusuf] was dug up above in Bontobiraeng and brought down here to Lakiung and buried

14 Jakr 1117 nanikekkeseq bainenna irate ri Bontobiraeng nierang manaung mae ri Lakiun niawang

8 Oct (R eve) I Kamboja and a step child of I Daeng Manyampaq Alluq married

20 Jakr 1117 nasikalabini I Kamboja anaq aona I Daeng Manyampaq Alluq

9 Oct (S) the merchant I Kare Uppa died

21 Jakr 1117 namate pabandangang I Kare Ruppa

11 Oct (N eve) I Daeng Manruppai and I Yakung I Daeng Tommi married

23 Jakr 1117 nasikalabini I Daeng Manruppai I Yakung I Daeng Tommi

13 Oct $(\mathrm{W}) \quad$ the ruler of Sumbawa [Ammasaq] and Arung Timurung [Datu ri Citta] divorced

25 Jakr 1117 nasipelaq karae Sambawa Aruq Timurun

15 Oct (R eve) Karaeng Lambengi and I Daeng Marannu I Bokuq married

27 Jakr 1117 nasikalabini Karae Lambengi I Daeng Marannu I Bokuq 
18 Oct ( $\mathrm{N}$ eve) I Daeng Baine died

1 Raj 1117 namate I Daeng Baine

22 Oct (F) Matinroa ri Nagaulang [La Patauq] sailed to go into Toraja with Karaeng Anaq Moncong

5 Raj 1117 namamise Matinroa ri Nagaulan mantama ri Toraja siagaang Karae Anaq Moncong

$28 \operatorname{Oct}(\mathrm{R})$ it is said that Kartasura, the seat of the ruler of Mataram, was conquered by the Dutch ${ }^{49}$

11 Raj 1117 nanikana nibetami Kartasura naempoia Karae Mataran ri Balandaya

31 Oct (S eve) Datu Lokaq [Mas Banten] ${ }^{499}$ and the ruler of Sumbawa [Ammasaq] sailed over to their homeland [on Sumbawa] 14 Raj 1117 namamise Datu Lokaq siagaang karae Sambawa taqle ri paqrasanganna

$\begin{array}{ll}1 \text { Nov (T) } & \text { I Jamilah and Anciq Daeng divorced } \\ 15 \text { Raj 1117 } & \text { nasipelaq I Jamilah Anciq Daeng }\end{array}$

$21 \operatorname{Nov}(\mathrm{N}) \quad$ Ratu Hayati died

5 Syab 1117 namate Ratu Hayati

4 Dec (F eve) the night of I Kare Taqgalaq the brave warrior's death inside Toraja

18 Syab 1117 banngi nakamateang I Kare Taqgalaq tubarani ilalang ri Toraja

5 Dec $(\mathrm{N}) \quad$ Karaeng Bontolangkasaq circumcised 19 Syab 1117 nanisunnaq Karae Bontolangkasaq

498 This was a key moment in the First Javanese War of Succession (1704-1708). With VOC support and an army that included Bugis and Makassarese Pakubuwana I occupied Kartasura in Sepember 1705 with little resistance from his nephew Amangkurat III, the new ruler of Mataram (Ricklefs 2001:110). It is quite possible that word of this event reached Makassar a month later via the Bugis or Makassarese warriors participating in the campaign. Word reached Makassar about a month after the Sepember occupation of Kartasura.

499 Datu Lokaq was the title of the former ruler of Sumbawa Mas Banten. He abdicated in 1701 and was succeeded by his son, Mas Madina. 
$13 \operatorname{Dec}(\mathrm{M}) \quad$ I Kamariah ${ }^{500}$, a wife of the elder Ratu Bagus ${ }^{501}$, had a daughter

27 Syab 1117 namammanaq I Kamariah bainenna Ratu Bagusu matoa baine

20 Dec (M) Matinroa ri Nagaulang [La Patauq] arrived from Toraja without gaining [victory]

4 Ram 1117 nabattu ri Toraja Matinroa ri Nagaulan tanakulleai

22 Dec (W) Karaeng Anaq Moncong arrived also

6 Ram $1117^{502}$ nabattutommo Karae Anaq Moncong

1706

13 Jan (W eve) I Daeng Tapallaq had a son, Sayyid Husain

28 Ram 1117 namammanaq I Daeng Tapallaq buraqne Sayyid Husin

28 Jan (F) I Kare Battu expelled from his supervisory position for freeing people who were imprisoned; I Daeng Talesang replaced him 503

13 Syaw 1117 nanipasuluq I Kare Battu ri panjannanginna napalari tau nirante naIDaeng Talesang assambeangi

8 Feb (M eve) Karaeng Tabaringang Nafisah ${ }^{504}$ had a child on just the same day as the death of I Kare Sitaba, an expert builder

24 Syaw 1117 naanaq Karae Tabaringan Nafisah julu alloji matena I Kare Sitaba panrita ballaq

13 Feb (N) I Kare Basse died and I Kare Taqgalaq I Parampang replaced him

1 Zulk 1117 namate I Kare Basse naIKare Taqgalaq I Parampang assambeangi

3 Mar (R) I Manguluang circumcised

19 Zulk 1117 nanisunnaq I Manguluang

500 She was also called Daeng Nisanga.

501 Ratu Bagus was a title borne by children of lower-ranking wives or concubines of the sultans of Banten.

502 A copyist mistakenly wrote the 2nd instead of the 6 th.

503 Tumakkajannang, the supervisory position referred to here, was the title of those charged with overseeing groups of people who performed specific tasks.

504 She was a daughter of Sirajuddin (Ligtvoet 1880:178). 
21 Mar (M) I Totammaq died

7 Zulh 1117 namate I Totammaq

10 Apr (S eve) Daengta Daeng Tuna Bulukumba died

27 Zulh 1117 namate Daengta Daeng Tuna Buluq Kumba

$28 \operatorname{Apr}(\mathrm{R}) \quad$ Arung Belo and Daengta Daeng Mami divorced

16 Muh 1118 nasipelaq Aruq Belo Daengta Daeng Mami

8 May (S) I Daeng Mambani Dulang and I Sayedah married

26 Muh 1118 nasikalabini I Daeng Mambani Dulan I Sayedah

16 Jun (R) I Cammaq and I Daeng Rikong I Jaga divorced

6 Rawl 1118 nasikalabini I Cammaq I Daeng Rikong I Jaka

18 Jun (S) Karaeng Manjalling and I Nanuq Daeng Nisanga

divorced

8 Rawl 1118 nasipelaq Karae Manjalling I Nanuq Daeng Nisanga

$28 \mathrm{Jul}(\mathrm{R})^{505} \quad$ the younger Ratu Bagus and I Kare Teqne I Jambang married

18 Rakr 1118 nasikalabini Ratu Bagusu Malolo I Kare Teqne I Jambang

6 Aug (F eve) Karaeng Tumamenang ri Lakiung [Abdul Jalil] had great sores in his thigh

27 Rakr 1118 nanabattui sakkaq lompo bongganna Karaenga

Tuammenang ri Lakiun

11 Sep (S eve) Karaeng Bontomateqne and the karaeng [Sirajuddin] divorced

4 Jakr 1118 nasipelaq Karae Bontomateqne karaenga

29 Oct (S) Tuammenang ri Lakiung [Abdul Jalil] went down to the ground after [healing from] the swelling [in his thigh] and was lavished with offerings

22 Raj 1118 namanaungmo ri butta Tuammenang ri Lakiun leqbaqna makambang nanikiori

$12 \mathrm{Nov}$ (F eve) there were thieves went up into [a house or royal hall] and stabbed each other in Ujung 
7 Syab 1118

naniaq palukkaq appanaiki sitoboki para palukkaq ri Ujung

14 Nov (N eve) Ratu Bagus and I Kare Teqne divorced

9 Syab 1118 nasipelaq Ratu Bagusu I Kare Teqne

2 Dec (R eve) Karaeng Anaq Moncong and Sitti Labibah ${ }^{506}$ married 27 Syab 1118 nasikalabini Karae Anaq Moncong Sitti Labibah

2 Dec (F) Friday public prayers first established this Friday in Taenga

27 Syab 1118 nauru mamenteng jumaka ri Taenga jumaq

12 Dec ( $\mathrm{N}$ eve) I Mammaq and I Daeng Nisimba married

7 Ram 1118 nasikalabini I Mammaq I Daeng Nisimba

16 Dec (R eve) I Daeng Nisoqna had a son

11 Ram 1118 namammanaq I Daeng Nisoqna buraqne

1707

1 Jan (S eve) Karaeng Balaqsari and the karaeng [Sirajuddin] married

27 Ram 1118 nasikalabini Karae Balassari karaenga

2 Jan (M) I Cammaq and I Daeng Rikong divorced [again]

28 Ram 1118 nasipelaq I Cammaq I Daeng Rikong

4 Jan (W) Sayyid Muhammad was stabbed beneath the glands in his neck but did not die

30 Ram 1118 nanitoboq Sayyid Muhammad irawanganna kulanrereqna tamateai

6 Jan (R eve) I Kare Onoq Gallarrang Aeng died

2 Syaw 1118 namate I Kare Onoq Gallarang Aeng

16 Feb (R) Karaeng Majannang Abdul Kadir I La Sanresang507 born

506 Dutch sources report that she was a daughter of Shaykh Yusuf and a woman known as Kare Kontu (Ligtvoet 1880:178). As a daughter of Shaykh Yusuf, her marriage into the Gowa ruling family represents a significant moment in the carefully cultivated association between the rulers of Gowa and the Sufi movement that spread in eighteenth-century Sulawesi following the repatriation of Shaykh Yusuf's remains.

507 A son of Karaeng Bontosunggu and future sultan of Talloq also known as Tumamenang ri Buttana. 
14 Zulk 1118 naanaq Karae Majannang Abdul Kadir I La Sanresang

3 Mar (F) Haji Abdurrahman arrived bringing the haj payment of Tumatea ri Salaparang [Karaeng Jarannika]

29 Zulk 1118 nabattumo Hajji Abdurrahman angerangi pamalli hajjina Tumatea ri Salaparang

$26 \operatorname{Mar}(\mathrm{N}) \quad$ Daengta Daeng Tuang died at the age of 82

22 Zulh 1118 namate Daengta Daeng Tuang umuruqna 82

24 Apr (M) Karaeng Anaq Moncong went into Cenrana bringing [his wife] Sitti Labibah

22 Muh 1119 namantama ri Cenrana Karae Anaq Moncong angerangi Sitti Labibah

23 May (T) Datu ri Soppéng [Matinroe ri Salassana], former spouse of Karaeng ri Langeloq, died at the age of 53

22 Saf 1119 namate Datua ri Soppeng pallaloanna Karaengta ri Langeloq umuruqna 53

20 Jun (M eve) I Daeng Tapallaq had a daughter by Sayyid [Zain] 20 Rawl 1119 namammanaq I Daeng Tanpallaq ri Sayyidka baine

24 Jun (S) I Kamariah had a daughter

24 Rawl 1119 namammanaq I Kamariah baine

26 Jun (M) Karaeng ri Mangaraqbombang died in Talloq

26 Rawl 1119 namate Karaengta ri Mangaraqbombang ri Talloq

3 Jul (M) Haji Jaqfar died

4 Rakr 1119 namate Hajji Jaqpar

5 Jul (W) I Daeng Talesang I Coce died in Talloq 508

6 Rakr 1119 namate I Daeng Talesang I Coce ri Talloq

13 Jul (W eve) Anciq Terengganu and I Sayedah Sanrabone married 14 Rakr 1119 nasikalabini Ancet Tarangganu I Sayedah Sanrabone

$14 \mathrm{Jul}(\mathrm{F}) \quad$ Gallarrang Mangasa went with the ruler of Agangnionjoq to go into Toraja to summon Pati Manjawari 
15 Rakr 1119 namaqlampa Gallarang Mangasa siagaang karaengta ri Agangnionjoq mantama ri Toraja angkioki Pati Manjawari

17 Jul (M) Pangerang Aria went over to his homeland [Pamukang on Borneo] bringing his wife [I Daeng Nisayu]

18 Rakr 1119 namaqlampa Pangerang Aria taqle ri paqrasanganna angerangi bainenna

$21 \mathrm{Jul}(\mathrm{F})$

22 Rakr 1119

Daengta Daeng Singaraq and sabannaraq I Daeng Makkulle divorced but returned to each other later nasipelaq Daengta Daeng Singaraq I Daeng Makulle sabannaraq sipoleiji salla

25 Jul (M eve) Karaeng Balua, a great grandparent of I Padang, died 26 Rakr 1119 namate Karaengta Balua boena I Padang

8 Aug (W)

10 Jawl 1119

23 Aug (W)

25 Jawl 1119

3 Sep $(N)$

7 Jakr 1119

4 Sep (M)

8 Jakr 1119

15 Sep (R eve) the younger Ratu Bagus and I Kare Tonji I Maqmiq married

19 Jakr 1119

$1 \operatorname{Oct}(\mathrm{N})$

5 Raj 1119

4 Oct $(W)$

8 Raj 1119

Karaeng Boqdia and I Daeng Tongi returned to each other nasipolei Karae Boqdia I Daeng Tongi

the ruler of Agangnionjoq and Gallarrang Mangasa arrived from Toraja

nabattumo ri Toraja Karaengta ri Agangnionjoq Gallarang Mangasa

Gallarrang Mangasa again went with the ruler of Agangnionjoq to go into Toraja namaqlampa pole Gallarang Mangasa siagaang Karaengta ri Agangnionjoq mantama ri Toraja

work done to repair the mosque in Talloq nanijama nipakabajiki masigika ri Talloq

nasikalabini Ratu Bagusu malolo I Kare Tonji I Maqmiq

the day of Sayyid Muhammad's death across on Bima allo nakamateanga Sayyid Muhammad ibaqle ri Dima

I Daeng Nisayu, [a wife of] I Tuang [Rappang], had a daughter named Sitti Malikah

namammanaq I Daeng Nisayu I Tuan baine nikana Sitti Malikah 
14 Oct (S) teeth filed of Karaeng Bontojeqneq

18 Raj 1119 naniariq Karae Bontojeqneq

$15 \operatorname{Oct}(\mathrm{N})$

19 Raj 1119

I Baronang died at six years and six months of age namate I Baronang umuruqna 6 taun 6 bulan

3 Nov (R eve) I Daeng Tongi had a son

9 Syab 1119 namammanaq I Daeng Tongi buraqne

13 Nov $(\mathrm{M}) \quad$ the day of the elder Arung Tanete's death inside Cenrana 19 Syab 1119 allo nakamateanga Aruq Tanete matoa ilalang ri Cenrana

4 Dec (M) the ruler of Agangnionjoq with Gallarrang Mangasa arrived from Toraja; with them too was Pati Manjawari

10 Ram 1119 nabattu ri Toraja Karaengta ri Agangnionjoq siagaang Gallarang Mangasa niaqtommi Pati Manjawari

$22 \operatorname{Dec}(\mathrm{F}) \quad$ I Loqmoq, a grandparent of tumailalang Karaeng ri Lekoqboqdong, died

28 Ram 1119 namate I Loqmoq toana tumailalang Karaengta ri Lekoqboqdong

30 Dec (S) Karaeng Balaqsari had a daughter, Karaeng Tanasanga Mahbubah Mamuncaragi

6 Syaw 1119 namammanaq Karae Balassari baine Karae Tanasanga Mahbubah Mamuncaragi

1708

24 Jan (W) word arrived of the death of Dala Lemo Apaq509

2 Zulk 1119 nabattu nipabiritta matena Dala Lemo Apaq

14 Feb (T eve) Karaeng Anaq Moncong and Karaeng Paqbineang divorced

23 Zulk 1119 nasipelaq Karae Anaq Moncong Karae Paqbineang

$24 \operatorname{Mar}(\mathrm{N}) \quad$ Karaeng Tumamenang ri Lakiung [Abdul Jalil] sailed to go into Cenrana bringing Pati Manjawari

2 Muh 1120 namamise Karaenga Tuammenang ri Lakiun mantama ri Cenrana anggerangi Pati Manjawari

509 A wife of La Patauq whose low rank is indicated by the title Dala, similar to the Makassarese title Loqmoq. 
$11 \operatorname{Apr}(\mathrm{R})$

20 Muh 1120

29 Apr ( $\mathrm{N}$ eve) Karaeng Bontomateqne and Arung Lalolang510 married 9 Saf 1120

13 May (M)

23 Saf 1120

22 May (W)

2 Rawl 1120

6 Jun (W eve)

17 Rawl 1120 the karaeng [Abdul Jalil] arrived from Cenrana nabattu ri Cenrana karaenga nasikalabini Karae Bontomateqne Arung Lalolang

I Daeng Manruppai and I Yakung I Daeng Tommi divorced nasipelaq I Daeng Manruppai I Yokung I Daeng Tommi

the ruler of Sumbawa [Ammasaq] and Karaeng Pasiq married

nasikalabini karae Sambawa Karae Pasiq

Pati Manjawari went to go into Toraja to his wife nampaqlampa Pati Manjawari mantama ri Toraja ri bainenna

17 Jun (N eve) I Daeng Majannang I Daenne died

28 Rawl 1120 namate I Daeng Majannang I Daenne

24 Jun (M) I Mappaq, a child of Daengta Daeng Ngaseng, and I Singayah married

6 Rakr 1120 nasikalabini I Mappaq anaqna Daengta Daeng Ngaseng I Singayah

2 Jul (T)

14 Rakr 1120 I Daeng Marannu I Mamo died at the age of 61 namate I Daeng Marannu I Mamo umuruqna 61

7 Jul (S eve) I Durra and a child of Karaeng ri Bontokamase died, having stabbed each other

19 Rakr 1120 namate I Durra anaqna Karaengta ri Bontokamase sitoboki

$16 \mathrm{Jul}(\mathrm{T})$

28 Rakr 1120 nasipelaq Daengta I Daeng Singaraq I Daeng Makkulle sabannaraq 
5 Aug (M) Karaeng Jawere $\quad$ K11 and Karaeng Bontojeqneq wed 19 Jawl 1120 nabunting Karae Jawere Karae Bontojeqneq

1 Sep (N) I Sandewi killed from a blow by the arumpone [La Patauq] inside Cenrana

17 Jakr 1120 nanibuno patunrung I Sandewi ri arungpone ilalang ri Cenrana

20 Oct $(\mathrm{N}) \quad$ it is said that the Susuhunan of Mataram [Amangkurat III] was brought to Jakattaraq overseas ${ }^{512}$

6 Syab 1120 nanikana nierangmi kalauq ri Jakattaraq Susununga ri Matarang

4 Nov (N eve) the remains of Haji Barahing Abdulgaffar were brought back

21 Syab 1120 nabattu nierang mayaqna Hajji Barahin Abdulgappar

$4 \mathrm{Dec}(\mathrm{W}) \quad$ it is said that the Susuhunan of Mataram [Amangkurat III] was brought overseas to Ceylon with Daeng Massepe 21 Ram 1120 nanikana nierang kalauq ri Selang Susunanga ri Mataran siagaang Daeng Massepe

23 Dec (M) Tumamenang ri Jawaya Najamuddin I Manrabia ${ }^{513}$ born 21 Syaw $1120^{514}$ naanaq Tuammenanga ri Jawiya Najmuddin I Manrabia

1709

3 Jan (F) Karaeng Patukangang Zainab 515 born

22 Syaw 1120 naanaq Karae Patukangan Zainab

8 Jan (W) we were left by Karaeng Tumamenang ri Passiringanna [Abdul Kadir] at the age of 44

27 Syaw 1120 kinapilari Karaenga Tuammenanga ri Passiringanna umuruqna 44

511 Dutch sources report that this brother of the ruler of Sumbawa Mas Madina was also known as Palembang (Ligtvoet 1880:180).

512 The First Javanese War of Succession ended with the VOC breaking its assurances to Amangkurat III that he would be allowed to govern part of Java if he negotiated. He was instead arrested and exiled to Ceylon (Ricklefs 2001:110), an event recorded on 4 Dec 1708.

513 A son of Sirajuddin and Karaeng Balaqsari.

514 The Hijri date converts to 3 Jan 1709.

515 She was a daughter of Karaeng Anaq Moncong and Sitti Labibah (Ligtvoet 1880:181). 
$23 \operatorname{Jan}(\mathrm{R})$

12 Zulk 1120

$25 \mathrm{Feb}(\mathrm{T})$

15 Zulk 1120

$26 \operatorname{Mar}(\mathrm{M})$

28 Zulh $1120^{516}$

$26 \operatorname{Mar}(W)$

15 Muh 1121

22 Jun $(\mathrm{F})$

20 Rakr 1121

$14 \mathrm{Jul}(\mathrm{N}$ eve)

8 Jawl 1121

22 Jul ( $\mathrm{N}$ eve)

16 Jawl 1121

2 Aug (S)

26 Jawl 1121
Karaeng Tumamenang ri Lakiung [Abdul Jalil] first stricken with illness; he was unable to move himself nauru nabattui garrinna Karaenga Tuammenanga ri Lakiun tanakulleai nagioq kalenna

I Daeng Nisanga I Kamariah had a daughter namammanaq I Daeng Nisanga I Kamariah baine

Karaeng Panaikang and I Daeng Rikong I Jaga married nasikalabini Karae Panaikang I Daeng Rikong I Jaga

Karaeng Lambengi and I Daeng Marannu I Bokuq divorced nasipelaq Karae Lambengi I Daeng Marannu I Bokuq

Arung Palakka Puanna I Mattaq [La Padangsajati] arrived here in Gowa after fleeing from Cenrana ${ }^{517}$ nabattu mae ri Gowa Aruq Palakka Puanna I Mattaq malarina ri Cenrana

Karaeng Bontorambaq ${ }^{518}$ eloped with her husband ${ }^{519}$ who brought her into Toraja nanilariang Karae Bontoramba ri buraqnenna nierang mantama ri Toraja

\section{Karaeng Tompoqbalang died} namate Karae Tompoqbalang

I Mattaq Abdurrahman I Mappatawang520 born nanaq I Mattaq Abdulrrahman I Mappatawan

516 The Hijri date converts to 10 Mar 1709.

517 Dutch sources report that he fled Boné because he would not divorce his (pregnant) wife, a daughter of Daeng Mangemba, as his father La Patauq wished (Ligtvoet 1880:181).

518 It is unlikely that the Karaeng Bontorambaq who eloped here was the daughter of the Karaeng Karunrung who had previously married Daeng Mangemba. Dutch sources make it clear that the Karaeng Bontorambaq who had married Daeng Mangemba at this time was in Kutai, where she was married to the ruler (Ligtvoet 1880:159). Her karaeng-ship passed to another young woman, most likely a close relative, in her absence. The couple who eloped would not return to Makassar until 1715.

519 Daeng Mangemba, also known as Arung Tanete.

520 He was a son of La Padangsajati (Puanna I Mattaq) and a daughter of Daeng Mangemba (Ligtvoet 1880:181). 
4 Aug (N eve) Karaeng ri Mamampang and Karaeng ri Tana-Tana returned to each other

29 Jawl 1121 nasipolei Karaengta ri Mamampang Karaengta ri TanaTana

8 Aug (F) I Daeng Ngilauq Bantang died

3 Jakr $1121 \quad$ namate I Daeng Ngilauq Bantan

12 Aug (T) Karaeng ri Talloq Sultan Sirajuddin had a sunshade raised over his head ${ }^{521}$

7 Jakr 1121 nanipirangkakki laqlang Karaenga ri Talloq Sultan Sirajuddin

1 Sep (N eve) Karaeng Lambengi and I Kare Teqne I Jambang married 27 Jakr 1121 nasikalabini Karae Lambengi I Kare Teqne I Jambang

17 Sep (W) we were left by Karaeng Tumamenang ri Lakiung [Abdul Jalil] at the age of 59

14 Raj $1121 \quad$ kinapilari Karaenga Tuammenang ri Lakiun umuruqna 59

21 Sep (N) Sudanga and Baraya ${ }^{522}$ were ordered brought to Sultan Ismail ${ }^{523}$ by our karaeng [tumabicarabutta Karaeng Bontosunggu]

18 Raj $1121 \quad$ nanisuro erang Sudanga siagaang baraya ri karaengta mange ri Sultan Ismail

30 Sep (T) Matinroa ri Nagaulang [La Pataud] went down to Mandar to make war

27 Raj 1121 namanaung ri Mandaraq Matinroa ri Nagaulan maqbunduq

4 Oct (S) Karaeng ri Pangkajeqneq ordered overseas to Jakattaraq 1 Syab 1121 nakalauq ri Jakattaraq Karaengta ri Pangkajeqne nisuro

521 Succeeding his father Sultan Abdul Kadir who died on 8 Jan 1709, he thus formally became the ruler of Talloq.

522 Like Sudanga, Baraya was one of Gowa's chief kalompoang or sacred regalia. It was a waistband worn by the ruler of Gowa on ritual occasions.

523 Karaeng Anaq Moncong, a son of La Patauq and Karaeng Patukangang, a daughter of Abdul Jalil. He thus succeeded his grandfather on his mother's side as ruler of Gowa. 
7 Oct (M eve) Daengta Daeng Nisayu, a younger sibling of Karaeng ri Balloq, died

4 Syab 1121 namate Daengta Daeng Nisayu arinna Karaengta ri Balloq

8 Oct $(W)$

5 Syab 1121

Sayyid Zain and I Daeng Tapallaq divorced nasipelaq Sayyid Zain I Daeng Tapallaq

20 Oct ( $\mathrm{N}$ eve) the karaeng [Ismail] and Karaeng Paqbineang returned to each other

17 Syab $1121 \quad$ nasipolei karaenga Karae Paqbineang

$16 \operatorname{Nov}(\mathrm{N}) \quad$ Sulengkaya's covering replaced; people mustered to perform aru ${ }^{524}$

14 Ram 1121 nanisambei lekoqna Sulengkaya marewangangi taua mangarui

20 Nov (W eve) Datu Lokaq [Mas Banten] and Karaeng ri Bontoa wed [in accordance with Islamic custom]

18 Ram 1121 naninikkah Datu Lokaq Karaengta ri Bontoa

26 Nov (T eve) I Daeng ri Jonggoa died

24 Ram 1121 namate I Daeng ri Jonggoa

$27 \operatorname{Nov}(\mathrm{R}) \quad$ I Daeng Majannang Manrepe died

25 Ram 1121 namate I Daeng Majannang Manrepe

7 Dec (M) birth of Syafiuddin I Mappaingaq 525

5 Syaw 1121 nanianakkang Syafiuddin I Mappaingaq

21 Dec (S eve) sabannaraq I Daeng Buraqne died

19 Syaw 1121 namate sabannaraka I Daeng Buraqne

25 Dec (R) I Daeng Manyampakki and I Daeng Tasami divorced

23 Syaw 1121 nasipelaq I Daeng Manyampakki I Daeng Tasami

524 Aru were oaths of loyalty chanted while performing an aggressive, martial dance. Here this indicated their obedience and service to Sultan Ismail, Gowa's new ruler. The ceremonial act of replacing the cloth covering Sulengkaya, a banner that troops followed in war and another of Gowa's foremost kalompoang, was here connected to the elevation of a new karaeng. Sulengkaya was one of what the Gowa Chronicle called the 'Three Gaukang' first mentioned during Tumapaqrisiq Kallonna's c. 1530s pivotal war against Talloq, Maros, and Polombangkeng.

525 A son of Sirajuddin and Karaeng Balaqsari, he later became titled Karaeng Lempangang and succeeded his brother as ruler of Talloq in 1739. He also became one of the annalists of the lontaraq bilang, and first identifies himself as such on 8 Feb 1713. 
$29 \operatorname{Dec}(\mathrm{M})$ 27 Syaw 1121

$11 \operatorname{Jan}(\mathrm{N})$

11 Zulk 1121

27 Jan $(\mathrm{T})$

27 Zulk 1121

9 Feb (M)

10 Zulh 1121

16 Feb (M)

17 Zulh 1121
Karaeng ri Mangalliq died at the age of 56 namate Karaengta ri Mangalliq umuruqna 56

1710

I Callaq Belo was forcibly expelled and departed from

Gowa; two of his companions were killed nanicindei ewangan I Callaq Belo maqlampa ri Gowa rua aganna nibuno

I Daeng Makkulle installed as sabannaraq, replacing I Daeng Buraqne nanitannang sabannaraq I Daeng Makkullu assambeangi I Daeng Buraqne

I Daeng Rapanna installed to oversee the lesser anaq karaeng 526

naIDaeng Rapanna nitannang anjannanngi anaq karaeng salaya

the karaeng [Ismail] inaugurated on the installation stone $^{527}$

nanitogasaq karaenga ri batu palantikanga

\begin{abstract}
526 This refers to a lower rank of nobles who were children of nobles (thought not though of the highest rank) and a slave or free (but non-noble) parent (Friedericy 1933:9, 14-5)

527 The nature of the ritual described in this entry is uncertain. Ligtvoet 1880:183 explained this ceremony as an event in which the new ruler was freed from the influence of evil spirits. Cense and Abdurrahim (1979:857) remarked that the next to last ruler of Gowa reported that this term (nitogasaq) described a simpler ceremony than the formal installation rite (nilantiq), while noting that the verb annogasaq described an inauguration in which the ruler stood under the staircase leading into a royal hall specially constructed for the occasion. The installation stone was a sacred spot marking where the tumanurung first descended in Tamalate and one of several ritually important locations in the center of Gowa (Van Eerde 1930). By taking part in this ceremony Sultan Ismail affirmed his direct descent from the tumanurung and thus took his place in the chain of karaeng who ruled Gowa. Like the moment on 21 Sep 1709 when the regalia were brought to him, this occasion was one of several that a new ruler of Gowa underwent as part of the process of becoming karaeng. Indeed, the lontaraq bilang entries suggest there was no single transformative moment in which someone became Gowa's ruler. No consistent ceremonial pattern emerges at each succession, and in general there seems to have been several sets of ritual proceedings that collectively and publicly affirmed the new ruler's status. This inauguration rite may have been of special importance because Ismail's father was the ruler of Boné La Patauq and he may have felt there was political value in emphasizing his right to the position through his maternal grandfather Abdul Jalil.
\end{abstract}


7 Mar $(S)^{528}$

6 Muh 1122

$19 \operatorname{Mar}(\mathrm{R})$

18 Muh 1122

$24 \operatorname{Mar}(\mathrm{T})$

23 Muh 1122

12 Apr (N)

13 Saf 1122

13 Apr (M)

14 Saf 1122

4 May (M)

6 Rawl 1122

16 May (S)

18 Rawl 1122

21 May (R)

23 Rawl 1122

4 Jul (S)

8 Jawl 1122

13 Jul (T)
I Daeng Manaqgalaq Caqdi died in Talloq namate I Daeng Manangalaq Caqdi ri Talloq

I Daeng Manassaq Muhammad circumcised nanisunnaq I Daeng Manassaq Muhammad

Karaeng ri Pangkajeqneq dropped anchor at Ujung Pandang, arriving from Jakattaraq namaqlabu ri Jumpandang Karaengta ri Pangkajeqneq battu ri Jakattaraq

Karaeng ri Pangkajeqneq installed as tumailalang nanitannang tumailalang Karaengta ri Pangkajeqneq

Datu Lokaq [Mas Banten] sailed from Mangasa over to his homeland [on Sumbawa] bringing Karaeng ri Bontoa namamise ri Mangasa Datu Lokaq taqle ri paqrasanganna anngerangi Karaengta ri Bontoa

Governor Heer van Toll arrived nabattu Guranadur Heer Pantul

Daengta Daeng Masiang died at the age of 65 namate Daengta Daeng Masiang umuruqna 65

I Loqmoq, a wife of our karaeng [tumabicarabutta Karaeng Bontosunggu] had a daughter Sitti Hawa, a younger sibling of Karaeng Majannang namammanaq I Loqmoq bainenna karaengta baine Sitti Hawa arinna Karae Majannang

Sulengkaya smeared with blood ${ }^{529}$ as we opposed the people of Boné

naniceraq Sulengkaya kinasongkaang tuBoneya

the arumpone [La Patauq] advanced from Bontoalaq; we faced each other but did not fight

\footnotetext{
528 A copyist mistakenly wrote February instead of March.

529 The banner was strengthened before battle by being consecrated with sacrificial blood, strength that would flow to the warriors who fought beneath Sulengkaya.
} 
17 Jawl 1122

naosong arungpone ri Bontoalaq sidallekanngjaki tamaqbundukapaki

$17 \mathrm{Jul}(\mathrm{W})$

we fought at Pangkajeqneq

18 Jawl 1122

kimaqbunduqmo ri Pangkajeqneq

$20 \mathrm{Jul}(\mathrm{N})$

24 Jawl 1122

a blowdart wounded the karaeng [Ismail] by his nipple namalokoq sappuq batoran susunna karaenga

$25 \mathrm{Jul}(\mathrm{S})$

Dutch fired heavily from their fortifications in Bontomanaiq

29 Jawl 1122 namamaqdiliq lompo Balandaya ri bentenna ri Bontomanaiq

8 Aug (S) Karaeng Katangka [La Padangsajati] brought seawards to the fort with his wife

13 Jakr 1122 nanierang kalauq ri kotaya Karae Katangka sikalabini

$14 \operatorname{Aug}(\mathrm{F})$

19 Jakr 1122

the arumpone [La Patauq] retreated from Jonggaya

$19 \operatorname{Aug}(\mathrm{W})$ namamonoqmo ri Jongaya arungpone

24 Jakr 1122

the Dutch and the Tallu Boccoa [Boné, Wajoq, and Soppéng] retreated from their fortifications

$20 \operatorname{Aug}(\mathrm{R})$ namamonoqmo Balandaya Tallung Boccoa ri bentenna

25 Jakr 1122

Karaeng ri Tana-Tana had a daughter Zainab ${ }^{530}$

$22 \operatorname{Aug}(S)$

27 Jakr 1122 namammanaq Karaengta ri Tana-Tana baine Zainab

24 Aug (M) I Jamboq, a grandparent of I Papuq, died at 102 years of age

29 Jakr 1122 namate I Jamboq toana I Papuq umuruqna 102 taung

8 Oct $(\mathrm{R}) \quad$ Karaeng ri Bontopanno sailed overseas to Jakattaraq to ask forgiveness from the [governor] general ${ }^{532}$

\footnotetext{
530 Ligtvoet (1880:184) notes that it is probably this Zainab who was later titled Karaeng Sumannaq.

531 Probably but not necessarily the Daeng Talele who was Arung Palakka's wife.

532 For fighting against the Bugis and the VOC.
} 
16 Syab 1122 nasimombbalaq Karaengta ri Bontopanno kalauq ri Jakattaraq mapalaq popporoq ri jinarala

\section{1}

$16 \operatorname{Jan}(S)$

27 Zulk 1122 a wife of Karaeng Katangka [La Padangsajati] had a daughter Sitti Rahmah Malimbasanna

namammanaq bainenna Karae Katangka baine Sitti Rahmah Malimbasanna

$28 \mathrm{Feb}(\mathrm{N})$

37 from Selayar, including women, went amuk inside the fort; three escaped

11 Muh 1123 Silayaraq 37 nasiagang baine maqjalloq ilalang ri kotaya tallu lappasaq

9 Apr $(\mathrm{F})$

21 Saf 1123

23 Apr (F)

7 Rawl 1123

9 May (N)

21 Rawl 1123

29 Jun (T)

13 Jawl 1123

19 Jul (M)

4 Jakr 1123

17 Aug $(\mathrm{T})^{535}$

3 Raj 1123

2 Sep (R)

19 Raj 1123
Karaeng ri Bontopanno arrived from Jakattaraq nabattu ri Jakattaraq Karaengta ri Bontopanno

Daengta Daeng Tonji died in Lengkeseq namate Daengta Daeng Tonji ri Lengkeseq

Amirah I Tanitaja, also named I Manengratu ${ }^{533}$, born naanaq Amirah I Tanitaja nikanatodong I Manengratu

I Massallomo Muhammad Syadik Manriogauq ${ }^{534}$ born naanaq I Massallomo Muhammad Syadik Manriogauq

Gallarrang Talloka I Kare Tulusuq died namate Gallarang Talloka I Kare Tulusuq

Gallarrang Saumata died namate Gallarang Saumata

the karaeng [Ismail] and the arumpone [La Patauq] were brought to an agreement by the Dutch nanipasitabamo ri Balandaya karaenga arungpone

533 She was a daughter of Ismail and Karaeng Paqbineang and would later be titled Arung Palakka.

534 A son of Ismail and Sitti Labibah, he was known as Arung Sumaling Matinroe ri Luwuq and was a commander (punggawa) of Boné's troops.

535 A copyist mistakenly wrote July instead of August. 
24 Sep (F)

12 Syab 1123

27 Sep (M)

15 Syab 1123

19 Oct (T)

7 Ram 1123

10 Dec $(F)^{537}$

30 Syaw 1123

15 Zulh 1123

1 Mar (T eve)

23 Muh 1124

$26 \operatorname{Mar}(N)$

19 Saf 1124

13 Apr (W eve) Tumamenang ri Taenga sailed from Taenga up to

Bantaeng, letting go of what he had [brought there] $]^{538}$

birth of Karaeng Tangallaq Sitti Arifah I Tanripadaq ${ }^{536}$ nanianakkang Karae Tangallaq Sitti Arifah I Tanripadaq

people mustered for the installation of [VOC governor] Heer van Toll

namarewangan taua nilantiqna Heer Pantul

the manuscript that would be brought by Karaeng

Garassiq overseas to Jakattaraq was taken down to the ship

nanipanaung ri biseang lontaraq naeranga Karae Garassiq kalauq ri Jakattaraq

Gallarrang Paceqnongang died

namate Gallarrang Paceqnongan

1712

20 Jan (W eve) the karaeng [Ismail] seized Karaeng ri Bontoa's belongings

nanirappun ri karaenga Karaengta ri Bontoa

the people of Boriqsallo, the people of Manuju, the people of Sudiang were given the right to make decisions in their lands

nanisareang tuBoriqsalloa tuManujua tuSudiang bicara ri buttana

I Yabu went amuk in front of a house in Dataq namaqjalloq I Yabu ri dallekanna ballaka ri Dataq

the people were asked by the karaeng [Ismail] for one real per house

nanipappalakki taua ri karaenga sirealaq sibatu ballaq

\footnotetext{
536 A daughter of Sirajuddin and Karaeng Balaqsari.

537 A copyist mistakenly wrote October instead of December.

538 This apparently refers to some of Gowa's kalompoang and is a clear indication that Tumamenang ri Taenga (tumabicarabutta Karaeng Bontosunggu) sought Sultan Ismail's removal as ruler of Gowa and believed that the influence of La Patauq (to whom he brought the regalia in
} 
7 Rawl $1124 \quad$ namamise ri Taenga Tuammenanga ri Taenga manaiq ri Bantaeng tittiq laling-lalingi

14 Apr (R eve) I Daeng Pabila and a child of Gallarrang Mangasa married

8 Rawl 1124 nasikalabini I Daeng Pabila anaqna Gallarrang Mangasa

22 May (R eve) Karaeng Garassiq dropped anchor at Ujung Pandang, arriving from Jakattaraq

6 Rakr $1124^{539}$ namaqlabu ri Jumpandang Karae Garassiq battu ri Jakattaraq

25 May (R) Karaeng Bidara expelled ${ }^{540}$ and I Daeng Talarra replaced him

19 Rakr 1124 nanipasuluq Karaeng Bidara naIDaeng Talarra assambeangi

6 Jun (T)

2 Jawl 1124

$29 \operatorname{Jun}(\mathrm{R})$

25 Jawl 1124

7 Aug (M)

5 Raj 1124

$20 \operatorname{Aug}(\mathrm{N})$

18 Raj 1124
Governor Heer van Toll died

namate Gurnadura Heer Pantul

Karaeng ri Sanrabone Tumamenang ri Rateqna ${ }^{541}$ died; no one replaced him [as ruler of Sanrabone until December] namate Karaenga ri Sanrabone Tuammenang ri Rateqna tenapa assambeangi

Sayyid Zain died and was buried in Barrang namate Sayyid Zain niawang ri Barrang

Tumamenang ri Taenga arrived from Bantaeng with the arumpone [La Patauq]

nabattumo ri Bantaeng Tuammenanga ri Taenga siagaang arungpone

Bantaeng) would allow him to succeed. Nor was he incorrect, for a few days after they returned to Gowa in August Ismail was deposed. Tumamenang ri Taenga had been instrumental in overseeing Ismail's installation in 1709, and the cause of their fallout is not evident from the lontaraq bilang alone.

539 The Hijri date converts to 12 May 1712.

540 In what capacity is not certain, though probably not as one of the two tumailalang.

541 This individual is not mentioned elsewhere in the lontaraq bilang, but presumably replaced Abdul Jalil as Sanrabone's ruler when the former died in 1709. His posthumous name refers to his Islamic devotion, for rateq is the Makassarese pronunciation of the Arabic ratib, the collective recitation of Islamic prayers such as zikir. 
$24 \operatorname{Aug}(\mathrm{R})$

23 Raj 1124

29 Aug (T)

27 Raj 1124

31 Aug (R)

29 Raj $1124^{542}$

4 Sep (T)

4 Syab 1124

10 Sep $(N)$

10 Syab 1124

14 Sep (W eve)

14 Syab 1124

15 Sep (R eve) 15 Syab 1124

16 Sep (F eve)

16 Syab 1124

21 Sep (R)
Karaeng Anaq Moncong expelled [as ruler of Gowa] nanipasuluq Karae Anaq Moncong

the people of Boné, the people of Soppeng, the people of Wajoq arrived and took Karaeng Anaq Moncong and also brought Sudanga and the sunshade over [the river to Taenga] to our karaeng [tumabicarabutta Karaeng Bontosunggu]

nabattu tuBoneya tuSoppenga tuWajoka angallei Karae Anaq Moncong nanierangtommo Sudanga laqlang taqle ri karaengta

the Karaeng ri Talloq [Sirajuddin] installed as Karaeng ri Gowa, replacing Karaeng Anaq Moncong naKaraenga ri Talloq nitannang Karaeng ri Gowa assambeangi Karaeng Anaq Moncong

Gallarrang Cambaya I Kare Kanjaraq died namate Gallarrang Cambaya I Kare Kanjaraq

the karaeng [Sirajuddin] first shaded with the sunshade of Gowa

nauru nilaqlangi karaenga laqlang ri Gowa

I Daeng Manangaraq Layuq died

namate I Daeng Manangaraq Layuq

Karaeng Bontolangkasaq and I Eja married nasikalabini Karae Bontolangkasaq I Eja

Karaeng Anaq Moncong was brought into Cenrana [in Boné] nanierang mantama ri Cenrana Karae Anaq Moncong

Sudanga and Latea ri Duni renewed [our relationship] by being placed side by side in Ballaq Kiria ${ }^{543}$ for the second time

542 A copyist mistakenly wrote the 21st instead of the 29th.

543 This royal hall was first built on 12 Feb 1702 and must be connected to tumabicarabutta Tumamenang ri Taenga, who married a Karaeng ri Ballaq Kiria on 24 Oct 1687 and recently played the key role in expelling Sultan Ismail by forging a closer relationship with the ruler of Boné La Patau. 
21 Syab $1124 \quad$ naniberui nipasiempoang pole Sudanga Lateariduni ri Ballaq Kiria pinruangmi

8 Oct (S) the manuscript that would be brought by Karaeng ri Bontpanno overseas to Jakattaraq was taken down to the ship; it said they had taken the karaeng [of Talloq, Sirajuddin] as Karaeng ri Gowa

7 Ram $1124 \quad$ nanipanaung ri biseang lontaraq naeranga Karaengta ri Bontopanno kalauqna ri Jakattaraq angkana-kanai niallena karaeng ri Gowa karaenga

2 Nov $(W)^{544}$ the karaeng [Sirajuddin] sailed with his wife [Karaeng Balaqsari] up to Bantaeng for the circumcision of I La Useq $^{545}$

2 Syaw 1124 namamise karaenga sikalabini manaiq ri Bantaeng ala nisunnaqna I La Useq

12 Nov (F eve) a celebration of the arumpone [La Patauq] first took place in Bantaeng

12 Syaw 1124 nauru mammempo jagana arungpone ri Bantaeng

$14 \operatorname{Nov}(\mathrm{M}) \quad$ I La Useq circumcised

14 Syaw 1124 nanisunnaq I La Useq

28 Nov $(\mathrm{M}) \quad$ the karaeng [Sirajuddin] landed, arriving from Bantaeng 28 Syaw 1124 nasore karaenga battu ri Bantaeng

$11 \operatorname{Dec}(\mathrm{N}) \quad$ Datu ri Pammana [in Wajoq] taken as karaeng by the people of Sanrabone ${ }^{546}$

12 Zulk 1124 naDatua ri Pammana naalle karaeng tuSanrabonea

$15 \operatorname{Dec}(\mathrm{R}) \quad$ I Tarawe ordered killed by the karaeng [Sirajuddin]; I Daeng Talarra's belongings seized and he was ordered confined to his house by the sabannaraq [Daeng Makkulle] 16 Zulk 1124 nanisuro buno ri karaenga I Tarawe nanirappung I Daeng Talarra nisuro ballaki ri sabannaraq

544 A copyist mistakenly wrote the 7th instead of the 2nd.

545 A son of La Patau.

546 This is testament to the growing importance of the Wajorese community during the period that Amanna Gappa was their matoa or leader in Makassar (see Noorduyn 2000). Wajorese were a Bugis immigrant merchant community living in an autonomous settlement in Makassar, and the selection of one of their members as Sanrabone's ruler must have solidified Sanrabone's maritime trading connections. 
$22 \operatorname{Dec}(\mathrm{R})$ 23 Zulk 1124

12 Jan (W eve)

14 Zulh 1124

$12 \operatorname{Jan}(\mathrm{W})$

14 Zulh 1124

21 Jan (S)

23 Zulh 1124

$24 \operatorname{Jan}(W)$

27 Zulh 1124

8 Feb (T eve)

12 Muh 1125

10 Feb (F)

14 Muh 1125

17 Feb (R eve)

21 Muh 1125

1 Mar (T eve)

3 Saf 1125
I Daeng Talarra ordered brought east to Sandao nanisuro erang manraiq ri Sandawo I Daeng Talarra

\section{3}

Daengta Daeng Nganrenne Datu Doka died namate Daengta Daeng Nganrenne Datu Doka

teeth filed of I Sugi, a child of Karaeng ri Mandalleq, with those of I Nannuq, a child of I Daeng Mangalliq naniariq I Sugi anaqna Karaengta ri Mandalleq siagaang I Nannuq anaqna I Daeng Mangalliq

there was unusual thunder once and just after it boomed like a cannon; at night it happened again naniaq gunturuq maraqmaraeng sikali leqbaqji mangulappaq kamma mariang banngi niaq pole

a wife of Karaeng Katangka [La Padangsajati] had a son named I Andi Andi Muhammad Yusuf namammanaq bainenna Karae Katangka buraqne nikana I Andi Andi Muhammad Yusupu

my ${ }^{547}$ younger uncle Karaeng Patteqne and I Mindaq married

nasikalabini putoku Karae Patteqne I Mindaq

my younger uncle Karaeng Alluq and I Patimaq married nasikalabini putoku Karae Alluq I Patimaq

my younger uncle I Mappatangaraq died and was buried in Tamalate namate potoku I Mappatangaraq ri Tamalatei niawang

Dala Bantaeng 548 died inside Cenrana namate Dala Bantaeng ilalang ri Cenrana

547 Here a lontaraq bilang annalist identifies himself for the first time. The writer is Syafiuddin, a son of Sirajuddin and Karaeng Balaqsari who later became titled Karaeng Lempangang and in 1739 became ruler of Talloq.

548 Dutch sources report that she was a concubine of La Patauq named Rugiah and known as Dala Bantaeng because that was where she was from (Ligtvoet 1880:187-8). 
3 Mar (F)

5 Saf 1125

$31 \operatorname{Mar}(F)$

3 Rawl 1125

7 Apr (R eve)

10 Rawl 1125

$25 \operatorname{Apr}(\mathrm{T})$

28 Rawl 1125

31 May $(W)$

5 Jawl 1125

10 Jun (S)

15 Jawl 1125

21 Jun (W)

26 Jawl 1125

$15 \mathrm{Jul}(\mathrm{S})$

21 Jakr 1125

21 Aug $(\mathrm{M})^{549}$

28 Raj 1125

22 Aug (T) 550

29 Raj 1125

1 Sep (F)

10 Syab 1125
Sitti Labibah died inside Cenrana

namate Sitti Labibah ilalang ri Cenrana

Karaeng ri Bontopanno dropped anchor at Ujung

Pandang, arriving from Jakattaraq

namaqlabu ri Jumpandang Karaengta ri Bontopanno battu ri Jakattaraq

the mother of a great grandparent of I Nimbang died namate anronna boena I Nimbang

the karaeng [Sirajuddin] and his wife [Karaeng Balaqsari] sailed to go into Cenrana

namamise karaenga sikalabini mantama ri Cenrana

it is said that Datu Lokaq [Mas Banten] died nanikana matei Datu Lokaq

Sudanga and Latea ri Duni again placed side by side in Latimojong [a royal hall]; people performed aru for the third time

nanipasiempoang pole Sudanga Latea ri Duni ri

Latimojong mangarui taua pintallungmi

the karaeng [Sirajuddin] landed, arriving from Cenrana nasore karaenga battu ri Cenrana

nayaka I Loqmoq Rannu died

namate nayakaya I Loqmoq Rannu

teeth filed of my younger aunt Karaeng Barong Patola naniariq ayaku Karae Barong Patola

my younger uncle I Pallaq circumcised

nanisunnaq putoku I Pallaq

I Daeng Nganrenne, the mother of I Daeng Masseqre I Papippiq, died

namate I Daeng Nganrenne anronna I Daeng Masseqre I Papippiq 
10 Sep (N) I Daeng Maqleoq I Dulla and Sitti Lele married

19 Syab 1125 nasikalabini I Daeng Maqleoq I Dulla Sitti Lele

10 Oct $(\mathrm{T}) \quad$ I Daeng Tonji died

19 Ram 1125 namate I Daeng Tonji

17 Oct $(\mathrm{T}) \quad$ I Nenuq and I Manyanreri married

26 Ram 1125 nasikalabini I Nenuq I Manyanreri

7 Nov (T) I Manyaq, a child of Karaeng Bontosiamaq 551 , circumcised

17 Syaw 1125 nanisunnaq I Manyaq anaqna Karae Bontosiamaq

$18 \operatorname{Nov}(\mathrm{S}) \quad$ the karaeng [Sirajuddin] revealed to our karaeng [Tumamenang ri Taenga] that Tumanenang ri Jawaya [Najamuddin] would be Karaeng ri Talloq 552

28 Syaw 1125 nanapappasaqbiang karaenga ri karaengta Tuammenang ri Jawaya napataja Karaeng ri Talloq

8 Dec (F)

19 Zulk 1125

I Daeng Manyipi I Uang died namate I Daeng Manyipi I Uan

9 Dec (S)

20 Zulk 1125

a wife of Karaeng ri Lekoqboqdong died namate bainenna Karaengta ri Lekoqboqdong

$22 \operatorname{Dec}(\mathrm{F})$ I Mandaq 553 , a wife of my younger uncle Karaeng Patteqne, had a daughter I Bunga Suttaraq

4 Zulh 1125 namammanaq I Mandaq bainenna putoku Karae Patteqne baine I Bunga Suttaraq

$31 \operatorname{Dec}(\mathrm{N}) \quad$ I Saidi, a child of I Daeng Tapallaq by Sayyid [Zain], circumcised

13 Zulh 1125 nanisunnaq I Saidi anaqna I Daeng Tapallaq ri Sayyidka

1714

5 Jan (R eve) I Kare Mami, a child of our great lord [Shaykh Yusuf], died

551 Karaeng Bontosiamaq, also known as Mappakana Daeng Majanji, was a daughter of Karaeng Beroanging and one of his wives, a daughter of Karaeng ri Bulo-Bulo I Daeng Tatea (Ligtvoet 1880:footnote 188, 200).

552 Tumanenang ri Jawaya was only about five years old at the time.

553 This name was previously spelled Mindaq. 
18 Zulh 1125 namate I Kare Mami anaqna tuan loeta

8 Jan (W) I Daeng Makkappa and my grandparent I Daeng Nisali I Thaibah married

23 Zulh 1125 nasikalabini I Daeng Makkappa toaku I Daeng Nisali I Thaibah

15 Jan (M) Karaeng Balambaru I Daeng Riboko died

28 Zulh 1125 namate Karae Balambaru I Daeng Riboko

18 Jan (W eve) the night of Karaeng ri Bontoa's death across on Reok [on Flores] at the age of 51

1 Muh 1126 banngi nakamateanga Karaengta ri Bontoa ibaqle ri Rouq umuruqna 51

$1 \operatorname{Mar}(\mathrm{R}) \quad$ a child of I Todattia by Kare Tonji I Maqmiq was cut down by a slave of his

13 Saf 1126 nanijalloq ri atanna anaqna I Todattia ri Kare Tonji I Maqmiq

2 Mar (F) a child of I Todattia cut down yesterday died

14 Saf 1126 namatemo anaqna I Todattia nijalloki sabanngi

$9 \operatorname{Mar}(\mathrm{F}) \quad$ Daengta Daeng Marannu I Pandiq died

21 Saf 1126 namate Daengta Daeng Marannu I Pandiq

11 Mar (S eve) I Daeng Manyampaq Balambaru died

23 Saf 1126 namate I Daeng Manyampaq Balambaru

$20 \operatorname{Mar}(\mathrm{T}) \quad$ a karaengship given to I Sugi, now called Karaeng Bisangpole

3 Rawl 1126 nanisare pakkaraengang I Sugi nikana Karae Bisangpole

$12 \operatorname{Apr}(\mathrm{R}) \quad$ the people of Alluq went to my younger uncle Karaeng Alluq

26 Rawl 1126 nanipamange tuAlluka ri putoku Karae Alluq

3 May (R) the coffin of Karaeng ri Bontoa was brought back

18 Rakr 1126 nabattu nierang allunna Karaengta ri Bontoa

19 May (S) the people of Talloq revealed to the Dutch Tumamenang ri Jawaya [Najamuddin] as Karaeng ri Talloq 
4 Jawl 1126 nanapappasaqbiang tuTalloka ri Balandaya Tuammenang ri Jawaya Karaeng ri Talloq

29 May (T) I I Daeng Mabela I Mangassengi died; the ruler of Bima [Mappatalliq] arrived to marry [Karaeng Bisangpole] 14 Jawl 1126 namate I Daeng Mabela I Mangasengi nabattu karaenga ri Dima ala maqbaine

21 Jun (W eve) Karaeng ri Tana-Tana had a son named Muhammad Baki 8 Jakr 1126 namammanaq Karaengta ri Tana-Tana buraqne nikana Muhammad Baki

15 Aug (W eve) a child of my younger uncle Karaeng Alluq named Ummu Kalsyum died

4 Syab 1126 namate anaqna putoku Karae Alluq nikanaya Ummu Kalsyum

1 Sep (F eve) Karaeng ri Pasiq died at the age of 56

21 Syab 1126 namate Karaengta ri Pasiq umuruqna 56

13 Sep (W eve) the ruler of Bima [Mappatalliq] slept with Karaeng Bisangpole

3 Ram 1126 namaqlusereq karaenga ri Dima Karae Bisangpole

16 Sep ( $\mathrm{N}$ eve) Matinroa ri Nagaulang [La Patauq] died at the age of 43; he was placed in a coffin and buried in Bontoalaq

7 Ram 1126 namate Matinroa ri Nagaulan umuruqna 43 nibenei ri allung naniawang ri Bontoalaq

19 Sep (R) Karaeng ri Mamampang taken as karaeng by the people of Sanrabone

10 Ram 1126 naKaraengta ri Mamampang naalle karaeng tuSanrabonea

15 Oct (M) a karaengship given to Tumamenang ri Jawaya [Najamuddin], now called Karaeng Kanjilo

5 Syaw 1126 nanisare pakkaraengang Tuammenanga ri Jawaya nikana Karae Kanjilo

$6 \operatorname{Nov}(\mathrm{T})$ namammanaq toaku I Daeng Nisali I Thaibah buraqne 
$8 \mathrm{Nov}(\mathrm{R}) \quad$ the coffin of Matinroa ri Nagaulang [La Patauq] was dug up and brought into Cenrana

29 Syaw 1126 nanikekesseq allunna Matinroa ri Nagaulan nierang mantama ri Cenrana

$18 \operatorname{Dec}(\mathrm{T}) \quad$ the people of Lempangang went to myself [Syafiuddin]

10 Zulh 1126 nanipamae ri nakke tuLempanganga

19 Dec (W) Daengta Daeng Majarreq Camme died

11 Zulh 1126 namate Daengta Daeng Majarreq Camme

$20 \mathrm{Dec}(\mathrm{R}) \quad$ it is said that the arumpone ${ }^{554}$ and Datu ri Ulawang 555

divorced

12 Zulh 1126 nanikana sipelaki arungpone Datua ri Ulawang

21 Dec (R eve) I Kare Rannu, a widow of Puanna I Daeng, died

13 Zulh 1126 namate I Kare Rannu balunna Puanna I Daeng

31 Dec (M) a karaengship given to my mother, now called Karaeng Balaqsari

23 Zulh 1126 nanisare pakkaraengang ayaku nikana Karae Balassari

1715

$8 \operatorname{Mar}(\mathrm{F}) \quad$ a wife of Karaeng Katangka [La Padangsajati] had a son named Madyan I Mappasonriq

2 Rawl 1127 namamanaq bainenna Karae Katangka buraqne nikana Madyan I Mappasonriq

$15 \operatorname{Mar}(\mathrm{F}) \quad$ the people of Soppéng arrived to take Karaeng Katangka [La Padangsajati] as ruler

9 Rawl 1127 nabattu tuSoppenga angallei karaeng Karae Katangka

$17 \operatorname{Mar}(\mathrm{N}) \quad$ two suns were seen

11 Rawl 1127 naniciniq rua matanna alloa

19 Mar (F eve) I Daeng Maqleoq I Dulla and Sitti Lele divorced

13 Rawl 1127 nasipelaq I Daeng Maqleoq I Dulla Sitti Lele

554 Batari Toja Matinroe ri Tippulunna, La Patau's daughter who briefly succeeded him as ruler of Boné.

555 He was a Boné noble named Pabukajuwe (Ligtvoet 1880:190). 
$23 \operatorname{Mar}(S)$

17 Rawl 1127

I Judda, a child of Karaeng ri Mandalleq, died

$2 \operatorname{Apr}(\mathrm{T})$

27 Rawl 1127

namate I Judda anaqna Karaengta ri Mandalleq

7 Apr (S eve) I Sitti and Karaeng Tallampuang married

3 Rakr 1127

Arung Tanete ${ }^{556}$ and his wife ${ }^{557}$ arrived from Toraja nabattu ri Toraja Aruq Tanete sikalabini

10 Apr (T eve) Gallarrang Talloka I Biqduq died; the following day Karaeng Lambengi died

6 Rakr 1127 namate Gallarang Talloka I Biqduq ammuko ri alloya namate Karae Lambengi

13 Apr (S) I Kare Tonji I Maqmiq died

9 Rakr 1127 namate I Kare Tonji I Maqmiq

19 Apr (R eve) I Salamah died

15 Rakr 1127 namate I Salamah

4 May (F eve) Karaeng Bulukumba and I Daeng Nisoqna married 30 Rakr 1127 nasikalabini Karaeng Bulukumba I Daeng Nisoqna

6 May (M) I Ninuq and Watanglipua married

3 Jawl 1127 nasikalabini I Ninuq Watanglipua

15 May (W) Datu ri Soppéng [La Padangsajati] sailed from Ujung Pandang to go into Soppéng

12 Jawl 1127 namamise ri Jumpandang Datua ri Soppeng mantama ri Soppeng

20 May (M) I Daeng Nisayu, a wife of I Tuang Rappang, died 17 Jawl 1127 namate I Daeng Nisayu bainenna I Tuan Rappan

23 May (W eve) I Daeng Maqleoq and Sitti Lele returned to each other 20 Jawl 1127 nasipolei I Daeng Maqleoq Sitti Lele

27 May ( $\mathrm{N}$ eve) a wife of I Daeng Tulolo I Mangiq had a daughter 24 Jawl 1127 namamanaq bainenna I Daeng Tulolo I Mangiq baine

556 Daeng Mangemba, grandfather of La Padangsajati.

557 Karaeng Bontorambaq. 
1 Jun (S) my grandparent $\quad$ m58 I Daeng Maqleoq I Sumang [begins to] oversee the lesser anaq karaeng

29 Jawl 1127 natoaku I Daeng Maqleoq I Suman anjannanngi anaq karaeng salaya

3 Jun (M) a wife of my younger uncle Karaeng Bontolangkasaq had a son

1 Jakr 1127 namamanaq bainenna putoku Karae Bontolangkasaq buraqne

18 Jun (T) I Sumailiq, a grandchild of Karaeng ri Taruq, circumcised 16 Jakr 1127 nanisunnaq I Sumailiq cucunna Karaengta ri Taruq

9 Jul (T) my older uncle 559 arrived from Pulo Laut [an island off

7 Raj $1127 \quad$ nabattu puangku ri Lauq-pulo

18 Jul (R) my older uncle Karaeng Boqdia installed as lord in Talloq 560

16 Raj 1127 nanitannang malompo ri Talloq puangku Karae Boqdia

5 Aug (M) Datu ri Soppéng [La Padangsajati] made ruler of Boné by [his half-sister] Datu ri Citta, taking back the rulerships of Citta along with Timurung

4 Syab 1127 naDatua ri Soppeng nipakakaraeng ri Bone ri Datua ri Citta mamotereqmia mange ri kakaraenganna ri Citta siagaang ri Timurung

$8 \operatorname{Aug}(\mathrm{W})$

7 Syab 1127

$10 \operatorname{Aug}(\mathrm{S})$

10 Syab 1127
I Daeng Tamami died

namate I Daeng Tamami

I Paciq ${ }^{561}$ and I Sugi married nasikalabini I Paciq I Sugi

558 Makassarese frequently use kinship terms as honorifics. In the lontaraq bilang entries written by Karaeng Lempangang this is often the case with 'my grandparent' (toaku). His grandparents were Sultan Abdul Kadir and Karaeng ri Parang-Parang on one side, and Arung Teko and Daeng Nisayu I Thaibah on the other. Yet a wide variety of elders, beginning with I Daeng Maqleoq in this entry, are called 'grandparent' as a sign of respect and kinship. In general Karaeng Lempangang uses the kinship terms for uncles, aunts, and siblings with more precision.

559 This was Daeng Mammuntuli Arung Kaju (Ligtvoet 1880:190).

560 Dutch sources report that he became the formal guardian of the young ruler of Talloq Tumamenang ri Jawaya, and it is apparently this to which this entry refers (Ligtvoet 1880:190).

561 Also or later known as Daeng Manassaq. 
15 Aug (R) Karaeng Majannang circumcised; this the day that the arumpone [La Padangsajati] had a sunshade raised over his head

15 Syab 1127 nanisunnaq Karae Majannang iaminne alloya nanipirangkaki payung arungpone

2 Sep (N eve) I Patimaq had a son by my younger uncle Karaeng Alluq

3 Ram 1127 namamanaq I Patimaq ri putoku Karae Alluq buraqne

6 Sep (F) a karaengship name given to my younger ${ }^{562}$ uncle [Fathuddin], now called Karaeng Patteqne

7 Ram 1127 nanisare areng pakkaraengang puangku nikana Karae Patteqne

10 Oct (W eve) I Saidi, a child of I Daeng Tapallaq by Sayyid [Zain], died 11 Syaw 1127 namate I Saidi anaqna I Daeng Tapallaq ri Sayyidka

29 Oct (T) a wife of my younger uncle Karaeng Patteqne had a son

1 Zulk 1127 namamanaq bainenna putoku Karae Patteqne buraqne

$10 \operatorname{Nov}(\mathrm{N}) \quad$ I Kare Mamo, a child of our great lord I Daengta [Shaykh Yusuf] died

13 Zulk 1127 namate I Kare Mamo anaqna Tuang Loeang I Daengta

$16 \operatorname{Dec}(\mathrm{M}) \quad$ I Manrewakki, a child of I Pappi, and a child of I Daeng Mattulung married

19 Zulh 1127 nasikalabini I Manrewakki anaqna I Pappi naanaq I Daeng Mattulung

19 Dec (W eve) Karaeng ri Manuruki died

22 Zulh 1127 namate Karaengta ri Manuruki

1716

15 Jan (M eve) Karaeng Ujung I Daeng Nisanga and I Poqdo married

19 Muh 1128 nasikalabini Karae Ujung I Daeng Nisanga I Poqdo

17 Jan (R eve) Karaeng Bontotannga and I Ranti married; after only twenty-five nights they divorced

22 Muh 1128 nasikalabini Karae Bontotannga I Ranti ruampulo banngiji allima nasipelaq 
$11 \mathrm{Feb}(\mathrm{T})$

17 Saf 1128

$18 \mathrm{Feb}(\mathrm{T})$

24 Saf 1128

$20 \mathrm{Feb}(\mathrm{R})$

26 Saf 1128

$21 \mathrm{Feb}(\mathrm{F})$

27 Saf 1128

$19 \operatorname{Mar}(\mathrm{R})$

24 Rawl 1128

5 Apr (S eve)

12 Rakr 1128

$14 \operatorname{Apr}(\mathrm{T})$

21 Rakr 1128

$20 \operatorname{Apr}(\mathrm{M})$

27 Rakr 1128

$22 \operatorname{Apr}(\mathrm{W})$

29 Rakr 1128

8 May $(\mathrm{F})$

16 Jawl 1128

9 May (S)
I Daeng Manyampaq Sengoroq died namate I Daeng Manyampaq Sengoro

the arumpone [La Padangsajati] went down to and attacked Peneki [in Wajoq] nanipanaungi Peneki nibunduq ri arungpone

people warred briefly and Peneki was burned namaqbunduq taua sinampereq nanisussuluqmo Peneki

I Daeng Manaiq killed by the arumpone [La Padangsajati] nanibuno I Daeng Manaiq ri arungpone

the day a great grandparent of the karaeng [Sirajuddin] died across on Bima

allo nakamateanga boena karaenga ibaqle ri Dima

my grandparent I Daeng Nisali had a son namamanaq toaku I Daeng Nisali buraqne

the arumpone [La Padangsajati] landed, arriving from Cenrana for the first time as ruler of Boné nasore arungpone battu ri Cenrana uru karaenna ri Bone

my younger uncle Karaeng Bontolangkasaq and I Eja divorced nasipelaq putoku Karae Bontolangkasaq I Eja

the suns rays were shaded as if one wanted to [with ones hand]; darkness fell at the stroke of 5 and lasted one hour; Karaeng Alluq and I Patimaq divorced nakasapukang singaraqna matanna alloya kammai tueroq pattang mattunruq ri 5 garigantaya makaraqgai sijaang nasipelaq Karae Alluq I Patimaq

Karaeng ri Tuang Pandiq died namate Karaengta ri Tuan Pandiq

Karaeng ri Batangnionjoq [in Tanete] Matinroa ri Sumpangpoba ${ }^{563}$ died 
17 Jawl 1128 namate Karaengta ri Batangnionjoq Matinroa ri Sumpangpoba

15 May (R eve) I Pande and I Ranti married

22 Jawl 1128 nasikalabini I Pande I Ranti

23 May (F eve) my mother [Karaeng Balaqsari] divorced by the karaeng [Sirajuddin]

1 Jakr 1128 nanipelaq ayaku ri karaenga

28 May (R) my younger uncle Karaeng Patteqne and I Mindaq divorced

6 Jakr 1128 nasipelaq putoku Karae Patteqne I Mindaq

18 Jun (R) my older uncle Karaeng Boqdia and I Maimunah married 27 Jakr 1128 nasikalabini puangku Karae Boqdia I Maimunah

18 Jun (R) the karaeng [Sirajuddin] and Sitti Abidah Daeng Mateqne, 564 the mother of I Manimbang, married

27 Jakr 1128 nasikalabini karaenga ayana I Manimbang Sitti Abidah Daeng Mateqne

$16 \mathrm{Jul}(\mathrm{R}) \quad$ the coffin of a great grandparent of the karaeng [Sirajuddin] was brought back

26 Raj 1128 nabattu nierang alunna boena karaenga

$20 \mathrm{Jul}(\mathrm{M}) \quad$ Sudanga and Latea ri Duni again placed side by side in Ballaq Kiria for the fourth time

30 Raj 1128 nanipasiempoang pole Sudanga Latea ri Duni ri Ballaq Kiria makapingappaqna

$21 \mathrm{Jul}(\mathrm{T}) \quad$ work begun on the walls of a mosque

1 Syab 1128 nanipakaramula nijama batana masigika

24 Aug (M) Karaeng Binoang was cut down by a slave of his seawards in Ujung Pandang; after the next day he died 6 Ram 1128 nanijalloq Karae Binoang ri atanna ilauq ri Jumpandang ammukopa namate 
1 Sep (T) I Sitti, a wife of Karaeng Tallampuang, had a child

14 Ram 1128 namamanaq I Sitti bainenna Karae Tallampuang

8 Sep (T) my mother Karaeng Balaqsari and Arung Ujung married

21 Ram 1128 nasikalabini ayaku Karae Balassari Arung Ujung

11 Sep (F) I Loqmoq [Dayang], the mother of Karaeng ri Mangalliq, died

24 Ram 1128 namate I Loqmoq anronna Karaengta ri Mangalliq

12 Sep (S) tumailalang Karaeng ri Lekoqboqdong and I Daeng Tasami divorced

25 Ram 1128 nasipelaq tumailalang Karaengta ri Lekoqboqdong I Daeng Tasami

17 Sep (R) a wife of Karaeng Batupute had a son

30 Ram 1128 namamanaq bainenna Karae Batuputeh buraqne

28 Sep (N eve) Karaeng Bontomateqne taken as Karaeng ri Jipang

11 Syaw 1128 naKarae Bontomateqne niallei karaeng ri Jupang

1 Oct (R) it is said that I Daeng Manruppai I Okang killed across on Bima

14 Syaw 1128 nanikana nibunoi I Daeng Manruppai I Okang ibaqle ri Dima

8 Oct (R) people mustered for the installation of [VOC] Governor Sipman

21 Syaw 1128 namarewangan taua nilantiaqna Gurnadur Sipman

23 Oct (F) it is said that my younger uncle Karaeng Panaikang and I Daeng ri Ekong divorced

7 Zulk 1128 nanikana sipelaki putoku Karae Panaikang I Daeng ri Ekong

17 Nov (T) I Maimunah, a wife of my older uncle Karaeng Boqdia, died

2 Zulh 1128 namate I Maimunah bainenna puangku Karae Boqdia

$28 \mathrm{Nov}(\mathrm{S}) \quad$ I Pande and I Ranti divorced

14 Zulh 1128 nasipelaq I Pande I Ranti 
1717

11 Jan (M) my younger uncle Karaeng Patteqne married my younger aunt I Patimaq; Karaeng ri Kaballokang died

28 Muh 1129 nasikalabini putoku Karae Patteqne ayaku I Patimah namate Karaeng ri Kaballokang

20 Jan (W) tumailalang Karaeng ri Lekoqdoqdong and I Daeng Tasami divorced 565

7 Saf 1129 nasipelaq tumailalang Karaengta ri Lekoqdoqdong I Daeng Tasami

24 Jan (S eve) Sitti Lele died

11 Saf 1129 namate Sitti Lele

25 Jan $(M)^{566} \quad$ a replacement 'carved house' built in Bontoalaq 567

12 Saf 1129

nanibangun sambenna ballaq niukirika ri Bontoalaq

28 Jan (R)

15 Saf 1129

Arung Mampu and I Tuguq married

nasikalabini Arung Mampu I Tuguq

30 Jan (F eve) a child of a slave of Karaeng Garassiq named Abdul Muqmin died 568

17 Saf 1129 namate anaq ri atanna Karae Garassiq nikanaya Abdul Muqmin

18 Feb (R) I Mattayang and my grandparent I Daeng Mateqne I Sitti ${ }^{569}$ married

6 Rawl 1129 nasikalabini I Mattayang toaku I Daeng Mateqne I Sitti

23 Feb (T) I Mappapoke, a child of Karaeng Alluq, died

11 Rawl 1129 namate I Mappapoke anaqna Karae Alluq

26 Apr (M) I Kare Parampang I Caccaq and I Saidah married

14 Jawl 1129 nasikalabini I Kare Parampang I Caccaq I Saidah

565 They previously divorced on 12 Sep 1716 and must have returned briefly to each other.

566 A copyist mistakenly wrote the 15th instead of the 25th.

567 The original structure was built on 27 Jun 1652.

568 Karaeng Garassiq was presumably the father.

569 This is apparently not the Daeng Mateqne named Sitti Abidah who married Sirajuddin on 18 Jun 1716. 
3 May (M) teeth filed of I Aciq

21 Jawl 1129 naniariq I Aciq

5 May (W) my great grandparent I Daeng Nisimba I Rabiah died 23 Jawl 1129 namate boeku I Daeng Nisimba I Rabbiah

13 May (R) I Maqdaung and my younger aunt Karaeng Barong Patola married

2 Jakr 1129 nasikalabini I Maqdaun ayaku Karae Barong Patola

31 May (N eve) Karaeng Alluq and I Daeng Tongi married

20 Jakr 1129 nasikalabini Karae Alluq I Daeng Tongi

11 Jun (F) tumailalang Karaeng ri Mandalleq died

2 Raj $1129 \quad$ namate tumailalang Karaengta ri Mandalleq

14 Jun (M) coverings of the banners replaced 570

5 Raj 1129 nanisambei lekoqna cindea

21 Jun (M) the people of Mandalleq went to Kapparaq ${ }^{571}$, now called Karaeng Tumaqlalang

12 Raj 1129 nanipamange tuMandalleka ri Kapparaq nanikana Karae tumaqlalang

24 Jun (R) Karaeng Lekoqboqdong installed as tumailalang

15 Raj 1129 nanitannang tumailalang Karae Lekoqboqdong

25 Jun (F) Karaeng Sanrabone [Karaeng Mamampang] and Karaeng ri Tana-Tana divorced

16 Raj 1129 nasipelaq Karae Sanrabone Karaengta ri Tana-Tana

26 Jun (S) Gurudaya $\quad$ G72 $\quad$ smeared with blood and the people of Gowa mustered for the karaeng's [Sirajuddin's] journey into

Baroko [in Toraja]

17 Raj 1129 naniceraq Gurudaya namarewangan tuGowaya lamantamana karaenga ri Baroko

570 On 16 Nov 1709 this ceremonial practice was tied to the installation of a new ruler of Gowa, and here it may be connected to the death of tumailalang Karaeng ri Mandalleq.

571 A son of Karaeng Mandalleq.

572 Like Sulengkaya, this was a banner mentioned first mentioned in the Gowa Chronicle during the reign of Tumapaqrisiq Kallonna as one of Gowa's 'Three Gaukang'. 
29 Jun (T) the karaeng [Sirajuddin] sailed to go into Toraja with the arumpone [La Padangsajati]

20 Raj 1129 namamise karaenga mantama ri Toraja siagaang arumpone

$16 \mathrm{Jul}(\mathrm{N})$

1 Syab 1129

in Panaikang people mustered in great numbers again nari Panaikang taua marewangan lompo pole

7 Aug (S)

a cave in Tungko collapsed

29 Syab 1129

nanabangka leanga ri Tungko

10 Aug (T)

2 Ram 1129

I Parukka, maqdika573 of Baroko, submitted namanyomba I Parukka Maqdikaya ri Baroko

3 Sep $(F)$

26 Ram 1129

the karaeng [Sirajuddin] landed, arriving from Baroko nasore karaenga battu ri Baroko

$13 \operatorname{Sep}(\mathrm{M})$

7 Syaw 1129

Karaeng ri Kampong Beru died namate Karaengta ri Kampong Beru

17 Sep (F) word arrived of the death of Daengta Daeng Talebang below in Binoang

11 Syaw 1129 nabattu nipabiritta matena Daengta Daeng Talebang irawa ri Binoang

20 Sep (M) Karaeng Parangbone went over to Bima; Karaeng Bontomateqne too

14 Syaw 1129 namaqlampa Karae Parangbone taqle ri Dima Karae Bontomateqne tong

28 Sep (T) I Daeng Tasannging I Taloq died

22 Syaw 1129 namate I Daeng Tasannging I Taloq

27 Oct $(W)$

I Mattaq ${ }^{574}$ and my elder sibling Karaeng Tanasanga ${ }^{575}$ were pledged to each other

573 This chiefly title was used by some Central Sulawesi and Malukan groups, those that Ligtvoet (1880:193) termed 'Alfur'.

574 A son of La Padangsajati also known as Abdurrahman I Mappatawang. I Mattaq's mother may have been Zainab, a daughter of Karaeng Bontorambaq and Daeng Mangemba born on 2 Aug 1693. Four children of La Padangsajati are mentioned in the lontaraq bilang, but their mother (or mothers) are not named.

575 A daughter of Sirajuddin and Karaeng Balaqsari also known as Mahbubah Mamuncaragi. 
22 Zulk 1129 nanipasibayuanngan I Mattaq daengku Karae Tanasanga

31 Oct (S eve) my mother [Karaeng Balaqsari] died at the age of 34

26 Zulk 1129 namate ayaku umuruqna 34

3 Nov (T eve) I Kare Mangalle, anrongguru of the anaq buraqne ${ }^{576}$, died

29 Zulk 1129 namate I Kare Mangalle anrongguru anaq buraqne

8 Nov (M) I Daeng Manassaq Paciq and I Sugi divorced

4 Zulh 1129 nasipelaq I Daeng Manassaq Paciq I Sugi

23 Nov (M eve) the karaeng [Sirajuddin] celebrated [fulfilling] his vow on his arrival from Toraja

20 Zulh 1129 najaga karaenga tinjaqna battuna ri Toraja

$2 \operatorname{Dec}(\mathrm{R}) \quad$ my grandparent I Daeng Maingaq and my grandparent I Daeng Mangagaang divorced

29 Zulh 1129 nasipelaq toaku I Daeng Maingaq toaku I Daeng Mangagaang

$7 \mathrm{Dec}(\mathrm{T}) \quad$ a house was built for the karaeng [Sirajuddin] down here in Katangka so Ballaq Kiria could be torn down

4 Muh 1130 nanibangun ballaqna karaenga irawa mae ri Katangka lanigesaraqna Ballaq Kiria

$11 \operatorname{Dec}(\mathrm{S}) \quad$ I Patimaq, a wife of my younger uncle Karaeng Patteqne, had a son named I Mappabangung Abdul Aziz

8 Muh 1130 namamanaq I Patima bainenna putoku Karae Patteqne buraqne nikana I Mappabangun Abdul Aziz

1718

11 Jan (T) Muhammad Saleh, a child of the elder Ratu Bagus, circumcised

9 Saf 1130 nanisunnaq Muhammad Saleh anaqna Ratu Bagusuq matoa

27 Jan (W eve) I Daeng Manyampaq Alluq died

25 Saf $1130 \quad$ namate I Daeng Manyampaq Alluq

$4 \mathrm{Feb}(\mathrm{F}) \quad$ the arumpone [La Padangsajati] went up into his new house 
3 Rawl 1130 namanaiqmo ri ballaq beruna arungpone

$14 \mathrm{Feb}(\mathrm{N}$ eve) I Loqmoq Galorang, the mother of the elder Karaeng ri Mandalleq, died

12 Rawl 1130 namate I Loqmoq Galorang anronna Karaengta ri Mandalleq motoaya

$15 \mathrm{Feb}(\mathrm{W}) \quad$ I Daeng Manassaq I Muhammad and I Sugi married 14 Rawl 1130 nasikalabini I Daeng Manassaq I Muhammad I Sugi

2 Mar (W) a ship landed bringing my grandparent Arung Teko, arriving after being exiled from Ceylon

29 Rawl 1130 nasore kappalaq angerangai toaku Aruq Teko battuna nipelaq ri Selang

4 Mar (R eve) I Daeng Maingaq, an older sibling of the sabannaraq [Daeng Makkulle], died; I Daeng Nisanga I Puqdo577 had a son

2 Rakr $1130 \quad$ namate I Daeng Maingaq kakanna sabannaraka namamanaq I Daeng Nisanga I Puqdo buraqne

5 Mar (F) my younger uncle I Kalingkeriq circumcised by Karaeng ri Taruq

3 Rakr 1130 nanisunnaq putoku I Kalingkeriq ri Karaengta ri Taruq

6 Mar (F eve) Karaeng Bontolangkasaq and his wife fled seawards to Kampong Beru

3 Rakr $1130 \quad$ namalari Karae Bontolangkasaq sikalabini kalauq ri Kampong Beru

$14 \operatorname{Apr}(\mathrm{R}) \quad$ I Maimunah, a child of Daengta Daeng Mangaungi by a child of an orang kaya, died

14 Jawl 1130 namate I Maimunah anaqna Daengta Daeng Mangaungi ri anaqna orangkaya

4 May $(\mathrm{W}) \quad$ Anciq Jenalaq died in Talloq

4 Jakr $1130 \quad$ namate Anciq Jenalaq ri Talloq

18 May (W) Sayyid Husain, a child of I Daeng Tapallaq, circumcised

577 Possible but not necessarily the Daeng Nisanga mentioned on 18 Jun 1706. 
18 Jakr 1130 nanisunnaq Sayyid Husin anaqna I Daeng Tapallaq

24 May (T) teeth filed of my elder sibling Karaeng Tabaringang by the

24 Jakr 1130 naniariq daengku Karae Tabaringan ri arungpone

25 May (T eve) a wife of the arumpone [La Padangsajati] had a son who after just one night died

25 Jakr 1130 namamanaq bainenna arungpone buraqne sipattangji namate

28 May (S) it is said that a great wind struck Selayar

28 Jakr 1130 nanikana natabai angin lompo Silayaraq

3 Jun ( $\mathrm{R}$ eve) a karaengship given to my elder sibling, now called

Karaeng Tabaringang

5 Raj $1130 \quad$ nanisare pakkaraengang daengku nikana Karae

Tabaringan

8 Jun (W) it is said that Karaeng Barong Patola ${ }^{579}$ died across on

10 Raj 1130 nanikana matei Karae Barongpatola ibaqle ri Sambawah

24 Jun (R eve) my grandparent Arung Teko died

26 Raj $1130 \quad$ namate toaku Aruq Teko

24 Jun (F) I Shaykh installed as kadi

26 Raj $1130 \quad$ nanitannang kadhi I Syeikh

18 Jul (N eve) I Daeng Mangewai I Wasing and I Kare Tonji I Baedah married

19 Syab 1130 nasikalabini I Daeng Mangewai I Wasing I Kare Tonji I Baedah

578 Karaeng Tabaringang was a daughter of Sirajuddin and his wife Karaeng Majannang, and thus this ceremony was one of several during these years intended to strengthen the political relationship between the rulers of Gowa and Boné. The engagement of La Padangsajati's son I Mattaq and Sirajuddin's daughter Karaeng Tanasanga on 27 Oct 1717 should be viewed in the same light, as should Sirajuddin's participation in La Padangsajati's expedition to Toraja the same year and the periodic rituals in which the regalia swords Sudanga and Latea ri Duni were placed side by side in testament to the two kingdom's unity.

579 This is not Karaeng Lempangang's younger aunt, but the previous holder of this karaengship. 
$18 \mathrm{Jul}(\mathrm{M}) \quad$ it is said that I Mangiq, a child of I Daeng Mabela I Mangassengi, died across on Sandao

19 Syab 1130 nanikana matei I Mangiq anaqna I Daeng Mabela I Mangasengi ibaqle ri Sandao

$24 \mathrm{Jul}(\mathrm{N})$

25 Syab 1130

Daengta Daeng Talele, a child of Karaeng ri Taruq, died namate Daengta Daeng Talele anaqna Karaengta ri Taruq

31 Jul (S eve) I Daeng Kenna, a younger sibling of Karaeng ri Laikang, died

3 Ram $1130 \quad$ namate I Daeng Kenna arinna Karaengta ri Laikang

5 Aug (F) birth of I Mappatimung Wajihuddin

8 Ram 1130

nanianakkang I Mappatimung Wajihuddin

22 Aug (M) it is said that I Opu, widow of Datu ri Luwuq Matinroa ri Tompotikkaq, died

25 Ram 1130 nanikana matei I Opu balunna Datuya ri Luwuq Matinroya ri Tompoqtikkaq

25 Aug (W eve) my grandparent I Daeng Nisali I Thaibah had a son who reached just 12 nights of age

28 Ram 1130 namamanaq toaku I Daeng Nisali I Thaibah buraqne 10 banngiji anrua umuruqna

31 Aug (W) Karaeng Sanrabone [Karaeng Mamampang] was brought by the arumpone [La Padangsajati] here to the karaeng [Sirajuddin] as he went to the Dutch ${ }^{580}$

4 Syaw 1130 nanierang ri arungpone mae ri karaenga Karae Sanrabone mangena ri Balandaya

4 Sep (N) teeth filed of I Mangeranngi, a child of I Daeng Mallimpo, who was then celebrated

8 Syaw 1130 naniariq I Mangeranngi anaqna I Daeng Mallimpo nipaqjagangi

9 Sep (R eve) I Daeng Tommi and Karaeng Batupute divorced but returned to each other later

580 La Padangsajati brought Karaeng Mamampang, the ruler of Sanrabone, to Sirajuddin to ask forgiveness because Karaeng Mamampang earlier had sought Dutch intervention against Sirajuddin in a political struggle involving Sirajuddin and the Sanrabone noble Karaeng Lauq and his son Karaeng Manjalling (Ligtvoet 1880:194-5). 
13 Syaw 1130 nasipelaq I Daeng Tommi Karae Batuputeh sipoleiji salla

17 Sep (F eve) my grandparent I Daeng Mateqne I Sitti had a son 21 Syaw 1130 namamanaq toaku I Daeng Mateqne I Sitti buraqne

26 Sep (N eve) the karaeng [Sirajuddin] gave a celebration after I Mappatimung was fed 581

2 Zulk $1130 \quad$ namamempo jagana karaenga leqbaqna nipaemuq I Mappatimung

28 Sep (T eve) I Simba, a chambermaid, stabbed outside the grounds of Ballaq Kiria

3 Zulk $1130 \quad$ nanitoboq I Simba turibiliq ipantaranna embana Ballaq Kiria

2 Oct (N) a manuscript arrived from my younger uncle Karaeng Panaikang on Sumbawa saying that my younger aunt Karaeng Pasiq had been divorced [by the ruler of Sumbawa, Ammasaq]

7 Zulk $1130 \quad$ nabattu lontaraqna putoku Karae Panaikang ri Sambawah angkana nipelaqmi ayaku Karae Pasiq

7 Oct (F) I Mattaq and my elder sibling Karaeng Tanasanga separated [after having been pledged to each other]

12 Zulk 1130 nanipasisala I Mattaq daengku Karae Tanasanga

20 Oct (W eve) my younger uncle Karaeng Patteqne sailed over to Sumbawa to fetch my younger aunt Karaeng Pasiq

25 Zulk $1130 \quad$ namamise putoku Karae Patteqne taqle ri Sambawa angallei ayaku Karae Pasiq

23 Oct (S eve) the arumpone [La Padangsajati] sailed down to Mandar 28 Zulk 1130 namamise arungpone manaung ri Mandaraq

4 Nov (R eve) my younger uncle [Karaeng Panaikang] arrived from Sumbawa and fetching my younger aunt

11 Zulh $1130 \quad$ nabattu ri Sambawa putoku angallei ayaku

$13 \operatorname{Nov}(\mathrm{N}) \quad$ I Daeng Makkulle I Mappaq and I Nannuq married

581 This ritual (paemuq) marked took place some weeks (in this case a little under two months) after the child's birth. The child first tasted a small amount of mashed food placed in its mouth. 
20 Zulh 1130 nasikalabini I Daeng Makkulle I Mappaq I Nannuq

16 Nov (W) the arumpone [La Padangsajati] arrived from Mandar with pustules 582

22 Zulh 1130 nabattu ri Mandaraq arungpone apurui

25 Nov (M) I Daeng Mamo, formerly Karaeng ri Katapang, died

4 Muh 1131 namate I Daeng Mamo leqbaka Karaeng ri Katapang

8 Dec (N eve) I Daeng Masseqre I Papippiq and I Boaq married

14 Muh 1131 nasikalabini I Daeng Masseqre I Papippiq I Boaq

20 Dec $(\mathrm{T}) \quad$ the karaeng [Sirajuddin] occupied his house

26 Muh 1131 naniempoimo ballaqna karaenga

22 Dec (R) I Daeng Nisabeng and I Habibah married

28 Muh 1131 nasikalabini I Daeng Nisabeng I Habibah

2 Jan (M) my aunt I Daeng Tacuah I Patimaq, a wife of my younger uncle [Karaeng Patteqne], had a son

10 Saf 1131 namamanaq ayaku I Daeng Tacuah I Patimaq bainenna putoku buraqne

26 Jan (R) I Sumailiq and I Banri married

4 Rawl 1131 nasikalabini I Sumailiq I Banri

$14 \mathrm{Feb}(\mathrm{T}) \quad$ Karaeng Bontolangkasaq ordered expelled overseas

23 Rawl 1131 nanikalauq nisuro pasuluq Karae Bontolangkasaq

$19 \mathrm{Feb}(\mathrm{N}) \quad$ I Daeng Tulolo and I Aciq married

28 Rawl 1131 nasikalabini I Daeng Tulolo I Aciq

$20 \mathrm{Feb}(\mathrm{M}) \quad$ I Dorra and I Mida Bungko married

29 Rawl 1131 nasikalabini I Dorra I Mida Bungko

1 May (N eve) I Daeng Manassaq I Paciq and I Salira married 11 Jakr 1131 nasikalabini I Daeng Manassaq I Paciq I Salira

582 Probably smallpox. 
13 May (F eve) I Alija, a sibling of I Daeng Majannang, died

23 Jakr 1131 namate I Alija saqribattanna I Daeng Majannang

14 May (S eve) I Arapa, a child of I Daeng Mami, died

24 Jakr 1131 namate I Arapa anaqna I Daeng Mami

19 May (R eve) a wife of tumailalang Karaeng ri Lekoqboqdong had a son

29 Jakr 1131 namamanaq bainenna tumailalang Karaengta ri Lekoqboqdong buraqne

25 May (W eve) a wife of the arumpone [La Padangsajati] had a son I Mappasussung who reached just 6 months of age

5 Raj $1131 \quad$ namamanaq bainenna arungpone buraqne I Mappasussung umuruqna 6 bulanji

4 Jun $(\mathrm{N}) \quad$ teeth filed of my elder sibling Karaeng Tanasanga

15 Raj 1131 naniariq daengku Karae Tanasanga

19 Jun (N eve) I Daeng Nganne I Manguq died

1 Syab 1131 namate I Daeng Nganne I Manguq

21 Jun (W) it is said that Batara Tungkaq ${ }^{583}$ was expelled as Datu ri Luwuq

3 Syab 1131 nanikana nipasuluki Datu ri Luwuq Bataratungkaq

26 Jun (M) I Mappatimung died at 11 months of age

8 Syab 1131 namate I Mappatimung umuruqna 11 bulanna

28 Jun (W) [the people of] Luwuq arrived to take as ruler Datu ri Citta

10 Syab 1131 nabattu Luwuka angallei karaeng Datuya ri Citta

1 Aug (T) I Cucung died above in Sanrabone

14 Ram 1131 namate I Cucung irate ri Sanrabone

7 Aug (M) the karaeng [Sirajuddin] moved east to the house of Karaeng ri Bontomanompoq to live

20 Ram 1131 namaqletteq karaenga manraiq ri ballaqna Karaengta ri Bontomanompoq mamempo

583 A daughter of the ruler of Luwuq Topalaguna Matinroe ri Langkanana and Pateekketana Arung Pattiro of Tanete (Ligtvoet 1880:196). 
10 Aug (W eve) Arung Tanete I Maninrori died below in Bontoalaq and was buried in Tamalate

23 Ram 1131 namate Aruq Tanete I Maninrori irawa ri Bontoalaq ri Tamalatei niawang

22 Aug (T) I Mattayang and I Daeng Mateqne I Sitti divorced

6 Syaw 1131 nasipelaq I Mattayang I Daeng Mateqne I Sitti

27 Aug (N) I Mida, a wife of I Dorra, died

11 Syaw 1131 namate I Mida bainenna I Dorra

1 Oct (S eve) Karaeng ri Bontopanno went down to Lempangang to marry Karaeng Bontomasugi

17 Zulk 1131 namanaung ri Lempangang Karaengta ri Bontopanno ambaineang Karae Bontomasugi

9 Oct (M) I Buaq had a daughter

25 Zulk 1131 namamanaq I Buaq baine

16 Oct $(\mathrm{M}) \quad$ birth of Sitti Halimah

3 Zulh 1131 nanianakkang Sitti Halimah

30 Oct (M) teeth filed and ears pierced of I Sitti, a younger sibling of my elder brother Karaeng Majannang

17 Zulh 1131 nanikesoq nanitinting I Sitti arinna daengku Karae Majannang

$5 \operatorname{Nov}(\mathrm{N}) \quad$ a karaengship given to Daengta Daeng Takontu ${ }^{584}$, now called Karaeng Campagaya

23 Zulh 1131 nanisare pakkaraengang Daengta Daeng Takontu nikana Karae Campagaya

6 Nov (N eve) Gallarrang Rappokalling died

24 Zulh $1131 \quad$ namate Gallarang Rappokalling

$10 \operatorname{Nov}(\mathrm{F}) \quad$ I Alija and I Mappasanrang married

28 Zulh 1131 nasikalabini I Alija I Mappasanrang

13 Nov (M) I Daeng Nisoqna, a child of sabannaraq I Daeng Makkulle, died

584 A wife of Karaeng Lauq of Sanrabone, daughter of Hasanuddin, and mother of Karaeng Manjalling (Ligtvoet 1880:196). 
1 Muh 1132 namate I Daeng Nisoqna anaqna sabannaraka I Daeng Makkulle

$14 \operatorname{Nov}(\mathrm{T}) \quad$ my grandparent I Daeng Nisoqna and Karaeng Bulukumba divorced

2 Muh 1132 nasipelaq toaku I Daeng Nisoqna Karaeng Buluqkumba

$22 \operatorname{Nov}(\mathrm{W}) \quad$ the arumpone [La Padangsajati] sailed from the pier [at Makassar] to go into Cenrana and stopped in Gowa [on the way]

10 Muh 1132 namamise arumpone ri jambatanga mantama ri Cenrana nasumengka ri Gowa

11 Dec (N eve) my grandparent I Kare Tonji I Baedah died; she died giving birth

29 Muh 1132 namate toaku I Kare Tonji I Baedah mate mamanaki

13 Dec (T eve) I Daeng Nisomba I Okung and I Daeng Mangewai I Dandeq married

1 Saf 1132 nasikalabini I Daeng Nisomba I Okung I Daeng Mangewai I Dandeq

$26 \operatorname{Dec}(\mathrm{T}) \quad$ Muhammad Ali circumcised

14 Saf 1132 nanisunnaq Muhammad Ali

$27 \mathrm{Dec}(\mathrm{W}) \quad$ I Guru Kasing, anrongguru of the mokkeng ${ }^{585}$, died in Talloq

15 Saf 1132 namate I Guru Kasing anrongguru mukkinga ri Talloq

1720

15 Jan (M) I Daeng Memang died in Jonggoa

4 Rawl 1132 namate I Daeng Memang ri Jonggoa

16 Jan (T) I Sitti, a younger sibling of my elder sibling Karaeng Majannang, died at 10 years of age

5 Rawl $1132 \quad$ namate I Sitti arinna daengku Karae Majannang umuruqna 10 taungi

585 This Islamic official was charged with assembling the 40 mokkeng - from the Arabic word muqim, meaning 'inhabitant' - needed to make the Friday public prayer service valid according to Shafi'ite doctrine. 
21 Jan (S eve) an envoy of the karaeng [Sirajuddin] arrived from Luwuq saying that I To Sappaileq ${ }^{586}$ had been taken as Datu ri Luwuq

10 Rawl 1132 surona karaenga battu ri Luwuq angknana I To Sappaileq nialle Datu ri Luwuq

22 Jan (M) the arumpone Puanna I Mattaq [La Padangsajati] expelled by the people of Boné; Karaeng Anaq Moncong replaced him

11 Rawl 1132 nanipasuluq arungpone Puanna I Mattaq ri tuBonea naKarae Anaq Moncong assambeangi

7 Feb (T eve) Daengta Daeng Makkalle Cilallang died

27 Rawl 1132 namate Daengta Daeng Makkalle Cilallang

$11 \mathrm{Feb}(\mathrm{N}) \quad$ Ballaq Kiria torn down

2 Rakr 1132 nanigesaraq Ballaq Kiria

19 Feb (M) my younger aunt Mutiatullah with her parent-in-law arrived, brought by the people of Boné who were ordered to do so

9 Rakr 1132 nabattu nisuro erang rituBonea ayaku Matiatullahi siagaang matoanna

$20 \mathrm{Feb}(\mathrm{W}) \quad$ the elder tumailalang [Karaeng Bontopanno] and Karaeng Bontomasugi divorced

12 Rakr 1132 nasipelaq tumailalang matoaya Karae Bontomasugi

1 Mar (F eve) my younger aunt I Daeng Tacuah ${ }^{587}$ I Patimaq, a wife of my younger uncle [Karaeng Patteqne], had a daughter

22 Rakr 1132 namamanaq ayaku I Daeng Tacuaq I Patimaq bainenna putoku baine

$10 \operatorname{Mar}(\mathrm{N}) \quad$ a child of Karaeng Batupute died

30 Rakr 1132 namate anaqna Karae Batuputeh

586 A son of the cenning of Luwuq, killed 5 May 1693, and husband of Batara Tungkaq (Ligtvoet 1880:196-7).

587 This name was first spelled with a final ' $h$ ' rather than a glottal stop ' $q$ ' but they are essentially interchangeable. Similarly, a final ' $h$ ' is often simply dropped. These and other minor differences in spelling are the inevitable result of different writers employing the serang script to transcribe Makassarese. 
13 Mar (W) I Mutaq, a younger sibling of my younger uncle Karaeng Alluq, died

3 Jawl 1132 namate I Mutaq arinna putoku Karae Alluq

$28 \operatorname{Mar}(\mathrm{R})^{588} \quad$ I Kare Pole, anrongguru of the anaq buraqne, died

18 Jawl 1132 namate I Kare Pole anrongguru anaq buraqne

$11 \operatorname{Apr}(\mathrm{R}) \quad$ a Wajorese was driven amuk in front of the karaeng [Sirajuddin] below in the market ${ }^{589}$ and I Kare Lewa clashed with and killed him; I Kare Lewa was wounded

2 Jakr 1132 nanipajalloki dallekanna karaenga irawa ri pasaraq tuWajoka naI Kare Lewa anruppai ambunoi namalokoq I Kare Lewa

22 Apr (W) a karaengship given to my younger uncle Karaeng Patteqne

13 Jakr 1132 nanisare pakkaraengang putoku Karae Patteqne

26 Apr (R eve) I Pandi, a child of Daengta I Daeng Manjijjiliq, died 17 Jakr 1132 namate I Pandi anaqna Daengta I Daeng Manjijjiliq

3 May (R eve) 590 I Kare Lewa I Sule died; his wound brought him to this 24 Jakr 1132 namate I Kare Lewa I Sule lokoqnaji angerangi

4 May (S) I Kare Mangalle I Maliq installed as anrongguru of the anaq buraqne, replacing I Kare Pole

25 Jakr 1132 nanitannang anrongguru anaq buraqne I Kare Mangalle I Maliq I Kare Pole nasambeang

6 May (M) Karaeng ri Laikang [Daeng Marannu], a widow of Tunisombaya [Arung Palakka], died above in Laikang

27 Jakr 1132 namate Karaengta ri Laikang balunna Tunisombaya irate ri Laikang

11 May (S) I Kare Mambani I Jamila installed as anrongguru in Kamanakang [in Gowa], replacing his father

3 Raj 1132 nanitannang anrongguru Kamanakang I Kare Mambani I Jamila manggenna nasambeang

588 The Hijri day is missing but must be the 28th.

589 This is the first mention in the lontaraq bilang of a market (pasaraq, from Malay).

590 A copyist mistakenly wrote the 8 th instead of the $3 \mathrm{rd}$. 
18 May (S) Karaeng Balua [Daeng Maingaq] ${ }^{591}$ went to go into Cenrana

10 Raj 1132 namaqlampa Karaengta Balua mantama ri Cenrana

23 May (R) teeth filed of I Kundaq

15 Raj 1132 naniariq I Kundaq

8 Jun (S) my grandparent I Daeng Tongi had a daughter Latifah by my younger uncle Karaeng Alluq

2 Syab 1132 namamanaq toaku I Daeng Tongi ri putoku Karae Alluq baine Latifah

17 Jun (N eve) I Daeng Manangaraq and my grandparent I Daeng Tamami married

11 Syab 1132 nasikalabini I Daeng Manangaraq toaku I Daeng Tamami

29 Jun (S) Tumamenang ri Jawaya [Najamuddin] circumcised

23 Syab 1132 nanisunnaq Tuammenang ri Jawaya

$16 \mathrm{Jul}(\mathrm{T}) \quad$ Karaeng Balua [Daeng Maingaq] arrived from Cenrana 10 Ram 1132 nabattu ri Cenrana Karaengta Balua

9 Aug (R eve) I Daeng Nisayu Junggo died 4 Syaw 1132 namate I Daeng Nisayu Junggo

15 Aug (R) a child of Sayyid Bukhari named Kiamuddin circumcised 10 Syaw 1132 nanisunnaq anaqna Sayyid Bukhari nikanaya Kiamuddini

1 Sep (S eve) I Daeng Marannu I Sugi had a child by Daeng Manassaq I Muhammad, a boy Jamaluddin

27 Syaw 1132 namamanaq I Daeng Marannu I Sugi ri Daeng Manassaq I Muhammad buraqne anaqna Jamaluddin

27 Sep (R eve) birth of I Manimbang-gauq Muhiiddin 592

24 Zulk 1132 nanianakkang I Manimbanggauq Muhiiddini

\footnotetext{
591 'Karaeng Balua' refers to her status as a widow of both Amir Hamzah and Abdul Jalil.

592 A son of Sirajuddin and Sitti Abidah Daeng Mateqne. His personal name is spelled Manimbang in the 18 Jun 1716, 20 Sep 1722, and 7 Dec 1731 entries and Nimbang in the 5 Mar 1724 entry.
} 
6 Oct (N)

4 Zulh 1132

10 Oct (R)

8 Zulh 1132

11 Oct (F)

9 Zulh 1132

16 Oct (W)

14 Zulh 1132

24 Oct (R)

22 Zulh 1132

$15 \operatorname{Nov}(\mathrm{F})$

14 Muh 1133

18 Nov (M)

17 Muh 1133

$10 \operatorname{Dec}(\mathrm{T})$

9 Saf 1133 part of Boriqsallo made a vassal 593

nanipareq paliliq Boriqsallo sipue

the manuscript that would be brought by Karaeng ri Bontopanno overseas to Jakattaraq was taken down to the ship; it offered thanks for giving us Topejawa ${ }^{594}$ nanipanaung ri biseang lontaraq naeranga Karaengta ri Bontopannoh kalauq ri Jakattaraq antarimakasihi nasareanta Topejawa

I Daeng Tatonji I Talluq died namate I Daeng Tatonji I Talluq

my grandparent I Thaibah [Daeng Nisali] had a son namamanaq toaku I Thaibah buraqne

I Saenaq, former spouse of Karaeng Tamaqlaqlang I Kapparaq, had a daughter namamanaq I Saenaq pallaloanna Karae Tamaqlaqlang I Kapparaq baine anaqna

Puanna I Mattaq [La Padangsajati] came seawards to Kampong Beru, arriving after he fled out of there [Boné] to the Dutch after being expelled [as arumpone] naniaq ilauq ri Kampong Beru Puanna I Mattaq battu malaria suluq mae ri Balandaya leqbaqna nipasuluq

the arumpone [Karaeng Anaq Moncong] landed, arriving from Cenrana with his wife nasore arumpone battu ri Cenrana sikalabini

I Daeng Nisanga I Kamariah, a wife of the elder Ratu Bagus, died namate I Daeng Nisanga I Kamariah bainenna Ratu Bagusuq matoa

593 As Ligtvoet (1880:197-8) notes, this probably was a punishment of some sort. Boriqsallo was one of the original communities that came together to form Gowa and there is no other reason why it should be demoted to the status of vassal (paliliq).

594 The VOC had given Topejawa to Karaeng Laikang, a widow of Arung Palakka, but after her death on 6 May 1720 gave it back to Sirajuddin as a token of friendship (Ligtvoet 1880:198). 
11 Dec (W) I Daeng Manassaq I Muhammad and I Daeng Marannu I Sugi divorced

10 Saf 1133 nasipelaq I Daeng Manassaq I Muhammad I Daeng Marannu I Sugi

$15 \operatorname{Dec}(\mathrm{N}) \quad$ my grandparent I Daeng Maqleoq's belongings were seized and he was expelled

14 Saf 1133 nanirappung nanipasuluq toaku I Daeng Maqleoq

$17 \operatorname{Dec}(\mathrm{T}) \quad$ I Aciq, a wife of I Daeng Tulolo, had a son

16 Saf 1133 namamanaq I Aciq bainenna I Daeng Tulolo buraqne

18 Dec (W) I Daeng Masseqre I Papippiq installed to supervise the lesser anaq karaeng

17 Saf 1133 naI Daeng Masseqre I Papippiq nipantama anjannangi anaq karaeng salaya

$22 \operatorname{Dec}(\mathrm{N}) \quad$ there arrived from Sandao my grandparent I Daeng Talarra, arriving from exile

21 Saf 1133 naniaqmo battu ri Sandao toaku I Daeng Talarra battu nicinde

1721

9 Jan (R) I Manrewakki, a child of I Pappi, died

10 Rawl 1133 namate I Manrewakki anaqna I Pappi

13 Jan (M) Puanna I Mattaq [La Padangsajati] and the arumpone [Karaeng Anaq Moncong] were reconciled by the Dutch

14 Rawl 1133 nanipaqbajikang Puanna I Mattaq arumpone ri Balandaya

18 Jan (S) my elder sibling Karaeng Majannang and my elder sibling Karaeng Tabaringang wed

19 Rawl 1133 nabunting daengku Karae Majannang daengku Karae Tabaringan

11 Feb (M eve) Karaeng ri Ballaq Jawaya died at the age of 89

13 Rakr 1133 namate Karaengta ri Ballaq Jawaya umuruqna 89

19 Feb (T eve) I Daeng Rikong I Jaga had a son

21 Rakr 1133 namamanaq I Daeng Rikong I Jaga buraqne 
$21 \mathrm{Feb}$ (R eve) Karaeng Bontotannga and I Salira married 23 Rakr 1133 nasikalabini Karae Bontotannga I Salira

5 Mar (T eve) the ship carrying Karaeng ri Bontopanno dropped anchor, arriving from Jakattaraq

5 Jawl 1133 namaqlabu kappalaq nadongkokia Karaengta ri Bontopannoh battu ri Jakattaraq

14 Mar (R eve) I Daeng Manassaq Muhammad and I Saenaq, a child of I Papuq, married

14 Jawl 1133 nasikalabini I Daeng Manassaq Muhammad I Saenaq anaqna I Papuq

17 Mar (M) a child of I Daeng Manassaq I Paciq by [his former wife] Salira died

17 Jawl 1133 namate anaqna I Daeng Manassaq I Paciq ri Salira

$26 \operatorname{Mar}(\mathrm{W}) \quad$ the day of the elder Addatuanga ri Massepe's [Arung Ujumpuluq $]^{595}$ death

26 Jawl 1133 allo nakamateanga Aqdatuang ri Massepe matoaya

$4 \operatorname{Apr}(\mathrm{F}) \quad$ I Maqrumai, a wife of Karaeng Mangesuq, died

6 Jakr 1133 namate I Maqrumai bainenna Karae Mangesuq

19 May (M) I Daeng Manassaq and I Papuq went over to Sandao, sent to advance against Toring [on Flores]

22 Raj 1133 namantaqle ri Sandao I Daeng Manassaq I Papuq nisuro ampanaiki Tarin

20 May (W) I Daeng Tamami, a wife of I Daeng Manangaraq, had a son

23 Raj 1133 namamanaq I Daeng Tamami bainenna I Daeng Manangaraq buraqne

7 Jun $(\mathrm{T}) \quad$ ears pierced and teeth filed of Karaeng Patukangang; then she and Tumamenang ri Jawaya [Najamuddin] were engaged to each other

595 La Tenritippaq ToWalenae, the ruler of Sidénréng whom Speelman called Arung Ujumpuluq and who posthumously was known as Matinroe ri Pamantingang (Ligtvoet 1880:199). 
11 Syab 1133 nanitinting nanikesoq Karae Patukangang nanipasiparekanngang Tuammenang ri Jawaya

22 Jun (N) my younger uncle Karaeng Panaikang and my younger aunt I Daeng Ningai married

26 Syab 1133 nasikalabini putoku Karae Panaikang ayaku I Daeng Ningai

25 Jun (W) the envoy I Kare Takko died

29 Syab 1133 namate suroa I Kare Takko

3 Jul (R) my great grandparent I Kare Loqmoq, the mother of

7 Ram 1133 namate boeku I Kare Loqmoq anronna Daengta Daeng Singaraq

29 Aug (F) it is said that a horse gave birth to a water buffalo above in Sengka; the day of the mother of Datu ri Citta's ${ }^{596}$ death

6 Ram $1133^{597}$ nanikana niaq jarang amanaq tedong irate ri Sengka allo nakamateanga ayana Datua ri Citta

11 Jul (W eve) I Daeng Manassaq arrived from Sandao

19 Ram 1133 nabattu ri Sandao I Daeng Manassaq

9 Oct (W eve) I Nannuq, a wife of I Daeng Makkulle I Mappaq, had a daughter

17 Zulh 1133 namamanaq I Nannuq bainenna I Daeng Makkulle I Mappaq baine

9 Oct (R) my younger uncle Karaeng Bontolangkasaq ordered brought to our karaeng [Bontosunggu] to ask the karaeng's [Sirajuddin's] forgiveness

17 Zulh 1133 nanisuro erang ri karaengta putoku Karae Bontolangkasaq nipappalaq popporang ri karaenga

24 Oct (F) Karaeng Bontomateqne arrived from Sumbawa

3 Muh 1134 nabattu ri Sambawa Karae Bontomateqne

596 Known as Opu Larompong, Datu ri Citta was her daughter by La Patau.

597 This entry is chronologically out of order, possibly because news of the unusual event in Sengka arrived later. 
28 Oct (T) I Halimah died at the age of 2 years, one month, and five nights

7 Muh 1134 namate I Halimah umuruqna 2 taun assibulan allimang banngi

1 Nov (S) I Bangung, a child of my younger uncle Karaeng Patteqne, died

11 Muh 1134 namate I Bangun anaqna putoku Karae Patteqne

27 Nov (R) a child of Karaeng Bontomateqne died

7 Saf $1134 \quad$ namate anaqna Karae Bontomateqne

$28 \operatorname{Nov}(\mathrm{F}) \quad$ there arrived from Bima Karaeng ri Bontopaqja

8 Saf 1134 naniaqmo Karaengta ri Bontopaqja battu ri Dima

12 Dec (R eve) birth of I Punca Patula Sitti Hawa

22 Saf 1134 nanianakkang I Punca Patula Sitti Hawa

$12 \operatorname{Dec}(\mathrm{F}) \quad$ I Salira, a wife of Karaeng Bontotannga, had a son

22 Saf 1134 namamanaq I Salira bainenna Karae Bontotannga buraqne

$16 \operatorname{Dec}(\mathrm{T}) \quad$ the Malay Captain Anciq Cukka598 died

26 Saf $1134 \quad$ namate Kapitan Malayu Anciq Cukka

$23 \operatorname{Dec}(\mathrm{T}) \quad$ I Daeng Tonji I Ummi died

3 Rawl 1134 namate I Daeng Tonji I Ummi

1722

19 Jan (M) the people of Mandalleq went to Karaeng

Bontomajannang

1 Rakr 1134 nanipamange tuMandalleka ri Karae Bontomajannang

4 Feb (T eve) makkedangetana ${ }^{599}$ Arung Ujung died

17 Rakr $1134 \quad$ namate makkadangatana Arung Ujung

$13 \mathrm{Feb}(\mathrm{F}) \quad$ the people of Tallumpuang went to Bebuq, now called Karaeng Bontotannga

598 He was the first Malay Captain in Makassar (Ligtvoet 1880:199).

599 Arung Palakka created this position in Boné. Makkedangetana was a translation of the Makassarese title tumabicarabutta or 'speaker of the land' and as in Gowa was occupied by a person second only in power to the ruler (Andaya 1981:footnote 322). 
26 Rakr 1134 nanipamange tuTallumpuwanga ri Bebuq nikana Karae Bontotannga

$22 \mathrm{Feb}$ (N eve) Karaeng Bontosiamaq and her husband came here to entrust themselves to her Makassarese [relatives]

7 Jawl 1134 namae ri kamangkasaranna Karae Bontosiamaq sikalabini antambung kalenna

$4 \operatorname{Mar}(\mathrm{W}) \quad$ the mother of Karaeng Bidara died

16 Jawl 1134 namate anronna Karaeng Bidara

17 Mar (T) a wife of I Daeng Mangago died

29 Jawl 1134 namate bainenna I Daeng Mangago

$24 \operatorname{Mar}(\mathrm{T}) \quad$ I Massanira ${ }^{600}$ and I Anisah, a child of [Karaeng]

Bontosiamaq, married

6 Jakr 1134 nasikalabini I Massanira I Anisah anaqna Bontosiamaq

25 Mar (W) I Daeng Nisali I Thaibah had a son

7 Jakr 1134 namamanaq I Daeng Nisali I Thaibah buraqne

7 Apr (T) my younger uncle Karaeng Alluq and my younger aunt Karaeng Pasiq married

20 Jakr 1134 nasikalabini putoku Karae Alluq ayaku Karae Pasiq

13 Apr (N eve) I Saenaq, a wife of I Daeng Manassaq, had a daughter 26 Jakr 1134 namamanaq I Saenaq bainenna I Daeng Manassaq baine

25 Apr (S) I Punca taken and adopted by Karaeng Balua [Daeng Maingaq]

9 Raj 1134 nanialle I Punca nikatuoa ri Karaengta Balua

28 May (W eve) I Daeng Mateqne I Sitti had a daughter

12 Syab 1134 namamanaq I Daeng Mateqne I Sitti bainea

30 May (S) I Maqjuq, a child of I Daeng Memang, died

14 Syab $1134 \quad$ namate I Maqjuq anaqna I Daeng Memang

31 May (N) I Daeng Tamami had a daughter

600 A son of Pabukajuwe Datu Ulaweng of Bulo-Bulo, he was known as ToWappamole Datu Ulaweng (Ligtvoet 1880:200). 
15 Syab 1134 namamanaq I Daeng Tamami baine

19 Jun (F) my grandparent I Daeng Nisanga I Nanuq died

5 Ram 1134 namate toaku I Daeng Nisanga I Nanuq

3 Jul (F) $\quad$ Friday public prayers first established in Takalar this Friday

19 Ram 1134 nauru mammenteng jumaq ri Takalaraq jumaq

$30 \mathrm{Jul}$ (W eve) Karaeng ri Taruq died at the age of 95

16 Syaw 1134 namate Karaengta ri Taruq umuruqna 95

31 Aug $(\mathrm{M})^{601}$ my younger aunt Karaeng Barong Patola and I Daeng Maqrappo divorced

18 Zulk 1134 nasipelaq ayaku Karae Baron Patola I Daeng Maqrappo

10 Sep (R) I Daeng Masseqre I Papippiq and I Unnaq married

28 Zulk 1134 nasikalabini I Daeng Masseqre I Papippiq I Unnaq

15 Sep (T) I Manrannuang killed a grinder in the market

4 Zulh 1134 namamuno pakantisiq I Manranuang ri pasaraka

20 Sep (S eve) I Manimbang set foot on the ground

9 Zulh 1134 nanipaonjoq ri butta I Manimbang

26 Sep (S) I Nannuq, a child of Karaeng Bontorambaq, died

15 Zulh 1134 namate I Nannuq anaqna Karae Bontorambaq

17 Oct (S) war leaders sailed eastward to Sandao to make war;

Karaeng Batupute was commander with I Daeng

Manassaq

7 Muh 1135 namamise dulun manraika ri Sandao maqbunduq Karae Batuputeh punggawa siagaang I Daeng Manassaq

21 Oct (T eve) I Bidoq, a younger sibling of I Paceq, stabbed himself and died the next morning

11 Muh 1135 nanatoboq kalenna I Bidoq arinna I Paceq nabariqbasaqpa namate 
9 Nov (M) Tumamenang ri Jawaya [Najamuddin] and Karaeng Patukangang separated [after having been pledged to each other]

30 Muh 1135 nanipasisala Tuammenang ri Jawaya Karae Patukangan

$16 \operatorname{Nov}(\mathrm{M}) \quad$ the karaeng [Sirajuddin] occupied his house; the house was seawards of the mosque in Paqbineang

7 Saf 1135 naniempoimo ballaqna karaenga ballaq ilaukannaya masigika ri Paqbineang

$1 \operatorname{Dec}(\mathrm{T})$

22 Saf 1135

I Mappaingaq Syafiuddin circumcised ${ }^{602}$

nanisunnaq I Mappaingaq Syafiuddini

14 Dec (N eve) I Daeng Pabila, a child of I Tuang Rappang, died

5 Rawl 1135 namate I Daeng Pabila anaqna I Tuan Rappan

26 Dec (F eve) birth of myself, I Makkaraeng Zainuddin [Karaeng Tamasongoq] $]^{603}$

17 Rawl 1135 kunianakkang I Makkaraeng Zainuddini

30 Dec (T eve) I Maidah Arung Tanete and I Callaq married 21 Rawl 1135 nasikalabini I Maidah Aruq Tanete I Callaq

1723

21 Jan (R) Karaeng Batupute landed, arriving from Sandao; he warred and conquered Toring and Wangka [on Flores]

14 Rakr 1135 nasore Karae Batu Puteh battu ri Sandao maqbunduq ambetai Toring siagaang Wangka

22 Jan (F) a karaengship given to I Daeng Mattalliq, now called Karaeng Bungaya

15 Rakr 1135 nanisare pakkaraengang I Daeng Mattalliq nikana Karae Bungaya

25 Jan ( $\mathrm{N}$ eve) my younger aunt Karaeng Pasiq had a son who reached just 9 nights of age

602 Ligtvoet (1880:200) notes that in the manuscript he used the writer - Karaeng Lempangang - referred to himself as ' $\mathrm{I}$ ' in this entry. This is not found in VT 25. See note for 7 Dec 1709.

603 Also known as I Temasongeng, Karaeng Katangka, and Tumamenang ri Matoanging, he was later tumabicarabutta and then ruler of Gowa from 1770-1778 (Patunru 1993:78-9). This makes him the second lontaraq bilang annalist who identifies himself by name. 
18 Rakr 1135 namamanaq ayaku Karae Pasiq buraqne 9 banngiji umuruqna

8 Mar (M) Taluqmuq, a child of Karaeng ri Patteqne, died, killed on Buton

1 Jakr 1135 namate Taluqmuq anaqna Karaengta ri Patteqne niposoa ri Butun

5 May (T eve) death of I Tuang [Rappang] inside Rappang [in Sidénréng]

29 Raj 1135 nakamateang I Tuan ilalang ri Rappan

21 May (S) teeth filed of I Mattaq by the arumpone [Karaeng Anaq Moncong]

17 Syab 1135 nanibariq I Mattaq ri arungpone

25 May (M) I Mangeranngi and I Caciq married

20 Syab 1135 nasikalabini I Mangeranngi I Caciq

9 Jun (T eve) I Daeng Mami, a younger sibling of Daengta I Daeng Marimang, died

5 Ram 1135 namate I Daeng Mami arinna Daengta I Daeng Marimang

23 Jun (W) I Yunnaq had a daughter

19 Ram 1135 namamanaq I Yunnaq baine

27 Jun (S) it is said that Datu ri Ulawang died inside his homeland

22 Ram 1135 nanikana matei Ratua ri Ulawang ilalang ri paqrasanganna

25 Jul (N) the coffin of I Tuang [Rappang Abdul Bashir] brought back

21 Syaw 1135 nabattu nierang alunna I Tuan

$28 \mathrm{Jul}(\mathrm{W}) \quad$ I Kare Manaqgalaq replaced I Shaykh as kadi

24 Syaw 1135 naI Kare Manaqgalaq assambeangi kadi I Syeh

31 Jul (F eve) a younger sibling of Karaeng Garassiq named I Muhammad died

27 Syaw 1135 namate arinna Karae Garassiq nikanaya I Muhammad 
7 Sep (T) I Saqdaq, a child of my grandparent Karaeng Manjalling, circumcised

7 Zulh 1135 nanisunnaq I Saqdaq anaqna toaku Karae Manjalling

14 Oct (R) I Biqbuq, a child of Karaeng Manjalling, and I Saodah, a child of Karaeng Bontomajannang, married

14 Muh 1136 nasikalabini I Biqbuq anaqna Karae Manjalling I Saodah anaqna Karae Bontomajannang

18 Oct (M) Tumamenang ri Jawaya [Najamuddin] had a sunshade raised over his head

18 Muh 1136 nanipirangkakki laqlang Tuammenang ri Jawaya

10 Nov (T eve) I Daeng Tasami, former spouse of Karaeng ri Lekoqboqdong, had a daughter

12 Saf 1136 namamanaq I Daeng Tasami baine pallaloanna Karaengta ri Lekoqboqdong

18 Nov (R) Karaeng Laikang proposed to by Karaeng ri Talloq [Najamuddin]; 88 [reals was the brideprice]

20 Saf 1136 nanipassuroi Karae Laikang ri Karaenga ri Talloq 88

24 Nov (W) the people of Bontolangkasaq again went to Daeng Mamaro

26 Saf 1136 nanipamange pole ri Daeng Mamaro tuBontolangkasaka

29 Nov (M) teeth filed of Karaeng Tangallaq

1 Rawl 1136 naniariq Karae Tangallaq

20 Dec (M) Jineli Safi ${ }^{604}$ died seawards in Kampong Beru

22 Rawl 1136 namate Jineli Safi ilauq ri Kampong Beru

1724

8 Jan (F eve) Karaeng Anaq Moncong expelled by the people of Boné and Arung Mampu taken by the people of Boné [as arumpone]; Puanna I Mattaq [La Padangsajati] taken by the people of Soppéng [as ruler]; the karaeng [Sirajuddin] went seawards to get [La Padangsajati] 
11 Rakr 1136 nanipasuluq ri tuBonea Karae Anaq Moncong naArung Mampu nialle rituBonea Puanna I Mattaq naalle tuSoppenga nakalauq karaenga angallei

11 Jan (M eve) I Cinrana, a child of I Tuang ri Dima, died

14 Rakr 1136 namate I Cinrana anaqna I Tuan ri Dima

28 Jan (R eve) I Bunga Suttaraq, a child of my younger uncle Karaeng Patteqne, died

2 Jawl 1136 namate I Bunga Suttaraq anaqna putoku Karae Patteqne

1 Feb (M eve) Karaeng Pattallassang died

6 Jawl $1136 \quad$ namate Karaeng Pattallassang

$22 \mathrm{Feb}(\mathrm{T})$ the arumpone [Arung Mampu] sailed to go into Cenrana

27 Jawl 1136 namamise arungpone mantama ri Cenrana

5 Mar (S eve) Karaeng Bainea [Daeng Mateqne], the mother of I

Manimbang, died at the age of 25

9 Jakr 1136 namate Karaeng Bainea ayana I Nimbang umuruqna 25

$16 \operatorname{Mar}(\mathrm{R}) \quad$ Karaeng Anaq Moncong had sore(s) on his right cheek

2 Jakr $1136^{605}$ nanabattui sakkaq pilisiq kananna Karae Anaq Moncong

1 Apr (F eve) Karaeng Anaq Moncong died; he lived to 35

7 Raj $1136 \quad$ namate Karae Anaq Moncong 35 tallasaqna

3 Apr (N eve) Anciq Sammaq died

9 Raj $1136 \quad$ namate Anciq Sammaq

27 Apr (R) my younger aunt I Daeng Tacoa, a wife of my younger uncle Karaeng Patteqne, had a child, a daughter

3 Syab 1136 namamanaq ayaku I Daeng Tacoa bainenna putoku Karae Patteqne baine anaqna

3 May (T eve) I Daeng Mangalle died while asleep

9 Syab 1136 namate I Daeng Mangalle tinro-tinro

605 This date is incorrect. 2 Jakr 1136 converts to 27 Feb 1724. A copyist may have mistakenly written the 2nd instead of the 22nd, which converts to 18 Mar 1724; the 2nd in place of the 12th, which converts to 8 Mar 1724; or 2 Raj 1136, which converts to 27 Mar 1724. 
12 May (R eve) Daengta Daeng Mami died 18 Syab 1136 namate Daengta Daeng Mami

16 May (T) I Massallomo circumcised; teeth filed of Amirah 22 Syab 1136 nanisunnaq I Massanglomo naniariq Amirah

26 May (F) Karaeng ri Bontokamase died at the age of 74

2 Ram 1136 namate Karaengta ri Bontokamase umuruqna 74

6 Jun (T) the people of Somba Opu went to Daeng Makkulle I Kare, now called Kare Palemba

13 Ram 1136 nanipamange tuSombopua ri Daeng Makkulle I Kare nikana Kare Palemba

11 Jun (S eve) I Daeng Maqleoq ${ }^{606}$ and I Saidah married

18 Ram 1136 nasikalabini I Daeng Maqleoq I Saedah

16 Jun (R eve) I Daeng Mannyikkoq ri Kassiq died; during the day this Friday I Buang Nanang died

23 Ram 1136 namate I Daeng Mannyikkoq ri Kassiq ri allonna anne jumaka namate I Buang Nanang

22 Jun (R) Daeng Sitaba received I Kare Battu's supervisory position because he was infirm

29 Ram 1136 nanipamange ri Daeng Sitaba jannanganna I Kare Battu kamadodongmi

28 Jun (W) an envoy arrived from the people of Boné stating that they had expelled their ruler Arung Mampu and again taken Datu ri Citta [as arumpone]

6 Syaw 1136 nabattu surona tuBonea angkana-kanai napasuluqna karaenna Arung Mampu naDatua ri Cittasang naalle

4 Jul ( $\mathrm{T}$ ) I Sumailiq, a child of Daeng Malliongang, went amuk and was killed by the Dutch; he was hung

12 Syaw 1136 namaqjalloq I Sumailaq anaqna I Daeng Malliongang nanibuno ri Balandaya nigentung

606 I believe this and subsequent references to this Daeng Maqleoq refer to I Sumang, but this is not certain. 
17 Jul (N eve) my grandparent I Kare Kontu stabbed in the calf from beneath the floor; Daengta Daeng Tapallaq died below in Talloq 607

25 Syaw 1136 nanisoqlloroq toaku I Kare Kontu bitisiqna namate Daengta Daeng Tapallaq rawa ri Talloq

10 Aug (W eve) I Daeng Manassaq and a child of Gallarrang Mangasa ${ }^{608}$ who was a widow of I Daeng Pabila married

20 Zulk 1136 nasikalabini I Daeng Manassaq anaqna Gallaran Mangasa balunnaya I Daeng Pabila

14 Aug (M) Karaeng Bontomateqne had a daughter 24 Zulk 1136 namamanaq Karae Bontomateqne baine

$24 \operatorname{Aug}(\mathrm{R}) \quad$ I Aciq, a wife of I Daeng Tulolo, had a son; the Chinese Captain died

5 Zulh 1136 namamanaq I Aciq bainenna I Daeng Tulolo buraqne namate Kapitan Sanggalea

2 Oct $(\mathrm{M}) \quad$ ears pierced of I Jaenaq

14 Muh 1137 nanitinting I Jaenaq

3 Oct (T) I Muhammad [Baki], just the second of Karaeng ri TanaTana's children, circumcised

15 Muh 1137 nanisunnaq I Muhammad anaqna ruaji Karaengta ri TanaTana

14 Oct (S) I Kondaq died above in Lengkeseq and was brought down here

26 Muh 1137 namate I Kondaq irate ri Lengkeseq nanierang manaunmae

16 Oct (M) Karaeng ri Talloq [Najamuddin] and Karaeng Patukangang married

28 Muh 1137 nasikalabini Karaenga ri Talloq Karae Patukangang

19 Oct (R) S sabannaraq I Daeng Makkulle died

607 Possibly this entry is intended to be read as meaning that I Kare Kontu died, but then what happened involving Daengta Daeng Tapallaq in Talloq is unclear. Kamaruddin (1986:176) attempts to resolve this by stating that I Kare Kontu Daengta Daeng Tapallaq was one person, but this interpretation is not likely.

608 This individual is twice mentioned but never named in the annals (see 14 Apr 1712). 
1 Saf 1137 namate sabannaraka I Daeng Makkulle

29 Oct (S eve) I Umaraq, a child of Gallarrang Mangasa, died

11 Saf 1137 namate I Umaraq anaqna Gallarang Mangasa

1 Nov (W) Daengta Daeng Maingaq died in Talloq

14 Saf 1137 namate Daengta Daeng Maingaq ri Talloq

$16 \operatorname{Nov}(\mathrm{R}) \quad$ now the Chinese Captain was buried

29 Saf 1137 nanampa nitarawang Kapitan Sanggalea

27 Nov (M) I Daeng Mangewai609 installed as sabannaraq; he replaced his older uncle ${ }^{610}$ [I Daeng Makkulle]

10 Rawl 1137 nanitannang sabannaraq I Daeng Manngewai puanna nasambeang

$3 \operatorname{Dec}(\mathrm{N}) \quad$ I Sumailiq circumcised by Karaeng Majannang

16 Rawl 1137 nanisunnaq I Sumailiq ri Karae Majannang

7 Dec (R) I Kare Bangung I Biding died

20 Rawl 1137 namate I Kare Bangun I Biding

27 Dec (T eve) I Daeng ri Nakke died

11 Rakr 1137 namate I Daeng ri Nakke

1725

19 Jan (F) I Salira had a son

4 Jawl 1137 namamanaq I Salira buraqne

23 Jan $(\mathrm{T}) \quad$ my grandparent Karaeng Lauq died

8 Jawl 1137 namate toaku Karae Lauq

28 Jan (F) I Daeng Taiji, a child of Daengta Daeng Talele, died

11 Jawl 1137 namate I Daeng Taiji anaqna Daengta Daeng Talele

$11 \mathrm{Feb}(\mathrm{N}) \quad$ I Molla [Kare Manginruru] and I Maemunah, a grandchild of Anduq Puaq, married

27 Jawl 1137 nasikalabini I Molla I Maemunah cucunna Anduq Puaq

609 This was a different Daeng Mangewai than either I Wasing (18 Jul 1718) or I Dandeq (13

Dec 1719).

610 It is unlikely but possible that Daeng Makkulle was his father. 
12 Feb (M) there came a manuscript from Sumbawa reporting to the karaeng [Sirajuddin] the death of the ruler of Sumbawa [Ammasaq] and his sibling, slain by 'Javanese'611 from Bali

28 Jawl 1137 niaq lontaraq battu ri Sambawa angkana-kanai ri karaenga matena Karae Sambawa sisaqribattang niputtai ri Jawa Balia

13 Feb (M eve) it is said that Datu ri Lamuru612 and Arung Gowa-Gowa were killed by Datu ri Soppéng [La Padangsajati]; they were strangled 613

29 Jawl 1137 nanikana nibunoi ri Datua ri Soppeng Datua ri Lamuru siagaang Aruq Gowa Gowa nijarroki

17 Feb (F eve) the elder kadi I Kare Tappaq died

4 Jakr 1137 namate qadia matoaya I Kare Tappaq

18 Feb (N) I Saidah, a wife of I Daeng Maqleoq, had a daughter; I Manrewakki, a child of I Pappi, died 614

5 Jakr 1137 namamanaq I Saidah bainenna I Daeng Maqleoq baine namate I Manrewakki anaqna I Pappi

$25 \mathrm{Feb}(\mathrm{N}) \quad$ I Daeng Majannang I Salamah died

12 Jakr 1137 namate I Daeng Majannang I Salamah

$2 \operatorname{Mar}(\mathrm{F}) \quad$ I [Syafiuddin] went up to recite the sermon in the mosque 17 Jakr 1137 kumanaiq mamaca khutbah ri masigika

$22 \operatorname{Mar}(\mathrm{R}) \quad$ my younger uncle Karaeng Panaikang sent over to Sumbawa to fetch Datu Tannga, Karaeng Bontoa ${ }^{615}$, and Karaeng Buluq-Buluq

7 Raj $1137 \quad$ nanisuro taqle ri Sambawa putoku Karae Panaikang angallei Datu Tannga Karae Bontoa Karae Buluq-Buluq

611 That is, inhabitants of the archipelago to the west of Makassar, in this case Balinese. Ligtvoet (1880:203) reports that the ruler of Sumbawa Mas Madina and his brother were killed trying to recapture Salaparang, which since 1693 had been under the control of the Balinese.

612 La Cella Matinroe ri Tengana Soppéng (Ligtvoet 1880:203).

613 Ligtvoet (1880:203) reports they were killed because they were accused of slandering La Padangsajati.

614 This was the second young child of I Pappi named Manrewakki to die young; see the entry for 9 Jan 1721.

615 Probably I Sugi who was born on 19 Jul 1704. All three were summoned back to Makassar in the wake of the death of the ruler of Sumbawa Mas Madina the previous month (Ligtvoet 1880:203). 
27 Mar (T) I Kare Jarreq I Yokong installed as anrongguru of the anaq buraqne, replacing I Kare Mangalliki I Jalaq

12 Raj 1137 nanipantama anrongguru anaq buraqne I Kare Jarreq I Yokong asambeangi I Kare Mangalliki I Jalaq

9 Apr (N eve) I Salahu, a nephew ${ }^{616}$ of Karaeng Mangesuq, died

25 Raj 1137 namate I Salahu kamanakanna Karae Mangesuq

14 Apr (F eve) Daengta Daeng Marimang died

1 Syab 1137

namate Daengta Daeng Marimang

15 May (T) I Sadiq, a child of a Tamboran [on Sumbawa] and Tumatea ri Salaparang [Karaeng Jarannika], died

2 Ram 1137 namate I Sadiq anaq Tamboran Tumatea ri Salaparan

24 May (R) a child of I Yunnaq died

11 Ram 1137 namate anaqna I Yunnaq

7 Jun (R) Muhammad Ali, a grandchild of I Tuang617, and I Bole618 stabbed each other above in Galesong after arriving together from Sumbawa with Karaeng Bontomajannang

25 Ram 1137 nasitoboq Muhammad Ali cucunna I Tuan I Bole sipoleangi irate ri Galesong battui ri Sambawa siagaang Karae Bontomajannang

8 Jun (F) my younger uncle Karaeng Panaikang arrived from fetching Karaeng Buluq-Buluq and Karaeng Bontoa but not Datu Tannga

26 Ram 1137 nabattu putoku Karae Panaikang angallei Karae BuluqBuluq Karaeng Bontoa tenai Datu Tang

17 Jun (N) Daengta Daeng Manaqgalaq, a younger sibling of the widow $^{619}$, died

5 Syaw 1137 namate Daengta Daeng Manaqgalaq arinna balua

22 Jun (R eve) Daengta Daeng Talele, a younger sibling of Karaeng ri Ballaq Jawaya, died

616 Or niece, as no gender is indicated.

617 This probably refers to Tuang Rappang.

618 Alternately, these names could be read as Muhammad Ali and a grandchild of I Tuang I

Bole.

619 Presumably Daeng Maingaq, also known in the lontaraq bilang as Karaeng Balua. 
10 Syaw 1137 namate Daengta Daeng Talele arinna Karaengta ri Ballaq Jawaya

$6 \mathrm{Jul}(\mathrm{F}) \quad$ my [step]mother I Sapiah, a wife of the karaeng [Sirajuddin] had a son Syarfuddin Manngambu Jawa

24 Syaw 1137 namamanaq anrongku I Sapiah bainenna Karaenga buraqne Syarfuddin Manngambu Jawa

9 Aug (W eve) Daenga Daeng Tamemang, who lived with my younger uncle $^{620}$, died

29 Zulk 1137 namate Daenga Daeng Tamemang siballaqna putoku

13 Aug (N eve) Karaeng Boriqsallo died

4 Zulh 1137 namate Karaeng Boriqsallo

23 Aug (R) I Mattaenai and I Sabirah, a child of Karaeng Batupute by Minaq, married

14 Zulh 1137 nasikalabini I Mattaenai I Sabirah anaqna Karae Batuputeh ri Minaq

16 Sep $(N) \quad$ it is said that the new ruler of Sumbawa died on the $15^{\text {th }}$ of Zulhijah 621

8 Muh 1138 nanikana matei Karae Sambawa berua ri 15 Zulhijah

1 Oct (M) an envoy from the arumpone [Datu ri Citta] arrived bringing news of the death of Arung Jalieng622 below in Luwuq; I Mappaq, a child of Karaeng Mangesuq, circumcised

23 Muh 1138 nabattu surona arungpone ampabirittai matena Aruq Jalieng irawa ri Luwuq nanisunnaq I Mappaq anaqna Karae Mangesuq

6 Oct (S) I Tipa had a daughter by the karaeng [Sirajuddin] named Hasanah

28 Muh 1138 namamanaq I Tipa baine ri karaenga nikana Hasanah

7 Oct $(\mathrm{N}) \quad$ Arung Tanete I Callaq arrived here in Gowa

29 Muh 1138 nabattu Aruq Tanete I Callaq maei ri Gowa

620 Either Karaeng Panaikang, Alluq, or Patteqne.

621 Quite possibly he too died fighting the Balinese in Salaparang like his predecessor.

622 Ruler of Sidénréng and Datu ri Citta's third husband (Ligtvoet 1880:204). 
12 Oct (R eve) I Saodah, a wife of I Biqbuq, had a daughter Latifah 5 Saf 1138 namamanaq I Saodah bainenna I Biqbuq baine Latifah

30 Oct (T) Karaeng Patukangang had a son Muhammad Jamala; I Mappatollaq was his Makassarese name ${ }^{623}$

24 Saf 1138 namamanaq Karae Patukangan buraqne Muhammad Jamala I Mappatollaq aren Mankasaraqna

3 Nov (S) Amirah and I [Syafiuddin] married

27 Saf $1138 \quad$ kusikalabini Amirah

$12 \mathrm{Nov}(\mathrm{M}) \quad$ a child of Karaeng Bontomateqne died

6 Rawl 1138 namate anaqna Karae Bontomateqne

21 Nov (W) a child of Karaeng Bontotannga died

15 Rawl 1138 namate anaqna Karae Bontotannga

1 Dec (S) I Maemunah, a wife of I Kare Manginruru I Molla, died 25 Rawl 1138 namate I Maemunah bainenna I Kare Manginruru I Molla

9 Dec (S eve) nayaka I Yasing died

3 Rakr $1138 \quad$ namate nayakaya I Yasing

29 Dec (S) Karaeng Bontoa had a son Abdul Gafur; he lived just 9 months

24 Rakr 1138 namamanaq Karae Bontoa buraqne Abdul Gafur 9 bulanji tallasaqna

\section{6}

13 Jan (N) I Daeng Memang, a grandparent of I Daeng Rikong I Jaga, died

9 Jawl $1138 \quad$ namate I Daeng Memang toana I Daeng Rikong I Jaga

16 Jan (W) a child of I Daeng Masseqre I Papippiq died in Buaq 12 Jawl 1138 namate anaqna I Daeng Masseqre I Papippiq ri Buaq 
19 Jan (M eve) ${ }^{624}$ my [step]mother I Saidah, a wife of the karaeng [Sirajuddin] had a daughter Aminah Sarimba Raja

15 Jawl 1138 namamanaq anrongku I Saidah bainenna karaenga baine Aminah Sarimba Raja

31 Jan (W eve) Daengta Daeng Mangaungi died at 70 years of age 27 Jawl 1138 namate Daengta Daeng Mangaungi umuruqna 70 taun

8 Feb (R eve) I Daeng Tonji Balambaru died

5 Jakr $1138 \quad$ namate I Daeng Tonji Balambaru

$11 \mathrm{Feb}(\mathrm{M}) \quad$ I Mangeranngi and I Malikah married

8 Jakr 1138 nasikalabini I Mangerang I Malikah

15 Feb (S) a child of I Papuq who was a wife of I Dadi died 13 Jakr 1138 namate anaqna I Papuq nabaneanga I Dadi

$25 \mathrm{Feb}(\mathrm{M}) \quad$ I Salama, a child of I Daeng Bonang, divorced by the karaeng [Sirajuddin], repudiated three times [in accordance with Islamic custom]

22 Jakr 1138 nanipelaq I Salama anaqna I Daeng Bonang ri karaenga nitallaq tallui

16 Mar (S) I Kare Sallo, a child of Tumatea ri Salaparang [Karaeng Jarannika], died

12 Raj 1138 namate I Kare Sallo anaqna Tumatea ri Salaparang

$19 \operatorname{Mar}(\mathrm{T})^{625}$ the karaeng [Sirajuddin] and Karaeng Agangjeqneq ${ }^{626}$ married

15 Raj 1138 nasikalabini karaenga Karae Agangjeqneq

22 Mar (R eve) it is said that my older uncle Arung Kaju and the arumpone [Datu ri Citta] married

18 Raj 1138 nanikana sikalabinimi puangku Aruq Kayu arungpone

30 Mar (S) my younger aunt Karaeng Bontojeqneq arrived from Kaju; she said she had been divorced by my older uncle [Arung Kaju]

626 A former wife of the ruler of Sumbawa Mas Madina and, according to Dutch sources, of Arung Jalieng as well (Ligtvoet 1880:204). 
26 Raj 1138 nabattu ayaku Karae Bontojeqneq ri Kayu nikana nipelaqmi ripuangku

29 Apr (T) Karaeng Bisei ${ }^{627}$, ordered brought by the arumpone [Datu ri Citta], arrived

26 Syab 1138 nabattu Karae Bisei nisuro eran ri arungpone

2 May $(\mathrm{R})$

a child of a slave of Karaeng Bisei died ${ }^{628}$

29 Syab 1138

namate anaq ri atanna Karae Bisei

8 May $(W)$

my grandparent I Daeng Nganrenne, a grandparent of

Karaeng Bontolangkasaq, died

5 Ram 1138

namate toaku I Daeng Nganrenne toana Karae

Bontolangkasaq

19 May $(\mathrm{N})$

I Daeng Masseqre I Papippiq expelled from supervising the lesser anaq karaeng

16 Ram 1138 nanipasuluq I Daeng Masseqre I Papippiq anjannangi anaq karaeng salaya

10 Jun (N eve) I Capoaq, a widow of Tumamenang ri Rateqna, died

9 Syaw 1138 namate I Capoaq balunna Tuammenang ri Rateqna

3 Jul (T eve) we were left by [tumabicarabutta] Karaeng Tumamenang ri Taenga at the age of 85

3 Zulk $1138 \quad$ kinapilari Karaengta Tuammenang ri Taenga umuruqna 85

6 Jul (S) $\quad$ my younger uncle Karaeng Panaikang installed to supervise the lesser anaq karaeng

6 Zulk 1138 naputoku Karae Panaikang nipantama anjannangi anaq karaeng salaya

9 Jul (T) I Dorra and a grandchild of I Daeng Masseqre stabbed each other above in Maradekaya and after one night died $^{629}$

\footnotetext{
627 A former ruler of Boné for a brief time in 1724. He was also known as Arung Mampu and La Panaungi Topawawoi.

628 Karaeng Bisei was presumably the father.

629 I believe the intent of this is that I Dorra died, but it could mean that they both died from their wounds.
} 
9 Zulk 1138 nasitoboki I Dorra cucunna I Daeng Masseqre irate ri Maradekaya sipattangpi namate

17 Jul (W) Karaeng Balambaru died below in Baru-Baru

17 Zulk 1138 namate Karae Balambaru irawa ri Baru-Baru

2 Aug (F) the karaeng [Sirajuddin] would speak for the land 630

4 Zulh 1138 nakaraenga ampakkanangi buttana

10 Sep (T) the karaeng [Sirajuddin] given the 3 communities of Gantaq, Kassiq, and Sangkalaq ${ }^{631}$

13 Muh 1139 nanisareang karaenga Gantaq Kassiq Sangkala 3 paqrasangan

9 Sep (M) Gallarrang Camba I Kare Parampang installed as speaker632

12 Muh 1139633 nanitannang maqbicara Gallarrang Camba I Kare Parampang

7 Oct (M) my grandparent I Daeng Mangewai I Waseq $\quad$ m34, a younger sibling of Karaeng Manjalling, died

11 Saf 1139 namate toaku I Daeng Mangewai I Waseq arinna Karae Manjalling

17 Oct (R) the manuscript that would be brought by my younger uncle Karaeng Alluq overseas to Jakattaraq was taken down to the ship; it said we had been left by our karaeng [Tumamenang ri Taenga]

21 Saf 1139 nanipanaung ri biseang lontaraq naeranga putoku Karae Alluq kalauq ri Jakattaraq angkana-kanai napilarinta Karaengta

23 Oct (W) I Daeng Taiji, a wife of Karaeng Garassiq, died 27 Saf 1139 namate I Daeng Taiji bainenna Karae Garassiq

630 In other words, following the death of Karaeng Bontosunggu Tumamenang ri Taenga, Sirajuddin decided that he would not appoint a new tumabicarabutta, the chief advisor and minister of Gowa known as 'The Speaker of the Land'. Sultan Hasanuddin had done this once before in 1654 .

631 By the arumpone Datu ri Citta and her husband Arung Kaju (Ligtvoet 1880:205).

632 This either means that he became tumabicarabutta or that he was given some of those duties performed by the tumabicarabutta before Sirajuddin decided he would do this himself.

633 It is not clear why this and the preceding entry are in reverse chronological order.

634 Elsewhere spelled I Wasing. 
30 Oct (T eve) my older uncle Karaeng Boqdia and Karaeng Barrung married

4 Rawl 1139 nasikalabini puangku Karae Boqdia Karae Barrung

6 Nov (W) the ruler of Bima [Mappatalliq] and his wife [Karaeng Bisangpole] arrived

11 Rawl 1139 nabattu Karae Dima sikalabini

$26 \operatorname{Nov}(\mathrm{T}) \quad$ a Selayarese named I Pundamaq installed as nayaka of the bissu

1 Rakr 1139 nanipantama nayaka bissu Silayaraka nikanaya I Pundamaq

10 Dec (T) the nayaka [Pundamaq] conducted a great exorcism ritual 15 Rakr 1139 namakkawaru lompo nayakaya

$14 \operatorname{Dec}(\mathrm{S})$

birth of I Cumaq Sitti Salehah Rimba Bulaeng635

19 Rakr 1139 nanianakkang I Cumaq Sitti Salehah Rimba Bulaeng

$15 \operatorname{Dec}(\mathrm{N}) \quad$ my grandparent I Daeng Maqleoq killed to the east in Pareq by his companion he had gone to find 20 Rakr 1139 nanibuno toaku I Daeng Maqleoq iraya ri Pareq ri aganna mangea naboya

16 Dec (M) [I Daeng Maqleoq] was brought seawards here, then across to Taenga and buried

21 Rakr 1139 nanierang kalauq mae naibaqle ri Taenga niawan

\section{7}

7 Jan $(\mathrm{T})$

13 Jawl 1139

it is said that I Daeng Mattara died in Jakattaraq nanikana matei I Daeng Mattara ri Jakattaraq

13 Jan (N eve) all the people of Dompu fled overseas from Kampong Beru as they were about to be given to their ruler

19 Jawl 1139 namalaringaseng Dompua ilauka ri Kampong Beru lanipamangen ri karaengna

17 Jan $(\mathrm{F}) \quad$ there was a very great flood [tidalwave] in the river like never before 
23 Jawl 1139

19 Jan (S eve)

25 Jawl 1139

31 Jan (F)

8 Jakr 1139

8 Feb (S)

16 Jakr 1139

16 Feb (N)

24 Jakr 1139

20 Feb (R)

28 Jakr 1139

24 Feb (M) namalompo dudu aqbaya ri binangaya tinang kammai

the ruler of Dompu I Daeng Manombong died namate Karae Dompu I Daeng Manombong

Anduq Puaq died

namate Anduq Puaq

Sudanga and Latea ri Duni were placed side by side in the house in Paqbineang [Sirajuddin's new royal hall] for the 5th time; the people of Takalar, whose overseer was I Bagusuq, were given to the karaeng [Sirajuddin] with all that belonged to their community 636 nanipasiempoang Sudanga Latea ri Duni ri ballaka ri Paqbineang maka 5 nanisareang karaenga tuTakalaraka jannangannaya I Bagusuq lollong paqrasanganna

the arumpone [Datu ri Citta] and her husband [Arung Kaju] sailed from Ujung Tana down to Padang-Padang [Pare-Pare] to suppress what was said to be Datu ri Soppéng [La Padangsajati] inside Boné inciting the people of Boné [to revolt]

namamise arumpone sikalabini ri Juntana manaung ri Padang-Padang makkaruru nikananna niaki Datua ri Soppeng ilalang ri Bone ampakewai tuBonea

I [Syafiuddin] went also with my friend Karaeng Garassiq I Daeng Mattulung to follow the arumpone [Datu ri Citta]; the Patambirang ${ }^{637}$ were ordered to accompany [us]

kumaqlampa todong siagaang belaku Karae Garassiq I Daeng Mattulung ampinawang arumpone Patamberanga nisoro ampinawangaq

my older uncle Karaeng Boqdia and Karaeng Barrung divorced

636 Like Gantaq, Kassiq, and Sangkalaq the previous year, the arumpone and Arung Kaju gave Takalar to Sirajuddin (Ligtvoet 1880:206).

637 Patambirang refers to a collection of communities north of Gowa established by Bugis nobles who, according to oral tradition, settled there with the ruler of Talloq's permission after they returned from Boné bearing the body of Gowa's ruler Tunibatta in 1565. These lords were given special honors and (at least originally) freed from paying tribute to Gowa (Friedericy 1929:425-7; Ligtvoet 1880:footnote 206). 
2 Raj 1139

nasipelaq puangku Karae Boqdia Karae Barrun

$4 \operatorname{Mar}(\mathrm{T})$

10 Raj 1139

it is said that Datu ri Soppéng [La Padangsajati] was in Batangnionjoq [Agangnionjoq] and was ordered guarded because it was said he was going to the Dutch nanikana niaki Datua ri Soppeng ri Batangnionjoq nanisuro kammiq kanikana alamaei ri Balandaya

10 Mar (M) I Laiqjiq arrived here with his blood relatives ${ }^{638}$, saying that all the people went from the Datu [ri Soppéng], who also was brought down to the arumpone [Datu ri Citta]

16 Raj 1139 nabattu I Laiqjiq mae ri katuguana nakana maqlampa ngasengmi taua ri Datua nieran tommi manaung ri arungpone

$13 \operatorname{Mar}(\mathrm{R}) \quad$ it is said that Datu ri Soppéng [La Padangsajati] was there beside the arumpone [Datu ri Citta]

19 Raj 1139 nanikana niaqmi Datua ri Soppeng irawa ri arumpone

20 Mar (W eve) I Cocoq, a wife of I Kare Mangalle, died

26 Raj 1139 namate I Cocoq bainenna I Kare Mangalle

$22 \mathrm{Mar}(\mathrm{S}) \quad$ I arrived from following the arumpone [Datu ri Citta]; it is said that my older uncle I Mattaq [La Padangsajati] and his wife and family were exiled down beneath [i.e. to the north side of] Luwuq639

28 Raj 1139 kubattumo ampinawangi arungpone nanikana nicindei puanna I Mattaq sikalabini sipamanakang manaung irawanganna Luq

$5 \operatorname{Apr}(S)$

17 Syab 1139

my elder sibling Karaeng Tanasanga and Bumi Partiga ${ }^{640}$ married nasikalabini daengku Karae Tanasanga Bumi Partiga

9 Apr (T eve) my older uncle Karaeng Boqdia and Karaeng Barrung returned to each other

21 Syab 1139 nasipolei puangku Karae Boqdia Karae Barrung

\footnotetext{
638 'Blood relatives' is Ligtvoet's (1880:207) translation of 'katuguana'.

639 This was his punishment for attempting to foment revolt in Boné.

640 The appointed successor or crown prince of Bima bore this title, which here referred to Ala'uddin Muhammad Syah, a son of Mappatalliq Hasanuddin.
} 
26 Apr (F) my younger uncle Karaeng Alluq landed at Ujung Pandang, arriving from Jakattaraq

3 Ram 1139 nasore ri Jumpandang putoku Karae Alluq battu ri Jakattaraq

3 May (F eve) the ruler of Bima [Mappatalliq] went with his wife [Karaeng Bisangpole] over to his homeland [on Sumbawa]

10 Ram 1139 namaqlampamo Karae Dima sikalabini taqle ri paqrasangana

7 May (W) Karaeng ri Talloq [Najamuddin] asked that I Kare Lesang be installed as gallarrang [of Talloq]

14 Ram 1139 nanapalaq Karaenga ri Talloq I Kare Lesang natannang gallarrang

13 Jul (S eve) I Saidah, a wife of I Daeng Maqleoq, had a daughter

23 Zulk 1139 namamanaq I Saidah bainenna I Daeng Maqleoq baine

31 Jul (W eve) I Daeng Nisimba, former spouse of Karaeng ri Bontopanno, died

12 Zulh 1139 namate I Daeng Nisimba pallaloanna Karaengta ri Bontopannoh

13 Aug (W) an envoy from the arumpone [Datu ri Citta] arrived bringing news of the death of my older uncle I Mattaq and his wife and family; they were cut down

25 Zulh 1139 nabattu surona arungpone ampabirittai matena puanna I Mattaq sikalabini sipamanakang nijalloki

$25 \operatorname{Aug}(\mathrm{M})$

8 Muh 1140

$2 \operatorname{Sep}(\mathrm{T})$

16 Muh 1140

14 Oct $(\mathrm{T})$

28 Saf 1140
Amirah had a son Manshur I Mallawang Gauq ${ }^{641}$ namamanaq Amirah buraqne Manshur I Mallawang Gauq

my younger aunt Karaeng Barong Patola and I Daeng Makkulle I Tipu married nasikalabini ayaku Karae Barong Patola I Daeng Makkulle I Tipu

a house for the karaeng [Sirajuddin] built outside of Mallengkeri

nanibangun ballaqna karaenga ipantaraq ri Mallengkeri

641 A son of Karaeng Lempangang also known as Tumamenang ri Gowa (Ligtvoet 1880:207). 
24 Oct (R)

30 Saf $1140^{642}$

$2 \operatorname{Nov}(\mathrm{N})$

17 Rawl 1140

$10 \operatorname{Nov}(\mathrm{M})$

25 Rawl 1140

$23 \operatorname{Nov}(\mathrm{N})$

9 Rakr 1140

$26 \operatorname{Nov}(W)$

12 Rakr 1140

15 Dec (M)

1 Jawl 1140

17 Dec (W)

3 Jawl 1140

$21 \operatorname{Dec}(\mathrm{N})$

5 Jawl 1140

$27 \operatorname{Dec}(S)$

13 Jawl 1140
I Mattenai and a child of I Daeng Ngago [Isa] married nasikalabini I Mattenai anaqna I Daeng Ngago

I Mattayang and I Daeng Mateqne I Sitti divorced nasipelaq I Mattayang I Daeng Mateqne I Sitti

I Mandi, a grandchild of Daengta I Daeng Talarra, circumcised

nanisunnaq I Mandi cucunna Daengta I Daeng Talarra

I Sitti, former spouse of I Mattayang, had a daughter namamanaq I Sitti palloloanna I Mattayang baine

my older uncle Karaeng Boqdia and Karaeng Barrung divorced again

nasipelaq pole puangku Karae Boqdia Karae Barrung

I Maliq, a child of Puaq Ikkuq, died

namate I Maliq anaqna Puaq Ikkuq

there arrived an Arab from Bait al Faqih [in Yemen] named Abu Bakar Ibnu Muhammad Syaibi niaq Arab Baitalfaqih battu nikana Abu Bakar Ibnu Muhammad Syaibi

teeth filed of I Didaq, a child of Karaeng Bontomateqne naniariq I Didaq anaqna Karae Bontomateqne

Daengta I Daeng Ngampa, a child of Karaeng Rappociniq, died namate Daengta I Daeng Ngampa anaqna Karaengta Rappociniq

1728

29 Jan (W eve) Karaeng ri Bontopaqja ${ }^{643}$ died at the age of 76

17 Jakr 1140 namate Karaengta ri Bontopaqja umuruqna 76

642 The Hijri date converts to 16 Oct 1727.

643 Probably a daughter of the ruler of Bima Ambela Sirajuddin and Karaeng Bontojeqneq (Ligtvoet 1880:207-8). 
7 Feb (S) there 13 Torajans, people from Tallung Lipu, brought into Islam by Shaykh

26 Jakr 1140 niaq Toraja tuTallung Lipu 13 nipantama Islam ri Syekh

9 Feb (N eve) I Daeng Manassaq I Muhammad died at 30 years of age 28 Jakr 1140 namate I Daeng Manassaq I Muhammad talassaqna 30 taun

15 Feb (N) the day I Ninuq ${ }^{644}$, a child of Karaeng Bontorambaq, died below in Batangnionjoq

4 Raj $1140 \quad$ allo nakamateanga I Ninuq anaqna Karae Bontorambaq irawa ri Batangnionjoq

21 Feb (F eve) I Daeng Marewa and I Karimah married

10 Raj 1140 nasikalabini I Daeng Marewa I Karimah

$22 \mathrm{Feb}(\mathrm{N}) \quad$ I Daeng Mateqne, a child of Daengta Daeng Marimang, died

11 Raj $1140 \quad$ namate I Daeng Mateqne anaqna Daengta Daeng Marimang

26 Feb (W eve) I Saqdaq and I Mindaq married

15 Raj 1140 nasikalabini I Saqdaq I Mindaq

$26 \mathrm{Feb}(\mathrm{R}) \quad$ Karaeng Bulo-Bulo I Rimba died, having lived to be 19

15 Raj $1140 \quad$ namate Karae Bulo-Bulo I Rimba tallasaqna 19

21 Mar (F eve) I Dadiq killed, recognized as having a kris hilt [that belonged to another]

8 Syab 1140 nanibuno I Dadiq nipanrupai pangulu

$21 \operatorname{Mar}(\mathrm{S}) \quad$ I Abu, a grandchild of Anro Malole, killed by the Dutch along with the child of I Jakuq

8 Syab 1140 nanibuno I Abu cucunna Anro Malole ri Balandaya siagaang anaqna I Jakuq

31 Mar (T eve) Karaeng Patukangang had a son Abdul Gafur who lived 3 nights

19 Syab 1140 namamanaq Karae Patukangang buraqne Abdul Gafur 3 banngi tallasaqna 
21 Apr (W) Sayyid Alwi died

10 Ram $1140 \quad$ namate Sayyid Alwi

$26 \operatorname{Apr}(\mathrm{M}) \quad$ I Malikah and I Mangeranngi divorced

15 Ram 1140 nasipelaq I Malikah I Mangeranngi

27 Apr (M eve) my elder sibling Karaeng Tanasanga had a daughter named Rante Patola Sitti Rabiah

16 Ram 1140 namamanaq daengku Karae Tanasanga baine nikana Rante Patola Sitti Rabiah

1 May (S) I Daeng Ngaseng I Saqbaraq died

20 Ram 1140 namate I Daeng Ngaseng I Saqbaraq

7 May (F) the day of Arung Pattojo's death

26 Ram 1140 allo nakamateanga Aruq Pattojo

8 May (F eve) the karaeng [Sirajuddin] grew a beard 645

27 Ram 1140 namaqjanggoq karaenga

10 May (N eve) birth of Ratu Bulaeng Sitti Radiah

29 Ram $1140 \quad$ nanianakkang Ratu Bulaeng Sitti Radiah

25 May (M) I Manrewakki, a child of Karaeng Batupute, circumcised and then adopted by Karaeng Manjalling

15 Syaw 1140 nanisunnaq I Manrewakki anaqna Karae Batu Puteh nakatuoa Karae Manjalling

31 May (N eve) my great grandparent I Daeng Ngantu I Yociq died 21 Syaw 1140 namate boeku I Daeng Ngantu I Yociq

6 Jun $(\mathrm{N}) \quad$ Karaeng Barrung had a son named I Callaq 27 Syaw 1140 namanaq Karae Barrung buraqne nikana I Callaq

18 Jun (R eve) Gallarrang Parangloe I Laddin died 10 Zulk 1140 namate Gallarang Parangloe I Laddin

10 Jul (S) my grandparent I Daeng Masseqre I Jaga died and I Daeng Manjakkalaq I Luddin replaced him ${ }^{646}$ 
3 Zulh 1140 namate toaku I Daeng Masseqre I Jaga naIDaeng Manjakkalaq I Luddin assambeangi

28 Aug (S) I Manrannuang and I Buba married

22 Muh 1141 nasikalabini I Manrannuang I Buba

29 Aug $(\mathrm{N}) \quad$ Karaeng Balambaru and I Danruq married

23 Muh 1141 nasikalabini Karaeng Balambaru I Danruq

11 Sep (S) Karaeng ri Talloq [Najamuddin] came himself on account of what Monnoq did

7 Saf 1141 nanaerang kalenna Karaenga ri Talloq lanri gauka ri Monnoq

17 Sep (F) Addatuanga ri Massepe ${ }^{647}$ and Karaeng Tangallaq married

13 Saf 1141 nasikalabini Aqdatuan ri Massepe Karae Tangallaq

8 Oct (F) the ship carrying Bumi Partiga, who was bringing his wife [Karaeng Tanasanga] over to Bima, briefly went down to Kampong Beru

4 Rawl 1141 namaqdongkoq ri biseang Bumi Partiga angerangi bainenna taqle ri Dima manaungiji ri Kampong Beru

9 Oct (S) my younger aunt Karaeng Bontojeqneq was seawards in Kampong Beru; my older uncle [Arung Kaju] went to bring her [his former wife] up to Talloq; he and the arumpone [Datu ri Citta] also divorced

5 Rawl 1141 ilauki ri Kampong Beru ayaku Karae Bontojeqneq namange puangku angallei manraiq ri Talloq nasipelaq tommo arungpone

18 Oct (N eve) I Kare Nassa, a child of I Tuang648, died

14 Rawl 1141 namate I Kare Nassa anaqna I Tuan

22 Oct (R eve) I Daeng Tacoa I Alimah died

18 Rawl 1141 namate I Daeng Tacoa I Alimah

4 Nov (R) I Bimbang installed as nayaka, replacing the Selayarese nayaka [I Pundamaq]

648 This probably refers to Tuang Rappang. 
2 Rakr 1141 nanitannang nayaka I Bimbaga assambeangi nayaka Silayaraka

$5 \operatorname{Nov}(\mathrm{F}) \quad$ Isa, a child of I Daeng Ngago, had a son

3 Rakr 1141

namamanaq Isa anaqna I Daeng Ngago buraqne

13 Nov (S) people mustered for the installation of Governor Josua van Arrewijne

11 Rakr 1141 namarewangan taua nilantiqna Gurnadur Josawapan Arwin

6 Dec (M) belongings seized of Karaeng Bontojeqneq by the karaeng [Sirajuddin]; his Makassarese possessions [were taken]

4 Jawl 1141 nanirappung Karae Bontojeqneq ri karaenga panganuang Mankasaraqna

$9 \operatorname{Dec}(\mathrm{R}) \quad$ I Mappaq and I Yakiah married

7 Jawl 1141 nasikalabini I Mappaq I Yakiah

$21 \operatorname{Dec}(\mathrm{S}) \quad$ I Mammaq, a child of the younger Ratu Bagus, circumcised

19 Jawl 1141 nanisunnaq I Mammaq anaqna Ratu Bagusuq malolo

1729

10 Jan (M) I Tappaq, a child of Karaeng Palemba, circumcised

10 Jakr 1141 nanisunnaq I Tappaq anaqna Karae Palemba

28 Jan ( $R$ eve) Karaeng ri Campagaya died at the age of 73

28 Jakr 1141 namate Karaengta ri Campagaya umuruqna 73

29 Jan (F eve) I Kare Jannang, a widow of the kadi, died

29 Jakr 1141 namate I Kare Jannang balunna qadia

5 Feb (S) I Karimah, a wife of I Daeng Marewa, had a son

Muhammad Rajab

6 Raj 1141 namamanaq I Karimah bainenna I Daeng Marewa buraqne Muhammad Rajab

12 Feb (S)

I Nuh circumcised; Karaeng ri Mangaraqbombang died

13 Raj 1141 nanisunnaq I Nuh namate Karaengta ri Mangaraqbombang 
25 Feb (F) I Kare Sitaba I Jalani, a child of I Tuang ${ }^{649}$, died

26 Raj 1141 namate I Kare Sitaba I Jalani anaqna I Tuan

$14 \operatorname{Mar}(\mathrm{M}) \quad$ Gallarrang Mangasa I Kare Mangalle died but his child named I Kasing replaced him

13 Syab 1141 namate Gallarrang Mangasa I Kare Mangalle anaqnaji nikanaya I Kasing assambeangi

15 Mar (T) Gallarrang Bontoalaq, zakat650 official, died

14 Syab 1141 namate Gallarrang Bontoalaq suro pajakkoq

$20 \operatorname{Mar}(\mathrm{N}) \quad$ I Buba and Muhammad Ali married

19 Syab 1141 nasikalabini I Buba Muhammad Ali

29 Mar (T) I Liasaq, a child of I Daeng Mami Dalang, died

28 Syab 1141 namate I Liasaq anaqna I Daeng Mami Dalang

5 Apr (M eve) Gallarrang Tomboloq I Mangemba died

5 Ram 1141 namate Gallarrang Tomboloq I Mangemba

24 Apr (N) we were left by Karaeng ri Talloq Tumamenang ri Jawaya ${ }^{651}$ [Najamuddin]

24 Ram 1141 kinapilari Karaenga ri Talloq Tuammenanga ri Jawaya

$25 \operatorname{Apr}(\mathrm{M}) \quad$ Karaeng ri Gowa [Sirajuddin] again took hold of the land of Talloq 652

25 Ram 1141 naKaraenga ri Gowa pole antaqgalaki buttana ri Talloq

5 May (W eve) I Daeng Maniqgalli, a younger sibling of Karaeng Bidara, died

6 Syaw 1141 namate I Daeng Maniqgalli arinna Karaenga Bidara

649 This probably refers to Tuang Rappang.

650 Zakat refers to the tithing required of observant Muslims. Since a mosque was first constructed in Bontoalaq (completed on 10 Nov 1635) and Friday prayers established (30 Oct 1648), it had been the center of Islam in Makassar, and the comparatively few references to Islamic officials (such as the pakki mentioned on 10 Oct 1693) in the annals are generally tied to this location.

651 His posthumous name indicates that he died in Jawaya, a settlement just south of the Talloq river.

652 Following the death of his son Najamuddin Tumamenang ri Jawaya. 
15 May (N) I Daeng Maingaq's belongings seized and she was banished east to Moncongang; I Daeng Manyampakki banished; I Daeng Sangging left to go east to Sandao

16 Syaw 1141 nanirappung nanicindei I Daeng Maingaq manraiq ri Moncongan I Daeng Manyampakki nicindei maqlampa I Daeng Sangging lanipanraiq ri Sandao

16 May (M) I Kapparaq, a child of Karaeng ri Mandalleq, killed by La Maqdiq ${ }^{653}$ seawards in Ujung Pandang

17 Syaw 1141 nanibuno I Kapparaq anaqna Karaengta ri Mandalleq ri Lamaqdiq ilauq ri Jumpandang

18 May (W) Karaeng Bontolangkasaq arrived, followed, and killed I La Maqdiq

19 Syaw 1141 nabattu Karae Bontolangkasaq ampinawangi ambunoi I Lamaqdiq

10 Jun (R eve) I Maqmiq, a child of I Daeng Mattulung, died

12 Zulk 1141 namate I Maqmiq anaqna I Daeng Mattulung

9 Jul (S) I Mappaq, a grandchild of I Daeng Talarra, and a niece of Karaeng Bidara married

12 Zulh 1141 nasikalabini I Mappaq cucunna I Daeng Talarra kamanakanna Karaeng Bidara

$16 \mathrm{Jul}(\mathrm{S}) \quad$ the Dutch rice storehouse inside the fort burned

19 Zulh 1141 namakanre gaqdon berasaqna Balandaya ilalang kota

$29 \mathrm{Jul}$ (R eve) I Maidah had a daughter

2 Muh 1142 namamanaq I Maidah baine

$19 \operatorname{Aug}(\mathrm{F}) \quad$ it is said that [Governor] General Mattheus de Haan died in Jakattaraq

23 Muh 1142 nanikana matei Jenrala Matihus Dihana ri Jakattaraq

20 Aug (S) Amirah had a daughter named I Danradatu Sitti Napisah ${ }^{654}$

24 Muh 1142 namamanaq Amirah baine nikana I Danradatu Sitti Napisah

653 A son of La Patauq (Ligtvoet 1880:209).

654 Karaeng Langeloq. 
12 Sep (M) teeth filed of a child of I Daeng Maqruppa I Tinting

18 Saf 1142

5 Oct $(W)$

12 Rawl 1142

10 Oct (M)

17 Rawl 1142

14 Oct (R eve) Karaeng Patukangang had a daughter named I Sugiratu Sitti Aminah 655

21 Rawl 1142 namamanaq Karae Patukangan baine nikana I Sugiratu Sitti Aminah

15 Oct $(S)$

22 Rawl 1142

$13 \operatorname{Nov}(\mathrm{N})$

21 Rakr 1142 cumcised

nanisunnaq Abdussalam anaqna Karae Tallampuang Suluka

I Nunniq, a wife of I Daeng Ngago, died namate I Nunniq bainenna I Daeng Ngago will live in it

nanaempoimo ballaqna karaenga ipantaraka ri

Mallengkeri 2 taun anruambulan nanaempoi

I Daeng Marannu I Sugi had a daughter by Dadiq namamanaq I Daeng Marannu I Sugi ri Dadiq baine
Abdussalam, a child of Karaeng Tallampuang Suluka, cir-

the karaeng [Sirajuddin] goes to live in his house outside Mallengkeri; 2 years and two months [after being built] he

27 Nov (S eve) 656 the interpreter I Jakuq died

6 Jawl 1142

namate juru basaya I Jakuq

28 Nov $(M)^{657}$ the day of Datu ri Mario's ${ }^{658}$ death below in

Batangnionjoq

7 Jawl 1142 allo nakamatenga Datua ri Mario irawa ri Batangnionjoq

$29 \mathrm{Dec}(\mathrm{R}) \quad$ at the sun's setting Karaeng Tangallaq had a daughter who was already dead when she came out

8 Jakr 1142 ambanimi saqraq alloa namamanaq Karae Tangallaq baine mate memange battu suluq

655 Later known as Arung Teko and Arung Kaju.

656 A copyist mistakenly wrote the 17 th instead of the 27 th.

657 A copyist mistakenly wrote the 18th instead of the 28th.

658 Arung Patiro, a daughter of the ruler of Tanete Daeng Mattajang Matinroe ri Sumpampoba (Ligtvoet 1880:210). 


\section{0}

5 Feb $(\mathrm{N})$

17 Raj 1142

26 Feb (F eve)

8 Syab 1142

$10 \operatorname{Mar}(\mathrm{F})$

25 Syab $1142^{659}$

$11 \operatorname{Mar}(\mathrm{N})$

22 Syab 1142

$12 \operatorname{Apr}(\mathrm{W})$

23 Ram 1142

$14 \operatorname{Apr}(\mathrm{F})$

25 Ram 1142 I Sumang, a child of I Tuang Abu Bakar, and I Sarimba married nasikalabini I Suman anaqna I Tuan Abu Bakar I Sarimba

\section{Daeng Sitaba and I Cinra married} nasikalabini I Daeng Sitaba I Cinra

I Sabirah, a child of Karaeng Batupute, died namate I Sabirah anaqna Karae Batuputeh

I Thahirah and I Mangiq, a child of Abu Bakar, married ${ }^{660}$; yesterday during the night I Buba had a daughter nasikalabini I Thahirah I Mangiq anaqna Abu Bakar sibanngi ri banngia namamanaq I Buba baine

the envoy I Daeng Maqruppa arrived bringing news of the death of his wife across in Bontotalo 4 months [ago] nabattu surona I Daeng Maqruppa ampabirittai matena bainenna ibaqle ri Bontotalo 4 bulanmi

I Congaq arrived from Buton, ordered brought by the ruler of Buton here to the Dutch 661 nabattu ri Butong I Congaq nisuro erang ri karae Buton mae ri Balandaya

23 Apr (S eve) Karaeng ri Langeloq died at the age of 70 and four months 662

4 Syaw 1142 namate Karaengta ri Langeloq umuruqna 70 ampatambulan

659 The date appears to be out of chronological order, but the correct Hijri date is probably the 21st.

660 Abu Bakar was an Arab who arrived in Makassar on 17 Dec 1727, and the marriages of two of his children in rapid succession and their commemoration in the annals evidence his incorporation into the lower ranks of elite Makassarese society.

661 I Congaq is a short version of I Tamasongaq, La Temasonge in Bugis. This was Datu Baringang Matinroe ri Malimongeng, later ruler of Boné. In 1727 he and two brothers had fled to Buton to escape their half-sister Datu ri Citta, the arumpone of Boné and her husband Arung Kaju (Ligtvoet 1880:210).

662 Though precise, this reckoning is incorrect; she was born 29 May 1656, which means she died at almost age 74 according to the Gregorian solar calendar and 76 according to the Hijri lunar calendar. Annalists typically used the Hijri calendar to calculate ages. 
9 May (T)

20 Syaw 1142

20 May (S)

2 Zulk 1142

18 Jun (S)

2 Zulh 1142

26 Jun (T)

10 Zulh 1142

$12 \mathrm{Jul}(\mathrm{W})$

26 Zulh 1142

5 Aug (S)

20 Muh 1143

$20 \operatorname{Aug}(N)$

6 Saf 1143

6 Sep $(W)$

23 Saf 1143

14 Sep (W eve) 1 Rawl 1143

2 Oct (M)

19 Rawl 1143
I Doqdiq, a younger sibling of I Daeng Ningai, died namate I Doqdiq arinna I Daeng Ningai

the day of my grandparent's $\mathrm{s}^{663}$ death across on Bima; my younger uncle Karaeng Panaikang sailed [over to Bima] to fetch my elder sibling Karaeng Tanasanga allo nakamateanga toaku ibaqle ri Dima namamise putoku Karae Panaikang ambuntuli daengku Karae Tanasanga

a child of a slave of Karaeng Bisei died from smallpox ${ }^{664}$ namate mapuru anaq ri atanna Karae Bisei

I Karimah had a daughter Shafiah namamanaq I Karimah baine Shafiah

my younger uncle Karaeng Panaikang arrived from Bima bringing my elder sibling [Karaeng Tanasanga] nabattumo ri Dima putoku Karae Panaikang angerangi daengku

Karaeng Bontoa had a son named I Lotteng Salahuddin namamanaq Karae Bontoa buraqne nikana I Lotteng Salahuddin

a child of Karaeng Bulukumba named I Nojeng died, just suddenly dying outside Bontomanaiq namate anaqna Karaeng Bulukumbba nikanaya I Nojeng ipantaraq ri Bontomanaiq tiqring mateji

I Daeng Mangasa Jipang died namate I Daeng Mangasa Jipang

I Mattenai and a child of I Daeng Ngago married nasikalabini I Mattenai anaqna I Daeng Ngago

the [royal] banners were smeared with blood as people [warriors] went over to Sandao naniceraq batena tumantallea ri Sandao

663 Ligtvoet (1880:210) believed this grandmother was Daengta Daeng Nisayu, widow of Arung Teko and grandmother of Karaeng Tanasanga; however, Daengta Daeng Nisayu is recorded as having died on 7 Oct 1709.

664 'Mapuru' means to have sores or pustules, but probably indicates smallpox. 
5 Oct $(\mathrm{R}) \quad$ Karaeng Bontomajannang sailed with Karaeng Bontotannga over to Sandao to make war

22 Rawl 1143 namamise Karae Bontomajannang taqle ri Sandao maqbunduq siagaang Karae Bontotannga

9 Oct (M) the coffins of I Daeng Mateqne I Sipaya with his child were brought back

26 Rawl 1143 nabattu nierang allunna I Daeng Mateqne I Sipaya siagaang anaqna

13 Oct (F) Amirah had a daughter named I Rida Sitti Rahmah

1 Rakr 1143 namamanaq Amirah baine nikana I Rida Sitti Rahmah

16 Oct (N eve) I Yakiah, a child of Karaeng Lembang, died at the age of 18 and seven months

4 Rakr 1143 namate I Yakiah anaqna Karae Lembang umuruqna 18 antuju bulan

3 Nov (F) I Daeng Manangaraq arrived from Massepe [in Sidénréng], sent to request the consent of I Tanri ${ }^{665}$ for the Addatuanga [ri Massepe] to sever [his marriage to her] 22 Rakr 1143 nabattu I Daeng Manangaraq ri Massepe nisuro ampappalaq katuang I Tanrri ri Aqdatuangi kattomi

$12 \operatorname{Nov}(\mathrm{N}) \quad$ my younger uncle I Daeng Maqruppa I Sajaq died 1 Jawl 1143 namate putoku I Daeng Maqruppa I Sajaq

17 Nov (F) I Daeng Mattulung, anrongguru of the envoys, died 6 Jawl 1143 namate I Daeng Mattulung anronggurunna suroa

$18 \operatorname{Nov}(S) \quad$ I Mappaq, a child of I Daeng Tapallaq, circumcised by Arung Panaikang666

7 Jawl 1143 nanisunnaq I Mappaq anaqna I Daeng Tapallaq ri Aruq Panaikang

28 Nov (M eve) a wife of I Kare Jarreq, anrongguru of the anaq buraqne, died

17 Jawl 1143 namate bainenna I Kare Jarreq anrongguru anaq buraqne

665 Karaeng Tangallaq, whose personal name was Tanripadaq.

666 Presumably this refers to Karaeng Panaikang, a prominent figure in Makassar at the time who was supervisor of the lesser anaq karaeng and an envoy of the ruler Sirajuddin. 
$30 \operatorname{Nov}(\mathrm{R}) \quad$ ears pierced of a child of I Monnoq in Bantaeng

19 Jawl 1143 nanitinting anaqna I Monno ri Bantaeng

$3 \operatorname{Dec}(\mathrm{N}) \quad$ a karaengship given to I Daeng Ngago, now called Karaeng Paranggi

22 Jawl 1143 nanisare pakkaraengang I Daeng Ngago nikana Karae Paranggi

7 Dec (R) my younger uncle Karaeng Bontolangkasaq and Karaeng Bontoa divorced

27 Jawl 1143 nasipelaq putoku Karae Bontolangkasaq Karae Bontoa

1731

5 Jan (F) I Mappaq, a child of Karaeng Mangisuq, and I Patimaq, a child of Karaeng Paranggi, married

26 Jakr 1143 nasikalabini I Mappaq anaqna Karae Mangisuq I Patimaq anaqna Karae Paranggi

6 Jan (F eve) this was purportedly when a royal hall667 in Massepe and 3 houses burned

27 Jakr 1143 ia anne bedeng namakkanre salassaka ri Massepe 3 batu ballaq

23 Jan (T) this was purportedly the day the ruler of Bima [Mappatalliq] died across in Bima

14 Raj 1143 ia anne bedeng alloa nakamateang Karaenga ri Dima ibaqle ri Dima

24 Jan (W) I Mattayang cut down I Mammaq, a child of I Daeng Mipati; one of his slaves went amuk ${ }^{668}$; I Mattayang died

15 Raj 1143 namaqjalloq I Mattayang I Mammaq anaqna I Daeng Mipati najalloq sitaumi atanna namate I Mattayang

25 Jan (R) I Mammaq died too

16 Raj 1143 namatetommo I Mammaq

26 Jan (R eve) I Sarimba, a wife of I Sumang, had a daughter 17 Raj 1143 namamanaq I Sarimba bainenna I Suman baine

667 The term salassaq can also refer to a palisade.

668 This could also be read as meaning that Mattayang then cut down one of I Mammaq's slaves. 
6 Feb (M eve) tumailalang Karaeng ri Bontopanno died at the age of 81 28 Raj 1143 namate tumailalang Karaengta ri Bontopannoh umuruqna 81

10 Feb (F eve) Karaeng Bontomajannang arrived from Sandao and conquering Poma [on Flores]

3 Syab 1143 nabattumo ri Sandao Karae Bontomajannang ambetai Poma

18 Feb (S eve) I Saodah, a child of Karaeng Bontomajannang, died 11 Syab 1143 namate I Saodah anaqna Karae Bontomajannang

1 Mar (W eve) I Dandung, a wife of my grandparent I Daeng Manggappa ${ }^{669}$, died

22 Syab 1143 namate I Dandung bainenna toaku I Daeng Manggappa

3 Mar (S) a Bimanese envoy arrived bringing news of the death of the ruler of Bima [Mappatalliq] 1 month and 8 nights [ago]

24 Syab 1143 nabattu surona Dimaya ampabirittai matena Karae Dima1 bulanmi 8 banngi

5 Mar (M eve) my younger uncle Karaeng Panaikang broke off his relationship with [his wife] I Daeng Ningai

26 Syab 1143 nanitappuki I Daeng Ningai ri putoku Karae Panaikang

14 Mar (T eve) I Asiah, a child of Daengta Daeng Ngaseng by Maradiah, died

5 Ram 1143 namate I Asiah anaqna Daengta Daeng Ngaseng ri Maradiah

30 Mar (F) Tuang Abu Bakar broke off his relationship with I Daeng Tamemang

21 Ram 1143 nanitappuki I Daeng Tamemang ri Tuan Abu Bakkar

12 Apr (W eve) I Gacong, anrongguru 670 of the people of Takalar, was killed; it is not known who killed him

4 Syaw 1143 nanibuno I Gacong anronggurunna tuTakalaraka taniassengai tuambunoai

669 Probably but not necessarily the Daeng Manggappa was born on 6 Aug 1688.

670 Here the term anrongguru simply means a chief or leader. 
18 Apr (T eve) I Sitti, a child of the elder Ratu Bagus, died 10 Syaw 1143 namate I Sitti anaqna Ratu Bagusuq matoa

21 Apr (S) word arrived from Sumbawa reporting that the ruler of Sumbawa ${ }^{671}$ died; gunpowder exploded and he was blown into the air with his house

13 Syaw 1143 niaq kana battu ri Sambawa nikana matei Karae Sambawa nakanrei ubaq nipasiriqbakangi ballaqna

30 Apr (N eve) I Daeng Mambani I Bambiq and I Sapinah married 22 Syaw 1143 nasikalabini I Daeng Mambani I Bambiq I Sapinah

30 Apr (M) the people of Kadatong went to Mappatanre, now called Karaeng Masale

22 Syaw 1143 nanipamange tuKadatonga ri Mappatanre nikana Karae Masaleh

1 May (T) my grandparent I Daeng Talarra I Jaleka died 23 Syaw 1143 namate toaku I Daeng Talarra I Jaleka

9 May (W) the Bimanese arrived to take as ruler Bumi Partiga

2 Zulk 1143 nabattu Dimaya angallei karaeng Bumi Partiga

7 Jun (R) the people of Katapang went to Daeng Talarra because it was he they wanted, not Karaeng Bidara

1 Zulh 1143 nanipamange tuKatapanga ri Daeng Talarra kaia nakaeroki teami ri Karaeng Bidara

28 Jul (F eve) Karaeng Majannang brought to the karaeng [Sirajuddin]; his kris was taken away

22 Muh 1144 nanierang ri karaenga Karae Majannang nipalelei toboqna

2 Aug (R) my younger uncle Karaeng Bontolangkasaq and Karaeng Sumannaq ${ }^{672}$ married

27 Muh 1144 nasikalabini putoku Karae Bontolangkasaq Karae Sumannaq

16 Aug (R) I Karimah, a wife of Daeng Marewa, had a son Abdurrasyid

671 Jalaluddin.

672 Probably Zainab, a daughter of Karaeng ri Tana-Tana and the ruler of Sanrabone Karaeng Mamampang (Ligtvoet 1880:213). 
12 Saf 1144

namamanaq I Karimah bainenna I Daeng Marewa buraqne Abdurrasyid

23 Aug (R) my younger uncle I Kalingkeriq died below in Talloq

19 Saf 1144 namate putoku I Kalingkeriq irawa ri Talloq

2 Sep $(\mathrm{N})$

29 Saf 1144

I Karimah and Daeng Marewa divorced nasipelaq I Daeng Marewa I Karimah

10 Sep (N eve) I Niba, a child of tumailalang Karaeng ri Lekoqboqdong, died

8 Rawl 1144 namate I Niba anaqna tumailalang Karaengta ri Lekoqboqdong

26 Sep (W) I Manyanreri, a child of tumailalang Karaeng ri Lekoqboqdong, died

24 Rawl 1144 namate I Manyanreri anaqna tumailalang Karaengta ri Lekoqboqdong

3 Oct (T eve) I Taba acted as a thief above in the karaeng's [Sirajuddin's] house here inside Gowa, stabbing the banner bearer guarding the house; he was swarmed and brought down; only once it was morning did they knew it was I Taba; the thief was summoned, ordered bound, and made to speak; he confessed and also identifed the one who was with him, saying I Kauji, a child of I Kare Mambani, was guilty; then he was ordered surrounded and searched by I Taba for weapons

1 Rakr 1144 namaqgauq palukkaq I Taba irate ri ballaqna karaenga ilalang mae ri Gowa anoboki paerang bate angkammikai ballaq nanipangerrukang naniturungi bariqbasaqpa naniasseng I Tabaji makkioq palukkaq nanisuro sikkoq nipakana-kana nanaanimo mangerang tommi tau naagaanga nakana I Kauji anaqna I Kare Mambani naani nanisuroliungangmo naia I Taba nipappaboya-boyangi toboq

5 Oct (F) Karaeng Garassiq installed as tumailalang, replacing Karaeng ri Bontopanno

3 Rakr $1144 \quad$ nanitannang tumailalang Karae Garassiq assambeangi Karaengta ri Bontopannoh 
27 Oct (F eve) a house was built for Karaeng Paqbineang

25 Rakr 1144 nanibangun ballaqna Karae Paqbineang

$28 \operatorname{Oct}(\mathrm{N}) \quad$ I Muhammad 673 taken as karaeng by the people of Sanrabone

26 Rakr 1144 naI Muhammad naalle karaeng tuSanrabonea

7 Dec (F) I Manimbang circumcised

7 Jakr 1144 nanisunnaq I Manimbang

14 Dec (R eve) I Kare Mambani, anrongguru of the dammaq ${ }^{674}$, died 14 Jakr 1144 namate I Kare Mambani anronggurunna Dammaka

22 Dec (S) I Patimaq, a wife of I Mappaq, had a son

22 Jakr 1144 namamanaq I Patimaq bainenna I Mappaq buraqne

31 Dec ( $\mathrm{N}$ eve) I Syehu slept with I Saja

2 Raj $1144 \quad$ namaqlusereq I Sehu I Saja

1732

20 Jan (S eve) a great flood [tidalwave] in the river reached Mallengkeri

22 Raj $1144 \quad$ namalompo aqbaya ri binangaya naalle Mallengkeri

22 Jan (T) Gallarrang Rappo-Rappo Jawa I Kare Malliongi died

23 Raj 1144 namate Gallarang Rappo-Rappo Jawa I Kare Malliongi

30 Jan (W) I Daeng Manassaq fined one kati and one tai for opposing a decision 675

2 Syab 1144 nanipassala I Daeng Manassaq sikati assitaiq annumpaki bicara

31 Jan (R) I Balingkasaq fed ${ }^{676}$ and shorn; Karaeng ri Paqbineang gathered her family for her vow after her skin sores 677 were gone and ordered a recitation [from the Qur'an]; I

673 Also known as Muhammad Baki and Karaeng Barombong, he was a son of the former ruler of Sanrabone Karaeng Mamampang and Karaeng ri Tana-Tana.

674 They were black-clad guards who protected the ruler of Gowa.

675 The penalty is fairly mild, but the nature of the decision (bicara) is uncertain. The decision in question could have been made by Sirajuddin himself, but more likely was made by the tumabicarabutta or Gallarrang Camba (if in fact he was not tumabicarabutta - see the 9 Sep 1726 entry).

676 See the note for the 26 Sep 1718 entry.

677 Probably smallpox. 
3 Syab 1144

Kare Mangewai was surrounded seawards in Jawaya; he and two of his children died nanipaemuq I Balingkasaq nikattereq nanapasseqre pamanakanna Karaengta ri Paqbineang tinjaqna leqbaqna puru assuro maca naniliungang I Kare Mangewai ilauq ri Jawaya tallui sipa[a]nakang mate

Mar $(M)^{678} \quad$ the ruler of Bima [Ala'uddin] and his wife [Karaeng Tanasanga] went over to their homeland

Ram 1144 nataqle ri paqrasanganna karae Dima sikalabini

$18 \operatorname{Mar}(\mathrm{T})$

I Saidah Kare Rimang died; I Sumang and I Sarimba divorced

21 Ram 1144 namate I Saida Kare Rimang nasipelaq I Suman I Sarimba

2 Apr (W) I Rukiah, a child of I Daeng Mangitung, stabbed herself and died

6 Syaw 1144 nanatoboq kalenna I Rukiah anaqna I Daeng Mangitung matei

17 Apr (R) I Kare Mangalle ordered to go to Mangaseng, bringing the people of Mangasa

21 Syaw 1144 nanisuro I Kare Mangalle mange ri Mangasengi angeranngangi tuMangasaya

19 Apr (S) Karaeng Paranggi sent over to Sandao with Karaeng Bontotannga by the karaeng [Sirajuddin]

23 Syaw 1144 nataqle ri Sandao Karae Paranggi siagaang Karae Bontotannga nisuro karaenga

9 Jun (N eve) $)^{679}$ birth of I Sinddoq

15 Zulh 1144 nanianakkang I Sinddoq

18 Jun (W) I Daeng Marannu and I Dadiq divorced but returned to each other later

24 Zulh 1144 nasipelaq I Daeng Marannu I Dadiq sipoleanji salla

19 Jun (R) I Syehu arrived from Selayar

678 The dates are incomplete in VT 25, but based on the next entry can be identified as the 20th, 13th, or 6th of Ramadan and the 17th, 10th, or 3rd of March.

679 The date is omitted but based on the next entry must be the 9th. 
25 Zulh 1144 nabattu ri Silayaraq I Syehu

27 Jun (F) I Sumang, Gallarrang Bontomanaiq, and I Dadiq stabbed each other; the three died together

4 Muh 1145 nasitoboq I Suman Gallarrang Bontomanaiq I Dadiq tallu sikamateang

11 Sep (R) I Mappatimung killed by the ruler of Agangnionjoq ${ }^{680}$

21 Rawl 1145 nanibuno I Mappatimung ri karae Agangnionjoq

14 Sep (N) I Malikah proposed to by Tappaq

24 Rawl 1145 nanipassuroi I Malikah ri Tappaq

10 Oct (F) Karaeng Tabaringang died

20 Rakr 1145 namate Karae Tabaringang

17 Oct $(\mathrm{M})^{681} \quad$ a house was built for the karaeng [Sirajuddin] outside Mallengkeri in 6 sections on pillars

29 Rakr 1145 nanibangun ballaqna karaenga ipantaraq ri Mallengkeri 6 paqdaserang

27 Nov (R) Karaeng Sanrabone [Muhammad Baki] had a sunshade raised over his head

9 Jakr 1145 nanipirangkaki laqllang Karae Sanrabone

$30 \operatorname{Nov}(\mathrm{N}) \quad$ this was when I Borahima died across on Bima; he was a child of the ruler of Bima

12 Jakr 1145 ia anne nakamateang I Borahima ibaqle ri Dima anaqna karae Dima

11 Dec (R) Karaeng Tamasongoq circumcised with I Mammiq and a child of Karaeng Bontotannga; I Pattah died

23 Jakr 1145 nanisunnaq Karae Tamasongoq siagaang I Mammiq siagaang anaqna Karae Bontotannga namate I Pattah

$19 \operatorname{Dec}(\mathrm{F})$ Karaeng Manilingi died

680 I Mappatimung was probably the Bugis name of Arung Pattojo, known after his death as Matinroe ri Dunina. Ligtvoet (1880:213) explains the background to this killing. Tenrilele, the ruler of Luwuq, was raised and then married off by the ruler of Boné Batari Toja to the Soppéng noble Muhammad Arung Pattojo (who was also Arung of Lalolang, in Tanete). Because Arung Pattojo was of lesser birth rank than Tenrilele, her brother the ruler of Agangnionjoq (La Tenriodang Matinroe ri Musuna) shot and killed him and then married his sister to the Datu of Mario ri Awa La Samanglangiq, known as Tolaoé Sapirie.

681 A copyist mistakenly wrote November instead of October. 
2 Raj 1145

$31 \operatorname{Dec}(W)$

14 Raj 1145

22 Jan (W eve)

6 Syab 1145

1 Jun (M)

18 Zulh 1145

10 Jun (W)

27 Zulh 1145

15 Jun (N eve)

3 Muh 1146

15 Jun (M)

3 Muh 1146

23 Jun (T)

11 Muh 1146

15 Aug (N eve)

5 Rawl 1146

29 Aug (S)

19 Rawl 1146

1 Nov (S eve) namate Karae Manilingi

Karaeng Taipa died

namate Karaeng Taipa

\section{3}

we were left by Karaengta ri Bontomanompoq at the age of 88 , five months, and 13 nights

kinapilari Karaengta ri Bontomanompoq umuruqna 88 alima bulan 13 banngina

Karaeng Laikang died and was buried in Bontotannga namate Karae Laikang ri Bontotanngai niawan

Karaeng Tanasanga arrived from Bima bringing one of her children

nabattu ri Dima Karae Tanasanga sitau anaqna naerang

Karaeng Barombong [Muhammad Baki] went up to Sanrabone with Karaeng Lempangang [Syafiuddin] namanaiq ri Sanrabone Karae Barombong siagaang Karae Lempangang

the karaeng [Sirajuddin] went up to Sanrabone, angrily going [to help] the people of Gowa ${ }^{682}$

namanaiq ri Sanrabone karaenga turung rakka-rakkai tuGowaya

the ruler of Sumbawa died

nabattu karae Sambawa

Sayyid Bukhari died

namate Sayyid Bukhari

Gallarrang Tomboloq removed himself; I Sammiq replaced him

nanapasuluq kalenna Gallarang Tomboloq I Sammiq assambeangi

Daeng Mangalle I Laijiq died

682 What was happening in Sanrabone is unclear, but it was in the wake of the installation of Muhammad Baki as their new karaeng. 
23 Jawl 1146

$7 \operatorname{Nov}(S)$

29 Jawl 1146 namate Daeng Mangalle I Laijiq

the ruler of Sumbawa and Karaeng Bontoa married; a child of I Bebboq died

nasikalabini karae Sambawa Karae Bontoa namate anaqna I Bebboq

17 Nov (M eve) sabannaraq I Daeng Mangewai Jannatulfirdaus died 10 Jakr 1146 namate sabannaraka I Daeng Mangewai Jannatulfirdaus

26 Dec (F eve) Daengta Daeng Ngantu, the older uncle of tumailalang Karaeng Garassiq, died

19 Raj 1146 namate Daengta Daeng Ngantu puanna tumailalang Karae Garassiq

27 Dec (S eve) ${ }^{683}$ birth of I Mappabaqbasaq ${ }^{684}$

20 Raj 1146 nanianakkang I Mappabaqbasaq

1734

$3 \operatorname{Jan}(\mathrm{N})$

27 Raj 1146

$17 \operatorname{Jan}(\mathrm{N})$

11 Syab 1146

26 Jan $(\mathrm{T})$

20 Syab 1146

$1 \operatorname{Mar}(\mathrm{M})$

24 Ram 1146 2 Mar (M eve) Karaeng Parang-Parang went into Cenrana

Karaeng Alluq fined himself five tai for nearly killing his sibling in Arung Kaju's house

nanapassala lima taiq kalenna Karae Alluq natarawanna saqribattangna ri ballaqna Aruq Kayu

Karaeng Bontolangkasaq brought by the two tumailalang [Karaeng Garassiq and Karaeng Lekoqboqdong] up to the karaeng [Sirajuddin] to ask forgiveness nanierang ri tumailalang ia rua Karae Bontolangkasaq manaiq ri karaeng nipappalaq popporang

an envoy from the arumpone [Datu ri Citta] arrived bringing news of the presence of Karaeng Barombong [Muhammad Baki] inside Cenrana nabattu surona arungpone ampabirittai niaqna Karae Barombong ilalang ri Cenrana namantama ri Cenrana Karae Parang-Parang I Muhammad Saleh died and was buried in Talloq 
24 Ram 1146 namate I Muhammad Saleh ri Talloki niawang

29 Mar ( $\mathrm{N}$ eve) Karaeng Bisei died at the age of 42

23 Syaw 1146 namate Karae Bisei umuruqna 42

11 Apr (S eve) we were left by [Karaeng] Balua [Daeng Maingaq], the widow of Karaeng Tumamenang ri Lakiung [Abdul Jalil], at the age of 81

6 Zulk 1146 kinapilari Balua balunna Karaenga Tuammenang ri Lakiun umuruqna 81

23 May (S eve) there was a house burned in Katangka; the clock broke ${ }^{685}$ 19 Zulh 1146 naniaq ballaq makkaqdo ri Katangka nareppeq goyanga

13 Jul (T) the karaeng [Sirajuddin] went up to Pareq

12 Saf 1147 namanraiq ri Pareq karaenga

$16 \mathrm{Jul}(\mathrm{F}) \quad$ commissioner ${ }^{686}$ Laqnatullah died

15 Saf 1147 namate gumisarisiq Laqnatullahi

27 Aug (F) the people of Sanrabone arrived to inform the karaeng [Sirajuddin] that they had taken Karaeng Alluq as Karaeng ri Sanrabone

27 Rawl 1147 nabattu tuSanrabonea angkana-kanai ri karaenga naallena Karaeng ri Sanrabone Karae Alluq

6 Sep (M) the karaeng [Sirajuddin] and his wife [Karaeng Agangjeqneq] went up to Lekokang to dwell and erect irrigation works

8 Rakr 1147 namanraiq ri Lekokang karaenga ia kalabini aqballaqballaq appanai jeneq-jeneq panai

18 Sep (S) I Tahira, a child of I Syehu, died

20 Rakr 1147 namate I Tahira anaqna I Syehu

25 Oct (M) work was completed in Lekokang

27 Jawl 1147 naleqbbaq jamanga ri Lekokang

686 The nature of this position is unclear. 
2 Mar (W) Sulengkaya was brought out to Mallengkeri; people performed aru

6 Syaw 1147 nanierang massuluq ri Mallengkeri Sulengkaya mangarui taua

12 Apr (M eve) I Papoq Daeng Mamangung died

18 Zulk 1147 namate I Papoq Daeng Mamangun

16 Apr (S) the karaeng [Sirajuddin] went down to Datoq ri Paccelekang to fulfill a vow

22 Zulk 1147 namanaung ri Datoq ri Paccelekang karaenga amole tinjaq

15 Jun (W) I Daeng Muntuq died

23 Muh 1148 namate I Daeng Muntuq

7 Sep (T eve) the mother of I Syehu died

19 Rakr 1148 namate anronna I Syehu

26 Sep (M) we advanced on I Daeng Mamaro [Karaeng

Bontolangkasaq]; we were in Pattallassang and we watched, waiting

8 Jawl 1148 nakipanraiki I Daeng Mamaro kiri Pattallassang nakitingara taroan

13 Oct $(\mathrm{R}) \quad$ the karaeng [Sirajuddin] retreated seawards here to Mallengkeri and in Pakkato settled

25 Jawl 1148 namamonoqmo karaenga kalauq mae ri Mallengkeri nari Pakkato mattaroang

23 Oct $(\mathrm{N}) \quad$ Karaeng ri Mamampang arrived from Bantaeng

6 Jakr $1148 \quad$ nabattu ri Bantaeng Karaengta ri Mamampang

24 Oct (N eve) I Guru Daeng Manaqgalaq died

7 Jakr 1148 namate I Guru Daeng Manaqgalaq

5 Nov (F eve) the karaeng [Sirajuddin] went down to Talloq, removing himself [from power as ruler of Gowa]

19 Jakr 1148 namanaungmo ri Talloq karaenga napasuluq kalenna 
$5 \operatorname{Nov}(\mathrm{S}) \quad$ the people of Gowa all went to Mallawanggauq ${ }^{687}$, bringing him the collection of royal regalia and taking him as karaeng [Abdul Khair of Gowa]

19 Jakr 1148 namange ngaseng tuGowaya ri Mallawanggauq angeranngangi lullung gaukanga naiamo assambeangi karaenga

$6 \operatorname{Nov}(\mathrm{N}) \quad$ the treaties went to Karaeng Majannang688; [Karaeng] Bontotannga was anrongguru of the tumakkajannang; I Daeng Manangaraq and I Daeng Manggappa were the two sabannaraq

20 Jakr 1148 nanipamange ri Karae Majannang ulukanaya Bontotannga anrongguru tumakkajanannganga I Daeng Manangaraq I Daeng Manggappa sabannaraq ruai

7 Nov (M) Sulengkaya was brought in here to the house of the karaeng [Abdul Khair]

21 Jakr 1148 nanipaletteqmo Sulengkaya mantama mae ri ballaqna karaenga

$9 \operatorname{Nov}(W)$

23 Jakr 1148

I Mallawanggauq titled patimatarang689 naniareng patimatarang I Mallawanggauq

10 Dec (F eve) Karaeng Masale died

24 Raj 1148 namate Karae Masale

$15 \operatorname{Dec}(\mathrm{R}) \quad$ the child of I Syehu named I Dorra died

29 Raj 1148 namate anaqna I Syehu nikanaya I Dorra

$28 \operatorname{Dec}(W)$ 13 Syab 1148

Karaeng Baine ${ }^{690}$ died in Talloq at the age of 48 namate Karaeng Bainea ri Talloq umuruqna 48

1736

$12 \mathrm{Feb}(\mathrm{N}) \quad$ I Daeng Ningai died and was buried in Bontobiraeng

687 Sultan Abdul Khair Almansur Tumamenang ri Gowa, a son of Karaeng Lempangang and grandson of the recently abdicated Sirajuddin. He ruled Gowa from 1735 until his death in 1742, though he was briefly deposed by Karaeng Bontolangkasaq in 1739.

688 Signifying that he was tumabicarabutta for the new ruler.

689 Patimatarang was a title used by an heir designated as successor to the throne. Here it was briefly used to mark that even though he had already been chosen as Gowa's ruler, I Mallawanggauq had not yet been formally installed as Sultan Abdul Khair.

690 Sirajuddin's wife Karaeng Agangjeqneq. 
29 Ram 1148 namate I Daeng Ningai ri Bontobiraeng niawang

14 Feb (M eve) I Pappi died and was buried in Bontobiraeng

1 Syaw 1148 namate I Pappi ri Bontobiraeng niawang

$25 \mathrm{Feb}(\mathrm{S}) \quad$ patimatarang [I Mallawanggauq, Abdul Khair] had a sunshade of gold raised over his head ${ }^{691}$; I Tanisamaang weighed; it measured two kati and several tahils that measured 8 [to one real] ${ }^{692}$

12 Syaw 1148 nanipirangkaki laqllang nibulaengi patimataranga nanitaiq I Tanisamaan battalaqna rua kati assiapa taiqna 8 battalaqna

$16 \operatorname{Mar}(\mathrm{F}) \quad$ it was ordered by the karaeng [Abdul Kahir] that Karaeng Majannang be brought a sunshade; he also wished [that Karaeng Majannang] be paid homage, but he would not be paid homage 693

3 Zulk 1148 nanisuro pangeranngang laqllang ri karaenga Karae Majannang nikellai tongi nisomba natea ia nisomba

18 Mar (S eve) the Dutch ordered I Tuassah ${ }^{694}$ advanced on ${ }^{695}$ with 6 ships: 1 cutter and 5 sloops

5 Zulk 1148 nanisuropanaiki ri Balandaya I Tuassah 6 batu 1 kotaq 5 solloq

$23 \operatorname{Mar}(\mathrm{F}) \quad$ the karaeng [Abdul Khair] went out to Tuang with the speaker of the land ${ }^{696}$ [Karaeng Majannang] to order the supporting of Gallarrang Mangasa

691 This was the final ceremony in which I Mallawanggauq became fully invested with the sovereignty due to the ruler of Gowa, but the process began months before when the nobles of Gowa approached and took him as karaeng, brought him the royal regalia, and recognized him with the title patimatarang.

692 This is the first recorded instance of the golden chain Tanisamaang, bequeathed to Gowa's rulers by the tumanurung as recorded in the Gowa Chronicle, being weighed. This became a common practice later. Records were kept of the annual weighings, and it was believed that if Tanisamaang was heavier than the previous year that augured well, whereas if it weighed less that was a bad omen (Eerdmans 1897; Friedericy 1929).

693 These acts are perhaps indications of Abdul Khair's uncertainty and need for Karaeng Majannang's support. Royal sunshades (laqlang) were indications of sovereignty, and to be ceremonially paid homage (nisomba) a mark of exalted status hietherto reserved for the ruler of Gowa.

694 An ally of La Maddukelleng Arung Singkang, who in 1737 seized power in Wajoq and attempted but ultimately failed to expel the Dutch from South Sulawesi.

695 Makasaarsche historiën (1855:128) adds in this entry that I Tuassah was at Batu-Batu.

696 That is tumabicarabutta. 
10 Zulk 1148 namassuluq ri Tuang karaenga siagaang tuampakkanangai buttaya assuro binting ri Gallarang Mangasa

31 Mar (S) the [royal] banners were smeared with blood 18 Zulk 1148 naniceraq batea

1 Apr (N eve) Arung Singkang went to Batu

19 Zulk 1148 namaqlampa ri Batu Aruq Singkaang

1 Apr (M) I Daeng Mamaro [Karaeng Bontolangkasaq] went to Panakkukang

19 Zulk 1148 namaqlampa ri Pannakukang I Daeng Mamaro

$12 \operatorname{Apr}(\mathrm{R}) \quad$ the [royal] banners were raised

1 Zulh 1148 nanipanaiq batea

26 Apr (R) the speaker of the land [Karaeng Majannang] went down

15 Zulh 1148 namanaung ri Datoq mangunjungi tuampakkanangai buttaya ri Datoq ri Bandang

5 May (F eve) the mother of I Sarimba died

24 Zulh 1148 namate anrongnna I Sarimba

12 May (S) the karaeng [Abdul Khair] went out to Tinggimae with Karaeng Majannang to plead for rain

1 Muh 1149 namassuluq ri Tinggimae karaenga siagaang Karae Majannang appalaq-palaq bosi

31 May (W eve) Matoanging burned

20 Muh 1149 namakaqdo Mattoangin

17 Jun (S eve) Daengta Daeng Ngaseng died 8 Saf 1149 namate Daengta Daeng Ngaseng

$5 \mathrm{Jul}(\mathrm{R}) \quad$ an envoy from the makkedangetana [Arung Barrang] arrived, saying that the people of Boné were fighting Arung Singkang in Paniki [in Wajoq] ${ }^{697}$

697 Arung Singkang was a Bugis noble who returned from the east coast of Borneo to Sulawesi and quickly seized power in Wajoq. Even before his arrival the stage was set for confrontation with the pre-eminent Bugis power, Boné, and by August 1737 he successfully defeated Boné, as the lontaraq bilang notes (see Noorduyn 1953). 
26 Saf 1149 nabattu surona makkadangatana nikana maqbunduqmi tuBonea Aruq Singkaang ri Paniki

$26 \mathrm{Jul}(\mathrm{R}) \quad$ I Daeng Mamaro [Karaeng Bontolangkasaq] went down to Maros with Arung Kaju

17 Rawl 1149 nanamanaung ri Marusuq I Daeng Mamaro siagaang Aruq Kayu

30 Aug (R) Karaeng Barombong [Muhammad Baki] and Karaeng Bontoparang married

23 Rakr 1149 nasikalabini Karae Barombong Karae Bontoparang

6 Sep (R) I Didi had a son

30 Rakr 1149 namamanaq I Didi buraqne

13 Sep (W eve) Karaeng Mangisuq died

7 Jawl 1149 namate Karae Mangisuq

10 Oct (W) Karaeng Katinting died 698

5 Jakr 1149 namate Karae Katingting

25 Oct (R) Karaeng Lempangang [Syafiuddin] arrived from Cenrana

20 Jakr 1149 nabattu ri Cenrana Karae Lempangang

7 Dec (R eve) Arung Kaju died below in Maros

4 Syab 1149 namate Aruq Kayu irawa ri Marusuq

11 Dec (W) the makkedangetana [Arung Barrang] arrived from Segeri saying that I Daeng Mamaro [Karaeng Bontolangkasaq] had fled Segeri

8 Syab 1149 nabattu ri Segeri makkadangatana nikana nipilarimi Segeri I Daeng Mamaro

1737

2 Jan (W) Sayyid Umar and a child of I Daeng Masseqre ${ }^{699}$ married 30 Syab 1149 nasikalabini Sayyid Umara anaqna I Daeng Maseqre

24 Jan (W eve) Karaeng Bungaya died

22 Ram 1149 namate Karae Bungaya

699 This could refer to Jaga, Papippiq, or another Daeng Masseqre. 
5 Feb (M eve) a wife of I Syehu died

4 Syaw 1149 namate bainenna Syekhu

27 Jul (F eve) a sabannaraq,700 envoy ${ }^{701}$, and I Daeng Mangalle I

Mammaq went into Cenrana to fetch Arung Palakka [Amirah]

28 Rawl 1150 namantama ri Cenrana sabannaraka suroa I Daeng Manngalle I Mammaq anbungtuli Aruq Palakkah

$30 \mathrm{Jul}(\mathrm{T})$

2 Rakr 1150

I Galesong circumcised

nanisunnaq I Galesong

14 Aug (W) an envoy from the arumpone [Datu ri Citta] arrived, informing the governor ${ }^{702}$ that war between Wajoq and Boné had ended; the people of Boné had surrendered valuables [to the victorious Wajorese]

17 Rakr 1150 nabattu surona arungpone angkana-kanangi tumalompoa leqbaqnamo bunduqna Wajoq naBone leqbaqmi annyorong barang-barang tuBonea

20 Aug (T) I Daeng Mamaro [Karaeng Bontolangkasaq] advanced on by the governor with Datu ri Baringang703

23 Rakr 1150 nanipanaungi I Daeng Mamaro ri tumalompoa siagaang Datua ri Baringang

Dec (F eve) $)^{704}$ I Tuang Dima died above in Sanrabone and was buried in Dengkang705

Syab $1150 \quad$ namate I Tuan Dima irate ri Sanrabone ri Dengkang niawang

700 Either (or both) I Daeng Manangaraq and I Daeng Manggappa.

701 Probably Kare Gappa.

702 Previous annalists used a Makassarese transcription of the word 'governor' but he was now referred to as tumalompo, literally 'big man'. This refers to either Johan Sautijn, the outgoing governor for much of 1737, or Adriaan Hendrik Smout, the incoming governor.

703 Makasaarsche historiën (1855:129) adds that the governor's goal was to recapture Maros, which he did, and that Karaeng Bontolangkasaq fled when he heard of their approach.

704 The dates are incomplete in VT 25, but can be identified as the 7th, 14th, or 21st of December and, correspondingly, the 14th, 21st, or 28th of Syaban.

705 Kamaruddin et al. (1985-86:206) believe this should be 'Sengkang'. 
7 Jan $(\mathrm{T})$

15 Ram $1150^{707}$

4 Mar (T)

12 Zulk 1150

10 May (S)

20 Muh 1151

16 Jun (M)

27 Saf 1151

19 Jun (W eve)

1 Rawl 1151

$24 \operatorname{Jun}(\mathrm{T})$

6 Rawl 1151

$25 \operatorname{Aug}(\mathrm{M})$
I Jijaq and I Dadaq had lesbian relations and were drown 706

I Jijaq I Dadaq attampaki nanilabu

a wife of Karaeng Batupute died to the east in Bontokeke namate bainenna Karae Batupute iraya ri Bontokeke

it is said that Danradatu ${ }^{708}$ became ruler of Boné nikana Danraya karaeng ri Bone

the karaeng's [Abdul Khair's] sword fell; two of his wounded fingers were sprinkled [with medicinal powder] nanabubusi paqdang karaenga ruampappaq karemenna malokoq nikiori

Daengta Daeng Masingaraq died

namate Daengta Daeng Masingaraq

I Sendoq fell from a house and was treated [with medicinal powder]

natuqguruq ri ballaq I Sendoq nikiori

the karaeng [Abdul Khair] and Karaeng Majannang went seawards to the fort; the Malay imam recited Yasin, then Karaeng Majannang swore an oath, as the karaeng [Abdul

706 This is an extraordinary entry which may reflect the increasing presence of orthodox Islamic norms regarding sexual morality. The term translated as 'drown' (nilabu) literally means 'sunk' and usually refers to ships. It may be that they were simply drown, or it may mean that they were punished by having their limbs bound and being thrown overboard (nisikkoq bang$k e n g)$. This royal punishment is mentioned in the Gowa Chronicle when a young Tunijalloq committed some kind of sexual impropriety with a daughter of Gallarrang from Polombangkeng. 'Discovered by Karaeng Tunipalangga, who was angered' the chronicler reports, 'the woman was bound and thrown into the sea', after which Tunijalloq fled to Boné. Neither I Jijaq nor I Dadaq are mentioned elsewhere in the lontaraq bilang.

707 A copyist mistakenly wrote Syaban instead of Ramadan.

708 A daughter of Amirah Arung Palakka and Karaeng Lempangang. She was not yet nine years old. In Sepember 1737 La Tenrioddang (the ruler of Agangnionjoq posthumously known as Matinroe ri Musuna) drove Batari Toja from the throne of Boné, after which she came to live in Bontoalaq under the protection of the VOC. La Tenrioddang acted as arumpone until La Maddukelleng Arung Singkang objected and managed to have Boné's nobles put the young Danradatu on the throne. Yet she had limited support and lived in Wajoq. La Tenrioddang returned the following January to Boné to install himself as arumpone, but was expelled by La Maddukelleng's troops. With the aid of the VOC Batari Toja again became ruler of Boné and Soppéng (Patunru 1989:212-3). 
9 Jawl $1151 \quad$ nakalauq ri kotaya karaenga Karae Majannang nanabaca Yasi imanna Malayua nanampa nitalliq Karae Majannang karaeng nakana macaqdiiji nalampakki limanna passapu nanampa najama kurannga nanapanaiq ri tulunna 3 nanampa nabuqbuq toboqna nanapanaung ri jeqnneq nanainung nisarengasengi bate-batea jeqnneq mawaraq tassipontona

27 Aug (W) word was sent to the arumpone [Danradatu] that a child of the maqdanrang ${ }^{709}$ was there in Gowa

11 Jawl 1151 nanisuro kana-kanaang arungpone niaqna ri Gowa anaqna maqdanrranga

13 Oct ( $\mathrm{N}$ eve) I Daeng Jannang died

29 Jakr $1151 \quad$ namate I Daeng Jannang

$2 \operatorname{Nov}(\mathrm{N}) \quad$ the sabannaraq, 710 gallarrangs Mangasa and Bontomanaiq, envoy Kare Gappa, and interpreter Kare Mangewai went overseas to Jakattaraq

20 Raj $1151 \quad$ nakalauq ri Jakattaraq sabannaraka Gallarang Mangasa Bontomanaiq suro Kare Gappa jurubasa Kare Mangewai

$30 \operatorname{Nov}(\mathrm{N}) \quad$ the karaeng [Abdul Khair] and Karaeng Majannang went up to Takalar

18 Syab 1151 namanaiq ri Takalaraq karaenga Karae Majannang

$$
1739
$$

11 Jan $(\mathrm{N}) \quad$ it is said that the ruler of Agangnionjog [La Tenrioddang] took the royal sunshade [of Boné] and Samparajaya711; it is also said that Arung Kaju died 712

\footnotetext{
709 An official - in this case it was Arung Kajuwara - who ranked lower than the makkedangetana but higher than the tumarilalengs of Boné (Ligtvoet 1880:219).

710 Again, either (or both) I Daeng Manangaraq and I Daeng Manggappa.

711 Samparajaya was a banner that was the foremost regalia of Boné. By this act La Tenrioddang proclaimed himself arumpone.

712 Dutch sources report that the well-known Arung Kaju (Daeng Mamuntuli) had already died and the Arung Kaju mentioned here was probably his nephew and successor Daeng Mangeppe Arung Jokko (Ligtvoet 1880:220).
} 
30 Ram 1151 nanikana naallei payunga Samparajaya karae Agangnionjoq nikana tong matei Aruq Kayu

22 Jan (R) we were left by Karaeng Tumamenang ri Pasiq at the age of 52 years, 10 months; he was Sultan Sirajuddin ${ }^{713}$

11 Syaw 1151 kinapilari Karaenga Tuammenang ri Pasiq umuruqna taun 5210 bulan Sultan Sirajuddin

19 Feb (R) an envoy from Wajoq arrived saying that there our sibling Arung Matoaya [Arung Singkang] with the arumpone Datu ri Soppéng [Danradatu] twice recited together the Qur'an ${ }^{714}$

10 Zulk 1151 nabattu surona Wajoq nakana niaqminjo mae saqribattangta Arung Matoaya siagaang arungpone Datua ri Soppeng passiajinga 2

$2 \operatorname{Mar}(\mathrm{T}) \quad$ we heard of the death of I Bunda ${ }^{715}$, cut down by a person from Camba; Karaeng Balambaru ${ }^{716}$ wounded

21 Zulk 1151 nakilanngereq mate I Bunda nijalloki ri tuCambaya Karaeng Balambaru malokoq

$24 \operatorname{Mar}(\mathrm{T})$

13 Zulh 1151

we heard of the conquest of Macconggi by the people of Wajoq

$6 \mathrm{Apr}(\mathrm{N}$ eve) the speaker of the land [Karaeng Majannang] went down to Kampong Beru; he brought his wife; he brought Sudanga; Baraya, the two Panyangga Loe, I Buqle, Kulau Nagaya, Pamongko Kalapa, Kallang Bodo, and Butoa followed 717

713 He was succeeded by Syafiuddin (Karaeng Lempangang), former annalist and a son of Tumamenang ri Pasiq, but the date of his succession is not noted in the annals. However, it most likely took place in connection with the journeys of Makassar notables to Talloq in April or June.

714 Thus forming an alliance against La Tenrioddang.

715 A son of Karaeng Bontolangkasaq (Ligtvoet 1880:220).

716 According to Dutch sources he was a European soldier who joined Karaeng Bontolangkasaq (Ligtvoet 1880:220).

717 These items were all among the foremost regalia of Gowa. Sudanga was a sword, Baraya a waistband, the two Panyangga Loe a spear and a kris, I Buqle a blowpipe, Kulau Nagaya a stone, Pamongko Kalapa a gold ring, Kallang Bodo a kris, and Butoa a testicle of a water buffalo named Tamalaulung ('Makasaarsche historiën' 1855:135-6). 
namanaung ri Kampong Beru tuampakkanangai buttaya naerang bainenna naerang Sudanga Baraya Panyangga Loweya iaruppa I Buqlle Kulau Nagaya Pamongko Kalapaya Kallang Bodoi Butoya ribokopi

$9 \operatorname{Apr}(\mathrm{R})$

29 Zulh 1151

the karaeng [Abdul Khair], Karaeng ri Paqbineang, the younger tumailalang [Karaeng Garassiq], and Karaeng Sanrabone [Karaeng Alluq] went down to Talloq; they continued down to Kampong Beru; Karaeng Sanrabone did not go

namanaung ri Talloq karaenga Karaengta ri Paqbineang tumailalang maloloya Karae Sanrabone natulusuq manaung ri Kampong Beru tamangeami Karae Sanrabone

10 Apr (F)

1 Muh 1152

16 May (S)

8 Saf 1152

$15 \operatorname{Jun}(\mathrm{M})$

8 Rawl 1152

20 Jun $(S)$

13 Rawl 1152
Karaeng Bontolangkasaq taken as Karaeng ri Gowa718 nanialle Karaeng ri Gowa Karae Bontolangkasaq

the people of Wajoq pushed down to Baraya, Karaeng ri Bontolangkasaq seawards to Jongaya; they clashed [with the Dutch] at Maricaya [northeast of the VOC fort]; [Karaeng] Bontotannga wounded nasossong tuWajoka manaung ri Baraya Karaenga ri Bontolangkasaq kalauq ri Jongaya namaqruppa ri Maricaya Bontotannga malokoq

the tumailalang ${ }^{719}$ and karaengs of Batupute, Bontomajannang, Palemba, Tompobalang, Balambaru ${ }^{720}$, and Katangka went down to Talloq namanaung ri Talloq tumailalang Batuputeh Bontomajannang Palemba Tompobalang Balambaru Katangaka

anrongguru I Kare Jarreq died namate I Kare Jarreq anrongguru

718 This investiture took place with the royal regalia, which days before had been taken by the fleeing nobles of Gowa to Talloq and then to Kampong Beru where they sought the protection of the Dutch.

719 More likely Karaeng Garassiq, but possibly the elder tumailalang Karaeng Lekoqboqdong.

720 Ligtvoet (1880:221) believed this to be a different Karaeng Balambaru than the European soldier of the same title wounded on March 2nd, possibly because that individual sided with Karaeng Bontolangkasaq, but he may simply changed loyalties again. 
21 Jun (S eve) Daengta Daeng Iji, a child of Karaeng ri Mangallekana, died

14 Rawl 1152 namate Daengta Daeng Iji anaqna Karaengta ri Mangallekana

8 Jul (T eve) the carved house ${ }^{721}$ in Bontoalaq was burned

6 Rakr 1152 nanisussuluq ballaq niukirika ri Bontoalaq

$20 \mathrm{Jul}(\mathrm{T})$

14 Rakr 1152

Arung Matoaya [Arung Singkang] went with Daeng Mamaro [Karaeng Bontolangkasaq], fleeing Gowa namaqlampa Arung Matoaya siagaang Daeng Mamaro napilarimi Gowa

$21 \mathrm{Jul}(\mathrm{T}) \quad$ Gowa overrun, burned and plundered by the Dutch; Daeng Maqleoq I Dulla was beheaded; there was a lunar eclipse Monday evening ${ }^{722}$

15 Rakr 1152 nanibangkah Gowa nisussuluki namaqrappa Balandaya nanibatta Daeng Malleoq I Dulla namaqkaqdoq lekoka ri banngi Salasaya

$28 \mathrm{Jul}(\mathrm{T})$

22 Rakr 1152

the karaeng [Abdul Khair] went east here to Taenga namanraiq mae ri Taenga karaenga

3 Aug (M) one living with Karaeng Sanrabone [Muhammad Baki] died

28 Rakr 1152 namate siballaqna Karae Sanrabone

20 Aug (W eve) Karaeng ri Tana-Tana died at the age of 68 and four months

15 Jawl 1152 namate Karaengta ri Tana-Tana umuruqna 68 ampatangbulan

$22 \operatorname{Aug}(S)$

I Daeng Ngiji I Sitti died

17 Jawl 1152

namate I Daeng Ngiji I Sitti

$22 \operatorname{Aug}(S)$

I Sugi, the mother of I Nona, died; a child of Daeng Maqleoq died

721 Built on 27 Jun 1652. See the note accompanying that entry for more information.

722 This heavenly portent was certainly interpreted as recognition of the tumultuous events taking place in the wake of Karaeng Bontolangkasaq's defeat and Abdul Khair's pending restoration to power in Gowa. 
17 Jawl 1152 namate I Sugi anrongnna I Nona namate anaqna Daeng Maqleoq

27 Aug (R) I Jitaq, a child of Daeng Maqleoq, died

22 Jawl 1152 namate I Jitaq anaqna Daeng Maqleoq

28 Aug (F) I Loqmoq ri Taenga died

23 Jawl 1152 namate I Loqmoq ri Taenga

3 Sep $(\mathrm{R}) \quad$ the governor [Smout] and the people of Boné withdrew seawards to Ujung Pandang, then the Dutch and Arung Sumaling went into Gowa to guard Gowa

29 Jawl 1152 namamonoqmo kalauq ri Jumpandang tumalompoa tuBonea namantamamo ri Gowa Balandaya Aruq Sumaling angkammiki Gowa

4 Sep (F eve) tumailalang Karaeng Garassiq died

1 Jakr 1152 namate tumailalang Karae Garassiq

27 Sep (S eve) a great grandparent of Karaeng Beroanging and Kare Singaraq died

23 Jakr 1152 namate boena Karae Beroangin Kare Singaraq

4 Oct (S eve) I Muhammad died

1 Raj 1152

namate I Muhammad

8 Oct (R)

5 Raj 1152

a child of I Tuang Abu Bakar named Rahimah died namate anaqna I Tuan Abu Bakar nikanaya Rahimah

22 Oct (R)

19 Raj 1152

I Saleh, a grandchild of I Daeng Rikasammeng, died namate I Saleh cucunna I Daeng Rikasammen

26 Oct (N eve) I Sitti, a child of I Daeng Marannu Karaeng Bontoa, died 23 Raj 1152 namate I Sitti anaqna I Daeng Marannu Karae Bontoa

28 Nov (S) I Mappatolla circumcised

26 Syab 1152 nanisunnaq I Mappatolla

$29 \operatorname{Nov}(\mathrm{N}) \quad$ Gallarrang Talloq Kare Lesang died

27 Syab 1152 namate Gallarang Talloq Kare Lesang 
4 Dec ( $R$ eve) the speaker of the land [Karaeng Majannang] arrived from Kampong Beru bringing the collection of royal regalia [back to Gowa]

3 Ram 1152 nabattu ri Kampong Beru tuampakkanangai buttaya naerangmi lullung gaukanga

$21 \mathrm{Dec}(\mathrm{M}) \quad$ the people of Boné caught people in Allaq Tappampang; they were brought down and all their weapons taken

20 Ram 1152 tuBonea anjakkalaq tau ri Allaq tappamppang niturungi niallengaseng ewangannna

\section{0}

19 Jan (T) Karaeng Patukangang died and was buried in a kampong in Lakiung at the age of 32

19 Syaw 1152 namate Karae Patukangang ri kampong ri Lakiung niawang 32 umuruqna

26 Jan (M eve) Karaeng Taruq died at the age of 18

26 Syaw 1152 namate Karae Taruq umuruqna 18

29 Jan (F) Gallarrang Camba died

29 Syaw 1152 namate Gallarrang Cambah

13 Feb (S) Karaeng Tumamenang ri Gowa [Abdul Khair] circumcised

15 Zulk 1152 nanisunnaq Karaenga Tuammenang ri Gowa

8 Mar (T) this [day Karaeng] Bontomasugi died

10 Zulh 1152 ianne nakamateang Bontomasugi

$19 \operatorname{Mar}(\mathrm{S}) \quad$ the ruler of Agangnionjoq [La Tenrioddang] married Karaeng Tanasanga

21 Zulh 1152 namakkalabini karae Agangnionjoq Karae Tanasanga

28 Mar (M) I Patimah, a child of [Karaeng] Bontomajannang, died 30 Zulh 1152 namate I Patimah anaqna Bontomajannang

30 Mar (W) Sayyid Husain died and was buried in Tinggimae 6 Muh 1153 namate Sayyid Husaini niawan ri Tinggimaeng

28 May (F eve) a widow of Karaeng ri Bontomanompoq died below in Tambasaq 
6 Rawl 1153 namate balunna Karaengta ri Bontomanompoq irawa ri Tambasaq

17 Jun (R eve) Karaeng Beroanging died

22 Rawl 1153 namate Karae Beroangin

19 Jun (N) Haji Bainea died

24 Rawl 1153 namate Haqji Bainea

12 Jul (T) I Puaq died above in Sanrabone

18 Rakr 1153 namate I Puaq irate ri Sanrabone

$29 \mathrm{Jul}(\mathrm{F}) \quad$ the nayaka [Bimbang] conducted an exorcism ritual ${ }^{723}$

5 Jawl 1153 namakkawaru nayakkaya

25 Aug (R) Karaeng Sanrabone [Muhammad Baki] and Karaeng Sumannaq married

2 Jakr 1153 nasikalabini Karae Sanrabone Karae Sumannaq

8 Oct (S) the karaeng [Abdul Khair] and the speaker of the land [Karaeng Majannang] went seawards to the fort and swore oaths again 724

16 Raj 1153 nakalauq ri kotaya karaenga tuampakkanangai buttaya nanitalliq pole

11 Oct (T) the karaeng [Abdul Khair] and the speaker of the land [Karaeng Majannang] went into Gowa; a representative [from the VOC], the maqdanrang [Arung Kajuwara], Arung Sumaling, and Gallarrang Bontoalaq confer on the karaeng [Abdul Khair] the land of Gowa; all the Dutch and people of Boné go seawards to Ujung Pandang 19 Raj 1153 namantama ri Gowa karaenga tuampakkanangai buttaya gumitir Maqdanranga Aruq Sumaling Gallarang Bontoalaq ampitaqgalliangi karaenga buttaya ri Gowa nakalauq ngasengmo Balandaya tuBonea ri Jumpandang

1 Nov (T) Karaeng Majannang with Karaeng ri Talloq [Syafiuddin]

723 Presumably this was to purify the land after the chaos and destruction of the war with Karaeng Bontolangkasaq and to prepare for the formal re-installation of Abdul Khair as Gowa's ruler.

724 See the description of this ceremony in the 25 Aug 1738 entry. 
followed the way to Balang Puqrung; the ruler of Agangnionjoq [La Tenrioddang] arrived

11 Syab 1153 namange mangaga-agaan Karae Majannang siagaang Karaenga ri Talloq ri Balang Puqrrung nabattu karae Agangnionjoq

$18 \operatorname{Nov}(\mathrm{F}) \quad$ I Aluq and Karaeng Tamasongoq married 28 Syab 1153 nasikalabini I Aluq Karae Tamasongoq

5 Dec ( $\mathrm{N}$ eve) Karaeng Palemba died 15 Ram 1153 namate Karae Palembah

1741

14 Jan (S) kadi Kare Manaqgalaq died

25 Syaw 1153 namate kadia Kare Manaqgalaq

9 Feb (W eve) I Syehu and I Daeng Marannu married

22 Zulk 1153725 nasikalabini I Syehe I Daeng Marannu

$17 \operatorname{Mar}(\mathrm{F}) \quad$ Karaeng Majannang went seawards to Rappoalaka to build a house

28 Zulh $1153^{726}$ nakalauq ri Rappoalaka Karae Majannang mamangung ballaq

$23 \operatorname{Mar}(\mathrm{R}) \quad$ the envoy I Daeng Manjarreki I Mammaq arrived from Tosora [in Wajoq] to see the governor [Smout]

5 Muh 1154 nabattu suroa I Daeng Manjarreki I Mammaq ri Tosora anciniki tumalompoa

20 Apr (R) the admiral ${ }^{727}$ arrived from making war in Tosora

4 Saf 1154 nabattu ri Tosora aqbunduq Amarala

17 Jun (S) Karaeng Sumannaq had a son

3 Rakr 1154 namamanaq Karae Sumannaq buraqne

10 Aug (R) I Daeng Talele I Masiq died; Daeng Nisayu I Alima born 28 Jawl 1154 namate I Daeng Talele I Masiq naanaq Daeng Nisayu I Alima

725 A copyist mistakenly wrote Syawwal instead of Zulkaedah.

726 A copyist mistakenly wrote Zulkaedah instead of Zulhijah.

727 Ligtvoet (1880:223) believed this referred to Governor Smout, though in other entries he is referred to simply as 'governor' (tumalompo). 
25 Oct $(\mathrm{W}) \quad$ the manuscript that would be brought by [Karaeng] Garassiq, [Karaeng] Mangisuq, and sabannaraq Daeng Manggappa was taken down to the ship 15 Syab 1154 nanipanaung ri biseang lontaraq naeranga Garassiq Mangisuq sabannaraq Daeng Manggappa

31 Oct $(\mathrm{T})$

21 Syab 1154

I Syehu and I Daeng Marannu divorced nasipelaq I Syehu I Daeng Marannu

$2 \operatorname{Nov}(\mathrm{R})$

23 Syab 1154

the speaker of the land [Karaeng Majannang] went seawards to Rappoalaka nakalauq ri Rappoalaka tuampakkanangai buttaya

18 Dec (M)

9 Syaw 1154

Karaeng ri Katapang died at the age of 84 namate Karaengta ri Katapang umuruqna 84

30 Dec (F eve) Karaeng Langeloq I Danradatu died 21 Syaw 1154 namate Karae Langeloq I Danrra

1742

2 Jan $(\mathrm{T})$

24 Syaw 1154

I Daeng Jinne, a wife of I Syehu, died namate I Daeng Jinne bainenna I Syehu

$26 \mathrm{Feb}(\mathrm{M})$

20 Zulh 1154 seawards in Rappoalaka the speaker of the land [Karaeng Majannang] ascended into his house nakalauq ri Rappoalaka tuampakkanangai buttaya manaiqna ri ballaqna

$20 \operatorname{Mar}(\mathrm{T})$

12 Muh 1155

the remains of Karaeng Garassiq arrived from overseas in Jakattaraq 728

10 May (R) nabattu mayaqna Karae Garassiq ilauq ri Jakattaraq

5 Rawl 1155

the karaeng [Abdul Khair] landed, arriving from Bima bringing his wife with I Rante Patola ${ }^{729}$ nasoremo karaenga battuna ri Dima angerangi bainenna siagaang I Rante Patola

\footnotetext{
728 Obviously he died on his journey to Batavia as one of three representatives sent to the Dutch bearing the important manuscript mentioned in the 25 Oct 1741 entry.

729 His wife was a daughter of the ruler of Bima Alauddin Muhammad Syah and Karaeng Tanasanga; I Rante Patola was her sister (Ligtvoet 1880:223).
} 
28 May (N eve) Karaeng Majannang slept with Karaeng Bonto-Bonto 23 Rawl 1155 namaqlusereq Karae Majannang naKarae Bonto-Bonto

29 Jun (T) the ruler of Agangnionjoq [La Tenrioddang] went overseas to Jakattaraq

26 Rakr 1155 nakalauq ri Jakattaraq karae Agangnionjoq

28 Jul (F eve) we were left by Karaeng Tumamenang ri Gowa [Abdul Khair] at the age of 15, five months, and 16 nights; his own younger sibling ${ }^{730}$ replaced him as ruler

26 Jawl 1155 kinapilari Karaenga Tuammenang ri Gowa umuruqna 15 allimang bulan 10 angannang banginna aringnaji assambeangi maqgauq

$28 \mathrm{Jul}(\mathrm{S})$

26 Jawl 1155

Karaeng ri Mamampang died at the age of 82, 9 months, and 4 nights

namate Karaengta ri Mamampang umuruqna 829 bulan 4 banngi

19 Sep (W) the karaeng [the late Abdul Khair] had a daughter who just died as a baby

19 Raj 1155 namamanaq karaenga baine mate memangi anaqna

3 Oct (W) Karaeng ri Talloq [Syafiuddin] arrived with Karaeng Bontotannga; a ruling had been made during the reigns of Karaeng Tumamenang ri Lakiung [Abdul Jalil], Tumamenang ri Passiringanna [Abdul Kadir], and Tumamenang ri Taenga [Karaeng Bontosunggu] that if there was one who came between [Gowa and Talloq], we concur and we declare them wrongdoers ${ }^{731}$

3 Syab 1155 nabattu Karaenga ri Talloq siagaang Karae Bontotannga nanipareq pangempang ri rewasanna Karaenga Tumammenang ri Lakiun Tumammenang ri

730 Mappababasaq Abdul Kudus Tumamenang ri Kalaqbiranna.

731 This pronouncement of the relationship between Gowa and Talloq recalls Karaeng Matoaya's famous declaration in the Talloq Chronicle that they were 'Only one people, but two karaeng. Death to those who dream or speak of making Gowa and Talloq quarrel' (seqreji ata narua karaeng nibunoi tumassoqnaya angkanaya sisalai Gowa Talloq). More precisely, it appears that this was a reference to the practice during that golden age whereby the ruler of Talloq served as tumabicarabutta for the ruler of Gowa. Its intentional memoralizing now was a prelude to the appointment of Talloq's ruler Karaeng Lempangang - the father of Gowa's young new ruler Abdul Kudus - as tumabicarabutta in May the following year. 
Passiringanna Tumammenang ri Taenga punna niaq angagangi allaqna kiparipaqmaiki kikana tumannyala

4 Oct (R) the karaeng [Abdul Kudus] went into Gowa with the collection of royal regalia to live

4 Syab 1155 namantamamo ri Gowa karaenga mammempo siagaang lullung gaukanga

27 Oct (F eve) Karaeng ri Paqbineang died at the age of 55

27 Syab 1155 namate Karaengta ri Paqbineang umuruqna 55

1743

$24 \operatorname{Mar}(\mathrm{N}) \quad$ I Syehu arrived; Karaeng Tanasanga arrived with I Rante Patola

27 Muh 1156 nabattu I Syehu nabattu Karae Tanasanga siagaang I Rante Patola

16 Apr (T)

21 Saf $1156^{732}$

$5 \operatorname{May}(\mathrm{N})$

10 Rawl 1156

18 May (S)

24 Rawl 1156

28 May (T)

4 Rakr 1156

4 Jun (T)
I Baciq, former spouse of Karaeng Paqgannakkang, died namate I Baciq pallaloanna Karae Paqgannakkang

the karaeng [Abdul Kudus] went over to Taenga; the governor [Smout] came up here to Taenga; he stopped in Gowa and was given people [slaves], one by Karaeng Majannang and one by the karaeng [Abdul Kudus] too nataqle ri Taenga karaenga namanaiq mae tumalompoa ri Taenga nasumengka ri Gowa nisarei tau sitau ri Karae Majannang karaeng sitau todong

Karaeng Majannang expelled as speaker of the land nanipasuluq Karae Majannang ampakkanangai buttana

Karaeng ri Talloq [Syafiuddin] brought the treaties ${ }^{733}$ nanieranngang Karaenga ri Talloq ulukanaya

Karaeng Batupute ${ }^{734}$ installed as tumailalang, given the position of the karaengs of Patteqne ${ }^{735}$

\footnotetext{
732 A copyist mistakenly wrote Ramadan instead of Safar.

733 Signaling his replacement of Karaeng Majannang as tumabicarabutta or 'speaker of the land'.

734 An annalist mistakenly wrote Karaeng Bontopute, but this is incorrect.

735 This does not mean that he succeeded Karaeng Patteqne (a tumailalang who was given the post by Tunipasuluq in the 1590s) but rather that he occupied one of the two tumailalang posts that traditionally was held by a descendant of Karaeng Patteqne.
} 
11 Rakr 1156 nanitannang tumailalang Karae Bontopute empoana Karaengta ri Patenne nisareangi

15 Oct (T) I Sugiratu slept with Arung Ujumpuluq ${ }^{736}$; the maqdanrang [Arung Kajuwara] expelled ${ }^{737}$

26 Syab 1156 namaqlusereq I Sugiratu Arung Ujungpuluq nanipasuluq Maqdanranga

$21 \operatorname{Nov}(\mathrm{R}) \quad$ Karaeng Bonto-Bonto died

3 Syaw 1156 namate Karae Bonto-Bonto

\section{4}

29 Jan (W) Karaeng ri Bontomateqne died

13 Zulh 1156 namate Karaengta ri Bontomateqnne

15 Apr (W) the ruler of Agangnionjog [La Tenrioddang] arrived from Java738

2 Rawl 1157 nabattu ri Jawa karae Agangnionjoq

27 Apr (M) I Ninruq, a child of Karaeng Paqgannakkang, died

14 Rawl 1157 namate I Ninruq anaqna Karae Paqgannakkang

1 May (F) Karaeng Lembaya died

18 Rawl 1157 namate Karae Lembaya

$31 \mathrm{Jul}(\mathrm{F}) \quad$ an Arab died

21 Jakr 1157 namate Araka

29 Aug (S) I Sugiratu had a male child

21 Raj 1157 namamanaq I Sugiratu buraqne anaqna

8 Oct (R) the manuscript that would go overseas to Jakattaraq, brought by the karaengs of Paranggi and Paqbundukang, taken down to the ship

736 According to Bugis informants he was a brother of the ruler of Sidénréng Toampo Matinroe ri Sumpangminangaé and was known posthumously as Matinroe ri Tanamanridié (Ligtvoet 1880:225).

737 According to Dutch sources Datu Baringeng La Temmassongeq Matinroe ri Mallimongeng and later ruler of Boné, was behind his expulsion (Ligtvoet 1880:225).

738 There he had been aiding the VOC in war against Javanese rebels (Ligtvoet 1880:225). 
1 Ram 1157 nanipanaung ri biseang lontaraq kalauqna ri Jakattaraq naerang Karaengta ri Paranggi Paqbundukang

1745

$28 \operatorname{Mar}(\mathrm{N}) \quad$ there overseas in Jakattaraq people saw a star as asar ${ }^{739}$; it sank and a white cloud took its place

25 Saf 1158 niaq ilauq ri Jakattaraq tumacciniq bintoeng ri asaraka tallangi rammang keboq seng assambeangi

2 Apr (F)

a half-blackened sun was seen ${ }^{740}$

30 Saf 1158

naniciniq aleqlleng sipue matanna alloa

$9 \operatorname{Nov}(\mathrm{T})$

Karaeng Tumamenang ri Kalaqbiranna [Abdul Kudus] circumcised

14 Syaw 1158

nanisunnaq Karaenga Tuammenang ri Kalaqbirangna

$18 \operatorname{Nov}(\mathrm{R})$

23 Syaw 1158

a child of I Daeng Macoa was shorn and a water buffalo with gilded horns butchered

nanikattereq anaqna I Daeng Macoa nipattunuangi

tedong attanruq bulaeng

1746

21 Feb (M)

30 Muh 1159

I Daeng Mangalliq ${ }^{741}$ was caught, trusted by the Dutch nanijakkalaq I Daeng Mangalliki tappaq ri Balandaya

14 Mar (N eve) Karaeng ri Talloq [Syafiuddin] and Karaeng

Mangaraqbombang married

21 Saf 1159

nasikalabini Karaenga ri Talloq Karae Mangaraqbombang

$19 \operatorname{Mar}(S)$

26 Saf 1159

Daeng Mamuntuli brought by the younger arung ${ }^{742}$ to proceed to the elder karaeng [Syafiuddin] to ask forgiveness $^{743}$

nanierang I Daeng Mamuntuli ri Arung Maloloa mange ri karaenga matoaya nipappalaq popporang

\footnotetext{
739 The late afternoon prayer at about 4 PM.

740 A partial solar eclipse.

741 Probably the Daeng Mangalliq named Dondiq born 29 Sep 1692.

742 That is, the designated heir of the arumpone of Boné; here it refers to Datu ri Baringang (Ligtvoet 1880:226).

743 Daeng Mamuntuli had eloped with Karaeng Barong Patola over four decades before 25 Sep 1705 , and it may be this to which the entry refers.
} 
22 Mar (W eve) Karaeng Lembaya and Karaeng Tanasanga married

30 Saf 1159 nasikalabini Karae Lembaya Karae Tanasanga

21 May (S) Karaeng Tangallaq died at the age of 35

30 Rakr 1159 namate Karae Tangallaq umuruqna 35

17 Jun (R eve) Karaeng Bontoparang and Karaeng Jarannika married 27 Jawl 1159 nasikalabini Karae Bontoparang Karae Jaranika

3 Sep (S) the elder karaeng [Syafiuddin] went east to Pakkatto

17 Syab 1159 namanraiq ri Pakkatto karaenga matoaya

10 Sep (S) Dutch begin stonework

24 Syab 1159 nanajamamo batua Balandaya

15 Oct (F eve) a royal hall was built in Talloq

29 Ram 1159 nanibangung ballaq lompoa ri Talloq

8 Dec (R) birth of I Mannawarri Abdulhadi 744

24 Zulk 1159 nanianakkang I Manawarri Abdulhadi

$14 \mathrm{Dec}(\mathrm{W}) \quad$ the karaeng [Abdul Kudus] returned from the work

30 Zulk 1159 namamonoq ri jamanga karaenga

1747

8 Jan (N) a house was built for I Syehu; the elder karaeng [Syafiuddin] came up here

25 Zulh 1159 nanibangung ballaqna I Syehu manaiki mae karaenga matoaya

16 Jan (M) the people of Kadundungang went to Manyanreri ${ }^{745}$, now called Kare Bontopanno

4 Muh 1160 nanipamange tuKadundunganga ri Manyanreri nikana Kare Bontopanno

$16 \mathrm{Feb}(\mathrm{R}) \quad$ it was ordered by the elder karaeng [Syafiuddin] that a karaengship be brought to I Daeng Manassaq, now called Karaeng Maroanging

744 Tumamenang ri Lambusuqna, he was a son of Karaeng Tamasongoq and ruled Gowa from 1781 to 1810 .

745 Possibly the same Manyanreri who married on 17 Oct 1713. 
4 Saf 1160

nanisuro pangeranngang pakkaraengang I Daeng Manassaq ri karaeng matoaya nikana Karae Maroanging

28 Mar (M eve) Karaeng Karuwisi ${ }^{746}$ had a child, a daughter 15 Rawl 1160 namamanaq Karae Karuisi baine anaqna

11 May (R) it was ordered by the karaeng [Abdul Kudus] that a karaengship be brought to Daeng Marannu, now called Karaeng Bontoa

1 Jawl 1160 nanisuro pangeranngang pakkaraengang Daeng Marannu nikana Karae Bontoa ri karaenga

14 May (N) it was ordered by the karaeng [Abdul Kudus] that a karaengship be brought to Daeng Ningai, now called Karaeng Somba Opu

4 Jawl 1160 nanisuro pangeranngang pakkaraengang Daeng Ningai ri karaenga nikana Karae Sambopu

27 Jun (T) we hear that the ruler of Agangnionjoq [La Tenrioddang] was killed as he advanced on Nepo; Karaeng Loqmoq I Baeda died

18 Jakr 1160 nakilanngereq niposo karae Agangnionjoq napanaikin Nepo namate Karae Loqmoq I Baeda

3 Jul (M) I Syehu fulfilled a vow with the completion of a dome for [the grave of] I Tuang [Shaykh Yusuf]

24 Jakr 1160 nanapole tinjaqna I Syehu leqbaqna kobbangnna I Tuan

16 Oct $(\mathrm{M})$ [Karaeng] Bontomajannang, [Karaeng] Paqbundukang, anaq karaeng, and envoy(s) went over to Bima to fetch I Tajuq ${ }^{747}$; the karaeng [Abdul Kudus] went over here to Taenga; the elder karaeng [Syafiuddin] went east to Bianreng to work on a ferry raft

11 Syaw 1160 nataqle ri Dima Bontomajannang Paqbundukang anaq karaeng suro antaqle ambuntuli I Tajuq nataqle mae ri Taenga karaenga namanraiq ri Bianreng karaenga matoaya anjamai pappalimbangang rakika

\footnotetext{
746 A future ruler of Talloq and Taenga (Ligtvoet 1880:226).

747 Karaeng Balaqsari, a daughter of the ruler of Bima Ala'uddin and Karaeng Tanasanga (Ligtvoet 1880:226). They failed to return with her, or possibly had to return early, for others departed again on 16 May 1748 to make the same voyage.
} 
$31 \operatorname{Dec}(\mathrm{N}) \quad$ Sayyid Syarifah proposed to by Sayyid Husain; the brideprice was 5 taiq; the sayyid slept with her

28 Zulh 1160 nanipassuroi Syayyid Syarifa ri Sayyid Husain sunrangnna 5 lima taiq namaqlusereq sayyidka

\section{8}

27 Jan (S)

$\mathrm{I}^{748}$ went for the naming of the house of I Syehu with the karaeng [Abdul Kudus]

26 Muh 1161 kutaqle aqrenngeq ri ballaqna I Syehu siagaang karaenga

11 Apr (R)

12 Rakr 1161

Arung Sumaling and Karaeng Lempangang ${ }^{749}$ married

16 May (R)

nasikalabini Aruq Sumaling Karae Lempangang

18 Jawl 1161 namamise Karae Barombong siagaang Karae

Paqbundukang taqle ambuntuli I Taju anaq karaeng suro naagaang taqle

$20 \mathrm{Jul}(\mathrm{S})$

a clock was given by the karaeng [Abdul Kudus] to Karaeng Majannang

24 Raj $1161 \quad$ nanisareang karaenga goyangnna Karae Majannang

15 Aug (R) I Buqle 750 was brought over here by the karaeng [Abdul Kudus]; the elder karaeng [Syafiuddin] went up from here to Mangasa fully armed

20 Syab 1161 nanierang taqle mae ri karaenga I Buqle namanaiq mae karaeng matoaya ri Mangasa sangkaq ewangang

26 Aug (M) I Buqle was ordered brought by the karaeng [Abdul Kudus] to Karaeng Majannang

1 Ram 1161 nanisuro eranngang ri karaenga I Buqle Karae Majannang

748 Probably Karaeng Tamasongoq, the second annalist mentioned by name in the lontaraq bilang.

749 Not the ruler of Talloq Syafiuddin, but his daughter by Amirah. Her name before receiving this title was probably I Rida Sitti Rahmah, whose birth is recorded in the lontaraq bilang on 13 Oct 1730.

750 This blowpipe was part of Gowa's regalia and believed to make its bearer capable of defeating any enemy (Cummings 2002:131-3). 
7 Sep (F eve) Karaeng Kalukuang I Tola died

13 Ram 1161 namate Karae Kalukuang I Tola

16 Sep (M) Karaeng Barombong [Muhammad Baki] arrived from Bima bringing I Tajuq

22 Ram 1161 nabattu Karae Barombong ri Dima angerangi I Tajuq

$13 \mathrm{Dec}(\mathrm{F}) \quad$ the karaeng [Abdul Kudus] slept with Karaeng Balaqsari [Tajuq]; the elder karaeng [Syafiuddin] fell from a horse while escorting the karaeng [to meet his bride]

22 Zulh 1161 namaqlusereq karaenga Karae Balassari natuqguruq ri jarang karaenga matoaya nilekkaqna karaenga

24 Dec (R eve) birth of I Manappuki Ahaq

3 Muh 1162 nanianakkang I Manappuki Ahaq

1749

12 Jan (S eve) Daeng Takontu and Karaeng Paqgannakkang married 22 Muh 1162 nasikalabini Daeng Takongtu Karae Paqgannakkang

$3 \operatorname{Apr}(\mathrm{R}) \quad$ it was ordered by the karaeng [Abdul Kudus] that a karaengship be brought to Daeng Manginruru, now called Karaeng Baroqbosoq

14 Rakr $1162^{751}$ nanisuro pangeranngang pakkaraengang ri karaenga Daeng Manginruru nikana Karae Baroqbosoq

$21 \operatorname{Apr}(\mathrm{M}) \quad$ carried by ship, the arumpone [Datu ri Citta] went to go into Boné

3 Jawl 1162 namaqdongkoq ri biseang arungpone lamantama ri Bone

27 May $(\mathrm{T})^{752} \quad$ birth of I Mannapoi Mansur ${ }^{753}$

10 Jakr 1162 nanianakkang I Mannapoi Mansur

10 Jun (M eve $)^{754}$ Karaeng Lempangang had a male child Abdurrahman ${ }^{755}$; anrongguru of the anaq buraqne I Kare Mambani I Umaraq died

\footnotetext{
751 The Hijri month is omitted but must be Rabi'ul-akhir.

752 The day is missing but is probably the 27 th.

753 Karaeng Data, a son of Karaeng Tamasongoq (Ligtvoet 1880:227).

754 The Gregorian month is omitted but must be June.

755 Probably the son who was later known as Karaeng Bisei and was insane (Ligtvoet 1880:228)
} 
24 Jakr 1162 namamanaq Karae Lempangang buraqne anaqna Abdurrahman namate anrongguru anaq buraqnea I Kare Mambani I Umaraq

25 Aug (M) Karaeng Mannyiori, [Karaeng] Balloq, papuq 756 Daeng Manggappa, Daeng Maqruppa, and a wife of Daeng Malliongang arrived from Sandao

11 Ram 1162 nabattu ri Sandao Karae Mannyiori Balloq papuq Daeng Manggappa Daeng Maqruppa bainenna Daeng Malliongang

15 Oct $(\mathrm{W}) \quad$ Karaeng Jarannika arrived from Boné 3 Zulk 1162 nabattu ri Bone Karae Jarannika

$8 \operatorname{Nov}(S) \quad$ we hear of the death of the arumpone [Datu ri Citta]; the younger arung [Datu Baringeng] replaced her; this Saturday night was the arumpone's death

27 Zulk 1162 nakilanngereq matena arungpone arung maloloa assambeangi banngi Ahaq anne nakamateang arungpone

$9 \operatorname{Nov}(\mathrm{N})^{757} \quad$ birth of Batara Gowa ${ }^{758}$

28 Zulk 1162 nanianakkang Batara Gowa

$9 \operatorname{Dec}(\mathrm{N}) \quad$ Karaeng Baine [the ruler of Talloq's wife Karaeng Mangaraqbombang] had a male child I Mappatunruq Abdurrauf 759

28 Zulh $1162^{760}$ namamanaq Karaenga Bainea buraqne anaqna I Mappatungruq Abdurrauf

1750

14 Feb (F eve) Karaeng Panaikang died at the age of 59, 6 months, 7 nights

7 Rawl 1163 namate Karae Panaikang umuruqna 596 bulan 7 banngi

756 Papuq was a title of the head of the Bajo community traditionally loyal to the rulers of Gowa. This is apparently the same Daeng Manggappa who was sabannaraq.

757 The date is omitted but must be the 9 th.

758 A son of Abdul Kudus and Karaeng Balaqsari.

759 A son of Karaeng Lempangang, he was known as Karaeng Lembangparang Tumamenang ri Katangka and ruled Gowa from 1816 to 1825.

760 There are two possibilities for the date of this entry. I believe that the omitted Hijri month is most likely Zulhijah, in which case the day of the week should read Tuesday instead of Sunday. Ligtvoet (1880:footnote 228) prefers to read this as having the same date as the previous entry, which would mean that a copyist mistakenly wrote December instead of November. 
12 Jun (F eve) birth of I Gundah Bulaeq Dzuhariah

7 Raj $1163^{761}$ nanianakkang I Gungdah Bulaeq Dzuhariah

16 Jul (R) Datu ri Ulawang762 died, was placed in a coffin, and brought into his homeland; I Daeng Tasannging expelled as Karaeng ri Bontomanaiq

11 Syab 1163 namate Datua ri Ulawang nibonei ri allung nanierang antama ri paqrasanganna nanipasuluq I Daeng Tasannging Karaeng ri Bontomanaiq

22 Jul (W) I Mannyaurang arrived, sent by the elder karaeng [Syafiuddin] to formally bring a sunshade to Karaeng Majannang and shelter him with it; he was then given Tangke Jangang [in Talloq] with all its high ground and low ground

17 Syab 1163 nabattu I Mannyaurang nisuro ri karaenga matoaya ampangeranngangi laqlang Karae Majannang siagaang pallaqllanngi nanisareang Tangke Jangang lollong bontona kappoqna

$30 \mathrm{Jul}(\mathrm{R})$

25 Syab 1163

I Daeng Manangaraq expelled as sabannaraq; the ruler of Agangnionjoq ${ }^{763}$ was brought east to the arumpone [Datu Baringeng]; the chief interpreter brought her 764 nanipasuluq sabannaraq I Daeng Manangaraq nanierang karae Agangnionjoq anraiq ri arungpone jurubasa lompoa angerangi

$20 \operatorname{Aug}(\mathrm{R})$

a child of I Syehu adopted by Arung Palakka [Amirah] died

17 Ram 1163 namate anaqna I Syehu nakatuoa Aruq Palakka

29 Sep (M eve) the arumpone [Datu Baringeng] came east here to Syehu 27 Syaw 1163 namanraiq mae arungpone ri Syehu

761 A copyist mistakenly wrote the 17 th instead of the 7 th.

762 Dutch sources indicate that this must be Mappasawe, son of Towappamole who died in 1736 (Ligtvoet 1880:229).

763 Tenrilele Matinroe ri Soreyang (Ligtvoet 1880:229).

764 The two rulers met to reconcile, for Boné and Agangnionjoq had had poor relations since La Tenrioddang, brother of the ruler of Agangnionjoq Tenrilele Matinroe ri Soreyang, had seized the banner Samparajaya and forcibly taken control of Boné in 1739. 
7 Oct (W) a karaengship given by the karaeng [Abdul Kudus] to I Muqmin 765 , now called Karareng Bontomateqne

6 Zulk 1163 nanisare pakkaraengang I Muqmin ri karaenga nikana Karae Bontomateqnne

$22 \operatorname{Nov}(\mathrm{N}) \quad$ Datu ri Soppéng 766 and Karaeng Bontomateqne married 22 Zulh 1163 nasikalabini Datua ri Soppeng Karae Bontomateqnne

$29 \operatorname{Nov}(\mathrm{N}) \quad$ a nephew ${ }^{767}$ of Gallarrang Tamamangung was shot seawards of Masale; the karaeng [Abdul Kudus] angrily went [to Masale]; the wife of Datu ri Soppéng [Karaeng Bontomateqne] was escorted [to her marriage house]

29 Zulh 1163 nanibaqdiliq kamanakanna Gallarang Tamamangung ilaukanna Masale naturung rakka-rakka karaenga nanilekkaq bainenna Datua ri Soppeng

1751

13 Feb (F eve) Arung Sumaling and Karaeng Lempangang divorced 16 Rawl 1164 nasipelaq Aruq Sumaling Karae Lempangang

$14 \operatorname{Mar}(\mathrm{N}) \quad$ a wife of Karaeng Mangalliq died

15 Rakr 1164 namate bainenna Karae Mangalliq

25 Mar (R eve) ${ }^{768}$ birth of Putiri Raannakumala769

28 Rakr 1164 nanianakkang Putiri Raannakumala

23 Apr (R eve) Inciq Daeng died

26 Jawl 1164 namate Icciq Daeng

26 Apr ( N eve) the elder karaeng [Syafiuddin] and Karaeng Mangaraqbombang divorced

29 Jawl 1164 nasipelaq karaeng matoaya Karae Mangaraqbombang

16 Jun (F) I hear of the death of I Puaq Ninaq across on Sumbawa

22 Raj 1164 nakulanngereq matena I Puaq Ninaq ibaqle ri Sambawa

765 Ligtvoet (1880:229) believed I Muqmin was probably a daughter of Karaeng Barombong.

766 La Tongeng Arung Panyili, brother of the ruler of Boné (Ligtvoet 1880:229).

767 Or niece, as no gender is indicated.

768 The day is missing but must be the 25th.

769 Karaeng Tabaringang, a daughter of Abdul Kudus and Karaeng Balaqsari (Ligtvoet 1880:229-30). 
1 Aug (T eve) Karaeng ri Bontomanaiq, older uncle ${ }^{770}$ of Karaeng Mangaraqbombang, died

9 Ram 1164 namate Karaengta ri Bontomanaiq puanna Karae Mangaraqbombang

25 Aug (T) Karaeng Lembaya died; the elder karaeng [Syafiuddin] went down to Talloq

2 Syaw $1164^{771}$ namate Karae Lembaya namanaung ri Talloq karaeng matoaya

26 Aug (W) the karaeng [Abdul Kudus] went down to Talloq; someone went amuk on the grounds beneath [i.e. to the north side of] the karaeng's meeting hall

3 Syaw 1164 namanaung ri Talloq karaenga niaq tumaqjalloq ri embaya nairawa ri barugaya karaenga

3 Sep $(\mathrm{F})$

12 Syaw 1164

Kare Ruppa, a child of I Tuang Rappang, died namate Kare Ruppa anaqna I Tuan Rappang

10 Sep (R eve) Karaeng Bontomateqne had a child and died; only the child, a son, lived ${ }^{772}$; Allah grant him long life

19 Syaw 1164 namananaq Karae Bontomateqnne matei anaqna ia tallasaqji buraqne tulla Allahu umur

3 Oct (W)

a house was built for Arung Palakka [Amirah]

14 Zulk 1164 nanibangun ballaqna Aruq Palakkah

4 Oct (R)

15 Zulk 1164

news arrived of the death of Arung Guna ${ }^{773}$; it is said he died three nights [ago]

nabattu nipabiritta matenna Aruq Guna nikana tallung banngimi matena

1 Nov (T) Arung Taq ${ }^{774}$ and his sibling who were together incestu-

770 Possibly father.

771 The month is missing but must be Syawwal.

772 Ligtvoet (1880:230) notes that if Karaeng Bontomateqne was indeed a daughter of Karaeng Barombong, because she only had this one child from her marriage to the ruler of Soppéng La Tongeng Arung Panyili, this son can be none other than Karaeng Beroanging, who according to Dutch sources participated in the revolt of Sangkilang.

773 A Boné noble and close relative of the rulers of Ulawang (Ligtvoet 1880:230).

774 La Rukka, a son of the ruler of Boné Datu Baringeng later known as Arung Lakasi. According to Dutch sources, his sister was named Sidajang or I Dajang in Buginese. She died in 
13 Zulh 1164 nanipasissaqllaq rituBonea tuSoppenga Aruq Taq saqribattangna nagaang sioppoki

$20 \operatorname{Nov}(\mathrm{N}) \quad$ I Leppang and I Tipah married

2 Muh 1165 nasikalabini I Leppang I Tipah

$25 \operatorname{Dec}(S) \quad$ Sayyid Hamid circumcised Friday night; birth of Indundaq

5 Saf 1165 nanisunnaq Sayyid Hamid banngi Sattu nanianakkang Indundaq 



\section{III}

\section{A further annals ANRI 16/6}

As noted in the Introduction, ANRI 16/6 is a manuscript owned by the former karaeng of Gowa Andi Ijo. This text is unique and especially valuable because unlike the other manuscripts with entries from the seventeenth century, this text contains unique entries that provide valuable information beyond that contained in VT 25. This chapter transcribes and translates the thirty-two unique entries or substantially different entries found in ANRI 16/6. The text as a whole has 290 entries dating from 1605 to 1682; the thirty-two entries below span the years from 1632 to 1679 .

$9 \operatorname{Dec}(\mathrm{R}) \quad$ an envoy from Mataram, Ki Bangei, arrived bearing a manuscript, a manuscript with writing on long slats of bamboo woven together ${ }^{1}$

25 Jawl 1042 nabattu surona Mataranga Ki Bangei mangerang lontaraq sasaq loboa kaqdoq lontaraq

1633

7 Nov (M) Tumamenang ri Bontobiraeng [Pattingalloang] went into Pakenya [in Soppéng] to fulfill a vow

4 Jawl 1043 namantama ri Bakenya Tumamenang ri Bontobiraeng mamole tinjaq

1634

$19 \operatorname{Mar}(\mathrm{F}) \quad$ the Dutch left

19 Ram 1043 namaqlampao Balandaya

1 VT 25 contains this entry, but it states that the envoy was from Banten and brought the body of Tumatea ri Banten, not a manuscript. 
28 Mar (T) the people of Boné arrived

27 Ram 1043 nabattu tuBoneya

10 Nov (F) gunpowder exploded on the bastion; Karaeng Layu was burned by the powder; eleven anaq karaeng from Turatea were burned by the powder ${ }^{2}$

18 Jawl 1044 namakkaqdoq ubaka ri salekoia nanakaqdo ubaka Karaeng Layu sampulo asseqre anaq karaeng Turate nakaqdo ubaq

1637

$30 \operatorname{Aug}(\mathrm{N}) \quad$ a gleaming house built in Somba Opu on five rows of pillars

[10] Rakr 1047 nanibangung ballaka caya ri Sombopu 4 paqdaserang

1639

18 Jun (S) Karaeng Tumamenang ri Bontobiraeng [Pattingalloang] spoke for the land

18 Saf 1049 naKaraengta Tumamenang ri Bontobiraeng ampakkanangi buttaya

1640

4 Apr (W) Gallarrang Saumata fled into Boné

11 Zulh 1049 namalari Gallarrang Samata mantama ri Bone

1644

2 Jan (S) Tumamenang ri Ujung Tana [Karunrung] and Karaeng ri Panaikang divorced

21 Syaw 1053 nasipelaq Tumamenang ri Jungtana Karaengta ri Panaikang 1655

14 Apr (W) when we were at Buton we fired at the Dutch in their cutter [7] Jakr 1065 kiriButung kinabadiliq Balandaya ri kotaqna

$16 \operatorname{Apr}(\mathrm{F}) \quad$ the Dutch cutter's hull was ruptured; thirty three Dutchmen were beheaded; forty-one Butonese men were killed and seventy-two wounded

[9] Jakr 1065 nanibangka kotaqna Balandaya tallumpulo antallu Balanda nibatta Butung patampulo asseqre tumatena tujupulo anruwa tumalokoq

2 VT 25 contains an abbreviated version of this entry, stating only that 'gunpowder exploded on the bastion'. 
14 May (F) the karaeng [Hasanuddin] arrived from Buton; at this time [tribute? religious?] requirements were renewed; all were taken ashore; some were not held if their [obligation] was just about fulfilled; those who did not repay were held for payment and their possessions taken; the karaeng [Hasanuddin] returned after his trip of 64 [nights] ${ }^{3}$

7 Raj 1065 nabattu ri Butung karaeng iaminne rewasaya nanipole saraya nisore allengasemmi tananitaqgalaka punna kira-kira lappasaqmo taqgalaqna ri simana tanipapoleammi nanaalle patanna 64 lampana karaeng battu

24 Dec (F) a Dutch ship arrived bringing Karaeng Bijai

25 Saf 1066 nabattu kappalaqna Balandaya angerangi Karaengta Bijai

27 Dec $(\mathrm{M}) \quad$ we met with the Dutchman named Willem van der Beeck $[?]^{4}$

28 Saf 1066 kisitaba Balandaya nikanaya aala panadaribele

\section{8}

$10 \mathrm{Jul}(\mathrm{R}) \quad$ I Daengta Leqleng I Coco was married by Tumamenang ri Ballaq Pangkana [Hasanuddin]

[9] Syaw 1068 nanibaineang I Daengta Leqleng I Coco ri Tumamenang ri Ballaq Pangkana

1659

[4 May] (M) the Karaeng of Talloq [Harrunarasyid] was attacked when entering Abopada [in Mandar]; eighty-three men [were killed] and he set fire to Abopada

12 Syab $1069^{5}$ rinaKaraenga ri Talloq naosong taua mantama ri Abopada sagantuju antallu nanisusuluq Abopada

3 This entry is difficult to interpret and translate. The sense of it seems to be that Hasanuddin held a reckoning, presumably on Buton, but this is not certain. Payment or tribute, possibly phrased as a religious duty owed the sultan, was assessed and those freed who had met the bulk of their obligations. Those who had not had what they owned confiscated. VT 25 contains an entry for his journey on this date as well, but it is brief.

4 This identification is not certain. ANRI 16/6 p. 54 has this name in serang script that is not easily deciphered, then provides the awkward lontaraq beru script transliteration aala padarabele. Stapel (1922:53) mentions that Willem van der Beeck along with an Armenian named Chodja Soliman had peace talks in Makassar on 28 Dec 1655.

5 Where the Gregorian month is written this entry has nanayebaso, the meaning of which is unclear. 
$23^{\mathrm{rd}}(\mathrm{F})^{6}$

1 Jun $(\mathrm{N})$

10 Ram 1069

Gallarrang Mangasa ${ }^{7}$ was ordered to enter Langi ${ }^{8}$ and uproot it

nanisuro Gallarrang Mangasa antama ri Langi manyokkaq

the Portuguese burned Baroqbosoq; 13 houses were consumed by flames

namakanre Boroqbosoq ri Paranggia 13 ballaq nakaqdo

pepeq

\section{0}

1660

1070

I Wera's ships, two in number, were set fire to by someone rash; his ships were both slashed, one was taken ${ }^{9}$

kappalaqna I Wera ruwa batuna sussuluq sitatujong-jonga kappalaqna padereka sibatu nialle

13 Jun (F) the interpreter went down to the ship bringing the bloodprice for the Dutchman killed at Sape [Bima]; it was eleven kati [of gold] ${ }^{10}$

[5] Syaw 1070 namanaung ri kappalaka jurubasaya angerangi sapuqna Balanda nibunoa ri Sape sampulo asseqre katina

17 Jun (S) the interpreter arrived saying that in Mangindara [in Takalar] there were 32 ships; many ships were seen that went up to Patukangang and then conquered Panakukkang; we asked calmly to seek our deaths

[9] Syaw 1070 nabattu jurubasaya akkana ri Mangindarami kappalaqna 32 batuna nakacinika kappalaq jaiya nanapanaiki Patukangang nanabeta Panakukkang kimappalaq panaqnaki allena matena

6 A copyist did not record the date, noting of the source text that he 'could not get it' (tanikullei). He was only able to record that it was the 23rd of the Hijri month and a Friday. This is either incorrect, or the entry is out of chronological order and the two most likely dates are 23 Muh 1070 (which converts to 10 Oct 1659) or 23 Jakr 1070 (which converts to 5 Mar 1660).

7 Probably Kare Singaraq, who became the ruler of Mangasa on 14 Oct 1655.

8 This location is uncertain, but may be Lange-Lange in Bulukumba, or possibly Langga in Sawitto.

9 The meaning of this entry is vague and the identity of I Wera unknown, but must refer to a fierce fight off Tanakeke between Portuguese and Dutch ships described in Stapel (1922: 64). Two of the Portuguese vessels were driven aground. One was captured and added to the Dutch fleet and its Portuguese crew sent ashore. The Makassarese watched this transpire from the shore with dismay and began to fire on the Dutch ships, though without effect.

10 Stapel (1922:65) notes that Makassarese made payment in gold and cloth for Dutchmen who were robbed on Bima. 
14 Jun $[\mathrm{M}] \quad$ a wife of the ruler went up to the mountains

[6] Syaw 1070 namanraiq ri monconga karaeng bainea

1667

8 Jul (F) Karaengta ri Bontomajannang's fort in Bantaeng was breached ${ }^{11}$

15 Muh 1078 nanibanka bentenna Karaengta ri Bontomajannang ri Bantaeng

26 Jul (T) Daengta Daeng Manyeppeq was beheaded above in Pongoro

4 Saf 1078 nanibatta Daengta Daeng Manyeppeq irate ri Pongoro

7 Nov (M) the karaeng [Hasanuddin] ordered 4000 reals sent over to the Dutch ${ }^{12}$

21 Jawl 1078 namasuro karaeng taqle ri Balandaya mange releala patamcikkoanga bilanga

\section{8}

29 May (W) the people of Talloq came here to us [in Gowa]

[18] Zulh 1078 namae tuTalloka ri katte

1669

7 Oct (N) Admiral Speelman and Tunisombaya [Arung Palakka] went overseas to Jakattaraq

[11] Jawl ${ }^{13} 1080$ nakalauqmo ri Jakattaraq Amaralae Sepelemang siagang Tunisombaya

1678

3 Sep (F) Friday public prayers begin in Kampong Beru; living in Kampong Beru are the people of Gowa who serve Karaeng Assuluka [Muhammad Ali]

Raj 1089 namamenteng jumaka ri Kampong Beru mamemponamo ri Kampong Beru tuGowaya angatalai Karaeng Assuluka

4 Oct (T) Karaeng Assuluka [Muhammad Ali] went up from Gowa to Jakattaraq; eight nights [later] he was summoned by the

11 VT 25's version of this event is slightly more detailed.

12 Andaya (1981:97) notes that on this day envoys from Gowa brought 3394 reals and a letter requesting a three-day ceasefire.

13 A copyist mistakenly wrote Jumadeleq-aheraq instead of Jumadeleq-awalaq. 
Governor-General [?] and asked forgiveness; he was forgiven and then lived in Jakattaraq ${ }^{14}$

17 Saf $1089^{15}$ nanipanaiq ri Gowa ri Jakattaraq Karaeng Assuluka sagantuju banngi nanikioq ri janolaka (?) namappalaq popporoqna nipammopporaq namamempomo ri Jakattaraq

\section{9}

$22 \mathrm{Feb}(\mathrm{W}) \quad$ a great fish was found in Tamalaba; it was five arm-spans in length and one arm-span and four fingers wide in its body

Muh 1090 naniaq jukuq lompo rampe ri Tamalaba lima rappa laqbuna sirappa apatambatang karemeng batana

11 Mar (S) payment was taken from (?) the notables and the little people in Gowa; 230 large and small

Muh 1090 nanisorong alle ri tumalompoa tucaqdiawanganga ri Gowa malompoa macaqdia 230

1 Jul (S eve) Tunisombaya [Arung Palakka] sailed from Jakattaraq east to Keper

Jakr 1090 nasimombalaq Tunisombaya ri Jakattaraq manraiq ri Kapparaq

14 Apparently this entry records Muhammad Ali's arrival in Jakattaraq and his formal audience before who must be Governor-General Rijkloff van Goens (though difficult paleography coupled with Makassarese transliteration of Dutch makes this uncertain).

15 The Hijri date converts to 9 Apr 1678. 


\section{IV \\ Index of personal names}

An index of names is an important tool in using the annals. However, numerous obstacles have had to be overcome in the preparation of this index. Writers of the annals could refer to individual noble Makassarese by more than one name, and were not always consistent. Moreover, later copyists might replace a name with a later title, meaning that one individual could in different entries be referred to by the personal name they were given at birth, the karaeng-title they achieved as adults, or the posthumous title granted them upon their death. A further problem is the fact that over the course of the period covered by this text more than one person held major titles, meaning that it can be difficult to determine if a given annal entry refers to an earlier or later title-holder. In addition, some noble names were fairly common, such as 'Daing Maingaq', while other personal names such as 'Sitti' were born by several dozen Makassarese women. On occasion Makassarese annalists were themselves aware of the confusion that could result and made a point of distinguishing between two titleholders by including their personal name. Unfortunately, there is simply not enough consistency on the part of annalists for us to always be certain who is being discussed in a given entry. A certain amount of guess-work and inference is inevitable. Crosschecking entries can resolve some uncertainties, and at other times age, gender, positions, and kinship relations provide clues to distinguish between possible individuals. Dates marked with an asterisk are from entries found only in ANRI 16/6 (chapter III).

Abdul Gafur [1] 29 Dec 1725

Abdul Gafur [2] 31 Mar 1728

Abdul Jalil (Tumamenang ri Lakiung) 6 Feb 1651; 18 Aug 1652; 6 Feb 1664; 17 Apr 1664; 25 Nov 1664; 13 Mar 1667; 22 Mar 1667; 6 Jul 1667; 28 Mar 1668; 21 May 1668; 4 Feb 1669; 1 Mar 1669; 26 Nov 1669; 16 Apr 1670; 13 Feb 1675; 24 Feb 1676; 11 Apr 1676; 3 Apr 1677; 22 May 1677; 27 Jul 1677; 9 Aug 1678; 28 Oct 1678; 23 May 1680; 13 Jul 1680; 6 Sep 1680; 4 Sep 1683; 1 May 1684; 27 Sep 1684; 25 Apr 1686; 15 Oct 1689; 21 Oct 1692; 7 Sep 1694; 2 Nov 1694; 17 Dec 1694; 13 Apr 1696; 13 Jul 1701; 3 Dec 1702; 10 Nov 1703; 8 Jan 1704; 8 Mar 1704; 17 Jun 1704; 16 Nov 1704; 1 Jan 1705; 1 May 1705; 1 Sep 1705; 6 Aug 1706; 29 Oct 1706; 24 Mar 1708; 11 Apr 1708; 23 Jan 1709; 17 Sep 1709; 11 Apr 1734; 3 Oct 1742

Abdul Kadir (Tumamenang ri Passiringanna) 7 Jan 1666; 3 Jan 1676; 16 Jan 1676; 17 Jun 1676; 11 Mar 1677; 13 Aug 1680; 23 May 1684; 27 Nov 1684; 18 Jul 1686; 4 Jul 1688; 16 Sep 1688; 9 Jul 1689; 19 Dec 1693; 7 Apr 1702; 3 Nov 1703; 8 Jan 1709; 3 Oct 1742 
Abdul Karim 15 Nov 1674

Abdul Khair (Mallawanggauq, Tumamenang ri Gowa) 5 Nov 1735; 7 Nov 1735; 9 Nov 1735; 25 Feb 1736; 16 Mar 1736; 23 Mar 1736; 12 May 1736; 16 Jun 1738; 25 Aug 1738; 30 Nov 1738; 9 Apr 1739; 28 Jul 1739; 13 Feb 1740; 8 Oct 1740; 11 Oct 1740; 10 May 1742; 28 Jul 1742; 19 Sep 1742

Abdul Kudus, Sultan (Mappabaqbasaq) 27 Dec 1733; 28 Jul 1742; 4 Oct 1742; 5 May 1743; 9 Nov 1745; 14 Dec 1746; 11 May 1747; 14 May 1747; 16 Oct 1747; 27 Jan 1748; 20 Jul 1748; 15 Aug 1748; 26 Aug 1748; 13 Dec 1748; 3 Apr 1749; 7 Oct 1750; 29 Nov 1750; 26 Aug 1751

Abdul Mukmin 10 Oct 1693

Abdul Muqmin 30 Jan 1717

Abdul Rasyid 17 Nov 1672; 7 Jan 1673

Abdullah, Haji (Zamzami) 26 Jan 1687

Abdurrahman 10 Jun 1749

Abdurrahman, Haji 3 Mar 1707

Abdurrasyid 16 Aug 1731

Abil Kahir, Sultan (Ambela, Sirajuddin) 22 Jul 1682

Abu Bakar Ibnu Muhammad Syaibi 17 Dec 1727; 5 Feb 1730; 11 Mar 1730; 30 Mar $1731 ; 8$ Oct 1739

Abu 21 Mar 1728

Aciq 3 May 1717; 19 Feb 1719; 17 Dec 1720; 24 Aug 1724

Addatuang ri Massepe 17 Sep 1728

Aeng, Gallarrang (Kare Onoq) 6 Jan 1707

Agangjeqneq, Karaeng [1] 29 Sep 1659; 14 Jun 1671; 1 Mar 1674; 6 Dec 1675; 23 May 1677

Agangjeqneq, Karaeng [2] 10 Sep 1687; 29 Nov 1702; 29 Jun 1704; 19 Jul 1704; 19 Mar 1726; 6 Sep 1734; 28 Dec 1735

Agangnionjoq, Karaeng (Kasim, Puanna I Tikkaq) 21 Feb 1649

Ageng, Sultan (ruler of Banten) 23 Sep 1692

Ago, Daenta Daeng 26 Oct 1637; 25 May 1663

Ago, Kare (Timoroq) 23 Aug 1677

Ahmad [1] 1 Aug 1647

Ahmad [2] 29 May 1657

Aisyah [1] 13 Sep 1652

Aisyah [2] 6 Jan 1683

Ala'uddin (ruler of Bima) Mar 1732

Ala'uddin, Sultan (Tumamenang ri Gaukanna) 1586, 22 Sep 1605; 1626; 3 Jul 1626; 22 Aug 1631; 15 Sep 1631; 17 Nov 1631; 14 Aug 1632; 22 Oct 1632; 13 Nov 1632; 21 Jun 1633; 17 Jul 1634; 29 Jul 1634; 13 Jun 1635; 17 Sept 1635; 4 Aug 1636; 22 Jun 1637; 12 Feb 1638; 18 Aug 1638; 15 Jun 1639; 11 Nov 1660

Ali [1] 22 Sep 1677

Ali [2] 28 Sep 1682

Alija 13 May 1719; 10 Nov 1719

Alle, Kare 23 Sep 1673

Alluq, Daeng (Manyampaq) 27 Jan 1718

Alluq, Karaeng [1] (Barombong) 18 Oct 1651

Alluq, Karaeng [2] 22 Aug 1692 
Alluq, Karaeng [3] (Shalahuddin) 23 Jul 1693; 10 Feb 1713; 12 Apr 1714; 15 Aug 1714; 2 Sep 1715; 22 Apr 1716; 23 Feb 1717; 31 May 1717; 13 Mar 1720; 8 Jun 1720; 7 Apr 1722; 17 Oct 1726; 26 Apr 1727; 3 Jan 1734; 27 Aug 1734; 9 Apr 1739

Aluq 18 Nov 1740

Amangkurat III (ruler of Mataram) 20 Oct 1708; 4 Dec 1708

Amaq 25 Jan 1667

Amboq 1611

Aminah [1] 7 Jan 1682

Aminah [2] (Sarimba Raja) 19 Jan 1726

Amir Hamzah, Sultan (Tumammaliang ri Alluq) 31 Mar 1656; 7 Apr 1657; 29 May 1657; 25 Jan 1667; 21 Jan 1669; 29 Jun 1669; 13 Jul 1671; 10 Aug 1671; 13 Aug 1671; 18 Apr 1672; 22 Oct 1672; 28 Oct 1672; 11 Dec 1672; 29 Nov 1673; 4 Feb 1674; 13 Feb 1674; 7 May 1674

Amirah (Tanitaja, Manengratu) 9 May 1711; 16 May 1724; 3 Nov 1725; 25 Aug 1727; 20 Aug 1729; 13 Oct 1730; 27 Jul 1738; 20 Aug 1750; 3 Oct 1751

Ammasa Pamayan (ruler of Sumbawa) 30 Nov 1648; 24 Dec 1650; 21 Aug 1655; 18 Sep 1662; 3 Feb 1663

Ammasaq (Mas Madina, ruler of Sumbawa) 20 Mar 1688; 29 Nov 1702; 29 Jun 1704; 19 Jul 1704; 16 Dec 1704; 13 Oct 1705; 31 Oct 1705; 22 May 1708; 12 Feb 1725

Ampaq, Kare 2 Jul 1647

Amuq 26 Nov 1665

Anaq Moncong, Karaeng (Ismail, Tumamenang ri Somba Opu) 18 Jan 1690; 18 Aug 1700; 16 May 1702; 4 Oct 1703; 22 Oct 1705; 22 Dec 1705; 2 Dec 1706; 24 Apr 1707; 14 Feb 1708; 21 Sep 1709; 20 Oct 1709; 16 Feb 1710; 20 Jul 1710; 2 Sep 1711; 20 Jan 1712; 26 Mar 1712; 24 Aug 1712; 29 Aug 1712; 31 Aug 1712; 16 Sep 1712; 22 Jan 1720; 18 Nov 1720; 13 Jan 1721; 21 May 1723; 8 Jan 1724; 16 Mar 1724; 1 Apr 1724

Anciq Ajang 7 May 1683

Anciq Baru (Tuang) 8 Aug 1675

Anciq Cukka 16 Dec 1721

Anciq Daeng 2 Jul 1705; 1 Nov 1705

Anciq Jenalaq 4 May 1718

Anciq Majjah 9 Apr 1653

Anciq Sammaq 3 Apr 1724

Anciq Sumaileq 13 Nov 1631

Anciq Terengganu 13 Jul 1707

Anciq Using 28 Apr 1615

Andi (Andi Muhammad Yusuf) 24 Jan 1713

Anduq Puaq 11 Feb 1725; 31 Jan 1727

Anisah 24 Mar 1722

Anne, Daeng 28 Mar 1641

Anrenne, Daeng 6 Dec 1675; 19 Feb 1679

Anro Malole 21 Mar 1728

Arapa 14 May 1719

Arrewijne, Governor Josua van 13 Nov 1728

Arung Amali 3 Jun 1704 
Arung Balusu 27 Jun 1683; 1 May 1700

Arung Barrang 5 Jul 1736; 11 Dec 1736

Arung Belo 21 Oct 1684; 1 Nov 1704; 28 Apr 1706

Arung Gowa-Gowa 13 Feb 1725

Arung Guna 4 Oct 1751

Arung Jalieng 1 Oct 1725

Arung Kaballangang (ruler of Sawitto) 27 May 1683; 10 Apr 1684

Arung Kaju [1] 25 Sep 1675; 19 Mar 1703

Arung Kaju [2] (Daeng Mammuntuli, Ahmad) 29 Jan 1679; 9 Jul 1715; 22 Mar 1726; 30 Mar 1726; 16 Feb 1727; 9 Oct 1728; 3 Jan 1734; 26 Jul 1736; 7 Dec 1736

Arung Kaju [3] 11 Jan 1739

Arung Kajuwara 27 Aug 1738; 11 Oct 1740; 15 Oct 1743

Arung Lalolang 29 Apr 1708

Arung Mampu 28 Jan 1717; 8 Jan 1724; 22 Feb 1724; 28 Jun 1724;

Arung Maroangi 11 Aug 1677; 18 Apr 1678; 17 May 1678; 7 Jan 1688

Arung Matoa (Toali) 21 Aug 1630

Arung Meru 8 Sep 1703

Arung Palakka (Tunisombaya, Matinroa ri Bontoalaq) 15 Sept 1634; 11 Dec 1660; 25 Dec 1660; 20 Aug 1663; 16 Aug 1666; 18 Dec 1666; 23 Dec 1666; 25 Dec 1666; 17 Feb 1668; 16 Mar 1668; 7 Oct 1669*; 29 Mar 1670; 7 Aug 1670; 19 Dec 1670; 26 Jan 1671; 6 Oct 1671; 15 Nov 1671; 7 Dec 1671; 27 Apr 1673; 13 Jun 1673; 20 Jul 1673; 31 Oct 1673; 11 Sep 1674; 3 Oct 1674; 28 Mar 1676; 11 Apr 1676; 27 Apr 1676; 13 May 1676; 2 Sep 1676; 16 Dec 1676; 17 Apr 1677; 3 May 1677; 26 Nov 1677; 7 Oct 1678; 1 Jul 1679*; 14 Nov 1679; 12 Mar 1680; 4 Nov 1680; 9 Jan 1681; 14 Sep 1684; 7 Aug 1686; 15 Oct 1689; 4 Oct 1690; 21 Oct 1692; 5 Jan 1693; 25 Sep 1693; 6 Apr 1696; 6 May 1720

Arung Pattiro 6 Feb 1698

Arung Pattojo 7 May 1728

Arung Singkang 1 Apr 1736; 5 Jul 1736; 19 Feb 1739; 20 Jul 1739

Arung Sumaling 3 Sep 1739; 11 Oct 1740; 11 Apr 1748; 13 Feb 1751

Arung Tanete [1] 13 Dec 1682; 13 Nov 1707

Arung Tanete [2] (Daeng Mangemba, Maninrori) 14 Jul 1709; 2 Apr 1715; 10 Aug 1719

Arung Tanete [3] (Maidah) 30 Dec 1722

Arung Tanete [4] (Callaq) 7 Oct 1725

Arung Tanete Malolo 10 Feb 1681

Arung Taq 1 Nov 1751

Arung Teko 27 Jun 1675; 31 Oct 1677; 6 Feb 1678; 8 Feb 1678; 10 Feb 1678; 20 Mar 1678; 18 Apr 1678; 31 Oct 1680; 13 Feb 1681; 7 Jan 1682; 28 Aug 1683; 3 Jul 1687; 1 May 1700; 14 Oct 1701; 4 Jul 1702; 2 Mar 1718; 24 Jun 1718

Arung Timurung 19 Mar 1697

Arung Tosiada 17 Sep 1695; 29 Apr 1696

Arung Ujumpuluq (La Tenritippaq, ruler of Sidénréng) 16 Sep 1669; 26 Mar 1721; 15 Oct 1743

Arung Ujung 8 Sep 1716; 4 Feb 1722

Asiah 14 Mar 1731

Asseng 14 Aug 1672

Assing 9 Dec 1648 
Babanga, Karaeng (Mallelei Jafar) 21 Dec 1636

Baciq 16 Apr 1743

Bagusuq 8 Feb 1727

Baine, Daeng 18 Oct 1705

Baine, Karaeng 9 Dec 1749

Bainea, Haji 19 Jun 1740

Baku Sitti Abidah 31 Oct 1699

Balambaru, Daeng (Manyampaq) 12 Apr 1672

Balambaru, Karaeng [1] 23 Aug 1634; 1 Sep 1659

Balambaru, Karaeng [2] (Daeng Riboko) 15 Jan 1714

Balambaru, Karaeng [3] 17 Jul 1726

Balambaru, Karaeng [4] 29 Aug 1728; 2 Mar 1739; 15 Jun 1739

Balaqsari, Karaeng (Zainab) 9 Aug 1684; 1 Jan 1707; 30 Dec 1707; 31 Dec 1714; 2

Nov 1712; 25 Apr 1713; 31 Dec 1714; 23 May 1716; 8 Sep 1716; 31 Oct 1717

Balingkasaq 31 Jan 1732

Baliung 3 Feb 1642

Ballaq Jawaya, Karaeng [1] 1627

Ballaq Jawaya, Karaeng [2] 10 Sep 1634; 1 Mar 1637

Ballaq Jawaya, Karaeng [3] 12 Dec 1647; 10 Mar 1660; 29 Jun 1666; 16 Mar 1668; 26 Jan 1671; 11 Feb 1721; 22 Jun 1725

Ballaq Kiria, Karaeng 24 Oct 1687

Ballaq, Karaeng (Mappatambaq, Abdul Gaffur) 22 Jan 1646

Balloq, Karaeng [1] (Daeng Talarra, Karaeng Tabaringang) 1626; 5 Apr 1662; 23 Jul 1663; 26 Nov 1665; 13 Sep 1673; 18 Dec 1674; 2 Dec 1675; 16 Aug 1677; 24 May 1679; 18 Mar 1680; 8 Oct 1688; 7 Oct 1709

Balloq, Karaeng [2] 25 Aug 1749

Balua, Karaeng 25 Jul 1707

Banging 1 Nov 1721

Bangkalaq, Karaeng [1] 21 Sep 1671

Bangkalaq, Karaeng [2] 28 Aug 1674

Bangung, Kare 16 Nov 1693; 1 Jun 1694; 7 Dec 1724

Banri 26 Jan 1719

Bantaeng 13 Feb 1677

Bantaeng, Karaeng 30 Sep 1665

Banyuanyaraq, Karaeng 20 Feb 1678

Barahing, Haji Abdulgaffar 4 Nov 1708

Barania, Haji 17 Dec 1686

Barombong, Karaeng [1] 1572; 14 Aug 1642

Barombong, Karaeng [2] see Muhammad Baki

Baronang 7 Jul 1701; 15 Oct 1707

Barong Patola, Karaeng [1] [Mutipattulah] 15 Jun 1703

Barong Patola, Karaeng [2] 10 Nov 1704; 24 Jan 1705; 25 Sep 1705; 8 Jun 1718

Barong Patola, Karaeng [3] 21 Aug 1713; 13 May 1717; 31 Aug 1722; 2 Sep 1727

Baroqbosoq, Karaeng [1] 13 Apr 1663

Baroqbosoq, Karaeng [2] 22 Nov 1674; 21 Jan 1675; 16 Nov 1677

Baroqbosoq, Karaeng [3] (Daeng Manginruru) 3 Apr 1749

Barrung, Karaeng [1] 26 Apr 1675; 1 May 1675; 22 Apr 1678; 27 May 1682 
Barrung, Karaeng [2] 30 Oct 1726; 24 Feb 1727; 9 Apr 1727; 26 Nov 1727; 6 Jun 1728 Basse, Kare 13 Feb 1706

Batangnionjoq, Karaeng (Matinroa ri Sumpangpoba) 9 May 1716

Batara Gowa 9 Nov 1749

Battu, Daeng 13 Aug 1655

Battu, Kare 28 Jan 1706; 22 Jun 1724

Batu-Batu, Karaeng 12 Jun 1660; 20 Jan 1676

Batupute, Karaeng [1] 6 Dec 1651

Batupute, Karaeng [2] (Abdul Karim) 20 Mar 1683; 17 Sep 1716; 9 Sep 1718; 10 Mar 1720; 17 Oct 1722; 21 Jan 1723; 23 Aug 1725; 25 May 1728; 10 Mar 1730; 4 Mar 1738; 15 Jun 1739; 4 Jun 1743

Bauwaq 20 Feb 1703

Bayang [1] 7 Dec 1644; 11 Mar 1650

Bayang [2] 9 Dec 1675

Bebboq 7 Nov 1733

Beeck, Willem van der 27 Dec 1655*

Beroanging, Karaeng [1] (Mappaseppeq) 3 Dec 1635

Beroanging, Karaeng [2] (Muhiddin) 17 Aug 1661; 23 Aug 1673; 4 Dec 1673; 26 Nov 1674; 12 Feb 1679; 12 Mar 1695

Beroanging, Karaeng [3] 17 Jun 1740

Beroanging, Karaeng [3] 27 Sep 1739

Bewi 2 Oct 1699

Biba 19 May 1641

Bidara, Karaeng [1] 7 Jan 1678; 3 Dec 1680

Bidara, Karaeng [2] 6 Oct 1702; 25 May 1712; 4 Mar 1722; 5 May 1729; 9 Jul 1729

Bidoq 21 Oct 1722

Bijai, Karaeng 24 Dec $1655^{*}$

Bimbang 4 Nov 1728; 29 Jul 1740

Binamuq, Karaeng 5 Mar 1694

Binoang, Karaeng 24 Aug 1716

Bintang, Karaeng 26 Feb 1659

Biqbuq 14 Oct 1723; 12 Oct 1725

Bisangpole, Karaeng (Sugi) 12 Jan 1713; 20 Mar 1714; 13 Sep 1714; 6 Nov 1726; 3 May 1727

Bisei, Karaeng (Abdullah Manshur, Arung Mampu) 22 Jul 1693; 10 Nov 1703; 20 Dec 1703; 29 Apr 1726; 2 May 1726; 18 Jun 1730; 29 Mar 1734

Bissu Caqdi 1619

Bissu 8 Jan 1645

Boaq 8 Dec 1718

Boe Jawa 25 Dec 1693

Boe 24 Mar 1681

Bole 7 Jun 1725

Bonang, Daeng 25 Feb 1726

Bone, Karaeng 21 Mar 1645

Bontoa, Karaeng [1] (Sitti Muthiatullah, Ralle, Daeng Paikaq) 1626; 29 Jan 1643; 30 Aug 1658; 4 Apr 1665; 11 Nov 1687; 19 Jun 1691; 24 Oct 1703; 20 Nov 1709; 13 Apr 1710; 20 Jan 1712; 18 Jan 1714; 3 May 1714

Bontoa, Karaeng [2] 12 May 1648 
Bontoa, Karaeng [3] (Daeng Marannu, Sugi) 11 Jul 1692; 19 Jul 1704; 10 Aug 1715; 8 Nov 1717; 15 Feb 1718; 22 Mar 1725; 8 Jun 1725; 29 Dec 1725; 5 Aug 1730; 7 Dec 1730; 7 Nov 1733; 26 Oct 1739

Bontoa, Karaeng [4] (Daeng Marannu) 11 May 1747

Bontoalaq, Gallarrang [1] 15 Mar 1729

Bontoalaq, Gallarrang [2] 11 Oct 1740

Bonto-Bonto, Karaeng 28 May 1742; 21 Nov 1743

Bontojeqneq, Karaeng [1] (Saniq, Daeng Nisakking) 7 Aug 1628; 12 Jul 1637; 20 Oct 1638; 23 Oct 1638; 2 Jul 1640; 3 Sep 1646; 23 Jan 1653; 8 Dec 1655; 11 Nov 1656; 27 Mar 1658; 20 Jun 1658; 3 Jan 1660; 19 Apr 1661; 4 Jun 1662; 18 Sep 1662; 3 Feb 1663; 30 Jan 1665; 8 Feb 1669

Bontojeqneq, Karaeng [2] 14 Oct 1707; 5 Aug 1708; 30 Mar 1726; 9 Oct 1728; 6 Dec 1728

Bontokamase, Karaeng (Abdurrahman) 31 May 1652; 4 Apr 1674; 16 Jul 1679; 27 Jun 1681; 7 Jul 1708; 26 May 1724

Bontokappong, Karaeng 9 Aug 1671

Bontokeke, Karaeng 12 Mar 1676; 14 Nov 1679; 1 Jan 1681; 26 Dec 1681; 2 Feb 1682; 20 Mar 1683; 19 Jun 1691; 14 May 1700

Bontolangkasaq, Karaeng [1] 23 Sep 1643

Bontolangkasaq, Karaeng [2] 3 Oct 1676; 19 Feb 1679; 28 Aug 1692; 28 May 1699; 14 May 1700

Bontolangkasaq, Karaeng [3] 28 Aug 1692; 14 Mar 1694; 5 Dec 1705; 15 Sep 1712;

(Mappaseppeq, Daeng Mamaro) 3 Jun 1715; 20 Apr 1716; 6 Mar 1718; 14 Feb 1719; 9 Oct 1721; 8 May 1726; 18 May 1729; 7 Dec 1730; 2 Aug 1731; 17 Jan 1734; 26 Sep 1735; 1 Apr 1736; 26 Jul 1736; 11 Dec 1736; 20 Aug 1737; 10 Apr 1739; 16 May 1739; 20 Jul 1739

Bontomajannang, Karaeng [1] (Syaifulmuluq) 31 Aug 1643; 15 Jan 1660; 25 Jun 1661; 6 May 1662; 8 Mar 1663; 21 Mar 1663; 24 Nov 1664; 24 May 1666; 17 Apr 1667; 8 Jul 1667; 8 Jul 1667*; 27 Aug 1668; 10 Sep 1668; 8 Oct 1688

Bontomajannang, Karaeng [2] 19 Jan 1722; 14 Oct 1723; 7 Jun 1725; 5 Oct 1730; 10 Feb 1731; 18 Feb 1731; 15 Jun 1739; 19 Mar 1740; 16 Oct 1747

Bontomanaiq, Gallarrang 27 Jun 1732; 2 Nov 1738

Bontomanaiq, Karaeng [1] 21 Aug 1683; 10 Apr 1684; 15 Jul 1684

Bontomanaiq, Karaeng [2] see Tasannging, Daeng [2]

Bontomanaiq, Karaeng [3] 1 Aug 1751

Bontomangape, Karaeng $22 \mathrm{Feb} 1651$

Bontomanompoq, Karaeng [1] (Mahumd) 31 Mar 1647; 12 Jun 1660

Bontomanompoq, Karaeng [2] 13 Jul 1671; 5 Sep 1672; 18 May 1679; 27 Feb 1680; 29 Dec 1680; 27 Aug 1696; 1 May 1699; 11 May 1699; 29 Oct 1699; 16 Apr 1704; 14 Jul 1704; 7 Aug 1719; 22 Jan 1733; 28 May 1740

Bontomarannu, Karaeng 12 Dec 1647; 10 Mar 1660; 30 Jul 1665; 23 Oct 1666

Bontomasugi, Karaeng 1 Oct 1719; 20 Feb 1720; 8 Mar 1740

Bontomateqne, Karaeng [1] 5 Jun 1664; 25 Nov 1664; 4 Feb 1669; 10 May 1669; 13 Mar 1671

Bontomateqne, Karaeng [2] (Karaeng Jipang) 26 Oct 1697; 21 Jan 1702; 5 Dec 1704; 11 Sep 1706; 29 Apr 1708; 28 Sep 1716; 20 Sep 1717; 24 Oct 1721; 27 Nov 1721; 14 Aug 1724; 12 Nov 1725; 21 Dec 1727; 29 Jan 1744 
Bontomateqne, Karaeng [3] (Muqmin) 7 Oct 1750; 22 Nov 1750; 29 Nov 1750; 10 Sep 1751

Bontopanno, Karaeng (Abdul Gafar) 2 Nov 1650; 14 Apr 1652; 9 Jun 1689; 8 Oct 1710; 9 Apr 1711; 8 Oct 1712; 31 Mar 1713; 1 Oct 1719; 20 Feb 1720; 10 Oct 1720; 5 Mar 1721; 31 Jul 1727; 6 Feb 1731; 5 Oct 1731

Bontopaqdinging, Karaeng 11 Sep 1674

Bontopaqja, Karaeng 22 Apr 1654; 28 Nov 1721; 29 Jan 1728

Bontoparang, Karaeng 30 Aug 1736; 17 Jun 1746

Bontopattongkong, Karaeng (Baraq) 11 Mar 1681; 15 Dec 1695; 2 Jun 1700; 21 Aug 1703; 3 Oct 1703; 15 Apr 1705

Bontorambaq, Karaeng [1] 20 Oct 1673; 5 Sep 1676; 11 Mar 1677; 13 Aug 1680; 27 May 1682; 14 Mar 1683; 10 Sep 1687; 19 Sep 1688

Bontorambaq, Karaeng [2] 14 Jul 1709; 2 Apr 1715; 26 Sep 1722; 15 Feb 1728

Bontosiamaq, Karaeng 7 Nov 1713; 22 Feb 1722; 24 Mar 1722

Bontosunggu, Karaeng (Daeng Tasannging, Tumamenang ri Taenga) 11 Sep 1633; 26 Dec 1643; 24 Jan 1644; 10 Jan 1645; 29 Jun 1651; 12 Nov 1654; 6 Aug 1656, 19 Apr 1657; 8 Jan 1661; 17 Feb 1666; 21 Sep 1671; 6 Oct 1671; 20 Aug 1676; 22 Dec 1677;23 Apr 1680; 3 Feb 1687; 24 Oct 1687; 21 Sep 1709; 21 May 1710; 13 Apr 1712; 20 Aug 1712; 29 Aug 1712; 18 Nov 1713; 9 Oct $1721 ; 3$ Jul 1726; 17 Oct 1726; 3 Oct 1742

Bontotannga, Karaeng [1] 20 Sep 1675; 9 Dec 1675; 28 Nov 1681; 24 Feb 1694

Bontotannga, Karaeng [2] (Bebuq) 21 May 1698; 13 Feb 1722; 21 Nov 1725; 5 Oct 1730; 19 Apr 1732; 6 Nov 1735; 16 May 1739; 3 Oct 1742

Bontotannga, Karaeng [3] 18 Mar 1700; 17 Jan 1716; 21 Feb 1721; 12 Dec 1721; 11 Dec 1732

Boqdia, Karaeng 4 Dec 1698; 4 Jun 1702; 12 Jul 1702; 18 Jun 1705; 8 Aug 1707; 18 Jul 1715; 18 Jun 1716; 17 Nov 1716; 30 Oct 1726; 24 Feb 1727; 9 Apr 1727; 26 Nov 1727

Borahima 30 Nov 1732

Boriqsallo, Karaeng 9 Aug 1725

Buang Nanang 16 Jun 1724

Buaq 9 Oct 1719

Buba 28 Aug 1728; 20 Mar 1729; 11 Mar 1730

Bulekang, Daeng 3 Apr 1639; 29 Nov 1652; 19 Sep 1702

Bulo-Bulo, Haji 29 Feb 1668

Bulo-Bulo, Karaeng [1] 4 Nov 1638; 28 Sep 1639; 20 Dec 1659

Bulo-Bulo, Karaeng [2] (Daeng Tatea) 23 Jul 1663

Bulo-Bulo, Karaeng [3] (Rimba) 26 Feb 1728

Bulukumba, Karaeng 4 May 1715; 14 Nov 1719; 20 Aug 1730

Buluq Sipong, Karaeng 19 Feb 1635

Buluq-Buluq, Karaeng [1] (Fatimah) 23 Nov 1666; 23 May 1684; 18 Nov 1684; 18 Mar 1700; 4 Jun 1705

Buluq-Buluq, Karaeng [2] (Rusiah) 4 Jun 1702; 12 Jul 1702; 22 Mar 1725; 8 Jun 1725

Bumi Partiga 5 Apr 1727; 8 Oct 1728; 9 May 1731

Bunda 2 Mar 1739

Bunduq 18 Jan 1653

Bunga Suttaraq 22 Dec 1713 
Bunga Suttaraq 28 Jan 1724

Bungaya, Karaeng [1] 22 Dec 1640; 26 Apr 1665

Bungaya, Karaeng [2] (Salahuddin) 3 May 1643; 8 Nov 1657

Bungaya, Karaeng [3] (Daeng Mattalliq, Jusuf) 23 Jul 1680

Bungaya, Karaeng [4] (Daeng Mattalliq, Mangeranngi) 16 Apr 1703; 22 Jan 1723; 24 Jan 1737

Buqdia, Karaeng 1 Oct 1675

Buraqne, Daeng [1] (Siang) 8 May 1644; 19 Oct 1680

Buraqne, Daeng [2] 22 Jun 1685; 16 Nov 1693; 1 Jun 1694; 21 Dec 1709; 27Jan 1710

Buraqne, Karaeng 25 Nov 1632; 7 Apr 1633

Cabaq 31 Oct 1644

Caciq 25 May 1723

Cacong 10 Jan 1659

Cacoq Paqrappoang 30 Sep 1699

Callaq [1] 17 May 1678

Callaq [2] 30 Dec 1722

Callaq [3] 6 Jun 1728

Callaq Belo 11 Jan 1710

Camba, Gallarrang 29 Jan 1740

Cambaya, Gallarrang [1] 24 Jun 1639

Cambaya, Gallarrang [2] (Kare Kanjaraq) 4 Sep 1712

Cammaq 16 Jun 1706; 2 Jan 1707

Campagaya, Karaeng [1] (Sitti Hibatullah) 17 May 1688; 20 Oct 1698; 13 Sep 1699

Campagaya, Karaeng [2] 28 Jan 1729

Capoaq 10 Jun 1726

Cauccung 21 Mar 1663; 24 Nov 1664

Cenrana, Karaeng 20 Jan 1641; 29 Jan 1650; 10 Aug 1660; 2 Jun 1661; 30 Dec 1661; 16 Jan 1664

Cinra [1] 11 Nov 1656

Cinra [2] 26 Feb 1730

Cinrana 11 Jan 1724

Cocoq 20 Mar 1727

Cocuq 3 Aug 1674; 14 Jul 1675

Congaq 14 Apr 1730

Costa, Antoni da 22 Oct 1632

Cucung 1 Aug 1719

Cumaq (Sitti Salehah, Rimba Bulaeng) 14 Dec 1726

Dadaq 7 Jan 1738

Dadi 15 Feb 1726

Dadiq [1] 21 Mar 1728

Dadiq [2] 13 Nov 1729; 18 Jun 1732; 27 Jun 1732

Daeng Battu (Karaeng Butta Toa) 3 Feb 1642

Daeng 9 Apr 1649; 9 Jan 1656

Daenta Daeng 23 Oct 1638

Dala Bantaeng 1 Mar 1713

Dala Lemo Apaq 24 Jan 1708 
Dambo Abdurrahim 2 Oct 1660; 14 Nov 1668

Dandung 1 Mar 1731

Danradatu (Sitti Napisah) 20 Aug 1729; 10 May 1738; 27 Aug 1738; 19 Feb 1739

Danruq 29 Aug 1728

Daru ri Baringang 20 Aug 1737; 19 Mar 1746; 8 Nov 1749; 30 Jul 1750; 29 Sep 1750

Dasunting 29 Jul 1704

Datoq (Abdul Maula) 17 Feb 1660

Datoq Hafid 13 Nov 1629

Datoq ri Bandang 28 Sep 1701; 26 Apr 1736

Datoq ri Paccelekang 16 Apr 1735

Datoq ri Paqjeqnekang (Gafarullah) 30 Jan 1643

Datu Lokaq (Mas Banten, ruler of Sumbawa) 29 Jun 1684; 24 Jul 1693; 25 Sep 1705; 31 Oct 1705; 20 Nov 1709; 13 Apr 1710; 31 May 1713

Datu Pattiro (We Tenrisoloreng) 4 Jun 1636

Datu ri Citta [1] 19 Dec 1702

Datu ri Citta [2] (Batari Toja, Datu ri Luwuq) 16 Dec 1704; 13 Oct 1705; 5 Aug 1715; 28 Jun 1719; 29 Aug 1721; 28 Jun 1724; 1 Oct 1725; 22 Mar 1726; 29 Apr 1726; 16 Feb 1727; 20 Feb 1727; 10 Mar 1727; 13 Mar 1727; 22 Mar 1727; 13 Aug 1727; 9 Oct 1728; 26 Jan 1734; 14 Aug 1737; 21 Apr 1749; 8 Nov 1749

Datu ri Lamuru 13 Feb 1725

Datu ri Luwuq [1] (Matinroa ri Somba Opu) 13 Sep 1637

Datu ri Luwuq [2] (Sultan Ahmad Nazaruddin, Matinroa ri Gowa) 20 Nov 1639; 12 Jan 1640; 7 Jan 1654; 6 Feb 1664

Datu ri Luwuq [3] (Matinroa ri Langkanana) 6 Feb 1698

Datu ri Luwuq [4] (Matinroa ri Tompotikkaq) 11 May 1704; 22 Aug 1718

Datu ri Luwuq [5] (Batara Tungkaq) 21 Jun 1719

Datu ri Mari-Mari 18 Jan 1702

Datu ri Mario (Arung Patiro) 28 Nov 1729

Datu ri Pammana 11 Dec 1712

Datu ri Soppéng [1] (Beyoa) 2 Oct 1637

Datu ri Soppéng [2] (We Adda Datu ri Watu) 17 May 1705

Datu ri Soppéng [3] (Towesa, Matinroa ri Salassana) 23 May 1707

Datu ri Soppéng [4] (La Tongeng, Arung Panyili) 22 Nov 1750; 29 Nov 1750

Datu ri Ulawang [1] 20 Dec 1714; 27 Jun 1723

Datu ri Ulawang [2] 16 Jul 1750

Datu Tannga 22 Mar 1725; 8 Jun 1725

de Haan, Governor General Mattheus 19 Aug 1729

Didaq 21 Dec 1727

Didi 6 Sep 1736

Dodi 15 Nov 1646

Dododi 18 Mar 1660

Doqdiq 9 May 1730

Dorra [1] 20 Feb 1719; 27 Aug 1719; 9 Jul 1726

Dorra [2] 15 Dec 1735

Durra 7 Jul 1708

Eja 15 Sep 1712; 20 Apr 1716

Ekong, Daeng 23 Oct 1716

Erbervelt, Governor 30 Sep 1705 
Faqqia 24 Sep 1677

Gacong 12 Apr 1731

Galesong 30 Jul 1737

Galesong, Karaeng [1] 5 Jun 1633

Galesong, Karaeng [2] 29 Oct 1636

Galesong, Karaeng [3] (Maninrori) 4 Feb 1654; 29 Mar 1655; 1 Jul 1663; 5 Aug 1671; 22 Nov 1679

Gappa, Kare 3 May 1675; 10 Sep 1702

Gappe, Kare [2] 27 Jul 1737; 2 Nov 1738

Garassiq, Karaeng [1] 17 Aug 1632; 25 Apr 1638; 13 Jul 1640; 19 Dec 1649; 20 Jan 1653; 26 Feb 1659; 9 Jun 1668; 17 Sep 1687

Garassiq, Karaeng [2] (Daeng Mattulung) 3 Apr 1703; 2 Sep 1703; 31 Aug 1704; 19 Oct 1711; 22 May 1712; 30 Jan 1717; 31 Jul 1723; 23 Oct 1726; 20 Feb 1727; 5 Oct 1731; 26 Dec 1733; 17 Jan 1734; 9 Apr 1739; 15 Jun 1739; 4 Sep 1739; 20 Mar 1742

Garassiq, Karaeng [3] 25 Oct 1741

Gundah Bulaeq (Dzuhariah) 12 Jun 1750

Guru Kasing 27 Dec 1719

Habibah [1] 14 Jun 1648

Habibah [2] 29 Jul 1674

Habibah [3] 22 Dec 1718

Hadijah 22 Apr 1678

Halimah [1] 18 Oct 1658

Halimah [2] 28 Oct 1721

Harrunarasyid (Tumamenang ri Lampana) 3 Nov 1640; 11 Nov 1641; 8 Oct 1653; 27 Aug 1655; 10 Jan 1657; 4 May 1659*; 10 Aug 1660; 25 Aug 1664; 30 May 1667; 4 Feb 1669; 10 May 1669; 28 Mar 1670; 3 Jul 1670; 30 Oct 1670; 5 Aug 1671; 16 Jun 1673

Hartsink, Willem 3 Sep 1685

Hasanah 6 Oct 1725

Hasanuddin, Sultan (Tumamenang ri Ballaq Pangkana) 12 Jan 1631; 25 Dec 1640; 16 Jun 1642; 24 Jan 1643; 24 Dec 1643; 12 Feb 1645; 4 Apr 1650; 4 Feb 1654; 21 May 1654; 8 Jul 1654; 22 Oct 1654; 16 Dec 1654; 21 Mar 1655; 14 May 1655; 14 May 1655*; 5 Sep 1656; 19 Oct 1657; 10 Jul 1658*; 10 Jan 1659; 21 Apr 1659; 29 May 1659; 11 Dec 1660; 11 Jan 1661; 23 Nov 1661; 29 Dec 1662; 7 Sep 1663; 27 Jan 1664; 8 Nov 1664; 7 Nov 1667*; 17 Feb 1668; 13 Mar 1668; 12 Jun 1670

Ibrahim [1] 30 Sep 1646

Ibrahim [2] 11 Mar 1650; 4 Nov 1650

Iji, Daeng (Siqra) 24 Dec 1679; 13 Mar 1682

Iji, Daengta Daeng 21 Jun 1739

Inciq Daeng 23 Apr 1751

Indunaq 25 Dec 1751

Isa [1] 9 Mar 1681 
Isa [2] 24 Oct 1727; 5 Nov 1728

Ismail 5 May 1658

Ismail, Sultan see Anaq Moncong, Karaeng

Jabbing 7 Jan 1694

Jaenaq 2 Oct 1724

Jaga Azizah 30 Oct 1674

Jaga 18 Jun 1700

Jakuq 21 Mar 1728; 27 Nov 1729

Jamaluddin 1 Sep 1720

Jamboq 24 Aug 1710

Jamilah 2 Jul 1705; 1 Nov 1705

Jamuq 11 Dec 1704

Jannang, Daeng 13 Oct 1738

Jannang, Kare 29 Jan 1729

Japaraq 8 Dec 1672

Jappon, Jan 27 Dec 1681

Jaqfar Shadiq 11 May 1675; 24 Feb 1676

Jaqfar, Haji 3 Jul 1707

Jarannika, Karaeng [1] (Abdul Gafar, Tumatea ri Salaparang) 21 Apr 1641; 20 Jun 1658; 3 Jan 1660; 18 Jan 1661; 19 Apr 1661; 30 Jan 1665; 17 Apr 1671; 21 Jun 1671; 25 May 1673; 1 Feb 1676; 6 Jun 1688; 10 Mar 1694; 14 May 1694; 17 Sep 1695; 14 May 1700; 3 Mar 1707; 15 May 1725; 16 Mar 1726

Jarannika, Karaeng [2] 17 Jun 1746; 15 Oct 1749

Jarreq, Kare (Yokong) 27 Mar 1725; 28 Nov 1730; 20 Jun 1739

Jawere, Karaeng 5 Aug 1708

Jijaq 7 Jan 1738

Jineli Safi 20 Dec 1723

Jinne 1 Feb 1676

Jinne, Daeng 2 Jan 1742

Jipaling, Daeng 21 Oct 1675; 27 Dec 1676

Jipaling, Daengta Daeng 23 Jun 1671; 27 Jun 1681; 27 Jul 1682

Jipaliq, Daengta Daeng (Halimah) 1 Oct 1661

Jipamma, Karaeng 21 May 1674

Jipang, Karaeng [1] 25 Jan 1647

Jipang, Karaeng [2] 3 Aug 1648

Jipang, Karaeng [3] 23 May 1686

Jitaq 27 Aug 1739

Jonggoa, Daeng 21 Dec 1674; 26 Nov 1709

Jonggoa, Karaeng 21 Jan 1684

Judda 23 Mar 1715

Junggo, Karaeng 2 Nov 1677

Kaballokang, Karaeng 1 Mar 1669; 6 Apr 1673; 9 May 1673; 4 Sep 1673; 21 Feb 1674; 15 Jan 1675; 3 Mar 1675; 11 Jan 1717

Kacung 27 Aug 1655; 4 Feb 1669

Kaicili Kalamata 5 Sep 1656; 9 Jun 1664; 23 Feb 1676

Kaiq 21 May 1670 
Kalau, Daengta Daeng 16 Dec 1653

Kalingkeriq 5 Mar 1718; 23 Aug 1731

Kalling, Daeng 30 Mar 1631

Kalukuang, Karaeng (Tola) 7 Sep 1748

Kalula 22 Oct 1638

Kalula, Daeng 25 Jun 1631; 8 Nov 1651

Kamariah (Daeng Nisanga) 13 Dec 1705; 24 Jun 1707; 25 Feb 1709

Kamboja 8 Oct 1705

Kammisiq 23 Apr 1653; 18 Oct 1658

Kampong Beru, Karaeng (Sitti) 12 Sep 1670; 13 Sep 1717

Kanjaraq, Kare 1 Aug 1647; 19 Sep 1661

Kanjilo, Karaeng 1 Sep 1705

Kapetta, Daeng 18 Mar 1644

Kapparaq 16 May 1729

Kare Kontu 17 Jul 1724

Karimah 21 Feb 1728; 5 Feb 1729; 26 Jun 1730; 16 Aug 1731; 2 Sep 1731

Kariwisi, Karaeng 23 Feb 1641

Karunrung, Karaeng (Abdul Hamid, Tumamenang ri Ujung Tana) 4 Sep 1631; 28 Mar 1641; 22 Jun 1642; 2 Jan 1644*; 30 Oct 1645; 31 Aug 1646; 5 Apr 1648; 6 Jan 1650; 15 Feb 1655; 5 Feb 1658; 10 Aug 1660; 6 Feb 1664; 26 May 1664; 17 Feb 1666; 29 Jun 1666; 28 Nov 1666; 20 Jul 1667; 1 Aug 1670; 13 Nov 1671; 16 Sep 1672; 6 Dec 1675; 16 Jun 1676; 1 May 1684; 27 Jan 1685

Karuwisi, Daeng 22 Jun 1684

Karuwisi, Karaeng (Tumamenang ri Lambusuqna) 28 Mar 1747

Kasammeng, Daeng 1620; 12 Jun 1705

Kasing 14 Mar 1729

Kassiqjala, Karaeng Nov 1616; 19 Nov 1649; 25 Aug 1694

Kasuarrang, Karaeng 5 Jul 1637

Katangka, Karaeng 15 Jun 1739

Katapang, Karaeng [1] 18 Mar 1644; 5 Jul 1652; 7 Sep 1662; 31 Jul 1668

Katapang, Karaeng [2] (Daeng Mamo) 25 Nov 1718

Katapang, Karaeng [3] 18 Dec 1741

Katinting, Karaeng [1] 7 Aug 1627; 17 Mar 1645; 3 Feb 1650

Katinting, Karaeng [2] 10 Oct 1736

Kauji 3 Oct 1731

Kenna, Daeng 31 Jul 1718

Ki Ngabei Saradulla 9 Dec 1632*; 27 Jan 1633

Kiamuddin 15 Aug 1720

Kondaq 14 Oct 1724

Kopas, Heer 10 Jul 1684

Kundaq 23 May 1720

La Maqdaremmeng (Matinroa ri Bukaka) 4 Jun 1636; 23 Jul 1644; 19 Jun 1646 La Maqdiq 16 May 1729; 18 May 1729

La Padangsajati (Arung Palakka Puanna I Mattaq, Karaeng Katangka, Datu ri Soppéng) 23 Sep 1691; 2 Aug 1693; 27 Sep 1693; 22 Jun 1709; 8 Aug 1710; 16 Jan 1711; 24 Jan 1713; 8 Mar 1715; 15 Mar 1715; 15 May 1715; 5 Aug 
1715; 15 Aug 1715; 18 Feb 1716; 21 Feb 1716; 14 Apr 1716; 29 Jun 1717; 4 Feb 1718; 24 May 1718; 25 May 1718; 31 Aug 1718; 23 Oct 1718; 16 Nov 1718; 25 May 1719; 22 Nov 1719; 22 Jan 1720; 15 Nov 1720; 13 Jan 1721; 8 Jan 1724; 13 Feb 1725; 16 Feb 1727; 4 Mar 1727; 10 Mar 1727; 13 Mar 1727; 22 Mar 1727

La Patauq (Matinroa ri Nagaulang) 20 May 1671; 3 Nov 1672; 4 Apr 1687; 12 Mar 1692; 15 Oct 1696; 19 Mar 1697; 7 May 1700; 13 Jul 1701; 6 Oct 1702; 1 Sep 1705; 22 Oct 1705; 20 Dec 1705; 1 Sep 1708; 30 Sep 1709; 13 Jul 1710; 14 Aug 1710; 2 Sep 1711; 20 Aug 1712; 12 Nov 1712; 16 Sep 1714; 8 Nov 1714 La Tenrioddang 11 Jan 1739; 19 Mar 1740; 1 Nov 1740; 29 Jun 1742; 15 Apr 1744; 27 Jun 1747

La Useq 2 Nov 1712; 14 Nov 1712

Laikang, Karaeng [1] 22 Oct 1673

Laikang, Karaeng [2] (Daeng Marannu) 31 Jul 1718; 6 May 1720

Laikang, Karaeng [3] 18 Nov 1723; 1 Jun 1733

Laiqjiq 10 Mar 1727

Lakiung, Karaeng (Sitti Shafur, Daeng Niasseng, Manneratu) 13 Mar 1649; 20 Jun 1660; 5 Apr 1662; 26 Jun 1663; 13 Sep 1664; 1 Jun 1669

Lambengi, Karaeng (Ali) 10 Sep 1649; 17 Jul 1674; 4 Aug 1674; 9 Oct 1674; 1 Oct 1675; 13 May 1676; 31 Mar 1677; 7 Aug 1677; 21 Jan 1701; 22 Aug 1705; 15 Oct 1705; 26 Mar 1709; 1 Sep 1709; 10 Apr 1715

Langeloq, Karaeng (Danradatu) 30 Dec 1741

Langeloq, Karaeng (Latifah) 29 May 1656; 5 May 1658; 12 Jan 1668; 1 Mar 1669; 21 Oct 1671; 17 Nov 1672; 7 Jan 1673; 6 Apr 1673; 2 Jul 1673; 31 Jan 1674; 27 Jun 1675; 8 Feb 1678; 20 Mar 1678; 15 Aug 1680; 21 Feb 1682; 27 May 1683; 10 Apr 1684; 20 Oct 1687; 23 May 1707; 23 Apr 1730

Laqbakkang, Karaeng 17 Feb 1639

Laqnatullah 16 Jul 1734

Latifah [1] 5 Sep 1679

Latifah [2] 8 Jun 1720

Latifah [3] 12 Oct 1725

Lauq, Karaeng 5 Dec 1681; 6 Jan 1683; 23 Jan 1725

Layu, Karaeng 10 Nov $1634^{*}$

Lekoq Alaq, Karaeng 18 Aug 1675; 23 Feb 1691

Lekoqboqdong, Karaeng [1] (Tataraq) 28 Jun 1647; 6 Dec 1663; 2 Dec 1664; 18 Jul 1665; 19 Jun 1673; 2 Jul 1673; 31 Jan 1674; 4 Apr 1674; 4 Dec 1677; 16 Jul 1683; 22 Mar 1696

Lekoqboqdong, Karaeng [2] (tumailalang) 25 Mar 1674; 14 May 1674; 5 Sep 1674; 11 Aug 1677; 18 Apr 1678; 6 May 1678; 6 Oct 1702; 22 Dec 1707; 9 Dec 1713; 12 Sep 1716; 20 Jan 1717; 24 Jun 1717; 19 May 1719; 10 Nov 1723; 10 Sep 1731; 26 Sep 1731; 17 Jan 1734;

Lembang, Karaeng 16 Oct 1730

Lembaya, Karaeng [1] 25 Aug 1659

Lembaya, Karaeng [2] 1 May 1744

Lembaya, Karaeng [3] 22 Mar 1746; 25 Aug 1751

Lempangang, Karaeng [1] (Saqbe, Daeng Tamaga) 17 Aug 1632; 26 Oct 1637; 23 Dec 1646; 27 Sep 1650

Lempangang, Karaeng [2] see Syafiuddin 
Lempangang, Karaeng [3] 11 Apr 1748; 10 Jun 1749; 13 Feb 1751

Lengkeseq, Karaeng (Mammaliang Daeng Pole) 14 Oct 1627; 2 Oct 1641; 25 Feb 1649; 2 Feb 1655; 7 Sep 1655; 14 Feb 1656; 12 Feb 1657; 2 Mar 1657; 17 Sep 1657; 16 Jan 1664; 7 Feb 1667; 30 May 1667; 29 Dec 1667; 10 Apr 1695

Leoq, Kare 17 Jan 1694

Leppang, 20 Nov 1751

Leqleng, Daeng [1] 18 Oct 1649

Leqleng, Daeng [2] (Coco) 10 Jul 1658*

Lesang, Kare 7 May 1727; 29 Nov 1739

Lewa, Kare (Sule) 11 Apr 1720; 3 May 1720

Liasaq 29 Mar 1729

Liba 3 Jun 1631

Limaraq 31 Aug 1704

Lompo, Daeng 26 Oct 1637; 29 Feb 1643

Loqmoq [1] 12 Jul 1637

Loqmoq [2] 4 Feb 1654

Loqmoq [3] 27 Aug 1655; 4 Feb 1669

Loqmoq [4] 1 Mar 1669; 11 May 1675; 9 Aug 1678

Loqmoq [5] 13 Jun 1683

Loqmoq [6] 29 Jul 1691

Loqmoq [7] 14 May 1694

Loqmoq [8] 22 Dec 1707

Loqmoq Daeng 4 Jul 1653

Loqmoq Dayang 8 Jul 1654; 11 Sep 1716

Loqmoq Galorang 14 Feb 1718

Loqmoq Maroangi 2 Jul 1654

Loqmoq Saja $25 \mathrm{Jul} 1703$

Loqmoq Taenga 28 Aug 1739

Loqmoq, Karaeng (Baeda) 27 Jun 1757

Loqmoq, Kare 20 Jul 1673; 23 Nov 1674; 3 Jul 1721

Lotteng Salahuddin 5 Aug 1730

Lumbaq 28 Jan 1644

Lumu, Kare 27 Aug 1676

Mabela, Daeng [1] (Mangassengi) 24 May 1679; 29 May 1714; 18 Jul 1718

Mabela, Daeng [2] (Gacung) 15 Oct 1679; 18 Apr 1699

Macallaka Kanukunna 24 May 1666

Macoa, Daeng 18 Nov 1745

Madyan Mappasonriq 8 Mar 1715

Maeja, Daeng 12 Aug 1683

Maemunah 11 Feb 1725; 1 Dec 1725

Mahkota Alam 27 Dec 1636

Maidah 29 Jul 1729

Maimunah [1] 18 Jun 1716; 17 Nov 1716

Maimunah [2] 14 Apr 1718

Maingaq, Daeng [1] 28 Apr 1642

Maingaq, Daeng [2] 2 Mar 1657; 5 Nov 1666 
Maingaq, Daeng [3] (Karaeng Balua) 13 Apr 1670; 20 Aug 1671; 28 Oct 1672; 13 Feb 1675; 1 Feb 1676; 15 Oct 1691; 18 May 1720; 16 Jul 1720; 25 Apr 1722; 17 Jun 1725; 15 May 1729; 11 Apr 1734

Maingaq, Daeng [4] 9 Mar 1671

Maingaq, Daeng [5] 4 Apr 1678

Maingaq, Daeng [6] 8 Sep 1678; 5 Sep 1679; 26 Aug 1680; 9 Jan 1682; 14 Mar 1693; 2 Dec 1717; 4 Mar 1718

Maingaq, Daengta Daeng 14 Feb 1656; 1 Nov 1724

Maisanannga 13 Nov 1631

Majannang, Daeng [1] (Daenne) 17 Jun 1708

Majannang, Daeng [2] (Manrepe) 27 Nov 1709

Majannang, Daeng [3] (Salamah) 25 Feb 1725

Majannang, Daengta Daeng 29 May 1659; 13 Jul 1671; 10 Aug 1671; 21 Sep 1672; 30 Sep 1673; 26 Dec 1674; 20 Mar 1682; 7 Jan 1685; 7 Mar 1687; 14 Jun 1689

Majannang, Karaeng [1] 20 Jan 1636; 24 Jan 1644; 16 Mar 1645; 2 Sep 1650

Majannang, Karaeng [2] (Abdul Kadir La Sanresang) 16 Feb 1707; 21 May 1710; 15 Aug 1715; 13 May 1719; 30 Oct 1719; 16 Jan 1720; 18 Jan 1721; 3 Dec 1724; 28 Jul 1731; 6 Nov 1735; 16 Mar 1736; 23 Mar 1736; 26 Apr 1736; 12 May 1736; 25 Aug 1738; 30 Nov 1738; 6 Apr 1739; 4 Dec 1739; 8 Oct 1740; 11 Oct 1740; 1 Nov 1740; 17 Mar 1741; 2 Nov 1741; 26 Feb 1742; 28 May 1742; 5 May 1743; 18 May 1743; 20 Jul 1748; 26 Aug 1748; 22 Jul 1750;

Majarreq, Daengta Daeng (Camme) 19 Dec 1714

Majawang, Karaeng (Aisyah) 19 Nov 1649

Makaqbang, Daeng 12 Apr 1672

Makkalle, Daengta Daeng (Cilillang) 7 Feb 1720

Makkappa, Daeng 8 Jan 1714

Makkaraeng [1] 4 Dec 1673; 19 Sep 1676; 25 Jul 1677

Makkaraeng [2] 27 Aug 1696

Makkaruru 10 Feb 1678

Makkulle, Daeng [1] (Abdul Wahid) 24 Feb 1657; 28 Apr 1661; 3 Aug 1674; 14 Jul 1675; 7 Sep 1677

Makkulle, Daeng [2] (Ahmad) 24 Dec 1679; 13 Mar 1682; 18 Nov 1683; 12 Apr 1688; 5 Jun 1689; 17 Jun 1703; 21 Jul 1707; 16 Jul 1708; 27 Jan 1710; 15 Dec 1712; 4 Mar 1718; 13 Nov 1719; 19 Oct 1725; 27 Nov 1725

Makkulle, Daeng [3] (Mappaq) 13 Nov 1719; 9 Oct 1721

Makkulle, Daeng [4] (Kare, Kare Palemba) 6 Jun 1724

Makkulle, Daeng [5] (Tipu) 2 Sep 1727

Malikah 11 Feb 1726; 26 Apr 1728; 14 Sep 1732

Malikussaid, Sultan (Tumamenang ri Papambatuna, Karaeng ri Lakiung) 11 Dec 1607; Jun 1619; 13 Aug 1625; 4 Jun 1629; 3 Dec 1631; 3 Jul 1639; 19 Dec 1639; 14 Mar 1640; 13 Apr 1640; 21 May 1640; 18 Jun 1640; 27 Oct 1640; 15 Dec 1640; 27 Sep 1642; 31 Oct 1642; 29 Jan 1643; 8 Oct 1643; 19 Nov 1643; 3 Oct 1644; 18 Apr 1646; 25 May 1646; 15 Nov 1646; 12 May 1648; 13 Nov

Maliq 15 Dec 1727 1650; 18 Aug 1651; 9 Apr 1653; 5 Nov 1653

Maliq, Daeng 4 Jun 1679; 11 May 1682

Mallalanngang 30 Nov 1643

Mallimpo, Daeng 15 Dec 1700; 4 Sep 1718 
Malliongang, Daeng 4 Jul 1724; 25 Aug 1749

Malliongi, Kare (Gallarrang Rappo-Rappo Jawa) 22 Jan 1732

Mallulungang, Daeng (Mappaqngara) 18 Jul 1665; 16 Mar 1687; 5 Jul 1693

Malluq, Daeng 15 Nov 1646

Malung 13 Sep 1673

Mamampang, Karaeng [1] (Bahauddin) 18 Apr 1662; 3 Sep 1691; 28 Aug 1699; 8 Apr 1702; 24 Oct 1703; 4 Aug 1709; 19 Sep 1714; 25 Jun 1717; 31 Aug 1718; 23 Oct 1735; 28 Jul 1742

Mamampang, Karaeng [2] (Daeng Manarai) 8 Jun 1692

Mamangkasi 4 Apr 1634

Mamangkasi, Daeng (Mamminawang) 24 Nov 1664; 8 Oct 1688

Mamangung, Daeng [1] (Karisaq) 5 Sep 1672; 15 Mar 1684

Mamangung, Daeng [2] (Papoq) 12 Apr 1735

Mamaro, Daeng [1] (Papoq) 15 May 1675; 25 Apr 1693

Mamaro, Daeng [2] 24 Nov 1723

Mambani, Daeng [1] (Dulang) 8 May 1706

Mambani, Daeng [2] (Bambiq) 30 Apr 1731

Mambani, Kare [1] (Jamila) 11 May 1720; 3 Oct 1731; 14 Dec 1731

Mambani, Kare [2] (Umaraq) 10 Jun 1749

Mami 27 Jun 1683

Mami 31 Apr 1683

Mami, Daeng [1] 14 May 1719

Mami, Daeng [2] 9 Jun 1723

Mami, Daeng [3] (Dalang) 29 Mar 1729

Mami, Daengta Daeng [1] (Rukiah) 28 Aug 1670; 19 Mar 1682; 21 Oct 1684; 1 Nov 1704; 28 Apr 1706; 12 May 1724

Mami, Daengta Daeng [2] 9 Mar 1673; 3 Jan 1674; 21 Aug 1683; 10 Apr 1684; 15 Jul 1684

Mami, Kare 5 Jan 1714

Mammaliang, Daeng (Mappaonoq) 10 Jul 1649

Mammaq [1] 12 Dec 1706

Mammaq [2] 21 Dec 1728

Mammaq [3] 24 Jan 1731; 25 Jan 1731

Mamminawang 26 Apr 1678

Mamminawang 5 May 1683

Mammiq 11 Dec 1732

Mamo 17 Jan 1673; 21 Jan 1675; 4 Mar 1680

Mamo, Daeng (Nampa) 16 Aug 1677

Mamo, Daengta Daeng 3 Apr 1676

Mamo, Kare 10 Nov 1715

Mamuntuli, Daeng 10 Nov 1704; 24 Jan 1705; 25 Sep 1705; 19 Mar 1746

Managgalaq, Daeng [2] (Jamali) 12 Aug 1683

Manaiq, Daeng 21 Feb 1716

Manangaraq, Daeng [1] 26 Dec 1672

Manangaraq, Daeng [2] (Assang) 2 Jan 1673

Manangaraq, Daeng [3] (Ahmad) 17 Sep 1687; 17 Jun 1720; 20 May 1721; 3 Nov 1730; 6 Nov 1735; 27 Jul 1737; 30 Jul 1750 
Manangaraq, Daeng [4] (Layuq) 14 Sep 1712

Manappakki 20 Feb 1678

Manappuki Ahaq 24 Dec 1748

Manaqgalaq, Daeng [1] 10 Jan 1683

Manaqgalaq, Daeng [2] (Caqdi) 14 Mar 1693; 9 Aug 1702; 7 Mar 1710

Manaqgalaq, Daeng [3] (Guru) 24 Oct 1735

Manaqgalaq, Daengta Daeng 17 Jun 1725

Manaqgalaq, Kare 28 Jul 1723; 14 Jan 1741

Manassaq, Daeng [1] (Muhammad) 19 Mar 1710; 15 Feb 1718; 1 Sep 1720; 11 Dec 1720; 14 Mar 1721; 19 May 1721; 11 Jul 1721; 13 Apr 1722; 17 Oct 1722; 10 Aug 1724; 9 Feb 1728

Manassaq, Daeng [2] (Paciq) 10 Aug 1715; 8 Nov 1717; 1 May 1719; 17 Mar 1721; 30 Kan 1732; 16 Feb 1747

Mandalleq, Karaeng [1] (Tulolo Tajuddin) 27 Dec 1653; 30 Nov 1664; 24 Sep 1665; 7 Feb 1667; 13 Apr 1670; 20 Aug 1671; 1 Mar 1672; 1 May 1672; 21 Sep 1672; 29 Mar 1674; 29 May 1676; 9 Jun 1676; 5 Feb 1678; 7 Feb 1679; 26 Nov 1679; 8 Aug 1681; 25 Jul 1687; 11 Nov 1687; 9 Apr 1690; 14 Feb 1718

Mandalleq, Karaeng [2] (tumailalang, Daeng Sisila Ibrahim) 4 Dec 1658; 6 Apr 1673; 12 Jan 1713; 23 Mar 1715; 11 Jun 1717; 16 May 1729

Mandalleq, Luqmuq Apr 1618

Mandi 10 Nov 1727

Manena, Daengta Daeng 6 Feb 1701

Mangagaang, Daeng 2 Dec 1717

Mangago, Daeng 17 Mar 1722

Mangalle 9 Aug 1684

Mangalle, Daeng [1] 17 Oct 1633

Mangalle, Daeng [2] 3 May 1724

Mangalle, Daeng [3] (Laijiq) 1 Nov 1733

Mangalle, Daeng [4] (Mammaq) 27 Jul 1737

Mangalle, Daengta Daeng (Abdul Hamid) 12 Aug 1658; 13 Dec 1698

Mangalle, Kare [1] 3 Nov 1717

Mangalle, Kare [2] (Maliq) 4 May 1720; 20 Mar 1727; 17 Apr 1732

Mangallekana, Karaeng (Kurru, Zakaria) 20 Jul 1637; 25 May 1700; 21 Jun 1739

Mangalliki, Kare (Jalaq) 27 Mar 1725

Mangalliq, Daeng (Dondiq) 29 Sep 1692; 21 Feb 1746

Mangalliq, Gallarrang 10 Feb 1704

Mangalliq, Karaeng 8 Jul 1654; 13 Jan 1655; 12 Sep 1670; 23 Mar 1672; 17 Jan 1673; 25 May 1673; 20 Jun 1673; 13 Nov 1674; 27 Nov 1674; 25 Oct 1677; 20 Mar 1682; 7 Jan 1685; 21 Sep 1689; 29 Dec 1709; 12 Jan 1713; 11 Sep 1716; 14 Mar 1751

Mangamaraq, Daeng 17 Oct 1633

Mangambari 5 Apr 1684

Mangaraqbombang, Karaeng [1] 26 Jun 1707; 12 Feb 1729

Mangaraqbombang, Karaeng [2] 14 Mar 1746; 9 Dec 1749; 26 Apr 1751; 1 Aug 1751

Mangasa, Daeng (Jipang) 6 Sep 1730

Mangasa, Gallarrang [1] (Kare Naba) 14 Oct 1655

Mangasa, Gallarrang [2] (Kare Mangalle) 6 Feb 1664; 23 Aug 1693; 14 Jul 1707; 23 Aug 1707; 3 Sep 1707; 4 Dec 1707; 14 Apr 1712; 29 Oct 1724; 14 Mar 1729; 23 Mar 1736; 2 Nov 1738 
Mangasa, Gallarrang [3] (Kare Ruppa) 4 Apr 1678

Mangaungi, Daengta Daeng (Hasan) 5 Aug 1658; 31 Jan 1726

Mangaungi, Daengta Daeng 14 Apr 1718

Mangellai 13 Sep 1673; 18 Dec 1674

Mangemba, Daeng [1] (Kasim) 17 Sep 1657

Mangemba, Daeng [2] 9 Mar 1673

Mangemba, Daeng [3] 19 Feb 1679

Mangemba, Daeng 19 Sep 1688; 15 Feb 1692

Mangeppeq, Daeng 29 Jan 1650; 27 Mar 1676

Mangeppeq, Loqmoq 26 Jan 1660

Mangeranngi 4 Sep 1718; 25 May 1723; 11 Feb 1726; 6 Apr 1728

Mangesuq, Karaeng 4 Apr 1721; 9 Apr 1725; 1 Oct 1725

Mangewai, Daeng [1] (Wasing) 18 Jul 1718; 7 Oct 1726

Mangewai, Daeng [2] (Dandeq) 13 Dec 1719

Mangewai, Daeng [3] (Jannatulfirdaus) 27 Nov 1724; 17 Nov 1733

Mangewai, Kare 31 Jan 1732; 2 Nov 1738

Manggappa, Daeng (Mommiq) 6 Aug 1688; 1 Mar 1731; 6 Nov 1735; 27 Jul 1737; 25 Oct 1741; 25 Aug 1749

Manggaukang 21 Sep 1671; 22 Dec 1677

Manginruru, Kare (Molla) 11 Feb 1725; 1 Dec 1725

Mangiq [1] 18 Jul 1718

Mangiq [2] 11 Mar 1730

Mangisuq, Karaeng [1] 5 Jan 1731; 13 Sep 1736

Mangisuq, Karaeng [2] 25 Oct 1741

Mangitung, Daeng 13 Mar 1682; 2 Apr 1732

Manguluang 3 Mar 1706

Manilingi, Karaeng 19 Dec 1732

Manimbang 18 Jun 1716; 20 Sep 1722; 5 Mar 1724; 7 Dec 1731

Manimbang-gauq (Muhiiddin) 27 Sep 1720

Manina, Daengta Daeng 18 Feb 1680

Maniqgalli, Daeng 5 May 1729

Manjagai 26 Sep 1639

Manjakkalaq, Daeng (Luddin) 10 Jul 1728

Manjakkalaq, Kare (Uqdung) 9 Aug 1702

Manjalling, Karaeng [1] (Makkaraeng) 26 Dec 1683

Manjalling, Karaeng [2] 11 Sep 1674

Manjalling, Karaeng [3] 3 Oct 1703; 18 Jun 1706; 7 Sep 1723; 14 Oct 1723; 7 Oct 1726; 25 May 1728

Manjarreki, Daeng (Mammaq) 23 Mar 1741

Manjarreki, Daeng 2 Feb 1678

Manjawakkang 6 Feb 1651; 19 Sep 1651

Manjijjiliq, Daengta Daeng 26 Apr 1720

Manna 13 Sep 1652

Mannapoi Mansur 27 May 1749

Mannawarri (Abdulhadi) 8 Dec 1746

Manngallei 7 May 1675

Mannyaurang $22 \mathrm{Jul} 1750$

Mannyikkoq ri Kassiq, Daeng 16 Jun 1724

Mannyiori, Karaeng 25 Aug 1749 
Manombong, Daeng 19 Jan 1727

Manrannuang 15 Sep 1722; 28 Aug 1728

Manrewakki [1] 16 Dec 1715; 9 Jan 1721

Manrewakki [2] 18 Feb 1725

Manrewakki [3] 25 May 1728

Manruppai, Daeng (Okang) 11 Oct 1705; 13 May 1708; 1 Oct 1716

Manshur (Mallawang Gauq) 25 Aug 1727

Manuruki (Muhammad) 28 Mar 1641; 15 Feb 1655

Manuruki, Karaeng 19 Dec 1715

Manyallang, Daeng 27 Feb 1674

Manyampakki, Daeng (Mamminawang Pakki) 19 Feb 1682; 22 May 1701; 1 Apr 1705; 22 Apr 1705; 25 Dec 1709; 15 May 1729

Manyampaq, Daeng [1] (Alluq) 23 Sep 1673; 8 Oct 1705

Manyampaq, Daeng [2] (Sengoroq) 8 Apr 1678; 11 Feb 1716

Manyampaq, Daeng [3] (Balambaru) 11 Mar 1714

Manyanreri [1] 17 Oct 1713; 16 Jan 1747

Manyanreri [2] 26 Sep 1731

Manyaq 7 Nov 1713

Manyeppeq, Daengta Daeng 26 Jul 1667*

Manyikkoq, Daeng (Shadiq) 27 Feb 1670

Manyioi, Karaeng 12 Aug 1699

Manyipi, Daeng (Uang) 8 Dec 1713

Manyiwi, Daeng 21 May 1674

Mappabangka 9 Jan 1682; 3 Feb 1682

Mappabangung (Abdul Aziz) 11 Dec 1717

Mappajanji 9 Mar 1684

Mappakana 8 Nov 1675

Mappapoke 23 Feb 1717

Mappaq [1] 24 Jun 1708

Mappaq [2] 1 Oct 1725

Mappaq [3] 9 Dec 1728

Mappaq [4] 9 Jul 1729

Mappaq [5] 18 Nov 1730

Mappaq [6] 5 Jan 1731; 22 Dec 1731

Mappasanrang 10 Nov 1719

Mappasepeq 20 Jan 1653

Mappasussung 25 May 1719

Mappatalliq (Hasanuddin Syaad Syah, ruler of Bima) 7 Sep 1689; 29 May 1714; 13 Sep 1714; 6 Nov 1726; 3 May 1727; 23 Jan 1731; 3 Mar 1731

Mappatangaraq 17 Feb 1714

Mappatimung [1] (Wajihuddin) 5 Aug 1718; 26 Sep 1718; 26 Jun 1719

Mappatimung [2] (Arung Pattojo) 11 Sep 1732

Mappatolla 28 Nov 1739

Mappatunruq (Abdurrauf) 9 Dec 1749

Maqbayaraq, Daeng 26 Oct 1637

Maqdaeng 28 Nov 1650

Maqdaung 13 May 1717

Maqgeaq, Daeng 25 Jul 1672 
Maqjuq 30 May 1722

Maqlaqbaq, Daeng 9 May 1643

Maqleoq, Daeng [1] (Sumang) 12 Apr 1703; 1 Jun 1715; 15 Dec 1720; 11 Jun 1724; 18

Feb 1725; 15 Dec 1726; 16 Dec 1726; 13 Jul 1727; 22 Aug 1739; 27 Aug 1739

Maqleoq, Daeng [2] (Dulla) 10 Sep 1713; 19 Mar 1715; 23 May 1715; 21 Jul 1739

Maqminasa 15 Jul 1679

Maqmiq [1] (Syafiah, Daeng Sannging) 2 Mar 1633

Maqmiq [2] 10 Jun 1729

Maqnassa, Daengta Kare 6 Jun 1667

Maqrappo, Daeng 31 Aug 1722

Maqrumai 4 Apr 1721

Maqruppa, Daeng [1] 14 May 1674; 21 Dec 1674; 17 Jan 1675; 27 Jan 1677; 2 Jun 1677

Maqruppa, Daeng [2] (Tinting) 12 Sep 1729; 12 Apr 1730; 25 Aug 1749

Maqruppa, Daeng [3] (Sajaq) 12 Nov 1730

Maradiah 14 Mar 1731

Marajalang 10 Jan 1637

Marannu, Daeng [1] (Pandiq) 25 Dec 1647; 15 Jan 1660; 8 Mar 1663; 9 Mar 1714

Marannu, Daeng [2] 29 Dec 1680; 14 Sep 1684

Marannu, Daeng [3] (Biba) 21 Jan 1701; 22 Aug 1705

Marannu, Daeng [4] (Bokuq) 15 Oct 1705; 26 Mar 1709

Marannu, Daeng [5] (Mamo) 2 Jul 1708

Marannu, Daeng [6] (Sugi) 1 Sep 1720; 11 Dec 1720; 13 Nov 1729; 18 Jun 1732; 9 Feb 1741; 31 Oct 1741

Marannu, Daenta Daeng 20 Jan 1636; 24 Jan 1643

Marewa, Daeng 21 Feb 1728; 5 Feb 1729; 16 Aug 1731; 2 Sep 1731

Marimang, Daengta Daeng 9 Jun 1723; 14 Apr 1725; 22 Feb 1728

Maroanging, Karaeng Jun 1619; 17 Mar 1624

Maryam 16 Feb 1654

Masale, Karaeng [1] 10 May 1647

Masale, Karaeng [2] (Mappatanre) 30 Apr 1731; 10 Dec 1735

Masiang, Daengta Daeng 28 Feb 1647; 23 Nov 1661; 13 Jul 1671; 18 May 1671; 16 May 1710

Masingaraq, Daengta Daeng 19 Jun 1738

Massallomo Muhammad Syadik Manriogauq 29 Jun 1711

Massallomo 16 May 1724

Massanira (Datu Ulaweng) 24 Mar 1722

Massepe, Daeng 4 Dec 1708

Massepe, Karaeng 8 Jun 1673

Masseqre, Daeng (Jaga) 24 Dec 1678; 9 Jul 1726; 10 Jul 1728

Masseqre, Daeng (Papippiq) 1 Sep 1713; 8 Dec 1718; 18 Dec 1720; 10 Sep 1722; 16 Jan 1726; 19 May 1726

Massese, Daeng 1 Oct 1702; 8 Sep 1703

Massikkiq, Daeng 28 Apr 1639

Massuro, Daengta Daeng 21 Oct 1675; 27 Dec 1676; 8 Sep 1678; 5 Sep 1679; 26 Aug 1680; 31 Apr 1683; 7 May 1683; 26 Nov 1686

Matea ri Bima, Karaeng 1618

Mateqne, Daeng [1] (Sitti Abidah) 18 Jun 1716; 5 Mar 1724 
Mateqne, Daeng [2] (Sitti) 18 Feb 1717; 17 Sep 1718; 22 Aug 1719; 28 May 1722; 2 Nov 1727; 23 Nov 1727

Mateqne, Daeng [3] 22 Feb 1728

Mateqne, Daeng [4] (Sipaya) 9 Oct 1730

Mateqne, Karaeng 4 Sep 1673; 7 Sep 1684

Matinroa ri Bantaeng 28 Oct 1631

Matinroa ri Bukaka (La Maqdaremmeng) 7 Feb 1667; 30 May 1667; 5 Aug 1678

Matinroa ri Buliana (Ibrahim Daeng Matiring, ruler of Agangnionjoq) 10 Dec 1645; 30 Sep 1646

Matinroa ri Datunna (La Tenribali, ruler of Soppéng) 24 May 1666; 19 Aug 1676

Matinroa ri Gowa (Datu ri Luwuq) 17 Jun 1650; 9 Aug 1662

Matinroa ri Salemo (Addatuang) 11 Feb 1681

Matinroa ri Talloq 13 Aug 1630

Matinroa ri Tippulunna (Batari Toja) 20 Dec 1714

Matoaya, Karaeng (Sultan Abdullah, Karaeng Kanjilo, Karaeng Segeri, Tumamenang ri Agamana) 1573, 22 Sep 1605; 1626; 23 May 1634; 24 Nov 1635; 2 Jul 1636; 1 Oct 1636

Mattaq (Abdurrahman, Mappatawang) 2 Aug 1709; 27 Oct 1717; 7 Oct 1718; 21 May 1723; 13 Aug 1727

Mattara, Daeng 7 Jan 1727

Mattayang 18 Feb 1717; 22 Aug 1719; 2 Nov 1727; 23 Nov 1727; 24 Jan 1731

Mattenai 23 Aug 1725; 24 Oct 1727; 14 Sep 1730

Matti 4 Jun 1679

Mattiro, Daengta Daeng (Manginara Majduddin) 5 Apr 1648; 10 Feb 1663

Mattuju, Daeng 7 Aug 1677

Mattukung, Daeng 8 Aug 1656

Mattulung, Daeng 16 Dec 1715; 10 Jun 1729; 17 Nov 1730

Mattupuang (Abdul Wahid) 14 Mar 1683

Mau, Daeng 24 Dec 1638

Mawajang, Karaeng 9 Mar 1684

Mayiro, Daengta Daeng 6 Apr 1702

Memang, Daeng [1] (Munaq) 19 Jun 1673; 10 Feb 1681; 15 Jan 1720; 30 May 1722

Memang, Daeng [2] 13 Jan 1726

Mene 13 Nov 1676

Mida (Bungko) 20 Feb 1719; 27 Aug 1719

Minaq 16 Feb 1654; 20 Jul 1673; 23 Aug 1725

Mindaq 8 Feb 1713; 22 Dec 1713; 28 May 1716; 26 Feb 1728

Mininrori 4 Feb 1660

Minnah 25 Jul 1675

Mipati, Daeng 24 Jan 1731

Monnoq 11 Sep 1728; 30 Nov 1730

Muhammad [1] 31 Jul 1723

Muhammad [2] 4 Oct 1739

Muhammad Ali [1] (Tumatea ri Jakattaraq, Karaeng Bisei) 29 Nov 1654; 30 Nov 1664; 24 Sep 1665; 13 Mar 1667; 23 Mar 1667; 12 Sep 1670; 21 Oct 1672; 13 Dec 1672; 3 Oct 1674; 4 Sep 1675; 11 Oct 1675; 13 May 1676; 15 Apr 1677; 27 Jul 1677; 3 Sep 1678*; 16 Sep 1678; 4 Oct 1678*; 15 Mar 1681; 29 Mar 1682 
Muhammad Ali [2] 12 Jun 1705; 26 Dec 1719; 7 Jun 1725; 20 Mar 1729

Muhammad Baki (Karaeng Barombong, Karaeng Sanrabone) 21 Jun 1714; 3 Oct 1724; 28 Oct 1731; 27 Nov 1732; 15 Jun 1733; 26 Jan 1734; 30 Aug 1736; 3 Aug 1739; 25 Aug 1740; 16 May 1748; 16 Sep 1748

Muhammad Jamala (Mappatollaq) 30 Oct 1725

Muhammad Rajab 5 Feb 1729

Muhammad Said 20 Aug 1671

Muhammad Saleh 11 Jan 1718; 2 Mar 1734

Muhammad Shaleh 30 Jun 1672

Munaq 20 Jan 1676; 30 Apr 1676

Muntuq, Daeng 15 Jun 1735

Mutaq 13 Mar 1720

Mutiatullah 19 Feb 1720

Mutti 16 Jul 1683

Najamuddin, Sultan (Manrabia, Karaeng Kanjilo, Tumamenang ri Jawaya) 23 Dec 1708; 18 Nov 1713; 19 May 1714; 15 Oct 1714; 29 Jun 1720; 7 Jun 1721; 9 Nov 1722; 18 Oct 1723; 18 Nov 1723; 16 Oct 1724; 7 May 1727; 11 Sep 1728; 24 Apr 1729

Nakke, Daeng 27 Dec 1724

Nampa [1] 16 Dec 1644

Nampa [2] (Syahribanung) 3 Feb 1645

Nannuq [1] 12 Jan 1713; 13 Nov 1718; 9 Oct 1721

Nannuq [2] 26 Sep 1722

Naratang, Daengta Daeng [1] (Laji) 10 Aug 1646

Naratang, Daengta Daeng [2] 23 Oct 1638; 2 Oct 1641; 28 Jun 1647; 14 Jun 1648; 10 Sep 1649

Naratang, Daengta Daeng [3] (Sungguminassa Rabiah, Karaeng ri Sanggiringang) 8 Jan 1645; 29 Jun 1651; 2 Sep 1652; 7 Jul 1669

Nassa, Kare 18 Oct 1728

Naung, Karaeng 20 Jun 1645

Nenuq 17 Oct 1713

Neting, Haji 11 Jun 1647

Ngago, Daeng (Karaeng Paranggi) 24 Oct 1727; 5 Nov 1728; 10 Oct 1729; 14 Sep 1730; 3 Dec 1731; 19 Apr 1732; 5 Jan 1731; 8 Oct 1744

Ngampa, Daengta Daeng 27 Dec 1727

Nganne, Daeng (Manguq) 19 Jun 1719

Nganrenne, Daeng [1] 1 Sep 1713

Nganrenne, Daeng [2] 8 May 1726

Nganrenne, Daengta Daeng (Datu Doka) 12 Jan 1713

Ngantu, Daeng (Yociq) 31 May 1728

Ngantu, Daengta Daeng 26 Dec 1733

Ngaseng, Daeng [1] (Bataq) 25 Nov 1675

Ngaseng, Daeng [2] (Saqbaraq) 1 May 1728

Ngaseng, Daengta Daeng 24 Jun 1708; 14 Mar 1731; 17 Jun 1736

Ngiji, Daeng (Sitti) 22 Aug 1739

Ngilauq, Daeng (Bantang) 8 Aug 1709 
Niaq, Daeng 11 Sep 1633; 25 Feb 1645; 17 Aug 1673

Niaq, Daengta Daeng 23 Sep 1704

Niasseng, Daeng 29 Jul 1674

Niba 10 Sep 1731

Nibbang 1 Oct 1661

Nimbang 7 Apr 1713

Ningai, Daeng [1] 22 Jun 1721; 9 May 1730; 5 Mar 1731; 12 Feb 1736

Ningai, Daeng [2] 14 May 1747

Ninruq 27 Apr 1744

Ninuq [1] 6 May 1715

Ninuq [2] 15 Feb 1728

Nisabeng, Daeng 22 Dec 1718

Nisakking, Daeng (Shafiah) 15 Dec 1695; 15 Dec 1700

Nisali, Daeng [1] 4 Apr 1650

Nisali, Daeng [2] (Thaibah) 8 Jan 1714; 6 Nov 1714; 5 Apr 1716; 25 Aug 1718; 16 Oct 1720; 25 Mar 1722

Nisali, Daengta Daeng (Sitti Sarah) 17 Dec 1672

Nisanga, Daeng [1] (Nanuq) 18 Jun 1706; 19 Jun 1722

Nisanga, Daeng [2] (Puqdo) 4 Mar 1718

Nisanga, Daeng [3] (Kamariah) 10 Dec 1720

Nisayu, Daeng [1] (Dara) 29 Mar 1674

Nisayu, Daeng [2] 14 May 1674; 5 Sep 1674; 11 Aug 1677

Nisayu, Daeng [3] (Andoqpoaq) 23 Aug 1677

Nisayu, Daeng [4] 28 Jul 1699; 17 Jul 1707

Nisayu, Daeng [5] 9 Nov 1704; 4 Oct 1707; 20 May 1715

Nisayu, Daeng [6] (Junggo) 9 Aug 1720

Nisayu, Daeng [7] (Alima) 10 Aug 1741

Nisayu, Daengta Daeng 31 Oct 1677; 8 Feb 1678; 18 Apr 1678; 31 Oct 1680; 3 Jul 1687; 7 Oct 1709

Nisimba, Daeng [1] (Rabiah) 11 Aug 1671; 5 May 1717

Nisimba, Daeng [2] 22 Oct 1672; 11 Dec 1672; 5 Jul 1693; 12 Dec 1706

Nisimba, Daeng [3] 31 Jul 1727

Nisomba, Daeng (Okung) 13 Dec 1719

Nisoqna, Daeng [1] 16 Dec 1706; 4 May 1715; 14 Nov 1719

Nisoqna, Daeng [2] 13 Nov 1719

Nojeng 20 Aug 1730

Nona 22 Aug 1739

Nuh 12 Feb 1729

Numalo, Daeng 12 Mar 1703

Nunniq 10 Oct 1729

Nuruddin, Shaykh 21 Sep 1658

Nuruddun (Mapparabung, Karaeng Panaragang) 13 Dec 1651

Nurulmahalli 30 Oct 1645

Okong 27 Feb 1680

Onjoq, Daengta Daeng 2 Sep 1652; 19 Mar 1671

Opu [1] 3 Nov 1674

Opu [2] 22 Aug 1718 
Pabila, Daeng 14 Apr 1712; 14 Dec 1722; 10 Aug 1724

Paccocconga 27 Oct 1668

Pacellekang, Daeng 30 Nov 1643

Paceq 21 Oct 1722

Paceqnongang, Gallarrang 10 Dec 1711

Paciq 30 Apr 1698

Padang 25 Jul 1707

Padukka Dompu 29 Jan 1661; 10 Feb 1663; 6 Dec 1663; 18 Jul 1665; 29 Apr 1693; 21 Aug 1693

Pagang, Daeng 22 Jun 1634

Pakkemba 29 Dec 1680; 14 Sep 1684

Palemba, Karaeng [1] 27 Feb 1670; 31 Mar 1673; 24 Jun 1674; 11 Sep 1674; 23 Nov 1674; 9 Jun 1676; 9 Jun 1677

Palemba, Karaeng [2] 10 Jan 1729; 15 Jun 1739; 5 Dec 1740

Paleng 5 May 1683

Pallaq 22 Aug 1713

Pamolikang, Karaeng 25 Jul 1675; 20 Jan 1676; 30 Apr 1676; 19 Aug 1678; 21 Nov 1704

Panaikang, Karaeng [1] (Daeng Niaq) 15 Jan 1631; 2 Jan 1644*; 24 Dec 1650; 21 Aug 1655; 9 Jun 1664; 18 Mar 1686

Panaikang, Karaeng [2] (Khadijah) 20 Jan 1672; 13 Jun 1683

Panaikang, Karaeng [3] (Mappasaqbi, Muhammad Said) 16 May 1692; 18 Dec 1701; 26 Mar 1709; 23 Oct 1716; 4 Nov 1718; 22 Jun 1721; 22 Mar 1725; 8 Jun 1725; 6 Jul 1726; 20 May 1730; 12 Jul 1730; 18 Nov 1730; 5 Mar 1731; 14 Feb 1750

Panaikangciniq, Karaeng 27 Jun 1680

Panaiq, Kare (Guru) 22 Oct 1681

Panaragang, Karaeng (Alasaq, ruler of Bima) 7 May 1684; 23 Jul 1687; 21 Aug 1693; 27 Aug 1693; 30 Aug 1695; 6 Jul 1696

Pande 15 May 1716; 28 Nov 1716

Pandi 26 Apr 1720

Pangalaq 20 Aug 1632

Pangerang Aria 28 Jul 1699; 17 Jul 1707

Pangkajeqneq, Karaeng (Abdul Muqmin) 10 Mar 1670; 28 Jan 1672; 23 Nov 1681; 6 Jul 1691; 22 Aug 1692; 6 Oct 1702; 4 Oct 1709; 24 Mar 1710; 12 Apr 1710

Panjallingang, Karaeng [1] (Mattenai) 25 Dec 1638; 6 May 1662; 13 Aug 1668; 29 Aug 1670

Panjallingang, Karaeng [2] (Manguqrangi Sitti Shapora) 8 Jun 1639

Pannampuq, Daeng 30 Apr 1647

Pappi 16 Dec 1715; 9 Jan 1721; 18 Feb 1725; 14 Feb 1736

Papuq [1] 24 Aug 1710; 14 Mar 1721; 19 May 1721

Papuq [2] 15 Feb 1726

Paqbineang, Karaeng [1] (Maemuna) 17 Oct 1637; 30 May 1638; 12 Nov 1647; 21 May 1654; 16 Sep 1669; 13 Dec 1697

Paqbineang, Karaeng [2] (Sitti Rahimah) 2 Jan 1689; 16 May 1702; 4 Oct 1703; 20 Oct 1709; 27 Oct 1731; 31 Jan 1732; 9 Apr 1739; 27 Oct 1742

Paqbundukang, Karaeng [1] 2 Feb 1648 
Paqbundukang, Karaeng [2] 27 Apr 1744; 16 Oct 1747; 16 May 1748

Paqgannakkang, Karaeng 16 Apr 1743; 27 Apr 1744; 12 Jan 1749

Parampang, Kare (Caccaq) 26 Apr 1717; 9 Sep 1726

Parangbone, Karaeng 20 Sep 1717

Paranggi, Karaeng [1] 20 Oct 1644

Paranggi, Karaeng [2] (Daeng Mangago) 1 Feb 1689

Paranggi, Karaeng [3] see Ngago, Daeng

Parangloe, Gallarrang (Laddin) 18 Jun 1728

Parang-Parang, Karaeng [1] (Khadijah) 18 Nov 1671; 14 Mar 1683; 27 Nov 1684; 18 Jul 1686; 4 Jul 1688; 13 Jun 1689

Parang-Parang, Karaeng [2] 1 Mar 1734

Parukka 10 Aug 1717

Pasiq, Karaeng [1] 5 Apr 1660; 17 Apr 1671; 21 Jun 1671; 13 Feb 1681; 7 Jan 1682; 28 Aug 1683; 25 Jun 1704; 1 Sep 1714

Pasiq, Karaeng [2] (Sitti Aisyah) 19 Dec 1693; 22 May 1708; 2 Oct 1718; 20 Oct 1718; 4 Nov 1718; 7 Apr 1722; 25 Jan 1723;

Passeqre, Kare (Jaga) 3 Nov 1698; 7 May 1700

Pate, Daengta Kare 26 Nov 1679; 18 Nov 1683; 25 Jul 1687; 12 Apr 1688; 5 Jun 1689; 6 Jan 1691; 18 Mar 1704

Pate, Kare [1] 29 Sep 1656

Pate, Kare [2] (Sarampa) 8 Aug 1680; 26 Mar 1681; 13 Apr 1681

Pati Manjawari 14 Jul 1707; 4 Dec 1707; 24 Mar 1708; 6 Jun 1708

Patimah 28 Mar 1740

Patimaq [1] (Daeng Tacuah) 10 Feb 1713; 2 Sep 1715; 22 Apr 1716; 11 Jan 1716; 11 Dec 1717; 2 Jan 1719; 1 Mar 1720

Patimaq [2] 5 Jan 1731; 22 Dec 1731

Patolo, Daeng 8 Nov 1651

Pattah 11 Dec 1732

Pattallassang, Karaeng 1 Feb 1724

Patteqne, Karaeng [1] 3 Oct 1644; 5 Mar 1664

Patteqne, Karaeng [2] (Daeng Mabela) 3 Oct 1664; 2 May 1663

Patteqne, Karaeng [3] (Fathuddin) 20 Dec 1695; 8 Feb 1713; 22 Dec 1713; 6 Sep 1715; 29 Oct 1715; 28 May 1716; 11 Jan 1717; 11 Dec 1717; 20 Oct 1718; 4 Nov 1718; 2 Jan 1719; 1 Mar 1720; 22 Apr 1720; 1 Nov 1721; 8 Mar 1723; 28 Jan 1724; 27 Apr 1724;

Pattingalloang, Karaeng (Sultan Mahmud, Tumamenang ri Bontobiraeng) 1600; 1619; 28 Sep 1632; 7 Nov 1633*; 18 Jun 1639*; 15 Sep 1654

Pattunga, Karaeng [1] 16 Sep 1633

Pattunga, Karaeng [2] 14 Jun 1659

Pattunga, Karaeng [3] 23 Nov 1669

Patukangang, Karaeng [1] 25 Feb 1654

Patukangang, Karaeng [2] (Maryam) 1 Mar 1669; 9 Feb 1674; 24 Mar 1674; 11 May 1675; 25 Nov 1675; 16 Dec 1675; 9 Aug 1678; 4 Apr 1687; 26 Jul 1693

Patukangang, Karaeng [3] (Zainab) 3 Jan 1709; 7 Jun 1721; 9 Nov 1722; 16 Oct 1724; 30 Oct 1725; 31 Mar 1728; 14 Oct 1729; 19 Jan 1740

Pirannuang 26 Sep 1679

Pole, Kare 28 Mar 1720; 4 May 1720 
Popoq, Karaeng 3 Jun 1631; 26 Oct 1637; 7 Dec 1644; 20 Mar 1648; 11 Mar 1650; 2 Nov 1650; 4 Nov 1650; 23 Oct 1655; 29 Sep 1656; 5 Jul 1660; 24 Nov 1660; 8

Jan 1661; 25 May 1663; 16 Nov 1664; 29 May 1676; 7 Nov 1678; 7 Mar 1680

Poqdo 15 Jan 1716

Prins, François 5 Mar 1694

Puanna I Daeng (Mallimpo) 21 Dec 1714; 22 Aug 1710

Puanna I Jenalaq 23 Nov 1658; 28 Nov 1658

Puanna I Mattaq see La Padangsajati

Puaq Ikkuq 15 Dec 1727

Puaq Ninaq 16 Jun 1751

Puaq 12 Jul 1740

Puaq, Daengta 23 Sep 1705

Punbinduq 5 Dec 1702

Punca Patula (Sitti Hawa) 12 Dec 1721

Punca 25 Apr 1722

Pundamaq 26 Nov 1726; 10 Dec 1726; 4 Nov 1728

Putiri Raannakumala (Karaeng Tabaringang) 25 Mar 1751

Raba 7 Jan 1678

Rabiah 25 Oct 1677

Raden Sanggalea 14 Jul 1693; 22 Jul 1693; 24 Jul 1693

Radiah 9 Jan 1656

Radin 23 Apr 1653

Rahimah 8 Oct 1739

Rakhiah 11 Mar 1698

Raluq 13 May 1695; 22 Jun 1699

Rannu, Kare 21 Dec 1714

Rannu, Loqmoq 5 Dec 1702; 15 Jul 1713

Rante Patola (Sitti Rabiah) 27 Apr 1728; 10 May 1742; 24 Mar 1743

Ranti 17 Jan 1716; 15 May 1716; 28 Nov 1716

Rapanna, Daeng (Manuruki) 7 Jan 1685; 9 Feb 1710

Rappociniq, Karaeng [2] 27 Dec 1727

Rappociniq, Karaeng[1] 23 May 1680; 8 Aug 1680; 6 Sep 1680; 26 Mar 1681; 13 Apr 1681; 9 Aug 1684; 19 Mar 1686

Rappokalling, Gallarrang 6 Nov 1719

Ratu Agung 21 Jun 1705

Ratu Bagus (elder) 13 Dec 1705; 11 Jan 1718; 10 Dec 1720; 18 Apr 1731

Ratu Bagus (younger) 28 Jul 1706; 14 Nov 1706; 15 Sep 1707; 21 Dec 1728

Ratu Bulaeng (Sitti Radiah) 10 May 1728

Ratu Hiyati 21 Nov 1705

Riboko, Daeng 8 May 1644; 6 Aug 1661

Rida (Sitti Rahmah) 13 Oct 1730

Rikasammeng, Daeng 8 Mar 1690; 22 Oct 1739

Rikong, Daeng [1] (Shafiatuddin or Shafiah) 4 Feb 1660; 9 Mar 1673; 3 Jan 1674; 28 Nov 1681

Rikong, Daeng [2] 13 Nov 1676

Rikong, Daeng [3] (Jaga) 3 Apr 1703; 2 Sep 1703; 16 Jun 1706; 2 Jan 1707; 26 Mar 1709; 19 Feb 1721; 13 Jan 1726 
Rimang, Kare (Saidah) 18 Mar 1732

Riolo, Daeng 12 May 1643

Roking 19 Nov 1636

Rukiah 2 Apr 1732

Ruppa, Kare 3 Sep 1751

Sabirah 23 Aug 1725; 10 Mar 1730

Sadiq 15 May 1725

Saenaq 24 Oct 1720; 14 Mar 1721; 13 Apr 1722

Saidah [1] 3 Nov 1674

Saidah [2] 26 Apr 1717

Saidah [3] 11 Jun 1724; 18 Feb 1725; 13 Jul 1727

Saidah [4] 19 Jan 1726

Saidi 31 Dec 1713; 10 Oct 1715

Saja 31 Dec 1731

Salahu 9 Apr 1725

Salama 25 Feb 1726

Salamah 20 Sep 1675; 19 Apr 1715

Saleh 22 Oct 1739

Sali, Kare 9 Aug 1684

Salira 1 May 1719; 21 Feb 1721; 17 Mar 1721; 12 Dec 1721; 19 Jan 1725

Sallang 26 Sep 1679

Sallang, Daengta Karaeng 27 Sep 1668

Sallang, Kare 19 Sep 1676

Sallo, Kare 16 Mar 1726

Samata, Daeng 29 Oct 1680

Sammaraq 2 Aug 1693

Sammiq 29 Aug 1733

Sampulungan, Daeng 23 Jul 1668

Sandewi 1 Sep 1708

Sandiq 29 Jul 1691

Sangging, Daeng 15 May 1729

Sangging, Daengta Daeng [1] (Maqminasa) 12 Feb 1645; 11 Oct 1648

Sangging, Daengta Daeng [1] (Sarah) 23 Apr 1680

Sanggiringang, Karaeng 10 Jan 1645; 24 Feb 1656; 6 Aug 1656; 19 Apr 1657; 8 Nov 1657; 17 Feb 1666; 21 Sep 1671; 17 Mar 1675

Sanrabone Malolo, Karaeng 13 Jul 1642

Sanrabone, Karaeng [1] 31 Mar 1642

Sanrabone, Karaeng [2] 12 Nov 1647

Santbeek, Markus 6 Aug 1704

Saodah 14 Oct 1723; 12 Oct 1725; 18 Feb 1731

Saumata, Gallarrang [1] 17 Aug 1711

Saumata, Gallarrang [2] 4 Apr 1640*

Sapiah 6 Jul 1725

Sapinah 30 Apr 1731

Saqbaraq 19 Sep 1676

Saqbi 19 May 1641

Saqdaq 7 Sep 1723; 26 Feb 1728 
Sarah 15 May 1675; 4 Apr 1678

Sarampa 13 Jun 1673; 20 Jul 1673; 6 Dec 1675

Sarimba 5 Feb 1730; 26 Jan 1731; 18 Mar 1732; 5 May 1736

Sassang, Daeng 30 Oct 1641

Sayedah [1] 8 May 1706

Sayedah [2] (Sanrabone) 13 Jul 1707

Sayyid Alwi 21 Apr 1728

Sayyid Biringkassiq 11 Feb 1683

Sayyid Bukhari 15 Aug 1720; 15 Aug 1733

Sayyid Hamid 25 Dec 1751

Sayyid Husain [1] 11 Feb 1683

Sayyid Husain [2] 13 Jan 1706; 18 May 1718; 30 Mar 1740; 31 Dec 1747

Sayyid Muhammad 24 May 1703; 4 Jan 1707; 1 Oct 1707

Sayyid Syarifah 31 Dec 1747

Sayyid Umar 2 Jan 1737

Sayyid Zain 30 Apr 1700; 13 Jan 1705; 5 May 1705; 20 Jun 1707; 8 Oct 1709; 7 Aug 1712; 31 Dec 1713; 10 Oct 1715

Sendoq 24 Jun 1738

Shafiah [1] 14 Mar 1671; 19 Oct 1671

Shafiah [2] 27 Jul 1682

Shafiah [3] 26 Jun 1730

Shaleh 31 Mar 1677

Shaykh Abd al-Ra'uf 21 Jan 1696

Shaykh Abdullah Qussyasyi 15 Mar 1691

Shaykh Yusuf [1] 22 Mar 1684; 9 Jun 1689; 22 Dec 1694; 22 May 1699; 5 Apr 1705; 2 Oct 1705; 5 Jan 1714; 10 Nov 1715; 3 Jul 1747

Shaykh Yusuf [2] (Ipandi) 7 Sep 1694

Shaykh 12 Mar 1680; 24 Jun 1718; 28 Jul 1723; 7 Feb 1728

Simba 28 Sep 1718

Sinddoq 9 Jun 1732

Singaraq, Daeng [1] 19 Dec 1649

Singaraq, Daeng [2] 30 Oct 1673

Singaraq, Daeng [3] 6 Jul 1691

Singaraq, Daengta Daeng 4 Apr 1674; 12 Mar 1676; 16 Jul 1679; 14 Nov 1679; 1 Jan 1681; 11 Mar 1681; 26 Dec 1681; 2 Feb 1682; 24 Mar 1682; 20 Mar 1683; 21 Jul 1707; 16 Jul 1708; 3 Jul 1721

Singaraq, Kare Haji 11 Jun 1647; 14 Oct 1655; 1659*

Singaraq, Kare 27 Sep 1739

Singayah 24 Jun 1708

Sinukuq 2 Nov 1650

Sipman, Johannes 8 Oct 1716

Siqra 10 Sep 1634

Sirajuddin (Sultan Abil Khair, Ambela) 22 Dec 1640; 3 Sep 1646; 27 Mar 1658; 30 Aug 1658; 22 Jul 1682

Sirajuddin, Sultan (Tumamenang ri Pasiq, Tumammaliang ri Talloq) 17 Nov 1687; 3 Nov 1700; 21 Jan 1702; 11 Sep 1706; 1 Jan 1707; 12 Aug 1709; 31 Aug 1712; 10 Sep 1712; 8 Oct 1712; 2 Nov 1712; 28 Nov 1712; 15 Dec 1712; 25 Apr 
1713; 21 Jun 1713; 18 Nov 1713; 19 Mar 1716; 23 May 1716; 18 Jun 1716; 16 Jul 1716; 26 Jun 1717; 29 Jun 1717; 3 Sep 1717; 23 Nov 1717; 7 Dec 1717; 31 Aug 1718; 26 Sep 1718; 20 Dec 1718; 7 Aug 1719; 21 Jan 1720; 11 Apr 1720; 9 Oct 1721; 16 Nov 1722; 8 Jan 1724; 12 Feb 1725; 6 Jul 1725; 6 Oct 1725; 19 Jan 1726; 25 Feb 1726; 19 Mar 1726; 2 Aug 1726; 10 Sep 1726; 8 Feb 1727; 14 Oct 1727; 8 May 1728; 6 Dec 1728; 25 Apr 1729; 15 Oct 1729; 28 Jul 1731; 3 Oct 1731; 19 Apr 1732; 17 Oct 1732; 15 Jun 1733; 17 Jan 1734; 13 Jul 1734; 27 Aug 1734; 6 Sep 1734; 16 Apr 1735; 13 Oct 1735; 5 Nov 1735; 22 Jan 1739 Sisila, Daeng 7 Feb 1679

Sitaba, Daeng [1] 22 Jun 1724; 26 Feb 1730

Sitaba, Daeng [2] (Jalani) 25 Feb 1729

Sitaba, Karaeng 8 Feb 1706

Sitti [1] 20 Jan 1653

Sitti [10] 5 Apr 1684

Sitti [11] 7 Apr 1715; 1 Sep 1716

Sitti [12] 30 Oct 1719; 16 Jan 1720

Sitti [13] 18 Apr 1731

Sitti [14] 26 Oct 1739

Sitti [2] 12 Sep 1672; 21 Sep 1672; 20 Jun 1673; 13 Nov 1674

Sitti [3] 8 Dec 1672

Sitti [4] 27 Jan 1677

Sitti [5] 24 Sep 1677

Sitti [6] 8 Apr 1678

Sitti [7] 3 Feb 1682

Sitti [8] 11 May 1682

Sitti [9] 28 Sep 1682

Sitti Aminah [1] 23 Jan 1653

Sitti Aminah [2] 22 Jul 1672; 22 May 1677

Sitti Anisuh 21 Oct 1649

Sitti Fatimah 4 Sep 1673; 17 Jul 1674; 22 Aug 1675

Sitti Hadijah 26 Jun 1663

Sitti Hajar 12 Sep 1675

Sitti Halimah 16 Oct 1719

Sitti Hawa 21 May 1710

Sitti Labibah 2 Dec 1706; 24 Apr 1707; 3 Mar 1713

Sitti Lambengi 21 Oct 1672; 13 Dec 1672; 9 May 1673; 19 Nov 1677

Sitti Lele 10 Sep 1713; 19 Mar 1715; 23 May 1715; 24 Jan 1717

Sitti Maradiah 30 Dec 1673

Sitti Maryam 6 Aug 1680

Sitti Rahmah Malimbasanna 16 Jan 1711

Sitti Sarah 12 Sep 1674

Situju, Daeng 4 Dec 1677

Smout, Adriaan Hendrik 14 Aug 1737, 3 Sep 1739; 23 Mar 1741; 20 Apr 1741; 5 May 1743

Speelman, Cornelis 7 Oct 1669*; 11 Jan 1684

Sugi [1] (Karaeng Bontoa) see Bontoa, Karaeng [3]

Sugi [2] 22 Aug 1739 
Sugiratu (Sitti Aminah) 14 Oct 1729; 15 Oct 1743; 29 Aug 1744

Suleman 1 Jul 1663

Suli, Karaeng 6 Jan 1635; 4 Apr 1652

Sumailiq [1] 18 Jun 1715; 26 Jan 1719; 4 Jul 1724

Sumailiq [2] 3 Dec 1724

Sumang 5 Feb 1730; 26 Jan 1731; 18 Mar 1732; 27 Jun 1732

Sumannaq, Karaeng [1] 1619; 10 Jul 1649; 10 Aug 1660; 21 Sep 1660; 18 Oct 1660; 9 Oct 1661; 23 Sep 1666

Sumannaq, Karaeng [2] 2 Aug 1731; 25 Aug 1740; 17 Jun 1741

Sunggu 29 Aug 1670

Suriwaq, Karaeng 3 Mar 1675; 12 Jun 1677

Sutting 10 Mar 1694

Syafiuddin (Mappaingaq, Karaeng Lempangang) 7 Dec 1709; 18 Dec 1714; 1 Dec 1722; 2 Mar 1725; 6 Jul 1725; 3 Nov 1725; 20 Feb 1727; 15 Jun 1733; 25 Oct 1736; 1 Nov 1740; 3 Oct 1742; 28 May 1742; 14 Mar 1746; 19 Mar 1746; 3 Sep 1746; 8 Jan 1747; 16 Feb 1747; 16 Oct 1747; 15 Aug 1748; 13 Dec 1748; 3 Apr 1749; 22 Jul 1750; 26 Apr 1751; 25 Aug 1751

Syarfuddin (Manngambu Jawa) 6 Jul 1725

Syehu 31 Dec 1731; 19 Jun 1732; 18 Sep 1734; 7 Sep 1735; 15 Dec 1735; 5 Feb 1737; 9 Feb 1741; 31 Oct 1741; 2 Jan 1742; 24 Mar 1743; 8 Jan 1747; 3 Jul 1747; 27 Jan 1748; 20 Aug 1750; 29 Sep 1750

Syoga 5 Feb 1684

Taba 3 Oct 1731

Tabaringang, Karaeng [1] Oct 1627

Tabaringang, Karaeng [2] 29 Dec 1636

Tabaringang, Karaeng [3] (Daeng Talarra) 17 Mar 1645; 22 Jan 1646; 3 Jun 1669

Tabaringang, Karaeng [4] (Nafisah) 8 Feb 1706; 24 May 1718; 3 Jun 1718; 18 Jan $1721 ; 10$ Oct 1732

Tacoa, Daeng (Alimah) 27 Apr 1724; 22 Oct 1728

Tadumai 13 Jul 1640

Taduq, Daeng 19 Nov 1636

Taenga, Tumamenang ri see Bontosunggu, Karaeng

Tahira 18 Sep 1734

Tahiriq 16 Jan 1675

Taiji, Daeng [1] 28 Jan 1725

Taiji, Daeng [2] 23 Oct 1726

Taipa, Karaeng 31 Dec 1732

Taipaya, Karaeng 12 Jun 1653

Tajuq (Karaeng Balaqsari) 16 Oct 1747; 16 May 1748; 16 Sep 1748; 13 Dec 1748

Takenna, Daeng (Jaing) 12 Apr 1703; 10 Feb 1704

Takka, Daeng 12 Aug 1622

Takkikkiq 24 Mar 1682

Takko, Kare 10 Dec 1674; 25 Jun 1721

Takontu, Daeng 12 Jan 1749

Takontu, Daengta Daeng (Fatimah, Karaeng Campagaya) 10 Sep 1659; 6 Apr 1673; 4 Aug 1674; 9 Oct 1674; 26 Apr 1675; 1 May 1675; 22 Apr 1678; 5 Dec 1681; 6 Jan 1683; 26 Dec 1683; 5 Nov 1719 
Talarra, Daeng [1] (Mene) 22 Oct 1673

Talarra, Daeng [2] 11 May 1686; 25 May 1712; 15 Dec 1712; 22 Dec 1712; 9 Jul 1729; 7 Jun 1731

Talarra, Daeng [3] (Jaleka) 22 Dec 1720; 1 May 1731

Talarra, Daengta Daeng (Makku) 23 Mar 1667; 26 Nov 1669; 16 Apr 1670; 3 Jul 1670; 13 Aug 1671

Talarra, Daengta Daeng 10 Nov 1727

Talebang 21 Jan 1673

Talebang, Daeng 21 Feb 1674; 15 Jan 1675; 2 Feb 1678

Talebang, Daengta Daeng 24 Jun 1674; 15 Nov 1674; 17 Sep 1717

Talele, Daeng [1] 29 Mar 1670; 22 Aug 1710

Talele, Daeng [2] 21 Dec 1674; 16 Jan 1675; 17 Jan 1675

Talele, Daeng [3] (Masiq) 10 Aug 1741

Talele, Daengta Daeng [1] 24 Jul 1718; 28 Jan 1725

Talele, Daengta Daeng [2] 22 Jun 1725

Talesang, Daeng (Coce) 28 Jan 1706; 5 Jul 1707

Taliwang, Karaeng 14 Jul 1693

Tallampuang Suluka, Karaeng 5 Oct 1729

Tallampuang, Karaeng 7 Apr 1715; 1 Sep 1716

Talloka, Gallarrang [1] (Kare Tulusuq) 19 Jul 1711

Talloka, Gallarrang [2] (Biqduq) 10 Apr 1715

Taloqmoq, Daeng 1 Mar 1674

Taluqmuq 8 Mar 1723

Tamalaqba, Karaeng 20 Jun 1668

Tamalingu, Karaeng (Punngaq) 19 Feb 1672; 27 Sep 1676; 13 Jul 1681

Tamamangung, Gallarrang 29 Nov 1750

Tamami, Daeng [1] 8 Aug 1715

Tamami, Daeng [2] 17 Jun 1720; 20 May 1721; 31 May 1722

Tamammempo 14 May 1631; 14 Jan 1632

Tamaqdanggang, Karaeng 22 Oct 1673; 19 Nov 1677

Tamaqlaqlang, Karaeng (Kapparaq) 24 Oct 1720

Tamaqlili 16 Sep 1633

Tamasongoq, Karaeng [1] (Manguqrangi) 1627; 31 Aug 1646; 5 Apr 1648; 21 Oct 1649; 6 Jan 1649; 17 Jun 1650; 7 Jan 1654; 20 Dec 1659; 5 Jan 1672

Tamasongoq, Karaeng [2] (Sultan Zainuddin, Tumamenang ri Matoanging, Makkaraeng) 26 Dec 1722; 11 Dec 1732; 18 Nov 1740; 27 Jan 1748

Tamemang, Daeng (Maqminasa) 26 Nov 1674; 12 Feb 1679

Tamemang, Daeng 30 Mar 1731

Tamemang, Daengta Daeng 20 Jan 1672; 7 May 1684; 16 Sep 1688; 9 Aug 1725

Tamemang, Daengta Daeng 7 Apr 1702; 1 Oct 1702; 8 Sep 1703

Tammattuq, Karaeng 12 Dec 1675

Tanang 30 Oct 1645

Tanasanga, Karaeng [1] (Halimah) 21 Jul 1693

Tanasanga, Karaeng [2] (Mahbubah Mamuncaragi) 31 Oct 1677; 30 Dec 1707; 27 Oct 1717; 7 Oct 1718; 4 Jun 1719; 5 Apr 1727; 27 Apr 1728; 8 Oct 1728; 20 May 1730; 12 Jul 1730; Mar 1732; 10 Jun 1733; 19 Mar 1740; 24 Mar 1743; 22 Mar 1746 
Tana-Tana, Karaeng (Fatimah) 21 Apr 1673; 22 Dec 1674; 5 Aug 1688; 28 Aug 1699; 8 Apr 1702; 4 Aug 1709; 20 Aug 1710; 21 Jun 1714; 25 Jun 1717; 3 Oct 1724; 20 Aug 1739

Tangallaq, Karaeng [1] (Sitti Maradiah) 12 Dec 1615; 30 Mar 1631; 3 Nov 1631; 31 Oct 1642; 25 Feb 1649; 2 Feb 1655; 7 Sep 1655; 12 Feb 1657; 28 May 1661

Tangallaq, Karaeng [2] (Sitti Arifah Tanripadaq) 24 Sep 1711; 29 Nov 1723; 17 Sep 1728; 29 Dec 1729; 3 Nov 1730; 21 May 1746

Taniciniq, Daeng 4 Nov 1638; 28 Sep 1639; 23 Sep 1666

Tanipaccoq 11 Jul 1681

Taniq 25 Jun 1631; 1 Aug 1670; 23 Mar 1672; 16 Sep 1672; 25 May 1673; 28 Aug 1674; 27 Nov 1674

Tanisanga, Karaeng 29 Jun 1684

Tanisunggu 6 Feb 1678

Taniuqrangi 3 May 1643

Tanriwela 2 Nov 1646

Tapallaq, Daeng [1] (Piqdaq) 13 May 1673

Tapallaq, Daeng [2] 30 Oct 1674

Tapallaq, Daeng [3] (Diqdaq) 17 Nov 1690; 30 Apr 1700; 13 Jan 1705; 5 May 1705; 13 Jan 1706; 20 Jun 1707; 8 Oct 1709; 31 Dec 1713; 10 Oct 1715; 18 May 1718; 18 Nov 1730

Tapallaq, Daengta Daeng 17 Jul 1724

Tappaq 10 Jan 1729; 14 Sep 1732

Tappaq, Daeng 5 Jan 1672

Tappaq, Karaeng 15 Jul 1645

Tappaq, Kare 17 Feb 1725

Taqbi Sattu 24 Feb 1705

Taqbiq Jawa 16 Aug 1698

Taqduq, Daengta Daeng 22 Aug 1637

Taqgalaq, Kare [1] 4 Dec 1705

Taqgalaq, Kare [2] (Parampang) 13 Feb 1706

Tarawe 15 Dec 1712

Taruq, Karaeng [1] 25 Jun 1704

Taruq, Karaeng [2] 31 Mar 1705; 18 Jun 1715; 5 Mar 1718; 24 Jul 1718; 30 Jul 1722

Taruq, Karaeng [3] 26 Jan 1740

Tasami, Daeng (Takkiq) 22 May 1701; 1 Apr 1705; 22 Apr 1705; 5 Sep 1705; 25 Dec 1709; 12 Sep 1716; 20 Jan 1717; 10 Nov 1723

Tasannging, Daeng [1] (Taloq) 28 Sep 1717

Tasannging, Daeng [2] (Karaeng Bontomanaiq) 16 Jul 1750

Tatonji, Daeng (Talluq) 11 Oct 1720

Tauq, Daengta Daeng 15 Jun 1699

Tenrilele (Matinroe ri Soreyang) 30 Jul 1750

Teqne, Kare [1] 8 Nov 1651

Teqne, Kare [2] (Jambang) 28 Jul 1706; 14 Nov 1706; 1 Sep 1709

Thahirah 11 Mar 1730

Tija 3 Feb 1645; 15 Jun 1646; 5 Jun 1653

Tinangga 15 Feb 1674

Tipa 6 Oct 1725 
Tippa 20 Nov 1751

To Sappaileq 21 Jan 1720

Toadaeng 12 Sep 1675

Toalaq 29 Nov 1651

Toaq Daeng 25 Mar 1678

Tobalaq 19 Nov 1643;7 Aug 1660; 10 Aug 1660; 21 Sep 1660; 11 Oct 1660

Todattia 1 Mar 1714; 2 Mar 1714;

Tojumaat 17 Sep 1695; 29 Apr 1696

Toll, Governor van 4 May 1710; 27 Sep 1711; 6 Jun 1712

Tomboloq, Gallarrang [1] (Mangemba) 5 Apr 1729

Tomboloq, Gallarrang [2] 29 Aug 1733

Tommaq, Daeng 13 Jan 1655

Tommi, Daeng [1] (Yakung) 11 Oct 1705; 13 May 1708

Tommi, Daeng [2] 9 Sep 1718

Tomponga, Karaeng 22 May 1651; 14 Oct 1668

Tompoqbalang, Karaeng [1] 12 Jun 1660

Tompoqbalang, Karaeng [2] 31 Oct 1673; 22 Jul 1709; 15 Jun 1739

Tongi, Daeng (Sapiah) 18 Jun 1705; 8 Aug 1707; 3 Nov 1707; 31 May 1717; 8 Jun 1720

Tonji, Daeng [1] (Saenaq) 25 Sep 1675; 10 Oct 1713

Tonji, Daeng [2] (Baedah) 18 Jul 1718; 11 Dec 1719

Tonji, Daeng [3] (Ummi) 23 Dec 1721

Tonji, Daeng [4] (Balambaru) 8 Feb 1726

Tonji, Daengta Daeng 23 Apr 1711

Tonji, Kare (Maqmiq) 29 Sep 1676; 15 Sep 1707; 1 Mar 1714; 13 Apr 1715

Topasonriq 8 Mar 1639

Tosaqdang (Arung Belo) 12 Oct 1668

Totammaq 21 Mar 1706

Tuang Anciq Jenalaq 7 Sep 1660; 2 Oct 1660

Tuang Dima Dec 1737

Tuang Pandiq, Karaeng 8 May 1716

Tuang Rappang (Abdul Bashir) 2 Mar 1678; 29 Jul 1704; 9 Nov 1704; 4 Oct 1707; 20

May 1715; 14 Dec 1722; 5 May 1723; 25 Jul 1723; 7 Jun 1725; 18 Oct 1728; 25 Feb 1729; 3 Sep 1751

Tuang ri Dima (Shaykh Umar Bamahsuna Rahmahtullah) 13 Feb 1637; 22 Mar 1684;

21 Apr 1684; 2 Apr 1688; 8 May 1694; 11 Jan 1724

Tuang, Daengta Daeng 26 Mar 1707

Tuassah 18 Mar 1736

Tuguq 28 Jan 1717

Tulolo, Daeng (Mangiq) 21 Dec 1701; 27 May 1715; 19 Feb 1719; 17 Dec 1720; 24 Aug 1724

Tulolo, Kare 19 Feb 1672

Tulusuq, Kare Gallarrang 22 May 1693; 23 Aug 1693

Tumamenang ri Jawaya see Najamuddin, Sultan

Tumamenang ri Lampana see Harunarrasyid

Tumamenang ri Passiringanna (Sultan Abdul Kadir) see Abdul Kadir

Tumamenang ri Rateqna 29 Jun 1712; 10 Jun 1726

Tumamenang ri Taenga see Bontosunggu, Karaeng 
Tumammaliang ri Timoroq (Mudhaffar) 1593; 26 Oct 1637; 25 Dec 1640; 15 Jan 1641; 20 Jan 1641; 7 May 1641; 18 May 1641

Tumammo, Daengta Daeng 10 Oct 1702

Tumaqdanggang, Karaeng 14 Mar 1671; 19 Oct 1671

Tumaqlalang, Karaeng (Kapparaq) 21 Jun 1717

Tumatea ri Banten (Daeng Mangemba) 14 May 1631; 20 May 1632; 27 Sept 1632; 9 Dec 1632

Tumatea ri Jakattaraq see Muhammad Ali

Tumbuq [1] 10 Dec 1645; 30 Sep 1646; 21 Feb 1649

Tumbuq [2] 12 Sep 1670

Tummamo, Daeng (Abdul Jalil) 26 Aug 1679

Tuna, Daeng [1] 2 May 1643; 18 Oct 1651

Tuna, Daeng [2] 22 Nov 1674; 23 Mar 1675

Tuna, Daeng [3] (Salamah) 24 Dec 1678

Tuna, Daengta Daeng [1] 19 Apr 1632; 8 Mar 1704

Tuna, Daengta Daeng [2] (Bulukumba) 10 Apr 1706

Tunijalloq 1545, 1590

Ujung Pandang, Karaeng 7 Apr 1665; 26 Dec 1672

Ujung Tana, Karaeng (Kelo, Daeng Uraga) 27 Sep 1632

Ujung, Karaeng [1] 2 Aug 1679

Ujung, Karaeng [2] (Daeng Nisanga) 15 Jan 1716

Umaraq 29 Oct 1724

Ummu Kalsum 15 Jun 1646

Ummu Kalsyum 15 Aug 1714

Unnaq 10 Sep 1722

Untaya 12 Aug 1647

Uppa, Kare 9 Oct 1705

Uru 30 Jun 1672

Uthman 24 Aug 1632; 18 Sep 1632; 8 Aug 1656

Watanglipua 6 May 1715

Wera $1660^{*}$

Wiherah 16 May 1642

Yabu 1 Mar 1712

Yakiah 9 Dec 1728; 16 Oct 1730

Yasing 9 Dec 1725

Yunnaq 23 Jun 1723; 24 May 1725

Yusuf, Shaykh 1626; 22 Sep 1644; 20 Oct 1644; 13 Dec 1666

Zainab [1] 2 Aug 1693

Zainab [2] 20 Aug 1710

Zalikha 4 Sep 1673 



\section{Glossary}

\begin{tabular}{|c|c|}
\hline naq buraqne & $\begin{array}{l}\text { a term applied to sons of nobles, it may have referred to a dis- } \\
\text { tinct group of young warriors }\end{array}$ \\
\hline anaq karaeng & a term applied to refer to noble offspring \\
\hline anrong guru & $\begin{array}{l}\text { leader/teacher; a common term for a chief of a community } \\
\text { or religious authority, it was also the title given to the one in } \\
\text { charge of the tumakkajannang }\end{array}$ \\
\hline ata mateqne & $\begin{array}{l}\text { a group or class of people translated as 'favored servants,' they } \\
\text { were often entrusted with important tasks }\end{array}$ \\
\hline ata ri kale & $\begin{array}{l}\text { this term is translated as 'bound followers' and describes a } \\
\text { group or class of people. It literally means 'personal slaves' but } \\
\text { does not carry the same connotations of ownership and power- } \\
\text { lessness that this translation implies }\end{array}$ \\
\hline ata & a group or class of people translated as 'slave' \\
\hline ballaq lompoa & $\begin{array}{l}\text { meaning 'great house,' this refers to a ruler's home and is used } \\
\text { as a proper name for the Gowa royal palace }\end{array}$ \\
\hline bembeng kaqdoq & a group or class of people translated as 'servants' \\
\hline bilang tau & a general term describing commoners translated as 'people' \\
\hline dacing & $\begin{array}{l}\text { a kind of portable scale with two arms of unequal length sepa- } \\
\text { rating fixed and moveable weights }\end{array}$ \\
\hline daeng & $\begin{array}{l}\text { a title distinguishing nobles from commoners, usually chosen to } \\
\text { reflect a physical or mental characteristic of the person named }\end{array}$ \\
\hline gallarrang & a title of local rulers beneath the level of karaeng \\
\hline jantang & $\begin{array}{l}\text { a unit of measurement equal to } 20 \mathrm{katti} \text {, or } 1 / 20 \text { th of a pikul } \\
\text { the oldest Makassarese script }\end{array}$ \\
\hline kali & $\begin{array}{l}\text { the chief Islamic official in the land and religious advisor to the } \\
\text { ruler }\end{array}$ \\
\hline kalompoang & $\begin{array}{l}\text { meaning 'greatness', it denotes sacred objects or regalia pos- } \\
\text { sessed by many Makassarese paqrasangang }\end{array}$ \\
\hline karaeng & $\begin{array}{l}\text { a title granted to high-ranking nobles, usually but not always } \\
\text { based on the toponym of a paqrasangang which became the } \\
\text { appanage of the title-holder }\end{array}$ \\
\hline koyang & a unit of measurement. Cense notes (1979: 338) that in \\
\hline & Makassar a 'small koyang' (koyang caqdi) was equal to thirty \\
\hline & $\begin{array}{l}\text { pikul (1 pikul equaled approximately } 60 \mathrm{~kg} \text { ), and a 'large koy- } \\
\text { ang' (koyang lompo) was equal to one hundred pikul, implying }\end{array}$ \\
\hline
\end{tabular}


laqlang sipue

lontaraq

lontaraq beru

lontaraq bilang

pajama

pakaiq

paqrasangang

patturioloang

patung

rapang

raqba bate

sabannaraq

saqbu katti

serang

Sudanga

taikang

Tallumbocco

Tanisamaang

tau taballaq

timbaq sareong

tumabicarabutta

tumailalang

tumakkajannang

tumalompo

tumanurung literally meaning 'half-umbrellas,' this refers to a sunshade made from lontar palm leaves that was held above the heads of rulers as a mark of their loftiness

this term is used in several different senses, but in this work usually refers to a physical manuscript (as they were originally written on lontar palm leaves)

meaning 'new lontar', it refers to the most common

Makassarese script

meaning 'counting manuscript', a genre of Makassarese writing. A court record of important events, dated and in chronological order

a group or class of people translated as 'laborers'

this term refers to a slave of the lowest rank, translated as

'thrall' to distinguish it from the more common word for 'slave'(ata)

settlement, village, community, polity, kampung

a genre of Makassarese writing. Literally 'that which is about the ancestors', it is usually translated as 'chronicle' a unit of measurement equal to a gantang or 20 katti a genre of Makassarese writing containing advice, guidelines, and declarations from renown ancestors

like saqbu kati, a fine imposed by the victor on the vanquished a title meaning 'harbourmaster'

a substantial fine imposed by the victor on the vanquished, usually paid in gold

Makassarese written in Arabic script

the sacred regalia-sword of Lakipadada given to the rulers of Gowa

a balance with two equal scales

an alliance formed by Boné, Wajoq, and Soppéng in an effort to withstand Gowa's rising power in the sixteenth century the sacred golden chain the tumanurung gave to her son and later rulers of Gowa

a group or class of people translated as 'household followers' a war indemnity or payment, but comprised of various valuables instead of gold

chief advisor and minister of Gowa known as 'The Speaker of the Land'

title of ministers that acted as intermediaries within Gowa a term or title describing those charged with supervising others who had specific tasks

a term used to refer to important persons

literally 'the person who descended', it refers to a heavenly ancestor of pure white blood who was recognized and installed as the first ruler of a new kingdom by the people of the land 


\section{Reign lists for the rulers of Gowa and Talloq}

Rulers of Gowa to 1753

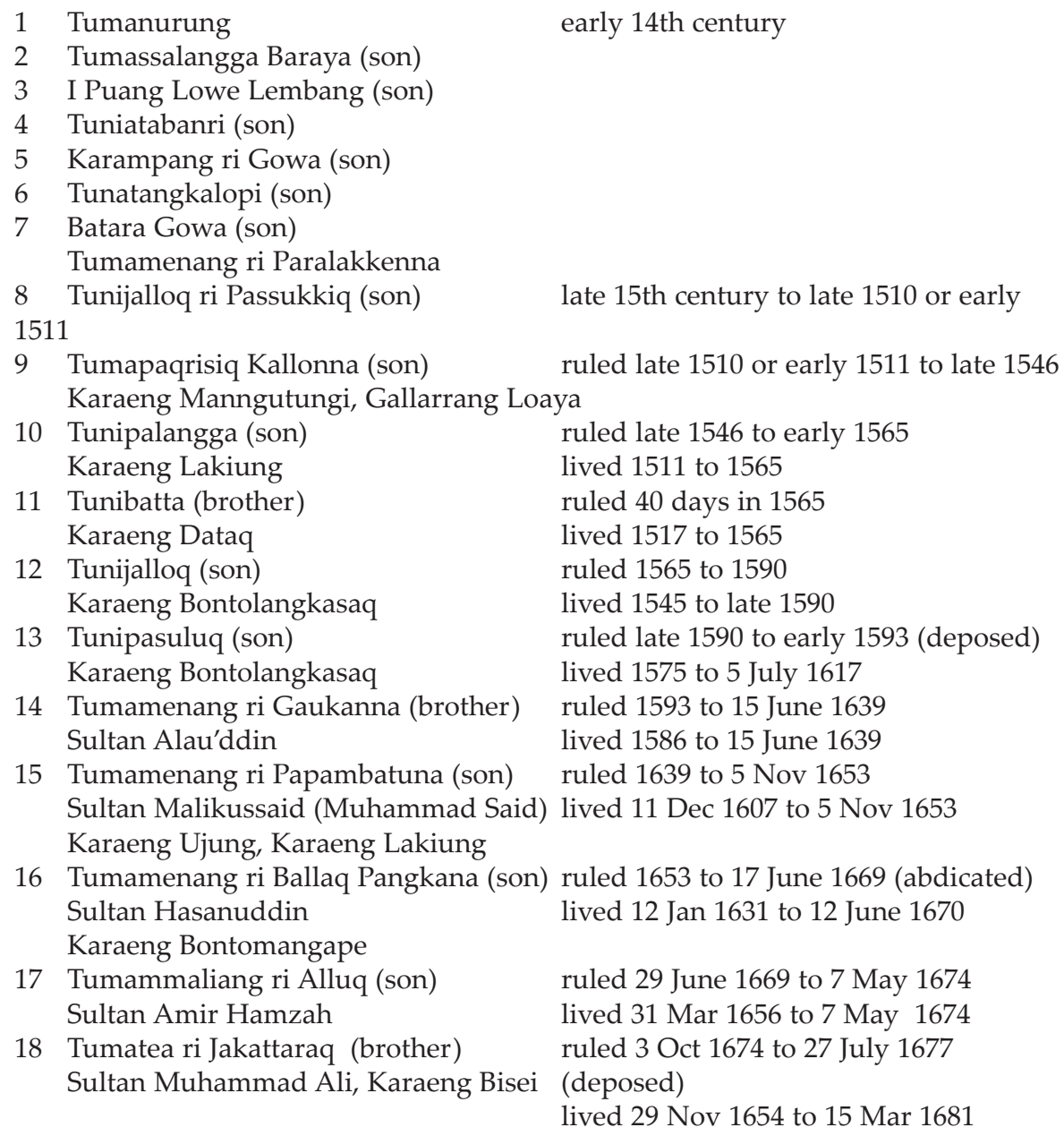


19 Tumamenang ri Lakiung (brother) ruled 27 July 1677 to 17 Sept 1709 Sultan Abdul Jalil, Karaeng Sanrabone lived 18 Aug 1652 to 17 Sept 1709

20 Tumamenang ri Sombaopu (grandson) ruled 21 Sept 1709 to 24 Aug 1712 Sultan Ismail, Karaeng Anaq Moncong (deposed)

lived 18 Jan 1690 to 1 Apr 1724

21 Tumamenang ri Pasiq (son of T11) Karaeng Kanjilo ruled 31 Aug 1712 to 5 Nov 1735 (abdicated)

Sultan Sirajuddin, Tumamaliang ri Talloq

22 Tumamenang ri Gowa (grandson of G21, son of T14) Sultan Abdul Khair Almansyur I Mallawanggauq

23 Karaeng Bontolangkasaq lived 14 Mar 1694 to 8 Sept 1739

24 Tumamenang ri Kalabiranna (brother of G22)

Sultan Abdul Kudus lived 17 Nov 1687 to 22 Jan 1739 ruled 5 Nov 1735 to 28 July 1742 lived 12 Feb 1727 to 28 July 1742 ruled 10 April 1739 to 8 Sept 1739 ruled 28 July 1742 to 1753 lived Dec 1733 to 1753

1 Karaeng Lowe ri Sero (son of G6)

2 Tunilabu ri Suriwa (son)

3 Tunipasuruq, Karaeng ri Passiq (son)

4 Tumenanga ri Makkoayang (son) Karaeng Pattingalloang

5 Karaeng Bainea (daughter)

Karaeng Pattingalloang

6 Tunipasuluq (son)

7 Karaeng Matoaya (son of T4) Sultan Abdullah, Tumamenang ri Agamana

Karaeng Kanjilo, Karaeng Segeri

8 Karaeng Kanjilo (son)

Sultan Mudhaffar

Tumammaliang ri Timoroq

9 Karaeng Pattingalloang (brother)

Sultan Mahmud Tumamenang ri Bontobiraeng

10 Tumamenang ri Lampana (son of T8) Sultan Harrunarasyid

11 Tumamenang ri Passiringanna (son) Sultan Abdul Kadir

12 Tumamenang ri Pasiq, Karaeng Kanjilo (son)

Sultan Sirajuddin, Tumamaliang mid to late 15th century late 15 th century to $1500 \mathrm{~s}$ 1500 s to 1540 or 1543 ruled 1540 or 1543 to 1576 lived 1520 to 1576 late 1576 to 1590

late 1590 to early 1593 ruled 1593 to 1623 (advised son to 1636) lived 1573 to 1636

ruled 1623 to 18 May 1641 lived 1598 to 18 May 1641

ruled 1641 to 15 Sept 1654 lived Aug 1600 to 15 Sept 1654

ruled 1654 to 16 June 1673 lived 3 Nov 1640 to 16 June 1673 ruled 1673 to 8 Jan 1709 lived 7 Jan 1666 to 8 Jan 1709 ruled 12 Aug 1709 to 1714 ruled 25 Apr 1729 to 1739 
ri Talloq

13 Tumamenang ri Jawaya (son) Sultan Najamuddin

14 Karaeng Lempangang (brother) Syafiuddin lived 17 Nov 1687 to 22 Jan 1739

ruled 1714 to 24 Apr 1729

lived 23 Dec 1708 to 24 Apr 1729

ruled 1739 to 1760

lived 7 Dec 1709 to 1760 



\section{Bibliography}

Abdurrazak, Dg. Patunru

1969 Sedjarah Gowa. Ujung Pandang: Jajasan Kebudajaan Sulawesi Selatan dan Tenggara.

Andaya, Leonard Y.

1981 The heritage of Arung Palakka; A history of South Sulawesi (Celebes) in the seventeenth century. The Hague: Nijhoff. [KITLV, Verhandelingen 91.]

Bellwood, Peter, James J. Fox, and Darrell Tryon, eds.

1995 The Austronesians; Historical and comparative perspectives. Canberra: Australia National University.

Blok, R.

1848 'Beknopte geschiedenis van het Makasaarsche Celebes en Onderhoorigheden,' Tijdschrift voor Nederlandsch Indie X:3-77.

Bulbeck, David

2008 Review of William Cummings, A chain of kings; The Makassarese chronicles of Gowa and Talloq (Leiden: KITLV Press, 2007), in Review of Indone-

Cense, A.A.

1966 'Old Buginese and Macassarese diaries', Bijdragen tot de Taal-, Land- en Volkenkunde 122:416-28.

Cense, A.A., with Abdurrahim

1979 Makassaars-Nederlands woordenboek. 's-Gravenhage: Nijhoff. [KITLV, Verhandelingen.]

Cummings, William

2002 Making blood white; Historical transformations in early modern Makassar. Honolulu: University of Hawai'i Press.

2005 'Historical texts as social maps; Lontaraq Bilang in Early Modern Makassar', Bijdragen tot de Taal-, Land- en Volkenkunde 161:40-62.

2007 A chain of kings; The Makassarese chronicles of Gowa and Talloq. Leiden: KITLV Press.

2007 'Islam, Empire and Makassarese Historiography in the reign of Sultan Ala'uddin (1593-1639)', Journal of Southeast Asian Studies 83:197-214.

Dagh-Register

1887-1931 Dagh-Register Gehouden int Casteel Batavia vant Passerende Daer ter Plaetse als over Geheel Nederlandts-India, 1624-1682. 's-Gravenhage: Nijhoff.

Fox, James and Clifford Sather (eds)

1996 Origins, Ancestry and Alliance; Explorations in Austronesian Ethnography. Canberra: Australian National University. 


\section{Bibliography}

Kamaruddin, H.D., H.D. Mangemba, P. Parawansa, M. Mappaseleng, Djirong Basang and Ny. Sugira Wahid

1985-86 Lontarak bilang Raja Gowa dan Tallok (Naskah Makassar). Ujung Pandang: Proyek Penelitian dan Pengkajian Kebudayaan Sulawesi Selatan LaGaligo. Two vols.

Khalidi, Tarif

1994

Arabic historical thought in the classical period. Cambridge: Cambridge University Press.

Ligtvoet, A.

1872

'Geschiedenis van de afdeeling Tallo (Gouvernement van Celebes),' Tijdschrift voor Indische Taal-, Land- en Volkenkunde (TBG) 18:43-66.

1880 'Transcriptie van het dagboek der vorsten van Gowa en Tello', Bijdragen tot de Taal-, Land-en Volkenkunde 28:1-259.

Makasaarsche historiën

1855 'Makasaarsche historiën', Tijdschrift voor Indische Taal-, Land- en Volkenkunde (TBG) 4:111-45.

Noorduyn, J.

1953 'Een Boeginees geschriftje over Arung Singkang', Bijdragen tot de Taal-, Land- en Volkenkunde 109:144-52.

1961 'Some aspects of Macassar-Buginese historiography', in: D.G.E. Hall (ed), Historians of Southeast East Asia, pp. 29-36. London: Oxford University Press.

1965

'Origins of South Celebes historical writing', in: Soedjatmoko, Mohammad Ali, G.J. Resink and G.McT. Kahin (eds), An introduction to Indonesian historiography, pp. 137-55. Ithaca NY: Cornell University Press.

'Makasar and the islamisation of Bima', Bijdragen tot de Taal-, Land- en Volkenkunde 142:312-342.

Omar, Rahilah

2003 'The history of Boné A.D. 1775-1795; The diary of Sultan Ahmed asPelras, Christian Salleh Syamsuddin.' PhD dissertation, University of Hull.

1994

'Religion, tradition and the dynamics of Islamization in South Sulawesi.' Indonesia 57:133-154. Originally published in Archipel 29 (1985):107-135.

Robinson, Chase F.

2003 Islamic Historiography. Cambridge: Cambridge University Press.

Tol, Roger

1993

'A royal collection of Bugis manuscripts', Bijdragen tot de Taal-, Land-en Volkenkunde 149:612-29.

Zerubavel, Eviator

2003 Time maps; Collective memory and the social shape of the past. Chicago: University of Chicago Press. 


\section{Index}

(to Introduction and selected notes in Chapter II)

Ala'uddin, Sultan 3, 4, 7-13, 25, 28

Arung Palakka 16, 25, 28, 31

birth 3, 5, 7, 10, 15-6, 19, 20, 25-7, 31-2,

$34 n-36 n, 38 n-39 n$

Boné 4, 8, 12, 16, 28

Bontojeqneq, Karaeng 18-9, 21

calendars and dating 3-7, 9, 25, 43n, 50n,

70n, 123n, 134n

Cense, A. A. 1, 3, 349

chronicles 5, 6n, 9, 10, 13, 16-7, 18

death $7,10,15-6,19-20,25-7,30-2$,

$35 n, 38 n-39 n$

divorce 13, 18-21, 23, 25-7, 35n, 38n-39n

empire 2, 4, 7-9, 11-2

historiography v-vi, 1-3

Islam 1, 2, 3-5, 6, 8-12, 17, 21, 23, 25, 28-9,

31-2

Islamization 1, 2, 3-5, 8-12, 21, 23, 25,

28,31
Kamaruddin, H. D. 22

Karunrung, Karaeng 18-9, 21

Ligtvoet, A. 15, 22

Makassar War 11-2, 22-3, 25, 28, 107n, 139n, 176n

Malikussaid, Sultan 3, 13, 20

marriage 19-20, 21, 25-9, 32, 34n-35n,

38n-39n

Matoaya, Karaeng 3, 4, 7-11, 25, 28

Noorduyn, J. 8

Said, Muhammad 3, 13

Soppéng 3-4, 8, 28

Tol, Roger 3

Tunijalloq 3, 10, 25

VOC $3,9,12,16,18,20,25,28-9,31$

Wajoq 4, 8, 28

White, Hayden 1-2, 12

Yusuf, Shaykh 7, 16, 20-1 
